\title{
ESTUDO TEÓRICO-EXPERIMENTAL DA INFLUÊNCIA DAS CARGAS CÍCLICAS NA RIGIDEZ DE VIGAS DE CONCRETO ARMADO
}

Josafá de Oliveira Filho

Tese apresentada à Escola de Engenharia de São Carlos da Universidade de São Paulo, como parte dos requisitos para a obtenção do Título de Doutor em Engenharia de Estruturas.

Orientadora: Dr ${ }^{\mathrm{a}}$ Ana Lúcia H. de C. El Debs

São Carlos

2005 
Ficha catalográfica preparada pela Seção de Tratamento da Informação do Serviço de Biblioteca - EESC/USP

\footnotetext{
Oliveira Filho, Josafá de

048e Estudo teórico-experimental da influência das cargas cíclicas na rigidez de vigas de concreto armado / Josafá de Oliveira Filho. -- São Carlos, 2005.

Tese (Doutorado) -- Escola de Engenharia de São Carlos-Universidade de São Paulo, 2005.

Área: Engenharia de Estruturas.

Orientador: Profa. Dra. Ana Lúcia H. de C. El Debs.
}

1. Concreto Armado. 2. Aderência. 3. Contato. 4. Carga cíclica. 5. Carga de serviço. 6. Método dos elementos finitos. 7. Dano. 8. Perda de rigidez. I. Título. 
FOLHA DE JULGAMENTO

Candidato: Engenheiro JOSAFÁ DE OLIVEIRA FILHO

Tese defendida e julgada em 07-10-2005 perante a Comissão Julgadora:

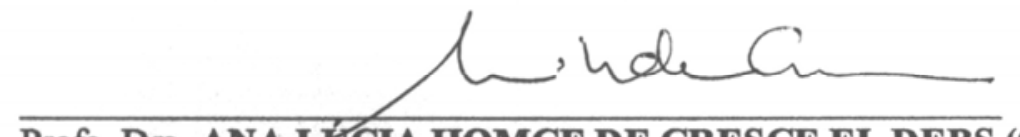
APROUAR

Profa. Dra. ANA EUCIA HOMCE DE CRESCE EL DEBS (Orientadora)

(Escola de Engenharia de São Carlos/USP)

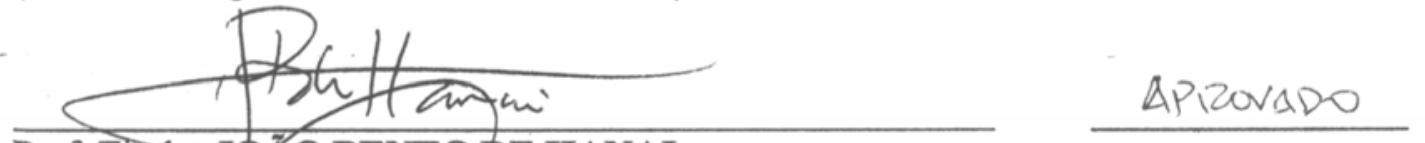

Prof. Titutar JOAXO BENTO DE HANAI

(Escola de Engenharia de São Carlos/USP)

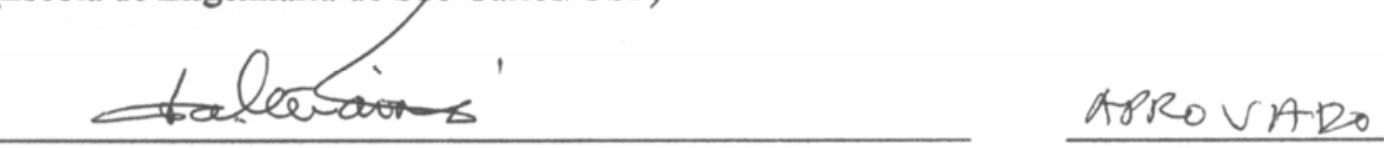

Prof. Titular WALTER SAVASSI

(Escola de Engenharia de São Carlos/USP)

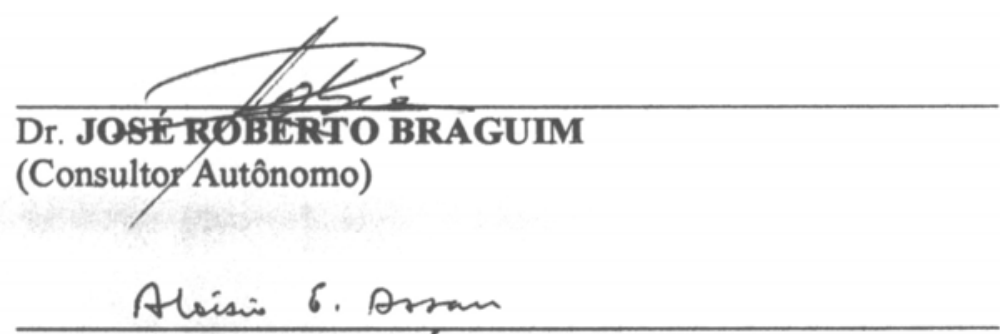

APKOUADU

Prof. Livre-Docente ALOÍSIO ERNESTO ASSAN

(Universidade Estadual de Campinas/UNICAMP)
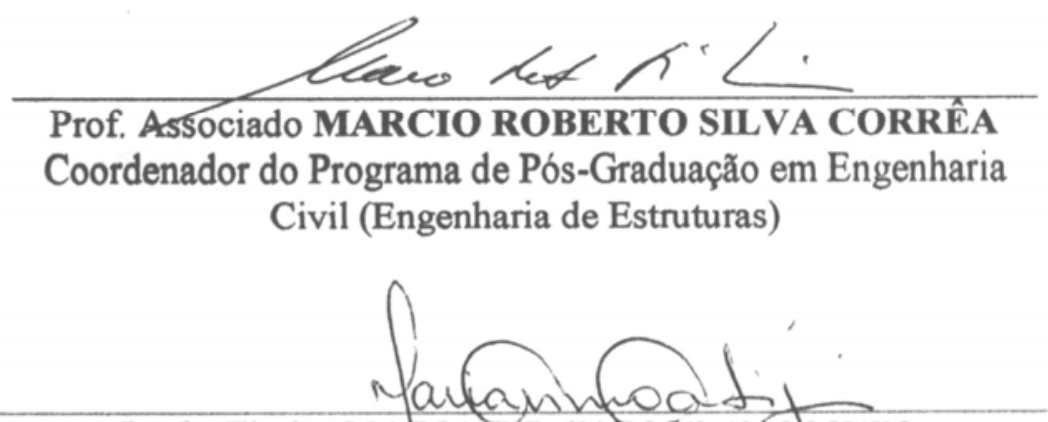

Profa. Titular MARIA do CARMO C IL IJURI

Presidente da Comissão de Pós-Graduação 
"...porque sem mim nada podeis fazer". Palavras de Jesus, registradas em João 15:5 
À minha esposa Dilma, grande amor da minha vida,

às minhas filhas Daniela, Rosa Alina e Mariana, jóias preciosas, dádivas de Deus,

dedico esse trabalho. 


\section{AGRADECIMENTOS}

A Deus, pelo dom da vida. Pela saúde e pela paz sempre presentes. Toda honra e glória sejam dadas a Ele.

À Prof ${ }^{a}$ Ana Lúcia pela confiança e pelo permanente apoio, especialmente nas horas de dúvidas e indecisões.

À minha querida esposa Dilma, pelo incentivo sempre presente durante essa jornada; sem seu estímulo não estaria aqui e nem teria tido a capacidade para desenvolver este trabalho.

Às minhas queridas filhas Dani, Rosinha e Mamá, pelo carinho e pela compreensão da ausência física de todos esses anos.

A papai (em Memória) e mamãe; pais amorosos, zelosos e incentivadores; a eles devo tudo e sem eles aqui não teria chegado. Às minhas queridas irmãs Dora, Dione e Daisy, pelas orações e incentivo. A eles ofereço, com carinho, este trabalho.

Ao Prof ${ }^{\circ}$ Savassi pelo apôio e preciosos conselhos; obrigado pela amizade de todos esses anos.

Aos colegas Gerson Alva e Francisco Adriano pela inestimável ajuda disponibilizando e adaptando seus programas relativos à Mecânica do Dano às minhas necessidades.

Aos colegas Claudius Barbosa e Sandra Almeida pela preciosa ajuda na execução dos ensaios de caracterização do concreto.

Ao Laboratório de Estruturas (LE-SET) por todo o suporte oferecido e aos seus funcionários Eng ${ }^{\mathrm{o}}$ Luiz Vareda, Amaury, Mário, Mauri, Valdir, Fabiano, Waldemir e Wagner, pelo apoio eficiente e constante na execução dos ensaios.

À Universidade Federal de Sergipe (UFS) e, em especial, ao Departamento de Engenharia Civil, pelo afastamento concedido possibilitando o desenvolvimento deste trabalho.

À Coordenação de Aperfeiçoamento de Pessoal de Nível Superior (CAPES) pela concessão de bolsa e apoio financeiro.

A todos os professores e funcionários do SET, em especial a Nadir, Rosi, Toninho, Eli e Sylvia pela disponibilidade e atenção sempre constantes.

Aos amigos da Igreja em São Carlos que me ajudaram a manter a comunhão com Cristo durante todos esses anos, em especial Eliziara, Mario, Léo, Pr. Josafá e família, Chiquinho e família.

Finalmente, a todos os colegas com quem prazerosamente convivi durante todos esses anos e que me acolheram como se da mesma faixa etária fosse, em especial a Rodrigo e Raissa, Oscar, Joel e Tatiana, Yuri e Patrícia, Walter e Suzana, Wesley Góis, Luciano Gobo, Petrus e Selma, Alex e Silvana, Alex Minah, Vladimir, Valério e Wesley. 


\section{SUMÁRIO}

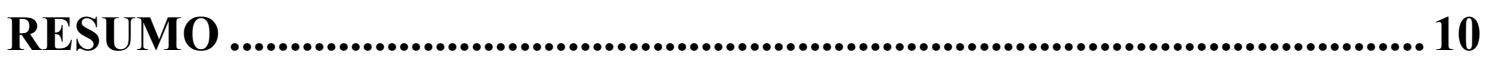

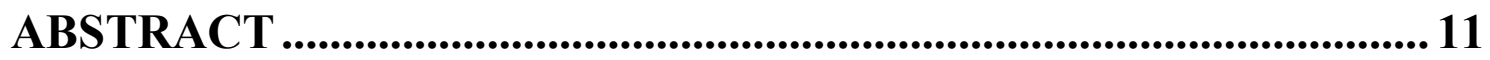

1. INTRODUÇÃO..................................................................................... 12

1.1 CONSIDERAÇÕES INICIAIS..............................................................12

1.2 OBJETIVO E JUSTIFICATIVAS ...................................................14

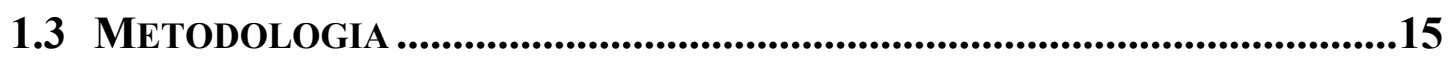

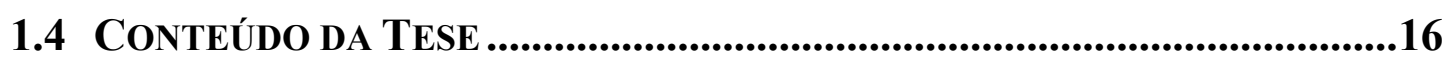

2. SOBRE A ADERÊNCIA ............................................................18

2.1 MOBILIZAÇÃ̃ DA AdERÊNCIA .....................................................19

2.2 DISTRIBUIÇÃO DAS TENSÕES DE ADERÊNCIA ........................................22

2.3 MECANISMOS DE RESISTÊNCIA DA ADERÊNCIA ......................................24

2.4 A FERRAMENTA COMPUTACIONAL ................................................25

2.5 MODELOS TEÓRICOS ...............................................................26

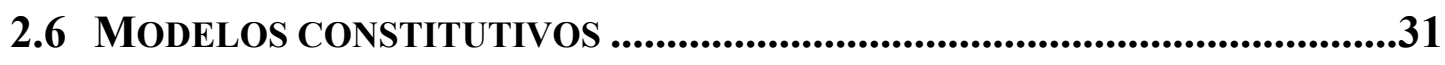

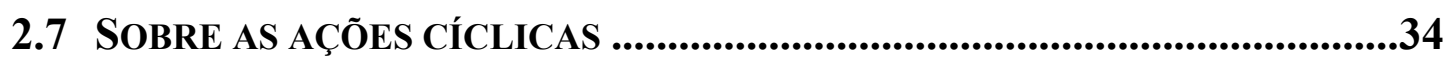

2.8 OUTROS ARTIGOS DE INTERESSE ...............................................36

3. ANÁLISE NUMÉRICA ................................................................... 70

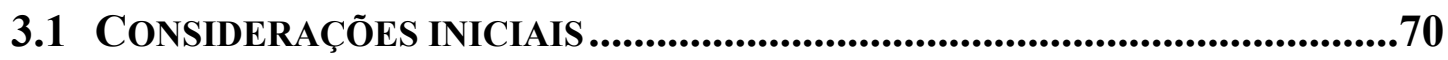

3.2 ELEMENTOS FINITOS DISPONÍVEIS ....................................................71

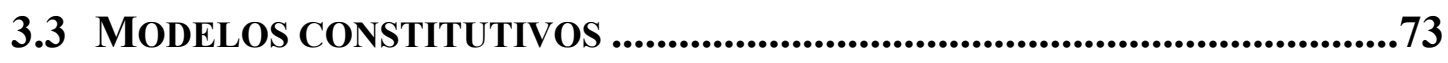

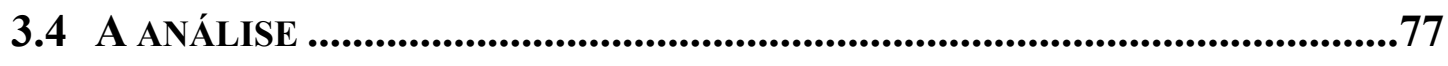

3.5 SOBRE O CONTATO ........................................................................79

3.6 UMA PALAVRA SOBRE O ALGORITMO..............................................82

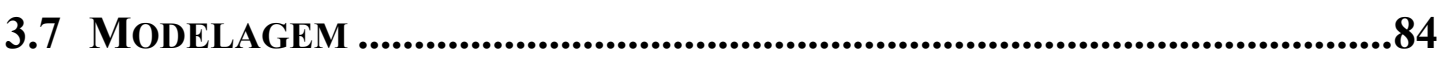

3.7.1 CP's de concreto armado................................................................8

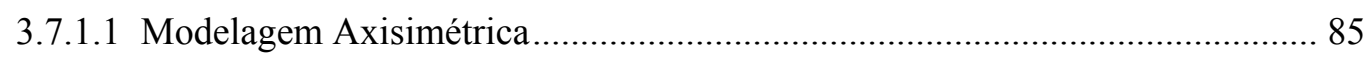

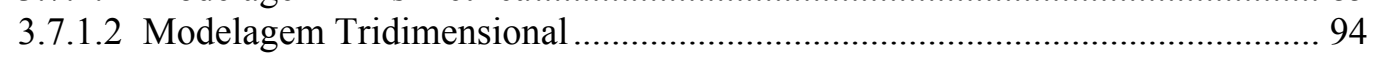

3.7.2 Vigas de concreto armado ..............................................................98

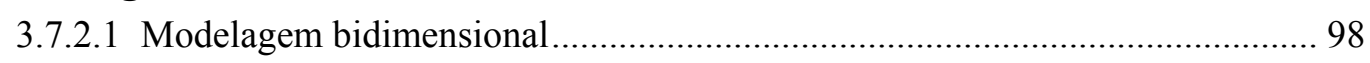

3.7.2.2 Modelagem tridimensional para a viga inteira............................................. 99 
3.7.2.3 Modelagem tridimensional para metade da viga ......................................... 104

3.7.2.4 Modelagem tridimensional para 1/4 da viga.............................................. 106

3.7.2.5 Programas baseados na mecânica do dano ..................................................... 110

4. ANÁLISE EXPERIMENTAL ............................................................. 111

4.1 ENSAIO PILOTO ..............................................................................................112

4.1.1 Ensaio de caracterização dos materiais ............................................. 112

4.1.1.1 Determinação da resistência à compressão do concreto: ................................ 113

4.1.1.2 Determinação da resistência à tração do concreto: .......................................... 114

4.1.1.3 Determinação do módulo de elasticidade do concreto: ................................. 115

4.1.2 Ensaio com CP's de concreto armado ...............................................117

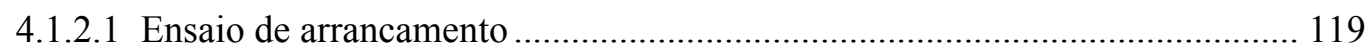

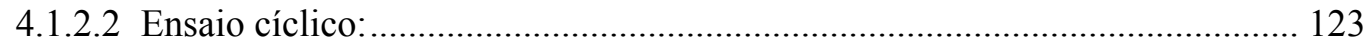

4.1.3 Ensaio com vigas de concreto armado ............................................... 125

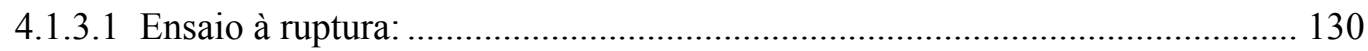

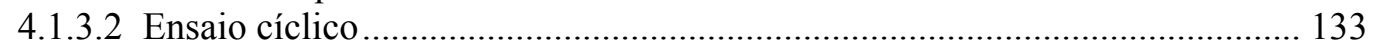

4.2 ENSAIO DEFINITIVO .................................................................................135

4.2.1 Ensaio de caracterização dos materiais ................................................... 135

4.2.1.1 Determinação da resistência à compressão do concreto ................................. 136

4.2.1.2 Determinação da resistência à tração do concreto ........................................... 137

4.2.1.3 Determinação do módulo de elasticidade do concreto.................................... 138

4.2.1.4 Comparação dos resultados de resistência obtidos para o concreto................ 139

4.2.1.5 Resumo das propriedades mecânicas dos materiais...................................... 139

4.2.2 Ensaio com vigas de concreto armado .................................................. 141

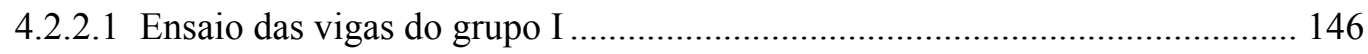

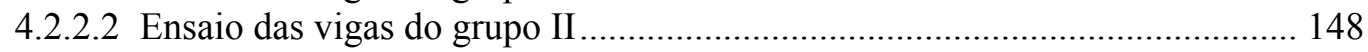

4.2.2.3 Ensaio das vigas do grupo III.................................................................. 151

5. ANÁLISE DOS RESULTADOS .................................................. 155

5.1 CARACTERIZAÇÃo do AÇO E DO CONCRETO............................................155

5.2 CP'S DE CONCRETO ARMADO …........................................................157

5.2.1 Análise experimental......................................................................................... 158

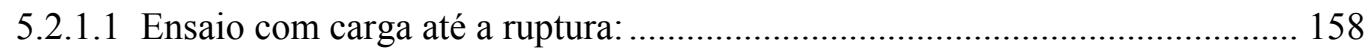

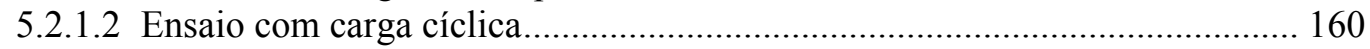

5.2.2 Análise numérica................................................................................. 163

5.3 VIGAS DE CONCRETO ARMADO ................................................172

5.3.1 Análise experimental............................................................................172

5.3.2 Vigas sub-armadas.........................................................................................173

5.3.3 Vigas com armadura dupla .......................................................................185

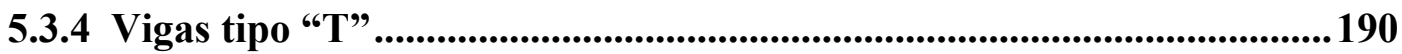

5.3.5 Quantificação da perda de rigidez................................................................194 
6. CONCLUSÕES .......................................................................... 205

6.1 INTRODUÇÃ̃̃ .....................................................................................205

6.2 CONCLUSÕES GERAIS ........................................................................206

6.2.1 CP's de concreto armado.........................................................................206

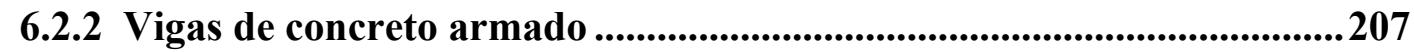

6.3 SUGESTÕES PARA NOVOS TRABALHOS ..........................................211

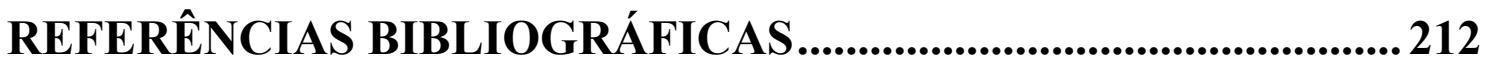




\section{RESUMO}

OLIVEIRA FILHO, J. (2005). Estudo teórico-experimental da influência das cargas cíclicas na rigidez de vigas de concreto armado. Tese (Doutorado) - Escola de Engenharia de São Carlos, Universidade de São Paulo, São Carlos.

O objetivo principal do trabalho é analisar o comportamento experimental e teórico de vigas de concreto armado de modo a quantificar a perda de rigidez global através do cálculo de flechas sucessivas ocorridas durante a aplicação de carregamento cíclico, em regime de serviço. A ênfase da pesquisa é dada à análise numérica; a aderência na interface aço-concreto é tratada com uma estratégia onde cada parte é modelada isoladamente de modo a se considerar o contato entre a barra de aço (com o desenho de suas nervuras) e o concreto envolvente. A análise numérica foi feita com o auxílio do aplicativo ABAQUS, baseado no método dos elementos finitos. O modelo constitutivo usado para o concreto é fundamentado na mecânica do dano contínuo. Foram realizados ensaios experimentais com espécimes de concreto contendo uma barra de aço colocada em seu eixo e, também, com vigas de concreto armado sub-armadas e com armadura dupla, com seção transversal retangular e tipo "T". Comparações dos resultados obtidos nos ensaios experimentais com as respostas da análise numérica são apresentadas e discutidas. Ao final, propõem-se expressões que quantificam a perda de rigidez em função do número de ciclos aplicado.

Palavras chave: Concreto armado, Aderência, Contato, Carga cíclica, Carga de serviço, Método dos elementos finitos, Dano, Perda de Rigidez. 


\section{ABSTRACT}

OLIVEIRA FILHO, J. (2005). Theoretical and experimental analysis of cyclic loads on stiffness of the reinforced concrete beams. Ph.D. Thesis - Engineering School at São Carlos, São Paulo University, São Carlos.

The main purpose of this research is to analyze the experimental and theoretical behavior of reinforced concrete beams, in order to quantify the stiffness loss, by calculating successive deflections during the cyclic loads application, under service loads. The emphasis of this research is the numerical analysis. The modeling of steelconcrete interface is done taking into account the contact between the steel bars (with their ribs) and the concrete surrounding the bars. The numerical analysis was made by using the software ABAQUS, based on the finite element method. The concrete's constitutive model is based on the continuous damage mechanics. The experimental tests were made with cylinder concrete specimens with an axial bar and rectangular and $\mathrm{T}$ cross section reinforced concrete beams, where some had only tension reinforcement and others had tension and compression reinforcement. Comparisons between experimental and numerical results are presented and discussed. At the end expressions to quantify the stiffness loss due to number of cycles are proposed.

Keywords: Reinforced concrete, Bond, Contact, Cyclic load, Service loads, Finite element method, Damage, Stiffness loss. 


\section{Capítulo 1}

\section{INTRODUÇÃO}

\subsection{CONSIDERAÇÕES INICIAIS}

O concreto, desde o seu aparecimento, no início do século XIX, até hoje, vem experimentando contínuo desenvolvimento. Novas tecnologias têm surgido. O intuito é sempre o de conferir maior resistência e maior durabilidade às estruturas, por certo, motivado pelo aparecimento cada vez mais recorrente de recentes e danosas patologias. $\mathrm{O}$ interesse pelo desenvolvimento do concreto no Brasil não tem sido diferente. A evolução da tecnologia do concreto em todo o mundo tem sido acompanhada pelos técnicos brasileiros que, por sua vez, têm colocado à disposição de arquitetos, engenheiros e projetistas novos materiais para projeto, dando-lhes mais recursos para criar e ousar. A entrada em vigor da NBR 6118:2003 vem dar respaldo a essa evolução tecnológica quando privilegia aspectos ligados à durabilidade das estruturas.

$\mathrm{O}$ aumento significativo das características de resistência e durabilidade conferidas ao concreto em trabalho conjunto com o aço (que também experimentou grandes avanços ao longo do último século) tem proporcionado enormes ganhos à arte de projetar, conduzindo a seções transversais mais esbeltas, maiores vãos livres, maior leveza visual e conseqüente estética às obras projetadas. È o que se tem chamado de nova arquitetura do concreto estrutural. Contudo, mesmo com toda essa evolução, o concreto armado continua sendo estudado e pesquisado. Todo esse avanço ainda não 
conseguiu preencher e esgotar completamente o pleno conhecimento desse extraordinário material. $\mathrm{Na}$ outra ponta, também experimentando contínuo desenvolvimento, a evolução dos computadores tornou possível a expansão dos limites de aplicação de técnicas numéricas, como o método dos elementos finitos e o método dos elementos de contorno, impulsionando o cálculo estrutural dentro da engenharia civil. Todos os avanços conseguidos até aqui, no entanto, foram incapazes de acalmar o espírito sempre inquieto dos engenheiros e pesquisadores que buscam a cada pesquisa e empreendimento compreender definitivamente os fenômenos que envolvem esse intrincado material, composto do aço (material, de certa forma, de comportamento bem conhecido) e do concreto (esse sim, um material bastante complexo e ainda não totalmente explorado e compreendido). Entender plenamente cada um desses materiais (o aço e o concreto) e entender, principalmente, o funcionamento desses materiais quando trabalhando em conjunto (concreto armado) continua sendo, portanto, preocupação constante e atual.

O concreto armado é, na sua essência, dependente da aderência. A aderência é, portanto, o principal fenômeno que envolve o relacionamento entre o aço e o concreto. O funcionamento do concreto armado como material estrutural se apóia integralmente no fenômeno da aderência. Inexistindo a aderência entre o aço e o concreto as barras seriam incapazes de resistir e transmitir esforços de tração. A relação tensão de aderência $\mathrm{x}$ deslizamento tem sido costumeiramente utilizada para quantificar a eficiência da ligação aço-concreto. Essa relação representa a variação da tensão na interface de contato entre os dois materiais, sendo o deslizamento o deslocamento relativo entre a barra e o concreto que a envolve.

Grandes esforços têm sido despendidos no estudo e entendimento da perda de aderência, e conseqüente perda de rigidez das estruturas, entre os dois materiais em contato. A perda de aderência entre o aço e o concreto é influenciada pela resistência do concreto à compressão, pela presença de nervuras na barra de aço, pelo estado de fissuração do concreto e pela história do carregamento, dentre outras tantas variáveis.

Sob o ponto de vista do carregamento a aderência é fortemente afetada pelo tipo de ação imposta à estrutura. As ações cíclicas, que se fazem sentir pela variação do tempo de aplicação da carga, caracterizam-se por imprimir uma determinada amplitude de tensão. As ações cíclicas impõem diminuição da aderência e perda de rigidez à estrutura devido ao aumento e propagação das fissuras no concreto. Os efeitos das ações cíclicas sobre as estruturas têm sido estudados, correntemente, nos estados limites de 
ruptura por fadiga. Ultimamente diversas pesquisas têm sido dirigidas para o estudo dos efeitos das ações cíclicas no âmbito da degradação da ligação aço-concreto, no regime de serviço.

\subsection{OBJETIVO E JUSTIFICATIVAS}

A motivação para o desenvolvimento desta pesquisa veio como conseqüência do trabalho de mestrado realizado por FERNANDES (2000), inserido no grupo "sistemas estruturais em concreto" da área de estruturas da Escola de Engenharia de São Carlos; naquela pesquisa foi analisado o comportamento da aderência do concreto armado submetido a ações monotônicas e cíclicas. A influência de fatores como o diâmetro da armadura, tipo e amplitude do carregamento foi estudada. A investigação se deu através de análise numérica e experimental; na análise experimental foram feitos ensaios de arrancamento padronizados.

Partindo do enfoque dado ao trabalho acima referido, o objetivo da presente pesquisa é analisar o comportamento experimental e numérico da aderência açoconcreto em vigas de concreto armado quando submetidas a carregamento cíclico. A tarefa essencial é quantificar a perda de rigidez verificada nas vigas quando submetidas a ciclos de carga em regime de serviço, mediante cálculo de flechas sucessivas. Mais ainda, o ineditismo da pesquisa se traduz na contribuição dada, na análise numérica, ao tratamento da interface aço-concreto quando se considera o contato entre a barra de aço (com o desenho de suas nervuras) e o concreto que a envolve.

O comportamento da aderência é altamente influenciado pela história do carregamento, como afirmado anteriormente. As normas vigentes nos paises, notadamente no nosso, continuam, no entanto, a adotar suas recomendações baseadas em pesquisas realizadas com carregamento estático. Mais ainda, a introdução dos efeitos da interação entre o aço e o concreto, na análise de estruturas de concreto armado, se mostra de grande importância quando se deseja uma modelagem mais realista do funcionamento dessas estruturas.

$\mathrm{Na}$ literatura técnica internacional encontram-se diversos artigos relacionados a esse assunto.

$\mathrm{Na}$ literatura técnica nacional, no entanto, poucas são as pesquisas que têm dedicado atenção ao fenômeno da aderência em vigas de concreto armado com a ênfase 
voltada para cargas cíclicas em serviço. A NBR 6118:2003 aborda timidamente o problema das cargas cíclicas.

A relevância do tema fica evidente quando se percebe que a abordagem do problema da aderência ainda continua em franco desenvolvimento, justificando plenamente a necessidade de se continuar trilhando esse caminho.

A intenção do autor foi mostrar um espírito investigativo e ao mesmo tempo crítico ao longo de toda a pesquisa; objetivou-se, ao fim, ter sido dada uma pequena parcela de contribuição no entendimento do problema da perda de rigidez em vigas de concreto armado, quando submetidas a carregamento cíclico em serviço, especialmente com a inclusão da análise numérica da interface aço-concreto, tentando torná-la a mais realista possível.

Enfim, algumas perguntas continuam necessitando respostas satisfatórias. Qual a perda de rigidez de uma estrutura após ser submetida a um certo número de ciclos de carga? É possível obter um modelo numérico mais realista (que contemple as nervuras das barras de aço) que represente essa perda de rigidez? Como levar em conta o valor da flecha final após a aplicação desses ciclos de carga? Esse valor para a flecha está de acordo com as normas, mormente a NBR 6118:2003?

\subsection{Metodologia}

O presente trabalho de pesquisa foi dividido em duas fases distintas: uma fase de investigação experimental e outra de análise teórico/numérica.

$\mathrm{Na}$ fase experimental, com a realização de diversos ensaios cíclicos em vigas de concreto armado de dimensões reduzidas, procurou-se determinar a perda de rigidez destas vigas ao final de um certo número de ciclos aplicado, através medição de flechas no meio do vão e obter uma lei que preveja a flecha final dessas vigas. As atividades experimentais foram realizadas no Laboratório de Estruturas da Escola de Engenharia de São Carlos.

O estudo teórico consistiu numa análise numérica baseada no método dos elementos finitos, apoiado em modelos de dano e plasticidade. Foram realizadas duas abordagens distintas: uma com modelos de espécimes cilíndricos de concreto armado contendo uma única barra de aço em seu eixo e submetidos a carregamento cíclico, em nível de serviço, considerando o contato entre as duas superfícies aço-concreto (piloto); 
outra com modelos de vigas submetidas à flexão cíclica, em serviço, também considerando o contato entre as barras de aço e o concreto envolvente.

Ainda no bojo do objetivo da pesquisa inclui-se a comparação dos resultados da análise numérica com os resultados experimentais; tanto pela comparação entre esses resultados como pela observação do comportamento das vigas e espécimes nos ensaios experimentais isoladamente foi possível chegar a algumas conclusões. Por fim são apresentadas algumas sugestões ligadas ao tema específico da tese bem como para trabalhos futuros.

\subsection{CONTEÚdo DA TESE}

A tese foi dividida em seis capítulos. O primeiro capítulo é de introdução ao texto, sendo ali feitas algumas considerações sobre as estruturas de concreto armado e a importância de se estudar com profundidade o fenômeno da aderência entre o aço e o concreto envolvente, mormente quando se deseja verificar a perda de rigidez dessas estruturas estando elas submetidas a carregamento cíclico, em nível de serviço. $\mathrm{O}$ objetivo da pesquisa, uma breve justificativa e o conteúdo do texto são também apresentados.

No segundo capítulo é feita uma breve revisão do estado da arte das estruturas de concreto armado no tocante à aderência, às ações cíclicas e sua implicações. É dada ênfase aos mecanismos de aderência entre aço e concreto, aos modelos constitutivos disponíveis para o concreto e às técnicas empregadas para resolver o problema da aderência, sejam elas numéricas ou experimentais.

O terceiro capítulo trata da análise numérica empregada na pesquisa indicando a ferramenta, elementos, hipóteses e parâmetros utilizados na análise, a discretização dos modelos e técnicas de interação na interface aço-concreto. Apresenta os modelos axisimétrico e o tridimensional para o caso dos espécimes cilíndricos e os modelos tridimensionais de viga.

O quarto capítulo trata da etapa experimental da pesquisa. Neste capítulo abordam-se aspectos do planejamento, da metodologia empregada nos ensaios, do projeto piloto e do projeto experimental definitivo. São apresentados com detalhe os materiais empregados, a instrumentação utilizada, a montagem das peças, as concretagens realizadas, a montagem do pórtico de reação e os ensaios realizados. 
O quinto capítulo é dedicado à análise dos resultados obtidos tanto na fase experimental quanto na fase teórico-numérica. Por meio de figuras, tabelas, gráficos e equações os diversos resultados obtidos são confrontados, discutidos, avaliados e comentados.

O sexto e último capítulo contém as principais conclusões extraídas da presente pesquisa. Nele são observados o comportamento individual de cada peça analisada. São comentados os principais aspectos relativos à perda de rigidez de cada viga e a relação guardada entre cada tipo de viga analisada. São feitos comentários destacados da capacidade de simulação do aplicativo Abaqus no tocante à utilização de superfícies de contato entre o aço e o concreto envolvente e concomitantemente com o uso de leis constitutivas de dano para o concreto. Sugestões para futuras pesquisas também são apresentadas. 


\section{Capítulo 2}

\section{SOBRE A ADERÊNCIA}

Neste capítulo é apresentado um resumo do estado da arte do que se entende ser importante para a compreensão do fenômeno da aderência nas estruturas de concreto armado, mormente para as vigas; o estudo da aderência, os métodos de cálculo utilizados, os modelos analíticos propostos por diversos autores, os modelos constitutivos disponíveis para o concreto, a simulação do contato na interface açoconcreto e a influência das cargas cíclicas, são o maior objetivo dessa revisão.

São descritos sucintamente diversos trabalhos relacionados ao tema central da tese encontrados na literatura técnica estrangeira e de outros encontrados na literatura técnica nacional, além de alguns poucos encontrados em publicações avulsas. Inicialmente é dada uma visão panorâmica do fenômeno da aderência. Depois são mostradas formas de encarar o problema da aderência utilizando-se do método dos elementos finitos. Destaca-se, também, o comportamento da aderência na interface açoconcreto sob a ação de cargas cíclicas. Posteriormente são citados e descritos alguns trabalhos mais diretamente ligados ao interesse específico da tese, sempre que possível em ordem cronológica. 
A aderência concreto-aço é o fenômeno base sobre o qual se apóia o funcionamento do concreto armado como material estrutural. Se não existisse aderência, as barras seriam incapazes de receber o menor esforço de tração, já que o aço deslizaria sem encontrar resistência em todo o seu comprimento e não acompanharia o concreto em suas deformações, com o que, ao fissurar-se o concreto, ocorreria ruína brusca. Ao contrário, graças à aderência, as armaduras são capazes de trabalhar, inicialmente, junto com o concreto. Depois, quando o concreto se fissura, o faz de forma mais ou menos regularmente distribuída ao longo da peça, em virtude da aderência; e a aderência permite que o aço absorva os esforços de tração, mantendo a união entre os materiais nas zonas entre as fissuras. (MONTOYA et al (1976), p.167).

Sempre que ocorrer variação de tensão em um determinado trecho de uma barra de aço de um elemento de concreto armado, aparecerão tensões de aderência. Diversas são as causas apontadas para essas variações de tensão, segundo LEONHARDT e MONNIG (1977), destacando-se dentre outras: i) ações externas que alteram as tensões de tração e de compressão nas armaduras; ii) fissuras que propiciam grandes concentrações de tensões de aderência nas regiões de descontinuidade; iii) ancoragem das barras que, pela presença das tensões de aderência, permitem que a força atuante na barra seja integralmente transferida ao concreto.

\subsection{MobilizaÇão da AderênCIA}

A ligação entre a armadura e o concreto é responsável pelo controle da abertura de fissuras de uma peça de concreto armado. Para solicitações relativamente baixas o concreto ainda resiste à tração sem o aparecimento de fissuras (estádio I). O estado de fissuração começa a aparecer no início do estádio II, apos atingida a resistência à tração do concreto. Um modelo bastante representativo da forma de mobilização da aderência, apresentado por FUSCO (1995), é mostrado na Figura 2.1. 


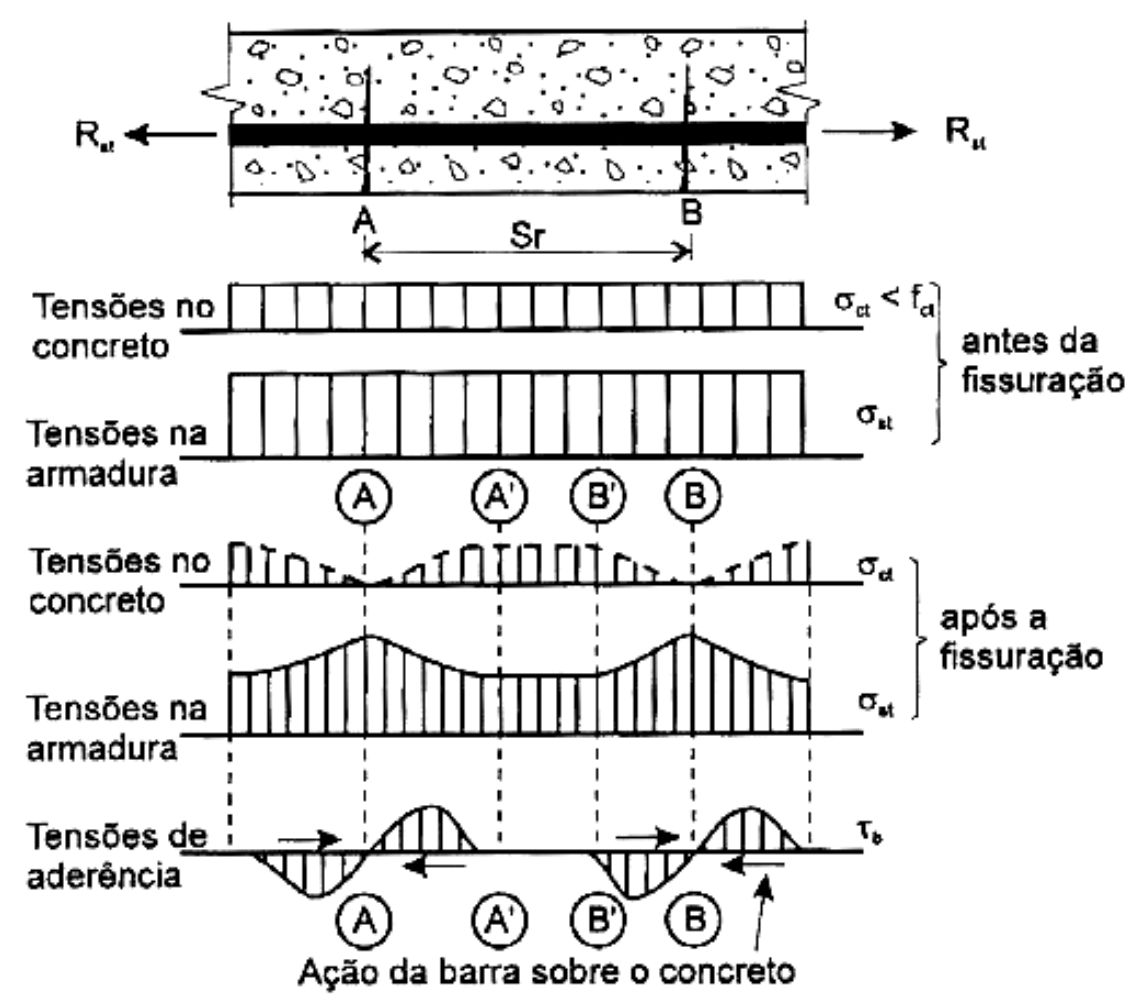

Figura 2.1 - Fissuração por tração (FUSCO, 1995)

Entre fissuras, uma parcela das tensões de tração é absorvida pelo próprio concreto através da mobilização das tensões de aderência. Esse mecanismo, denominado enrijecimento à tração, conhecido no meio técnico como tension stiffening, contribui para a rigidez da peça.

Na Figura 2.1 analisam-se apenas as duas fissuras A e B afastadas Sr uma da outra. As tensões de aderência são mobilizadas apenas nos trechos A-A' e B'-B. No trecho central, A'- B', a tensão no concreto é constante e contribuinte como parcela da aderência. Com o aumento da tensão de tração na armadura e, por conseguinte, da tensão de tração no concreto, naquele trecho central apresenta-se grande possibilidade de ser formada uma terceira fissura C, como mostra a Figura 2.2. 


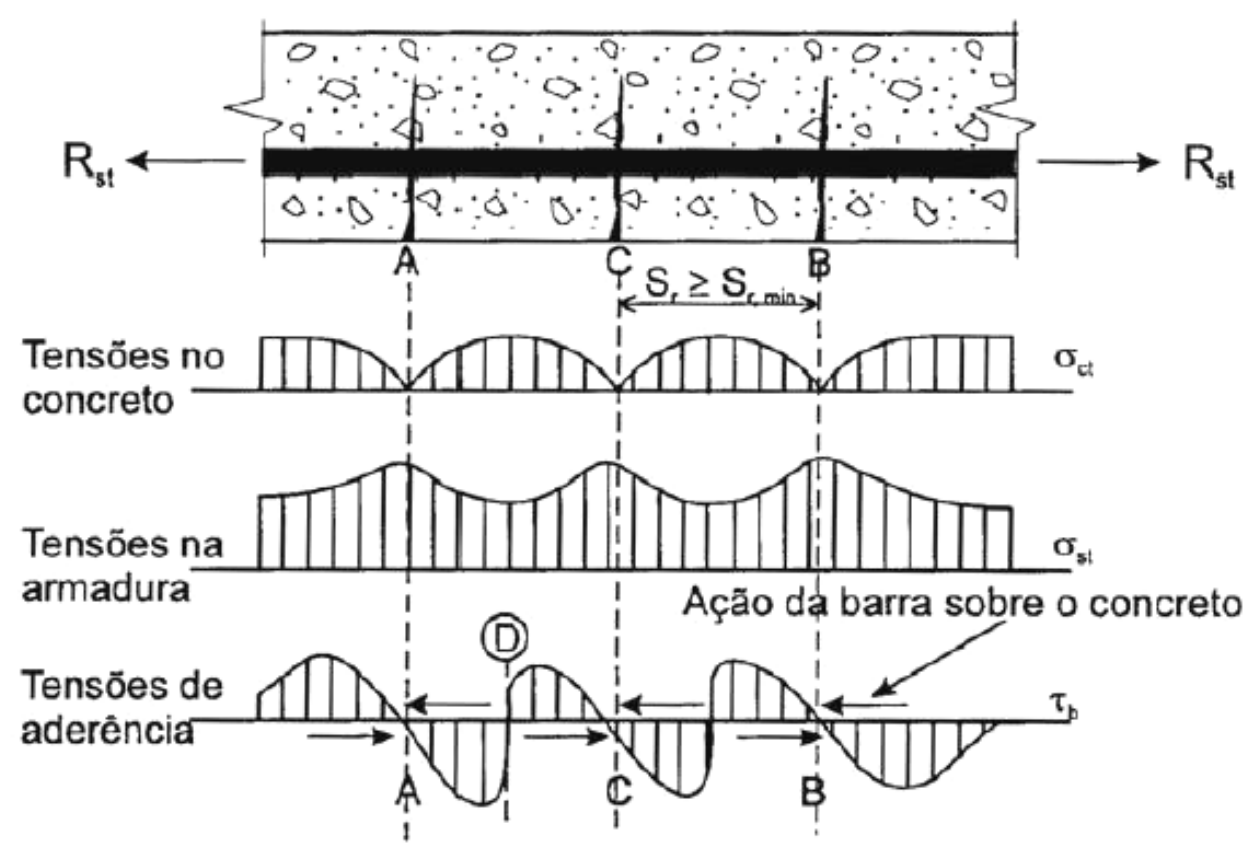

Figura 2.2 - fissuração estabilizada (FUSCO, 1995)

Em importante e esclarecedor artigo GOTO (1971) afirma que as características das fissuras formadas no concreto que envolve uma barra colocada no eixo de prismas de concreto armado são influenciadas pelo tipo da barra utilizada, seja ela lisa ou nervurada. As fissuras, quando são usadas barras nervuradas, influenciam ou determinam o mecanismo de aderência entre a barra e o concreto, produzindo fissuração radial, além da fissuração longitudinal, segundo esclarece a Figura 2.3.

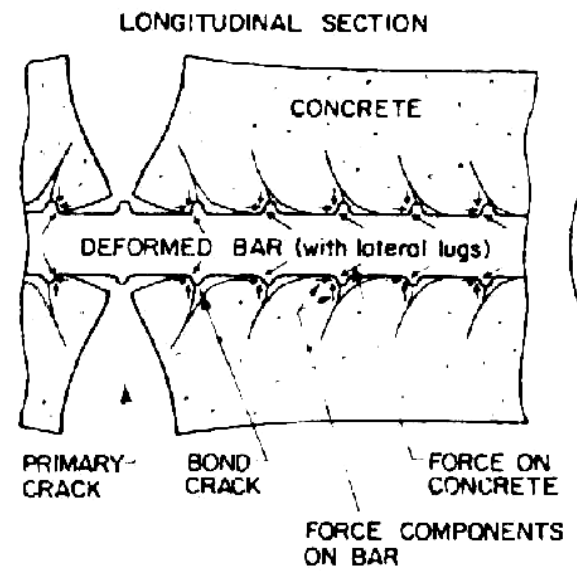

(a)

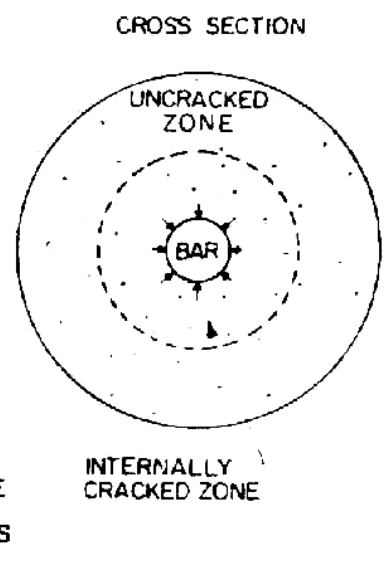

(b)

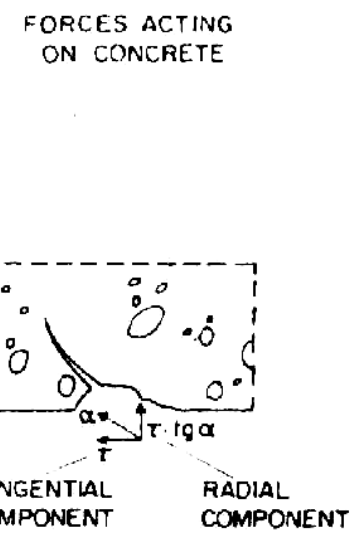

(c)

Figura 2.3 - microfissuração do concreto (GOTO, 1971) 
As fissuras radiais se propagam a partir da superfície da barra no sentido da face externa do concreto. As barras nervuradas tendem a romper o concreto por fendilhamento, devido a aderência mecânica, enquanto as barras lisas rompem por arrancamento. $\mathrm{O}$ autor conclui que a formação de fissuras longitudinais é fortemente influenciada pela forma e tipo das nervuras da barra.

\subsection{DisTRIBUIÇÃO DAS TENSÕES DE ADERÊNCIA}

Nas peças de concreto armado as armaduras sofrem variação de tensão ao longo do comprimento, especialmente nos trechos de ancoragem e de variação de momento fletor. A distribuição das tensões de aderência depende de fatores como o panorama de fissuração da peça, fluência e retração do concreto, dentre outros. Não segue, portanto, leis simples e fáceis de equacionar. Uma teoria simples para representar a distribuição das tensões de aderência foi apresentada pelo CEB (1982) BULLETIN D'INFORMATION N 151 baseada nos deslocamentos reais na zona de aderência próxima à superfície da armadura. Para um trecho em equilíbrio, forças atuantes numa barra tracionada imersa no concreto são mostradas na Figura 2.4.

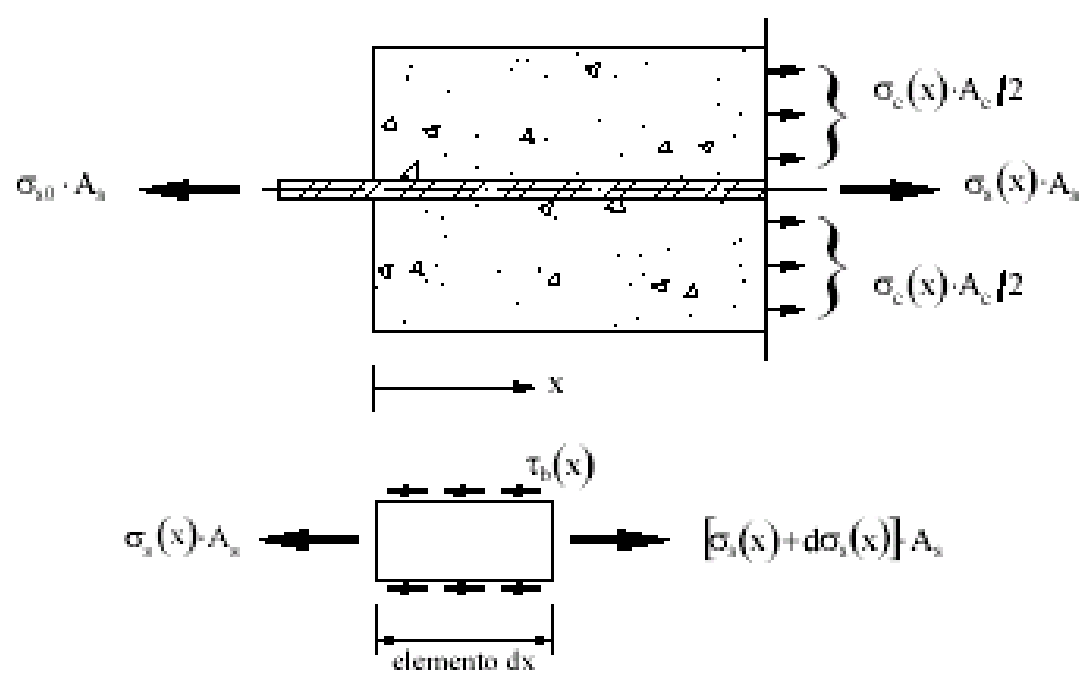

Figura 2.4 - Forças atuantes ao longo do comprimento de ancoragem de uma barra (CEB, 1982 - BULLETIN D'INFORMATION N 151) 
onde:

$\sigma_{\mathrm{s} 0} \quad$ Tensão normal na extremidade carregada da barra;

$\sigma_{\mathrm{s}}(\mathrm{x})$ Tensão normal na armadura ao longo do comprimento de ancoragem;

$\sigma_{c}(\mathrm{x})$ Tensão normal no concreto ao longo do comprimento de ancoragem;

$\tau_{\mathrm{b}}(\mathrm{x})$ Tensão de aderência ao longo do comprimento de ancoragem;

$\mathrm{A}_{\mathrm{s}} \quad$ Área da seção transversal da armadura;

$\mathrm{A}_{\mathrm{c}} \quad$ Área da seção transversal do concreto;

X Coordenada ao longo do trecho de ancoragem.

O equilíbrio do trecho infinitesimal é dado por:

$$
\begin{aligned}
& \sigma_{\mathrm{s}}(\mathrm{x}) \cdot \mathrm{A}_{\mathrm{s}}+\tau_{\mathrm{b}}(\mathrm{x}) \cdot \pi \cdot \phi \cdot \mathrm{dx}=\left[\sigma_{\mathrm{s}}(\mathrm{x})+\mathrm{d} \sigma_{\mathrm{s}}(\mathrm{x})\right] \cdot \mathrm{A}_{\mathrm{s}} \\
& \frac{\mathrm{d} \sigma_{\mathrm{s}}(\mathrm{x})}{\mathrm{dx}}=\frac{4}{\phi} \cdot \tau_{\mathrm{b}}(\mathrm{x})
\end{aligned}
$$

De igual modo, o equilíbrio do elemento também fornece a expressão:

$$
\begin{aligned}
& \sigma_{c}(x) \cdot A_{c}-\tau_{b}(x) \cdot \pi \cdot \phi \cdot d x=\left[\sigma_{c}(x)+d \sigma_{c}(x)\right] \cdot A_{c} \\
& \frac{d \sigma_{c}(x)}{d x}=-A_{c} \frac{4}{\phi} \cdot \tau_{b}(x)
\end{aligned}
$$

Observe-se que a variação da tensão no concreto é, em módulo e a menos de uma constante, igual a do aço.

Numa determinada seção, o deslizamento entre o aço e o concreto é dado pela relação:

$$
\mathrm{s}(\mathrm{x})=\mathrm{u}_{\mathrm{s}}(\mathrm{x})-\mathrm{u}_{\mathrm{c}}(\mathrm{x})
$$

A variação do deslizamento ao longo do comprimento $d x$ é dada pela diferença entre a deformação do aço e a do concreto, conforme a expressão:

$$
\begin{aligned}
& \frac{d s(x)}{d x}=\frac{d u_{s}(x)}{d x}-\frac{d u_{c}(x)}{d x}=\varepsilon_{s}(x)-\varepsilon_{c}(x) \\
& \frac{d s(x)}{d x}=\frac{\sigma_{s}(x)}{E_{s}}-\frac{\sigma_{c}(x)}{E_{c}}
\end{aligned}
$$


Derivando a eq. (2.7) e nela substituindo as eq. (2.2) e (2.4), resulta:

$\frac{\mathrm{d}^{2} \mathrm{~s}(\mathrm{x})}{\mathrm{dx}^{2}}=\frac{4 \cdot \phi}{\mathrm{E}_{\mathrm{s}}} \cdot \tau_{\mathrm{b}}(\mathrm{x})\left[1+\alpha_{\mathrm{e}} \cdot \rho\right]$

Sendo

$\alpha_{e}=\frac{E_{s}}{E_{c}} \quad$ e $\quad \rho=\frac{A_{s}}{A_{c}}$

\subsection{MECANISMOS DE RESISTÊNCIA DA ADERÊNCIA}

Diversos autores, dentre eles ELIGEHAUSEN et al (1983), ACI COMMITTE 408 (1991) e BULLETIN D'INFORMATION n. 230 (1996), afirmam que a aderência aço-concreto, nas peças de concreto armado (bem como no concreto protendido), é composta de três didaticamente distintas e não tão bem perceptíveis parcelas: a aderência por adesão química, a aderência por atrito e a aderência mecânica. A adesão é originada por ligações físico-químicas que ocorrem na interface aço-concreto durante a pega do cimento.

A aderência por atrito é função do coeficiente de atrito existente entre o aço e o concreto; na Figura 2.5 sugerida por (FUSCO, 1995) para representar a aderência por atrito, a rugosidade superficial da armadura, a retração do concreto e possíveis pressões de confinamento são os principais atores responsáveis por essa parcela.
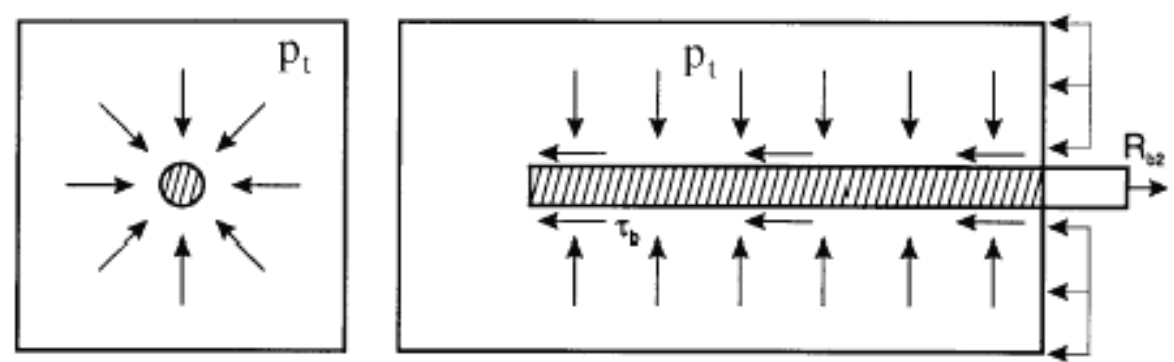

Figura 2.5 - Aderência por atrito (FUSCO, 1995)

A adesão e o atrito entre a superfície rugosa da barra e o concreto envolvente, no entanto, adicionam muito pouco à resistência total de aderência, segundo escreveu o mesmo ELIGEHAUSEN et al (1983).

A aderência mecânica é função da irregularidade da superfície da armadura, mesmo para barras lisas. As saliências (ou nervuras) na superfície das barras nervuradas (barras de alta aderência) funcionam como pontos de apoio que mobilizam as tensões de 
compressão no concreto (FUSCO, 1995), também conhecido como efeito cunha, conforme ilustra a Figura 2.6. Na região das nervuras são formadas micro-fissuras e micro-esmagamento do concreto. Ela é responsável, dentre as três parcelas, pelo maior percentual na composição da aderência, ainda segundo ELIGEHAUSEN et al (1983).

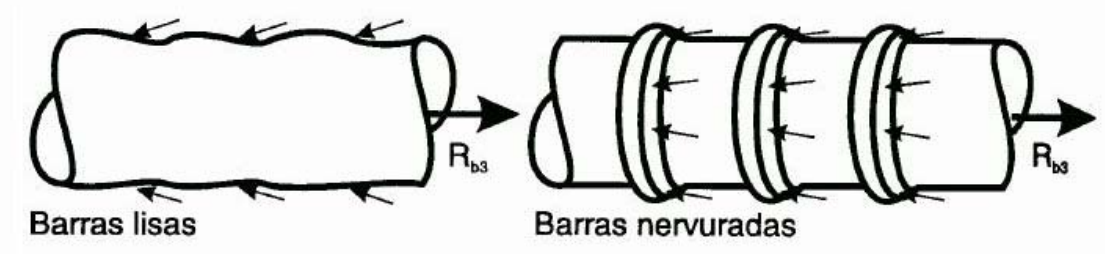

Figura 2.6 - Aderência mecânica (FUSCO, 1995)

LUNDGREN e GYLLTOFT (2000) reafirmam em seu artigo que o mecanismo de aderência entre as barras de aço e o concreto envolvente é influenciado por diversos parâmetros, dentre os quais podem ser citados como de destacada importância a resistência do concreto à compressão, o escoamento do aço e a presença de fissuras longitudinais.

\subsection{A FERRAMENTA COMPUTACIONAL}

Em discurso intitulado “A Revolução na Mecânica Aplicada”, Oden ${ }^{1}$ assim se expressa: "em mecânica aplicada, uma revolução especial ocorreu, que mudou para sempre a área e que vai afetar permanentemente a maneira como toda a ciência é feita. Falo, é claro, do surgimento do computador: a computação acrescentou um pilar aos dois clássicos pilares do método científico, teoria e experimento, um pilar que abrange os dois tradicionais, mas que os expande de forma nunca sonhada nos dias de Timoshenko".

Surge o Método dos Elementos Finitos (MEF) e, posteriormente, o Método dos Elementos de Contorno (MEC). Ambos vieram dar um grande suporte para que as pesquisas pudessem avançar rapidamente, notadamente o Método dos Elementos Finitos. Atualmente, na literatura brasileira, já encontramos diversos textos e livros tratando diretamente do MEF a exemplo dos livros editados por SAVASSI (1996) e ASSAN (1999). Já ao final da década de sessenta o MEF, poderosa ferramenta

\footnotetext{
1 J. Tinsley Oden, Professor da Universidade do Texas, em Austin, por ocasião da cerimônia de condecoração com a medalha Timoshenko a ele concedida no jantar da Divisão de Mecânica Aplicada da ASME, no Congresso Internacional de Engenharia Mecânica (IMECE).
} 
computacional de análise numérica (já consagrada como instrumento de resolução de problemas da elasticidade), passou a ser utilizado no estudo das estruturas de concreto armado, (PROENÇA, 1988, p.1.2). Alguns autores propuseram discretizar as armaduras por meio de elementos finitos de barra e reproduzir o panorama da fissuração através de modificações na malha inicialmente adotada. Na mesma época, outro estudo propunha que a não-linearidade proveniente da fissuração fosse considerada não por meio de redefinições da malha, mas através de alterações na matriz constitutiva, (RASHID apud PROENÇA, 1988, p.1.2). Para considerar a não-linearidade do concreto em compressão foi proposta a aplicação da teoria da plasticidade nos mesmos moldes daqueles usados para os aços, (CERVENKA apud Proença, 1988, p.1.2).

Com a intensificação das pesquisas e com a diversidade de pesquisadores se debruçando sobre o assunto, foi possível, já no final da década de setenta, estabelecer definitivamente as bases numéricas para procedimento computacional, com os processos de solução fundamentados em técnicas incrementais iterativas do tipo Newton-Raphson.

\subsection{MODELOS TEÓRICOS}

Alguns modelos teóricos utilizados por diversos pesquisadores são mostrados na seqüência do texto. Para carregamento monotônico as Figura 2.7a, b e c mostram um modelo qualitativo para o mecanismo de aderência, proposto por ELIGEHAUSEN et al (1983). São mostradas as fissuras inclinadas para baixos valores da tensão de aderência (ponto A); as fissuras começam a se propagar a partir do topo das nervuras; seu crescimento e tamanho são controlados pela pressão de confinamento. A transferência de forças ocorrerá principalmente pelo engrenamento mecânico, com um ângulo de inclinação próximo dos $30^{\circ}$, conforme esclarece a Figura $2.7 \mathrm{a}$. 


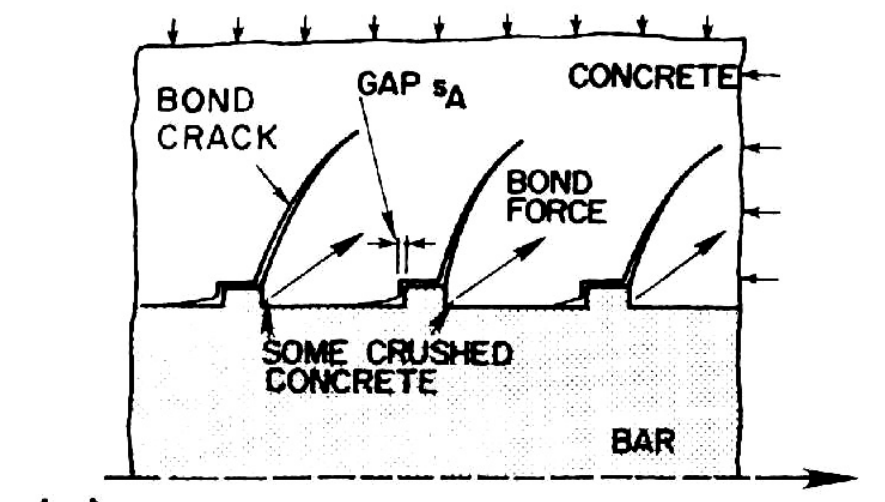

(a)

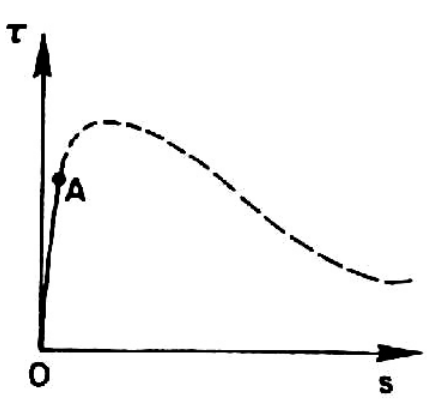

(b)
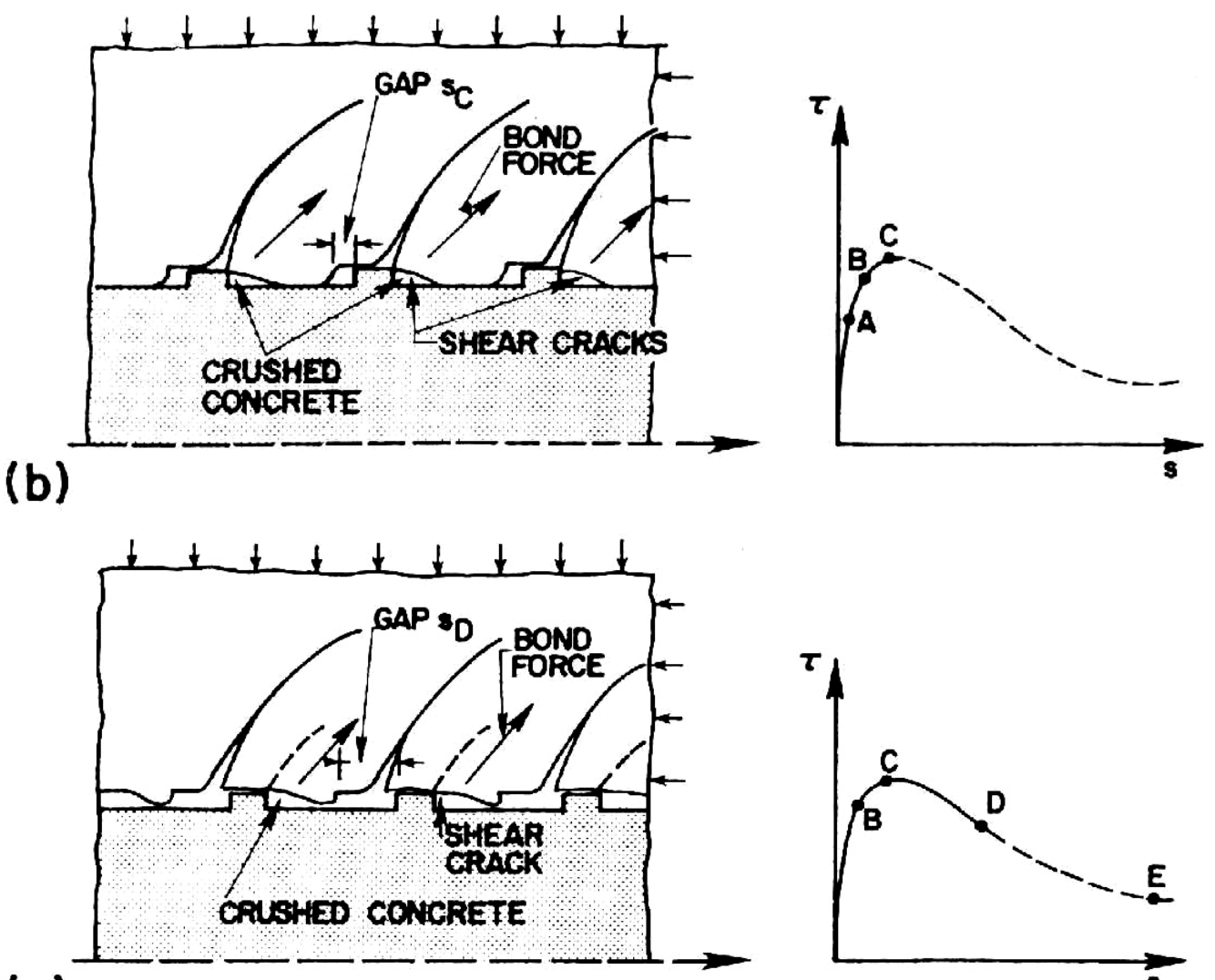

(c)

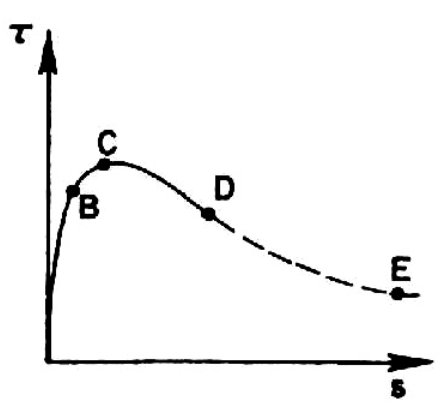

Figura 2.7 - Mecanismo de resistência da aderência, para carga monotônica (ELIGEHAUSEN et al, 1983)

Com o aumento do carregamento, o concreto localizado em frente às nervuras é esmagado, reduzindo a inclinação da tangente à curva (ponto B). Quando é atingida a tensão de aderência última (ponto $\mathrm{C}$ ) as fissuras estendem-se ao longo de um comprimento (s) aproximadamente igual a quatro vezes a altura da nervura. Neste estágio de carregamento, a transferência de forças ocorre com um ângulo de aproximadamente $45^{\circ}$ (ver Figura 2.7b). A partir desse ponto, aumentando-se o 
deslizamento a tensão de aderência decresce lentamente. Quando as fissuras de cisalhamento atingem a base da nervura adjacente (ponto D), as tensões de aderência começam a decrescer mais rapidamente. Quando o deslizamento (s) torna-se igual ao espaçamento entre as nervuras, apenas uma parcela do atrito passa a mobilizar a aderência (ponto E), conforme ilustra a Figura 2.7c.

Três modelos representativos do mecanismo de aderência para carregamento cíclico são também propostos por ELIGEHAUSEN et al (1983), como ilustram as Figura $2.8 \mathrm{a}, \mathrm{b}$ e c. $\mathrm{O}$ trecho inicial das curvas cíclicas apresentadas acompanham a envoltória monotônica; no entanto, o comportamento cíclico da aderência é sensível ao nível do deslizamento onde ocorre inversão de carregamento. 


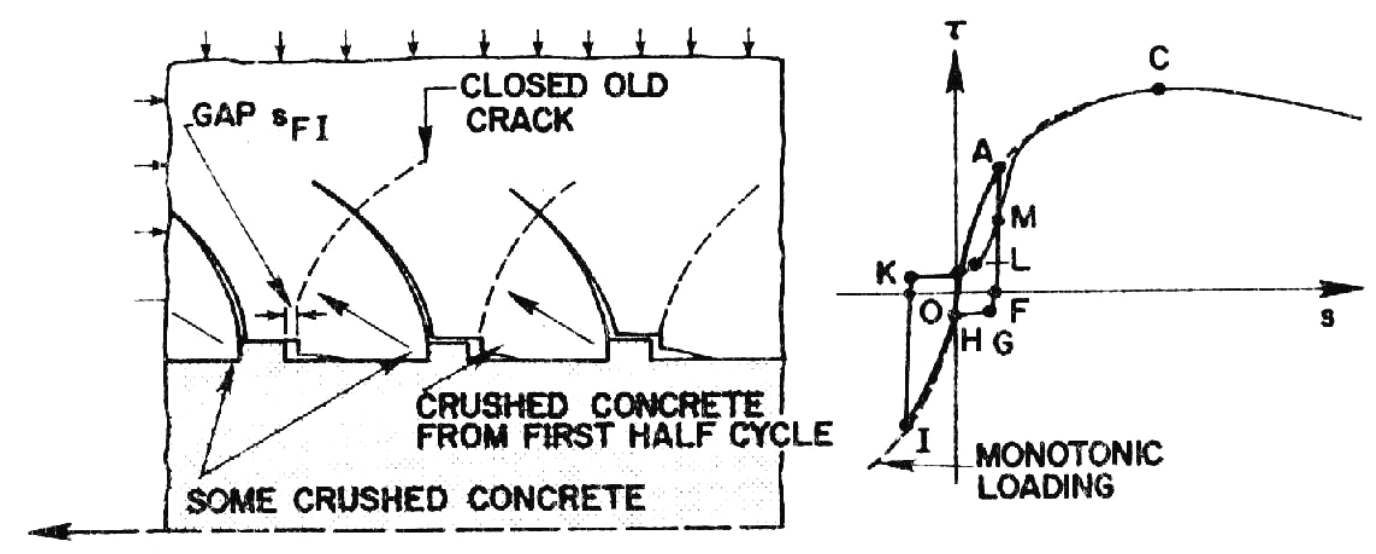

(a)
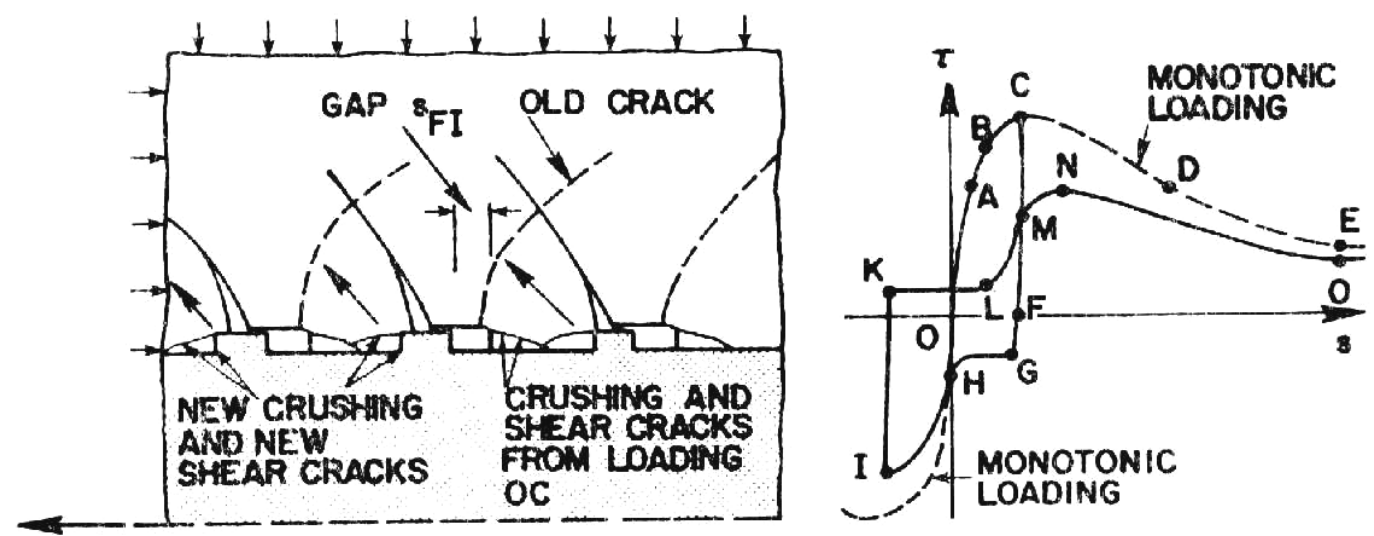

(b)
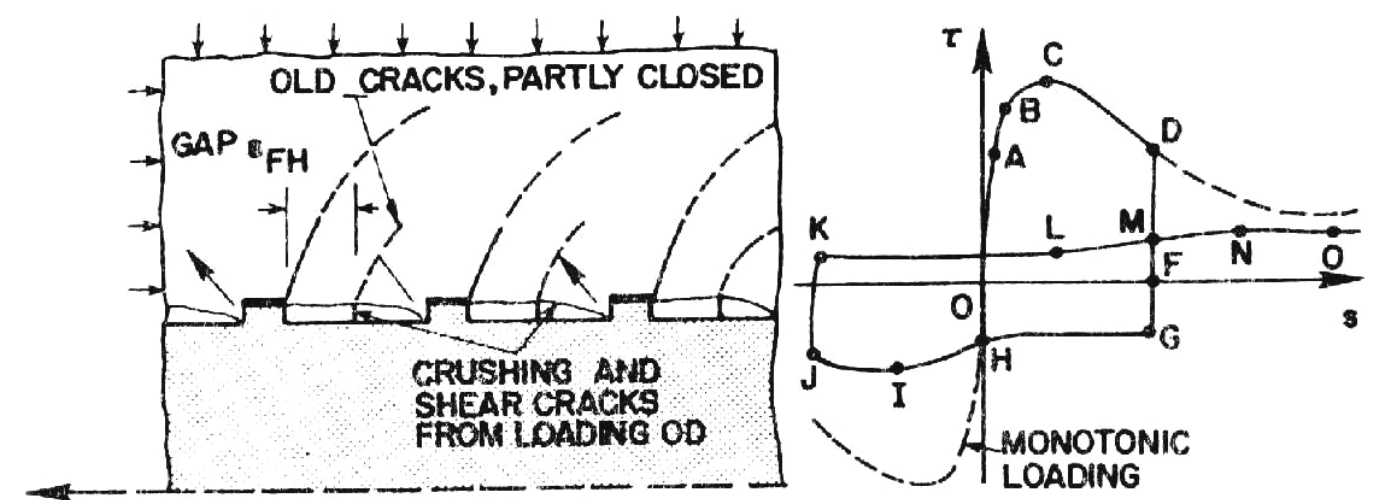

(c)

Figura 2.8 - Mecanismo de resistência da aderência, para carga cíclica (ELIGEHAUSEN et al, 1983)

A Figura 2.8a representa o primeiro modelo. Assumindo que o deslizamento é revertido antes de surgir uma fissura inclinada, para o carregamento cíclico OA a resposta é exatamente a mesma como descrito na Figura 2.7a. Iniciando o descarregamento a partir do ponto $\mathrm{A}$ o trecho AF mostra-se rígido, pois apenas uma pequena parte do deslizamento é causada pela deformação inelástica do concreto. $\mathrm{O}$ 
trecho $0 \mathrm{AF}$ corresponde ao primeiro meio ciclo. Quando o deslizamento na direção contrária é imposto à barra, a aderência se desenvolve devido apenas ao atrito (trecho FH). Como as fissuras de fecham, a rigidez se torna pouco diferente da envoltória monotônica (ponto I). A partir do ponto I a curva de descarregamento (trecho IKL) é muito semelhante à correspondente inicial (trecho AFH). A maior diferença ocorre no ponto, deslocado para direita da origem, onde as tensões de aderência começam a crescer novamente (ponto L). Isso se deve à fissuração de aderência anterior e ao esmagamento do concreto em frente às nervuras. $O$ engrenamento mecânico vai gradualmente se mobilizando, restabelecendo-se completamente no ponto M. Com o aumento do carregamento a curva segue até a envoltória monotônica. No segundo modelo, representado na Figura 2.8b, o descarregamento é feito após a formação de fissuras inclinadas de cisalhamento, e, portanto próximo do deslizamento correspondente à tensão de aderência última. $\mathrm{O}$ trecho de descarregamento é semelhante ao do primeiro caso até o ponto F. Como o dano no concreto é maior, a resistência de atrito mobilizada é um pouco mais elevada (ponto G). Quando o carregamento é invertido, o engrenamento mecânico nessa segunda direção é menor, devido às fisssuras de cisalhamento induzidas pelo primeiro meio ciclo. As fissuras de aderência criadas no primeiro meio ciclo fecham-se para uma tensão maior que a correspondente do primeiro modelo (ponto H), ocasionando formação precoce de fissuras de aderência na direção oposta. Devido a essas fissuras de aderência e as fissuras de cisalhamento existentes ao longo da barra, nessa segunda direção tem-se uma envoltória reduzida (trecho HI) e uma redução na capacidade de aderência (ponto I). Descarregando e recarregando a partir desse nível (trecho IKLMN), a rigidez e a tensão de aderência última são reduzidas, pois somente o concreto não esmagado remanescente entre as nervuras resiste ao cisalhamento. A tensão de aderência correspondente ao ponto $\mathrm{N}$ é substancialmente menor que a do ponto $\mathrm{C}$, e menor que a do ponto I. Um terceiro modelo é apresentado na Figura 2.8c, para o caso onde o descarregamento ocorre depois de atingir a tensão de aderência última (ponto $\mathrm{C}$ ), apresentando, portanto, maior degradação. Como ocorre grande degradação a resistência de atrito (ponto G) é maior que nos outros dois casos anteriores. Neste estágio o concreto entre as nervuras foi completamente danificado. É insignificante, portanto, a parcela de força que pode ser transmitida por aderência quando o carregamento é invertido (trecho HIJ). O descarregamento e recarregamento na direção oposta (trecho JKLMN) resulta em uma deterioração significativa da capacidade de aderência, sendo a maior parte mobilizada apenas pelo atrito. 
Um dos modelos analíticos utilizados para representar o comportamento da aderência em estruturas de concreto armado mais citados na literatura técnica é o modelo do CEB-FIP (1990), ilustrado na Figura 2.9.

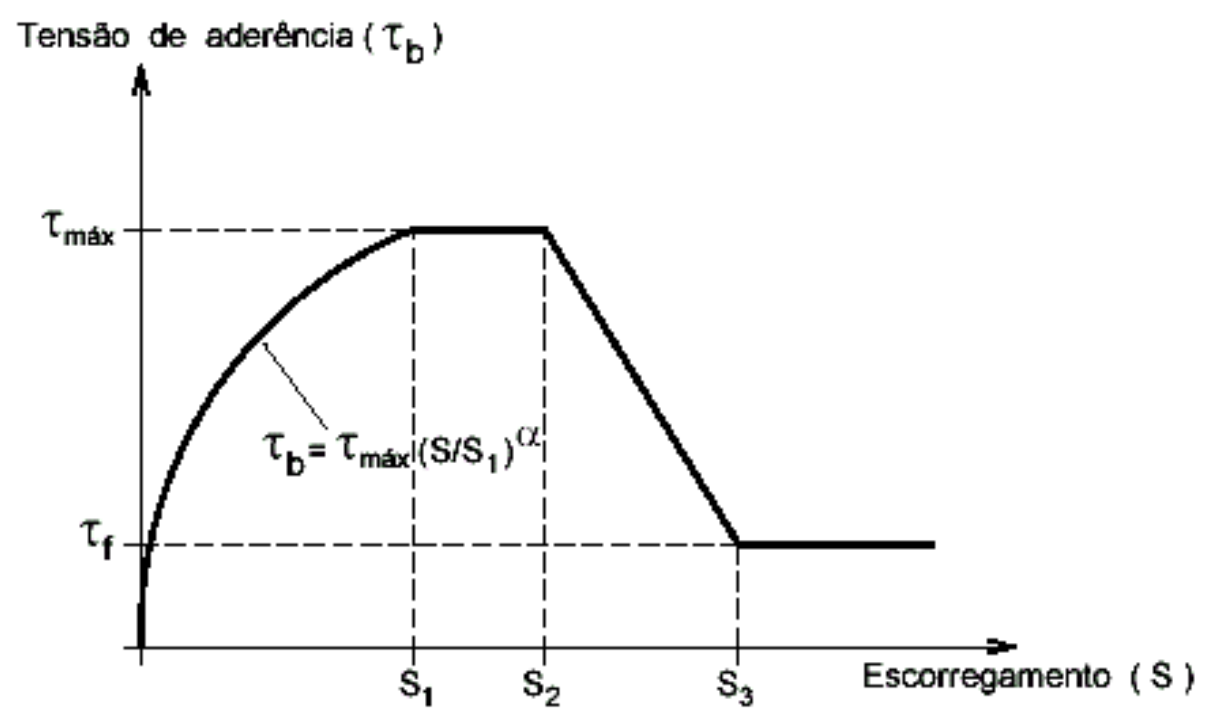

Figura 2.9 - Relação analítica da Tensão de aderência vs. Escorregamento (CEB-FIP, 1990).

O modelo é baseado numa curva média obtida de dados estatísticos. O primeiro trecho da curva, de 0 a $S_{1}$ (curva ascendente), representa a fase de fissuração inicial da matriz onde ocorre esmagamento local do concreto pelas nervuras. $\mathrm{O}$ segundo trecho, entre os pontos $\mathrm{S}_{1}$ e $\mathrm{S}_{2}$, representa um estágio mais avançado do esmagamento e do corte do concreto entre as nervuras. $O$ terceiro trecho, entre $S_{2}$ e $S_{3}$ (reta descendente), representa a redução da aderência devida ao fendilhamento ao longo da barra. Por fim o último trecho (reta horizontal depois do ponto $\mathrm{S}_{3}$ ) representa a capacidade resistente residual da aderência.

\subsection{Modelos Constitutivos}

O domínio das características e funcionamento dos materiais é de fundamental importância para o pleno conhecimento do problema da aderência, notadamente do concreto. O material concreto armado apresenta um comportamento não-linear, tornando o seu estudo ainda mais complexo. $\mathrm{O}$ estudo das não-linearidades física e geométrica das estruturas, particularmente da não-linearidade física do concreto armado, decorrentes da não-linearidade constitutiva dos materiais envolvidos (aço e concreto) e da fissuração no concreto, vem se desenvolvendo intensamente nos últimos 
anos. PROENÇA (1988), em seu trabalho de doutorado, faz um resumo bem consistente onde procura mostrar a natureza complexa do concreto; antes mesmo da aplicação de qualquer carregamento o concreto já apresenta um processo de microfissuração resultante do fenômeno da retração e da liberação de calor durante a cura. Essa microfíssuração inicial é, portanto, responsável pelo comportamento não-linear do concreto mesmo para baixos níveis de tensão. As diferentes características de resistência entre os agregados graúdos e a argamassa propiciam a propagação das fissuras. Além disso, outros fatores tais como a textura e tamanho dos agregados, índice de vazios, fator água-cimento influenciam o comportamento mecânico global do concreto.

É tarefa difícil, portanto, separar os fenômenos de deformação e de ruptura no concreto, pois as microfissuras e as cavidades existentes na interface entre agregado e matriz, antes mesmo da existência de qualquer solicitação, interferem diretamente na resposta inicial do material, criando degradações iniciais (dano) de natureza irreversíveis dando início a mecanismos de ruptura frágil e gerando deformações permanentes.

Os modelos de dano têm sido usados como uma ferramenta útil no contexto da análise da perda de rigidez de uma peça e mesmo da estrutura, para prever a degradação do material. Dentro da engenharia estrutural/computacional, seu interesse reside na simulação da degradação mecânica de materiais quasi-frágeis, como o concreto. Alcançada a resistência de pico do concreto (tensão limite de tração $f_{c t}$ ), após percorrido um tramo inicialmente elástico, ocorre descarga tensional a cada incremento de deformação, delineando comportamento não-linear do trecho. Os modelos escalares utilizam um parâmetro de dano para quantificar a perda de rigidez do meio. Vários modelos de dano são possíveis de serem criados pela combinação diversa das variáveis de estado e da lei de evolução do dano, que não são únicas.

LEE J. e FENVES G.L. (1998) apresentam um modelo de dano plástico para o concreto quando submetido a carregamento cíclico. O modelo é desenvolvido usando os conceitos da mecânica da fratura e degradação da rigidez na mecânica do dano contínuo. São consideradas duas variáveis de dano, uma para computar o dano em tração e outra para o dano em compressão; é introduzida uma função de plastificação com múltiplas variáveis de encruamento com a finalidade de medir diferentes estados de dano. Partindo da premissa que os modelos de dano contínuo e dano plástico são desenvolvidos usando conceitos da termodinâmica e que as relações constitutivas são derivadas de funções potenciais termodinâmicas e, conseqüentemente, são consistentes 
no contexto termodinâmico, adiante apresenta-se resumidamente a formulação adotada pelos autores. A relação tensão-deformação é dada por:

$$
\sigma=\mathrm{E} \cdot\left(\varepsilon-\varepsilon^{\mathrm{p}}\right)
$$

e a tensão efetiva,

$$
\bar{\sigma}=(1-\mathrm{D}) \cdot \mathrm{E}_{0} \cdot\left(\varepsilon-\varepsilon^{\mathrm{p}}\right)
$$

onde $\mathrm{E}_{0}$ é o tensor de rigidez inicial e $0<\mathrm{D}<1$ é a variável de dano escalar. Para levar em conta as diferentes respostas de dano em tração e em compressão é usado um critério de plastificação em hardening e softening, de tal modo que:

$$
F\left(\sigma, f_{t}, f_{c}\right) \leq 0
$$

onde $f_{t}$ e $f_{c}$ representam a tensão limite do concreto a tração e a compressão, respectivamente.

No modelo a função de plastificação da eq. (2.12) é expressa em função de dois parâmetros de dano $\mathrm{k}_{\mathrm{t}}$ e $\mathrm{k}_{\mathrm{c}}$; logo:

$$
\mathrm{F}(\sigma, \mathrm{k}) \leq 0
$$

e a tensão total é determinada pela degradação do dano, conforme:

$$
\sigma=(1-\mathrm{D}(\mathrm{k})) \cdot \bar{\sigma}
$$

A Figura 2.10 e a Figura 2.11 ilustram um dos exemplos publicados no artigo para o caso de carga cíclica.

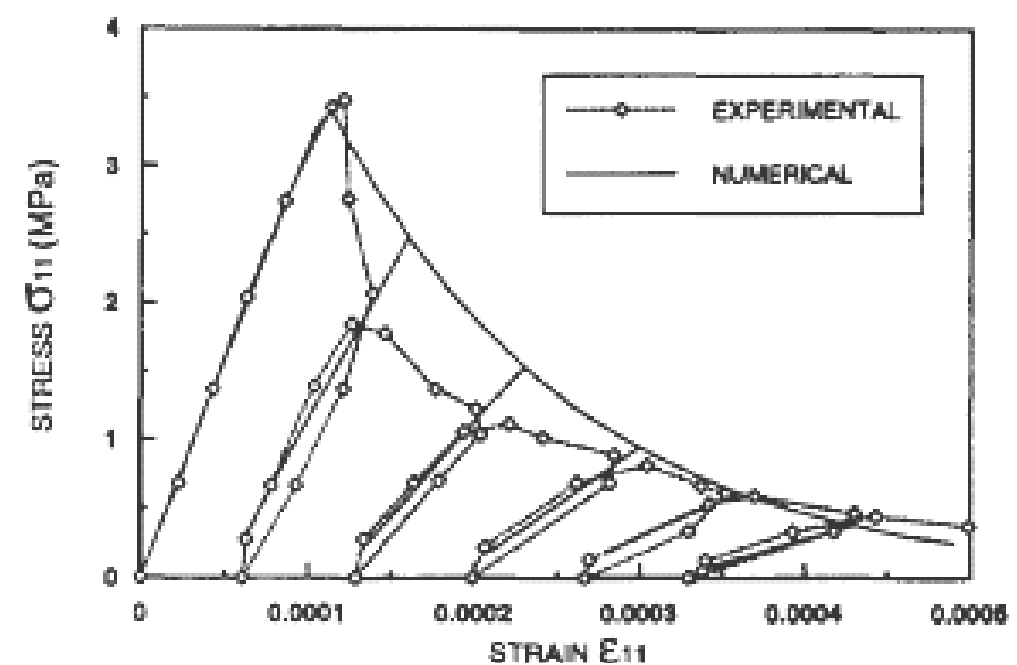

Figura 2.10 - Solução numérica para carregamento uniaxial cíclico em tração, comparado com resultados experimentais (LEE e FENVES, 1998) 


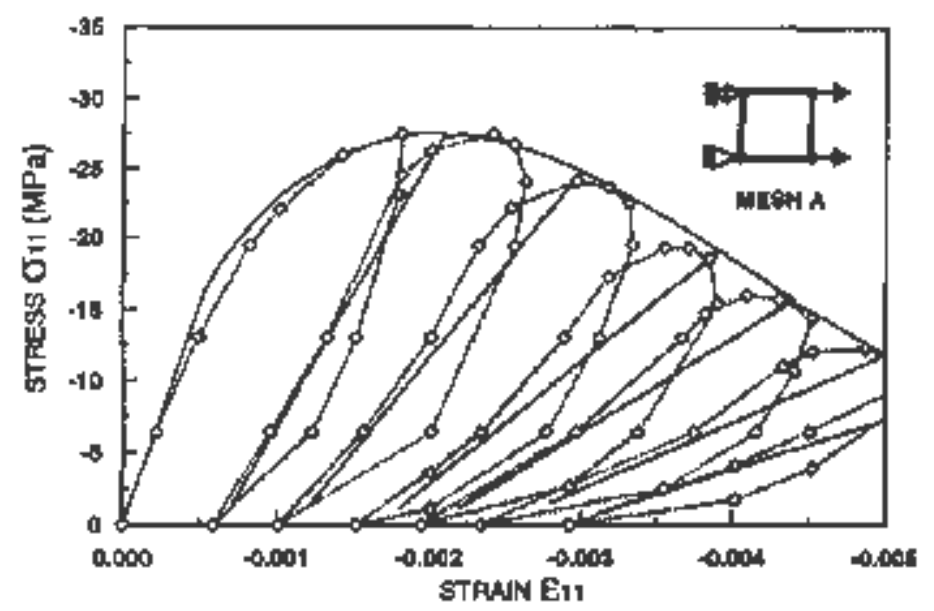

Figura 2.11 - Solução numérica para carregamento uniaxial cíclico em compressão, comparado com resultados experimentais (LEE e FENVES, 1998)

Em ambos os casos a degradação da rigidez é simulada para cada ciclo de carga e descarga.

\subsection{SOBRE AS AÇÕES CÍCLICAS}

O comportamento do concreto sob ações cíclicas repetidas pode ser comparado àquele sob ações de longa duração. Ou seja, o efeito de repetição das cargas irá produzir um aumento nas deformações, gerando acréscimos nas flechas de peças fletidas; este efeito é análogo ao que ocorre quando da manutenção das cargas, fenômeno conhecido como "fluência".

Desta forma, pode-se entender o efeito das ações repetidas como um tipo de "fluência cíclica".

Assim, é importante que se compreenda o que ocorre nas peças de concreto armado quando submetidas a cargas de longa duração para que se entenda melhor o efeito das ações repetidas.

O fenômeno da deformação lenta no concreto consiste no aumento das deformações quando submetido a tensões constantes decorridos um determinado tempo; ou seja, as deformações são influenciadas pela simples passagem do tempo.

As ações de um modo geral, exceto as ações devido ao peso próprio, podem não atuar por tempo indeterminado. O comportamento do concreto num processo de carga e descarga, após decorrido um determinado intervalo de tempo $t_{0}$ a $t$, pode ser resumido como mostrado na Figura 2.12. Quando da retirada do carregamento ocorre 
recuperação imediata de deformação, chamada de deformação elástica recuperável. Em função do tempo ocorre recuperação de parte da deformação decorrente da deformação lenta, denominada de elasticidade retardada. Observa-se, então, a permanência de uma deformação irrecuperável em função do tempo, denominada deformação residual ou fluência permanente. Ocorrendo um outro ciclo de carga/descarga é de se supor que ocorra um aumento das deformações residuais uma vez que o valor da deformação recuperável é sempre menor que o valor da deformação originado no processo de carga.
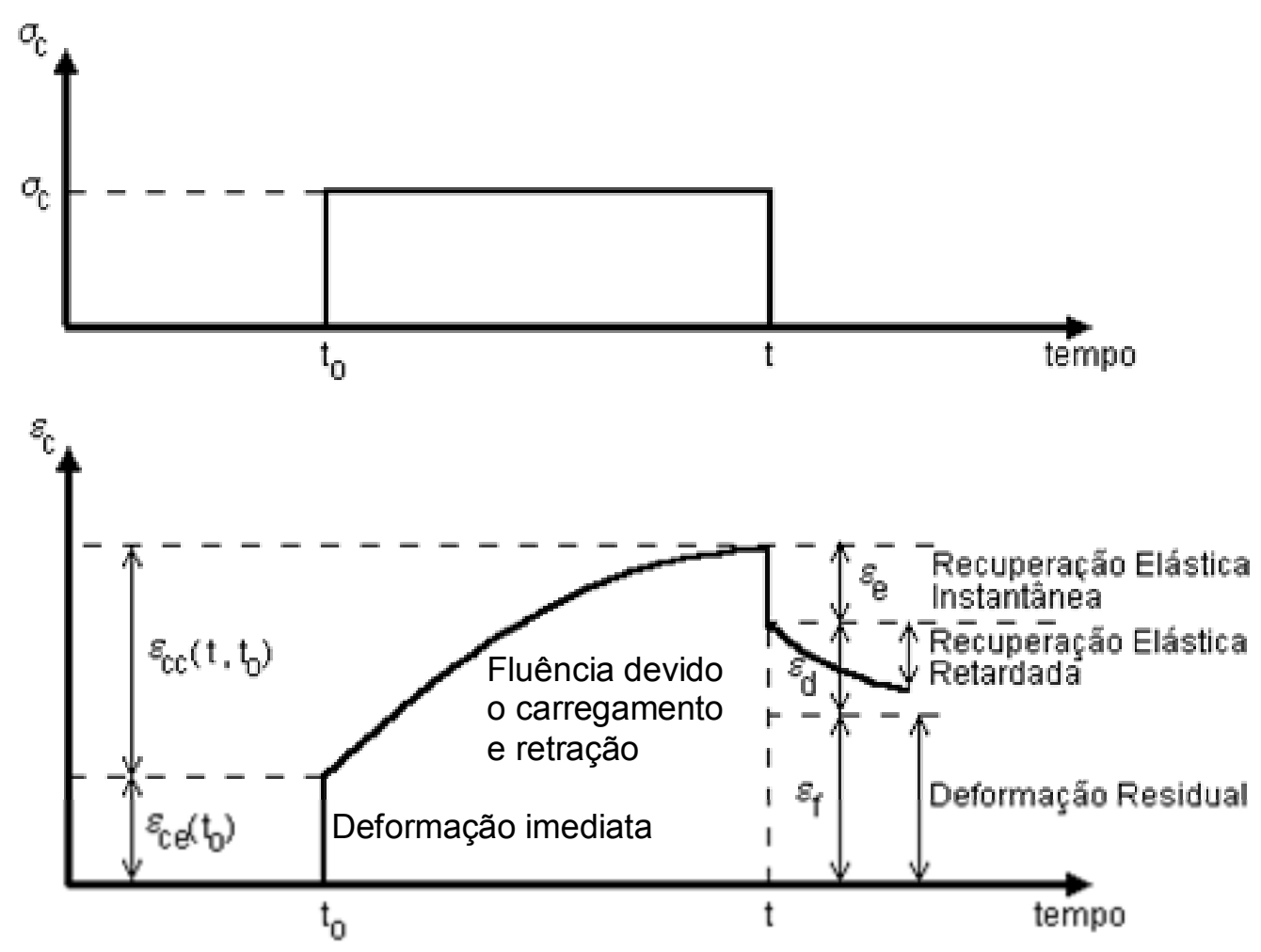

Figura 2.12 - Comportamento do concreto com o tempo

Sob o ponto de vista das ações, as estruturas correntes têm sido projetadas como se submetidas apenas a carregamentos monotônicos. Este tipo de ação tem como característica possuir alguns parâmetros sempre crescentes, como por exemplo, o deslocamento; nos projetos, além das cargas permanentes (carregamentos monotônicos), são também consideradas as cargas que atuam eventualmente na estrutura, ou que atuam de modo sistemático, mas que, no entanto, são tratadas como cargas estáticas; são as chamadas cargas acidentais.

$\mathrm{Na}$ prática as estruturas em geral, e algumas em particular como as pontes rodoviárias, as pontes ferroviárias, estruturas off-shore, são submetidas a cargas cíclicas; estas produzem ou não efeitos dinâmicos que se fazem sentir pela variação do 
tempo de aplicação dessas cargas, caracterizando-se por imprimir uma determinada amplitude de tensão.

Trabalhos relacionados ao estudo das cargas cíclicas aplicadas às estruturas de concreto armado podem ser citados, como os de BALÁZS (1991), YANNOPOULOS e TASSIOS (1991) e BALÁZS (1993), entre outros; tratando de cargas cíclicas alternadas podem ser citados os trabalhos de TASSIOS (1979), BALÁZS (1991), ACI COMMITTEE 408 (1991); tratando de nós de pórticos podem ser citados os trabalhos de TASSIOS (1979), POPOV (1984) e ALVA (2004); outros, ainda, tratando de ações sísmicas como o trabalho de POPOV (1984).

O comportamento da aderência sob carregamento cíclico pode ser subdividido de acordo com o tipo de tensão aplicada, segundo classificação encontrada em ACI COMMITTEE 408 (1991). Pode ser do tipo repetido, ou unidirecional, que se caracteriza pela manutenção do sinal da tensão nos componentes da estrutura (não ocorre mudança de tração para compressão ou vice-versa) durante a aplicação de um ciclo de carga, como é o caso típico da fadiga. O carregamento pode ser, também, do tipo alternado que se caracteriza pela alternância do sinal da tensão aplicada, como no caso de estruturas sujeitas a cargas sísmicas. Pela mesma classificação as cargas cíclicas são também divididas em duas outras categorias; a primeira é de baixo ciclo de carga (poucos ciclos de carga - algo menor que 100 ciclos) e elevadas tensões de aderência (algo acima de $4 \mathrm{MPa}$ ), caso dos terremotos. A outra é de alto ciclo de carga (milhares ou milhões de ciclos), porém baixas tensões de aderência (menores que $2 \mathrm{MPa}$ ), caso das pontes, estruturas offshore, elementos de máquinas, estruturas submetidas à ação do vento...etc.

\subsection{OUTROS ARTIGOS DE INTERESSE}

O fenômeno da aderência em peças de concreto armado submetidas a cargas monotônicas e cíclicas, como visto, vem sendo estudado há algum tempo. Há, no entanto, ainda muito o que pesquisar; um interesse cada vez maior no aprofundamento do conhecimento da influência das cargas cíclicas nas estruturas em geral se torna cada vez mais evidente e crescente. Alguns artigos são mostrados na seqüência, julgados de interesse direto na pesquisa

LARANJEIRAS (1976) utilizou em seus ensaios um dos tipos disponíveis de ensaios padronizados de arrancamento, conhecido na literatura com o nome de Double Pull-out test. Serve para medir, como é feito usualmente, a aderência na interface aço- 
concreto através da tensão de aderência no estado limite último; o teste pode ser feito tanto para carga monotônica quanto para cíclica. Observou-se que a história do carregamento tem fundamental importância na aderência; a repetição do carregamento reduz a rigidez de aderência das barras em contraposição ao carregamento estático. Em função da tensão média de aderência, calculada a partir do escorregamento da extremidade da barra, pode-se medir a eficiência da aderência. A destruição da aderência, portanto, pode ser definida através de valores máximos desse escorregamento, valores esses geralmente associados a um certo estado de deformação e fissuração do concreto. Os resultados indicaram que os deslizamentos crescem mais rapidamente com a manutenção do carregamento cíclico no início e mais lentamente com o passar do tempo, tendendo a estabilizar-se em um valor final. Esses acréscimos nos deslizamentos com o tempo de manutenção da força aplicada na barra são proporcionais à magnitude dessa força. Outros fatores mostraram grande influência na análise do fenômeno, tais como:

- A qualidade do concreto na região circundante à barra.

- Os deslizamentos devidos à ação dinâmica de uma carga crescem mais rapidamente nos primeiros instantes, diminuindo gradativamente à medida que o número de ciclos aumenta, se comparada com a mesma carga estática.

- A repetição de cargas altera a rigidez de aderência das barras, reduzindo-a, ao nível da carga repetida, pelo aumento dos deslizamentos e melhorando-a para cargas estáticas de valores imediatamente superiores ao da carga repetida.

TASSIOS (1979) publicou artigo contendo um modelo analítico para determinação da distribuição de tensões no aço, no concreto e na interface, partindo de uma relação entre a tensão de aderência e o escorregamento. O estágio inicial de fissuração não foi considerado pois o modelo parte da hipótese da existência de fissuração generalizada. Além disso, o estudo foi feito apenas para simular ensaios de corpos de prova, sem assumir uma distribuição de fissuras subjacente. O caso seguinte seria considerar a mobilização da aderência na flexão, em função de alterações da força na armadura, devida à variação de momento fletor, no problema usual de vigas.

TASSIOS e YANNOPOULOS (1981) apresentaram um método computacional analítico para a determinação da distribuição de tensões no aço, no concreto e do escorregamento entre a barra e o concreto. O método utilizado para carga cíclica é baseado em curvas constitutivas apropriadas para o aço e para o concreto, e 
relações entre aderência local e correspondente escorregamento. Várias aplicações analíticas foram feitas relativas a ensaios de arrancamento devido a carregamentos monotônico e cíclico. Membros fletidos também foram analisados com modelos simples, obtendo-se, por conseguinte, a relação momento-curvatura.

SOMAYAJI E SHAH (1981), propõem um modelo analítico para predizer a fissuração e o efeito tensão-deformação em barras de concreto armado submetidas a tração axial. Assume-se uma função para representar a distribuição de tensões de aderência. Um modelo analítico foi desenvolvido baseado numa assumida distribuição de tensão de aderência em lugar da relação tensão x escorregamento. São escritas as equações que governam o problema, em que parte da carga externa $\mathrm{P}$ é transmitida pela matriz de concreto ( $\mathrm{P}_{\mathrm{mx}}$ ) e parte pela barra de aço ( $\left.\mathrm{P}_{\mathrm{sx}}\right)$. O escorregamento local pode ser definido como a diferença total do alongamento entre a barra de aço e a matriz medida sobre o comprimento entre aquela seção e o centro (ponto de referência) do segmento. Para checar a validade analítica proposta, foi implementada uma investigação experimental em espécimes de concreto armado submetidos a tração axial, onde foram feitas medidas de alongamento e fissuração. O MEF pode ser facilmente implementado para o modelo proposto. A formulação abrange, inicialmente, o caso elástico; modificações posteriores nas relações constitutivas, no entanto, permitem a análise para o caso não-linear. Os autores concluem que os resultados obtidos com o modelo proposto foram comparados satisfatoriamente com os dados experimentais.

Em importante artigo ELIGEHAUSEN et al (1983) afirmam que a degradação da aderência, para carregamento cíclico, depende principalmente do número de ciclos, do deslizamento máximo nas duas direções do carregamento e da amplitude entre esses deslizamentos. Até 10 ciclos a curva tensão de aderência versus deslizamento não é influenciada significativamente, caso a tensão de aderência máxima durante os ciclos não exceda 70 a $80 \%$ da resistência de aderência monotônica. Se, no entanto, a tensão de aderência máxima ultrapassa $80 \%$ da resistência monotônica da ligação, o dano no comportamento da aderência torna-se significativo. O modelo de aderência proposto pelos autores (ver Figura 2.13), para cargas cíclicas alternadas, prevê o trecho inicial da curva tensão de aderência x deslizamento acompanhando a envoltória monotônica; para as inversões do carregamento o comportamento cíclico alternado da aderência mostra-se sensível ao nível do deslizamento, conforme comentado e detalhado a partir da Figura 2.8 . 


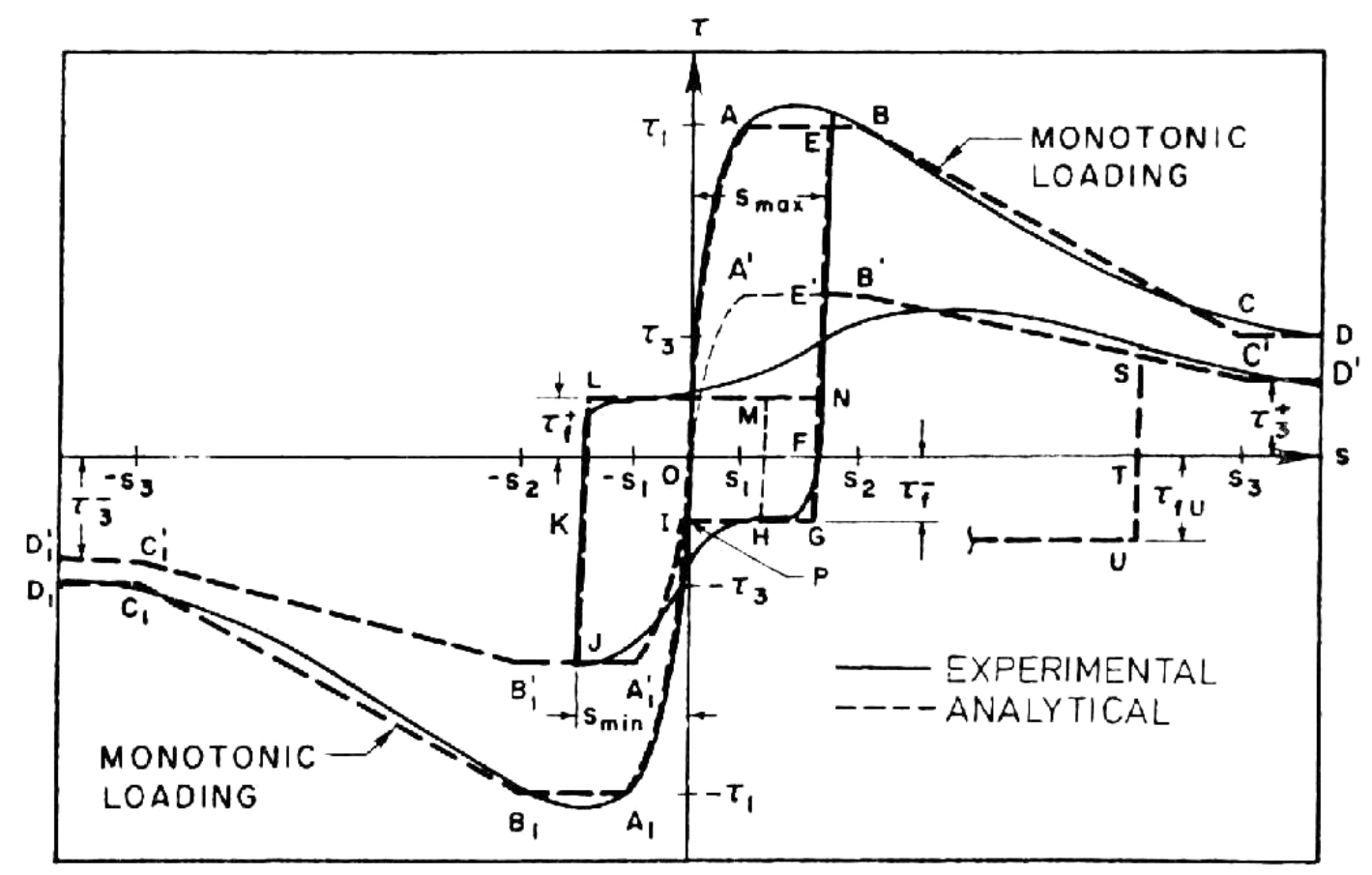

Figura 2.13 - Modelo analítico proposto por Eligehausen et al (1983)

LOVEGROVE E EL DIN (1982) apresentaram um trabalho experimental onde vigas de concreto armado de diferentes tamanhos e de diferentes arranjos das barras foram repetidamente carregadas a freqüências de 0.5 e $1 \mathrm{~Hz}$. Como resultado são apresentadas curvas típicas para a deflexão, deformação em compressão e máxima abertura de fissuras para diferentes números de ciclos de carga. Também é apresentado um método empírico simples através do qual flechas, curvaturas e máximas aberturas de fissuras para ciclos de carga de longa duração, em membros de concreto armado, podem ser preditos. Os valores obtidos das expressões propostas estão em razoável acordo com valores medidos por recentes pesquisadores. A Figura 2.14 apresenta a curva carga $\mathrm{x}$ flecha, a Figura 2.15 mostra a curva carga x deformação de compressão (na face superior das vigas) e a Figura 2.16 mostra a curva carga x máxima abertura de fissuras, todas em função do número de ciclos. Essas curvas mostram o incremento contínuo da flecha, da deformação e da abertura das fissuras com o número de ciclos de carga. Observa-se, ainda, que o incremento da flecha é ligeiramente maior na carga máxima do que na carga mínima. Isso indica um ligeiro decréscimo na rigidez das vigas com o número de repetições de carga. A área dentro do laço é maior para o primeiro ciclo de carga e ele decresce consideravelmente com o número de ciclos. 


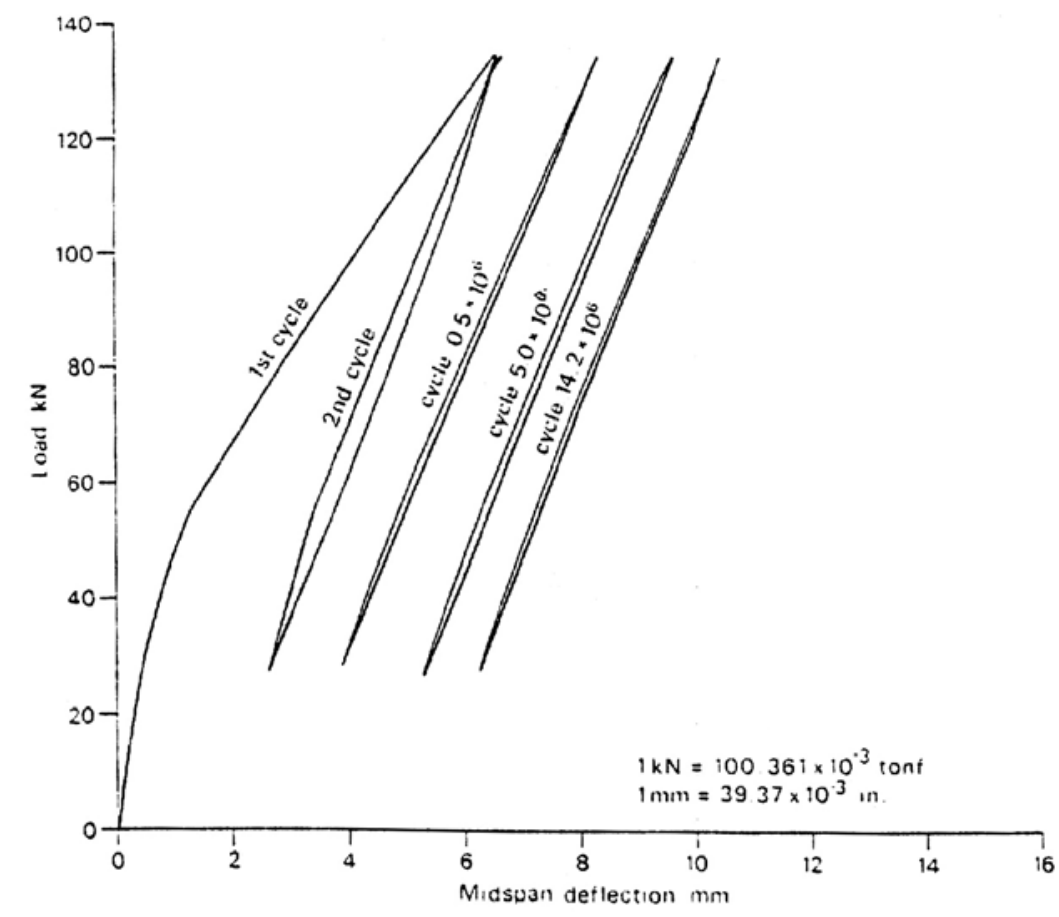

Figura 2.14 - Relação entre a carga - flecha $-\mathbf{n}^{0}$ de ciclos,

\section{LOVEGROVE e EL DIN (1982)}

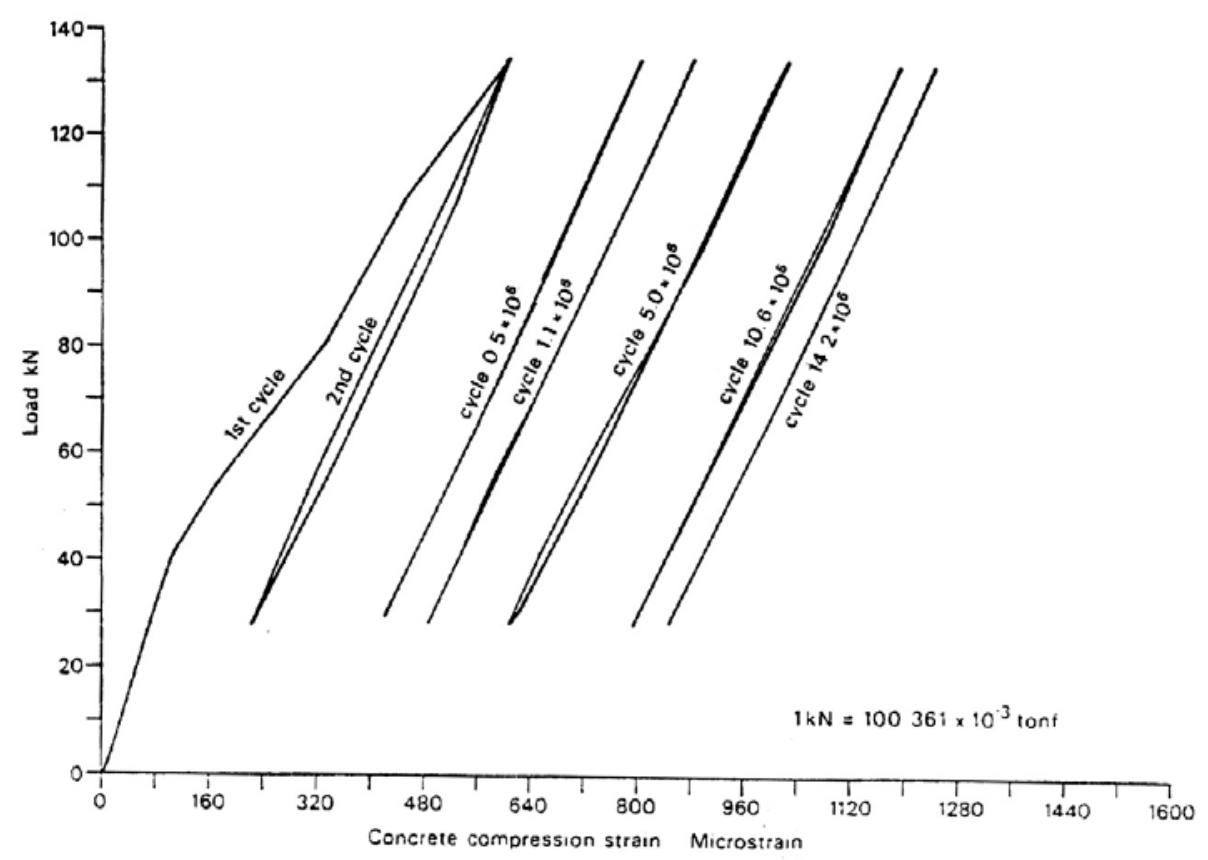

Figura 2.15 - Relação entre a carga - deformação - $\mathbf{n}^{0}$ de ciclos, LOVEGROVE E EL DIN (1982) 


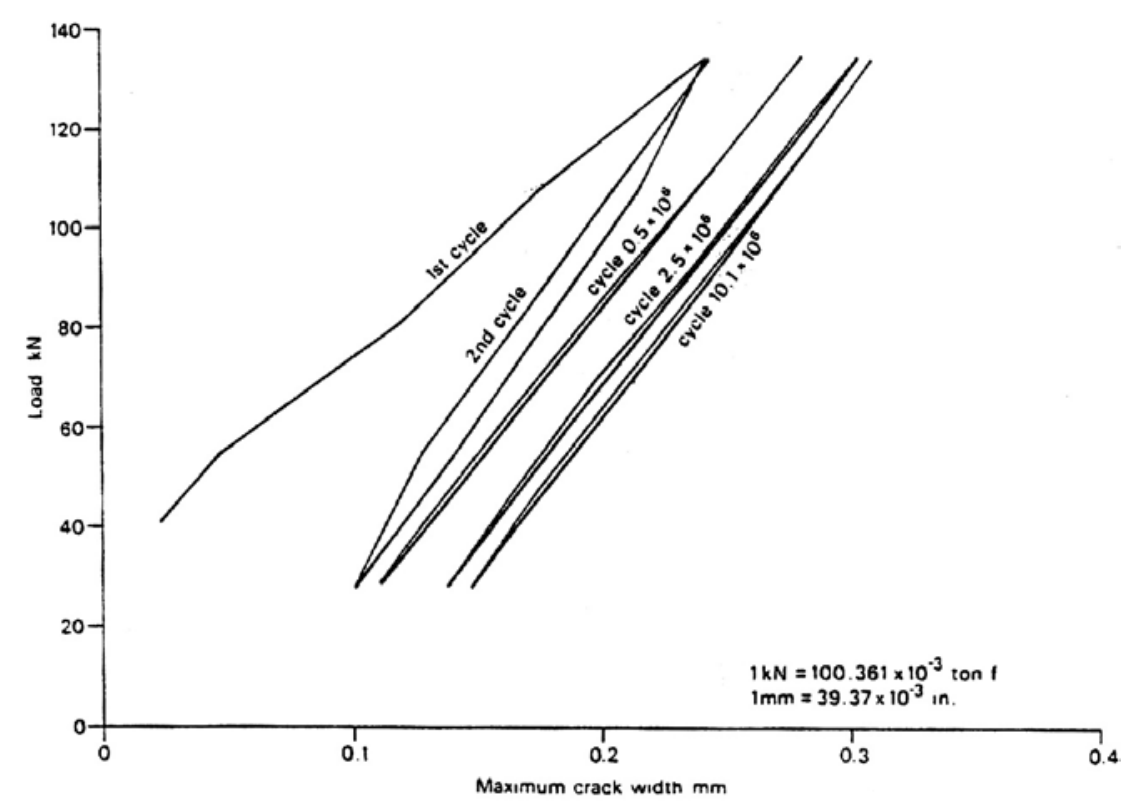

Figura 2.16 - Relação entre a carga - abertura de fissuras $-\mathbf{n}^{0}$ de ciclos, LOVEGROVE E EL DIN (1982)

POPOV (1984) realizando estudos sobre estruturas submetidas a severos carregamentos cíclicos, tais como as cargas sísmicas, afirma que devido à resposta inelástica das estruturas algum dano estrutural é antecipado, de forma que é muito importante prever a possibilidade de colapso. Esta ruptura ocorre se a resistência lateral da estrutura devido ao carregamento cíclico é severamente deteriorada. Isso pode acontecer devido ao arrancamento da armadura principal dos elementos, ou alternativamente, quando barras da armadura são expulsas das ligações internas. Essa constatação torna ainda mais importante a necessidade de se aprofundar no conhecimento do problema da aderência nas estruturas sujeitas a carregamento cíclico severo. Os estudos do autor mostram ainda o efeito de vários parâmetros na relação tensão de aderência local e escorregamento, tais como carregamento monotônico versus cíclico, carregamento de tração versus compressão, quantidade de armadura de confinamento, diâmetro da barra, resistência do concreto, espaçamento das barras, pressão transversal e taxa de escorregamento. Ele publicou resultados experimentais e analíticos de relações entre a tensão de aderência e o escorregamento, indicando ainda uma regra de implementação numérica do problema.

FILIPPOU (1986) propôs um modelo computacional simples e eficiente para resolver o problema da ancoragem de barras em peças sujeitas a cargas cíclicas. O modelo é baseado em uma linearização discreta da função distribuição de tensão ao longo do comprimento de ancoragem da barra, necessitando de apenas três pontos entre 
as extremidades da barra para produzir bons resultados. As tensões de aderência desses pontos são obtidas de forma iterativa, das condições de equilíbrio e compatibilidade do problema aderência.

MAZARS (1989) apresenta, de forma concisa, a teoria da mecânica do dano contínuo aplicada ao concreto; essa teoria foi introduzida no meio acadêmico por Kachanov em 1958. O material concreto é considerado como um sistema descrito por um grupo de variáveis e um potencial termodinâmico. Torna-se necessário fazer uma adequada escolha do potencial e da variável dano (escalar, tensorial, etc...). São apresentados vários modelos, com gradual complexidade, para o concreto simples e armado. É apresentado um caso de aplicação para uma viga de concreto armado. O método apresentado admite a aderência existente entre as barras de aço e o concreto envolvente definida pela relação tensão local de aderência $\left(\tau_{\mathbf{b}}\right)$ versus deslizamento relativo ( $s$ ) da barra, bem como o conhecimento das propriedades da matriz da pasta de cimento, do aço empregado e ainda o comportamento da interface aço-concreto, apresentados por SOMAYAJI E SHAH (1981). A ação da aderência é baseada na formação de fissuras paralelas à barra longitudinal, conforme GOTO (1971). A descrição constitutiva dos dois materiais é feita separadamente: para o concreto é utilizado um modelo de dano elástico, com uma variável de dano escalar; para o aço o comportamento usado é o elasto-plástico. As barras longitudinais são substituídas por uma área finita da seção transversal da viga. Foi utilizado o MEF com um algoritmo onde a matriz de rigidez secante apresentou boa convergência, na maioria dos casos. A simulação numérica foi comparada com resultados experimentais. Em síntese, do exposto no artigo, para baixas pressões de confinamento e carga monotônica, os resultados foram convincentes. Nem todos os modos de dano puderam ser descritos. No capítulo 4 serão tecidos maiores comentários sobre o modelo de Mazars.

DEBERNARDI (1989) apresenta um trabalho onde é analisado o comportamento das estruturas de concreto armado em serviço (o estudo é estendido às estruturas protendidas). É apresentada toda uma marcha de cálculo com a evolução do carregamento e a conseqüente evolução dos deslocamentos, deformações e fissuração. As leis constitutivas dos materiais são tiradas das recomendações do CEB-1978. São mostrados e examinados minuciosamente dois exemplos de cálculo. Nos exemplos são usados diversos métodos para calcular tensões, deformações e deflecções, tais como o método do módulo efetivo, o método de Favre, o método CEB-FIB 1990 Model Code e 
o método Eurocode 2. No trabalho não são levadas em conta o efeito das cargas cíclicas. $\mathrm{Na}$ presença de cargas cíclicas o autor apenas afirma que as deformações aumentam enquanto a rigidez diminui devido ao aumento do deslizamento.

RUSSO et al (1990), analisaram o problema da degradação da aderência em nós de pórticos, com uma solução analítica para o sistema de equações diferenciais que governam o comportamento da ancoragem da armadura no concreto, devido a excitações generalizadas. A solução foi experimentada para o caso de uma barra ancorada em um nó viga-pilar, tendo sido adotado um modelo bilinear para o aço e uma relação tensão de aderência local x escorregamento expressa por funções monomiais exponenciais ou por funções lineares. Para obtenção mais rápida da solução, em comparação com os procedimentos tradicionais, os autores sugeriram a utilização dos recursos computacionais.

YANNOPOULOS e TASSIOS (1991) retomaram os estudos sobre cargas cíclicas, mostrando a distribuição das tensões no aço e no concreto, e também na interface, ao longo dos elementos sujeitos a carregamentos cíclicos, considerando a relação tensão de aderência x escorregamento como uma ferramenta fundamental ao entendimento do comportamento do concreto armado durante e depois do processo de fissuração. Um método computacional foi proposto pelos autores, capaz de calcular as distribuições de tensão e características de deformação de elementos axiais de concreto armado, usando a curva tensão de aderência x escorregamento, de prever a formação de fissuras transversais principais e a variação das suas aberturas devido a cargas monotônicas e cíclicas. Testes analíticos foram feitos nos nós de elementos de concreto armado sujeitos aos dois tipos de carregamento ao longo dos seus lados.

BALÁZS (1991) publicou uma série de artigos analisando a ligação concretoarmadura durante o processo de fissuração, sob a ação de cargas cíclicas, apresentando resultados analíticos e experimentais relacionando definitivamente o problema da fadiga ao problema da aderência, objetivando a definição da rigidez da estrutura fissurada. $\mathrm{O}$ autor mostrou os resultados experimentais da fadiga da aderência. De posse desses dados foi possível ter uma melhor avaliação do comportamento conjunto da armadura e do concreto em estruturas sujeitas a cargas repetidas ou reversas. O referido autor chegou a duas importantes conclusões: uma delas é que o escorregamento inicialmente tende a crescer, depois permanece constante, e finalmente aumenta rapidamente antes de ocorrer a ruptura por arrancamento; a segunda conclusão é que, devido ao carregamento cíclico reverso, o dano se acumula mais rapidamente e a resistência de 
aderência é reduzida, sendo ela relacionada ao escorregamento ocorrido. O autor ainda propôs um critério de ruptura à fadiga, baseado no escorregamento, onde a resistência de aderência é atingida devido ao carregamento repetido.

YANKELEVSKY et al (1992), propôs uma relação aderência versus escorregamento para elementos sujeitos a cargas monotônicas e cíclicas. Essa relação é idealizada por três diferentes estágios de carregamento, ou seja, para carga ascendente, descendente e última, conforme esclarece a Figura 2.17. O modelo é baseado em dados experimentais de pesquisas anteriores, considerando curvas contínuas para a função tensão de aderência-escorregamento. Os resultados obtidos pelo modelo foram comparados com resultados experimentais, apresentando boa concordância entre eles.

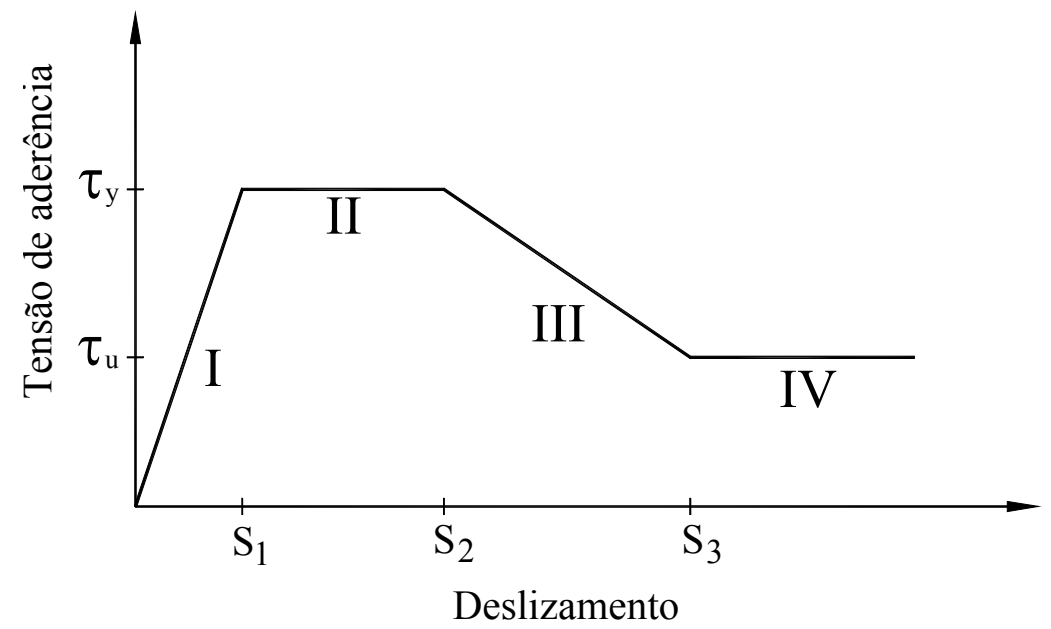

Figura 2.17 - curva tensão de aderência $x$ deslizamento, Proposta por Yankelevsky

BOLANDER et al (1992), em seu artigo, apresentam um método para modificar as propriedades de elementos da interface aço-concreto nas proximidades da fissura. Uma medida não localizada do dano é usada para quantificar a formação dessas fissuras. Para ilustrar a efetividade do método proposto foram analisadas três vigas de concreto armado submetidas a carregamento monotônico. Cada viga analisada é idêntica às demais exceto pela representação da interface aço-concreto.

Outra maneira de verificar a aderência, menos explorada pelos pesquisadores, é através dos ensaios de aderência na flexão, onde se explora a variação do momento fletor aplicado à estrutura, como os ensaios levados a efeito por MACGREGOR (1998) e FERGUSON et al (1998). O ensaio levado a efeito em vigas biapoiadas, com duas cargas simétricas, é o mais comum. 
O que se pretende com esses ensaios, independentemente do tipo utilizado, é obter a melhor representação possível do comportamento da aderência. Segundo DUCATTI (1993) “O modelo do comportamento da aderência é representado pela relação entre a tensão de aderência e o escorregamento. A primeira é identificada idealizadamente pela tensão de cisalhamento na interface barra-concreto, e o segundo pelo deslocamento relativo entre a armadura e o concreto, deslocamento este provocado pela diferença entre as deformações específicas do aço e do concreto", segundo esclarece a Figura 2.18.

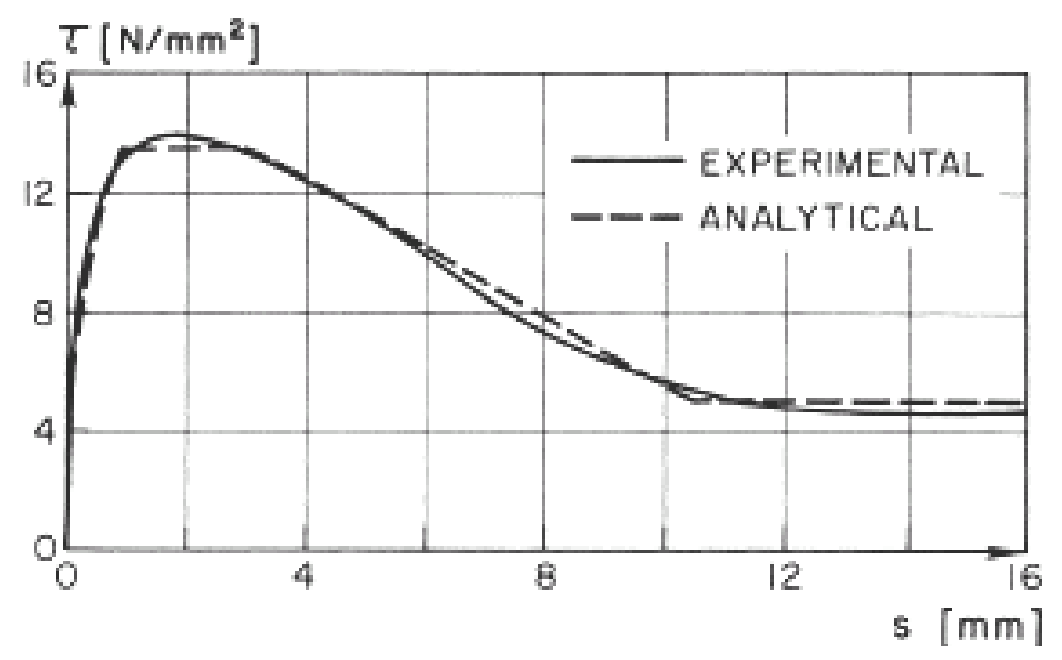

Figura 2.18 - Representação da aderência - Tensão de aderência local $(\tau)$ versus deslizamento local (s),para concretos com $\mathbf{f}_{\mathrm{ck}}=\mathbf{3 0}$ MPa, (ELIGEHAUSEN et al, 1983).

A perda de aderência ocorre basicamente por uma das duas formas: ruptura por arrancamento ou ruptura por fendilhamento, embora outros modos de ruptura ocorram associados a esses. A Figura 2.19 apresenta o gráfico característico para os dois tipos de rupturas, arrancamento (a) e fendilhamento (b).

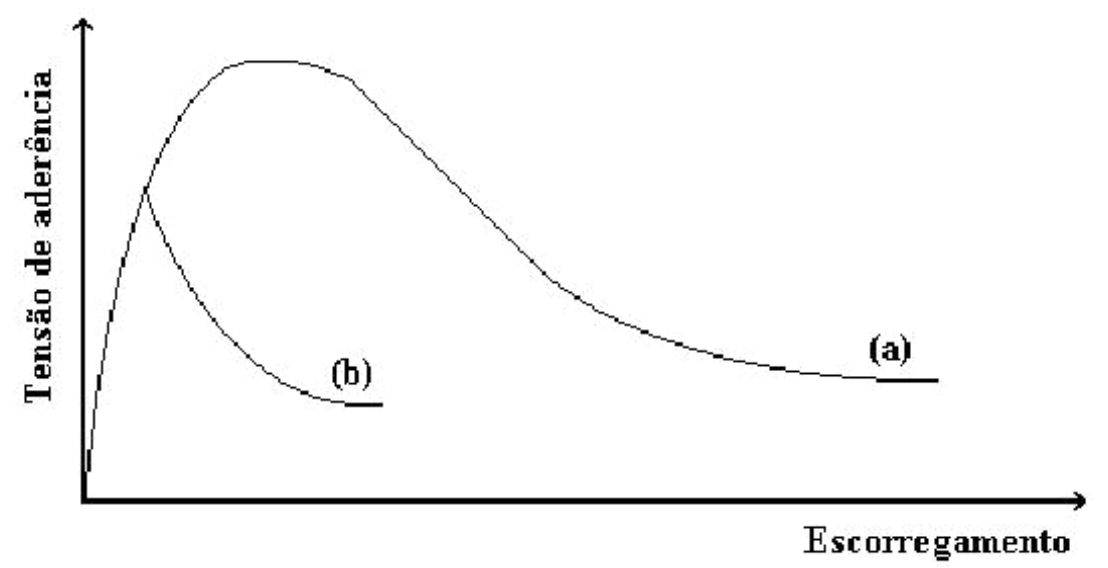

Figura 2.19 - Ruptura por arrancamento (a) e fendilhamento (b) 
Do gráfico da Figura 2.19 observa-se que a ruptura por arrancamento é mais dúctil que a ruptura por fendilhamento; supondo peças semelhantes, a que sofrer ruptura por arrancamento mobilizará maior tensão de aderência. Outros tipos de ruptura também podem ocorrer que não apenas os dois acima citados, especialmente quando as peças trabalham em serviço; esses outros tipos de ruptura são influenciados por vários fatores, dentre os quais podem ser destacados: tipo da armadura (barra, fio), tipo de conformação superficial da armadura (lisa ou nervurada), diâmetro da barra, existência ou não de armaduras de confinamento, distância entre barras de uma mesma camada, cobrimento, tensão na armadura, tensão característica do concreto à compressão, entre outros. Lembrando o que afirma BULLETIN D'INFORMATION n. 230 (1996) sobre as três parcelas resistentes que compõem a aderência aço-concreto pode-se afirmar que, de maneira geral, quando uma barra começa a ser solicitada, inicialmente a aderência é mantida pelas forças coesivas provindas da adesão. Essa parcela, porém, é rapidamente destruída, possivelmente devido a pequenos escorregamentos localizados, por conta do aumento da tensão. Depois, dando lugar à parcela de atrito, o concreto começa a fissurar, as forças de atrito vão sendo reduzidas e a aderência passa a ser função, praticamente, da aderência mecânica proveniente da irregularidade da superfície e das nervuras das barras. Para as barras lisas, onde a aderência mecânica pouco colabora, a barra vai perdendo aderência à medida que vão sendo destruídas as forças de atrito. Geralmente o que se verifica é que nesse processo a peça sofre ruptura por arrancamento da barra, como ilustra a Figura 2.20; trata-se de uma barra de $6.3 \mathrm{~mm}$ de diâmetro, embebida num $\mathrm{CP}$ de $10 \times 20 \mathrm{~cm}$; observar o concreto esmagado entre as nervuras. 


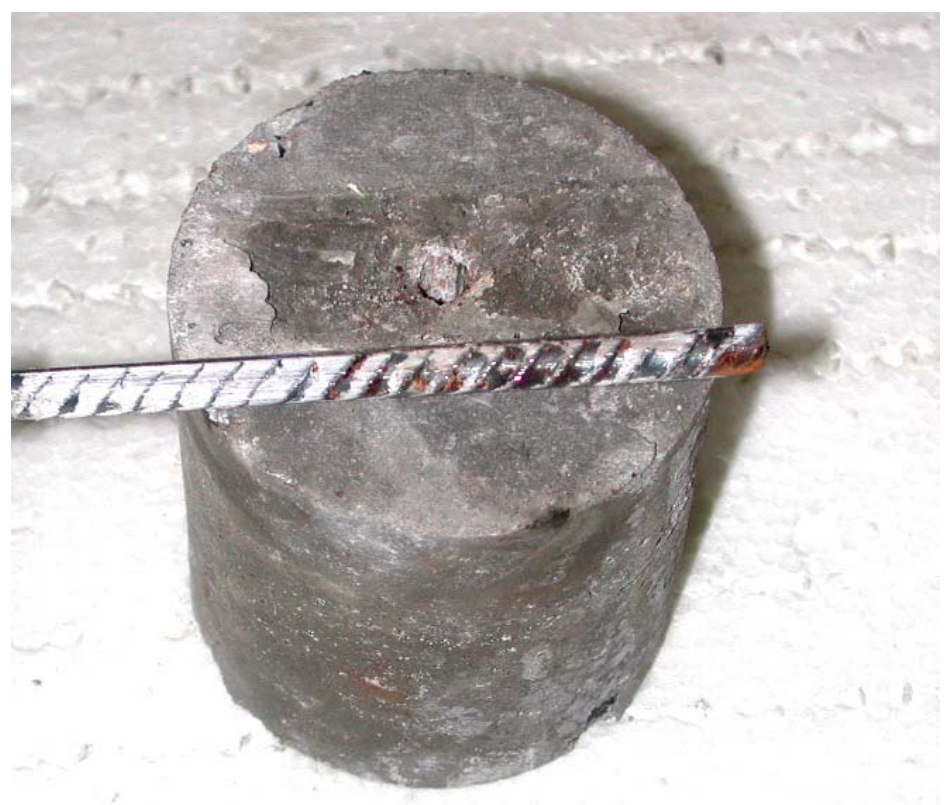

Figura 2.20 - ruptura por arrancamento

Para as barras nervuradas, a aderência passa a ser governada pela aderência mecânica (nervuras), segundo ELIGEHAUSEN et al (1983); eles afirmam que as parcelas da adesão e do atrito entre a barra e o concreto adicionam pouco à resistência de aderência. Portanto, quando começa a diminuir a aderência por atrito, as nervuras agem como pontos de apoio de bielas comprimidas, que impedem o deslocamento relativo da barra. Perpendiculares às bielas aparecem tensões de tração que geram um anel de tensão ao redor da armadura. Com o aumento crescente da força na armadura, o concreto vai sendo esmagado ao redor da barra, devido à compressão exercida pelas nervuras. Antes que ocorra esmagamento total do concreto e a barra escorregue dá-se o fendilhamento da peça, devido às altas tensões radiais de tração, como ilustra a Figura 2.21. Trata-se de uma barra de $10.0 \mathrm{~mm}$ de diâmetro, embebida num CP de 10x20 cm. 


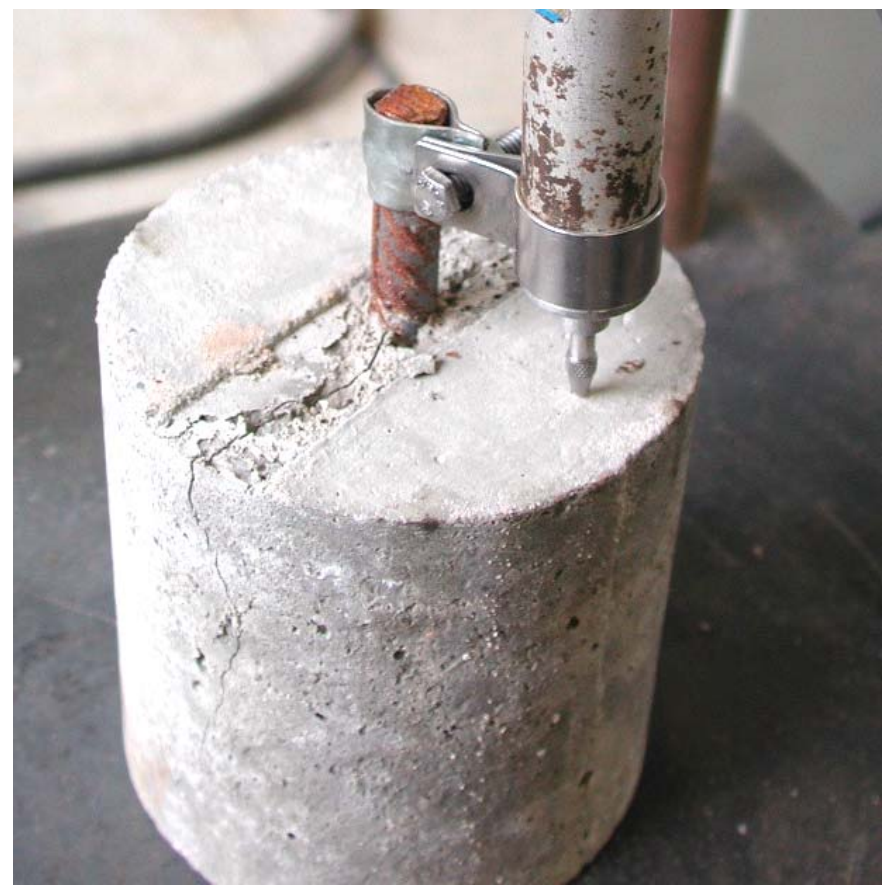

Figura 2.21 - ruptura por fendilhamento

Ressalte-se que o que foi mencionado anteriormente é característica, principalmente, do comportamento observado em ensaios de arrancamento. Quando a peça está submetida a cargas em regime de serviço a aderência é afetada, além desses, por outros fatores já assinalados anteriormente.

BALÁZS et al. (1993) publicaram resultados de ensaios de arrancamento em espécimes sujeitos a carregamentos monotônico e cíclico, com o intuito de analisar o comportamento da aderência-escorregamento utilizando emissão acústica. De acordo com os autores, a ruptura da aderência começa e progride na camada de concreto envolvente à armadura e leva ao arrancamento da barra se o cobrimento do concreto for capaz de resistir à tensão de tração circunferencial, para evitar o fendilhamento do cobrimento. A técnica de emissão acústica foi escolhida para detectar danos localizados na camada de concreto, associados com efeitos acústicos na liberação de energia, pois essa técnica é um método bastante usual para a investigação de danos locais na camada de interação aço-concreto, por ser preciso registrar apenas sinais de ruptura local progressiva envolvendo a armadura. A acumulação do dano interno, definida como as amplitudes de emissão acústica acumulativa, mostrou tendências similares no desenvolvimento do escorregamento devido à carga cíclica e de longa duração.

KOCH e BALÁZS (1993) fizeram comparações baseadas em dados experimentais do comportamento de interação entre as barras de aço e o concreto entre 
estruturas sujeitas a cargas de longa duração e a cargas cíclicas de amplitude constante. As curvas de duração da carga versus escorregamento entre a armadura e o concreto, obtidas experimentalmente, comparadas com as curvas provenientes da proposta do CEB-FIP 90 (Figura 2.9) mostraram que, para cargas de longa duração, há um aumento insignificante no escorregamento inicial em relação aos resultados experimentais. Já para as cargas cíclicas, há uma diferença no curso das curvas e na sua inclinação, onde os valores dos escorregamentos obtidos experimentalmente são consideravelmente maiores que os do CEB-FIP 90.

BALÁZS (1993) analisa, em seu artigo, a formação de fissuras em elementos de concreto armado, baseado na análise do escorregamento, da tensão de aderência e da tensão no aço, supondo que as fissuras se formam quando a tensão principal de tração devido a cargas ou reações de apoio ultrapassa a resistência à tração do concreto. Devido à formação de fissuras, a compatibilidade de deformações entre o aço e o concreto não é mantida. Logo, o acúmulo de diferenças na deformação produz deslocamentos relativos, ou seja, escorregamento entre o aço e o concreto, que influenciam fortemente a fissuração. $O$ autor propôs uma avaliação semi-analítica do comportamento da fissuração no concreto armado no escorregamento e na tensão de aderência. Desta maneira, no trabalho referido, não foi assumida a hipótese da distribuição de tensão de aderência entre fissuras, a qual provém dos escorregamentos relativos, pela aplicação experimental da relação não-linear entre tensão de aderência versus escorregamento.

VALLE (1994), em seu trabalho de mestrado, verifica o comportamento da aderência entre armadura e concreto sob cargas repetidas através de ensaios de arrancamento, na busca de uma relação entre os valores experimentais e os prescritos em normas. Para tanto, dentre outros, utilizou um tipo de ensaio denominado ensaio das quatro barras, que consiste de uma emenda por traspasse ligando três barras a uma outra central. Foram realizados dois tipos de ensaios, com corpos de prova intactos e com corpos de prova submetidos previamente à carga cíclica. A intensidade do carregamento repetido e o número de ciclos são aplicados com valores tais que não conduzam à ruptura da ancoragem da armadura. Restringindo a análise do trabalho ao ensaio acima descrito, conclui a autora que para espécimes previamente submetidos a carregamento cíclico as parcelas de adesão e atrito se rompem; mobilizam, por conseguinte, a aderência mecânica, ou seja, o engrenamento mecânico entre a armadura e o concreto envolvente. Os ciclos de carga provocam a ruptura dos pontos de ligação mais frágeis 
em virtude do deslizamento da barra. A analise dos resultados dos ensaios indica que o carregamento repetido ocasiona uma deterioração da aderência diminuindo a capacidade ultima de ancoragem da armadura. As curvas representadas na Figura 2.22, na Figura 2.23 e na Figura 2.24 apontam os resultados dos ensaios das quatro barras para um concreto com $30 \mathrm{MPa}$ e barras de diâmetro 16,0 mm.

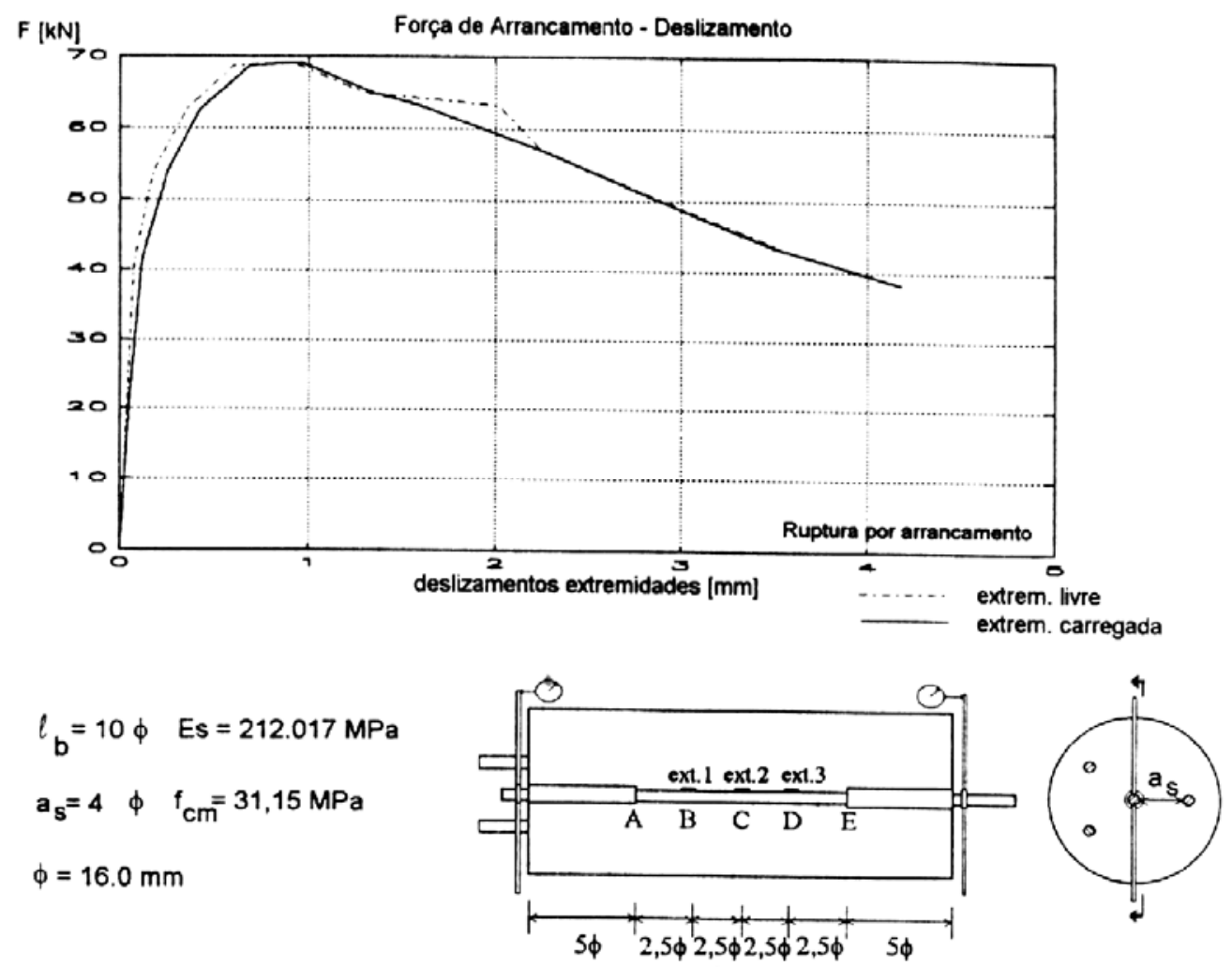

Figura 2.22 - Força x Deslizamento (VALLE, 1994)

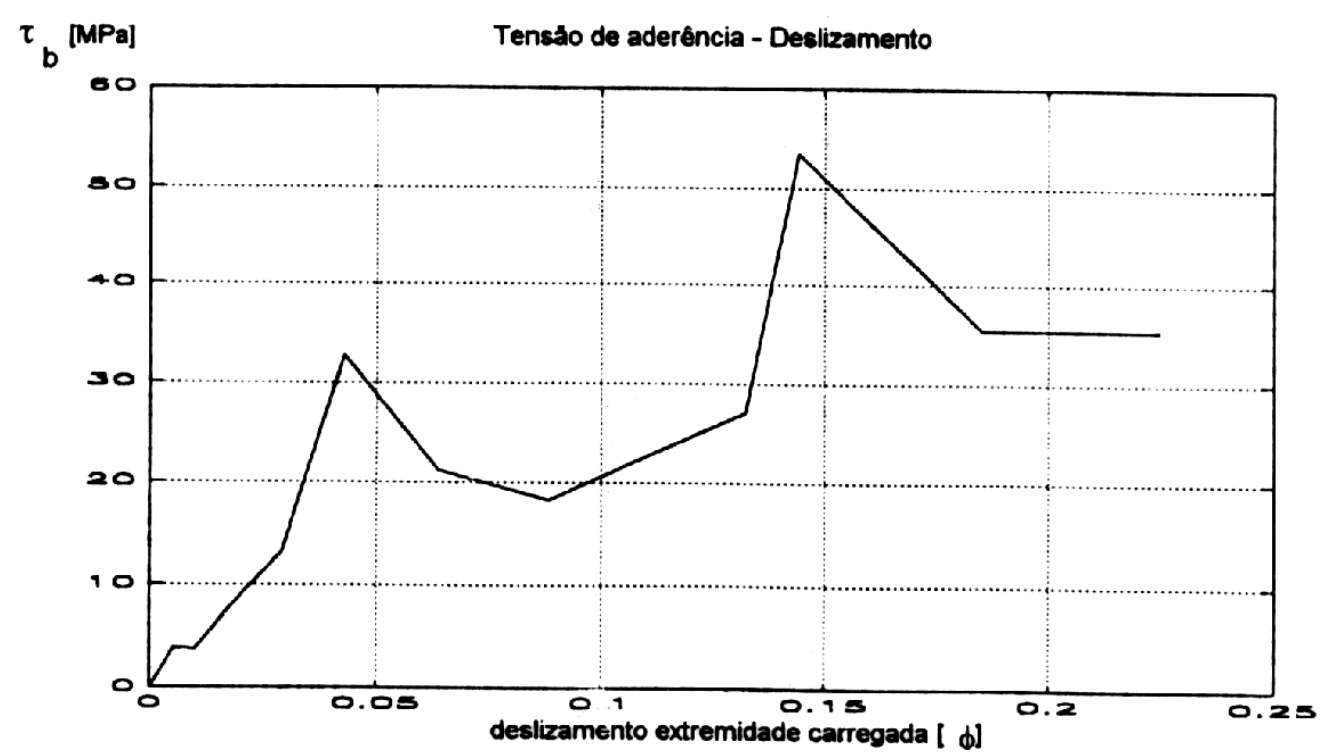

Figura 2.23 - Tensão de aderência x deslizamento (VALLE, 1994) 


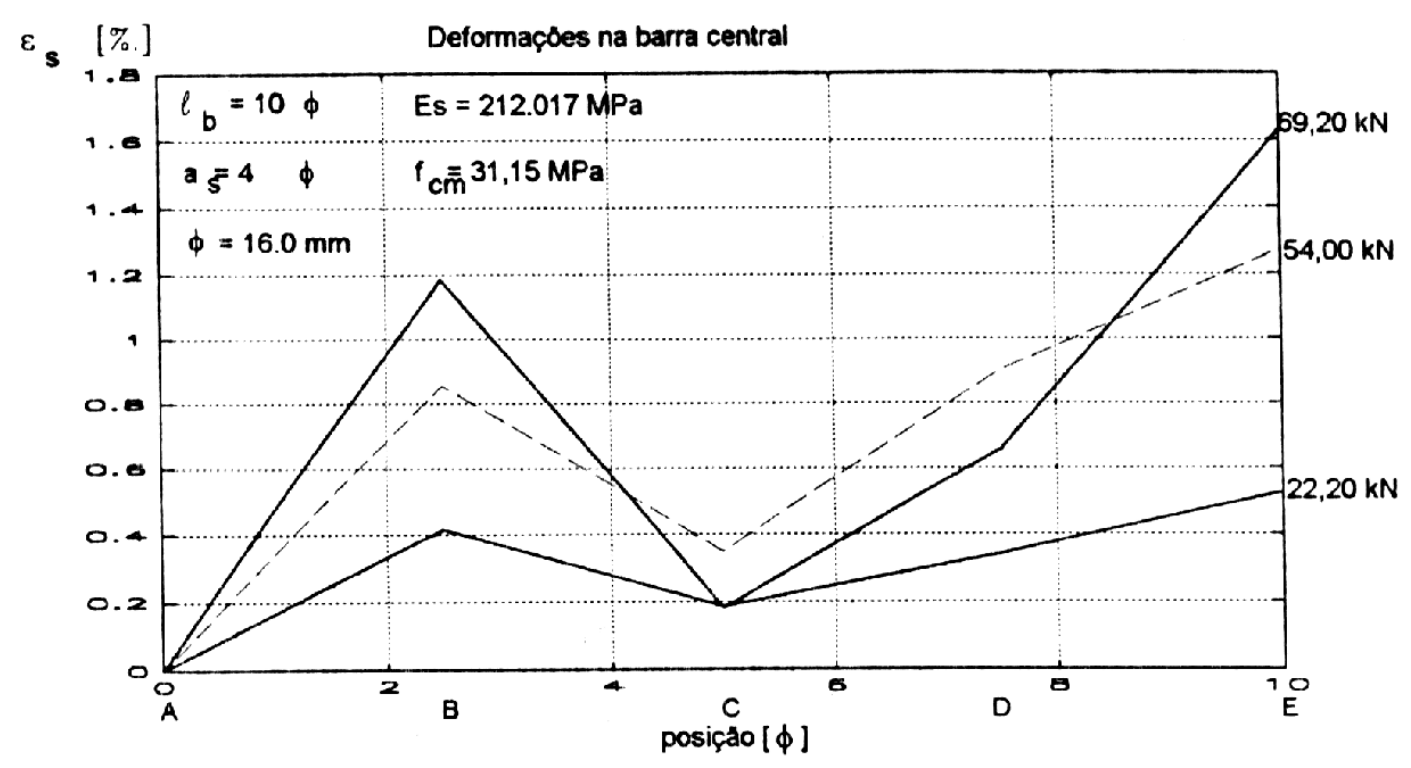

Figura 2.24 - Deformações em pontos da barra central (VALLE, 1994)

DRIEMEIER (1995) dá ênfase ao estudo da microestrutura dos metais e também do concreto com o objetivo de caracterizar os mecanismos físicos elementares de deformação e ruptura. A fadiga em metais é vista pela ótica microscópica dos processos de iniciação e propagação de trincas. Analisa-se, ainda, o comportamento dos metais quando submetidos a cargas cíclicas. Para o concreto, além de se estudar a fissuração e o comportamento do material sob a ação de cargas cíclicas, apresenta-se um modelo constitutivo não-linear baseado na mecânica do dano contínuo; para o modelo isótropo são analisados todos os seus aspectos (hipóteses, critérios, lei de propagação) e a influência do carregamento cíclico. São apresentados três exemplos para vigas de concreto armado, analisando-se as diferenças observadas entre carregamento monotônico e cíclico, usando um sistema não-linear com processo incremental-iterativo pelo método explícito. A análise não considerou aspectos como o contato entre concreto e armadura e a plastificação da armadura, nem a aplicação de carregamento alternado.

BRAGUIM (1995), trabalhando com vigas de concreto armado, realizou um estudo experimental com a finalidade de obter a ordem de grandeza dos acréscimos de flechas nas vigas submetidas à ação de cargas cíclicas em serviço. Observou-se que a evolução da flecha é da mesma ordem de grandeza da deformação lenta, produzida pelo carregamento permanente, sugerindo a existência de uma "fluência cíclica"; o efeito das ações cíclicas seria, portanto, levado em conta no cálculo da deformação lenta adicionando-se à parcela das ações permanentes uma parcela das ações acidentais. $\mathrm{O}$ autor assinala o pequeno número de informações encontradas na literatura referente à 
fadiga, como também a pequena quantidade de trabalhos que tratam da evolução da rigidez de elementos estruturais de concreto armado em função do número de ciclos de carga e dos níveis de solicitação aplicados. Apresenta, em seguida, um resumo do conteúdo de artigos encontrados e que tratam do assunto tais como o de SPARKS, P. R. and MENZIES, J.B. (1973), que, através de resultados experimentais, fornece uma relação exponencial bastante simples entre o aumento do deslocamento e o número de ciclos de carregamento, conforme a expressão (2.15):

$$
\delta \mathrm{d}=\mathrm{AN}^{\mathrm{b}}
$$

onde $\delta$ d é o aumento de deslocamento em mm, $\mathrm{N}$ é o número de ciclos de carga e os parâmetros A e b são obtidos de dados tirados dos ensaios realizados em vigas. Exemplificando, para uma viga com $312 \mathrm{~cm}$ de vão, seção transversal de 20x20 cm e resistência à compressão de $45 \mathrm{MPa}$, o valor de $\mathrm{A}=0.222, \mathrm{~b}=0.16$ e o aumento da flecha correspondente ao primeiro ciclo $(\mathrm{N}=1)$ é de $\delta \mathrm{d}=9.12 \mathrm{~cm}$ e para o ciclo de número $\mathrm{N}=1000000, \delta \mathrm{d}=11.14 \mathrm{~cm}$; o erro registrado entre o deslocamento medido e o teórico varia entre -0.8 e $3.8 \%$. O autor cita ainda os trabalhos de LOVEGROVE, J.M. and SALAH, E.D. (1982) e BALAGURU, P. and SHAH, S.P. (1982). Cita também a expressão apresentada pelo CEB e publicada no trabalho CEB-FIP MODEL CODE 1990 (1991); a expressão (2.16) se refere diretamente ao aumento de deslocamento devido à fluência cíclica que ocorre na peça estrutural, cujo valor deve ser adicionado ao correspondente deslocamento oriundo da fluência convencional.

$$
\mathrm{d}_{\mathrm{N}}=\mathrm{d}_{0}\left(1.5-0.5 \mathrm{e}^{-0.03 \mathrm{~N}^{0.25}}\right)
$$

onde $\mathrm{d}_{\mathrm{N}}$ representa o deslocamento da peça no $\mathrm{N}^{\mathrm{o}}$ ciclo, $\mathrm{d}_{0}$ o deslocamento no $1^{\circ}$ ciclo de carga e N o número de ciclos de carga aplicado.

Na Figura 2.25 são mostradas as flechas máximas e mínimas em função do número de ciclos (as vigas foram submetidas a um número máximo de 20.000 ciclos). Refere-se a um dos ensaios realizados com vigas normalmente armadas. 


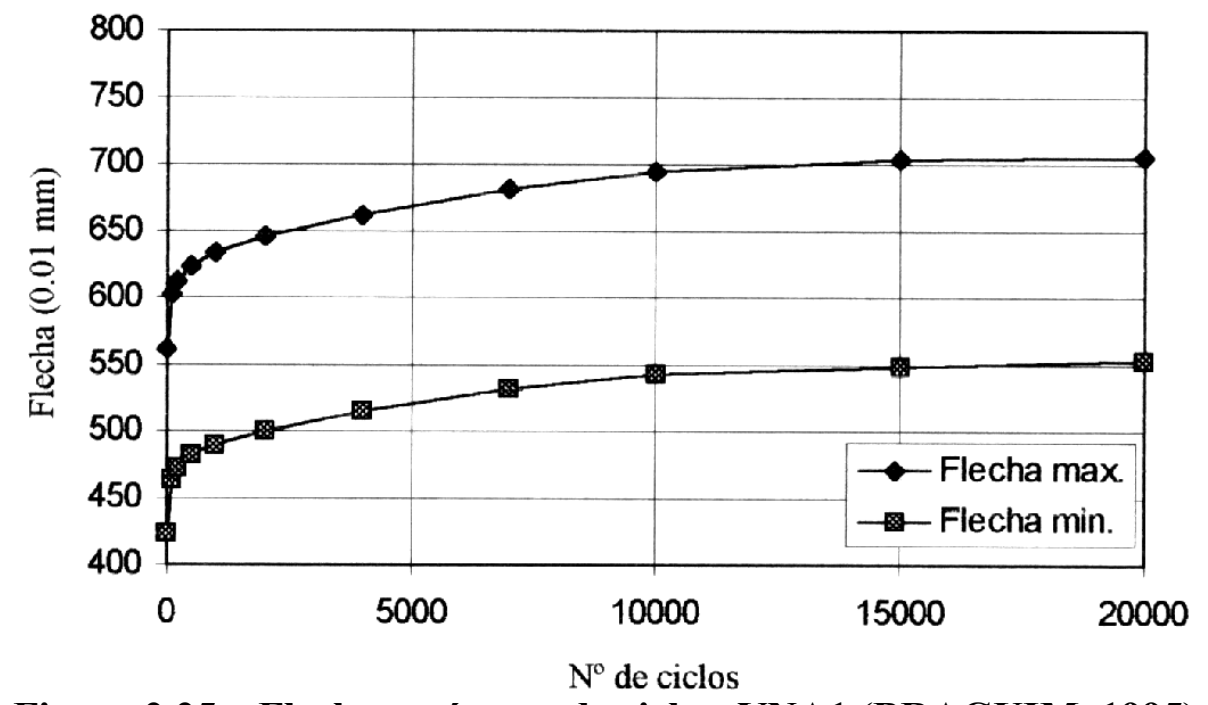

Figura 2.25 - Flecha $x$ número de ciclos, VNA1 (BRAGUIM, 1995)

Na Figura 2.26 são mostradas as flechas máximas e mínimas em função do número de ciclos aplicados. Refere-se a um dos ensaios realizados com vigas super armadas.

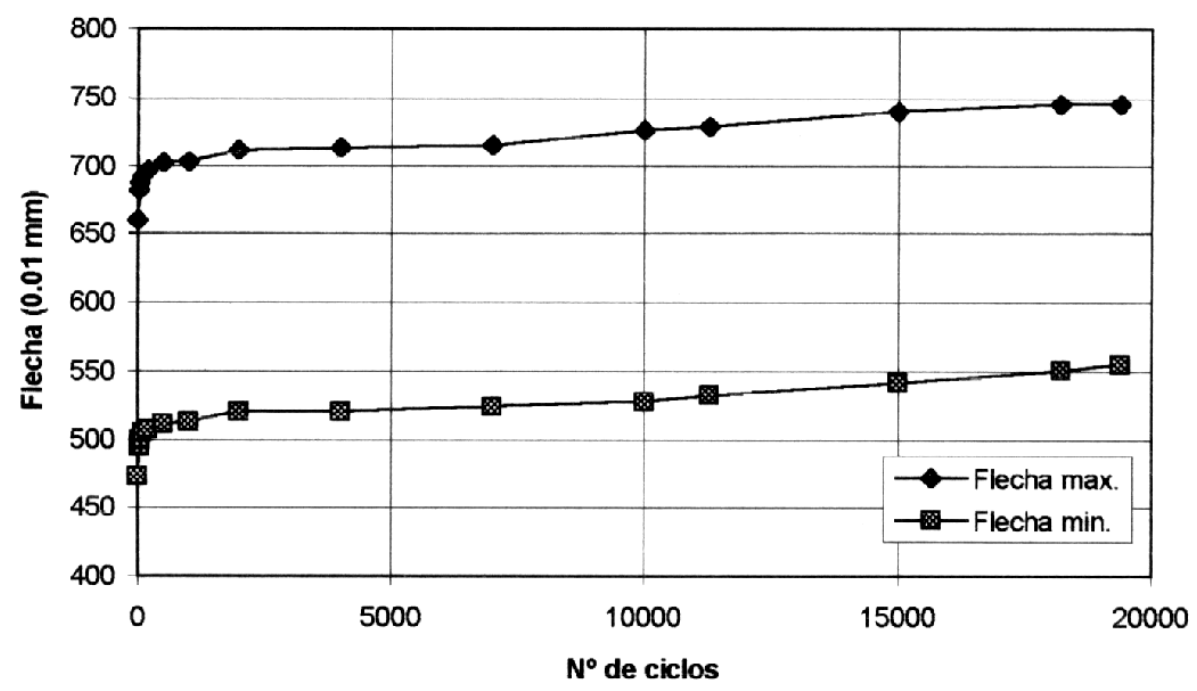

Figura 2.26 - Flecha $x$ número de ciclos, VSA3 (BRAGUIM, 1995)

ALLWOOD e BAJARWAN (1996) publicaram um algoritmo que incorpora a rigidez da aderência na análise dos elementos finitos, que é o elemento de ligação entre o aço e o concreto. O método representa o comportamento aderência-escorregamento por um modelo não-linear da rigidez de aderência, baseado em estudos teóricos e experimentais anteriores. O método foi experimentado em ensaios de arrancamento, com boa concordância entre os resultados e dados experimentais, mostrando que não é necessária a consideração da rigidez de aderência dependente da posição, como sugerido por outros pesquisadores. 
MONTI et al (1997) estudaram o problema da ancoragem de barras no concreto através de um novo elemento finito, com o uso de uma função de interpolação de força, ao invés de deslocamento, onde a função satisfaz o equilíbrio e garante a estabilidade numérica dos resultados, mesmo em barras de armadura com comprimento de ancoragem insuficiente. Dados experimentais anteriores mostram a habilidade do modelo para simular a degradação da aderência e arrancamento das barras ancoradas no concreto sob solicitações cíclicas.

HOTA e NAAMAN (1997) investigaram o comportamento da tensão de aderência versus escorregamento em espécimes de concreto armado reforçado com fibras, submetidos a carregamentos monotônico, cíclico unidirecional e cíclico reverso. Os autores observaram que, na ausência de fibras, a ruptura dos espécimes foi mais frágil, pois as fibras de aço fornecem ao elemento mais ductilidade e, além disso, melhoram as propriedades de aderência da barra. Observou-se, por conseguinte, que a adição de fibras aumenta a resistência de aderência, a absorção de energia, a ductilidade e a segurança das barras.

PLIZZARI et al (1997) estudaram o comportamento do concreto fissurado devido a cargas cíclicas de baixa freqüência, como as sísmicas, através de ensaios de tração direta de espécimes cilíndricos, com carregamento e deformação controlados. A envoltória que representa as deformações versus tensão foi determinada experimentalmente. Com base nesses resultados, uma nova expressão para o crescimento das fissuras no concreto sob carregamento cíclico foi proposta.

ALVIN (1997), em seu trabalho de mestrado, avaliou experimentalmente a rigidez efetiva de vigas de concreto armado quando submetidas a cargas estáticas e dinâmicas; a finalidade foi obter uma estimativa mais realista da rigidez a adotar em projetos. Sugere fatores de redução da rigidez devido aos efeitos da fissuração e da nãolinearidade dos materiais. Nas peças de concreto armado submetidas a flexão nem todas as seções transversais fissuram; a redistribuição de esforços que se instala impõe uma limitação no espaçamento entre as fissuras que vão se formando de modo que a linha neutra e a curvatura variam ao longo da viga. Torna-se necessária a adoção de um valor médio para a rigidez da viga. A variação da taxa de armadura mostrou ser um aspecto importante na determinação da rigidez equivalente. Os valores encontrados para o módulo de deformação do concreto nos ensaios de compressão mostraram-se coerentes com os experimentais se aproximando dos estimados pela expressão do CEB; ao contrário, os resultados se afastaram bastante dos estimados pela expressão da NB-1/78. 
O CEB, no trabalho CEB-BULLETIN D'INFORMATION No 235 (1997), apresenta algumas expressões para cálculo de flechas em vigas de concreto armado quando submetidas a ciclos de carga. Além dos trabalhos de SPARKS and MENZIES (1973) e LOVEGROVE and DIN (1982), citados e comentados por BRAGUIM (1995), são apresentados dois outros interessantes trabalhos sobre o tema. Um deles foi desenvolvido por LENKEI, P. (1987) que, baseado nos resultados de testes com vigas bi apoiadas de $290 \mathrm{~cm}$ de vão, seção transversal retangular, armadas com $3 \phi$ de 12,0 mm em tração e $2 \phi$ de $8,0 \mathrm{~mm}$ em compressão, propõe valores práticos para o aumento da flecha no meio do vão em função do nível de carga $\left(\mathrm{F}_{\max } / \mathrm{F}_{\mathrm{u}}\right)$, da relação entre o valor máximo e mínimo da carga cíclica $\left(\mathrm{F}_{\min } / \mathrm{F}_{\max }\right)$ e do número de ciclos de carga. A Tabela 2.1 apresenta valores obtidos da pesquisa.

Tabela 2.1 - Aumento da flecha no meio do vão relativa a flecha imediata (LEIKEI, 1987)

\begin{tabular}{|c|c|c|c|c|c|c|}
\hline \multirow{2}{*}{$\begin{array}{c}\text { Numero de } \\
\text { ciclos de } \\
\text { carga }\end{array}$} & \multicolumn{2}{|c|}{0.4} & \multicolumn{2}{c|}{0.6} & \multicolumn{2}{c|}{0.8} \\
\cline { 2 - 7 } & \multicolumn{2}{|c|}{$\mathrm{F}_{\min } / \mathrm{F}_{\max }$} & \multicolumn{2}{c|}{$\mathrm{F}_{\mathbf{u}}$} & \multicolumn{2}{c|}{$\mathrm{F}_{\max }$} \\
\hline $2.10^{4}$ a $10^{5}$ & 0.1 & 0.5 & 0.1 & 0.5 & 0.1 & 0.5 \\
\hline $2.10^{6}$ & 0.15 & 0.075 & 0.2 & 0.1 & 0.3 & 0.15 \\
\hline $10^{7}$ & 0.3 & 0.15 & 0.4 & 0.2 & 0.6 & 0.3 \\
\hline
\end{tabular}

No mesmo texto é apresentado um outro trabalho desenvolvido por PITONAK, A. (1992). O autor testou 124 vigas de concreto armado com diferentes vãos, seções transversais, diâmetro das barras e parâmetros de carga, como $F_{\min } / F_{\max }=0.2$ a 0.6 e $\mathrm{F}_{\max } / \mathrm{F}_{\mathrm{u}}=0.3$ a 0.75 . Os espécimes foram inicialmente carregados monotonicamente até atingir $\mathrm{F}_{\max }$ e daí então aplicados os ciclos de carga a uma freqüência de $5 \mathrm{~Hz}$ com amplitude constante. Foram medidas deformações, flechas e aberturas de fissuras para valores de $\mathrm{N}=10^{4}, 10^{5}, 5 \times 10^{5}, 10^{6}, 1.5 \times 10^{6}$ e $2 . \times 10^{6}$ correspondentes a $F_{\max }$ e $F_{\min }$. Valores das flechas cíclicas $\left(\mathrm{a}_{\mathrm{n}}\right)$ medidas em função da flecha no primeiro ciclo $\left(\mathrm{a}_{0}\right)$ são mostrados na Figura 2.27 para $\mathrm{N}=10^{5}$ e na Figura 2.28 para $\mathrm{N}=2$. x $10^{6}$. A relação entre $\mathrm{a}_{\mathrm{n}}$ e $\mathrm{a}_{0}$ é avaliada por uma regressão linear, conforme eq. (2.17).

$$
\mathrm{a}_{\mathrm{n}}=\kappa \cdot \mathrm{a}_{0}
$$

que pode ser rearranjada da seguinte forma: 


$$
\mathrm{a}_{\mathrm{n}}=\mathrm{a}_{0}\left(1+\beta_{\mathrm{rn}}\right)
$$

onde

$$
\beta_{\mathrm{rn}}=\kappa-1
$$

sendo $\beta_{\mathrm{rn}}$ obtido dos resultados dos ensaios cíclicos para os dois parâmetros da análise de regressão, os quais resultaram na Figura 2.29.

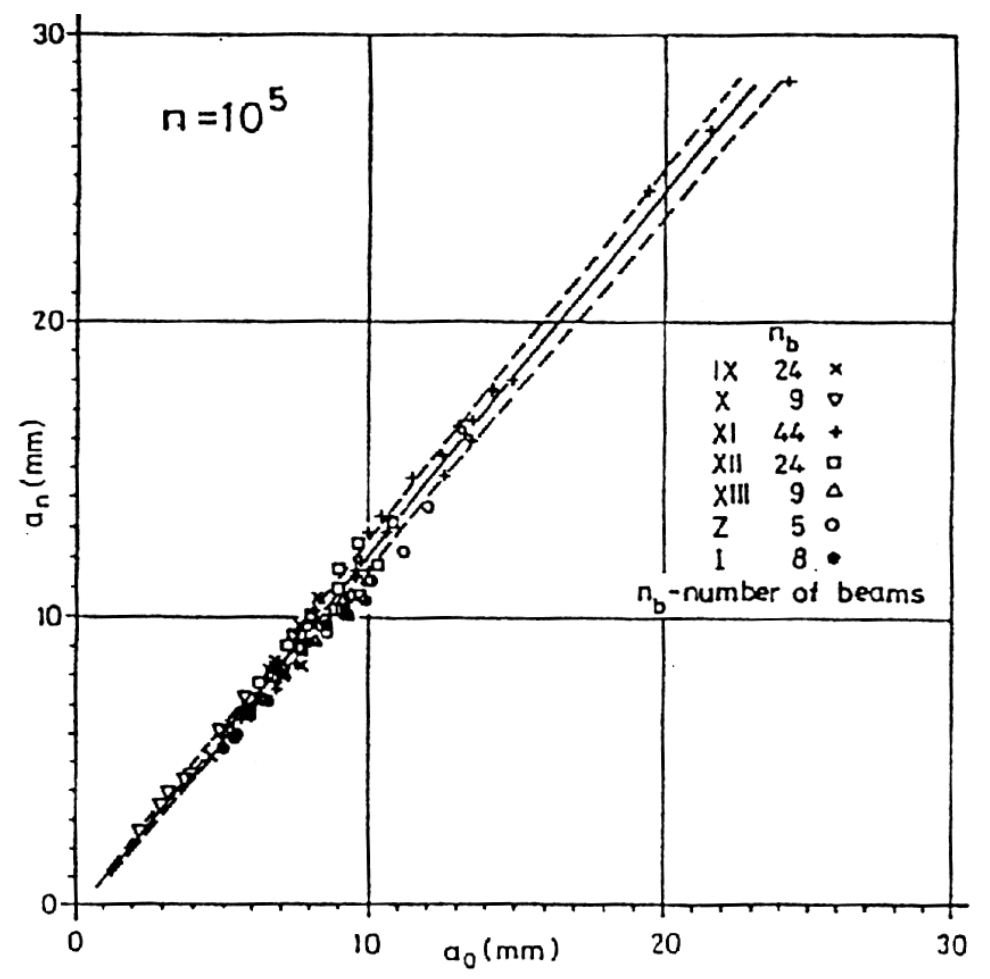

Figura 2.27 - Relação entre $a_{n}$ e $a_{0}$ para $N=10^{5}$ (PITONAK, 1992) 


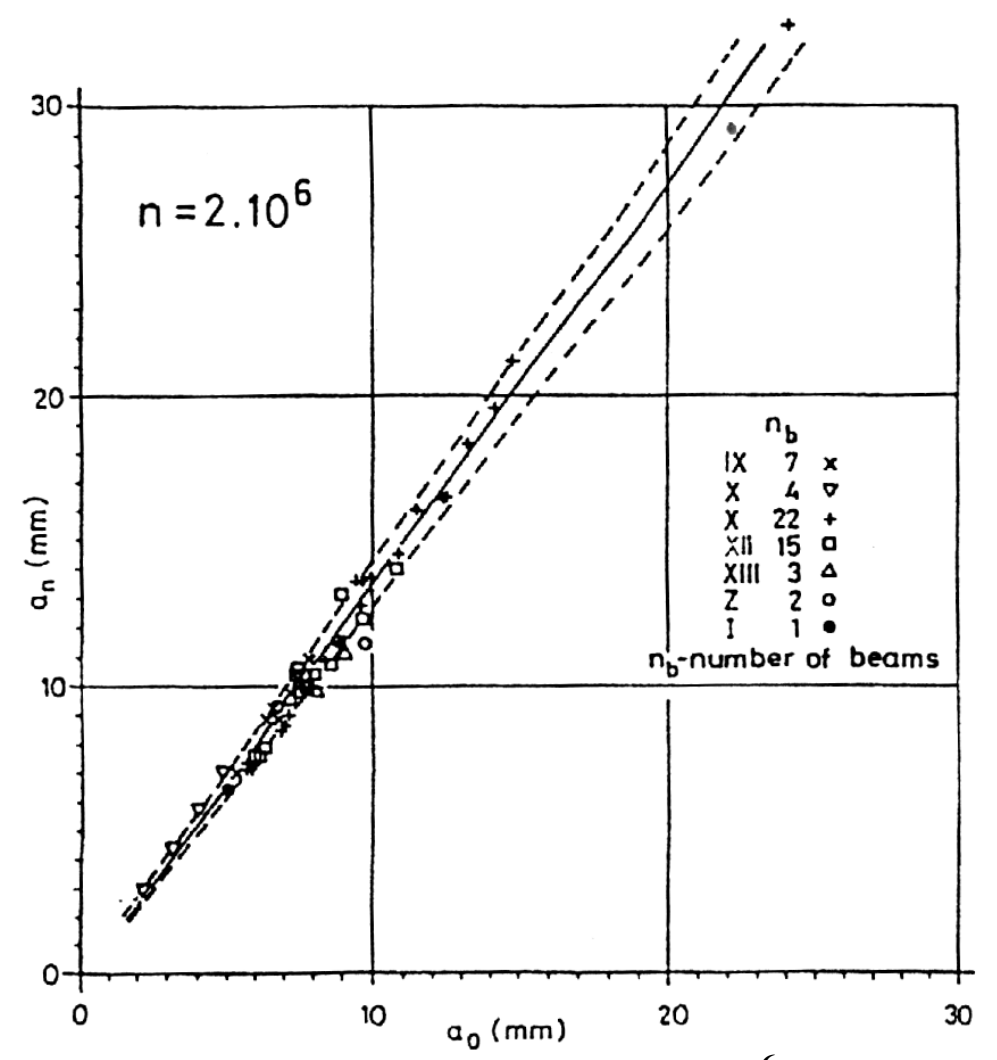

Figura 2.28 - Relação entre $a_{n}$ e $a_{0}$ para $N=2 . x 10^{6}$ (PITONAK, 1992)

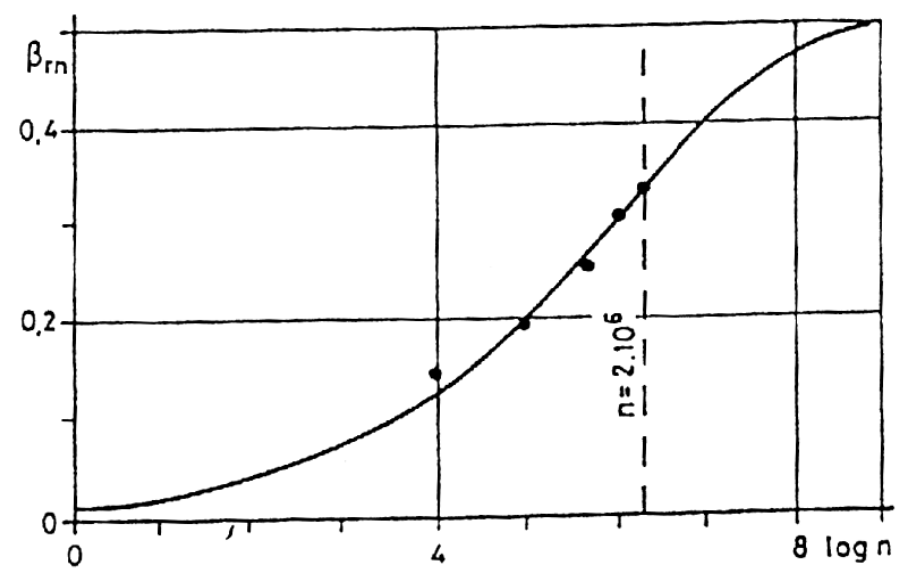

Figura 2.29 - Valores experimentais de $\beta_{\text {rn }}$ (PITONAK, 1992)

Baseado nos resultados dos testes com carga cíclica em vigas de concreto armado o autor conclui que uma relação linear pode ser assumida entre flechas cíclicas $\left(a_{n}\right)$ e a flecha imediata $\left(a_{0}\right)$ independentemente do nível de carga cíclica aplicada ou da relação entre carga mínima e máxima para um dado número de ciclos de carga, conforme expressão definida pela eq. (2.16), comentada em BRAGUIM (1995).

PROENÇA (1988), em seu trabalho de doutorado, apresenta um estudo bastante amplo sobre modelos matemáticos para representar o comportamento não- 
linear físico do concreto. Mostra os recentes desenvolvimentos, àquela época, dos modelos para o comportamento do concreto em tração e em compressão. Apresenta, também, um modelo de fraturamento do concreto baseado na formulação variacional. Com um programa computacional baseado no MEF, adaptado pelo autor, apresenta um exemplo de viga de concreto armado. O concreto em compressão foi tratado como um material elastoplástico perfeito; em regime de tração admitiu-se um comportamento elástico linear limitado pela resistência à tração $f_{t}$ seguido de um regime de "amolecimento" proporcionado pelo fenômeno do enrijecimento à tração (tension stiffening). As armaduras de aço são tratadas através de um modelo elastoplástico perfeito com mesmas características na tração e na compressão. A discretização adotada para a viga fez uso da simetria transversal e longitudinal, usando dois elementos isoparamétricos de oito nós. Cada elemento foi, por sua vez, dividido ao longo da altura da viga em seis extratos de concreto aos quais foram superpostos outros dois representativos da armadura, conforme esclarece a Figura 2.30 .
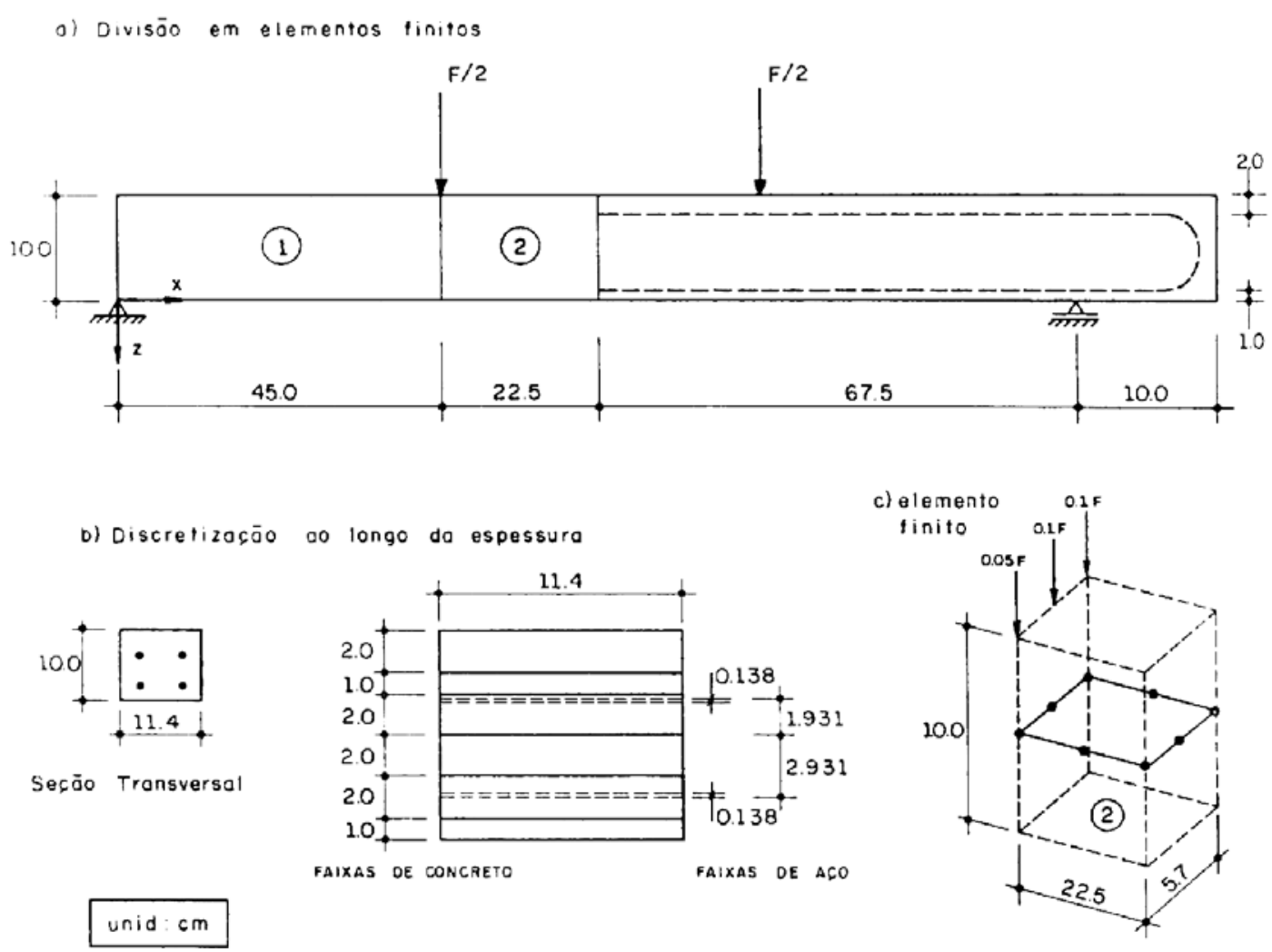

Figura 2.30 - Discretização da viga (dupla simetria), (PROENÇA, 1988)

A comparação entre os deslocamentos no meio do vão da viga, obtidos nas experimentações numérica e do modelo físico, está reproduzida na Figura 2.31. 


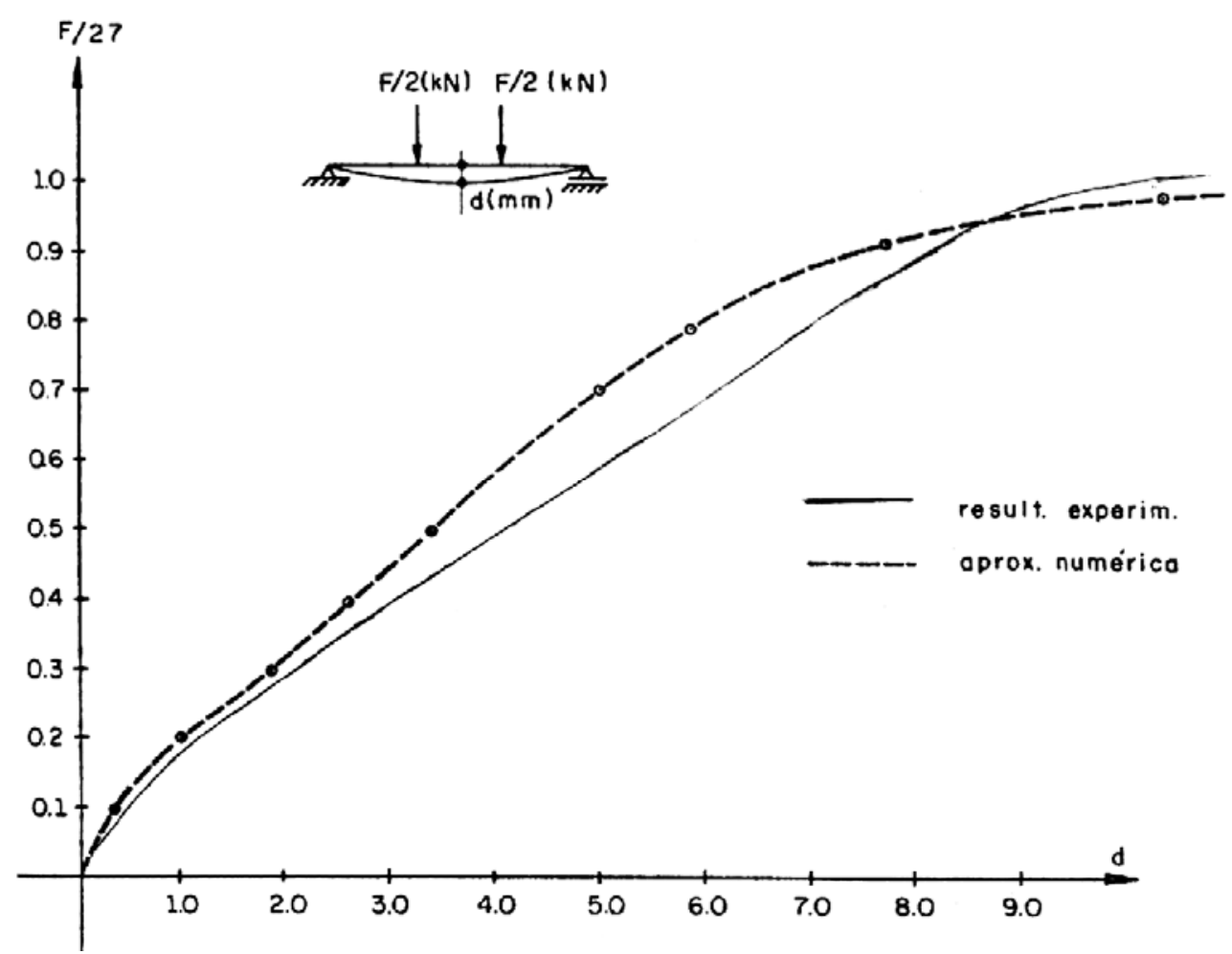

Figura 2.31 - Deslocamento da viga de concreto armado, (PROENÇA, 1988)

A divergência entre os resultados mostrados na Figura 2.31 podem ser atribuídos, de início, e como conseqüência da elevada taxa de armadura utilizada (no modelo, a representação das armaduras não se dá por uma discretização individual, mas através da soma das áreas das barras de aço na mesma camada), à não linearidade inicial do problema devido ao aparecimento da fissuração (trecho em que o parâmetro de carga varia entre 0.0 e 0.4 ). Além desse limite, e até 0.7 , a resposta numérica passa a ser muito rígida apresentando menores deslocamentos do que os resultados experimentais. Aparentemente a diferença é devida ao modelo elastoplástico perfeito adotado para o concreto. A partir do parâmetro de carga 0.7 os deslocamentos crescem rapidamente em função da não linearidade resultante da "plastificação" do concreto. O autor sugere, a partir dos resultados obtidos, a adoção de um modelo plástico com endurecimento para o concreto, como forma de melhorar a resposta do processo.

ÁLVARES (1999), em sua tese de doutorado, destaca, da bibliografia existente, cinco modelos de dano simplificados aplicados a estruturas de concreto armado; cada um deles apresenta, na sua formulação, diferentes abordagens quanto à modelagem da evolução da degradação da estrutura. Tomando como ponto de partida dois desses modelos, os modelos desenvolvidos por LA BORDERIE (1991) e FLÓREZ-LÓPEZ (1993), o autor propõe um novo procedimento para a determinação 
da matriz de rigidez de um elemento onde o fenômeno da danificação é considerado localizado em suas extremidades. Como aplicação dos modelos simplificados a estruturas de concreto armado o autor apresenta um exemplo para uma viga bi-apoiada, fazendo-se uso da simetria de carregamento e geometria. Para análise pelo método de LA BORDERIE foram utilizados elementos finitos de barra, adotando-se para cada caso (cada caso tem um determinado número de barras de aço) uma malha composta de 20 elementos finitos, 21 nós e 15 camadas na discretização da seção transversal, conforme Figura 2.32.

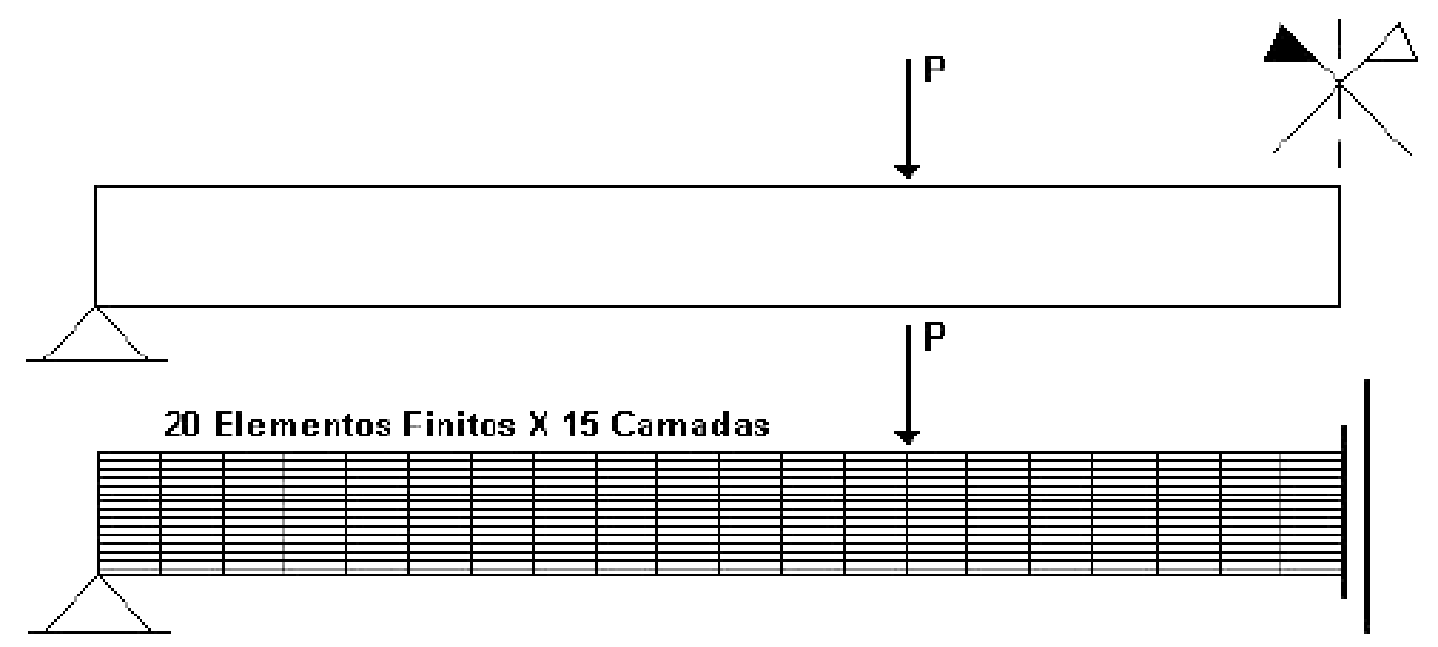

Figura 2.32 - Discretização em elementos finitos - modelo de LA BORDERIE (ÁLVARES, 1999)

Para análise feita com o modelo de dano concentrado nas extremidades, implementado utilizando-se a matriz de rigidez proposta pelo autor e as funções limites de dano e plasticidade propostas por FLÓREZ-LÓPEZ (1993), foram usados 2 (dois) elementos finitos, 3 (três) nós e nenhum extrato ao longo da altura da seção transversal, conforme Figura 2.33. 

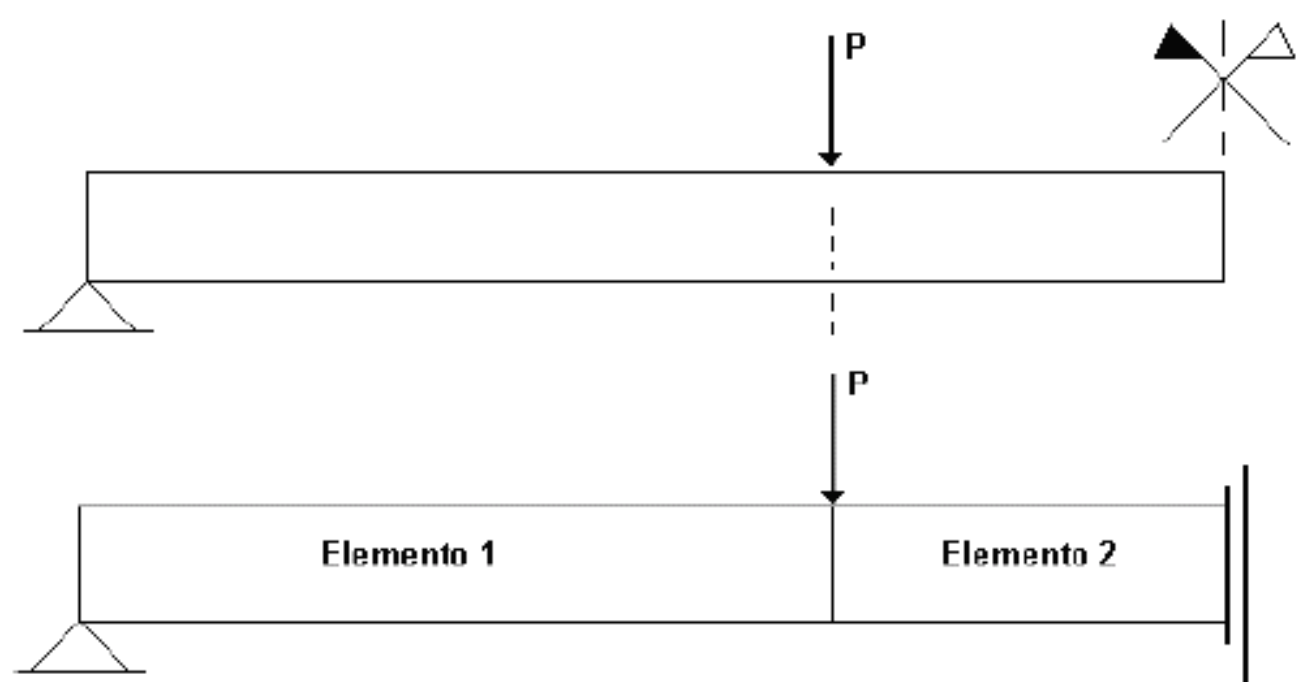

Figura 2.33 - Discretização em elementos finitos - modelo de dano concentrado nas extremidades (ÁLVARES, 1999)

Os resultados numéricos fornecidos pelos dois modelos, aqui mostrados apenas para o caso de uma camada de armadura representativa do aço com $3 \varnothing$ de $10.0 \mathrm{~mm}$, confrontados com resultados experimentais, são mostrados na Figura 2.34 que ilustra o comportamento da curva carga aplicada versus flecha no meio do vão.

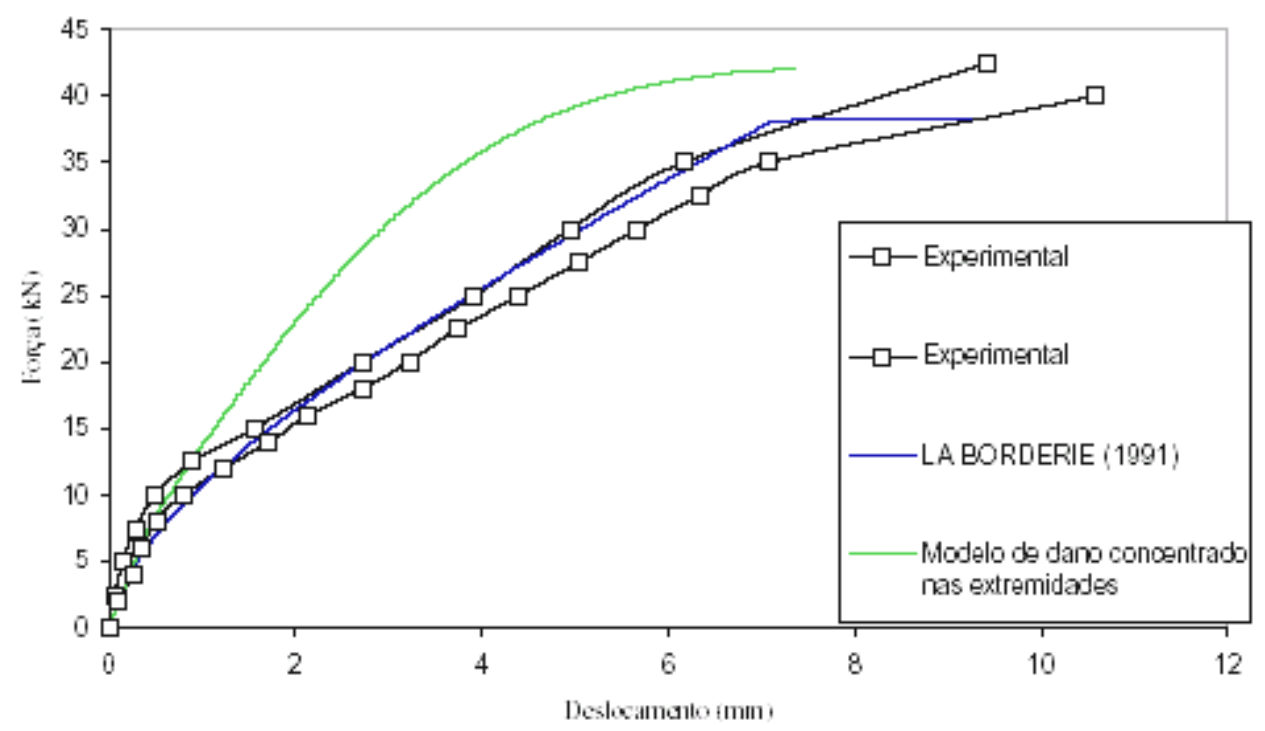

Figura 2.34 - Resultados numéricos - viga com 3申 de 10.0 mm (ÁLVARES, 1999)

Analisando a Figura 2.34 observa-se que o modelo de LA BORDERIE (1991) apresenta melhores resultados pois, apesar de ser um modelo simples, leva em consideração deformações residuais e a eventual plastificação da armadura, fatores não 
considerados no modelo de dano e plasticidade concentrada que considera a barra com um comportamento elástico.

FERNANDES (2000) apresenta um trabalho bastante extenso sobre o fenômeno da aderência apresentando uma revisão detalhada de temas ligados à aderência, mais especificamente sobre o comportamento da aderência do concreto armado quando submetido a ações monotônicas e cíclicas. A influência de fatores como o diâmetro da armadura, tipo e amplitude do carregamento foi estudada. A investigação se deu através de análise numérica e experimental; na análise experimental foram feitos ensaios de arrancamento padronizado, para carregamento monotônico e cíclico. A análise numérica, utilizando o MEF, foi realizada com o auxílio do programa comercial ANSYS $^{2}$; foram utilizados elementos de contato para simular a interface aço-concreto; o comportamento da aderência cíclica não foi possível de ser analisada pelo programa porque, quando do descarregamento da força repetida, o deslizamento residual tornavase nulo, impossibilitando, portanto, a análise. Os elementos bidimensionais usados na análise para representar o aço e o concreto são mostrados na Figura 2.35 e para representar o contato são mostrados na Figura 2.36.

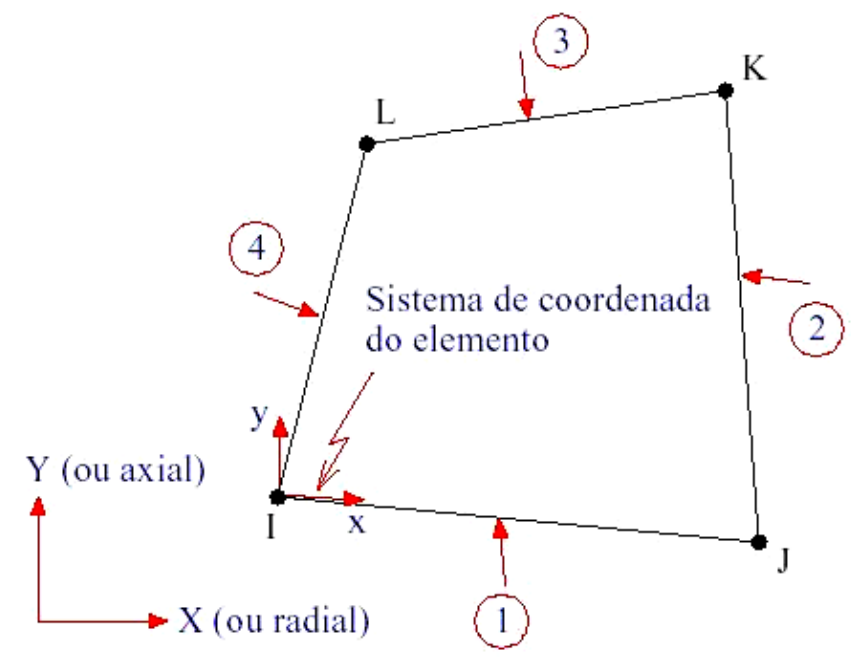

Figura 2.35 - Elemento finito para o aço e o concreto (FERNANDES, 2000)

\footnotetext{
${ }^{2}$ Engineering Analysis System, versão 5.5
} 


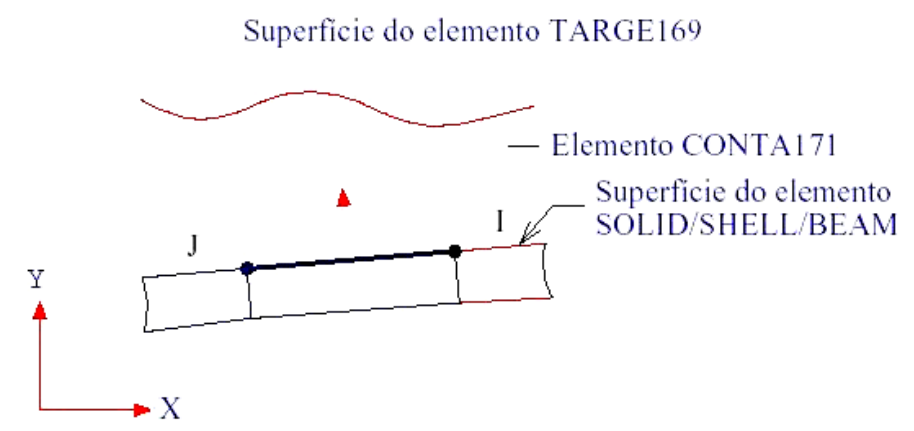

Figura 2.36 - Elemento finito para o contato (FERNANDES, 2000)

BUCHAIM (2001) tenta esclarecer e quantificar a influência na deformabilidade e na capacidade portante de elementos unidimensionais de concreto armado, decorrentes da não-linearidade física dos materiais concreto e aço, bem como da fissuração e do enrijecimento da armadura tracionada. Determinam-se a rigidez à flexão e a capacidade de rotação plástica dos elementos estruturais. Descrevem-se os comportamentos não-lineares do concreto e do aço, aplicando-se conceitos da Mecânica da Fratura, bem como a atuação conjunta destes materiais, sob os aspectos de aderência e de fissuração. Com a obtenção do diagrama momento-curvatura para as vigas, dentre alguns dos casos analisados, determina-se a capacidade de rotação plástica e suas influências.

CASTRO (2002) apresenta um texto bem completo sobre o fenômeno da aderência, apresentando uma revisão extensa e detalhada de temas ligados à aderência tais como causas e distribuição das tensões de aderência, esforços mobilizados na aderência, modos de ruptura, mecanismos de resistência da aderência, comportamento da aderência sob a ação de cargas cíclicas, modelos analíticos disponíveis, prescrições das normas, entre outras abordagens. Em seguida apresenta uma análise experimental com corpos de prova para concretos de alto desempenho sob a ação de cargas repetidas. Citando diversos autores encontrados na literatura nacional e internacional o autor relata que "com relação aos carregamentos, pode-se afirmar que a aderência é influenciada pela sua historia. A ação cíclica acarreta diminuição da resistência de aderência e perda de rigidez devido à maior propagação de fissuras. $\mathrm{O}$ efeito dos carregamentos cíclicos tem sido analisado através do estudo da fadiga. Contudo, ultimamente o problema também está sendo pesquisado por meio do estudo da degradação da ligação açoconcreto". O autor afirma que a despeito dos inúmeros trabalhos existentes sobre o assunto, ainda é difícil prever o comportamento da aderência. Os modelos teóricos e numéricos existentes não têm resposta satisfatória, seja pela complexidade do 
fenômeno, pelos erros na conduta de pesquisas ou pelas dificuldades em desenvolver modelos numéricos, como, por exemplo, o modo de se considerar o contato açoconcreto e a dificuldade em implementar modelos que considerem deformações residuais sob ações cíclicas. Outra importante contribuição foi a implementação, embora bastante laboriosa, da técnica de instrumentação interna das barras de aço com extensômetros elétricos; dessa forma foi possível determinar com mais confiabilidade a distribuição das tensões de aderência (Figura 2.37 e Figura 2.38).

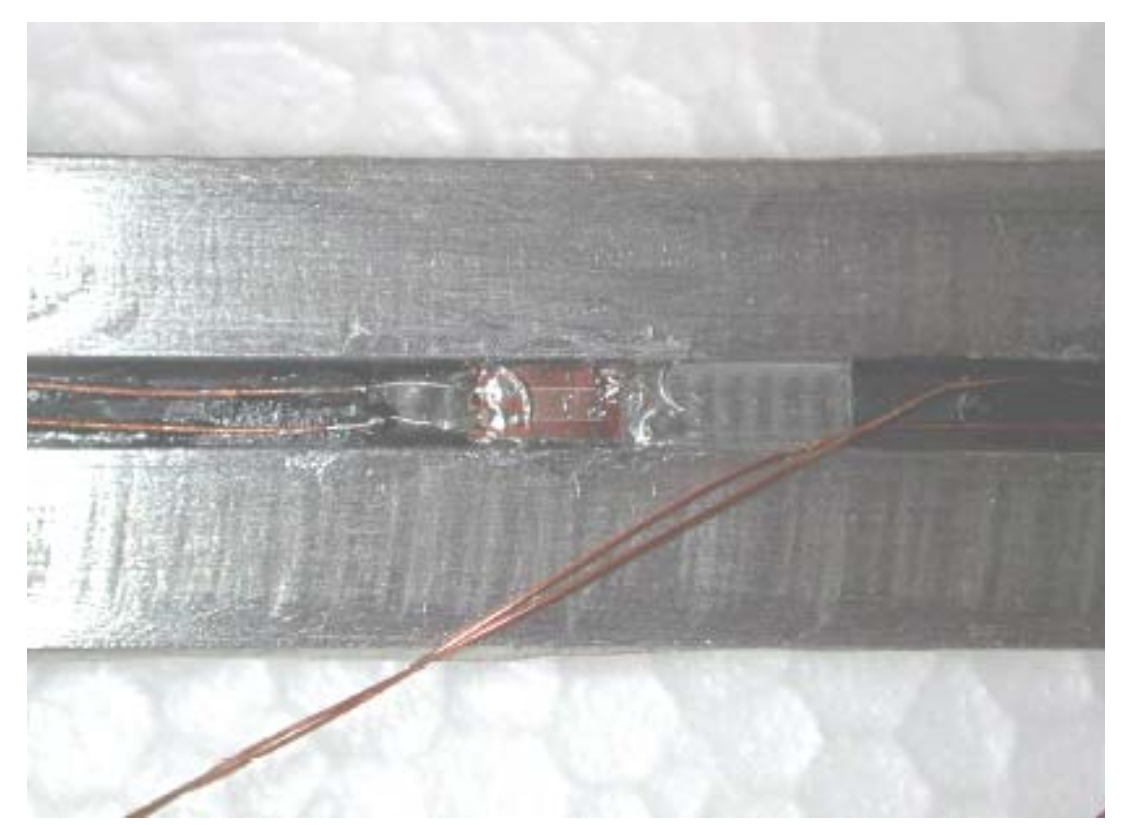

Figura 2.37 - Detalhe do extensômetro colocado internamente, (CASTRO, 2002)

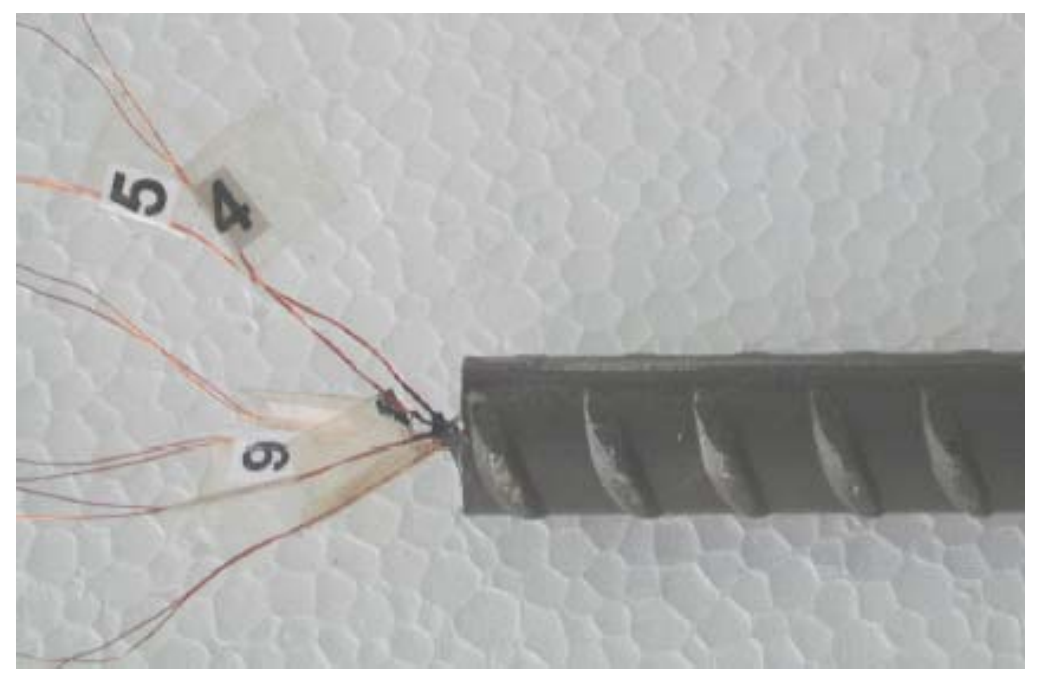

Figura 2.38 - Detalhe da saída dos fios na barra instrumentada internamente, (CASTRO, 2002) 
NETO e ASSAN (2003) consideraram os efeitos da interação aço-concreto através de uma modelagem numérica, com o uso do MEF, onde se interpõem elementos finitos bidimensionais de contato entre os elementos finitos que formam a malha da superfície da barra de aço e os elementos finitos que formam a malha da superfície do concreto envolvente. O elemento de contato é retangular contendo oito nós e dois graus de liberdade por nó; recebeu o nome de LSR (Linear Strain Rectangle). A rigidez da interface é determinada a partir da curva tensão de aderência $(\tau)$ versus deslizamento (s), proposta por YANKELEVSKY (1985). A Figura 2.39 mostra a representação da conexão entre a barra de aço, o concreto e o elemento de interface.

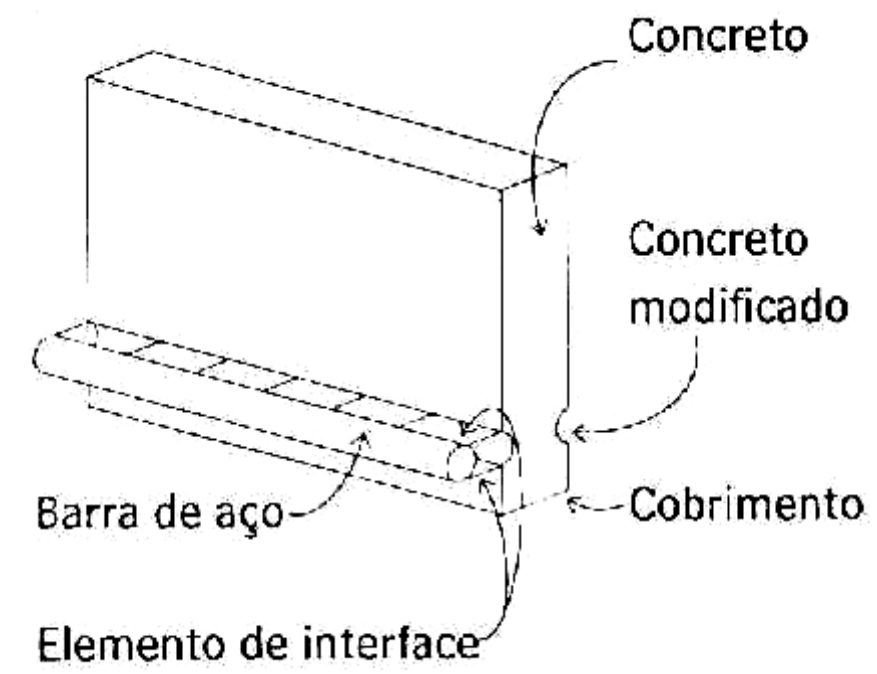

Figura 2.39 - conexão entre a barra de aço e o concreto (NETO e ASSAN, 2003)

AURICH e CAMPOS FILHO (2003), apresentaram um modelo computacional para análise tridimensional de peças de concreto armado, utilizando o MEF. O principal objetivo do trabalho é a modelagem da armadura e de um adicional reforço nas peças de concreto armado, através de um modelo de aderência entre o concreto e o material adjacente, permitindo a previsão dos deslizamentos relativos e das tensões de aderência na interface entre as barras de armadura/reforço e o concreto. A armadura é introduzida no modelo como uma linha de material mais rígido dentro do elemento finito de concreto. A consideração da degradação da aderência é realizada através de um modelo onde os efeitos da aderência imperfeita são incluídos pela introdução de graus de liberdade para os deslocamentos relativos entre os materiais. Como aplicação numérica os autores compararam os resultados obtidos pelo programa computacional com os resultados experimentais disponíveis na literatura com o intuito de validar o modelo proposto. Os exemplos foram testados com uma malha de elementos finitos de concreto 
com dez elementos tridimensionais de vinte nós e aplicou-se uma regra de integração numérica que utiliza apenas 15 pontos de integração dispostos simetricamente no domínio tridimensional do elemento. Foram analisados três conjuntos de vigas. Para um deles foram ensaiadas duas vigas, uma sem reforço (V1) e outra reforçada com chapa de aço colada com resina epóxi na face inferior da viga (V2), conforme Figura 2.40.
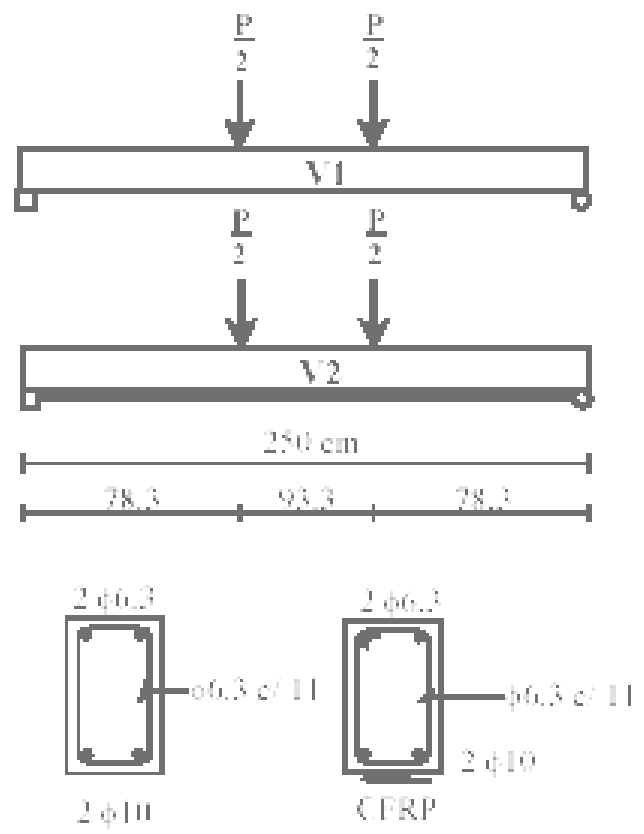

$12 \times 25 \mathrm{~cm}$

Figura 2.40 - Geometria e carregamento das vigas V1 e V2, (AURICH e CAMPOS FILHO, 2003)

A Figura 2.41 e a Figura 2.42 representam, respectivamente, a curva carga $\mathrm{x}$ flecha no meio do vão para as vigas V1 e V2.

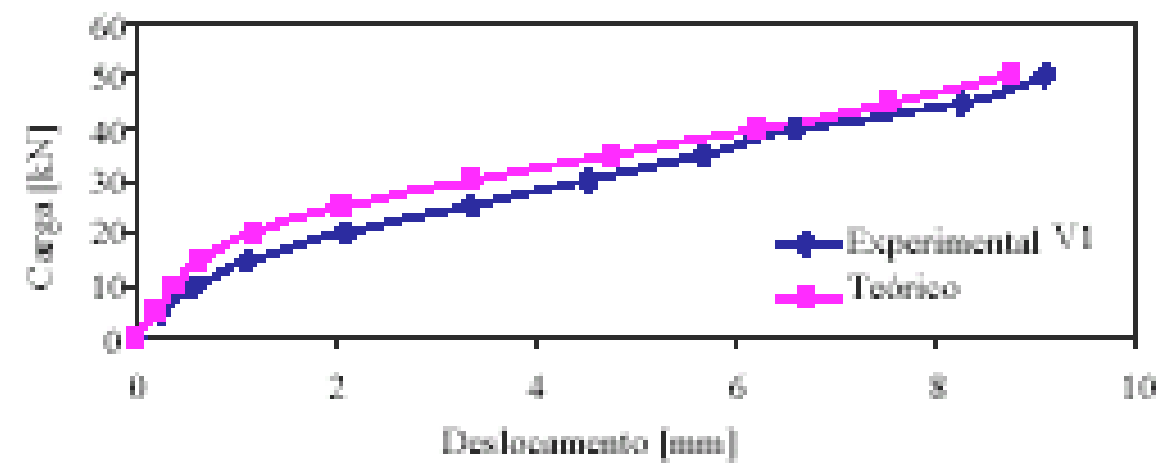

Figura 2.41 - Flecha no meio do vão da viga V1, AURICH e CAMPOS FILHO (2003) 


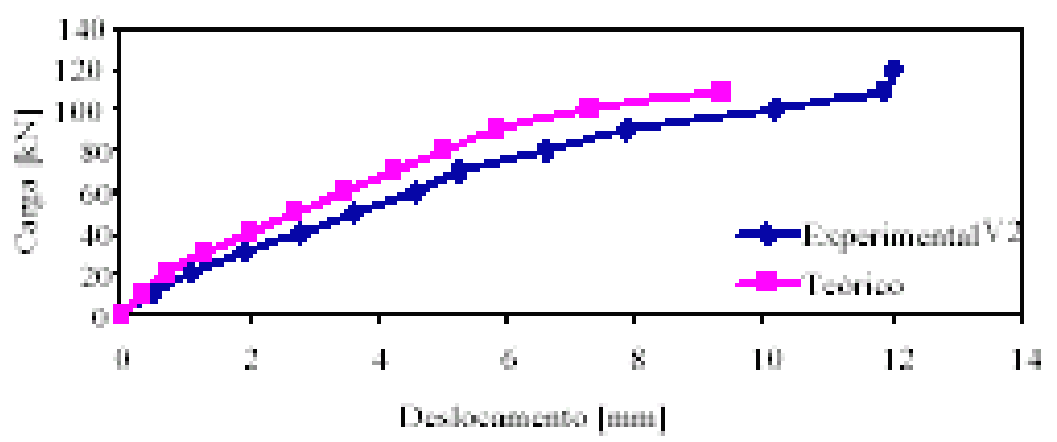

Figura 2.42 - Flecha no meio do vão da viga V2, AURICH e CAMPOS FILHO (2003)

A Figura 2.43 apresenta a curva carga x deformação na armadura longitudinal inferior para a viga V1, e a Figura 2.44 mostra a tensão de aderência na interface do reforço ao longo do comprimento da viga V2, para diferentes níveis de carga.

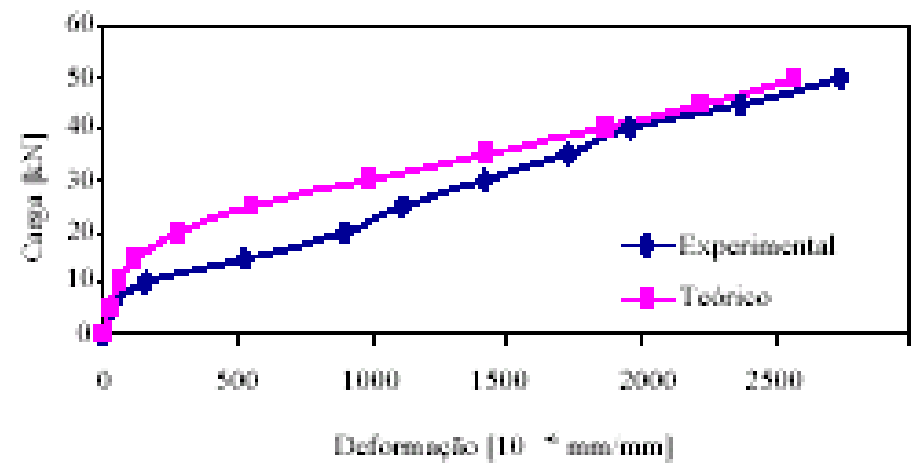

Figura 2.43 - Deformação na armadura da viga V1, AURICH e CAMPOS FILHO (2003)

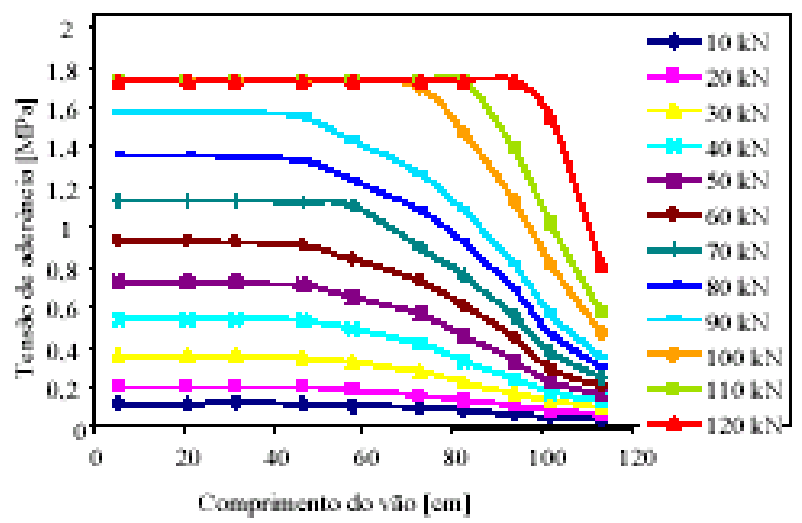

Figura 2.44 - Tensão de aderência na interface do reforço da viga V2, AURICH e CAMPOS FILHO (2003) 
Os resultados alcançados foram considerados excelentes frente à maioria dos resultados experimentais analisados. O estudo evidenciou uma ótima precisão do modelo implementado para a previsão das tensões normais e de aderência ao longo das barras da armadura e elementos de reforço. A concordância entre os valores confrontados é uma indicação da validade do modelo proposto para o estudo de outras situações nas estruturas de concreto armado.

MAGGI (2004) apresenta um trabalho numérico e experimental para estudar o comportamento de pavimentos de concreto armado submetidos a cargas verticais estáticas e cargas cíclicas. Na análise numérica foi utilizado o programa $\mathrm{ABAQUS}^{3}$, baseado no MEF. O modelo do concreto utilizado na análise permitiu levar em conta a fissuração, o comportamento pós-fissuração, o comportamento plástico na compressão e a presença da armadura. Para simular o concreto foram utilizados elementos contínuos tridimensionais com oito nós, com interpolação linear e integração completa. $O$ ABAQUS possibilita a introdução das barras posicionadas no elemento de concreto; esses elementos são unidimensionais e denominados "rebar". Nas aproximações do modelo o comportamento do concreto é considerado independente do das barras de aço; os efeitos associados à interface do aço e do concreto envolvente são simulados pelo comportamento pós-fissuração. A autora concluiu que o modelo numérico desenvolvido no trabalho representou bem o comportamento dos pavimentos de concreto armado, fornecendo uma grande flexibilidade à análise estrutural permitindo avaliar diversas posições do carregamento e diferentes condições de contorno. No modelo numérico não foram consideradas as cargas cíclicas.

Como fechamento do que foi levantado nesta breve revisão bibliográfica, podese afirmar diante das constatações observadas:

- O modo de ruptura por aderência é influenciado por diversos fatores, dentre os quais podem ser destacados a resistência do concreto à compressão, as tensões de tração radiais ou tangenciais desenvolvidas em volta da barra, a presença de fissuras longitudinais, o escoamento do aço, a presença de nervuras na barra e a história do carregamento.

- Para o concreto armado, principalmente para os de resistência da ordem de $30 \mathrm{MPa}$, existe um grande número de pesquisas que estudaram (e continuam a

\footnotetext{
${ }^{3}$ Versão 6.3
} 
estudar) a influência das cargas monotônicas e cíclicas no comportamento da aderência.

- Muitos trabalhos se concentraram na formulação analítica de modelos representativos da aderência.

- Muitos outros trabalhos apresentam modelos numéricos cada um dos quais visando melhor representar o fenômeno da aderência; quase todos utilizam o MEF.

- Outro tanto de trabalhos se concentraram na análise experimental na tentativa de comprovar a veracidade de soluções analíticas e/ou numéricas ou mesmo no afã de descobrir novos conceitos. Alguns desenvolveram conjuntamente a análise numérica e experimental.

- Poucos foram os trabalhos encontrados que utilizaram elementos finitos para representar a interface entre o aço e o concreto.

- Poucos trabalhos foram encontrados que relacionam a perda de rigidez global da estrutura com a perda de rigidez de aderência.

- Poucos foram os trabalhos que se dedicaram ao estudo da perda de rigidez em vigas submetidas a carregamento cíclico.

- Não foi encontrado na literatura nacional trabalho algum que implemente a barra de aço como elemento separado do concreto envolvente e considere suas nervuras como parte integrante da superfície de interação aço-concreto com a intenção de obter uma modelagem mais realista. 


\section{Capítulo 3}

\section{ANÁLISE NUMÉRICA}

\subsection{CONSIDERAÇÕES INICIAIS}

Antes mesmo de iniciar a presente análise é bom ter em mente algumas verdades sabidas e consolidadas no atual estágio em que se encontra o conhecimento do material concreto armado, tais como:

Nenhum modelo matemático é capaz de descrever completamente a resistência de concretos reais sobre todas as situações de carregamento possíveis. Mesmo se tal modelo fosse desenvolvido, ele seria muito complexo para servir de base para análise de tensões de problemas práticos. (CHEN, 1982).

Mesmo antes da aplicação de qualquer carregamento o concreto já apresenta um processo de microfissuração resultante do fenômeno da retração e da liberação de calor durante a cura. Essa microfissuração inicial é, portanto, responsável pelo comportamento nãolinear do concreto mesmo para baixos níveis de tensão. As diferentes características de resistência entre os agregados graúdos e a argamassa propiciam a propagação 
das fissuras. Além disso, outros fatores tais como a textura e tamanho dos agregados, índice de vazios, fator água-cimento influenciam o comportamento mecânico global do concreto. (PROENÇA, 1988, p.1.8).

O deslizamento entre uma barra de aço e o concreto envolvente é causado, principalmente, pelo esmagamento do concreto na região das nervuras tendo como conseqüência a formação de micro-fissuras. $\mathrm{O}$ estado de fissuração modifica a resposta do concreto ao carregamento. (ELIGEHAUSEN ET AL, 1983, p.5).

Pois bem, diante dessas e de outras constatações, tudo isso nos leva a aceitar que o concreto é mesmo um material de comportamento complexo. A não linearidade decorrente da fissuração, proveniente de causas diversas e por vezes desconhecidas (algumas apontadas aqui), portanto, torna bastante complexa a execução de uma simulação numérica que permita reproduzir fielmente o comportamento do concreto ao longo de um processo de carregamento.

Neste trabalho o MEF é utilizado para avaliar, primordialmente, os níveis de tensões de aderência, o deslizamento relativo entre as superfícies na interface açoconcreto e a perda de rigidez da estrutura pela degradação progressiva da seção transversal da estrutura, utilizando-se, para tanto, dos múltiplos recursos do programa comercial ABAQUS, disponível no laboratório de computação do SET. No que segue serão fornecidas algumas informações, julgadas de interesse, sobre os principais passos na elaboração dos modelos numéricos utilizados na análise.

\subsection{ELEMENTOS FINITOS DISPONÍVEIS}

Cada tipo de elemento usado na composição da malha de um determinado modelo é reconhecido por algumas características próprias. O nome de cada elemento está associado à família a que pertence, aos graus de liberdade, ao número de nós, à formulação empregada e ao modo de integração. $\mathrm{Na}$ análise serão utilizados basicamente elementos axisimétricos e tridimensionais. Para exemplificar, sejam os elementos tridimensionais mostrados na Figura 3.1. 


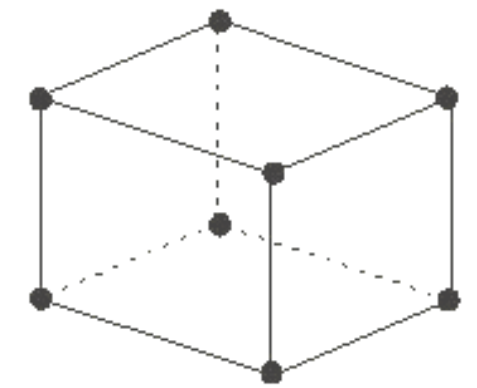

a) elemento linear

(8 nós, C3D8)

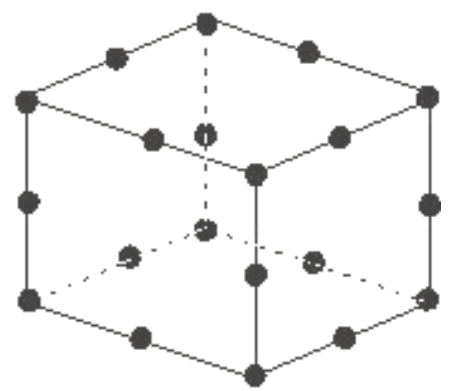

(b) elemento quadrático (20 nós, C3D20)

Figura 3.1 - Elementos tridimensionais (Abaqus v.6.3)

O C3D8 é um elemento contínuo (C), tridimensional (3D), com oito nós (8) e formulação baseada numa interpolação de $1^{\mathrm{a}}$. ordem ou linear. O C3D20 é um elemento contínuo, tridimensional, com 20 nós e interpolação de $2^{\mathrm{a}}$. ordem ou quadrática. Opcionalmente a integração pode ser reduzida (a letra $\mathbf{R}$ depois do $\mathbf{8}$ ou do $\mathbf{2 0}$ ) se contrapondo ao caso natural onde o número de pontos de integração é cheio. Sejam, também, os elementos axisimétricos mostrados na Figura 3.2.
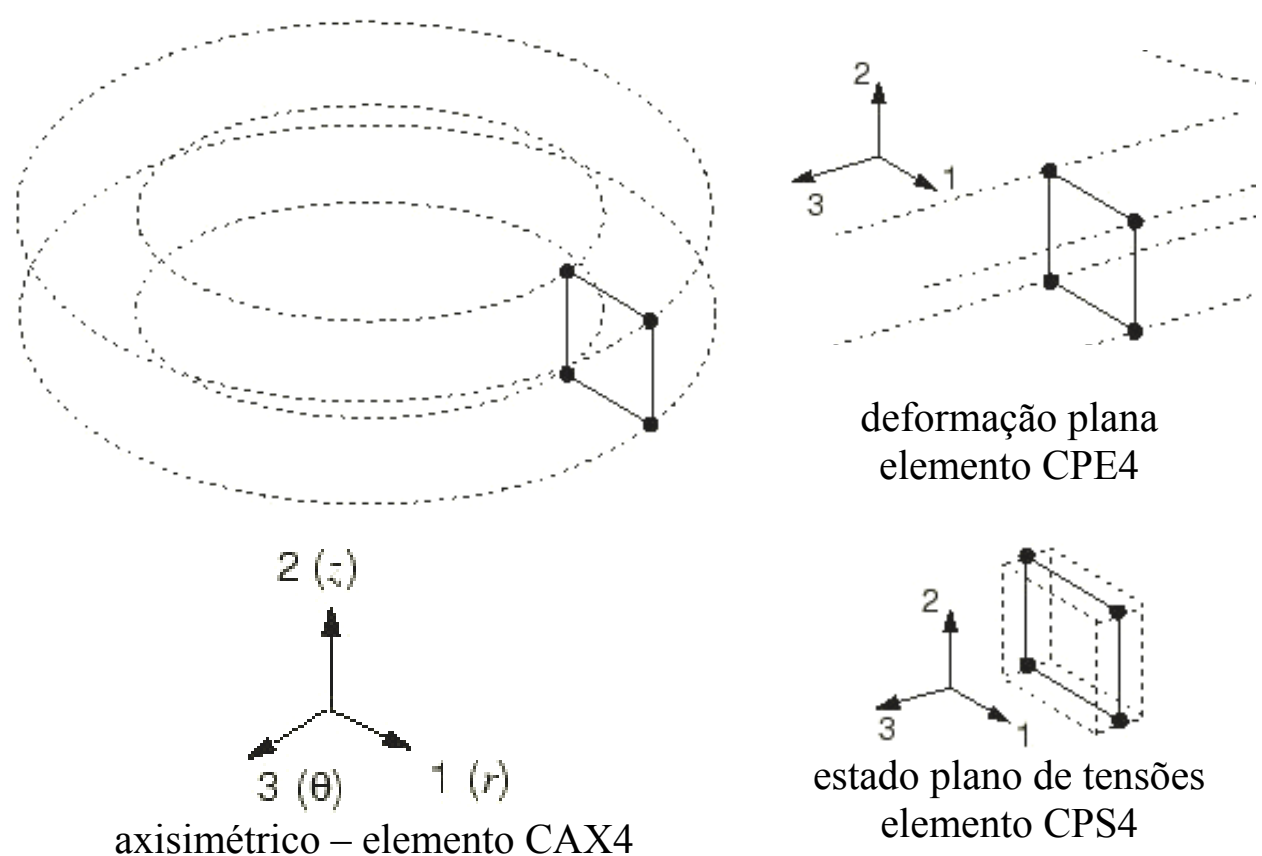

Figura 3.2 - Elementos do tipo axisimétrico (Abaqus v. 6.3)

O CAX4, por exemplo, é um elemento contínuo (C), axisimétrico (AX), com quatro nós (4) e formulação linear. É possível gerar sólidos 3D a partir de elementos axisimétricos revolvendo-os em torno de um eixo de simetria, como mostrado na Figura 3.2 . 


\subsection{MODELOS CONSTITUTIVOS}

O programa disponibiliza uma grande variedade de modelos constitutivos para descrever o comportamento de diversos materiais. Durante uma análise não linear, do ponto de vista numérico, a implementação de um modelo constitutivo envolve a integração do estado do material num ponto de integração até um incremento de tempo. Os modelos constitutivos mecânicos contidos no programa geralmente consideram respostas elásticas e inelásticas. Para respostas inelásticas, além dos modelos plásticos baseados na teoria da plasticidade, estão disponíveis também modelos com conceito da mecânica do dano. A distinção entre os dois conceitos é que na teoria da plasticidade a elasticidade não é afetada pela deformação inelástica enquanto que os modelos de dano incluem a degradação da elasticidade causada pela aplicação de severo carregamento, tal como a perda de rigidez elástica sofrida por um espécime de concreto após ser submetido a um grande carregamento axial de compressão.

Os modelos constitutivos usados para o concreto armado, nesta pesquisa, podem ser divididos em duas partes:

1) um modelo elástico para o concreto e para o aço;

2) um modelo inelástico com dano para o concreto e um modelo elasto-plástico perfeito para o aço.

Serão feitas, adiante, sucintas considerações apenas para o concreto do segundo modelo.

O modelo de dano plástico para o concreto, no ABAQUS chamado de “Concrete Damaged Plasticity”, pode ser utilizado em análises com carregamento cíclico, para baixas pressões de confinamento. Os principais mecanismos de ruptura são a fissuração na tração e o esmagamento na compressão. O comportamento frágil do concreto desaparece quando as pressões de confinamento são suficientemente grandes para prevenir a propagação de fissuras. Nessas circunstâncias a ruptura passa a ser governada pelo colapso da microestrutura microporosa do concreto levando a uma resposta microscópica que lembra aquela de um material dúctil trabalhando com endurecimento. Portanto, o modelo visa capturar os efeitos do dano irreversível associado com os mecanismos de ruptura que ocorrem no concreto, para baixas pressões de confinamento, o que, no caso, atende ao que se deseja nesta pesquisa. Esses efeitos são manifestados através de algumas importantes propriedades, a saber: 
- diferentes tensões limites para a tração e compressão, sendo a tensão limite de tração da ordem de $10 \%$ da tensão limite de compressão;

- diferentes degradações da rigidez elástica em tração e em compressão;

- efeitos de recuperação da rigidez durante carregamento cíclico;

- $\quad$ aumento da tensão de pico com a taxa de deformação.

Além disso, as equações constitutivas elasto-plásticas são construídas estabelecendo-se para o modelo:

- uma decomposição aditiva para o tensor das deformações totais

- uma lei de evolução do tensor de deformações plásticas

- um critério de danificação

- uma lei de evolução do vetor que reúne os parâmetros de dano.

A expressão da deformação total $\varepsilon$ é obtida em função da parte elástica ( $\left.\varepsilon^{\varepsilon}\right)$ e da parte plástica da deformação $\left(\varepsilon^{\mathbf{p}}\right)$,

$$
\varepsilon=\varepsilon^{\varepsilon}+\varepsilon^{p}
$$

A decomposição da taxa de deformação é admitida para o modelo e pode ser escrita da forma:

$$
\dot{\varepsilon}=\dot{\varepsilon}^{\varepsilon}+\dot{\varepsilon}^{p}
$$

onde $\dot{\varepsilon}$ é a taxa de deformação total, $\dot{\varepsilon}^{\varepsilon}$ é a parte elástica da taxa de deformação e $\dot{\varepsilon}^{\mathbf{p}}$ é a parte plástica da taxa de deformação.

As relações tensão-deformação são governadas pelo dano elástico escalar traduzido pela expressão:

$$
\sigma=(1-d) D_{0}^{\varepsilon} \cdot \varepsilon^{\varepsilon}
$$

ou ainda,

$$
\sigma=(1-d) D_{0}^{\varepsilon}:\left(\varepsilon-\varepsilon^{p}\right)=D^{\varepsilon}:\left(\varepsilon-\varepsilon^{p}\right)
$$

onde $D_{0}{ }^{\varepsilon}$ é a rigidez elástica inicial (sem danificação) do material; $D^{\varepsilon}=(1-d) D_{0}{ }^{\varepsilon}$ é a rigidez elástica danificada do material e d é a variável de dano escalar podendo tomar valores de zero (material sem dano) a um (material completamente danificado), ou seja, $\mathbf{0} \leq \mathbf{d} \leq \mathbf{1}$. Dentro do contexto da teoria do dano escalar a degradação da rigidez é isotrópica e caracterizada por uma simples variável de degradação d. O dano associado com os mecanismos de ruptura do concreto (fissuração e esmagamento) resulta numa redução da rigidez elástica. 
A tensão efetiva é definida como:

$$
\bar{\sigma}=D_{0}^{\varepsilon}:\left(\varepsilon-\varepsilon^{p}\right)
$$

e, portanto, a tensão de Cauchy é relacionada à tensão efetiva como:

$$
\sigma=(1-d) \bar{\sigma}
$$

Para uma dada seção transversal do material o fator (1-d) representa a proporção da área efetiva ( $A_{\text {eff }}$ ) para a área total $\left(A_{0}\right)$, ou seja, a área total menos a área danificada $\left(A_{d}\right)$, conforme esclarece a Figura 3.3.

Quando a área está íntegra $\left(\mathrm{A}_{0}\right)$, sem dano $(\mathbf{d}=0)$, a tensão efetiva é equivalente à tensão de Cauchy.

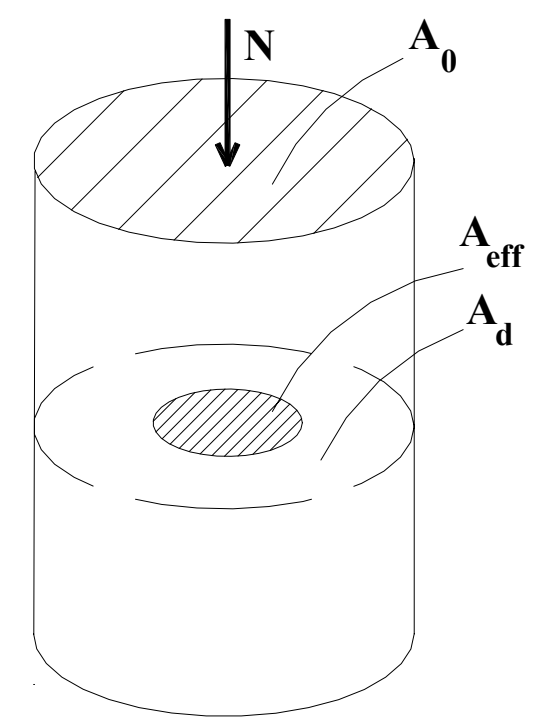

\section{Figura 3.3 - Área efetiva e área danificada}

Quando, no entanto, ocorre dano a tensão efetiva é mais representativa que a tensão de Cauchy porque é a área efetiva quem realmente resiste às cargas externas. Portanto, é conveniente formular o problema da plasticidade em função da tensão efetiva e pode-se então dizer que a evolução da variável de dano d é governada pelas variáveis de deformação plástica e pela tensão efetiva; ou seja,

$$
d=d\left(\bar{\sigma}, \varepsilon^{p}\right)
$$

Estados de danificação em tração e compressão são caracterizados independentemente por duas variáveis de plastificação $\varepsilon_{\mathbf{t}}^{\mathbf{p}}$ e $\varepsilon_{\mathbf{c}}^{\mathbf{p}}$, respectivamente deformação plástica de tração e de compressão. A evolução dessas variáveis é governada pela relação descrita abaixo,

$$
\dot{\varepsilon}^{p}=h\left(\bar{\sigma}, \varepsilon^{p}\right) \cdot \dot{\varepsilon}^{p}
$$


onde a microfissuração e o esmagamento no concreto são representados pelo aumento do valor dessas variáveis, que, por outro lado, controlam a evolução da função limite de dano $\mathbf{F}$ e a perda de rigidez elástica. A função $\mathbf{F}$, que representa uma superfície no espaço das tensões efetivas, é dada pela expressão:

$$
F\left(\bar{\sigma}, \varepsilon^{p}\right) \leq 0
$$

O fluxo plástico é governado por um potencial plástico $\mathbf{G}$ dado pela expressão,

$$
\dot{\varepsilon}^{p}=\dot{\lambda} \frac{\partial G(\bar{\sigma})}{\partial \bar{\sigma}}
$$

onde $\dot{\lambda}$ é o multiplicador plástico não negativo e o potencial plástico $\mathbf{G}$ é definido no espaço das tensões efetivas e dado pela função hiperbólica de Drucker-Prager:

$$
G=\sqrt{\left(\varepsilon \sigma_{t 0} \tan \psi\right)^{2}+\bar{q}^{2}}-\bar{p} \tan \psi
$$

Sendo

$$
\bar{p}=-\frac{1}{3} \bar{\sigma}: I
$$

a pressão hidrostática efetiva e

$$
\bar{q}=\sqrt{\frac{2}{3} \bar{S}: \bar{S}}
$$

a tensão efetiva equivalente de Mises, com

$$
\bar{S}=\bar{p} I+\bar{\sigma}
$$

sendo a parte desviatória do tensor de tensão efetiva $\bar{\sigma} ; \psi$ é o ângulo de dilatação medido no plano p-q e $\sigma_{\text {t0 }}$ é a tensão limite de tração do concreto.

A curva tensão-deformação do concreto para o caso uniaxial pode ser representada para a tração e para a compressão como mostra a Figura 3.4. 

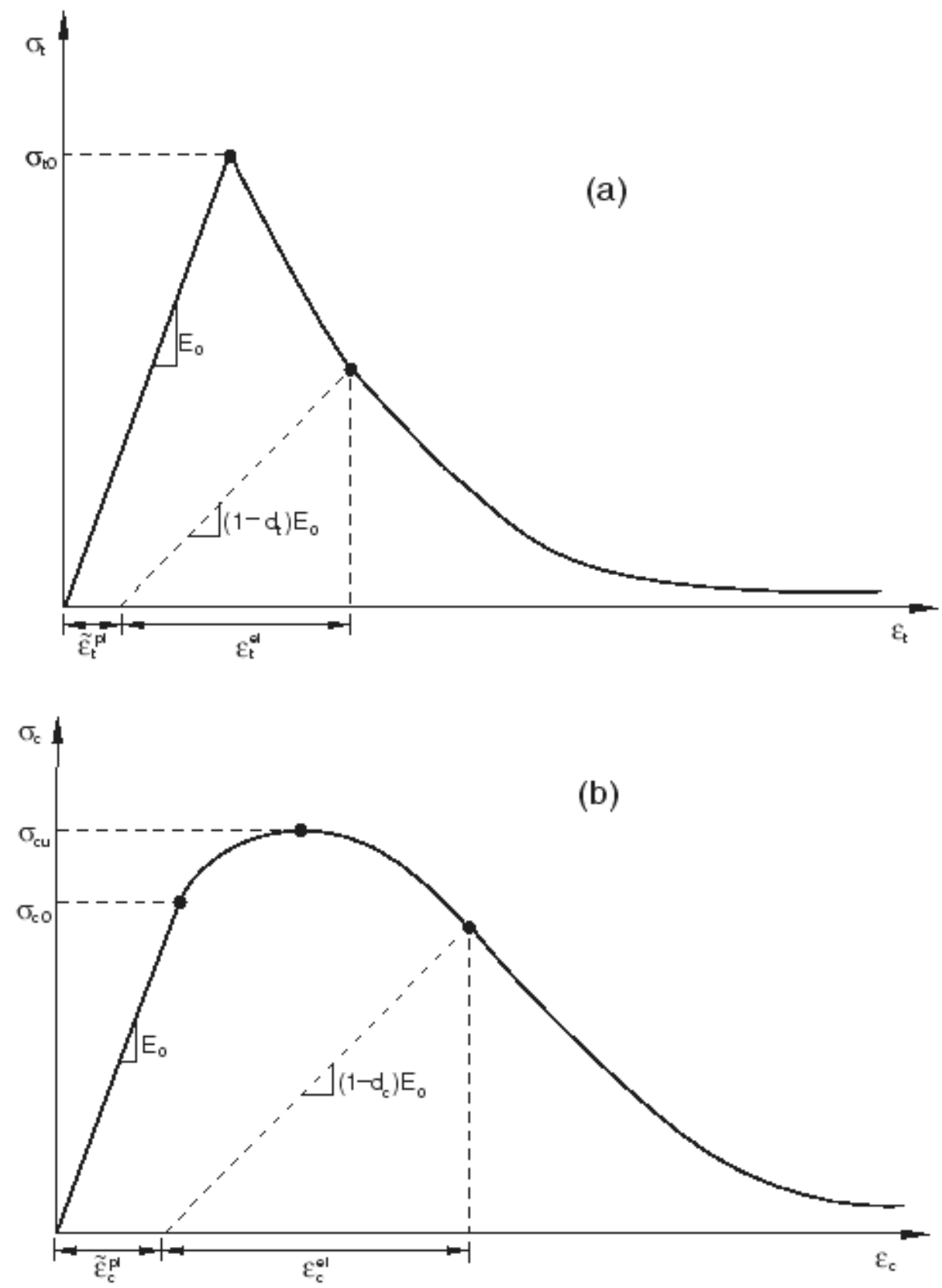

Figura 3.4 - Resposta do concreto para carregamento uniaxial em tração (a) e em compressão (b) (ABAQUS v. 6.3)

\subsection{A ANÁLISE}

As simulações numéricas realizadas neste trabalho foram de dois tipos:

a) Modelagem com CP's cilíndricos de concreto armado;

b) Modelagem de vigas de concreto armado. 
Inicialmente todo o esforço foi concentrado na modelagem dos CP's. Como dito anteriormente, a idéia de realizar essa etapa de análise teve o propósito principal de servir de condutor na busca de um modelo teórico mais propício e eficiente a ser implementado na etapa seguinte; que testasse, também, o comportamento e a eficiência do algoritmo de contato quando simulando o efeito da aderência aço-concreto através do contato entre suas superfícies; pretendeu, ainda, que o ensaio experimental do projeto piloto pudesse servir de calibragem para o modelo teórico utilizado nas vigas.

A análise numérica se deu, portanto, da seguinte forma:

a) Para os CP's cilíndricos:

- modelagem bidimensional axisimétrica, tanto da barra nervurada quanto do concreto envolvente, considerando o contato entre os dois materiais, com modelo constitutivo elástico.

- modelagem bidimensional axisimétrica, tanto da barra nervurada quanto do concreto envolvente, considerando o contato entre os dois materiais, com modelo constitutivo inelástico com dano para o concreto.

- modelagem tridimensional de $1 / 4$ do volume do corpo de prova, tanto da barra nervurada quanto do concreto envolvente, considerando o contato entre os dois materiais, com modelo constitutivo elástico.

- Modelagem tridimensional de 1/4 do volume do corpo de prova, tanto da barra nervurada quanto do concreto envolvente, considerando o contato entre os dois materiais, com modelo constitutivo inelástico com dano para o concreto.

b) Para as vigas de concreto armado:

- modelagem tridimensional para a viga inteira, para $1 / 2$ da viga e para $1 / 4$ da viga, tanto da barra nervurada quanto do concreto envolvente, considerando o contato entre os dois materiais, com modelo constitutivo elástico para ambos os materiais.

- modelagem tridimensional para a viga inteira, para $1 / 2$ da viga e para $1 / 4$ da viga, tanto da barra nervurada quanto do concreto envolvente, considerando o contato entre os dois materiais, com modelo constitutivo inelástico com dano para o concreto e elasto-plástico perfeito para o aço. 


\subsection{SOBRE O CONTATO}

Em problemas de contato envolvendo dois materiais, caso da interface açoconcreto em estudo nesta pesquisa, forças normais às duas superfícies contactantes atuam sobre as duas partes quando uma toca a outra. Havendo atrito entre as superfícies são despertadas forças cisalhantes com a finalidade de resistirem ao movimento tangencial, podendo gerar deslizamento entre as partes. $\mathrm{O}$ alvo das simulações de contato é identificar as áreas das superfícies que estão em contato e calcular as pressões de contato geradas.

Numa análise utilizando o MEF como ferramenta básica, as condições de contato se colocam como uma classe especial de restrições de contato (descontínuas) permitindo a transmissão de forças de uma para a outra parte do modelo. As restrições de contato são descontínuas porque são aplicadas apenas quando as duas superfícies estão em contato. Estando elas separadas nenhuma restrição é aplicada às superfícies. A análise deve ser capaz de detectar quando duas superfícies estão em contato e aplicar corretamente as restrições de contato e, do mesmo modo, remove-las quando estiverem separadas.

Devem ser definidos, também, os modelos constitutivos que governam as interações entre as duas superfícies.

Como dito acima, a interação entre as duas superfícies consiste de duas componentes: uma normal e outra tangencial às superfícies. As restrições de contato são aplicadas quando a abertura entre as duas superfícies se torna zero. Por outro lado, as superfícies se separam quando a tensão de contato entre elas se torna zero ou negativa e, então, as restrições de contato são removidas.

É possível também determinar se ocorreu contato em um determinado ponto; para isso a análise deve calcular o deslizamento relativo entre as duas superfícies, o que, geralmente, leva a um cálculo bastante complexo podendo também criar problemas de convergência. Para contornar esse problema o programa dispõe de duas alternativas: uma onde a magnitude do deslizamento é considerada pequena (small-sliding) e outra quando o deslizamento é finito (finite-sliding); entende-se como pequeno deslizamento, apenas como recomendação geral, o caso em que um ponto em contato com uma superfície não desliza mais que a dimensão do elemento finito utilizado para discretizar aquela superfície. 
Quando existe rugosidade entre as duas superfícies a análise necessita considerar a existência de forças de atrito que resistirão ao movimento relativo ( $\mathbf{s}$ ) entre as duas superfícies. O Modelo de fricção de Coulomb, disponível no programa, é comumente usado para descrever a interação entre duas superfícies. É utilizado o coeficiente de atrito $\mu$ para levar em conta o comportamento friccional entre as duas partes. O produto $\mu \mathbf{p}$ fornece a tensão limite cisalhante de contato para as superfícies em contato, sendo $\mathbf{p}$ a tensão de contato entre as duas superfícies. A Figura 3.5 ilustra bem o comportamento do modelo de Coulomb, onde relaciona as tensões de aderência e o deslizamento.

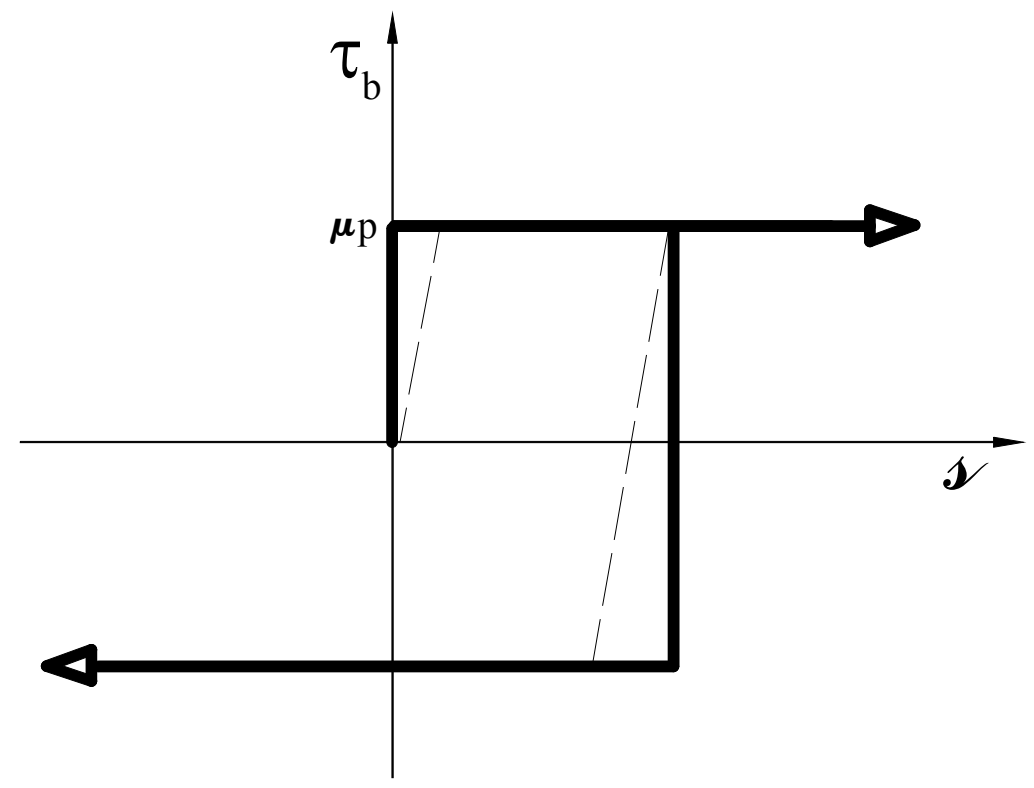

Figura 3.5 - Modelo friccional de Coulomb

Apenas para registro, dois outros modelos de atrito estão disponíveis e podem ser usados na análise: uma formulação friccional com penalização que permite um “deslizamento elástico", sendo esse deslizamento elástico a menor quantidade do movimento relativo entre as superfícies; ocorre quando as superfícies ainda não atingiram a tensão limite $\mu \mathbf{p}$, representado na Figura 3.5 pelas linhas tracejadas; outro modelo, o modelo de Lagrange, utiliza uma maior quantidade de variáveis em cada nó com o propósito de obter um comportamento aderência-deslizamento das superfícies em contato mais próximo do ideal.

É interessante registrar que a inclusão da fricção num modelo adiciona termos não simétricos à matriz de rigidez do sistema. Para valores de $\mu<0.3$ a magnitude e 
influência desses termos são pequenas e regulares de modo que o sistema trabalha bem como matriz simétrica.

Numa simulação de contato, como a desta pesquisa, duas superfícies de contato devem ser criadas e identificadas - uma para o aço e outra para o concreto envolvente. Essas superfícies são chamadas, respectivamente, de mestre (master) e escrava (slave). O programa utiliza um algoritmo de contato apropriado de modo que os nós da superfície escrava não podem penetrar a superfície mestre, conforme esclarece a Figura 3.6.

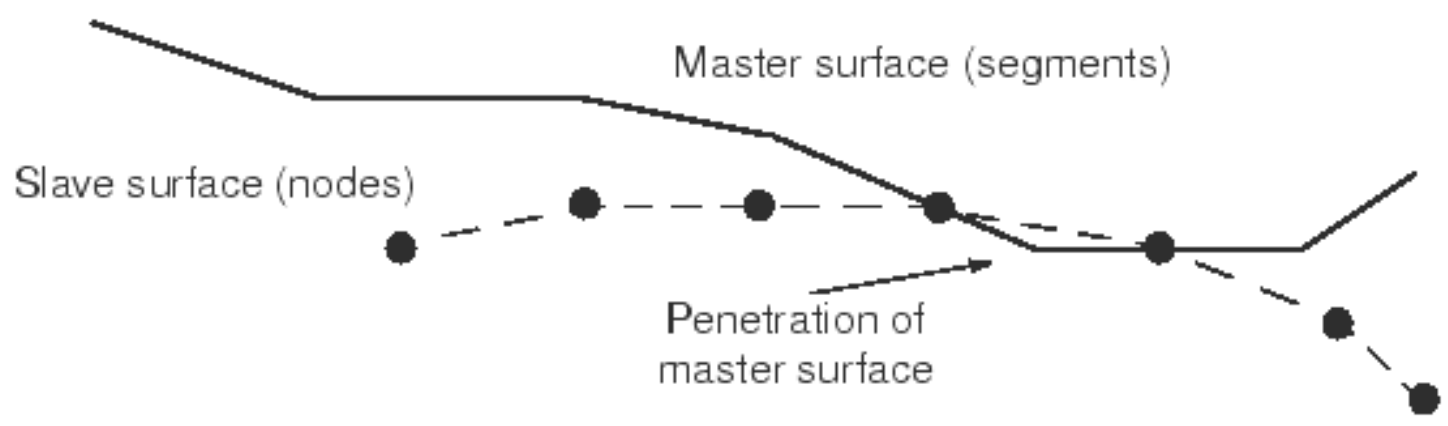

Figura 3.6 - Superfície mestre penetrando a superfície escrava (ABAQUS v. 6.3)

A superfície escrava deve ter a malha mais refinada. Se a malha das duas superfícies for igual, a superfície escrava deve ser a que possui a menor rigidez.

Se a formulação usada é a de pequenos deslizamentos o relacionamento entre os nós das duas superfícies é feito no início da simulação, determinando-se o segmento da superfície mestre que irá interagir com os nós da superfície escrava; esse relacionamento é mantido durante toda a análise, não sendo necessário atualização alguma enquanto as superfícies interagem. Se na análise for considerada não-linearidade geométrica o algoritmo leva em conta qualquer rotação e deformação da superfície mestre e atualiza a direção através da qual as forças de contato são transmitidas.

Por outro lado, se a formulação usada é a de deslizamentos finitos o algoritmo requer que seja determinada constantemente qual parte da superfície mestre está em contato com cada nó da superfície escrava, tornando esse procedimento bastante complexo especialmente se ambas as superfícies forem deformáveis.

Quanto aos elementos a serem utilizados na análise é recomendado, em geral, usar elementos de primeira ordem para as partes que comporão a superfície escrava; elementos de segunda ordem devem ser evitados. 


\subsection{UMA PALAVRA SOBRE O ALGORITMO}

O algoritmo utilizado pelo programa nas simulações de contato é construído em torno de técnicas do tipo Newton-Raphson, como mostra o diagrama da Figura 3.7.

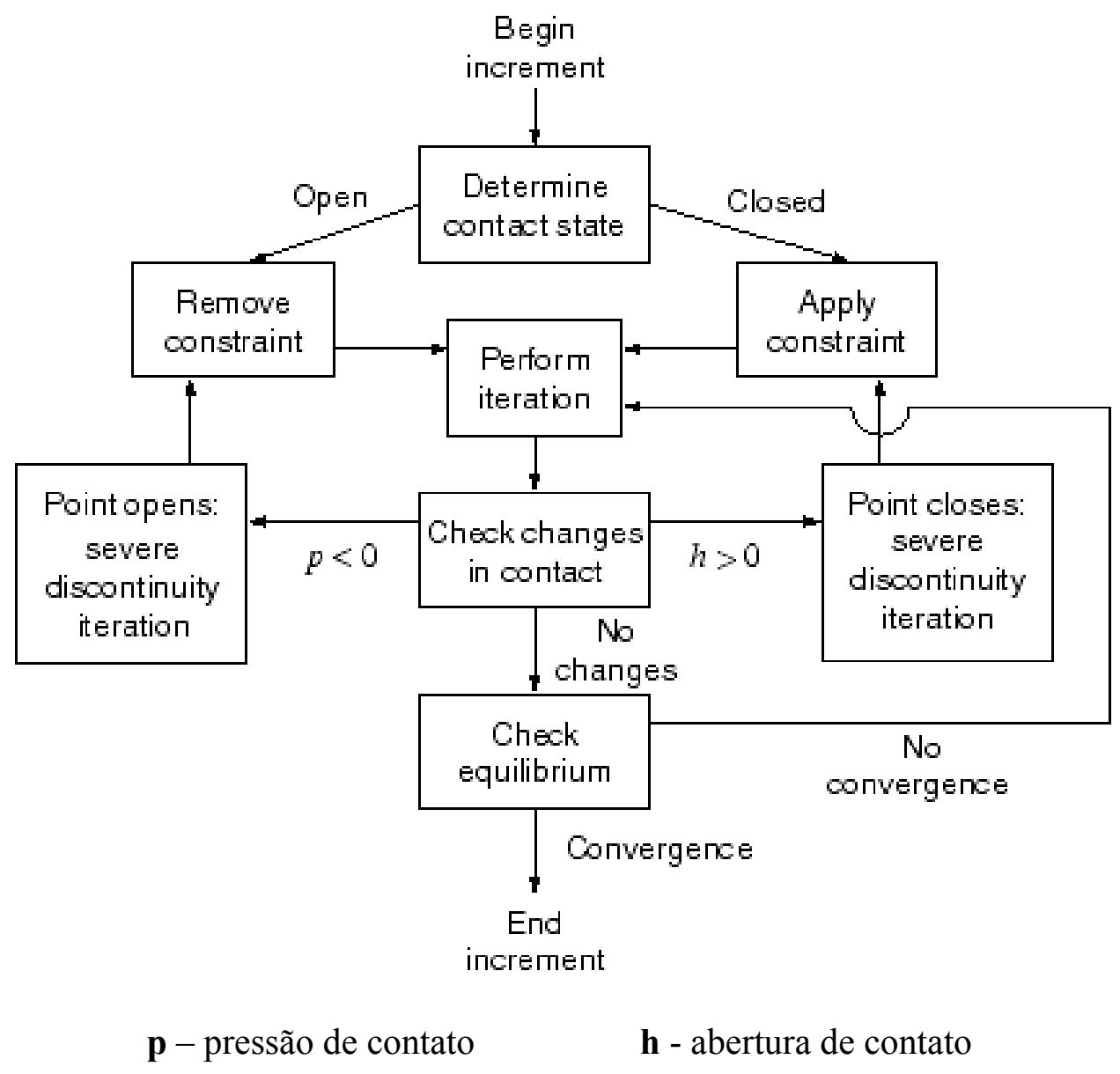

Figura 3.7 - Lógica do algoritmo de contato (ABAQUS v.6.3)

Resumidamente, a lógica do algoritmo segue a seguinte ordem: no início de cada incremento é examinado o estado de todos os pares de contato (cada uma das duas superfícies) para estabelecer se os nós escravos estão abertos ou fechados. Se um nó está fechado determina-se se ele deslizou ou permaneceu parado e aplica-se, então, uma restrição para cada nó fechado e removem-se as restrições de todos os nós onde o estado de contato mudou de fechado para aberto. Feito isso, uma iteração é concluída e a configuração do modelo é atualizada usando as correções efetuadas.

Passando para a etapa seguinte, a etapa de equilíbrio, antes mesmo de verificar o equilíbrio de forças e momentos o algoritmo primeiro verifica as mudanças nas condições de contato nos nós escravos. Qualquer nó escravo onde, após a iteração, a 
abertura de contato se tornou zero ou negativa, mudou de "aberto" para "fechado"; por sua vez, tendo a pressão de contato se tornado negativa, mudou de "fechado" para “aberto". Pois bem, se for detectada qualquer mudança no estado de contato dos nós naquela iteração o algoritmo modifica as restrições de contato, para refletir as mudanças no estado de contato após a primeira iteração e tenta uma segunda iteração, chamada de iteração de severa descontinuidade. Repete-se o procedimento até uma iteração ser completada sem mudanças no estado de contato. Essa iteração, portanto, passa a ser a primeira iteração de equilíbrio e o algoritmo executa a verificação da convergência de equilíbrio. Se o equilíbrio não for alcançado outra iteração é executada. A todo tempo uma iteração de severa descontinuidade pode ocorrer e, então, o algoritmo despreza todas as iterações de equilíbrio já executadas (a quantidade de iterações de equilíbrio será usada para determinar se um incremento deverá ser abandonado devido a uma lenta taxa de convergência). $\mathrm{O}$ algoritmo repete todo o processo até a convergência final ser alcançada.

Separando os dois tipos de iterações, como faz o algoritmo, é possível observar e entender como ele trata o estado de contato dos nós escravos e como é alcançado o equilíbrio. Se o número de iterações de severa descontinuidade é alto porem existem poucas iterações de equilíbrio, o algoritmo está tendo dificuldades para estabelecer as condições de contato. Internamente o algoritmo assume abandonar qualquer incremento onde seja necessário mais que doze iterações de severa descontinuidade e tenta de novo o mesmo incremento com um tamanho de incremento menor.

Detalhadas informações sobre o estado de contato de cada par e sobre a resolução do algoritmo podem ser obtidas com o auxílio de alguns arquivos que são gerados da análise. Seja como exemplo, um modelo qualquer que, ao final da análise, necessitou de cinco iterações totais para alcançar o equilíbrio. A Tabela 3.1 mostra cópia da mensagem que é armazenada num dos arquivos de saída de resultados do programa.

Tabela 3.1 - Relatório de análise (ABAQUS v. 6.3)

\begin{tabular}{|c|c|c|c|c|c|c|c|c|}
\hline STEP & INC & ATT & $\begin{array}{c}\text { SEVERE } \\
\text { DISCON } \\
\text { ITERS }\end{array}$ & $\begin{array}{c}\text { EQUIL } \\
\text { ITERS }\end{array}$ & $\begin{array}{c}\text { TOTAL } \\
\text { ITERS }\end{array}$ & $\begin{array}{c}\text { TOTAL } \\
\text { TIME/FREQ }\end{array}$ & $\begin{array}{c}\text { STEP } \\
\text { TIME/LPF }\end{array}$ & $\begin{array}{c}\text { INC OF } \\
\text { TIME/LPF }\end{array}$ \\
\hline 1 & 1 & 1 & 2 & 3 & 5 & 1.00 & 1.00 & 1.00 \\
\hline
\end{tabular}

O algoritmo de resolução necessitou de duas iterações para estabelecer as condições de contato entre as partes contactantes do modelo, ou seja, se os nós da 
superfície escrava estavam ou não em contato com a superfície mestre. A terceira iteração não produziu qualquer mudança nas condições de contato do modelo de modo a permitir que fossem verificadas as condições de equilíbrio de forças; no entanto, nessa iteração, as condições de convergência de equilíbrio não foram alcançadas o que tornou necessário mais duas iterações, a quarta e a quinta, para se obter a convergência da solução.

\subsection{MODELAGEM}

Para criar e analisar um determinado modelo o programa ABAQUS dispõe, dentre outros ambientes, do ABAQUS/STANDARD e do ABAQUS/CAE. O primeiro exige que seja criado ou importado (do aplicativo ANSYS, por exemplo) um arquivo de dados que contenha todos os comandos exigidos pelo código para que a análise seja realizada. Os resultados tais como deformações, tensões, deslocamentos podem ser observados utilizando uma outra parte do programa chamada ABAQUS/VIEWER. O ABAQUS/CAE, por sua vez, é um ambiente do ABAQUS que oferece uma simples e consistente interface para criar, submeter, monitorar e avaliar os resultados de simulações do ABAQUS/STANDARD. O ABAQUS/CAE está dividido em módulos onde cada módulo define um processo de moldagem como, por exemplo, definir a geometria, as propriedades dos materiais e gerar a malha, gerando o arquivo para processamento. O processador lê o arquivo de entrada gerado, executa a análise e gera uma base de dados de saída. Finalmente é possível visualizar os resultados da análise pelo módulo visualização.

Como anteriormente assinalado as simulações numéricas realizadas neste trabalho foram de dois tipos: modelagem com CP's cilíndricos de concreto armado; e modelagem de vigas de concreto armado. No que segue são apresentados os modelos, os tipos de material, o modelo constitutivo adotado, os elementos finitos usados, a discretização da malha e mostrados e comentados alguns resultados obtidos.

\subsubsection{CP's de concreto armado}

Os CP's de concreto armado foram modelados de duas maneiras: uma modelagem axisimétrica e outra tridimensional. 


\subsubsection{Modelagem Axisimétrica}

Uma das opções para simular o comportamento de CP's de concreto confeccionados com uma barra de aço colocada axialmente, é a modelagem axisimétrica. A Figura 3.8 mostra um corte do CP; mostra também uma seção (aço e concreto) geradora do modelo axisimétrico. Dimensões em mm.

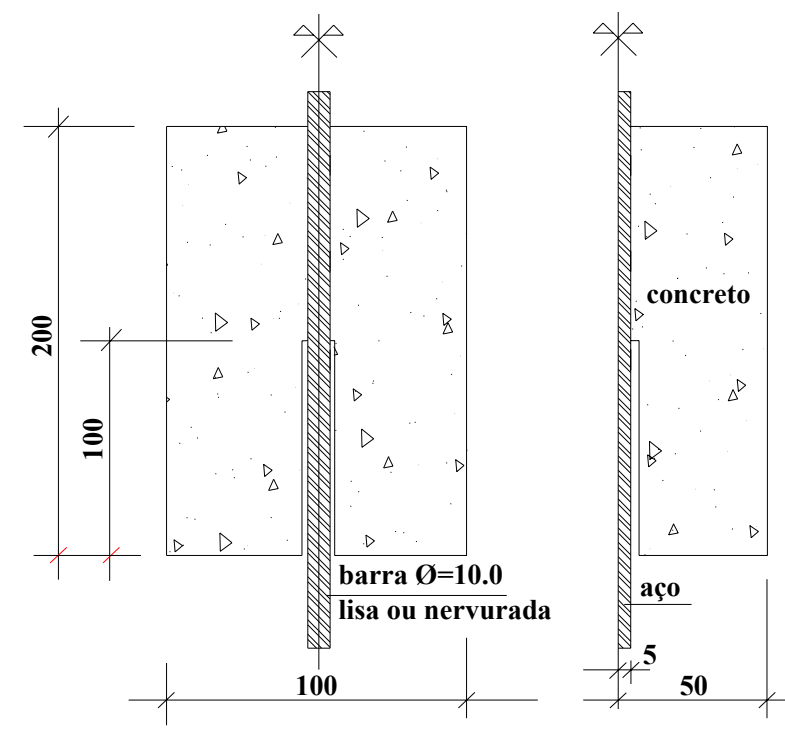

Figura 3.8 - CP com barra de $10.0 \mathrm{~mm}$

Os elementos utilizados na análise, tanto para o aço quanto para o concreto, foram os do tipo CAX4 que são elementos contínuos, axisimétricos, com quatro nós, sendo dois deslocamentos por nó, um radial e outro axial. Permite calcular tensões e deformações nas direções radial, axial e tangencial. Permite, também, determinar o deslizamento relativo entre os nós situados sobre as superfícies de contato (escrava e mestre), na direção axial, que é um dos pontos de interesse na análise.

A numeração dos pontos de integração do elemento está mostrada na Figura 3.9.
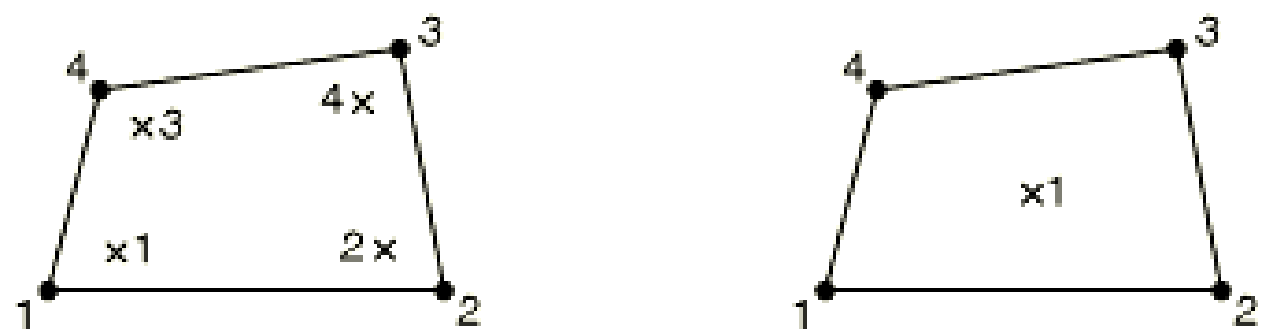

Figura 3.9 - Pontos de integração dos elementos CAX4 e CAX4R 
A análise, não-linear, levou em conta o contato entre o aço e o concreto. $\mathrm{O}$ modelo constitutivo adotado numa primeira abordagem foi elástico, tanto para o aço quanto para o concreto. $\mathrm{O}$ intuito foi apenas o de testar o algoritmo de contato, os elementos utilizados e os passos de carga.

Com o ABAQUS/CAE, utilizando-se dos seus diversos módulos, foi possível criar o modelo axisimétrico representativo dos CP's de concreto armado. A Figura 3.10 mostra as partes (criadas no módulo parte) que representam, respectivamente, a barra de aço, com suas nervuras, e o concreto que a envolve.

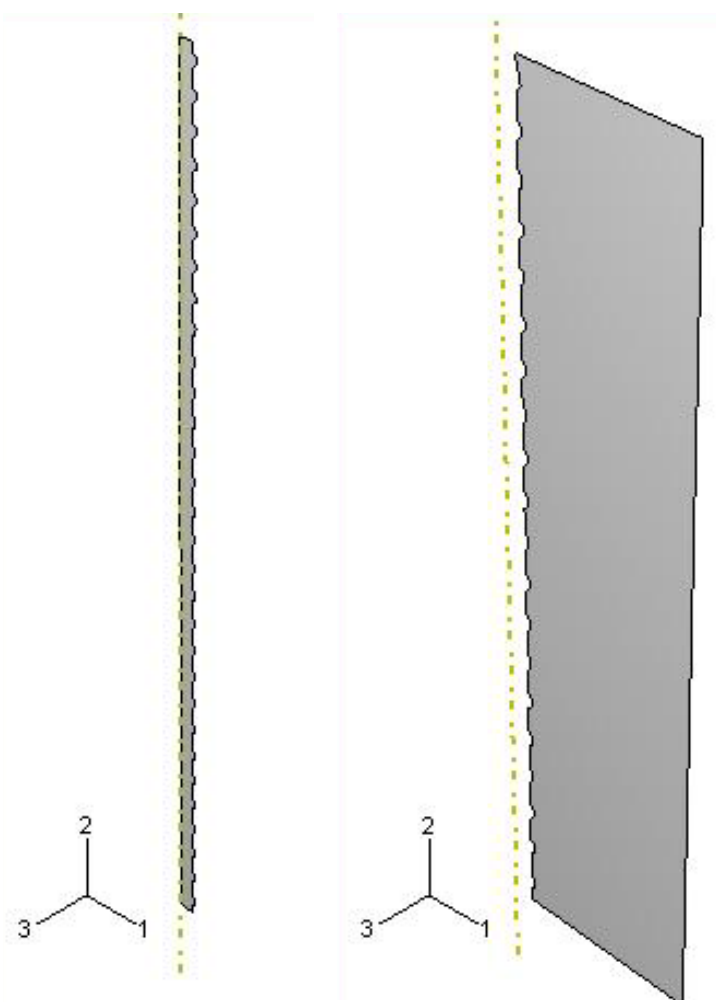

Figura 3.10 - Partes do modelo - barra nervurada e concreto envolvente

Importante na análise é definir com cuidado as superfícies de contato entre as partes. Na Figura 3.11 são mostradas, respectivamente, as superfícies de contato da barra de aço e do concreto. Elas aparecem na cor vermelha. Na Figura 3.12 as superfícies de contato são mostrados com mais detalhe. 

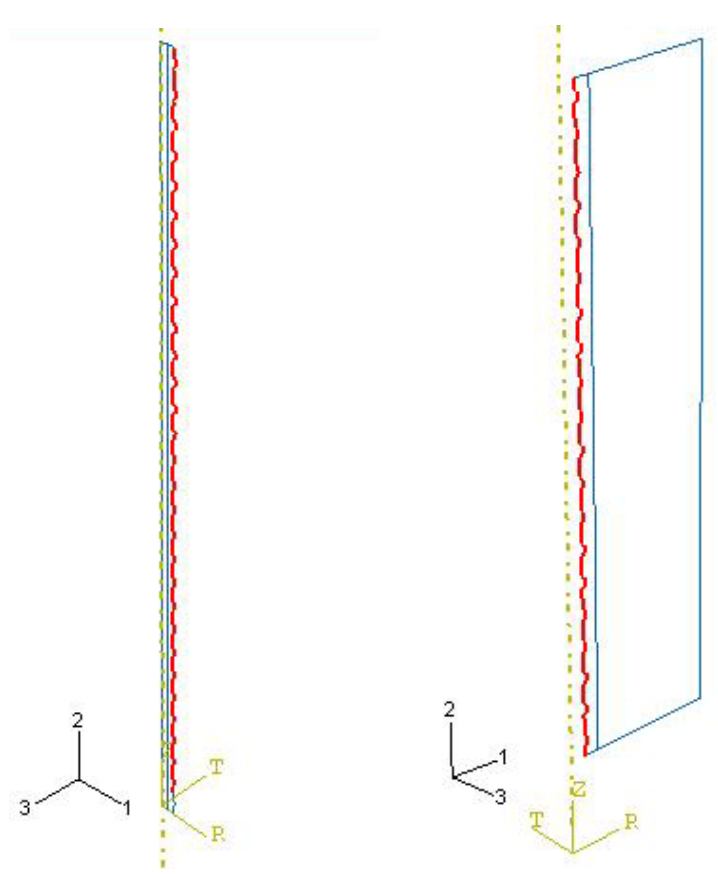

Figura 3.11 - Superfícies de contato para o aço e para o concreto
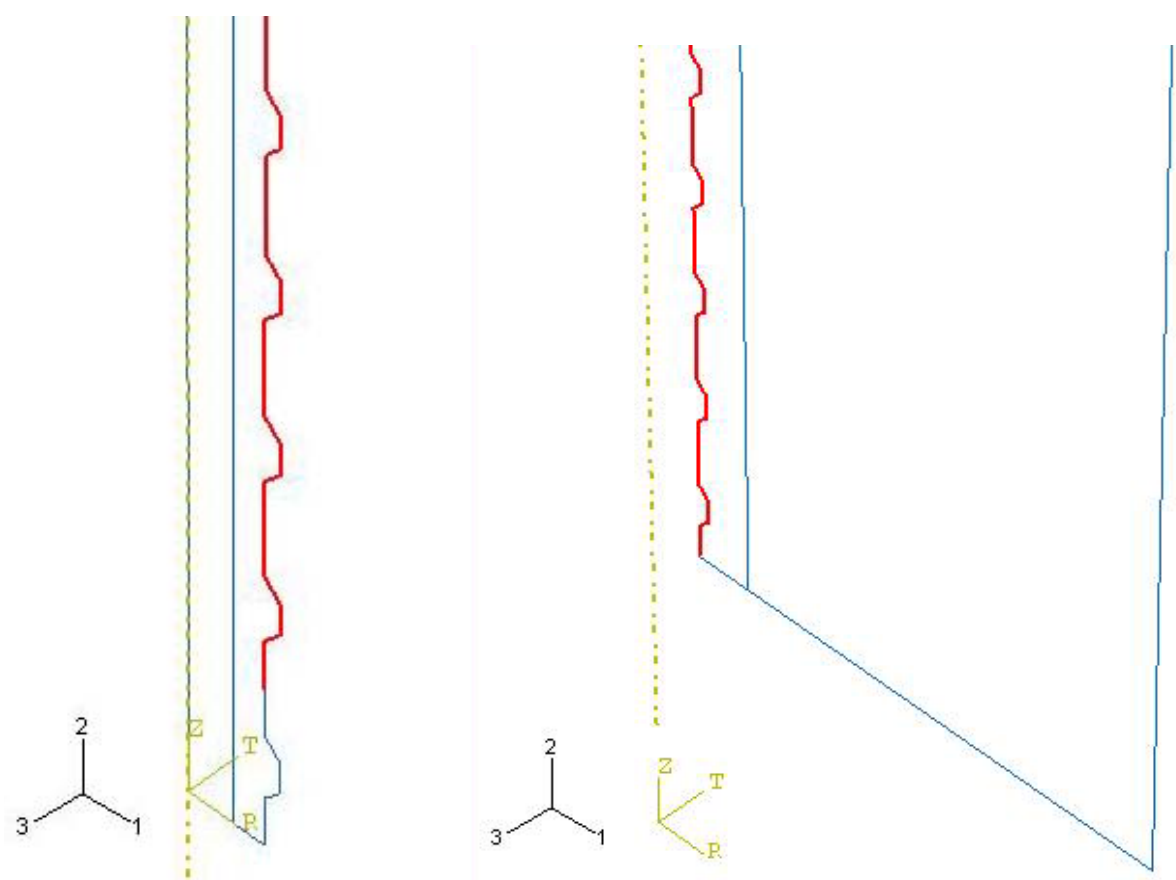

Figura 3.12 - Detalhe das superfícies de contato

A malha de elementos finitos e destaque para os elementos utilizados tanto para a barra quanto para o concreto estão mostrados na Figura 3.13. 


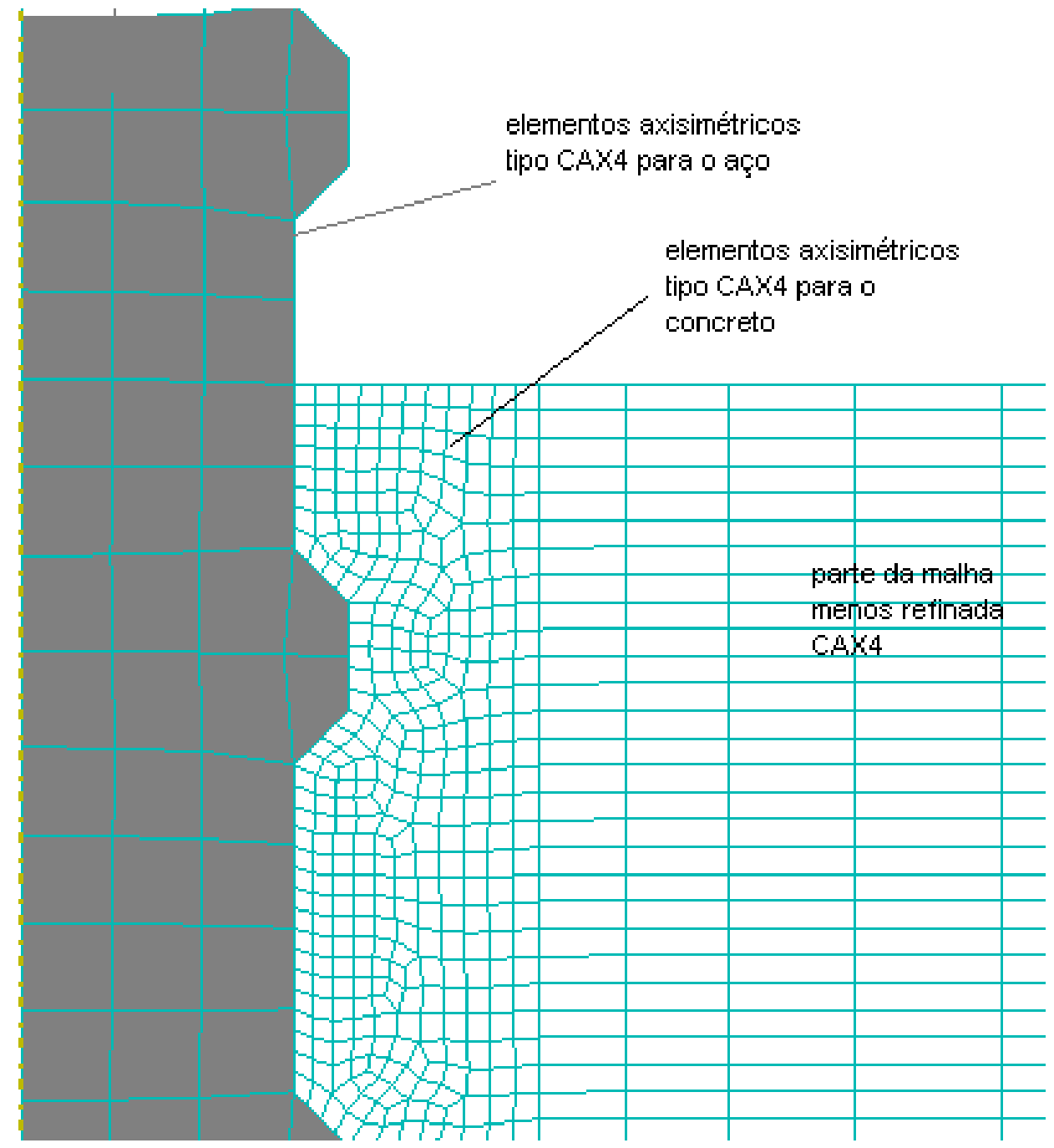

Figura 3.13 - Malha e elemento finito utilizado para o aço e para o concreto

Concluída a análise os resultados podem ser vistos através o módulo visualização, como, por exemplo, tensões de Mises, deformada, etc. Da Figura 3.14 até a Figura 3.18 são apresentados alguns resultados sob o ponto de vista apenas da visualização. 

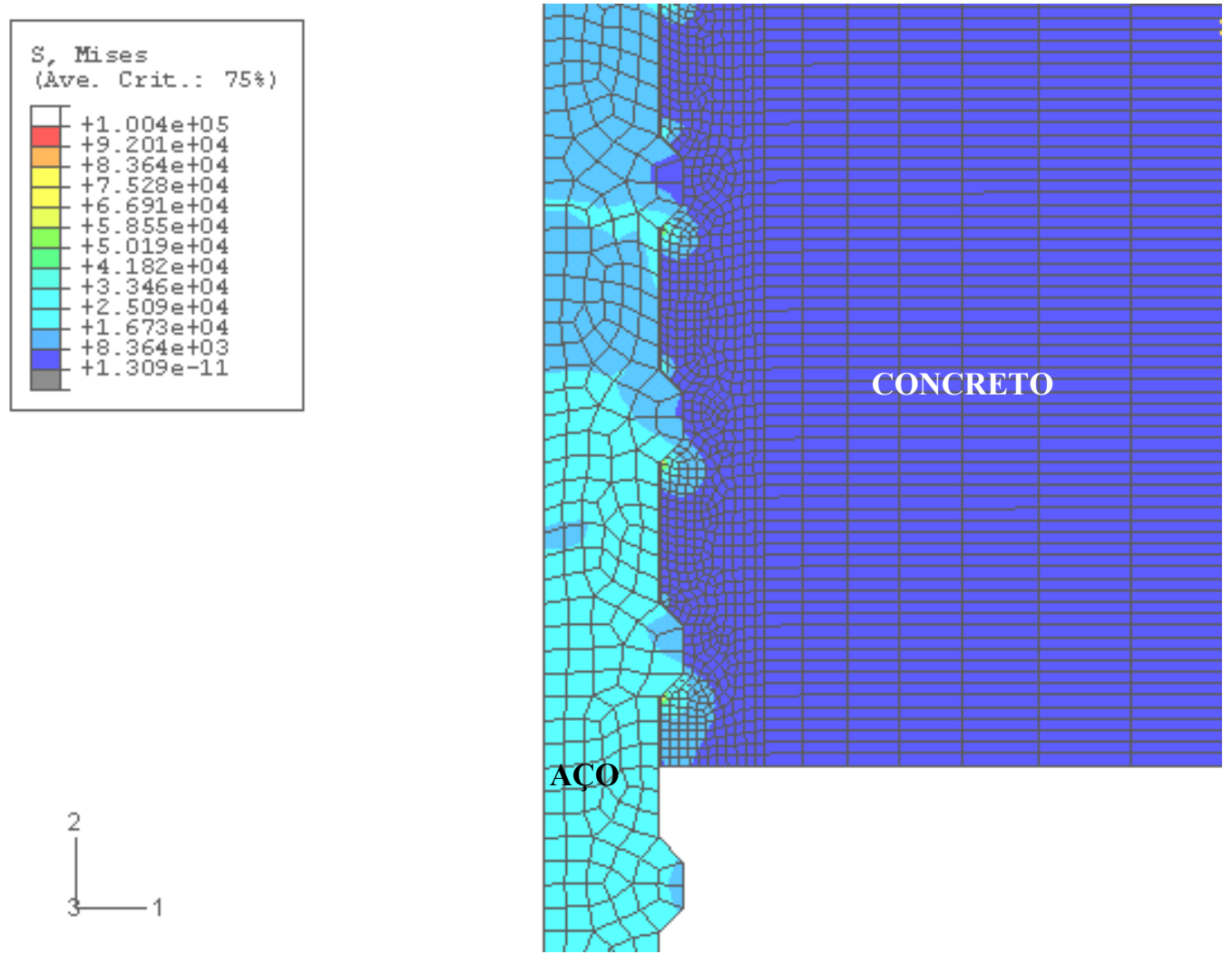

Figura 3.14 - Aspecto das tensões na direção 2 (axial)

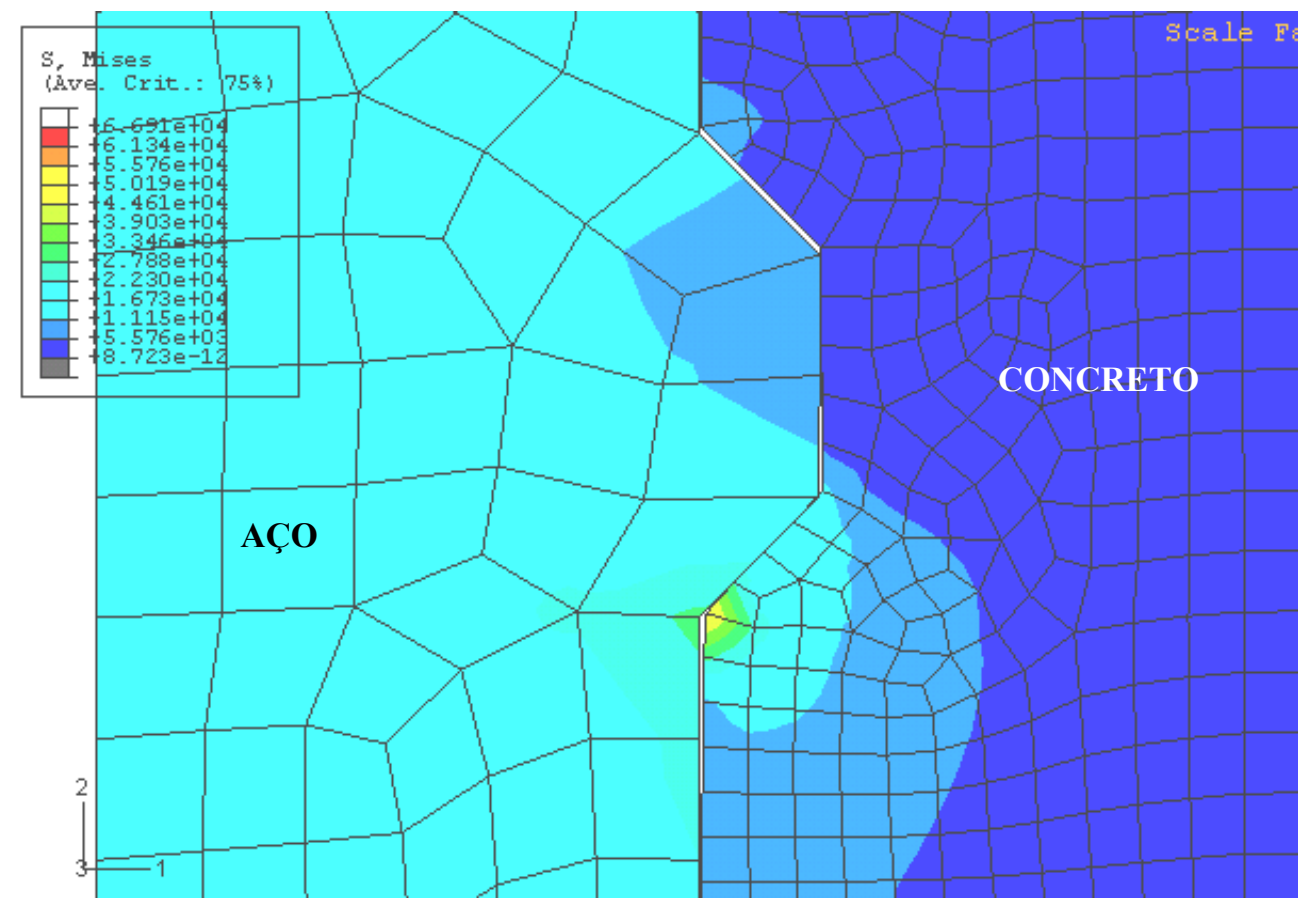

Figura 3.15 - Detalhe do descolamento do concreto num lado na nervura (tração) e compressão no outro lado da nervura (esmagamento), para 30\% da carga aplicada 


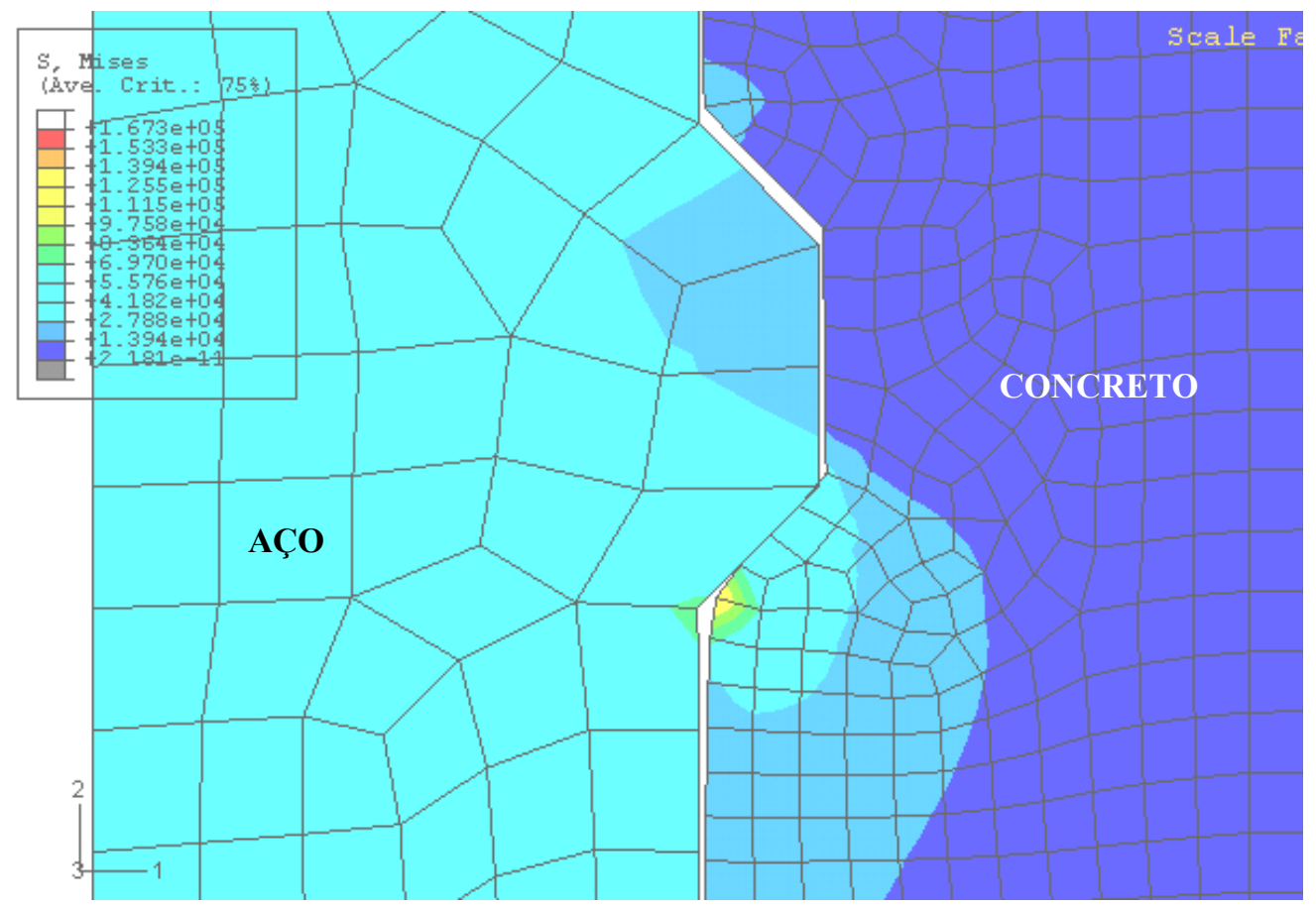

Figura 3.16 - Detalhe do descolamento do concreto num lado na nervura (tração) e compressão no outro lado da nervura (esmagamento), para $70 \%$ da carga aplicada

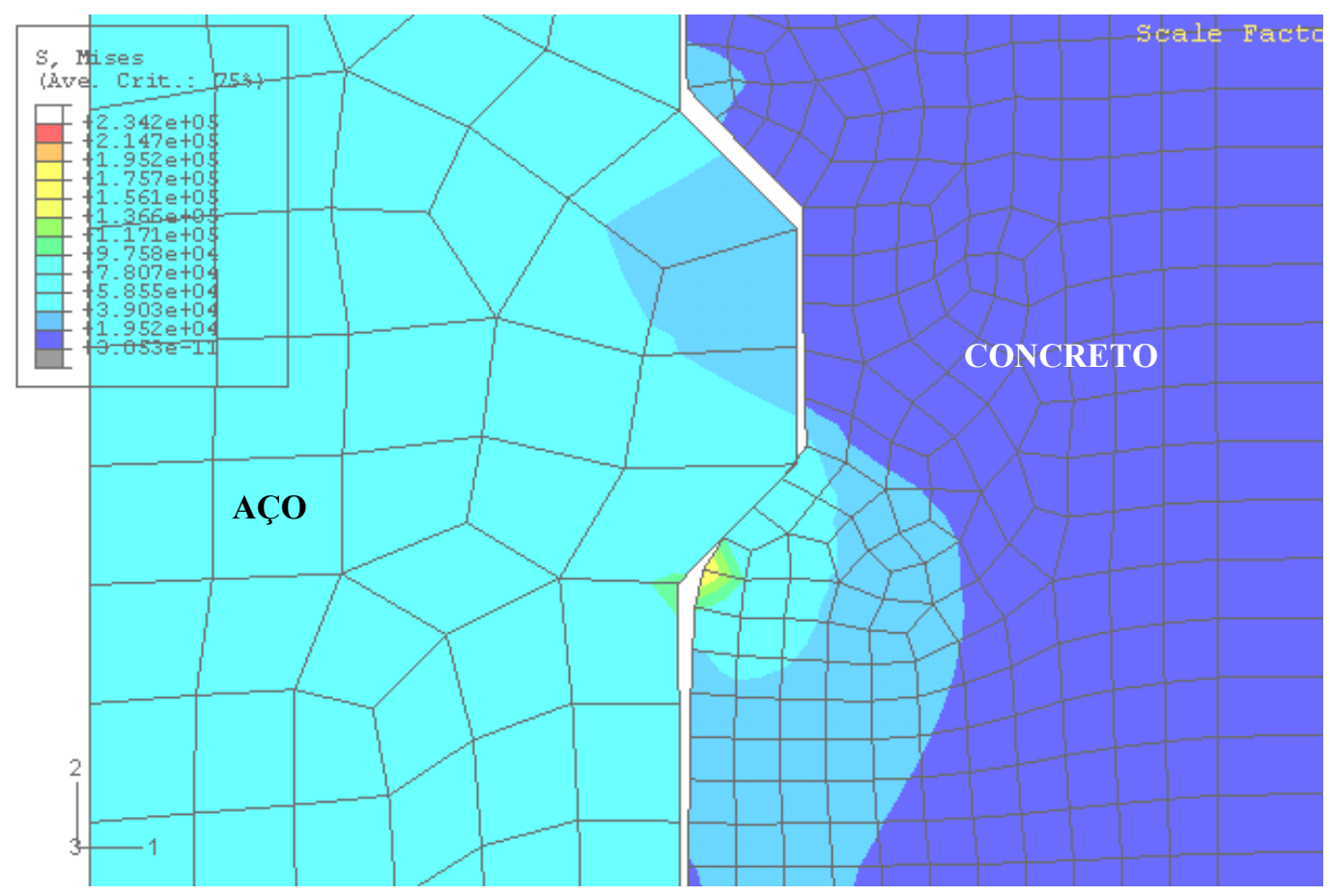

Figura 3.17 - Detalhe do descolamento do concreto num lado na nervura (tração) e compressão no outro lado da nervura (esmagamento), para 100\% da carga aplicada 


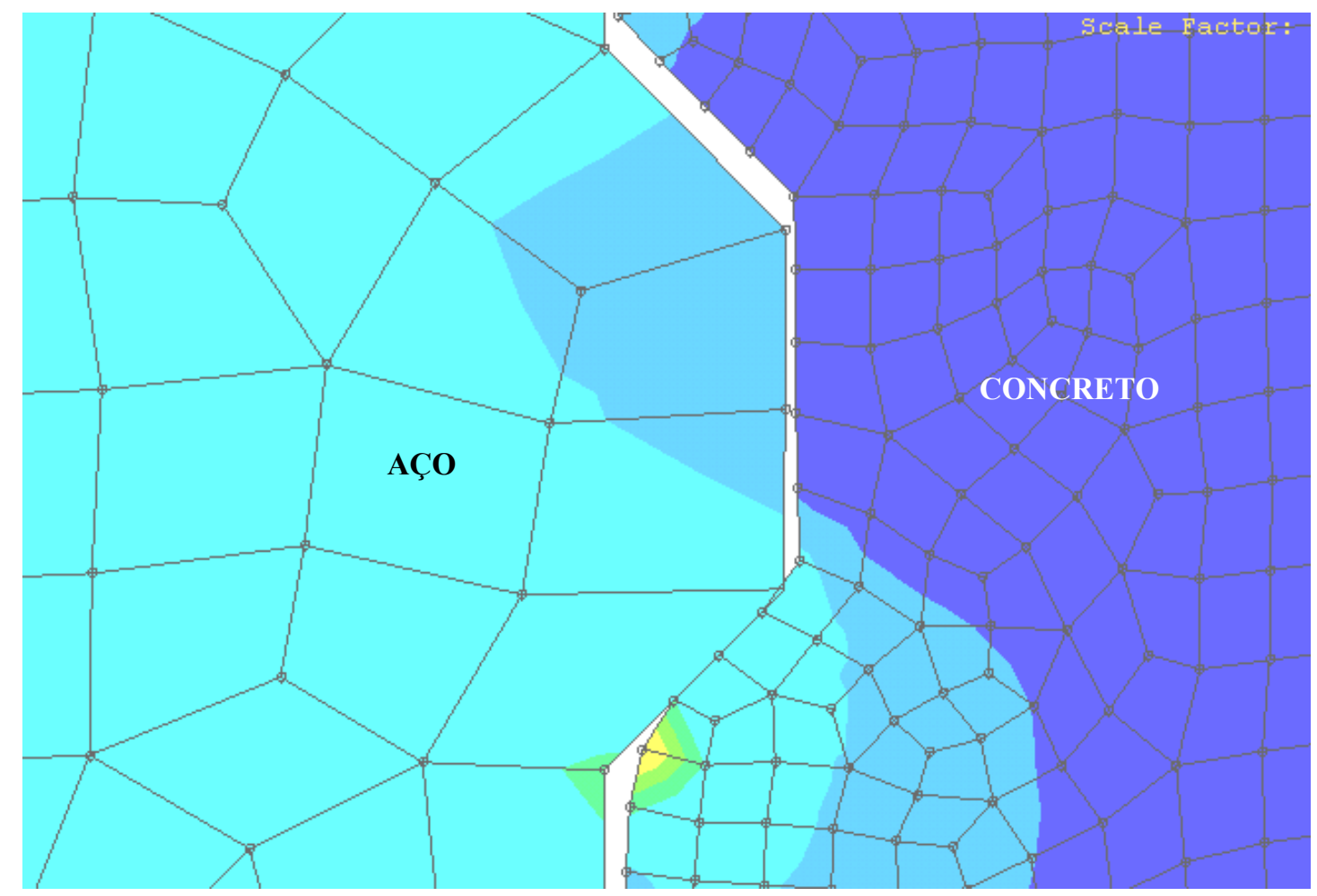

Figura 3.18 - Detalhe ampliado de uma nervura, com destaque para o descolamento e deslizamento dos nós da superfície escrava, bem como do esmagamento do concreto

No início da pesquisa, antes mesmo de serem utilizados os recursos do préprocessador do ABAQUS/CAE (Versão 6.3) mostrados neste item, os CP's foram modelados e analisados pelo ABAQUS/STANDARD (não possui recursos de préprocessamento). Para tanto, foi criado um arquivo de dados com extensão INP contendo todos os comandos exigidos pelo código para que a análise pudesse ser realizada no ambiente ABAQUS. Abaixo, o conteúdo do arquivo denominado CP-01.INP, desenvolvido pelo autor:

\section{*HEADING}

Corpo de Prova (CP-01)

sistema de unidades usado: SI

Sist. coord. glob.: eixo $\mathrm{z}=$ eixo do $\mathrm{CP}$

**

** Malha com elementos sólidos axisimétricos com 4 nós, modo imcompatível.

** Consideração do contato entre aço/concreto:

$* *$

** DEFINIÇÃO DO MODELO

$* *$

** Coordenadas nodais (para o plano teta $=0$ ) 
** p/ a barra de aço:

$* \mathrm{NODE}$

$1,0 ., 0$.

$3,0.005,0$.

$181,0 ., 0.3$

$183,0.005,0.3$

*NGEN, NSET $=$ APOIO

$1,3,1$

*NGEN, NSET=EXTACO

$181,183,1$

*NFILL

APOIO,EXTACO,60,3

**

$* * \mathrm{p} /$ o concreto envolvente:

*NODE

$1001,0.005,0$.

$1003,0.01,0$.

$1017,0.075,0$.

$1681,0.005,0.2$

$1683,0.01,0.2$

$1697,0.075,0.2$

*NGEN, NSET $=$ BASE

1001,1003,1

1003,1017,1

*NGEN, NSET $=$ EXTCONC

$1681,1683,1$

$1683,1697,1$

*NFILL

BASE,EXTCONC,40,17

** Fim da numeração dos nós

** Numeração, tipo e conectividade dos elementos:

** para o AÇO:

** Será usado um elemento finito sólido axisimétrico bilinear, modo imcompatível,

** 2 graus de liberdade por nó, com um total de 4 nós.

** OBS.: serão criados automaticamente 5 nós por elemento

$* *$

*ELEMENT, TYPE=CAX4I, ELSET=BARRAACO

$1,1,2,5,4$

*ELGEN, ELSET=BARRAACO

$1,2,1,1,60,3,2$

**

** para o CONCRETO:

** Será usado um elemento finito sólido axisimétrico bilinear, modo imcompatível,

** 2 graus de liberdade por nó, com um total de 4 nós.

$* *$

*ELEMENT, TYPE=CAX4I

$1001,1001,1002,1019,1018$

*ELGEN, ELSET=EBASE

$1001,16,1,1,1,1,1$

*ELGEN, ELSET=CONCRETO 
$1001,16,1,1,40,17,16$

$* *$

*ELGEN, ELSET $=$ LADOCONC

$1016,1,1,1,40,17,16$

** Propriedades dos materiais

**

*SOLID SECTION, ELSET=BARRAACO, MATERIAL=STEEL

*SOLID SECTION, ELSET $=$ CONCRETO, MATERIAL=CONCRETE

*MATERIAL, NAME=STEEL

*ELASTIC

20716700.,0.3

*MATERIAL, NAME $=$ CONCRETE

*ELASTIC

$2567800 ., 0.2$

$* *$

** Definição das superfícies de contato:

$* *$

*ELSET, ELSET=SUPBARRA, GENERATE

$42,80,2$

*SURFACE DEFINITION, NAME=CONTATOACO

SUPBARRA,

**

*ELSET, ELSET=SUPCONCRETO, GENERATE

$1321,1625,16$

*SURFACE DEFINITION, NAME=CONTATOCONCRETO, TRIM=YES

SUPCONCRETO,

**

*CONTACT PAIR, INTERACTION=ADERENCIA, SMALL SLIDING

$* *<$ superficie escrava $><$ superficie master $>$

CONTATOCONCRETO, CONTATOACO

*SURFACE INTERACTION, NAME=ADERENCIA

*FRICTION

0.2

$* *$

** Condicoes de contorno:

$* *$

*BOUNDARY

APOIO, ENCASTRE

$* *$

** Fim dos comandos para geracao dos nos, da malha, dos elementos, dos materiais e

** suas propriedades, e das superfícies de contato.

$* *$

** HISTÓRICO DOS DADOS:

$* *$

*STEP, PERTURBATION

*STATIC

$* *$

** Carregamento aplicado ao CP:

** A carga última aplicada ao CP, na base, é de 19,46 KN. A força/un. de área aplicada

** será de 1107 tf $/ \mathrm{m} 2$. Nessa simulação está sendo aplicada somente $60 \%$ da carga. 
** OBS: está sendo aplicada uma carga lateral de 50\% da carga vertical p/ simular

** confinamento.

$* *$

*DLOAD

LADOCONC, P2, -330 .

EBASE, P1, 660.

$* *$

** Opcoes de saida de resultados:

$* *$

*RESTART, WRITE, FREQUENCY=1

*EL PRINT, POSITION=AVERAGED AT NODES, SUMMARY=YES

*CONTACT PRINT

*PRINT, CONTACT $=$ YES

$*$ NODE FILE, NSET $=$ BASE

$\mathrm{U}$

*NODE FILE, NSET=EXTCONC

$\mathrm{U}$

*NODE FILE, NSET=EXTACO

$\mathrm{U}$

*NODE FILE, NSET=APOIO

$\mathrm{U}, \mathrm{RF}$

*END STEP

\subsubsection{Modelagem Tridimensional}

Uma outra opção para simular o comportamento de CP's de concreto confeccionados com uma barra de aço colocada axialmente, é a modelagem tridimensional. Na modelagem foram utilizados elementos tridimensionais, tanto para o aço quanto para o concreto, do tipo C3D8 que são elementos contínuos, tridimensionais, de oito nós, com três deslocamentos por nó. Permitem calcular tensões e deformações nas três direções além de determinar o deslizamento relativo entre os nós contidos na superfície de contato (escrava e mestre) na direção axial. A Figura 3.19 mostra o elemento C3D8. 


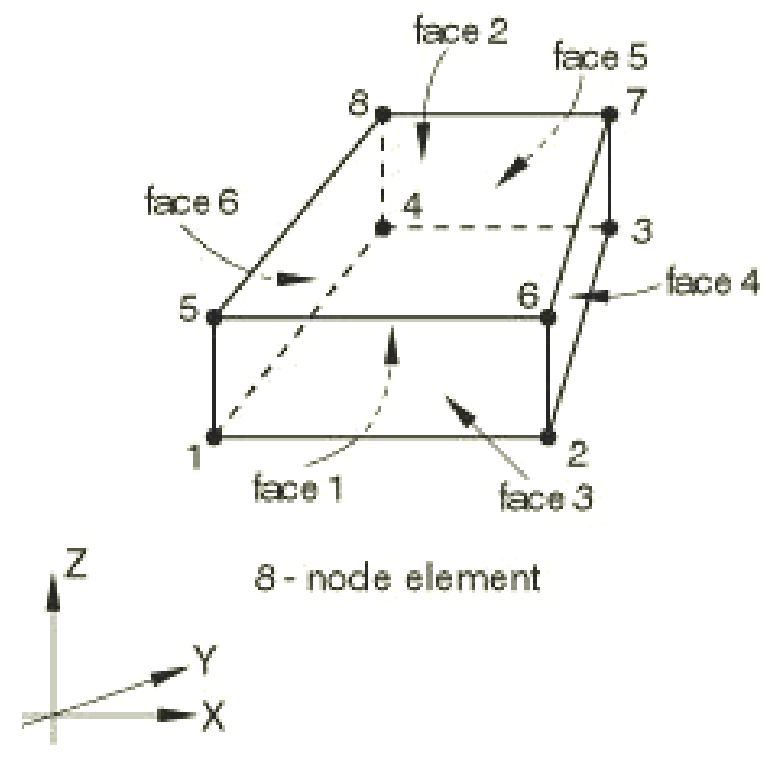

Figura 3.19 - Elemento C3D8 (Abaqus 6.3)

A Figura 3.20 mostra a numeração dos pontos de integração do elemento com e sem integração reduzida.

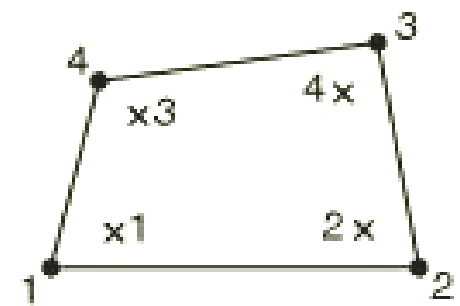

8 - node element

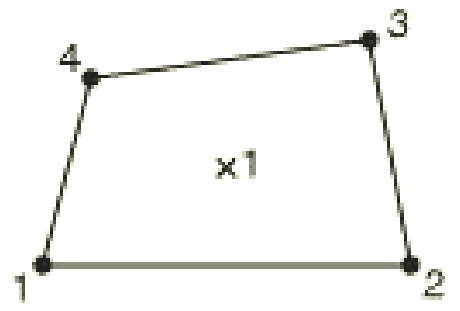

8 - node reduced integration element

Figura 3.20 - Pontos de integração dos elementos C3D8 e C3D8R (Abaqus 6.3)

A análise foi feita apenas para 1/4 da estrutura original. Da mesma forma que para o modelo axisimétrico a análise, não-linear, levou em conta o contato entre o aço e o concreto. $\mathrm{O}$ modelo constitutivo adotado nessa fase foi o elástico, tanto para o aço quanto para o concreto. A Figura 3.21 mostra a parte que representa $1 / 4$ da barra de aço no modelo e a quarta parte que representa o concreto envolvente, com destaque para os detalhes das nervuras das barras e os correspondentes encaixes no concreto. Verificouse, posteriormente, que a parte de concreto poderia ter sido representada lisa; o programa, devidamente instruído, faz as devidas aproximações na malha da superfície de contato do concreto (escrava) fazendo com que ele se molde à malha da superfície de contato do aço (mestre). Essa observação é válida, também, para a análise axisimétrica. 


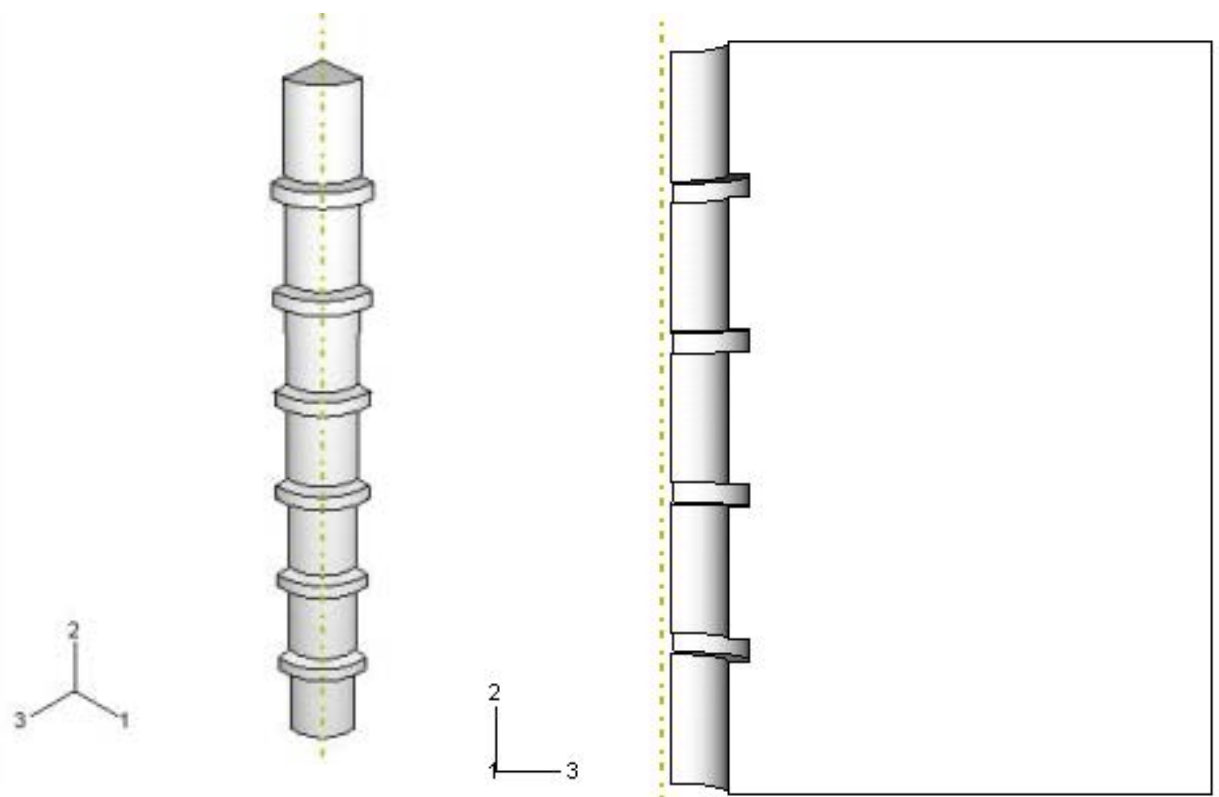

Figura 3.21 - 1/4 da barra de aço (esquerda) e 1/4 do concreto envolvente (direita)

A Figura 3.22 mostra as partes, aço e concreto, conectadas. As partes são geradas separadamente através do módulo PART (tantas quanto sejam necessárias) e depois unidas na posição desejada através do módulo ASSEMBLE.

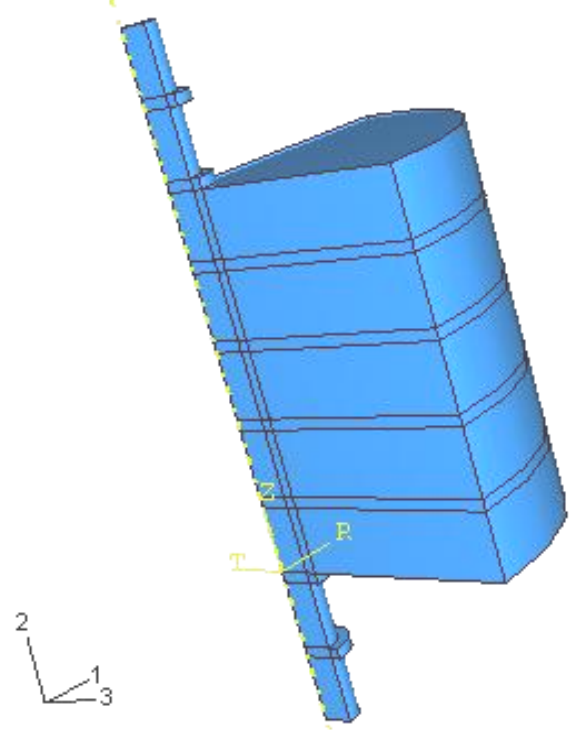

Figura 3.22 - Partes conectadas - barra nervurada e concreto envolvente

A Figura 3.23 mostra a superfície de contato da barra de aço e a superfície de contato do concreto. São mostradas na cor vermelha. 

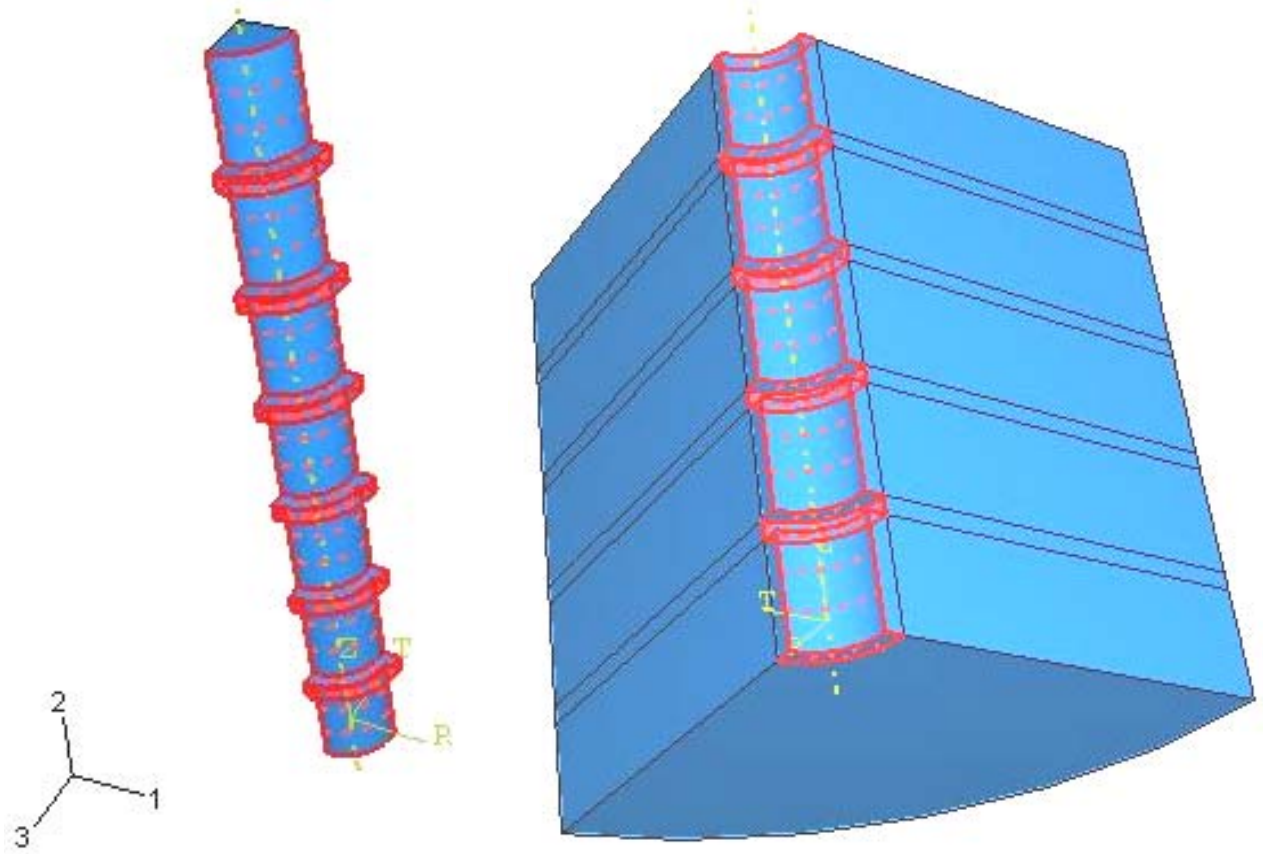

Figura 3.23 - Superfície de contato da barra de aço e do concreto

Uma visão geral da malha de elementos finitos utilizada no modelo é mostrada na Figura 3.24.

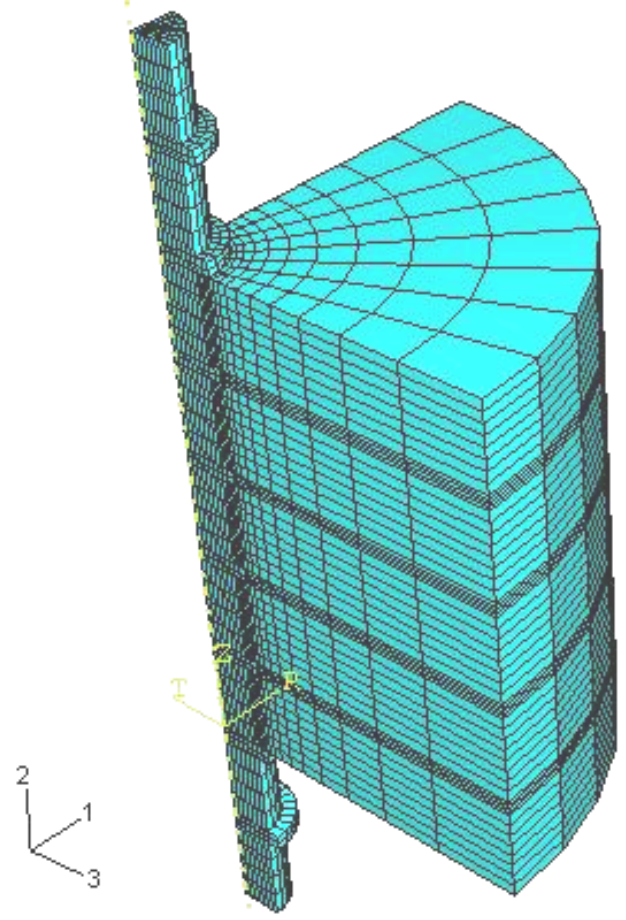

Figura 3.24 - Vista geral da malha utilizada no modelo

Detalhes da malha para a barra e para o concreto são mostrados na Figura 3.25. 

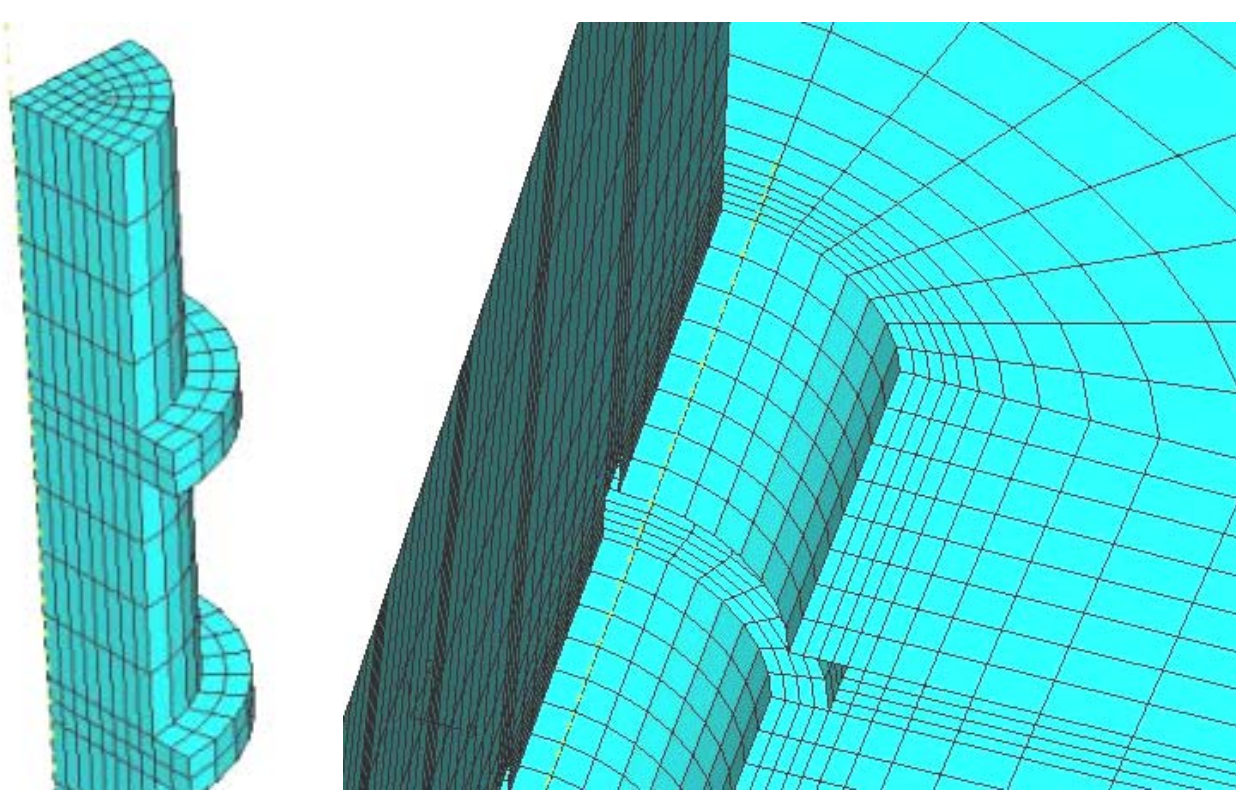

Figura 3.25 - Detalhe da malha para o aço e para o concreto

\subsubsection{Vigas de concreto armado}

As vigas de concreto armado foram modeladas como bidimensionais (chapa) e como tridimensionais (viga inteira, metade da viga e 1/4 da viga), com malhas cada vez mais refinadas.

Os elementos utilizados na análise tridimensional, tanto para o aço quanto para o concreto, foram os do tipo C3D8 (ver Figura 3.19 e Figura 3.20) que são elementos contínuos, tridimensionais, oito nós cada um, com três deslocamentos por nó. Permite calcular tensões e deformações nas três direções. Permite, também, determinar o deslizamento relativo entre os nós situados sobre as superfícies de contato (escrava e mestre), em duas direções.

A análise, não-linear, levou em conta o contato entre o aço e o concreto. $\mathrm{O}$ modelo constitutivo adotado foi elástico com dano, tanto para o aço quanto para o concreto. Na seqüência são mostrados aspectos da modelagem para os diversos tipos utilizados na análise.

\subsubsection{Modelagem bidimensional}

A Modelagem da viga utilizando elementos bidimensionais de chapa não se mostrou um bom caminho de análise; um dos motivos, segundo pôde constatar o autor, 
foi o de ter um número de opções bastante reduzido para definição da superfície de contato e suas características. O modelo mostrou-se muito rígido.

Adiante, nas Figura 3.26, Figura 3.27 e Figura 3.28, são mostradas algumas etapas da modelagem bidimensional da viga.

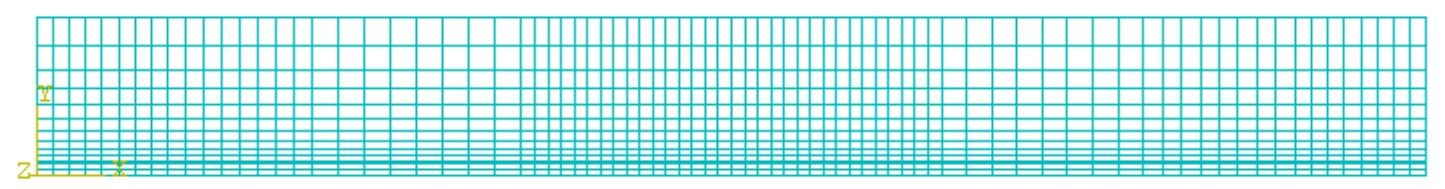

Figura 3.26 - Malha para o aço e concreto

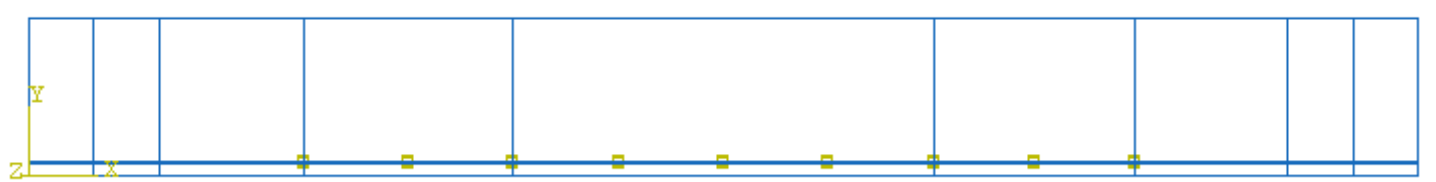

Figura 3.27 - Superfícies de contato

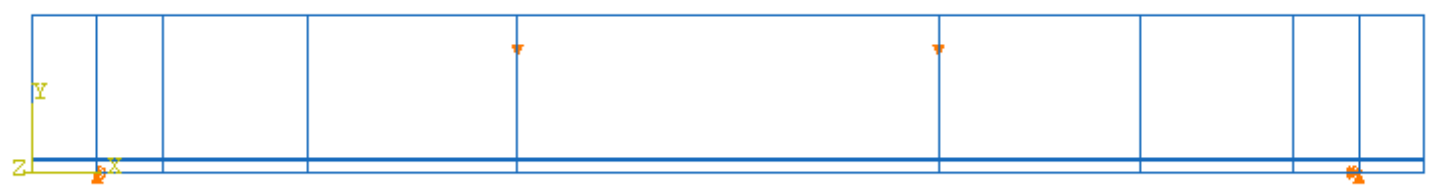

Figura 3.28 - Condições de contorno - apoios e carregamento

\subsubsection{Modelagem tridimensional para a viga inteira}

Considerar a viga inteira nessa fase da análise acarretou um enorme esforço na escolha e definição de cada parte, na junção dessas partes, no delineamento das superfícies mestre e escrava e, principalmente, na obtenção da malha tanto para o concreto quanto para o aço.

A análise, não-linear, levou em conta o contato entre o aço e o concreto. $\mathrm{O}$ modelo constitutivo adotado foi elástico com dano, tanto para o aço quanto para o concreto. Os três desenhos que compõem a Figura 3.29 mostram, na seqüência, a parte superior do concreto, a parte inferior (cobrimento do concreto) e a parte do aço. A parte de aço no modelo representa as barras de aço como sendo uma barra de seção transversal retangular cuja largura é igual à largura da seção de concreto. 


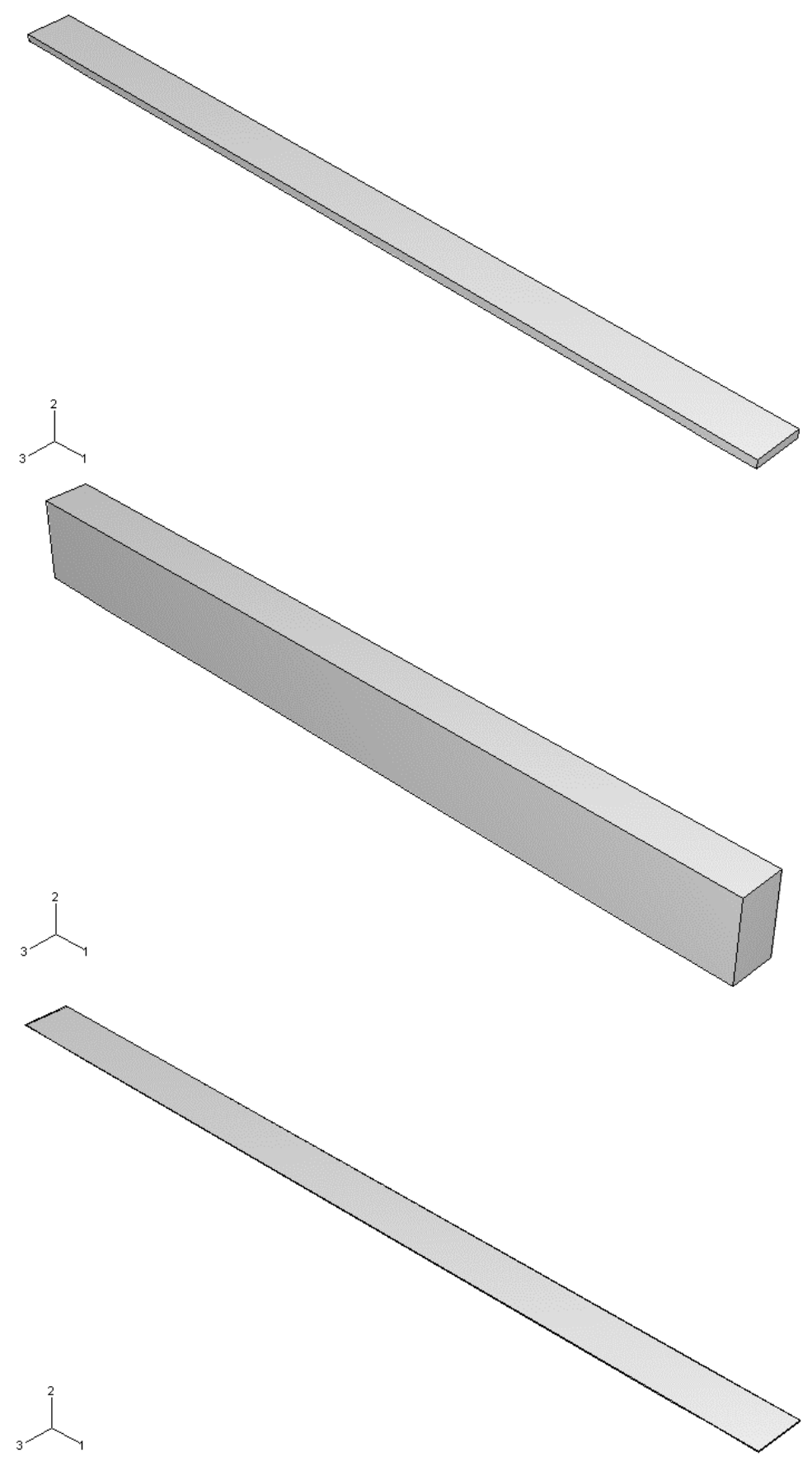

Figura 3.29 - Partes: duas para o concreto e outra para o aço

A viga obtida das partes devidamente conectadas está mostrada na Figura 3.30 “conectadas" aqui tem o significado de posicionadas; necessário se faz, posteriormente, estabelecer as condições de contorno e, se necessário, as condições de contato. 


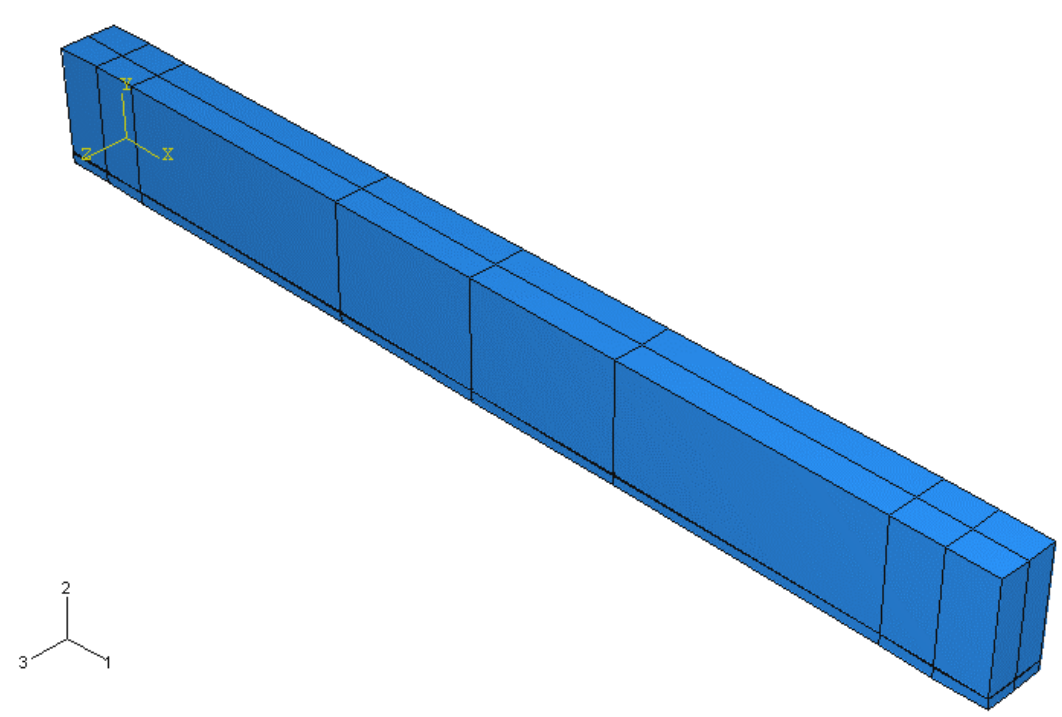

Figura 3.30 - Partes conectadas

As superfícies de contato se fazem necessário para dar ao conjunto a possibilidade de ocorrer deslizamento entre pontos da malha tanto do aço quanto do concreto. A Figura 3.31 mostra apenas uma parte da superfície de contato do aço.

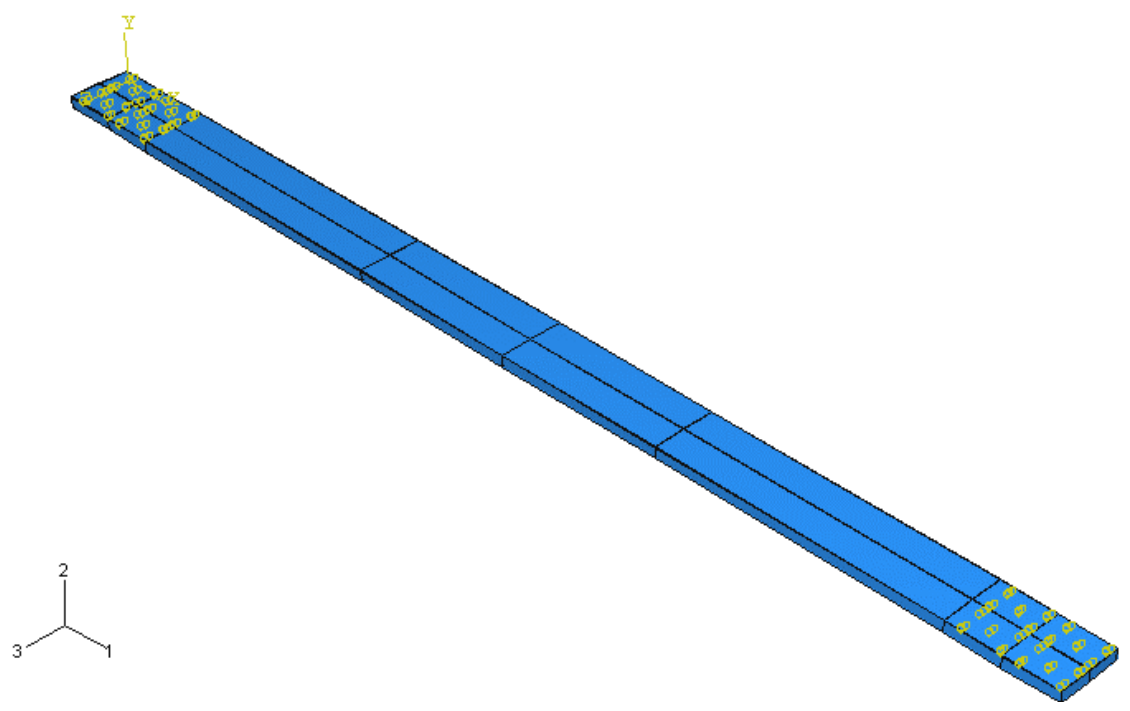

Figura 3.31 - Superfície de contato do aço

As condições de contorno impostas e o carregamento aplicado são mostrados na Figura 3.32. 


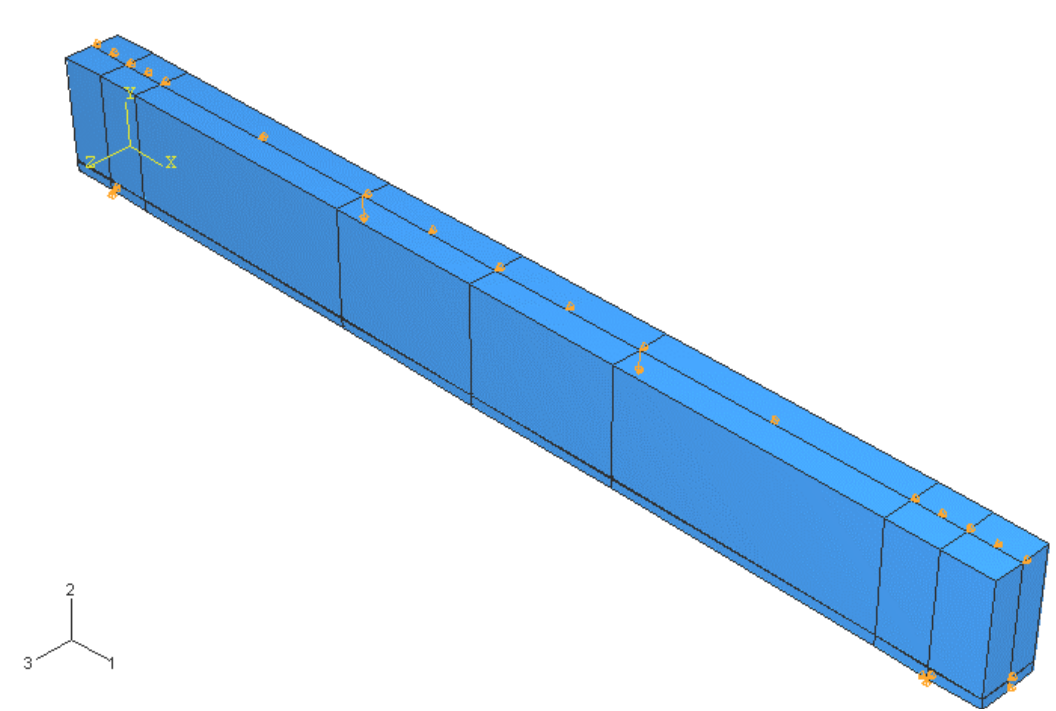

Figura 3.32 - Condições de contorno e carregamento

A Figura 3.33 mostra a malha adotada para o modelo. Mostra também um detalhe da malha do aço, em escuro.
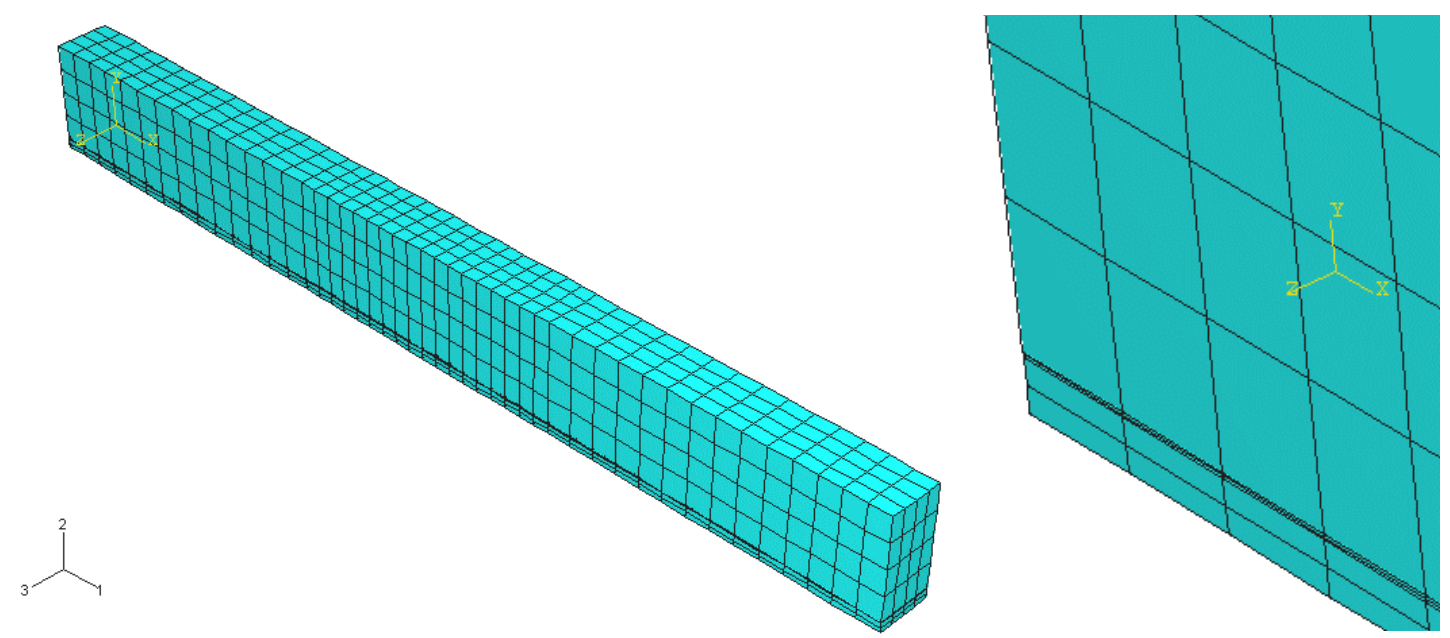

Figura 3.33 - Malha adotada. Detalhe para a malha do aço

O modelo mostrou-se bastante rígido; diversas foram as tentativas de torná-lo mais flexível a ponto de se obter uma resposta compatível e esperada. A Figura 3.34 mostra o aspecto das tensões normais num passo de carga imediatamente anterior ao programa abortar a solução, após inúmeras tentativas de convergência da solução. 


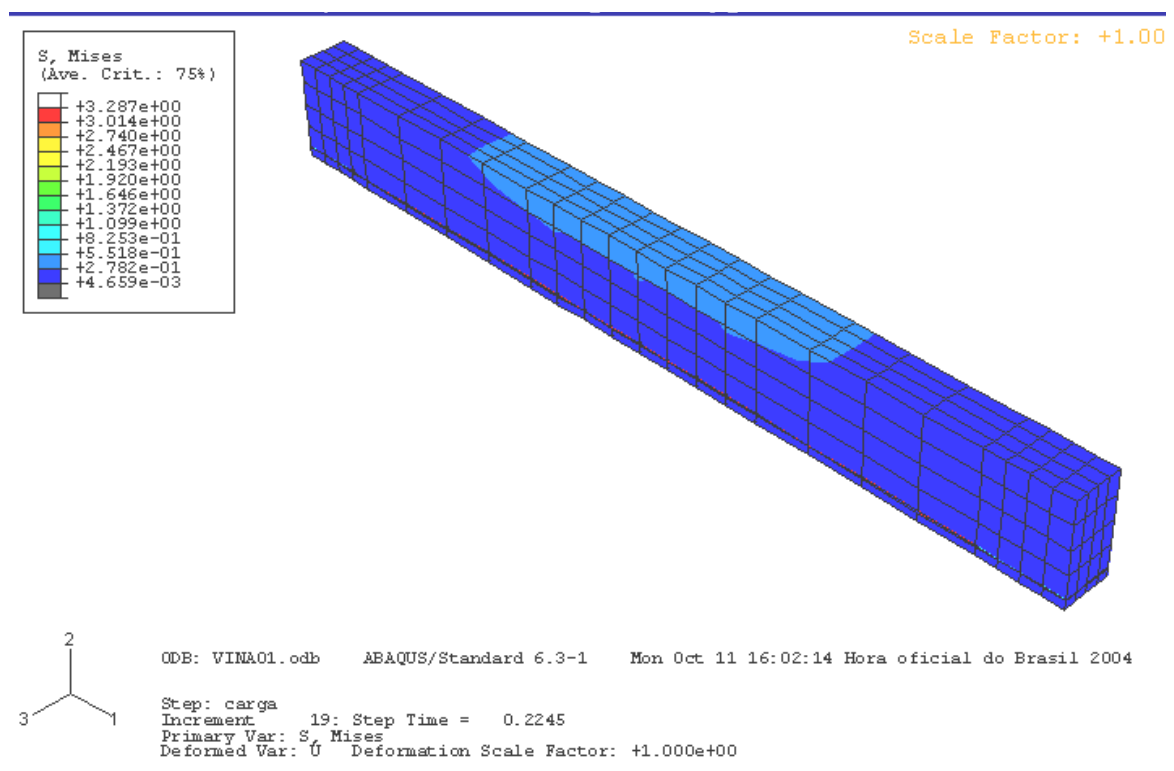

Figura 3.34 - Tensões normais na viga

A Figura 3.35 e a Figura 3.36 mostram cada uma, o aspecto da flecha no meio do vão, bem como o valor do dano medido num nó da superfície escrava (de concreto) posicionado no meio do vão. Observar que essas medidas foram tomadas apenas para um pouco mais de $20 \%$ da carga, antes de ocorrer travamento da solução. "Time" significa o tamanho do passo de carga, geralmente igual à unidade.

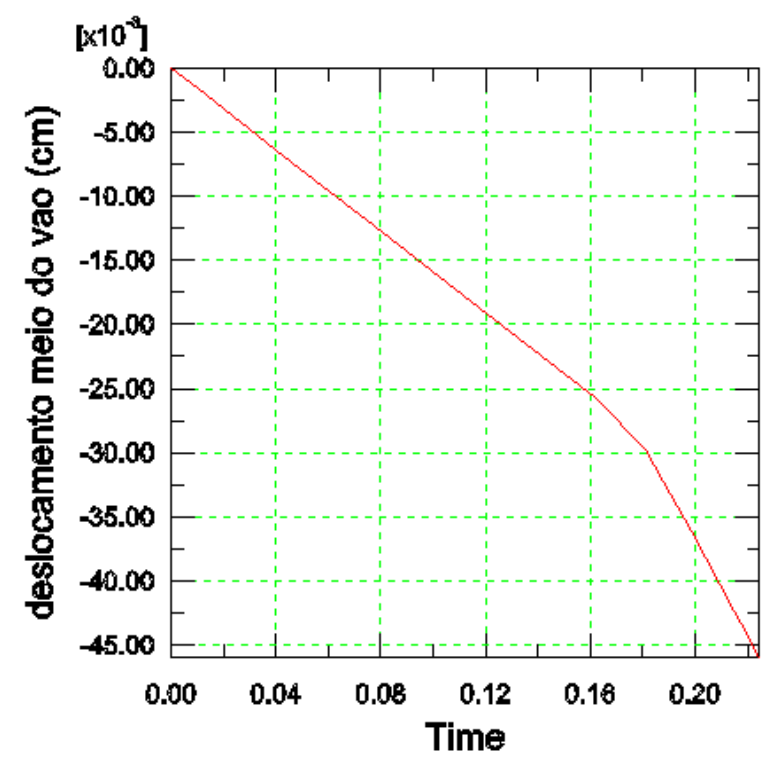

Figura 3.35 - Deslocamento no meio do vão da viga 


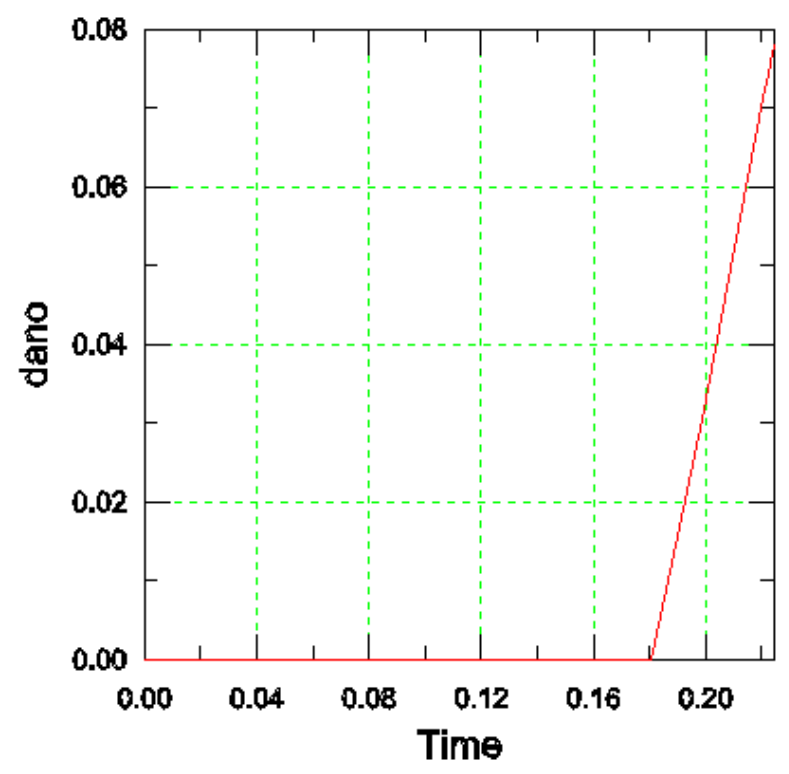

Figura 3.36 - Medida do dano num nó escravo no meio do vão da viga

\subsubsection{Modelagem tridimensional para metade da viga}

Num esforço de minimizar os problemas verificados com a análise feita para a viga inteira optou-se por analisar apenas metade da viga. As definições de partes, superfícies de contato, condições de carregamento e principalmente a obtenção da malha diminuiriam bastante o tempo de execução e o tempo computacional.

A análise continuou levando em conta a não-linearidade dos materiais e o contato entre o aço e o concreto. $\mathrm{O}$ modelo constitutivo adotado foi o mesmo, elástico com dano tanto para o aço quanto para o concreto. A Figura 3.37 mostra a parte do aço relativa à metade da viga; representa, na verdade, uma das duas barras da armadura da viga; observar as nervuras da barra do modelo.

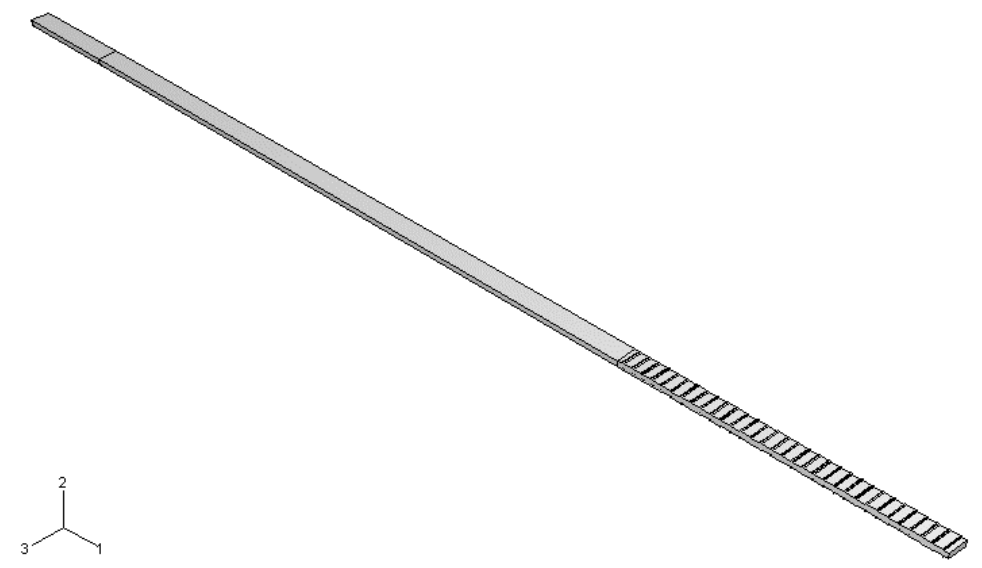

Figura 3.37 - Parte aço para o modelo-metade da viga 
Para minimizar a obtenção da malha as nervuras foram consideradas apenas na zona do apoio.

A Figura 3.38 mostra a parte concreto representando a metade da viga.

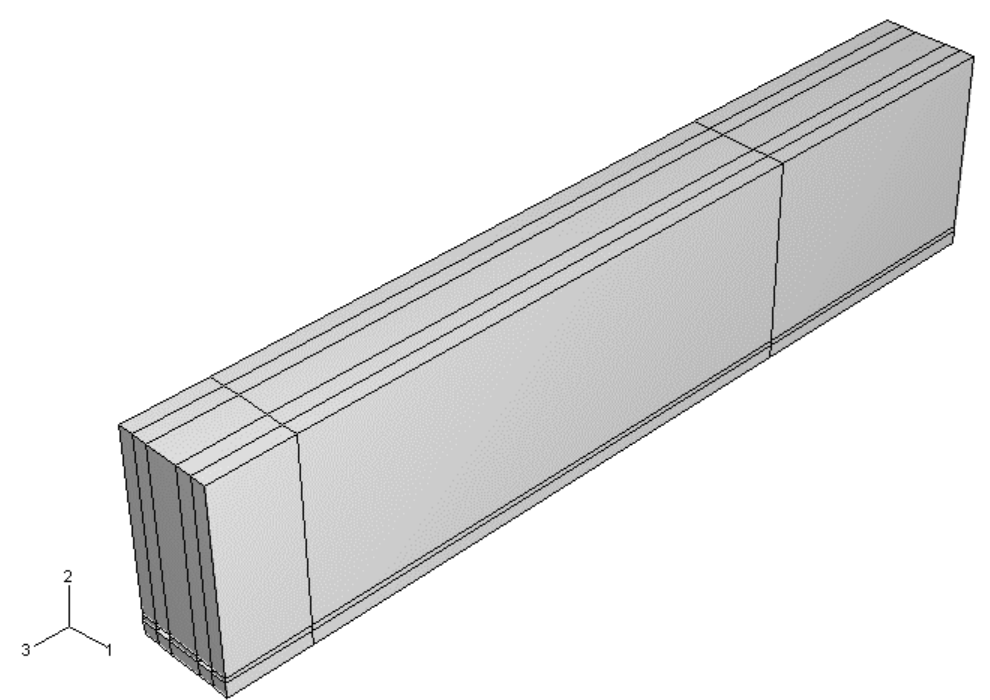

Figura 3.38 - Parte concreto para o modelo-metade da viga

Observar, na Figura 3.39, os furos deixados para a colocação das duas barras da armadura da viga.
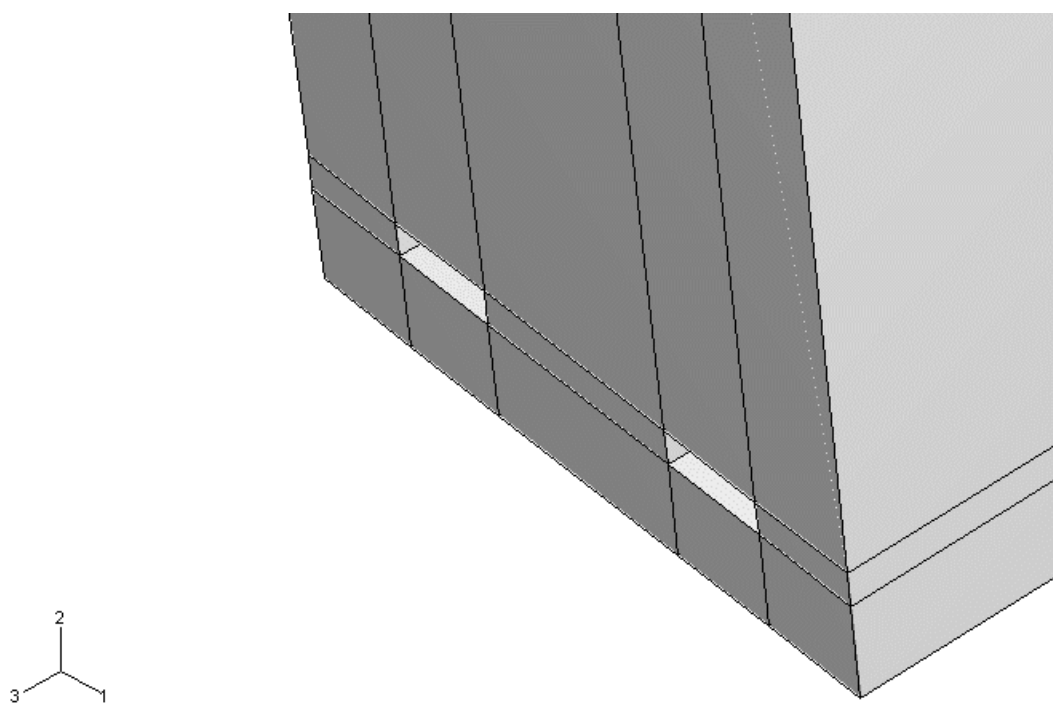

Figura 3.39 - Detalhe dos furos para as armaduras

As condições de contorno impostas e o carregamento aplicado são mostrados na Figura 3.40. Observar a carga aplicada num único ponto; os demais pontos pertencentes à linha de aplicação da carga, por imposição, se deslocam igualmente. 


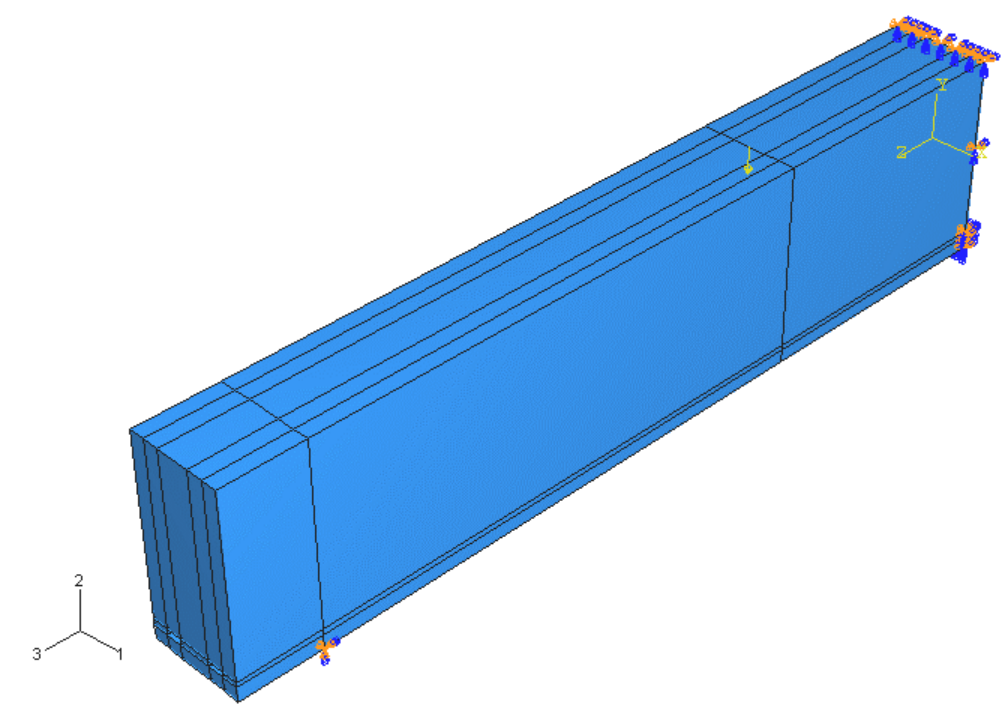

Figura 3.40 - Condições de contorno e carregamento

O modelo mostrou-se ainda bastante rígido; foram feitas diversas tentativas para torná-lo mais flexível; os mesmos resultados obtidos para as tensões normais, flecha no meio do vão e medida do dano mostrados, respectivamente, na Figura 3.34, na Figura 3.35 e na Figura 3.36, para pouco mais de $20 \%$ da carga, se repetiram para o modelo de metade da viga.

\subsubsection{Modelagem tridimensional para 1/4 da viga}

Finalmente, num último esforço para minimizar ainda mais os problemas verificados nas análises feitas para os modelos viga-inteira e viga-metade tentou-se a análise com o modelo de viga - 1/4. As definições de partes, superfícies de contato, condições de carregamento e principalmente a obtenção da malha diminuiriam ainda mais o tempo de execução e o tempo computacional despendido.

A análise continuou levando em conta a não-linearidade dos materiais e o contato entre o aço e o concreto. O modelo constitutivo adotado foi o mesmo, elástico com dano para o concreto. Para o aço o modelo elasto-plástico perfeito. A Figura 3.41 mostra a parte de concreto relativa a $1 / 4$ da viga e o detalhe do furo para a colocação da armadura; a parte de aço é a mesma utilizada no modelo metade-viga mostrado na Figura 3.37. 

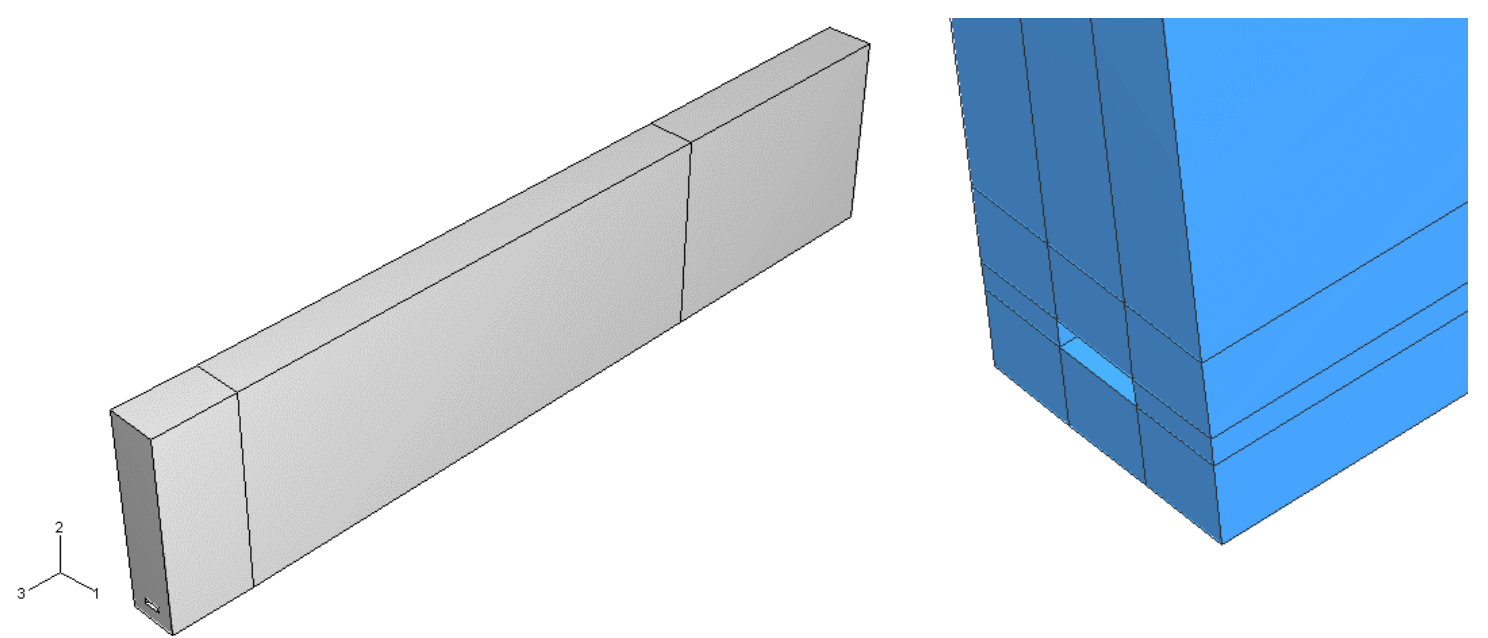

Figura 3.41 - Parte de concreto e detalhe do furo para a barra de aço

As condições de contorno impostas e o carregamento aplicado são mostrados na Figura 3.42. Do mesmo modo que no caso anterior a carga foi aplicada num único ponto tendo os demais pontos pertencentes à linha de aplicação da carga o mesmo deslocamento, por imposição.

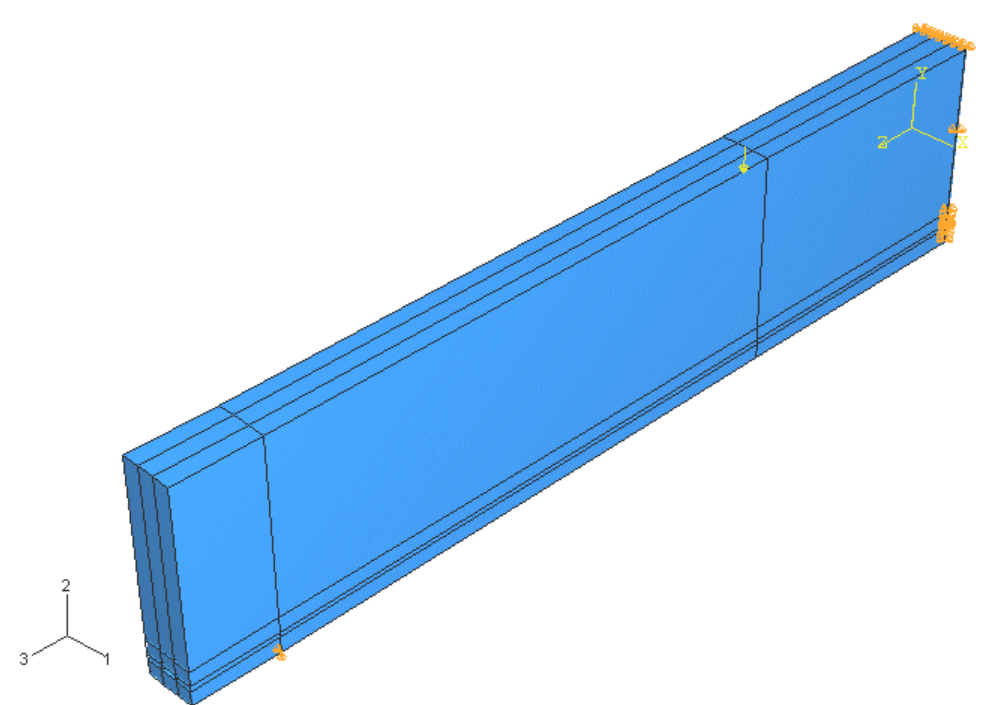

Figura 3.42 - Condições de contorno e carregamento

A Figura 3.43 mostra a malha e uma parte ampliada da malha adotada para o modelo. 


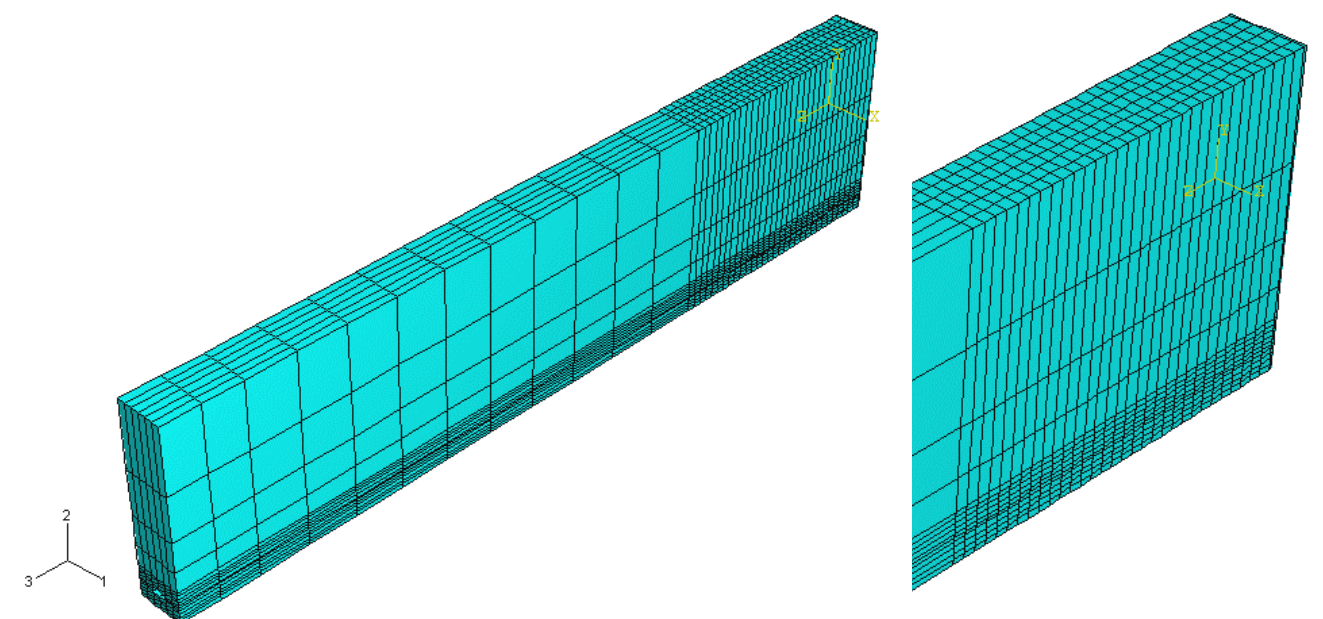

Figura 3.43 - Malha e malha ampliada

Após inúmeras tentativas e esforços despendidos a solução finalmente convergiu. O modelo mostrou-se, de igual modo aos anteriores, bastante rígido. A convergência foi lenta e progressiva exigindo muitas iterações de severa descontinuidade. Não foi possível, portanto, aplicar carga cíclica ao modelo que era o desejado pelo autor. A resposta se afastou bastante dos resultados esperados. A Figura 3.44 mostra o aspecto das tensões normais no último passo de carga.

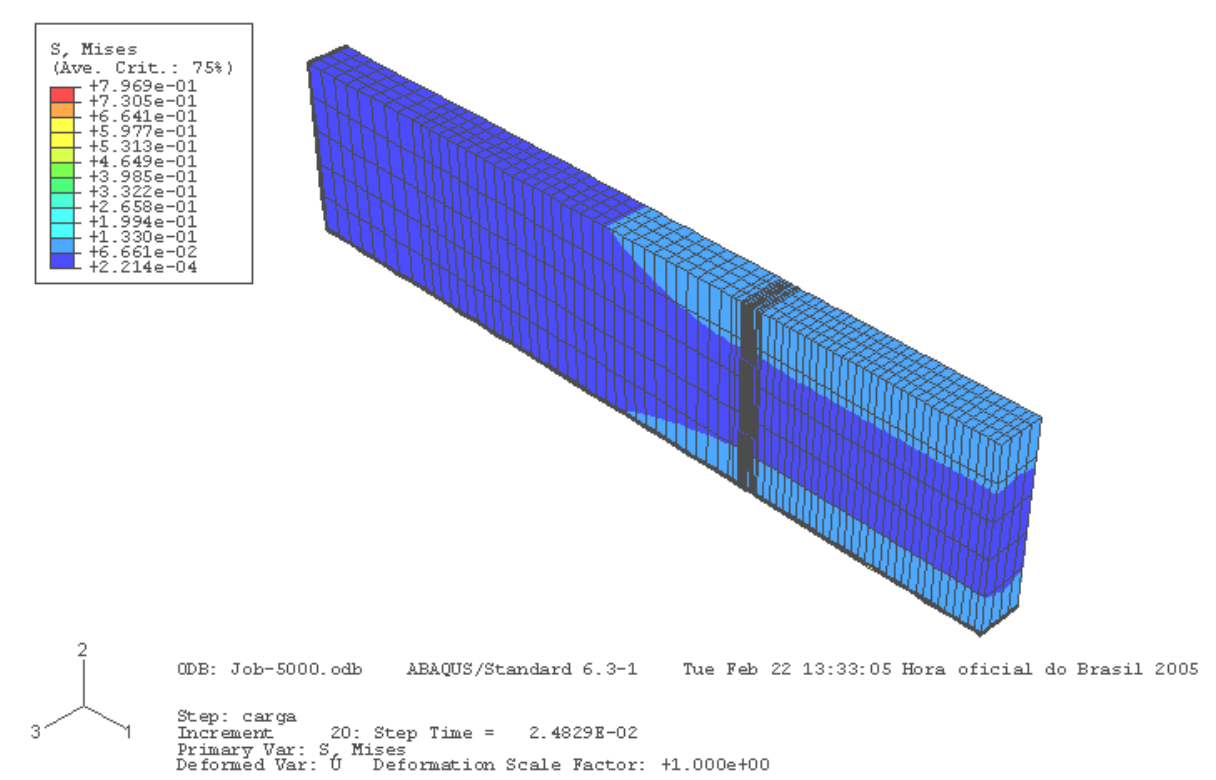

Figura 3.44 - Tensões normais na viga 1/4

A Figura 3.45 mostra a flecha no meio do vão da viga. O valor encontrado foge do resultado esperado; como já dito, provavelmente pela grande rigidez apresentada pelo modelo. 


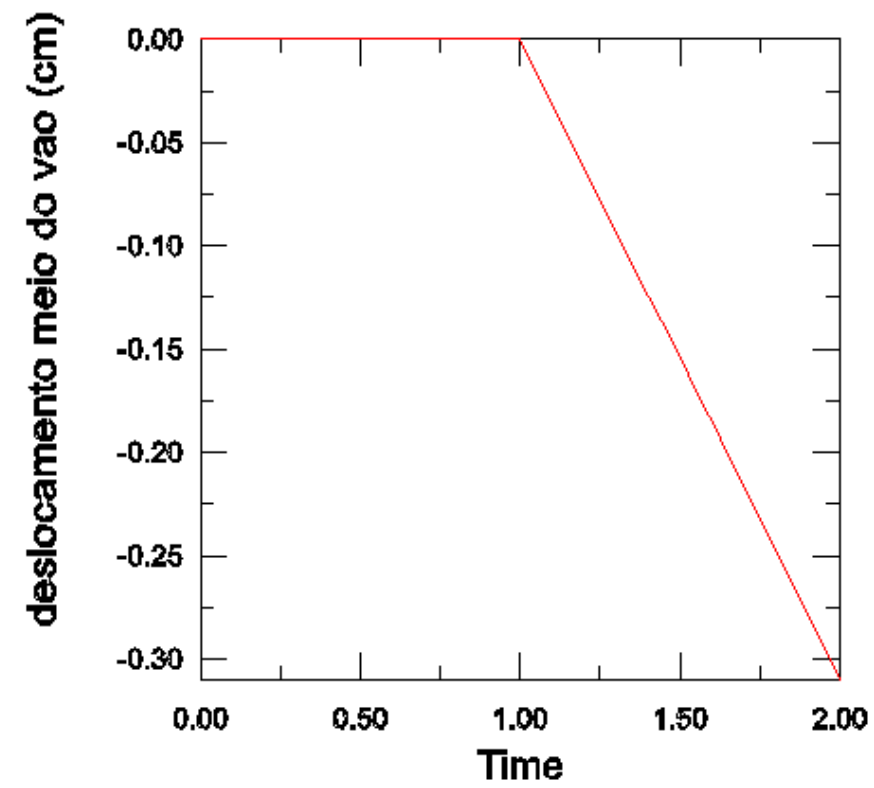

Figura 3.45 - Flecha no meio do vão

A Figura 3.46 mostra a flecha no meio do vão da viga para os pontos pertencentes à superfície escrava inferior, ou seja, pontos pertencente à parte de concreto localizados na interface inferior do concreto e do aço.

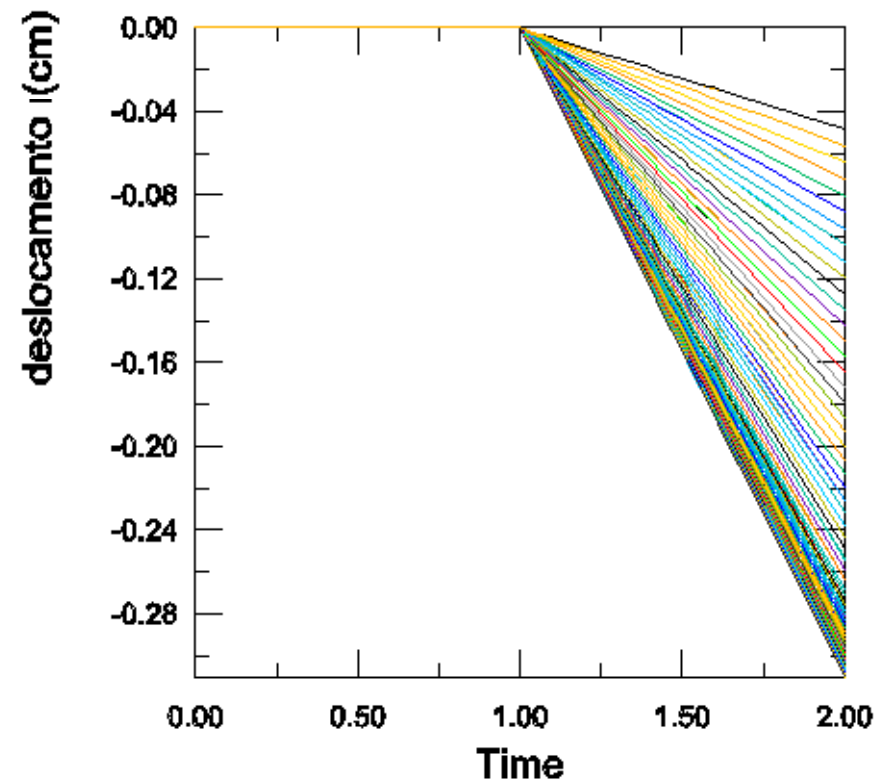

Figura 3.46 - Flecha no meio do vão para pontos da superfície escrava

A Figura 3.47 mostra a tensão normal em pontos das superfícies máster (para a barra de aço, à esquerda e escrava (para o concreto circundante, à direita). 


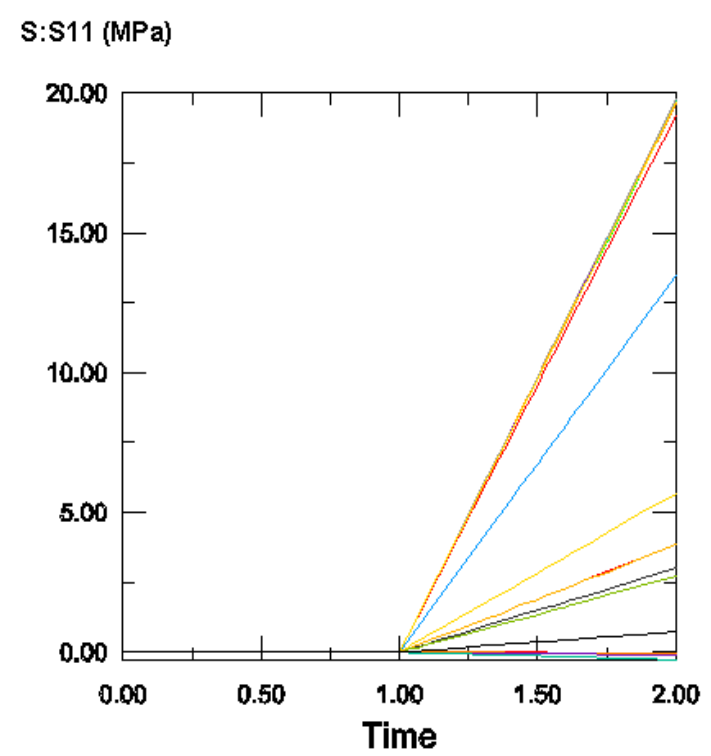

$\mathrm{S}: \mathrm{S11}(\mathrm{MPa})$

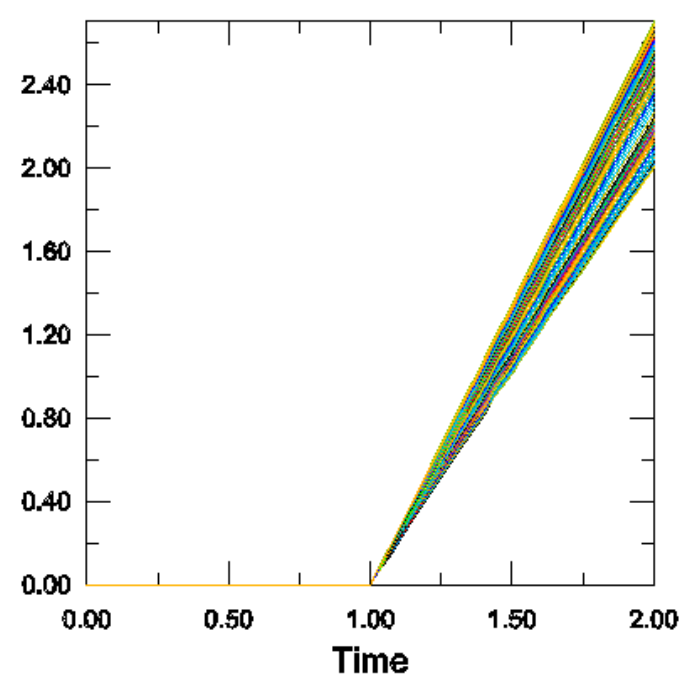

Figura 3.47 - Tensão normal no aço e no concreto

3.7.2.5 Programas baseados na mecânica do dano

O autor ao longo desta tese não elaborou um programa computacional específico baseado no MEF e na Mecânica do Dano para confrontar com os resultados obtidos nos ensaios experimentais. Utilizou, como já visto, um pacote pronto baseado no MEF denominado ABAQUS. No entanto, com o intuito de dar maior substância à análise numérica, o autor utilizou os códigos desenvolvidos por ARAÚJO (2003) e ALVA (2004). Ambos os programas, desenvolvidos em linguagem FORTRAN, foram adaptados pelos respectivos autores para atenderem a algumas necessidades da presente tese, destacando-se a possibilidade de solicitar a estrutura com diferentes e sucessivos casos de carregamentos, com ciclos de carga e descarga. As características dos elementos finitos utilizados, a discretização desses elementos ao longo da seção transversal, os algoritmos de integração e outras particularidades dos programas podem ser consultados em ARAÚJO (2003) e ALVA (2004). 


\section{Capítulo 4}

\section{ANÁLISE EXPERIMENTAL}

A análise experimental foi dividida em duas etapas:

$1^{\mathrm{a}}$ etapa - ensaios estáticos e cíclicos em corpos cilíndricos (CP's) de concreto armado e em vigas de concreto armado. A etapa é também chamada de ensaio piloto.

$2^{\mathrm{a}}$ etapa - ensaios cíclicos em vigas de concreto armado; a etapa é também chamada de ensaio definitivo.

O objetivo principal da etapa experimental foi o de submeter vigas de concreto armado a um certo número de ciclos de carga extraindo, ao final do ensaio, o valor da perda de rigidez dessas vigas através medição sucessiva de flechas. Foram ensaiadas, no total, 15 (quinze) vigas, além dos ensaios de caracterização dos materiais, realizados a cada etapa. Um outro objetivo, considerado também imprescindível, foi a realização dos ensaios cíclicos com os CP's.

A seguir serão apresentadas de forma concisa a metodologia empregada como a descrição dos materiais envolvidos, a preparação dos modelos e a execução dos ensaios. 


\subsection{ENSAIO PILOTO}

O ensaio piloto foi subdividido em três partes:

- Ensaio de caracterização dos materiais;

- Ensaio, estático e cíclico, realizado com 4 (quatro) CP's de concreto armado;

- Ensaio, estático e cíclico, realizado com 4 (quatro) vigas de concreto armado.

O cronograma elaborado para a realização do ensaio piloto teve que ser adiado algumas vezes. Alguns motivos, tais como problemas ocorridos na máquina de ensaio, sobrecarga de trabalho na marcenaria e no laboratório, justificaram o adiamento. Esses imprevistos vieram, por conseguinte, a causar atraso na programação previamente elaborada. A preparação das fôrmas dos CP's e das vigas, bem como a aquisição, instrumentação e montagem das barras de aço somente tiveram início em fins de novembro de 2003; a concretagem das vigas, dos CP's e dos corpos de prova para caracterização dos materiais aconteceu na tarde do dia 16 de dezembro de 2003, no LE$\mathrm{SET}^{4}$.

\subsubsection{Ensaio de caracterização dos materiais}

A resistência à compressão desejada para o concreto foi de $30 \mathrm{MPa}$ aos 28 dias. O traço utilizado para atingir tal objetivo foi desenvolvido no LE-SET por outros pesquisadores; apresentou, no entanto, alguma divergência nos resultados quanto à resistência. O consumo dos materiais utilizados na confecção do concreto, com respectivo traço em massa, é mostrado na Tabela 2.1.

Tabela 4.1 - Consumo dos materiais $\left(\mathrm{Kg} / \mathrm{m}^{3}\right)$

\begin{tabular}{|l|c|}
\hline Cimento ITAU CP-32 & 338,1 \\
\hline areia & 676,3 \\
\hline Pedrisco (\# 8mm) & 913,0 \\
\hline água & 226,5 \\
\hline \multicolumn{2}{|c|}{ Traço em massa: 1: 2: 2,7 : 0,67 } \\
\hline
\end{tabular}

\footnotetext{
${ }^{4}$ Laboratório de Estruturas do Departamento de Estruturas da Escola de Engenharia de São Carlos EESC-USP
} 
Ao todo foram concretados 30 (trinta) corpos de prova. Sabendo-se, de antemão, que os ensaios com os CP's e vigas não começariam no tempo inicialmente previsto foram programados, então, dois ensaios de caracterização. Um, após os 28 dias de efetuada a concretagem, no dia 15/01/2004 e outro, quando da realização dos ensaios com os CP's e vigas, que somente aconteceu no dia 14/05/2004. Foram realizados os ensaios de compressão uniaxial, para determinar a resistência do concreto à compressão e o módulo de elasticidade do concreto, e o ensaio de tração indireta, de compressão diametral, para determinar a resistência do concreto à tração. O ensaio para caracterização das barras de aço não foi executado. Em cada ensaio de caracterização foram utilizados 15 (quinze) corpos de prova cilíndricos de dimensões $100 \mathrm{~mm} \mathrm{x}$ 200mm, sendo 5 (cinco) unidades para cada ensaio específico.

\subsubsection{Determinação da resistência à compressão do concreto:}

Todos os ensaios, tanto os do dia 15/01/2004 quanto os do dia 14/05/2004 foram realizados na máquina $\mathrm{ELE}^{5}$. A Figura 4.1 mostra a máquina e o detalhe de um CP pronto para o ensaio.
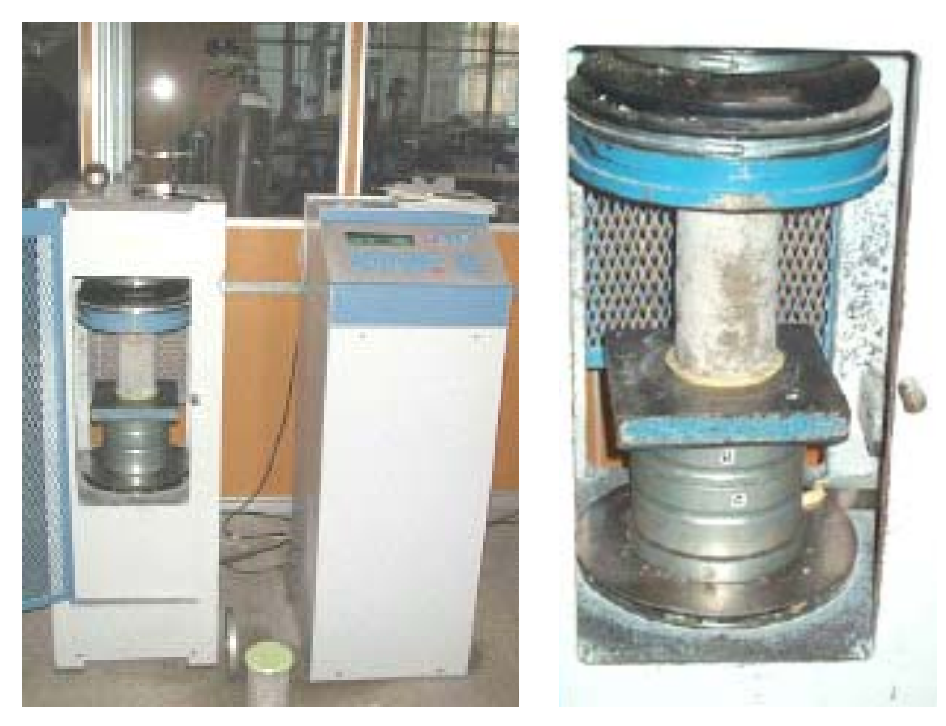

Figura 4.1 - Ensaio de compressão - Vista da máquina ELE

A força de compressão foi aplicada com velocidade controlada de $2,4 \mathrm{kN} / \mathrm{s}$. A leitura final para cada CP em ambas as oportunidades está descrita na Tabela 4.2.

\footnotetext{
${ }^{5}$ Máquina de ensaio de corpos de prova à compressão da marca ELE, modelo Autoteste 2000.
} 
Tabela 4.2 - Resultado dos ensaios à compressão simples

\begin{tabular}{|c|c|c|c|c|}
\hline \multirow{2}{*}{} & \multicolumn{2}{|c|}{ Força (kN) } & \multicolumn{2}{c|}{ Tensão (MPa) } \\
\cline { 2 - 5 } & $15 / 01 / 04$ & $14 / 05 / 04$ & $15 / 01 / 04$ & $14 / 05 / 04$ \\
\hline CP01 & 201,7 & 299,2 & 25,69 & 38,10 \\
\hline CP02 & 255,6 & 306,6 & 32,54 & 39,04 \\
\hline CP03 & 200,4 & 338,8 & 25,52 & 43,14 \\
\hline CP04 & 227,3 & 307,0 & 28,94 & 39,09 \\
\hline CP05 & 227,3 & 337,6 & 26,01 & 42,98 \\
\hline média & - & - & $\mathbf{2 7 , 7 4}$ & $\mathbf{4 0 , 5 0}$ \\
\hline
\end{tabular}

Observação: A diferença entre o tempo de realização do primeiro para o segundo ensaio foi de exatos 121 (cento e vinte e um) dias. O aumento registrado para a resistência à compressão do concreto $(46 \%)$ foi acima do esperado.

\subsubsection{Determinação da resistência à tração do concreto:}

Este ensaio, também conhecido como "ensaio Lobo Carneiro"6, foi realizado utilizando a máquina ELE e aplicando uma força de compressão com velocidade controlada de $0,94 \mathrm{kN} / \mathrm{s}$. No ensaio de compressão diametral o corpo de prova é posicionado longitudinalmente (como se deitado estivesse) de forma que seu contato com a máquina se dá apenas ao longo de geratrizes diametralmente opostas, conforme mostra a Figura 4.2.
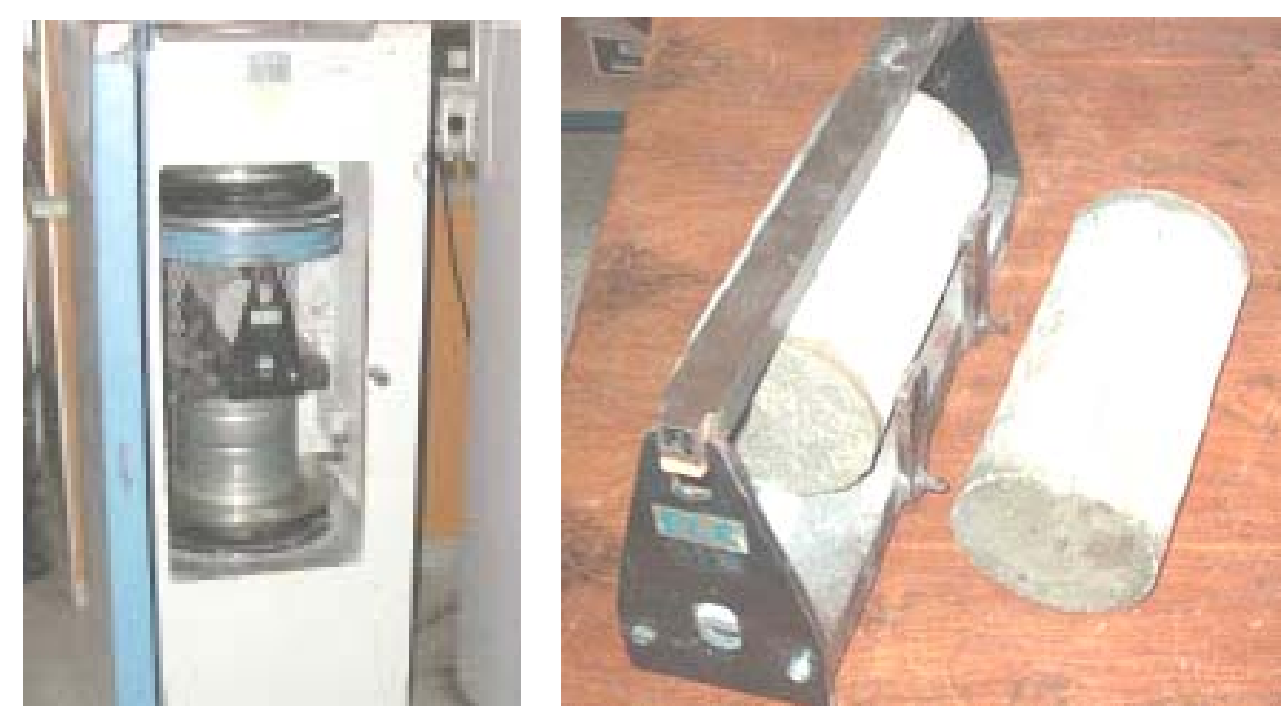

Figura 4.2 - Ensaio de tração - máquina ELE

De igual modo, a leitura final para cada CP é mostrada na Tabela 4.3.

\footnotetext{
${ }^{6}$ Fernando Luiz Lobo Barbosa Carneiro, grande Engenheiro e pesquisador, professor Dr. da UFRJ.
} 
Tabela 4.3 - Resultado dos ensaios de resistência à tração

\begin{tabular}{|c|c|c|c|c|}
\hline \multirow{2}{*}{} & \multicolumn{2}{|c|}{ Força (kN) } & \multicolumn{2}{c|}{ Tensão (MPa) } \\
\cline { 2 - 5 } & $15 / 01 / 04$ & $14 / 05 / 04$ & $15 / 01 / 04$ & $14 / 05 / 04$ \\
\hline CP01 & $47,6^{*}$ & 119,5 & $1,52^{*}$ & 3,80 \\
\hline CP02 & 97,2 & 93,7 & 3,09 & 2,98 \\
\hline CP03 & 79,0 & 96,6 & 2,52 & 3,07 \\
\hline CP04 & 78,1 & 112,9 & 2,49 & 3,59 \\
\hline CP05 & 76,4 & 101,7 & 2,43 & 42,98 \\
\hline média & - & - & $\mathbf{2 , 6 3}$ & $\mathbf{3 , 3 4}$ \\
\hline
\end{tabular}

* valores desconsiderados.

Observação: A NBR 6118:2003 estabelece um valor médio para a resistência à tração do concreto que é função da resistência à compressão, traduzido pela expressão (4.1):

$$
\mathrm{f}_{\mathrm{ctm}}=0,3 \cdot \mathrm{f}_{\mathrm{ck}}^{2 / 3}
$$

Para valores de $\mathrm{f}_{\mathrm{ck}}=27,74 \mathrm{MPa}$ e $\mathrm{f}_{\mathrm{ck}}=40,50 \mathrm{MPa}$ (obtidos na Tabela 4.2), aplicando-os na eq. (4.1), tem-se, respectivamente, $\mathrm{f}_{\mathrm{ctm}}=2,75 \mathrm{MPa}$ ( contra $2,63 \mathrm{MPa}$ ) e $\mathrm{f}_{\mathrm{ctm}}=3,53 \mathrm{MPa}$. (contra 3,34 MPa). A diferença aproximada de 5\% está de acordo com o esperado. No entanto a diferença registrada entre os dois ensaios $(27 \%)$ conduz a um resultado acima do esperado. Note-se, ainda, que o valor da resistência à tração obtido pela eq. (4.1) é maior que o obtido experimentalmente.

\subsubsection{Determinação do módulo de elasticidade do concreto:}

O ensaio do dia 15/01/2004 foi realizado na ELE. A força de compressão foi, também, aplicada com velocidade controlada de $2,4 \mathrm{kN} / \mathrm{s}$. A leitura dos deslocamentos foi registrada pelo próprio deslocamento do pistão da máquina além de 2 (dois) extensômetros de $100 \mathrm{~mm}$ de comprimento fixados em duas geratrizes diametralmente opostas. O ensaio do dia 14/05/2004 foi realizado na máquina INSTRON $^{7}$ (Figura 4.3), com controle de deslocamento do pistão. A taxa de incremento se deu a uma velocidade de $0,005 \mathrm{~mm} / \mathrm{s}$. A aquisição dos dados foi de 1 registro/segundo. A leitura dos deslocamentos, de igual modo ao que foi feito na ELE, foi registrada pelo deslocamento do pistão da máquina além de 2 (dois) extensômetros (ver detalhe na Figura 4.3).

\footnotetext{
${ }^{7}$ Máquina de ensaio em corpos de prova à compressão e à tração, modelo 8506, com capacidade para $2500 \mathrm{KN}$.
} 


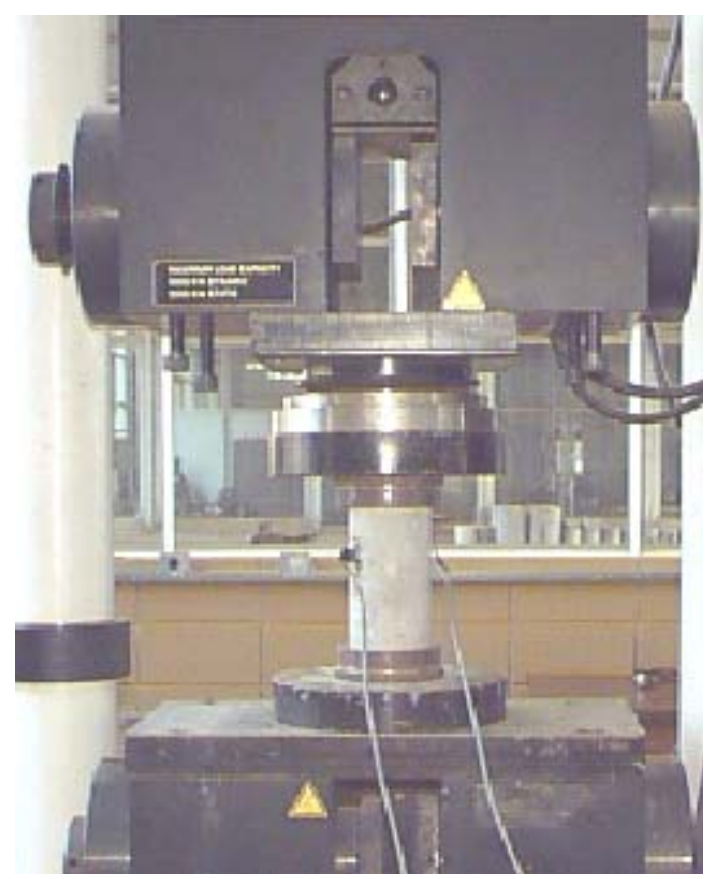

Figura 4.3 - Determinação do módulo de elasticidade do concreto - ensaio realizado na máquina INSTRON

O gráfico da Figura 4.4 mostra o diagrama tensão x deformação para os ensaios realizados em Janeiro (realizados na máquina ELE) e maio de 2004 (na INSTRON), com o fim de determinar o módulo de elasticidade do concreto utilizado.

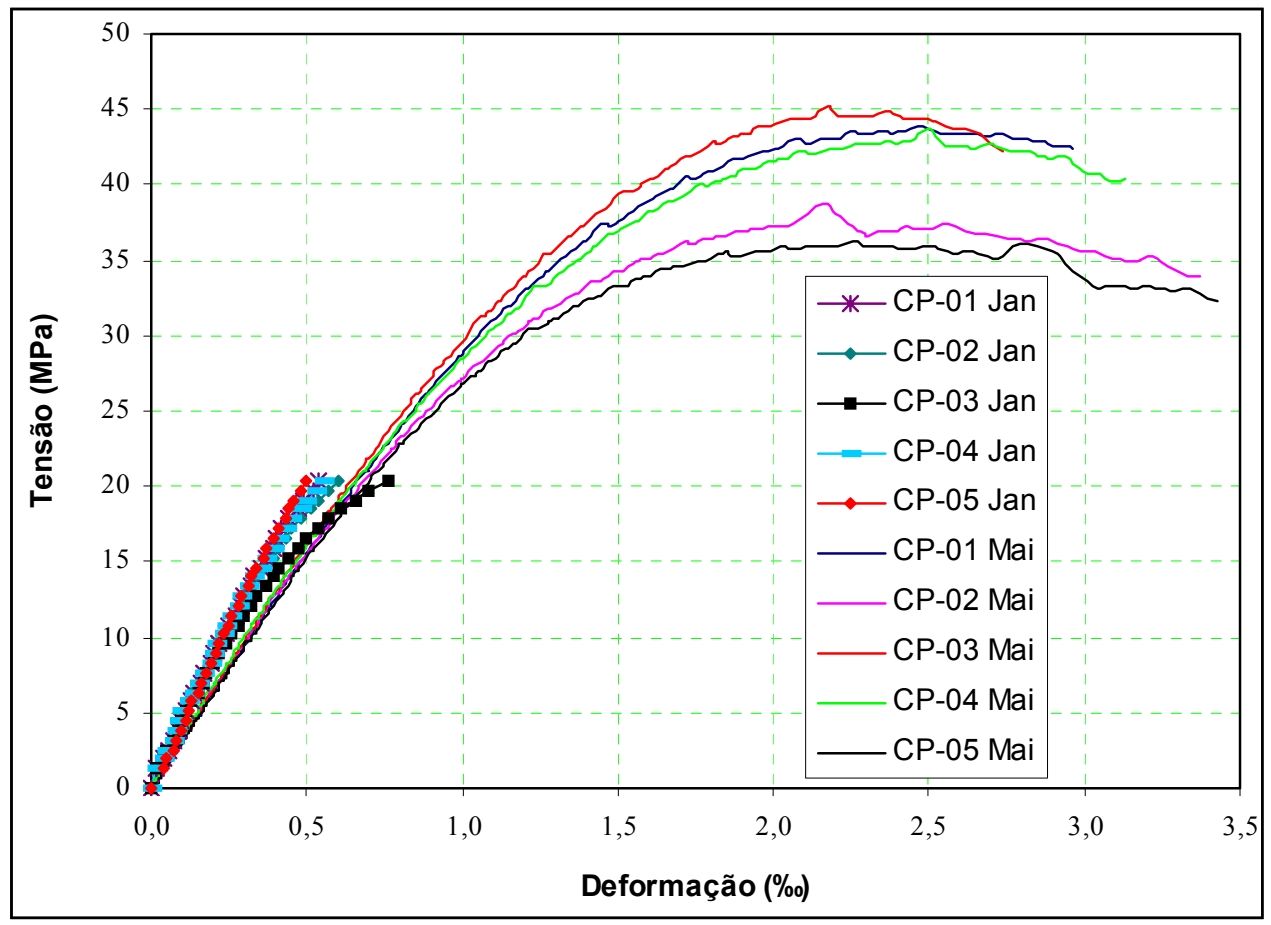

Figura 4.4 - Determinação do módulo de elasticidade do concreto 
Com base nos dados colhidos foi possível determinar o valor aproximado do módulo de elasticidade secante aos 121 dias, com tensão de $40 \%$ da tensão última:

$\mathbf{E}_{121}=32.607 \mathrm{MPa}$.

\subsubsection{Ensaio com CP's de concreto armado}

$\mathrm{O}$ ensaio, estático e cíclico, foi realizado com 4 (quatro) CP's de concreto armado. A Figura 4.5 mostra, esquematicamente, a forma e as dimensões (em mm) do modelo adotado no ensaio;

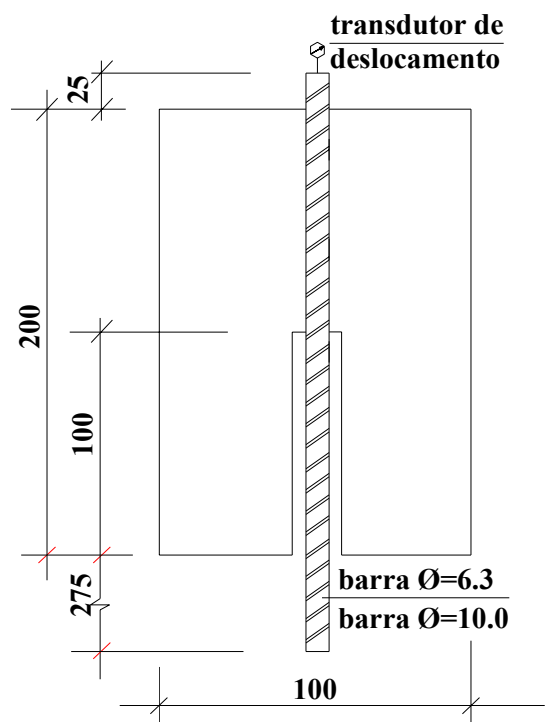

Figura 4.5 - Esquema do ensaio realizado com CP's - dimensões em (mm).

O ensaio foi realizado nos dias 13 e 14 de maio de 2004. Foram realizados dois tipos de ensaios:

a) ensaio padronizado de arrancamento (até a ruptura);

b) ensaio cíclico com carga de serviço.

Dois CP's, contendo uma barra de diâmetro $6.3 \mathrm{~mm}$ em seu eixo, foram submetidos a cada um dos dois tipos de ensaio acima mencionados. Outros dois CP's, contendo uma barra de $10.0 \mathrm{~mm}$ de diâmetro em seu eixo, também foram submetidos aos mesmos ensaios, conforme ilustra a Figura 4.6. O equipamento usado foi a máquina INSTRON. Os CP's foram tirados da câmara úmida no dia 15/04/04. 


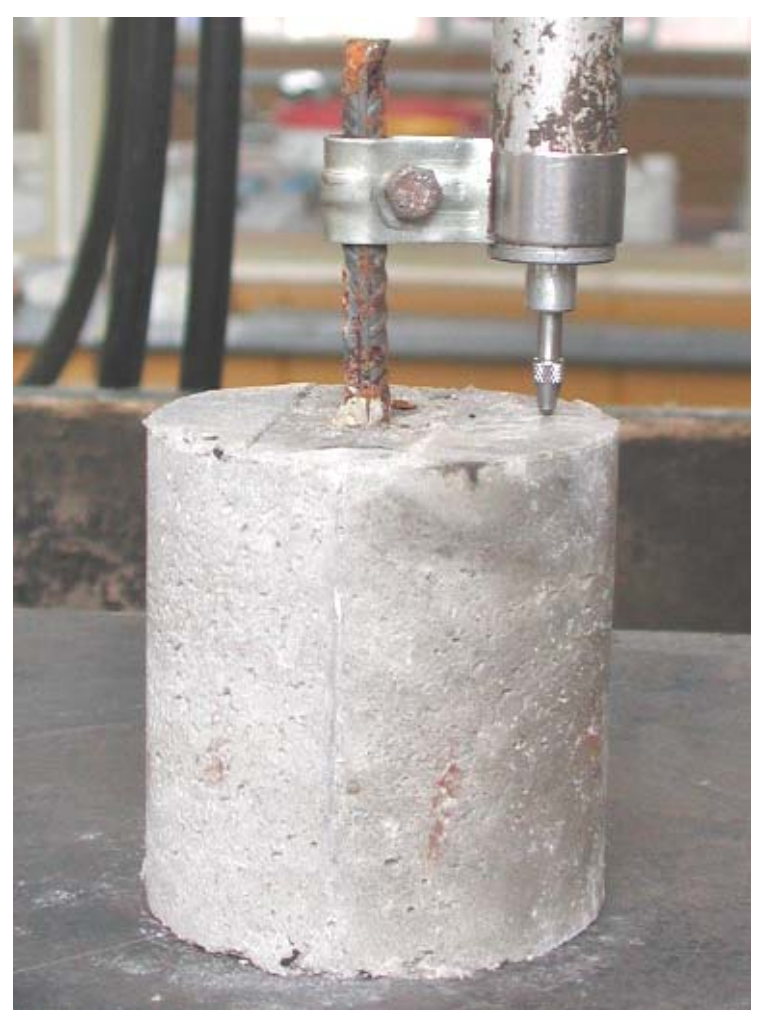

Figura 4.6 - CP's com barra axial (instrumentação com transdutor)

A instrumentação dos CP's para medida de deformação foi feita apenas com um transdutor de deslocamento colocado no extremo da barra (ver Figura 4.6). Os ensaios realizados por FERNANDES (2000) (ver dimensões mostradas na Figura 4.5) mostraram que a utilização de extensômetros elétricos colados à barra não surtiram os efeitos desejados. A superfície de aderência da barra com o concreto ficou bastante reduzida, prejudicando, por conseguinte, a leitura pelos extensômetros. A Figura 4.7 mostra a fôrma dos CP's e as diminutas dimensões do espécime, o que levou o autor a prescindir da instrumentação interna. 


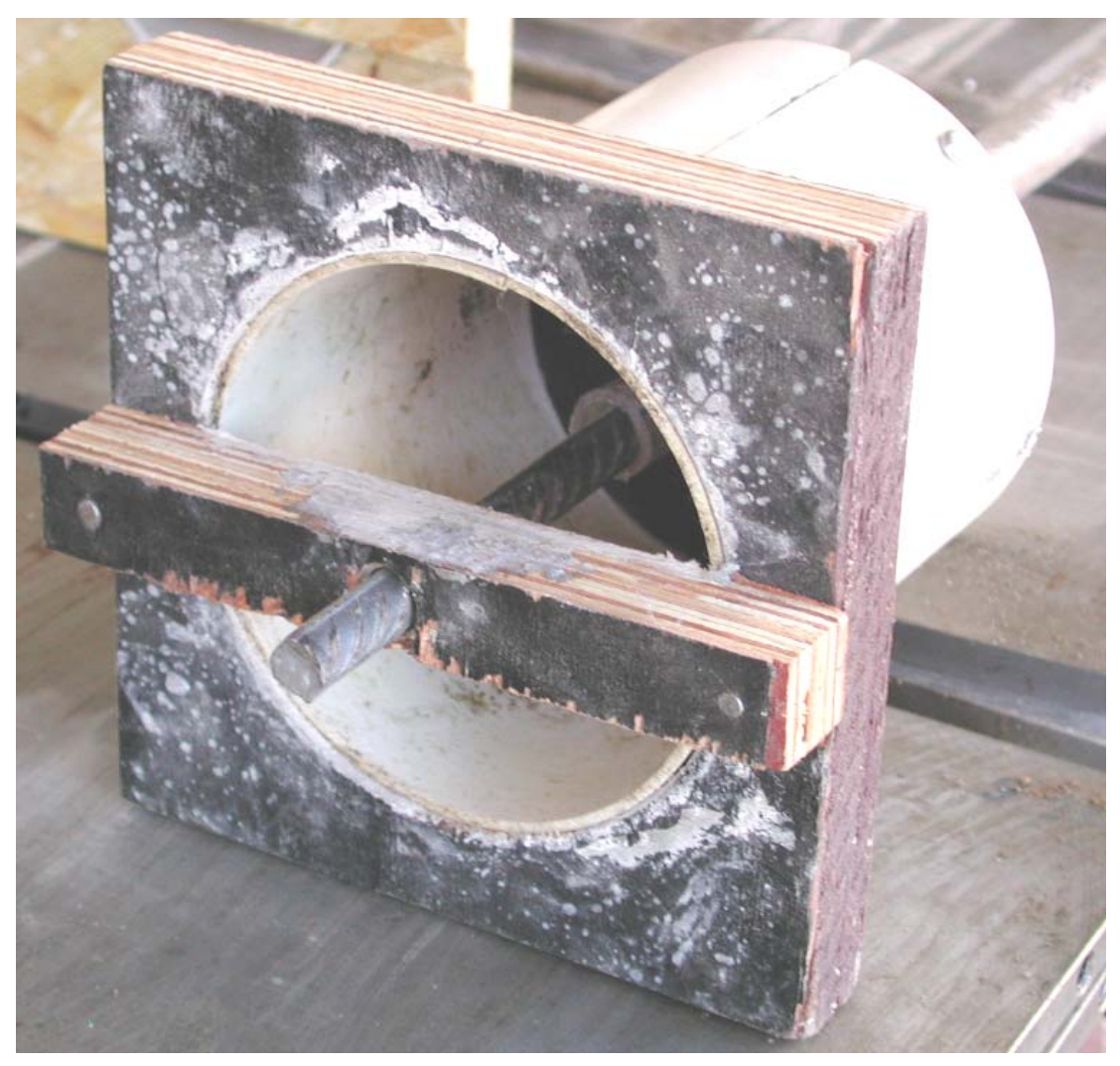

Figura 4.7 - Fôrma dos CP's com barra axial

A realização desse tipo de ensaio, antes mesmo da realização dos ensaios com as vigas (principal objetivo da pesquisa), é plenamente justificada pelo desejo de estudar e fixar o aprendizado de fenômenos elementares e específicos da aderência; ainda mais, teve o propósito de auxiliar na modelagem teórica testando o algoritmo de contato usado pelo programa ABAQUS que simula o efeito da aderência entre o aço e o concreto através do contato entre suas superfícies; pretendeu-se, também, que o ensaio pudesse servir de calibragem para o modelo teórico desenvolvido.

A etapa foi acompanhada dos ensaios clássicos de caracterização dos materiais. Na seqüência são mostrados de forma sucinta estes ensaios.

\subsubsection{Ensaio de arrancamento}

O ensaio de arrancamento para o CP com barra de $6.3 \mathrm{~mm}$ foi realizado com controle de deslocamento a uma taxa de $0,05 \mathrm{~mm} / \mathrm{s}$. Para o CP com barra de $10.0 \mathrm{~mm}$ foi usada uma taxa de $0,02 \mathrm{~mm} / \mathrm{s}$; os registros para aquisição de dados foram feitos com uma leitura a cada segundo. A Figura 4.8 mostra o resultado do ensaio de arrancamento para o CP com barra de $6.3 \mathrm{~mm}$. 


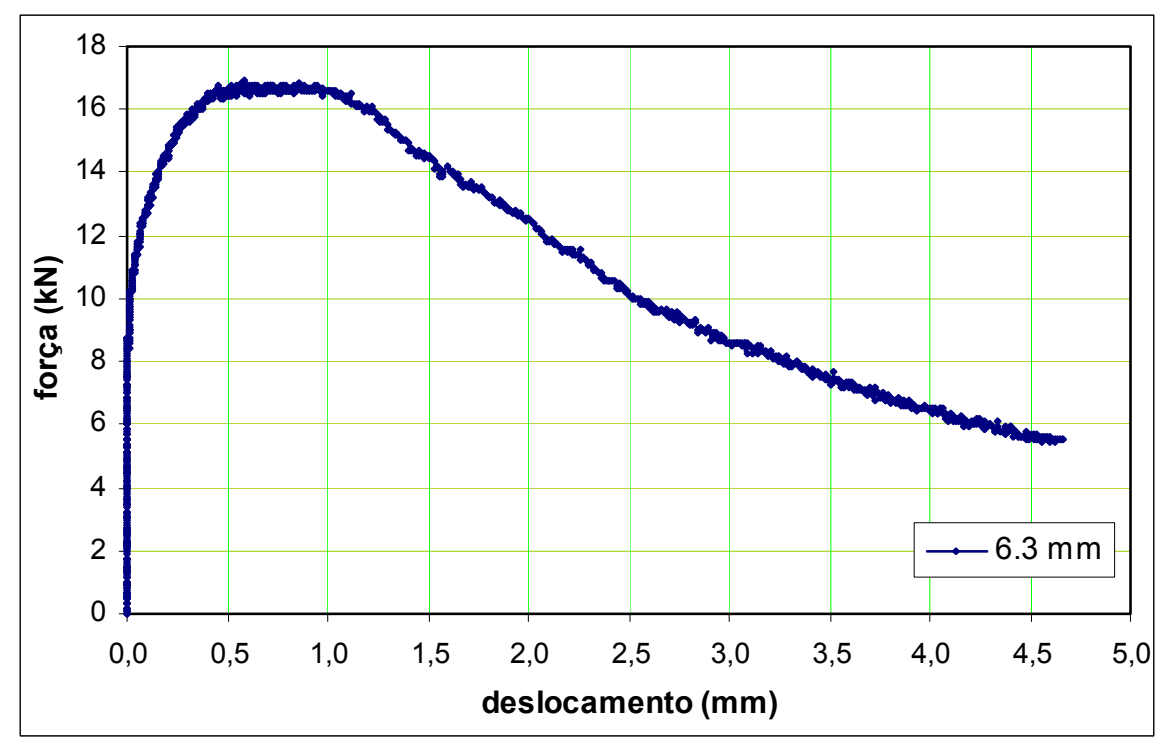

Figura 4.8 - Ensaio de arrancamento para o CP de $6.3 \mathrm{~mm}$

A Figura 4.9 mostra o resultado do ensaio de arrancamento realizado feito para o CP com barra de $10.0 \mathrm{~mm}$.

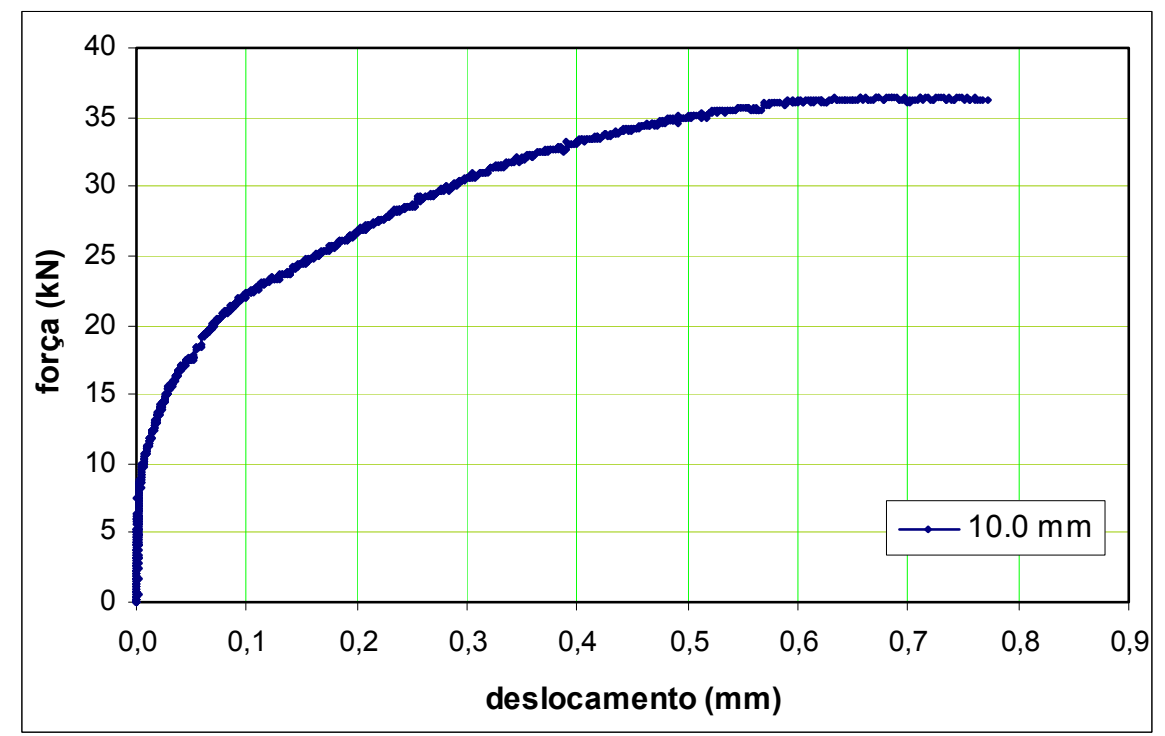

Figura 4.9 - Ensaio de arrancamento para o CP de $10.0 \mathrm{~mm}$

A Figura 4.10 mostra curva comparativa para os dois CP's. 


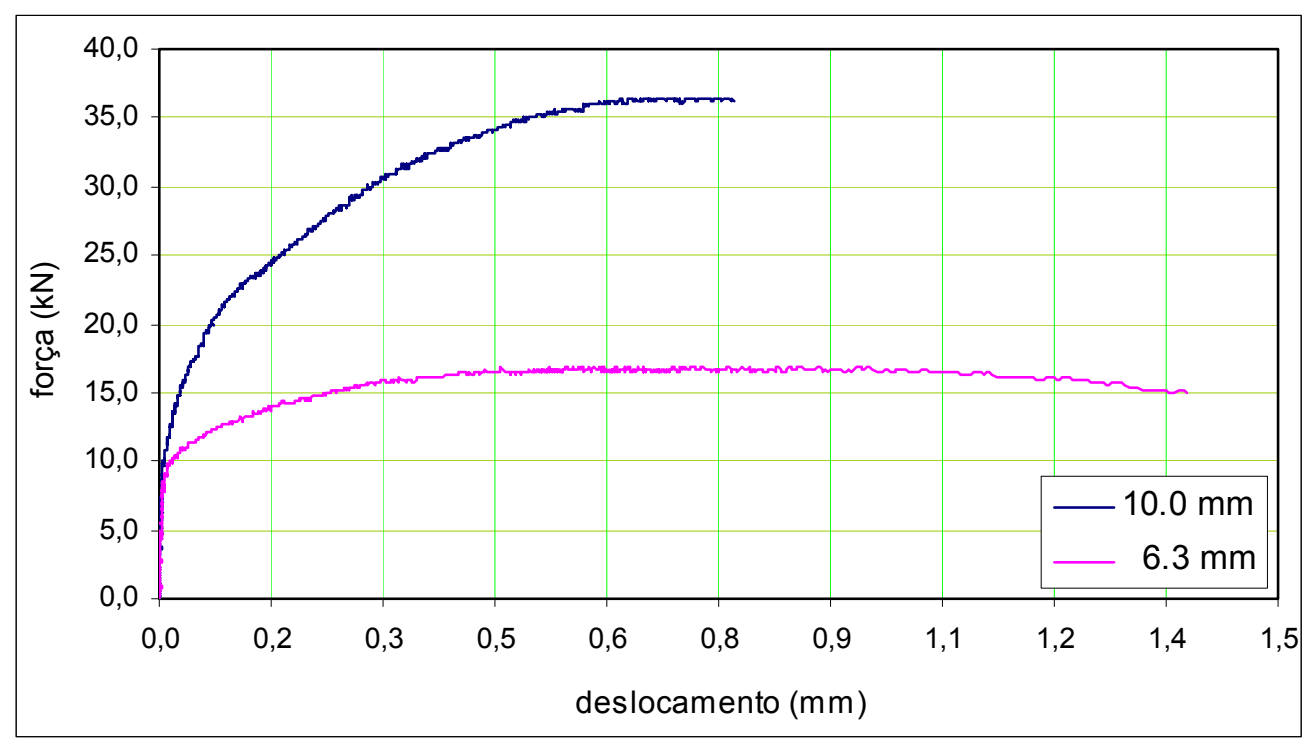

Figura 4.10 - Ensaio de arrancamento - comparativo

Da análise dos ensaios, como mostram as Figura 4.8, Figura 4.9 e Figura 4.10, podem-se extrair os resultados mostrados na Tabela 4.4, com as respectivas cargas de ruptura e deslocamento último da barra.

Tabela 4.4 - Carga de ruptura e deslocamento para os CP's

\begin{tabular}{|c|c|c|}
\hline CP & $\begin{array}{c}\text { Carga de ruptura }(\mathbf{k N}) / \\
\text { deslocamento }(\mathbf{m m})\end{array}$ & OBS. \\
\hline $\mathbf{6 . 3} \mathbf{~ m m}$ & $\mathbf{1 6 , 6}-\mathbf{0 , 4 9}$ & Não apresentou fissuras - arrancamento \\
\hline $\mathbf{1 0 . 0} \mathbf{~ m m}$ & $\mathbf{3 6 , 1}-\mathbf{0 , 5 8}$ & Apresentou fissuras - fendilhamento \\
\hline
\end{tabular}

O ensaio veio comprovar o que já havia sido escrito por GOTO (1971), ELIGEHAUSEN et al (1983), BULLETIN D'INFORMATION n. 230 (1996), entre outros. A aderência passa a ser função, praticamente, da aderência mecânica proveniente da irregularidade da superfície e das nervuras das barras. Verificou-se que no ensaio com barra de $6.3 \mathrm{~mm}$ o espécime sofreu ruptura por arrancamento da barra, como ilustra a Figura 4.11 (a); observar o concreto esmagado entre as nervuras. 

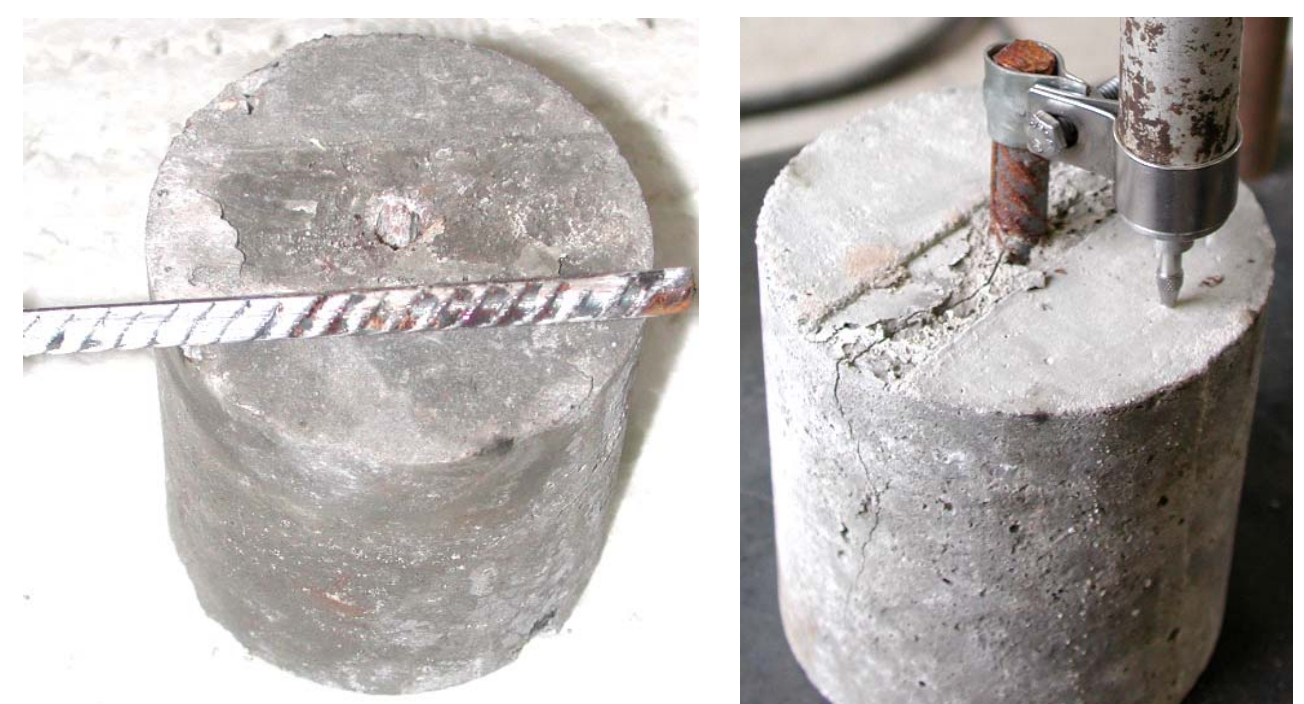

Figura 4.11 - Ruptura por arrancamento (a) e por fendilhamento (b)

Corroborando o relato dos autores acima citados, quando afirmam que devido ao aumento crescente da força na armadura o concreto vai sendo paulatinamente esmagado ao redor da barra, devido à compressão exercida pelas nervuras; e, mais, que antes mesmo que ocorra esmagamento total do concreto e a barra escorregue, aconteça o fendilhamento da peça, provavelmente devido às altas tensões radiais de tração, o ensaio veio a comprovar essas afirmativas, como mostra a Figura 4.11 (b).

A curva que relaciona a tensão de aderência média com o deslizamento medido pelo transdutor de deslocamento fixado no extremo do CP, obtida do ensaio tanto para o CP com barra de $6.3 \mathrm{~mm}$ quanto para o CP com barra de $10.0 \mathrm{~mm}$, é mostrada, respectivamente, nas Figura 4.12 e Figura 4.13.

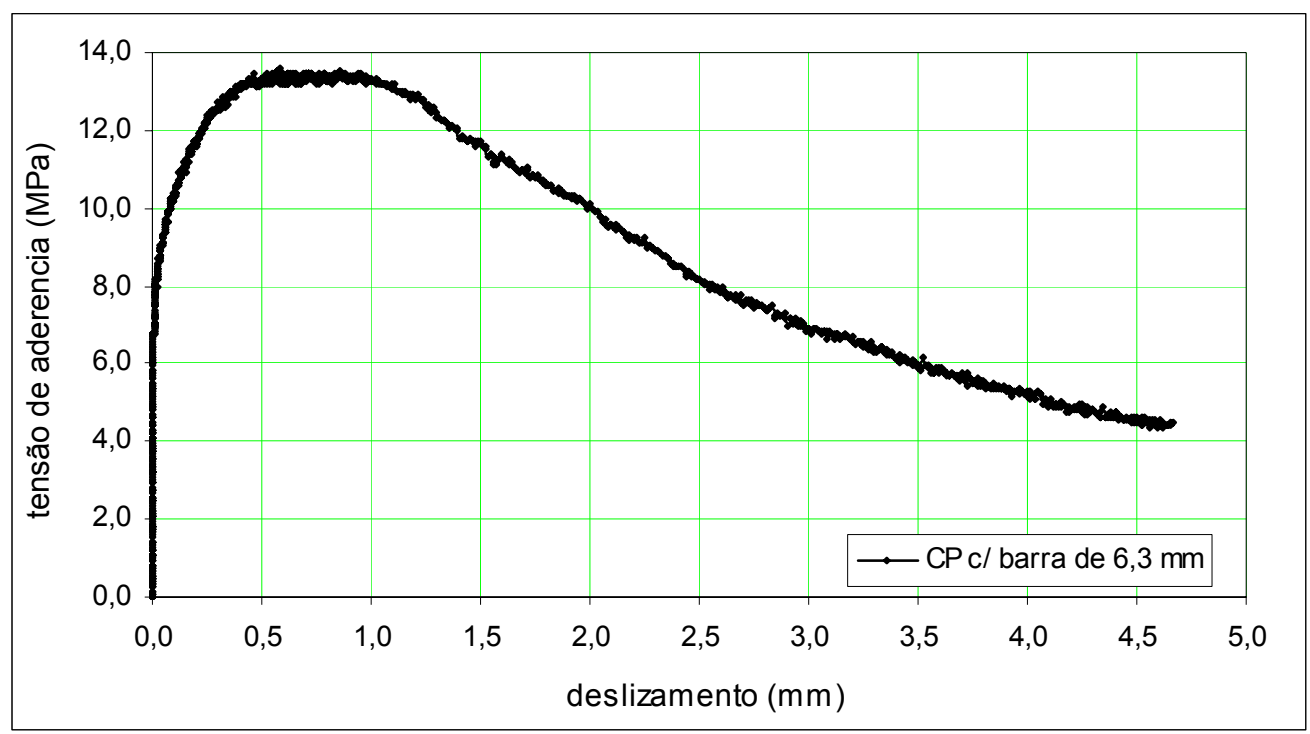

Figura 4.12 - Tensão de aderência x deslizamento para o CP de $6.3 \mathrm{~mm}$ 


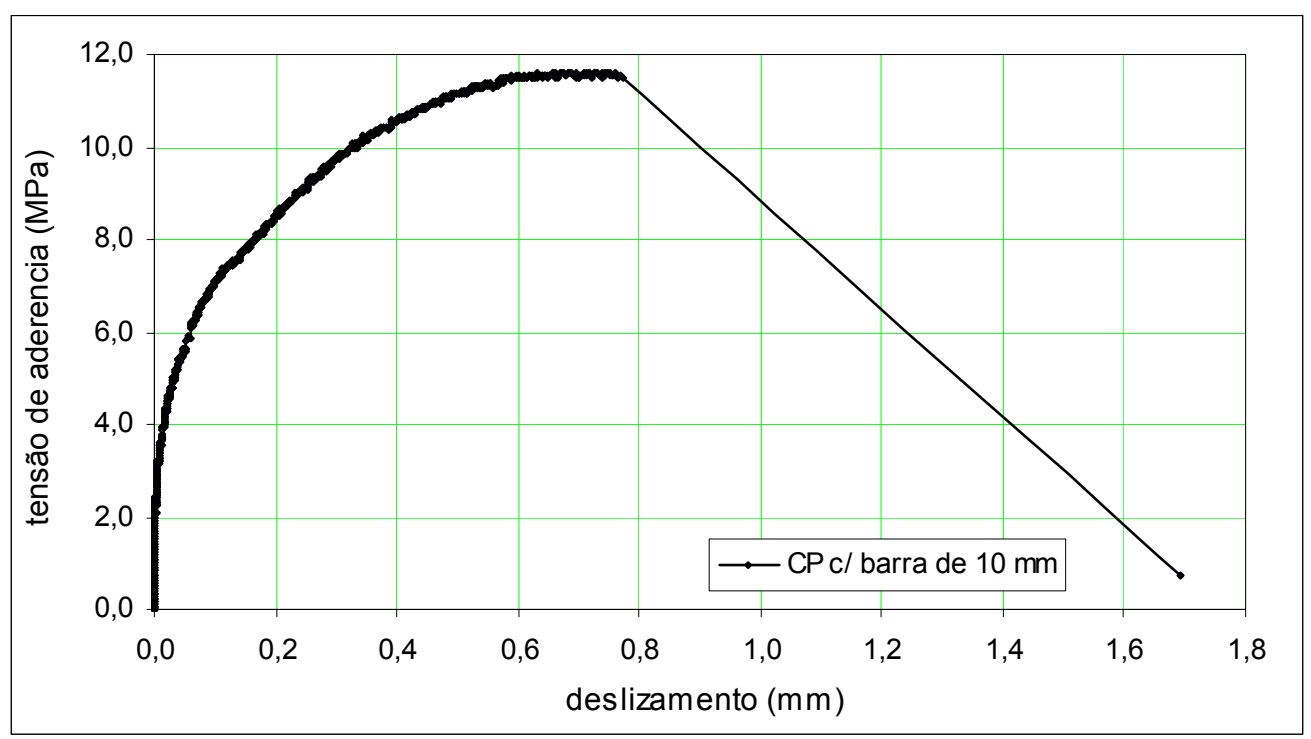

Figura 4.13 - Tensão de aderência x deslizamento para o CP de $10.0 \mathrm{~mm}$

\subsubsection{Ensaio cíclico:}

O ensaio cíclico para o CP de $6.3 \mathrm{~mm}$ foi um tanto conturbado. Ao longo do ensaio foram sendo alteradas as velocidades de deslocamento do pistão e de aquisição de dados. $\mathrm{O}$ ensaio teve que ser interrompido (já aplicados aproximadamente 51 ciclos). No início do ensaio a velocidade era de $0,02 \mathrm{~mm} / \mathrm{s}$ até o 39 ciclo de carga e descarga; à partir daí passou a ser $0,03 \mathrm{~mm} / \mathrm{s}$. A leitura de aquisição variou de $0,1 \mathrm{reg}$./s a 0,2 reg./s. A carga máxima aplicada foi de $13 \mathrm{kN}$ (aproximadamente $80 \%$ da carga última) e a carga mínima de $7 \mathrm{kN}$ (aproximadamente 40\% da carga última). Foram aplicados um total estimado de 230 ciclos. Após o último ciclo, o CP foi levado à ruptura sendo atingida a carga de 19,8 kN. A Figura 4.14 mostra a curva força $\mathrm{x}$ deslocamento para o CP com barra de $6.3 \mathrm{~mm}$. 


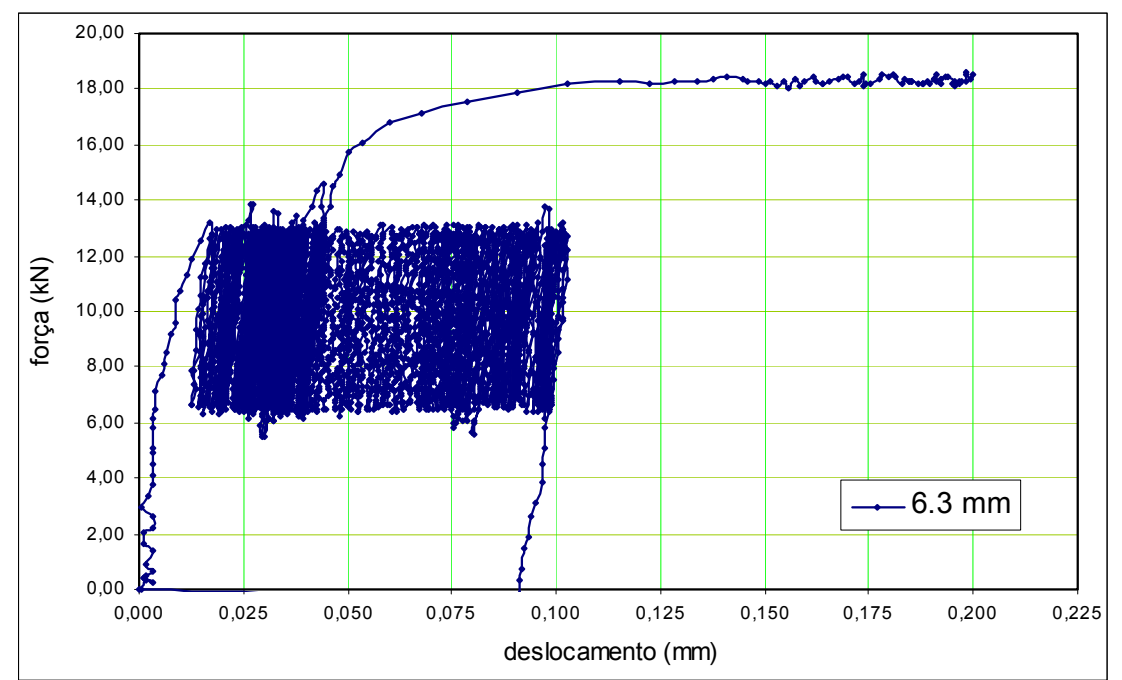

Figura 4.14 - Curva cíclica força x deslocamento para o CP de $6.3 \mathrm{~mm}$

O ensaio cíclico para o $\mathrm{CP}$ de $10.0 \mathrm{~mm}$ foi realizado sem maiores problemas. A velocidade de deslocamento do pistão foi de $0,03 \mathrm{~mm} / \mathrm{s}$ e a velocidade de aquisição dos dados foi de 2 reg./s. A carga máxima foi de $30 \mathrm{kN}$ (aproximadamente $80 \%$ da carga última) e a carga mínima de $22 \mathrm{kN}$ (aproximadamente $60 \%$ da carga última). Foram aplicados um total estimado de 200 ciclos. Após o último ciclo, o CP foi levado à ruptura sendo atingida a carga de $37 \mathrm{kN}$. A Figura 4.15 mostra a curva força $\mathrm{x}$ deslocamento para o CP com barra de $10.0 \mathrm{~mm}$. Vale ressaltar que todo o ensaio cíclico foi realizado manualmente.

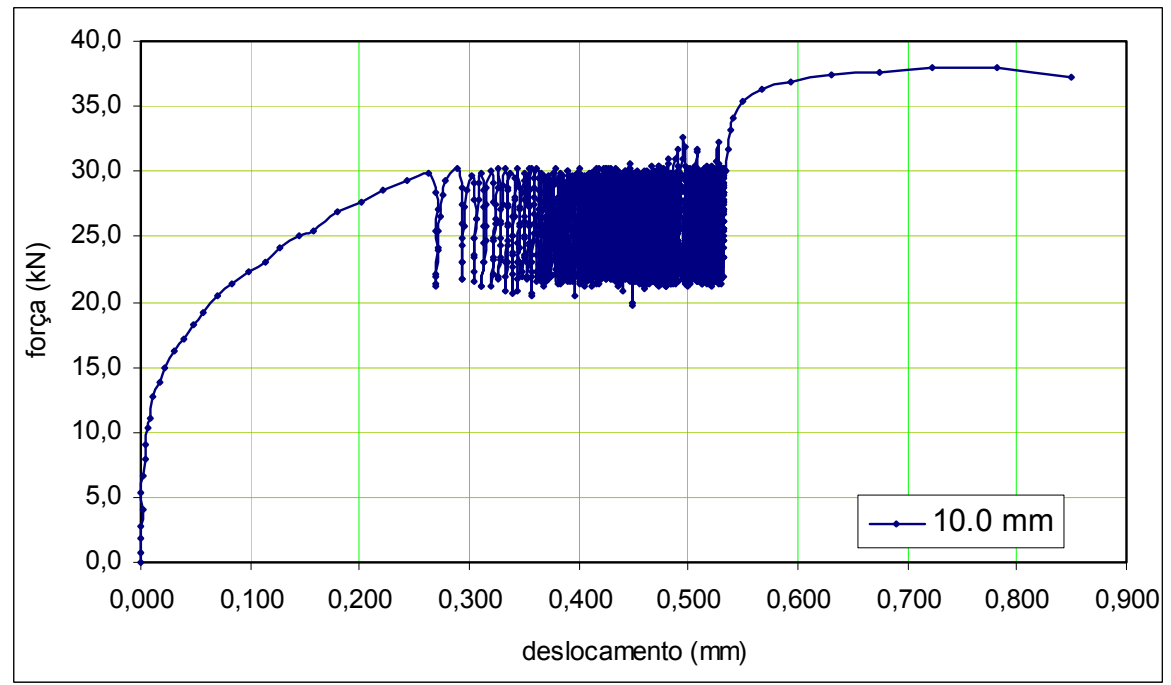

Figura 4.15 - Curva cíclica força x deslocamento para o CP de $10.0 \mathrm{~mm}$

A Figura 4.16 ilustra, para o ensaio com CP de $10.0 \mathrm{~mm}$, o primeiro e os últimos ciclos de carga. 


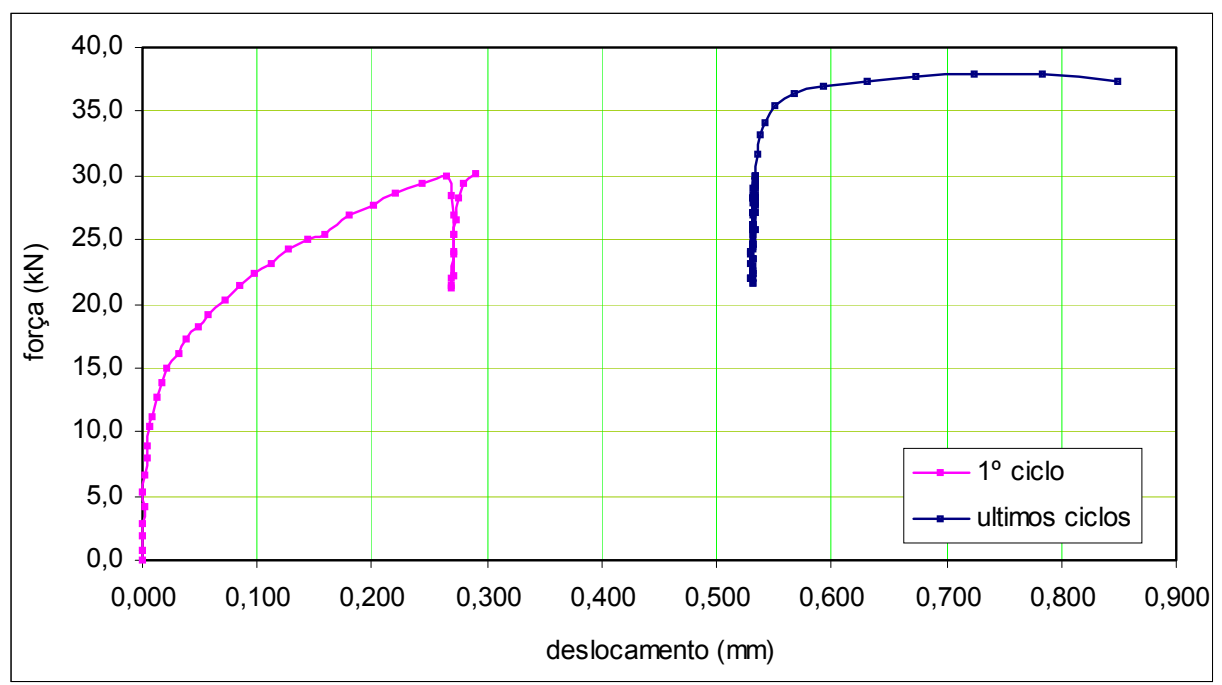

Figura 4.16- $1^{\circ}$ e últimos ciclos para o CP de $10.0 \mathrm{~mm}$

\subsubsection{Ensaio com vigas de concreto armado}

Nessa primeira etapa experimental, ou etapa piloto, foram ensaiadas 04 (quatro) vigas de concreto armado de tamanho reduzido. Na Figura 4.17 são mostradas, esquematicamente, a geometria das vigas, suas dimensões e esquema de carregamento.

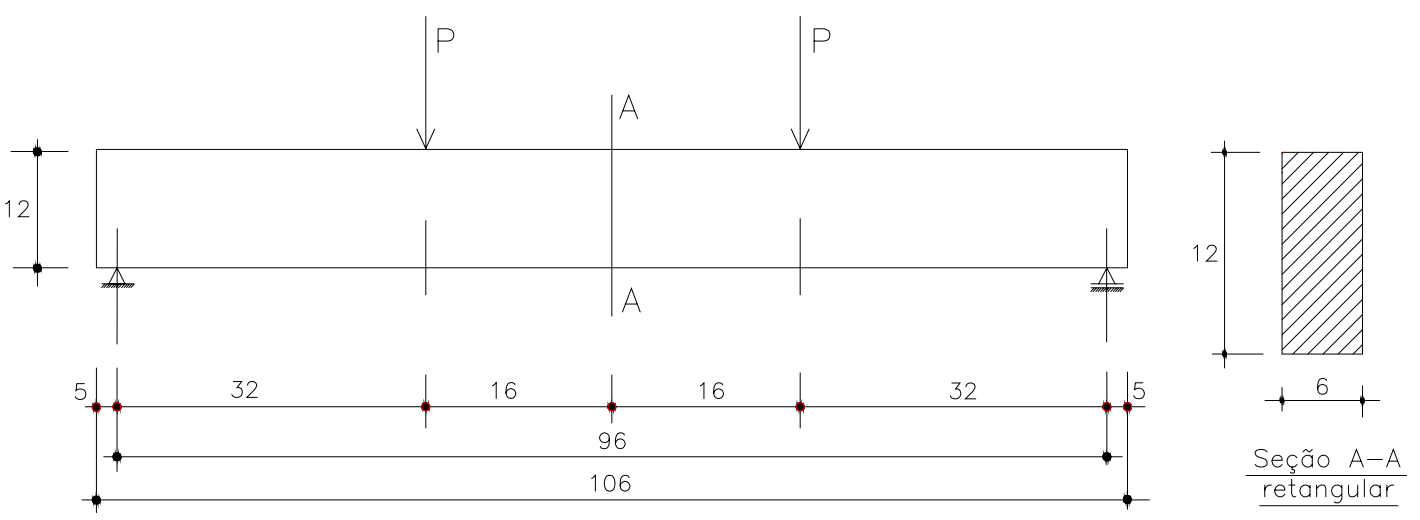

Figura 4.17 - Representação esquemática das vigas

Os ensaios foram divididos em dois grupos:

- Grupo I - vigas do tipo VP-NA.

- Grupo II - vigas do tipo VP-AD. 
O primeiro grupo, grupo I, foi composto de 2 (duas) vigas de seção transversal retangular. As vigas foram dimensionadas próximo à fronteira dos domínios 2 e 3, portanto como seção sub-armada (NA). Não possuem armadura longitudinal de compressão, nem estribos, na zona de momento constante (trecho entre as duas cargas) e tem armadura transversal mínima nas zonas de força cortante. Elas foram denominadas de VP-NA (Viga piloto, sub-armada). A Figura 4.18 mostra o detalhe das armaduras empregadas nas vigas do grupo I.

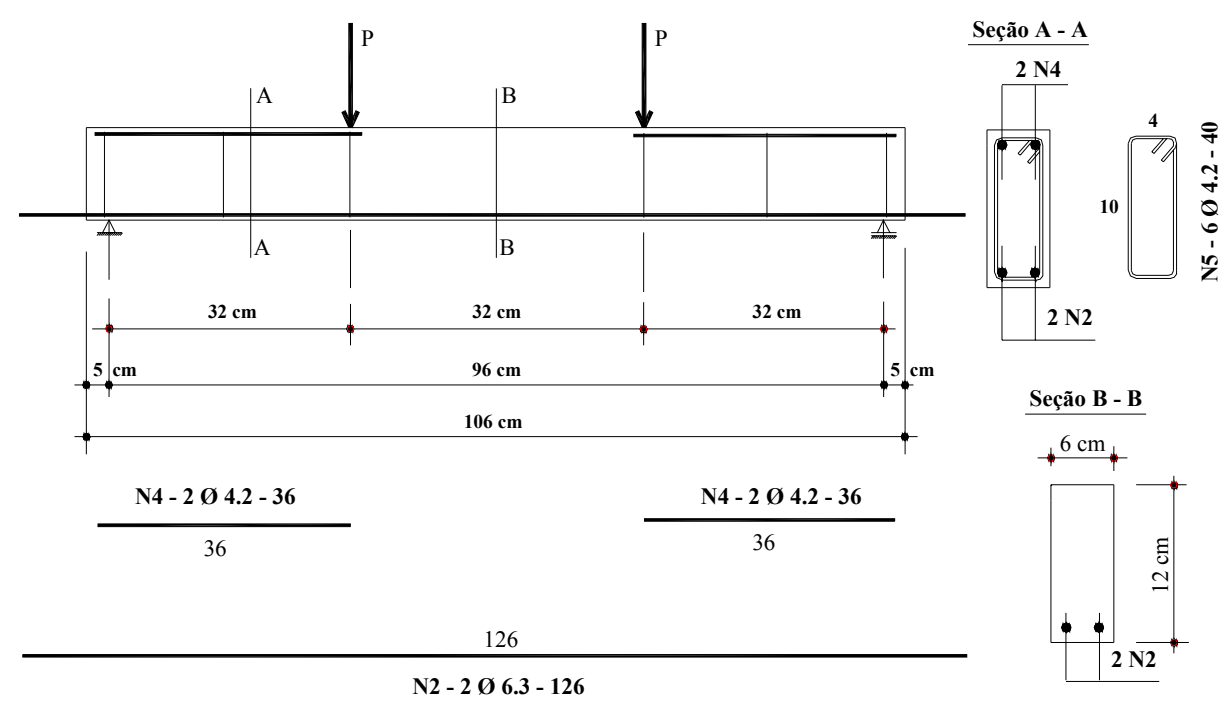

Figura 4.18 - Viga sub-armada - detalhe da armadura

O segundo grupo, grupo II, é composto de 2 (duas) vigas de seção transversal retangular. As vigas foram dimensionadas com armadura dupla (AD), portanto com armadura longitudinal de compressão (evitando assim o domínio 4) com o intuito, inclusive, de avaliar a alteração no comportamento da ductilidade do concreto em compressão. Não possuem estribos na zona de momento constante (trecho entre as duas cargas) e foram dimensionadas com armadura transversal mínima nas zonas de força cortante. Elas foram denominadas de VP-AD (Viga piloto, armadura dupla). A Figura 4.19 mostra o detalhe das armaduras empregadas nessas vigas. 

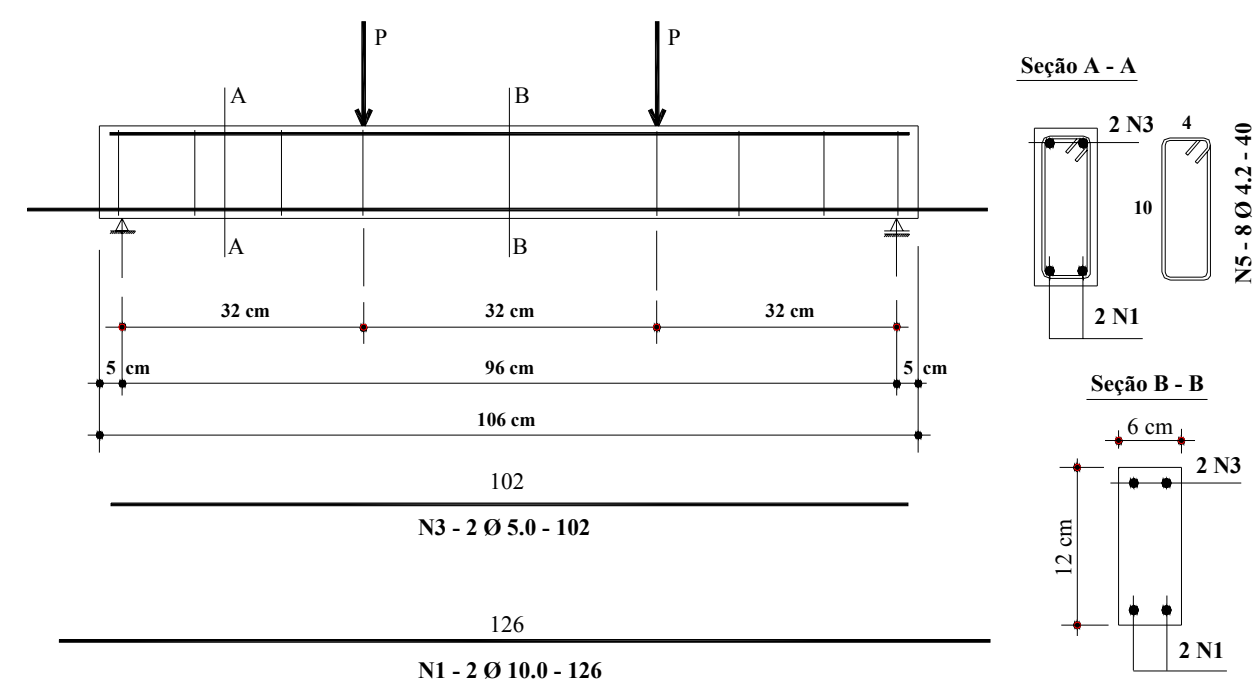

Figura 4.19 - Viga com armadura dupla - detalhe da armadura

As barras longitudinais empregadas em todas as vigas são de aço CA-50 nervuradas. Todos os estribos foram confeccionados com barras de diâmetro $4.2 \mathrm{~mm}$ (CA-60). Todas as vigas são simétricas e foram submetidas a um carregamento simétrico aplicado a uma distância dos apoios de 1/3 do vão, conforme esclarece a Figura 4.17. A instrumentação de todas as vigas foi feita com extensômetros elétricos colocados na armadura e na superfície do concreto para os dois grupos de vigas e são mostrados na Figura 4.20. Os extensômetros de $n^{\circ} 1$ e 2 foram colocados em cada uma das barras de flexão e o extensômetro $\mathrm{n}^{\mathrm{o}} 3$ na face superior do concreto, nas posições mostradas na Figura 4.20.

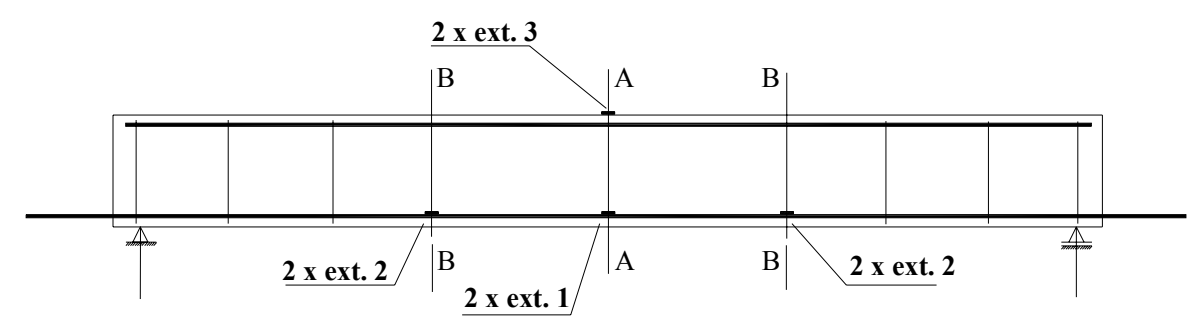

Seção A - A

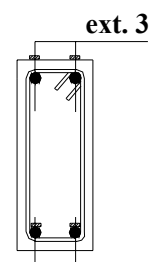

ext. 1

Seção B - B

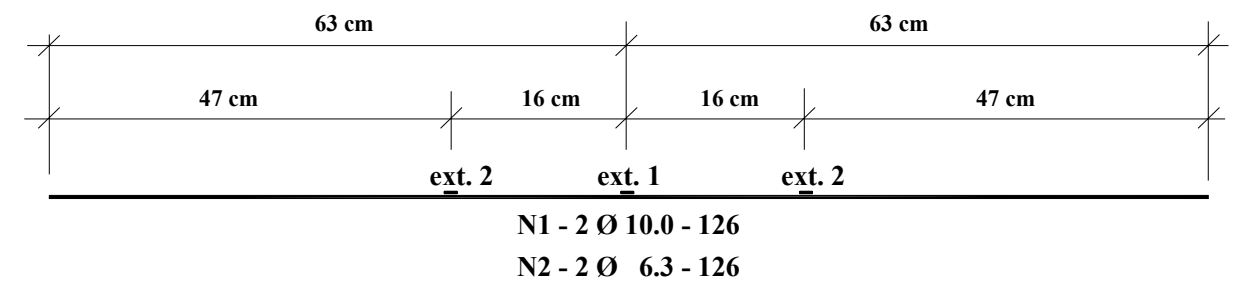

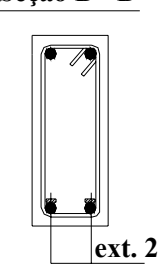

Figura 4.20 - Posicionamento dos extensômetros nas vigas 
A Figura 4.21 mostra o posicionamento dos extensômetros colocados nas barras de uma das vigas, nos pontos correspondentes à seção transversal do centro da viga e nas seções transversais correspondentes aos pontos de aplicação da carga.

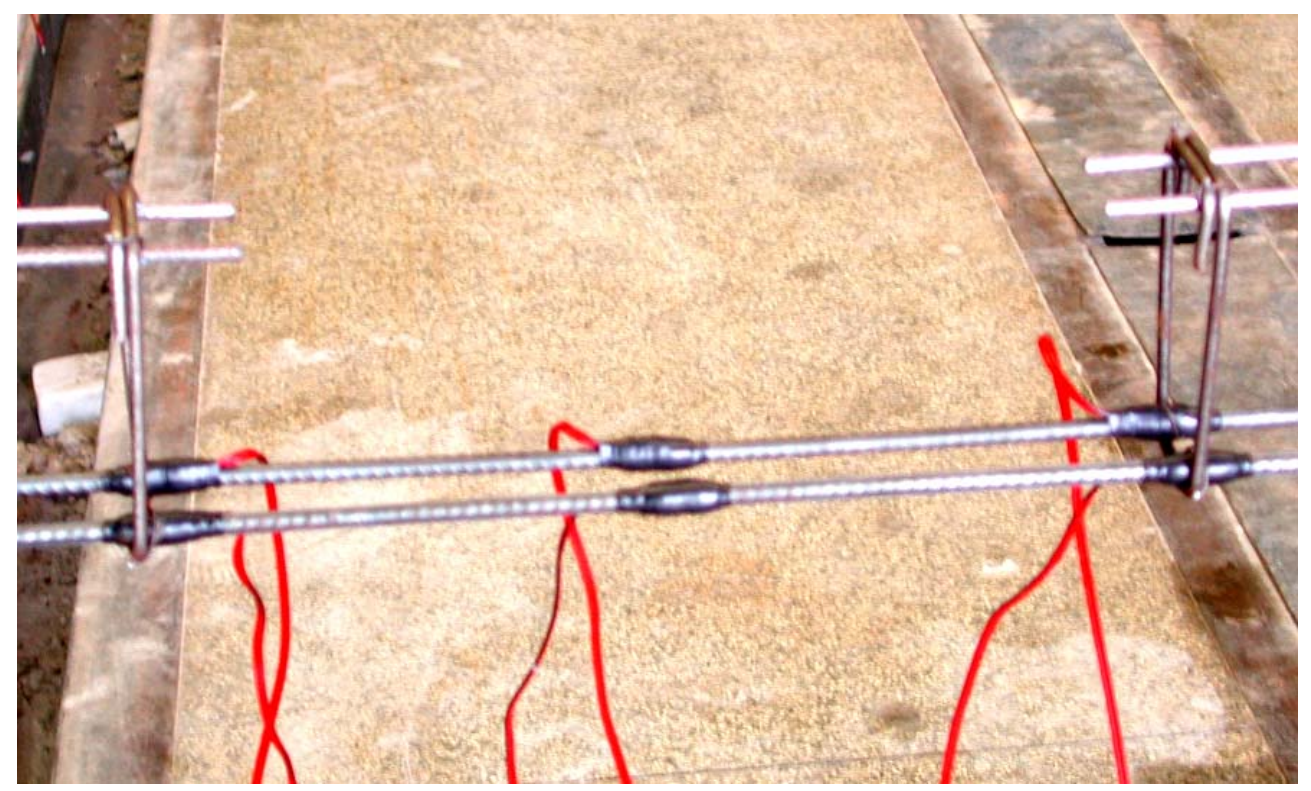

Figura 4.21 - Detalhe dos extensômetros nas barras das vigas

$\mathrm{Na}$ fase de elaboração preliminar do plano de ensaio experimental idealizava-se usar vigas de concreto armado de dimensões reais, comumente utilizadas em estruturas correntes da prática. Os resultados obtidos da pesquisa com o uso destas vigas de dimensões "reais" seriam comparados com os resultados obtidos e publicados por diversos pesquisadores do assunto.

A realização desses ensaios com vigas, por exemplo, de vão $L=240 \mathrm{~cm}$, seção

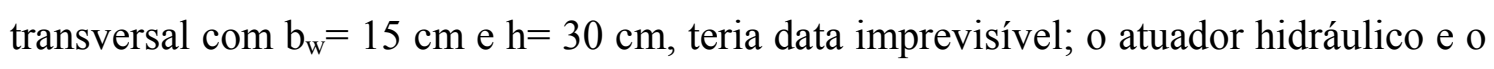
sistema de aquisição de dados utilizados nos ensaios no LE-SET, necessários para a realização do tipo de ensaio proposto, estavam indisponíveis. $\mathrm{Na}$ ocasião do ensaio esses equipamentos estavam sendo utilizados na realização de três grandes projetos de pesquisa no galpão principal do LE-SET. Por outro lado a máquina INSTRON, uma máquina moderna e eficiente, não menos requisitada, mostrava-se incapaz de realizar ensaios com estruturas de maior porte possivelmente por ter dimensões limitadas (a Figura 4.3 dá mostras das dimensões da máquina). Daí a idéia de utilizar vigas com dimensões reduzidas e, por conseguinte, realizar todos os ensaios na INSTRON. Essa tomada de decisão, no entanto, demandaria a confecção de uma estrutura metálica para servir de suporte para as vigas (a ser afixado na INSTRON). Surge, então, um espaço e tempo disponíveis no galpão do laboratório, suficiente para a realização do ensaio. 
Prescindir da máquina INSTRON e usar o atuador hidráulico foi, portanto, a decisão tomada; mantendo, no entanto, as dimensões reduzidas das vigas.

Esta idéia, a da utilização de dimensões reduzidas, é plenamente respaldada por Borges \& Arga e Lima (1961), dentre outros, quando afirmam que "quando modelos de estruturas correntes são construídos com os mesmos materiais (concreto e aço), é possível reproduzir todos os detalhes com bastante precisão para reduções de escala até $1 / 4$ “. As razões listadas abaixo servem como limitadoras da escala de redução das dimensões do modelo ao valor de $1 / 4$, quais sejam: dificuldade em obter barras de aço de pequeno diâmetro com convenientes propriedades mecânicas e de superfície (nervuradas, por exemplo); dificuldade em obter concretos com dimensões menores para as máximas dimensões do agregado graúdo e que sejam proporcionais ao concreto do protótipo; dificuldade em detectar e medir as fissuras de poucas dimensões. Foi adotado, então, um fator de redução da ordem de $1 / 2.5$ em relação às dimensões inicialmente previstas. As vigas do projeto piloto (e do projeto definitivo) ficaram, portanto, com as dimensões mostradas na Figura 4.17: vão livre $\mathrm{L}=96 \mathrm{~cm}$; seção transversal: $b_{w}=6 \mathrm{~cm}$ e $h=12 \mathrm{~cm}$. Adiante são mostrados alguns aspectos do ensaio. A Figura 4.22 mostra as dimensões reduzidas das vigas, o pórtico de reação, o atuador hidráulico e a célula de carga, a Figura 4.23 mostra a instrumentação da viga, apoio e sistema de carga e a Figura 4.24 o detalhe do apoio.

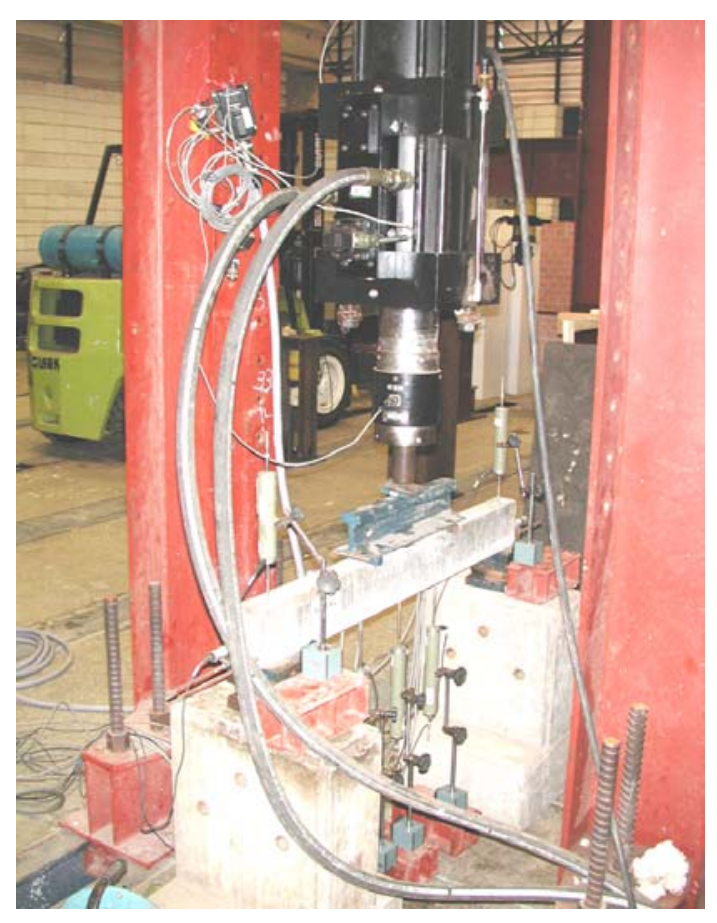

Figura 4.22 - Vista do pórtico, viga e atuador hidráulico 


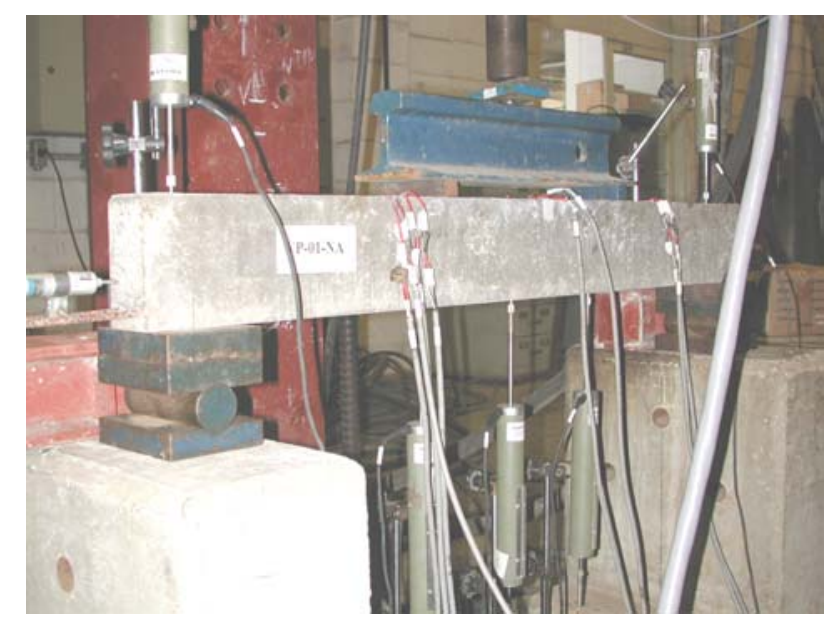

Figura 4.23 - Instrumentação, apoio e sistema de carga

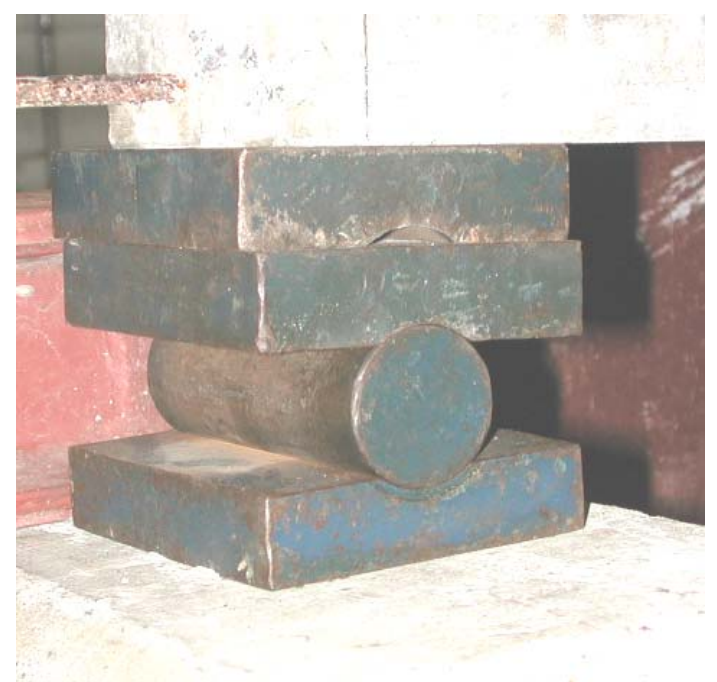

Figura 4.24 - Detalhe do apoio

O ensaio foi realizado nos dias 26 a 29 de abril de 2004. As vigas, num total de 4 (quatro), foram tiradas da câmara úmida no dia 15/04/04. Das duas vigas do grupo I (NA), uma foi levada à ruptura e a outra foi submetida a um determinado número de ciclos de carga, em serviço. O mesmo ocorreu para as duas vigas do grupo II (AD). O dimensionamento das vigas foi elaborado com o auxílio das tabelas de Diaz (1974) adaptadas às condições do ensaio proposto.

\subsubsection{Ensaio à ruptura:}

Inicialmente foram realizados os ensaios para determinação da carga de ruptura. Um quadro resumo contendo o valor da carga de ruptura prevista e o valor da carga de ruptura obtida no ensaio é apresentado na Tabela 3.1. 
Tabela 4.5 - Quadro resumo de cargas para as vigas

\begin{tabular}{|c|c|c|}
\hline VIGAS & Carga de ruptura $(\mathrm{kN})$ - previsto & Carga de ruptura $(\mathrm{kN})$ - ensaio \\
\hline VP-01-NA & $\mathbf{2 1 , 0}$ & $\mathbf{2 2 , 0}$ \\
\hline VP-01-AD & $\mathbf{5 2 , 0}$ & $\mathbf{5 5 , 4}$ \\
\hline
\end{tabular}

A Figura 4.25 apresenta a curva força x flecha para a viga VP-01-NA onde são mostradas as flechas medidas nas seções transversais do meio do vão (seção $\mathbf{A}$ da Figura 4.20) e seções à esquerda e à direita do centro do vão (seções B da Figura 4.20). Os valores medidos mostraram-se coerentes e dentro do esperado. A Figura 4.26 mostra a viga VP-01-NA no momento da ruptura.

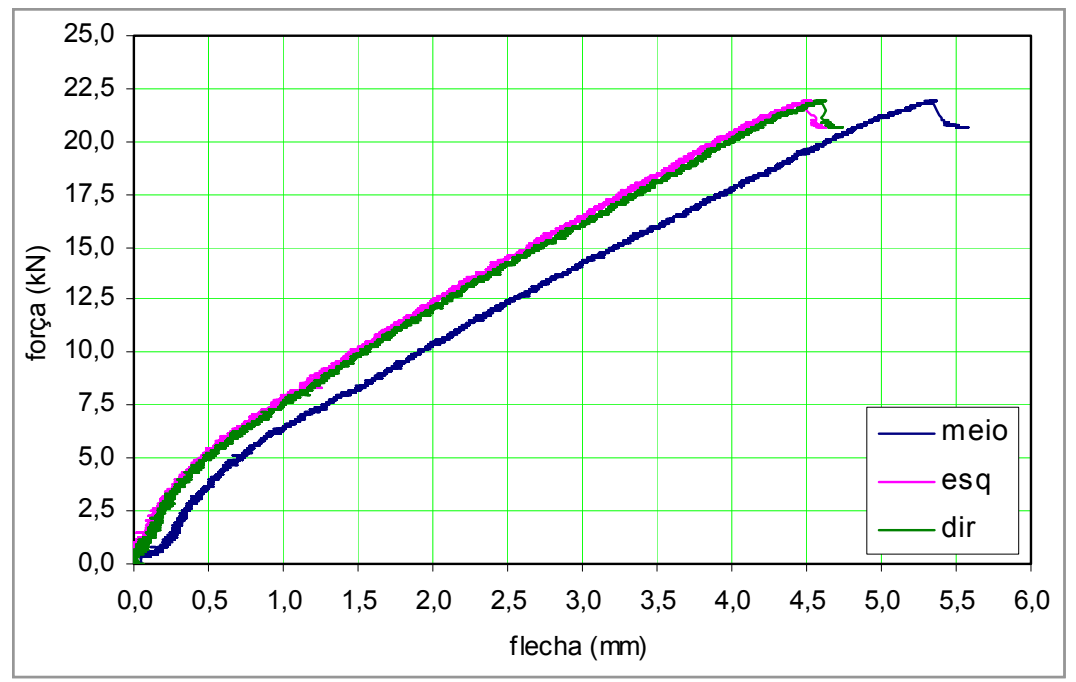

Figura 4.25 - flecha nas seções A e B da viga VP-01-NA

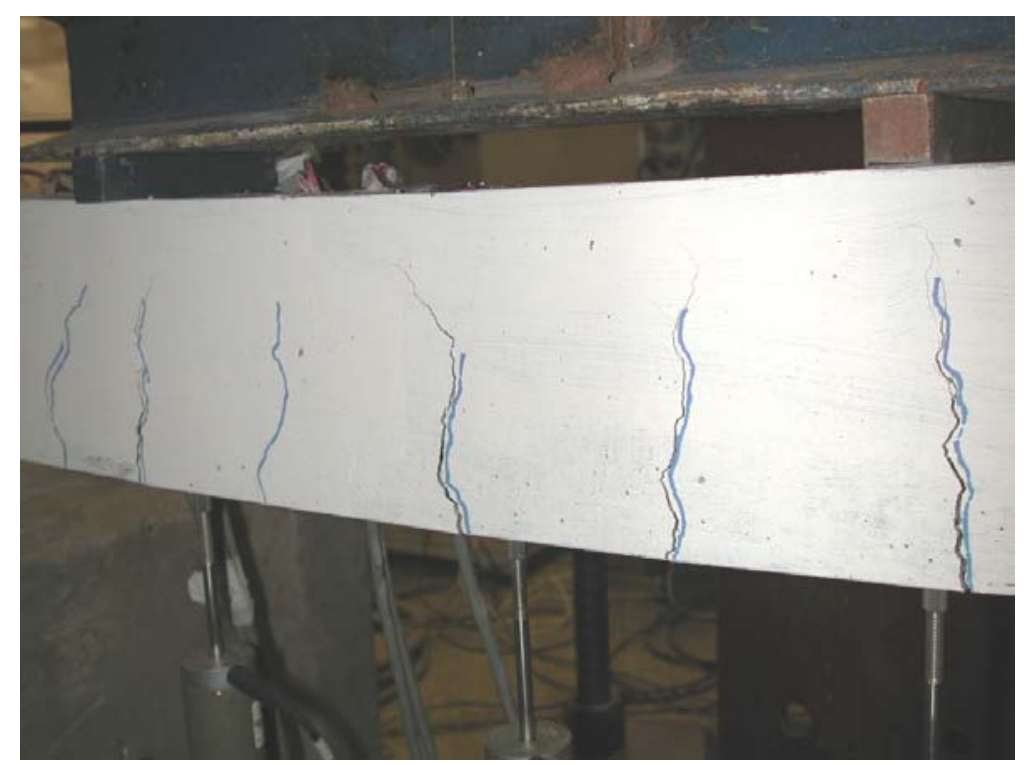

Figura 4.26 - Ruptura da viga VP-01-NA 
Observa-se o nível de fissuração com a linha neutra bastante alta e o concreto esmagado por falta de área de compressão. Na ruptura a armadura já entrou em escoamento.

A Figura 4.27 apresenta a curva força $x$ flecha para a viga VP-01-AD onde são mostradas as flechas medidas nas seções transversais do meio do vão (seção A da Figura 4.20) e seções à esquerda e à direita do centro do vão (seções B da Figura 4.20). Os valores medidos mostraram-se coerentes e dentro do esperado (cálculo da flecha imediata, por BRANSON). A Figura 4.28 mostra a viga VP-01-AD no momento da ruptura.

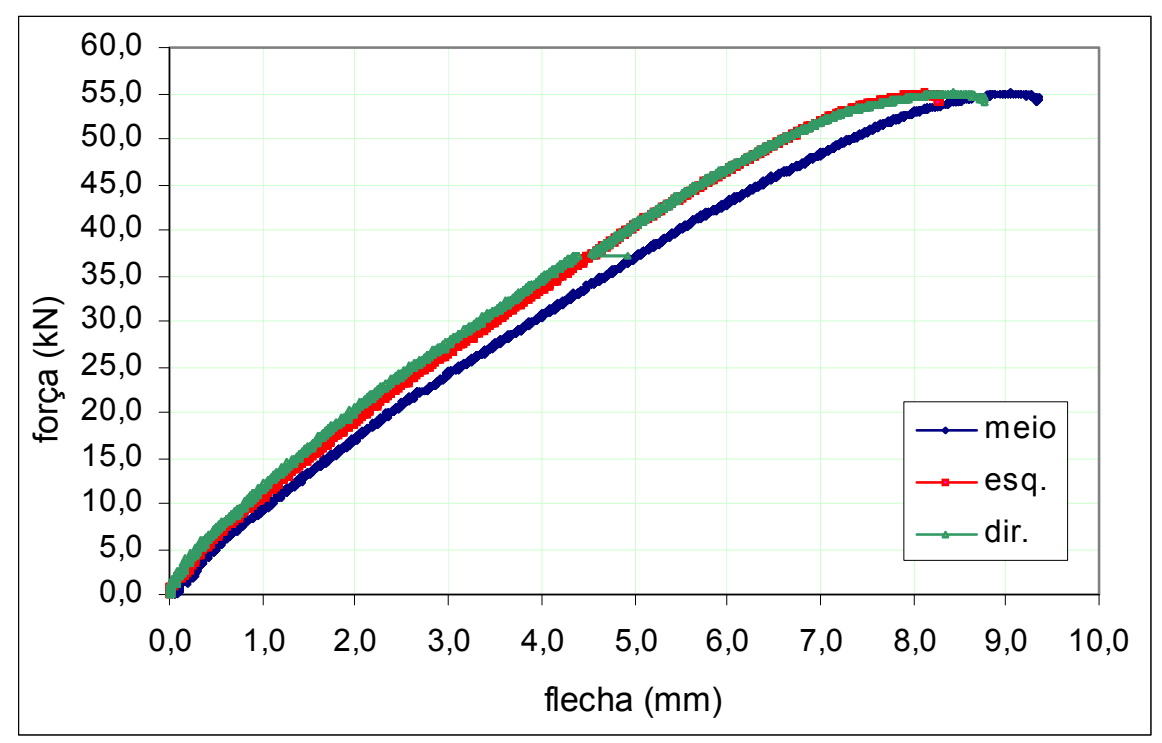

Figura 4.27 - flecha em seções do vão da viga VP-01-AD

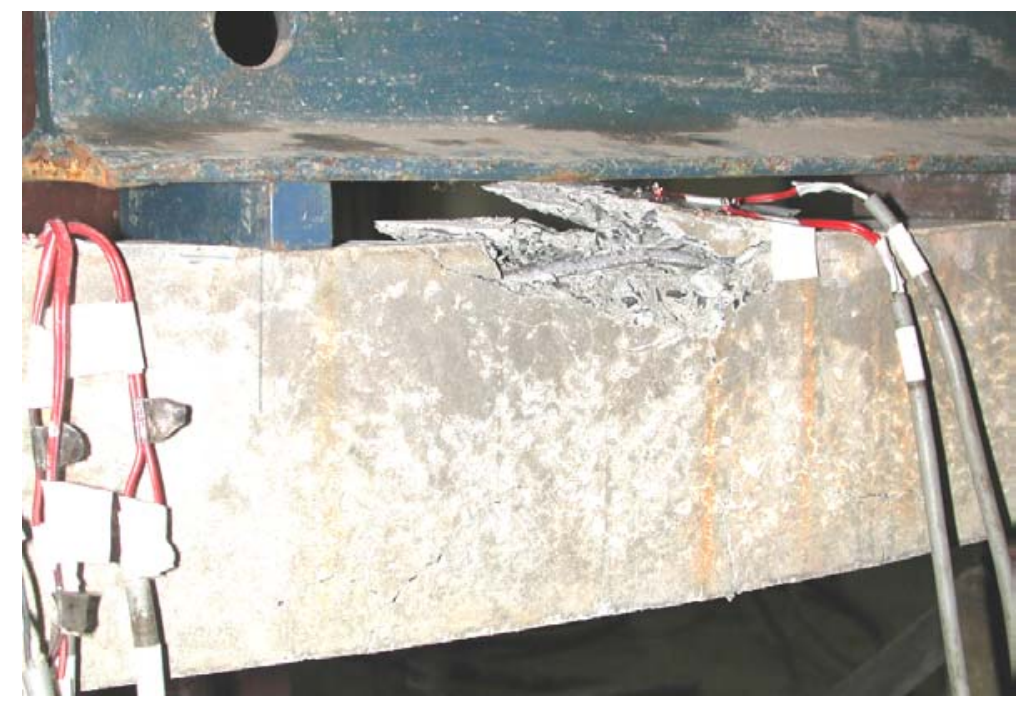

Figura 4.28 - Ruptura da viga VP-01-AD 
Observa-se o baixo nível de fissuração com a linha neutra se movimentando pouco e o concreto esmagado por ter sido suplantada sua resistência máxima à compressão. A armadura superior flambou e a armadura de tração não escoou.

A Figura 4.29 mostra a flecha máxima prevista e a flecha medida em função do momento fletor, no meio do vão da viga VP-01-NA.

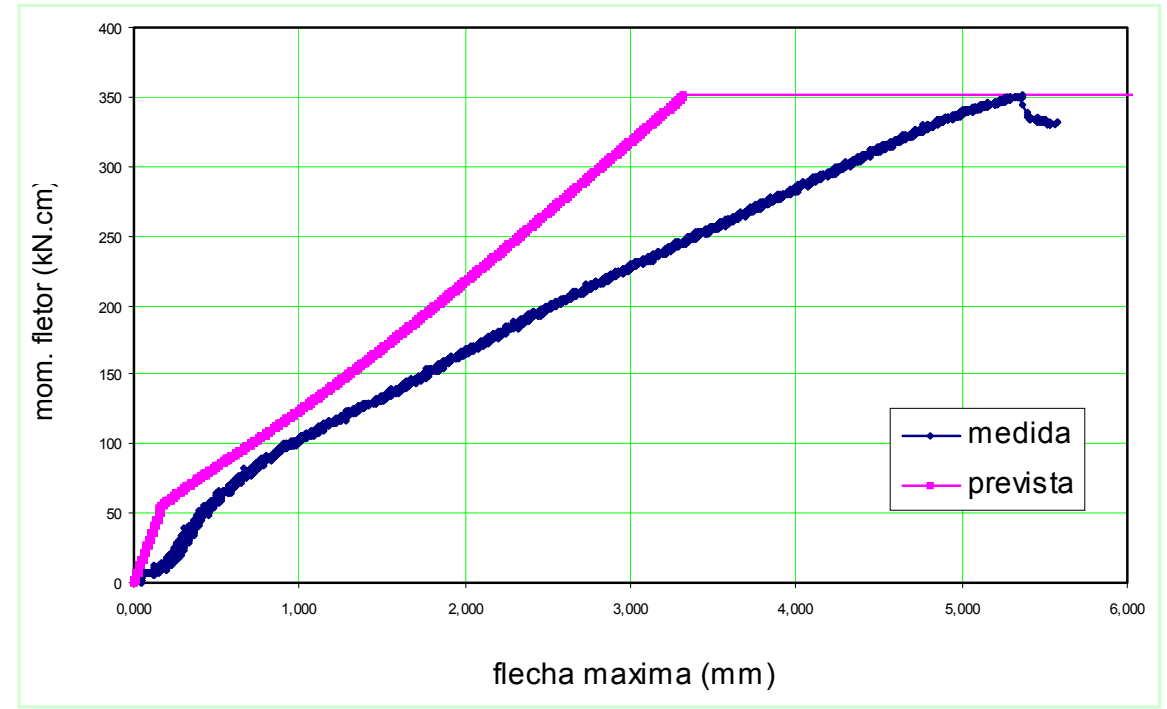

Figura 4.29 - Flecha em seções do vão da viga VP-01-NA

\subsubsection{Ensaio cíclico}

No presente trabalho supõe-se que a deformação residual seja decorrente apenas da aplicação da carga cíclica, desprezando-se, por conseguinte, a influência do tempo. Justifica-se essa tomada de decisão em face do tempo decorrido em cada ensaio ter sido de no máximo oito horas seguidas.

O procedimento de aquisição dos dados (flecha em determinados pontos da viga) foi planejado para registrar os dados com a estrutura trabalhando a uma freqüência de $0,5 \mathrm{~Hz}$, durante alguns ciclos, após o que a viga voltava a trabalhar na freqüência pré-estabelecida para cada viga.

O ensaio cíclico para a viga VP-02-NA foi realizado com velocidade de carga e descarga de $0,02 \mathrm{~mm} / \mathrm{s}$ com leitura de aquisição de 3 registros/segundo. A carga máxima aplicada foi de $14 \mathrm{kN}$ (aproximadamente 65\% da carga última) e a carga mínima de $2 \mathrm{kN}$ (aproximadamente 10\% da carga última). Foram aplicados um total estimado de 50 ciclos. As fissuras na face inferior da viga foram bastante visíveis, quando atingida a carga máxima de cada ciclo. Após o último ciclo a viga foi levada à 
ruptura. A Figura 4.30 mostra a curva que registra o valor da flecha no meio do vão para os 50 ciclos.

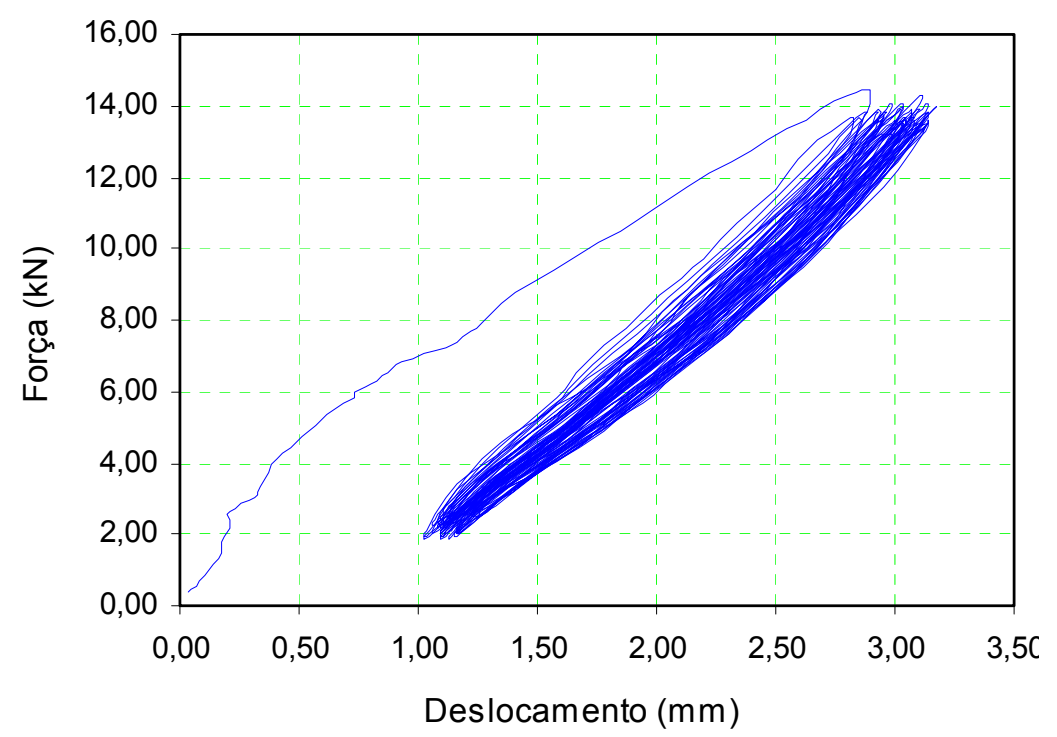

Figura 4.30 - flecha no meio do vão após 50 ciclos - viga VP-02-NA

O ensaio cíclico com a viga VP-02-AD foi realizado com velocidade de carga e descarga maior, ou seja, $0,06 \mathrm{~mm} / \mathrm{s}$ e com leitura de aquisição de $3 \mathrm{reg} / \mathrm{s}$. A carga máxima aplicada foi de $35 \mathrm{kN}$ (aproximadamente 65\% da carga última) e a carga mínima de $3 \mathrm{kN}$ (aproximadamente $5 \%$ da carga última). Foram aplicados um total estimado de 190 ciclos. Após o último ciclo, a viga foi levada à ruptura. A Figura 4.31 mostra a curva que registra o valor da flecha no meio do vão para os 190 ciclos.

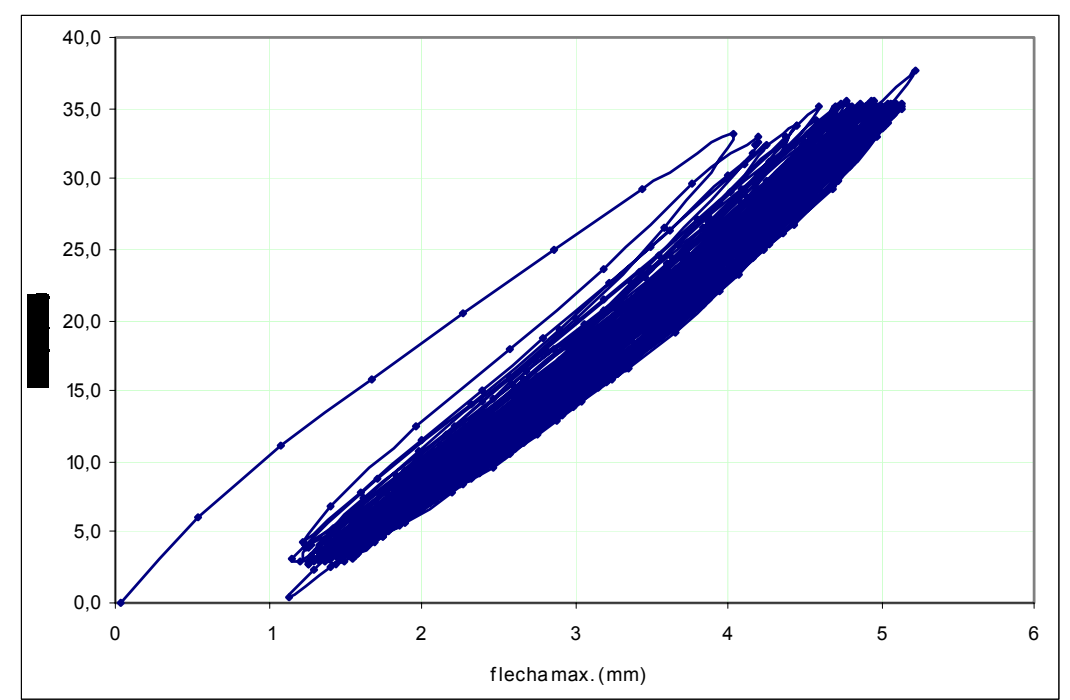

Figura 4.31 - flecha no meio do vão após 190 ciclos - viga VP-02-AD 
OBS.: Apareceram fissuras visíveis na parte central da viga; menos fissuras, no entanto, que na viga VP-02-NA. Apareceram fissuras inclinadas; flecha máxima medida no pico do $24^{\circ}$ ciclo $=4,87 \mathrm{~mm}$; deformação do concreto no pico do $24^{\circ}$ ciclo $=1400$ ue; deformação do aço no pico do $24^{\circ}$ ciclo $=2150$ unidades de deformação. As fissuras verticais (na zona central - entre as cargas) e inclinadas (entre o apoio e a carga) se abrem na carga e fecham na descarga, como esperado.

Observar, também, o acréscimo de flecha acumulado após o último ciclo.

\subsection{ENSAIO DEFINITIVO}

O ensaio definitivo foi subdividido em duas partes:

- Ensaio de caracterização dos materiais;

- Ensaio, estático e cíclico, realizado com 11 (onze) vigas de concreto armado.

Com o cronograma preparado para o ensaio definitivo já apertado, pelos mesmos motivos já comentados, as ações necessárias para concretizá-lo foram sendo cada vez mais urgentes e simplificadoras. A aquisição dos materiais para a confecção das formas e da armação teve início no mês de junho de 2004, logo após a realização do ensaio piloto. A confecção das formas, no entanto, só ocorreu em agosto. A instrumentação e montagem das barras aconteceram em setembro; a concretagem das vigas e dos corpos de prova para caracterização dos materiais aconteceu no dia 29 de setembro de 2004.

\subsubsection{Ensaio de caracterização dos materiais}

Para a confecção do concreto empregado nas vigas e corpos de prova foi utilizado, nessa etapa de trabalho, cimento de alta resistência inicial, o ARI V Plus CIMINAS com o intuito de, com apenas 14 dias de cura, dar início aos ensaios. A resistência à compressão desejada para o concreto foi de $30 \mathrm{MPa}$ (classe C30), a mesma almejada no ensaio piloto. O traço utilizado foi o mesmo usado no ensaio piloto. Como era desejo reduzir o tempo de cura do concreto para ter um início mais breve dos ensaios, foi apenas mudada a composição do cimento passando do anteriormente usado, o CP-32 ITAU, para um cimento de alta resistência inicial, o ARI V Plus da CIMINAS. 
O consumo dos materiais utilizados na confecção do concreto, com respectivo traço em massa, é o mesmo mostrado na Tabela 2.1 (apenas com a mudança do tipo de cimento).

$\mathrm{Na}$ manhã nublada do dia 30/09/2004 foram concretadas as 11 (onze) vigas e 23 (vinte e três) corpos de prova cilíndricos de dimensões 100mm x 200mm.

Foram realizados os ensaios de compressão uniaxial, para determinar a resistência do concreto à compressão e o módulo de elasticidade do concreto, e o ensaio de tração indireta, de compressão diametral, para determinar a resistência do concreto à tração. O ensaio para caracterização das barras de aço não foi executado.

A previsão inicial foi realizar três ensaios de caracterização do concreto distribuídos aos 7, 14 e 28 dias, conforme mostra a Tabela 4.6.

Tabela 4.6 - Previsão das quantidades de CP's por dia de ensaio

\begin{tabular}{|c|c|c|c|}
\hline aos & $\mathbf{7}$ dias & $\mathbf{1 4}$ dias & $\mathbf{2 8}$ dias \\
\hline $\mathbf{f}_{\mathbf{c}}$ & $\mathbf{2}$ & $\mathbf{3}$ & $\mathbf{3}$ \\
\hline $\mathbf{f}_{\mathbf{t}}$ & $\mathbf{2}$ & $\mathbf{2}$ & $\mathbf{2}$ \\
\hline $\mathbf{E}_{\mathbf{c}}$ & $\mathbf{3}$ & 3 & 3 \\
\hline total & 7 & 8 & 8 \\
\hline
\end{tabular}

Os ensaios com os 21 (vinte e um) corpos de prova foram realizados, no entanto, aos $21^{\circ}$ e $28^{\circ}$ dias, conforme mostra a Tabela 4.7. Os ensaios foram realizados na máquina ELE International e na INSTRON.

Tabela 4.7 - Quantidades de CP's por dia de ensaio

\begin{tabular}{|c|c|c|c|}
\hline aos & 21 dias & 28 dias & 28 dias \\
\hline equipamento & ELE & ELE & INSTRON \\
\hline $\mathbf{f}_{\mathbf{c}}$ & 2 & 5 & - \\
\hline $\mathbf{f}_{\mathbf{t}}$ & - & 5 & - \\
\hline $\mathbf{E}_{\mathbf{c}}$ & 4 & - & 5 \\
\hline total & 6 & 10 & 5 \\
\hline
\end{tabular}

\subsubsection{Determinação da resistência à compressão do concreto}

A força de compressão foi aplicada com velocidade controlada de 2,4 kN/s. O ensaio dos CP's aos 21 dias ocorreu no dia 21/10/2004 e o ensaio aos 28 dias foi levado a efeito no dia 28/10/2004. A Tabela 4.8 mostra os resultados obtidos aos 21 e 28 dias. 
Tabela 4.8 - Resultado dos ensaios à compressão simples

\begin{tabular}{|c|c|c|c|c|}
\hline \multirow{2}{*}{} & \multicolumn{2}{|c|}{ Força (kN) } & \multicolumn{2}{c|}{ Tensão (MPa) } \\
\cline { 2 - 5 } & $21 / 10 / 04$ & $28 / 10 / 04$ & $21 / 10 / 04$ & $28 / 10 / 04$ \\
\hline CP01 & 372,6 & 348,3 & $\mathbf{4 7 , 4 4}$ & 44,35 \\
\hline CP02 & 261,0 & 293,2 & 33,23 & 37,34 \\
\hline CP03 & 337,9 & 351,6 & 43,02 & 44,77 \\
\hline CP04 & 286,5 & 292,7 & 36,48 & 37,27 \\
\hline CP05 & 336,3 & 270,0 & 42,84 & 34,38 \\
\hline CP06 & 231,0 & 376,4 & $\mathbf{2 9 , 4 1}$ & $\mathbf{4 7 , 9 5}$ \\
\hline CP07 & - & 305,5 & - & 38,92 \\
\hline CP08 & - & 369,6 & - & 47,08 \\
\hline CP09 & - & 249,2 & - & $\mathbf{3 1 , 7 4}$ \\
\hline CP10 & - & 294,7 & - & 37,54 \\
\hline média & - & - & $\mathbf{3 8 , 7 4}$ & $\mathbf{4 0 , 1 3}$ \\
\hline
\end{tabular}

$$
\begin{aligned}
& \mathrm{f}_{\mathrm{c}, \max }=\mathbf{4 7 , 4 4} \mathrm{MPa} \\
& \mathrm{f}_{\mathrm{c}, \min }=\mathbf{2 9 , 4 1} \mathrm{MPa} \\
& \mathrm{f}_{\mathrm{c}, \max }=\mathbf{4 7 , 9 5} \mathrm{MPa} \quad(+1,08 \%) \\
& \mathrm{f}_{\mathrm{c}, \min }=\mathbf{3 1 , 7 4} \mathrm{MPa} \quad(+7,92 \%)
\end{aligned}
$$

\subsubsection{Determinação da resistência à tração do concreto}

O ensaio foi realizado no dia 28/10/2004, portanto decorridos 28 dias da concretagem, utilizando a máquina ELE e aplicando uma força de compressão com velocidade controlada de $0,94 \mathrm{kN} / \mathrm{s}$. A leitura final para cada CP é mostrada na Tabela 4.9 .

Tabela 4.9 - Resultado dos ensaios de resistência à tração

\begin{tabular}{|c|c|c|}
\hline & Força $(\mathbf{k N )}$ & Tensão $(\mathbf{M P a})$ \\
\hline CP01 & 107,0 & 3,41 \\
\hline CP02 & 92,5 & 2,94 \\
\hline CP03 & 79,5 & $\mathbf{2 , 5 3}$ \\
\hline CP04 & 126,6 & $\mathbf{4 , 0 3}$ \\
\hline CP05 & 97,5 & 3,10 \\
\hline média & - & $\mathbf{3 , 2 0}$ \\
\hline
\end{tabular}




\subsubsection{Determinação do módulo de elasticidade do concreto}

O ensaio foi realizado na máquina INSTRON, com taxa de incremento a uma velocidade de $0,005 \mathrm{~mm} / \mathrm{s}$ e aquisição de dados de $1 \mathrm{reg} . / \mathrm{s}$. A leitura dos deslocamentos foi registrada pelo próprio deslocamento do pistão da máquina além de 2 (dois) extensômetros de $100 \mathrm{~mm}$ de comprimento fixados em duas geratrizes diametralmente opostas. A Figura 4.32 mostra a curva tensão x deformação para o extensômetro $\mathrm{n}^{\circ} 01 \mathrm{e}$ a Figura 4.33 para o extensômetro ${ }^{\circ}$ 02, obtidos no ensaio aos 28 dias.

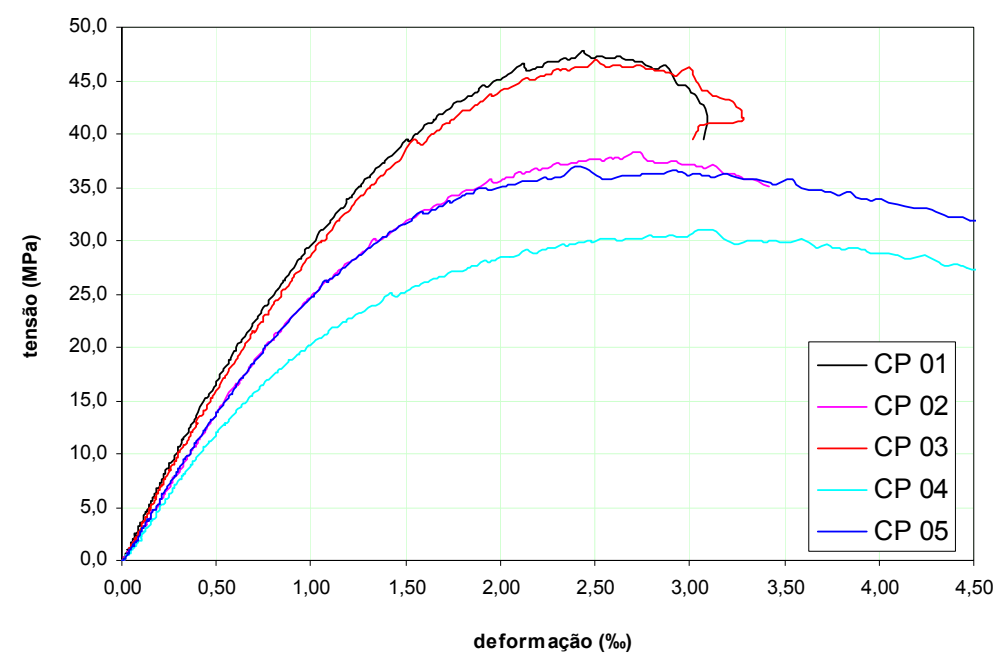

Figura 4.32 - Tensão x deformação para o extensômetro 01

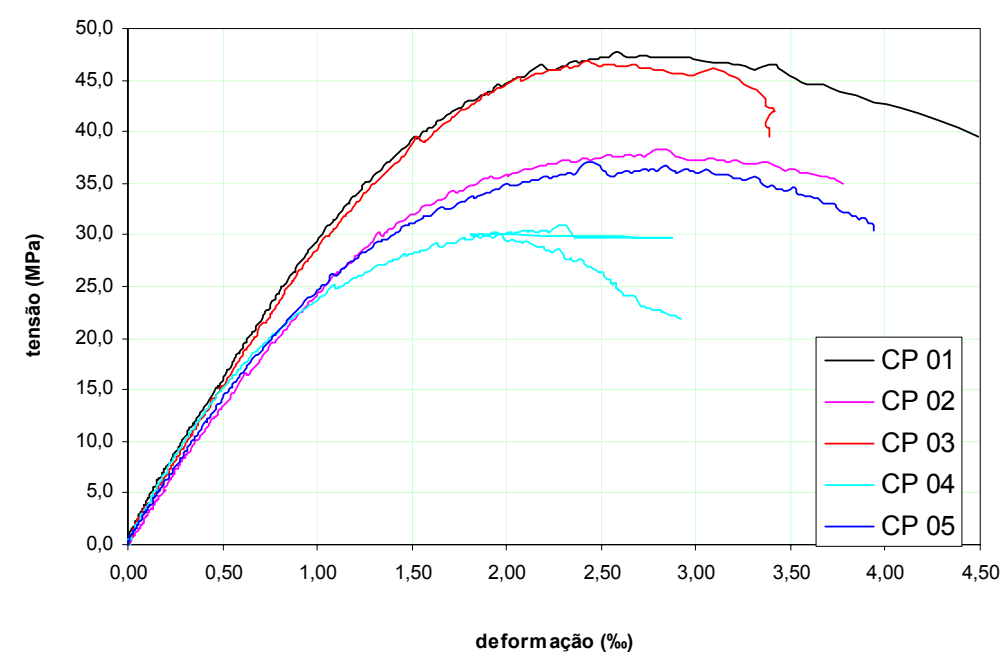

Figura 4.33 - Tensão x deformação para o extensômetro 02

Considerando a média tirada para cada extensômetro o valor aproximado do módulo de elasticidade secante aos 28 dias é:

$\mathbf{E}_{28}=33.700 \mathrm{MPa}$ 
Observa-se que, em relação à rigidez adotada para o ensaio piloto (aos 121 dias), o valor do módulo de elasticidade secante para o ensaio definitivo é praticamente coincidente.

\subsubsection{Comparação dos resultados de resistência obtidos para o concreto}

A Tabela 4.10 reflete as variações encontradas para as resistências à compressão do concreto nos ensaios de caracterização para o projeto definitivo; a Tabela 4.11, por outro lado, compara os resultados entre resistências do concreto obtidos no ensaio piloto (aos 121 dias) e no ensaio definitivo (aos 28 dias).

Tabela 4.10 - Relação entre resistências à compressão aos 21 e 28 dias

\begin{tabular}{|c|c|c|c|}
\hline & 21 dias & 28 dias & Acréscimo (\%) \\
\hline $\mathrm{f}_{\mathrm{c}, \text { min }}$ & 29,41 & 31,74 & 7,92 \\
\hline $\mathrm{f}_{\mathrm{c}, \text { medio }}$ & 38,74 & 40,13 & 3,59 \\
\hline $\mathrm{f}_{\mathrm{c}, \max }$ & 47,44 & 47,95 & 1,07 \\
\hline
\end{tabular}

Tabela 4.11 - Relação entre resistências no piloto e no definitivo

\begin{tabular}{|c|c|c|c|}
\hline & $\begin{array}{c}\text { Piloto } \\
\text { (maio/2004) }\end{array}$ & $\begin{array}{c}\text { Definitivo } \\
\text { (outubro/2004) }\end{array}$ & $\begin{array}{c}\text { Acréscimo } \\
(\mathbf{\%})\end{array}$ \\
\hline $\mathrm{f}_{\mathrm{c}, \min }$ & 29,41 & 31,74 & 7,92 \\
\hline $\mathrm{f}_{\mathrm{c}, \text { medio }}$ & 38,74 & 40,13 & 3,59 \\
\hline $\mathrm{f}_{\mathrm{c}, \max }$ & 47,44 & 47,95 & 1,07 \\
\hline $\mathrm{f}_{\mathrm{t}, \min }$ & 2,98 & 2,53 & $-15,10$ \\
\hline $\mathrm{f}_{\mathrm{t}, \text { medio }}$ & 3,34 & 3,20 & $-4,19$ \\
\hline $\mathrm{f}_{\mathrm{t}, \max }$ & 3,80 & 4,03 & 6,05 \\
\hline
\end{tabular}

4.2.1.5 Resumo das propriedades mecânicas dos materiais

a) CONCRETO

Todas as vigas dos projetos piloto e definitivo foram concretadas de uma só vez, uma única betonada. O concreto foi produzido no laboratório com um traço já utilizado largamente por diversos alunos-pesquisadores do SET. O cimento utilizado no 
piloto foi o CP-32 da Itaú e no definitivo o ARI-V plus da Ciminas. Os agregados utilizados foram do Rio Mogi, região de São Carlos. A resistência à compressão requerida foi de $30 \mathrm{MPa}$. As propriedades mecânicas obtidas nos ensaios de caracterização do concreto, tanto no piloto quanto no definitivo, estão resumidas na Tabela 4.12.

Tabela 4.12 - Propriedades mecânicas do concreto

\begin{tabular}{|c|c|c|c|c|}
\hline & $\begin{array}{c}\mathbf{f}_{\mathrm{c}} \\
(\mathrm{MPa})\end{array}$ & $\begin{array}{c}\mathbf{E}_{\mathbf{c}} \\
(\mathrm{MPa})\end{array}$ & $\begin{array}{c}\mathbf{E}_{\mathrm{ct}} \\
(\mathrm{MPa})\end{array}$ & $\begin{array}{c}\mathbf{f}_{\mathrm{t}, \mathrm{diam}} \\
(\mathrm{MPa})\end{array}$ \\
\hline Piloto & 38,74 & 22.783 & 25.314 & 3,34 \\
\hline Definitivo & 40,13 & 24.103 & 26.781 & 3,20 \\
\hline
\end{tabular}

b) $\mathbf{A C ̧ O}$

Para a caracterização do aço das armaduras, foram utilizados os ensaios realizados por outros alunos pesquisadores. Os lotes para esta pesquisa foram adquiridos no mesmo local e na mesma data. A Figura 4.34 mostra o digrama tensão x deformação para as barras de diâmetro $5.0 \mathrm{~mm}$ e $6.3 \mathrm{~mm}$.

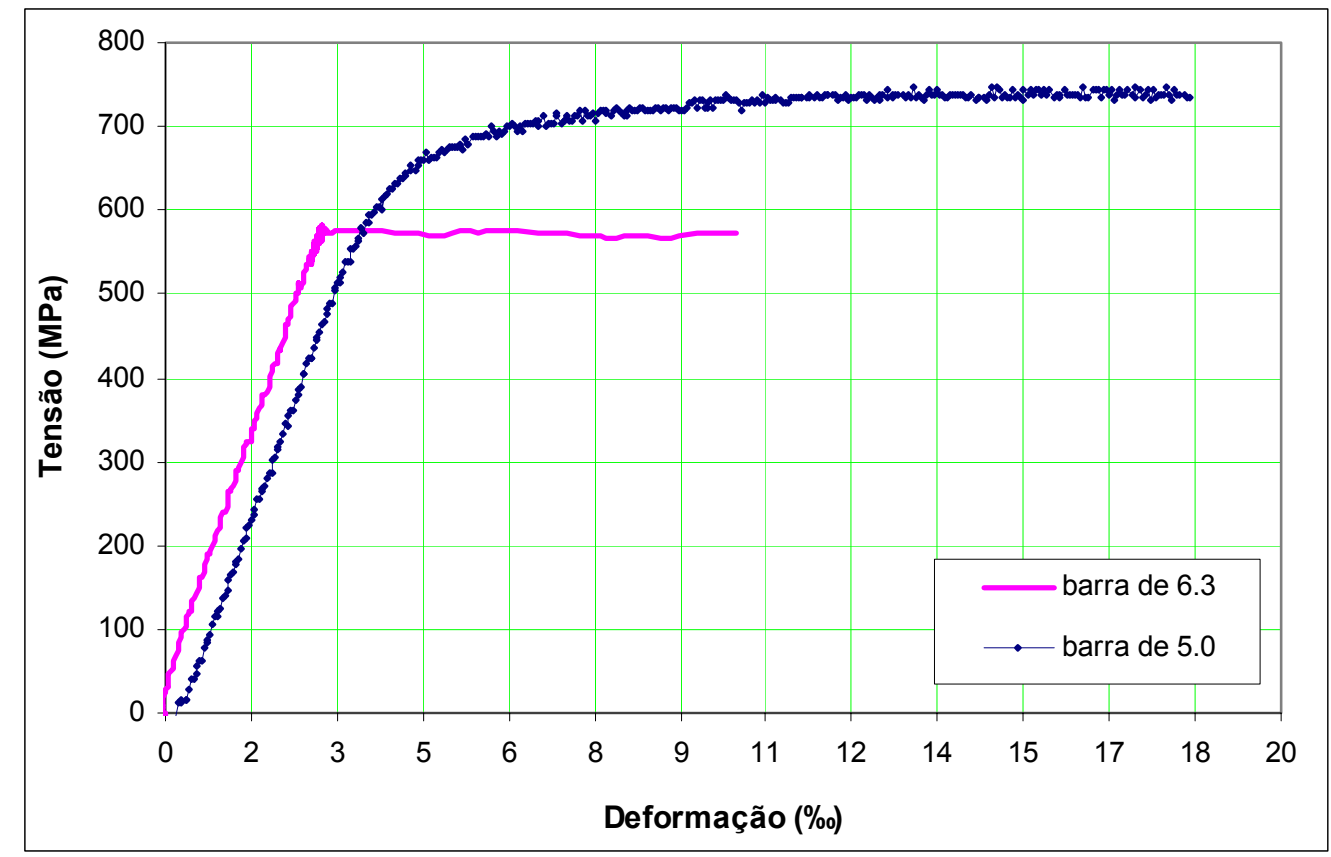

Figura 4.34 - Tensão x deformação para barras de 5.0 e $6.3 \mathrm{~mm}$

Os valores médios das principais características mecânicas do aço estão resumidas na Tabela 4.13. 
Tabela 4.13 - Propriedades mecânicas do aço das armaduras

\begin{tabular}{|c|c|c|c|}
\hline $\begin{array}{c}\varnothing \text { da barra } \\
(\mathbf{m m})\end{array}$ & $\begin{array}{c}\mathbf{E} \\
(\mathbf{M P a})\end{array}$ & $\begin{array}{c}\mathbf{f}_{\mathbf{y}} \\
(\mathbf{M P a})\end{array}$ & $\begin{array}{c}\mathbf{f}_{\mathbf{u}} \\
(\mathbf{M P a})\end{array}$ \\
\hline 5.0 & 194.330 & 666 & 756 \\
\hline 6.3 & 194.330 & 562 & 648 \\
\hline 10.0 & 194.330 & 515 & 658 \\
\hline
\end{tabular}

\subsubsection{Ensaio com vigas de concreto armado}

Nessa segunda etapa experimental, ensaio definitivo, foram ensaiadas 11 (onze) vigas de concreto armado. Na Figura 4.35 são mostradas, esquematicamente, a geometria das vigas, suas dimensões e esquema de carregamento.

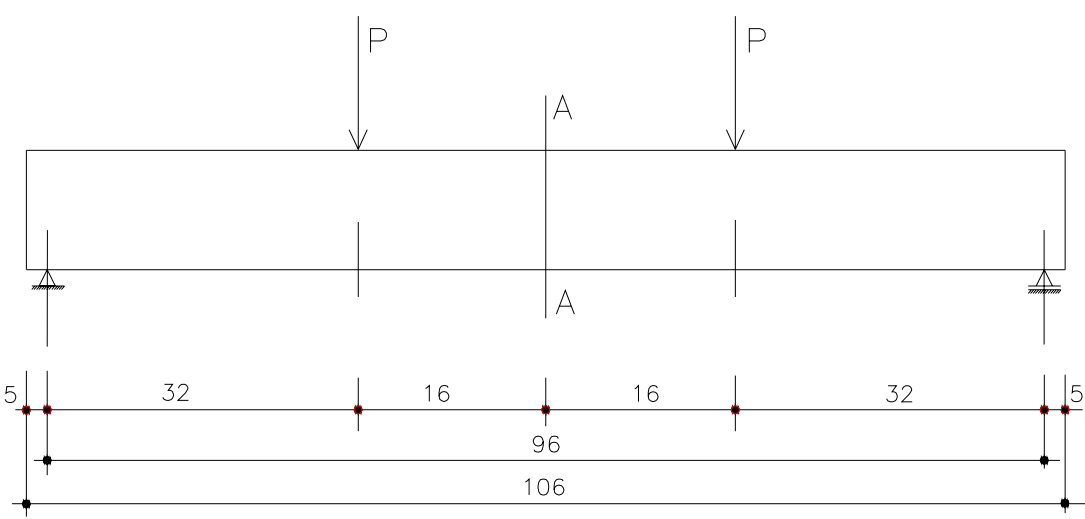

Figura 4.35 - Esquema estrutural das vigas

A Figura 4.36 mostra os tipos de seções transversais (retangulares e tipo “T”), com dimensões em cm, usados nessa etapa da pesquisa.
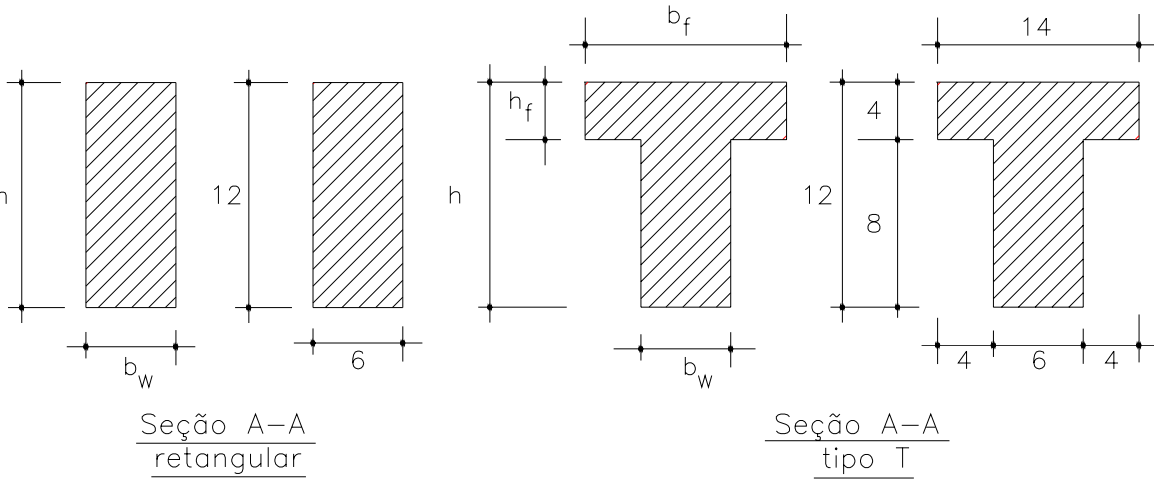

Figura 4.36 - Forma e dimensões das seções transversais utilizadas 
Os ensaios foram divididos em três grupos:

- Grupo I - três vigas do tipo VR-NA-CE.

- Grupo II - três vigas do tipo VR-AD-CE.

- Grupo III - três vigas do tipo VT-NA-CE.

- duas vigas do tipo VT-NA-SE.

Os dois primeiros grupos diferem dos dois correspondentes grupos do ensaio piloto apenas na quantidade de estribos colocados na zona de momento constante (trecho entre as duas cargas).

O primeiro grupo, grupo I, é composto de 3 (três) vigas de seção transversal retangular (VR). O dimensionamento à flexão foi feito propositadamente próximo à fronteira dos domínios 2 e 3, forçando a viga a trabalhar como seção normalmente armada (NA). As vigas são armadas com estribos em todo o trecho da viga (CE). Uma das vigas do grupo I, VR-NA-CE-T, foi usada como teste para confirmar a carga de ruptura e determinar a freqüência a ser usada no ensaio cíclico. Os detalhes das armaduras empregadas nas vigas do grupo I são mostrados na Figura 4.37.

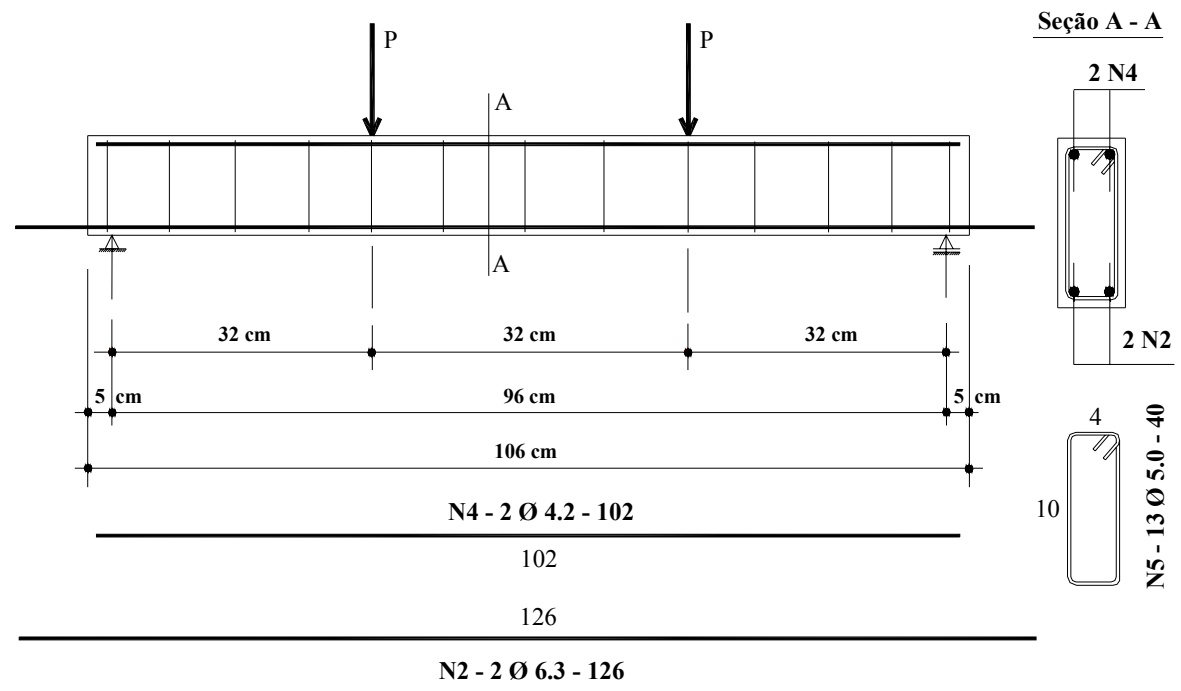

Figura 4.37 - Armação das vigas do tipo VR-NA-CE

O segundo grupo, grupo II, é composto de 3 (três) vigas, de seção transversal retangular (VR), dimensionadas com armadura dupla (AD), portanto com armadura longitudinal de compressão (evitando assim o domínio 4). A armadura transversal é devidamente dimensionada para resistir aos esforços na zona de força cortante com estribos em todo o trecho da viga (CE). Uma das vigas do grupo II, VR-AD-CE-T, foi 
usada como teste para confirmar a carga de ruptura. Os detalhes das armaduras empregadas nas vigas do grupo II são mostrados na Figura 4.38.

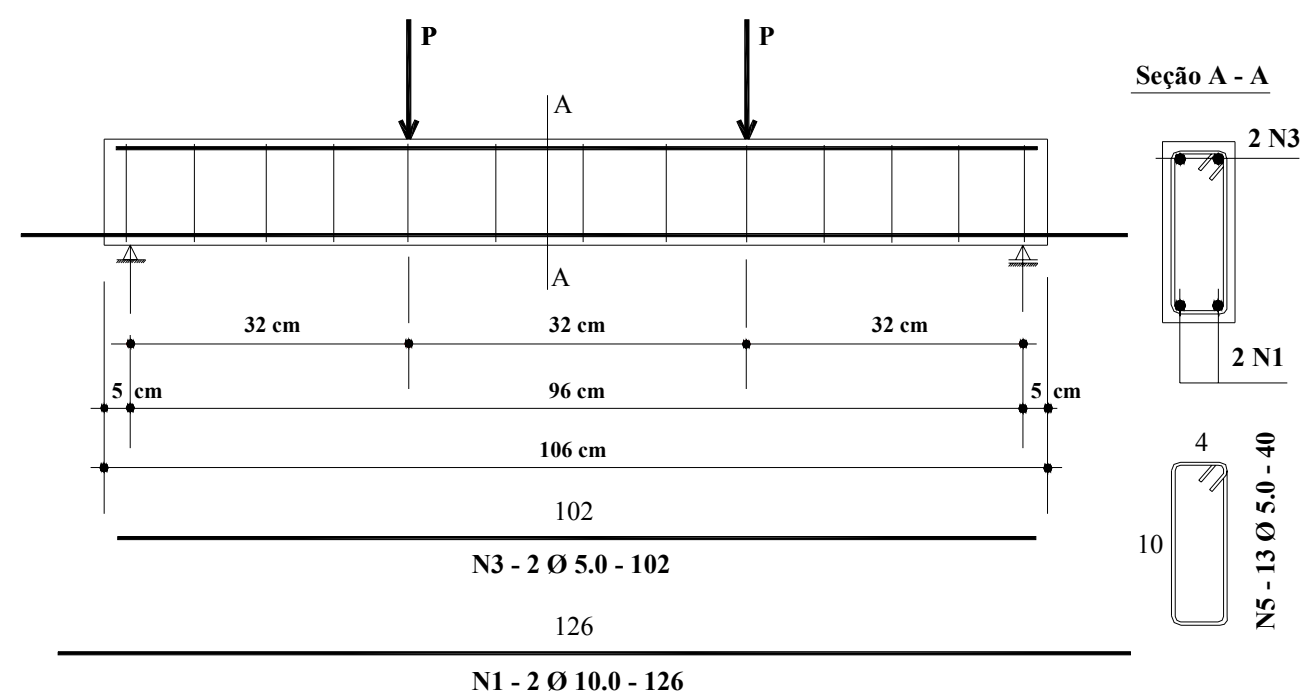

Figura 4.38 - Armação das vigas do tipo VR-AD-CE

O terceiro e último grupo, o grupo III, é composto de 5 (cinco) vigas com seção transversal do tipo T (VT), de modo a simular a contribuição das lajes adjacentes. $\mathrm{O}$ dimensionamento prevê o comportamento das vigas trabalhando bem próximo à fronteira dos domínios 2 e 3, como as do grupo I, forçando-as a trabalharem como seção normalmente armada (NA). Três das cinco vigas são armadas com estribos em todo o trecho da viga (CE). As outras duas não possuem armadura longitudinal de compressão, nem estribos, na zona de momento constante (trecho entre as duas cargas). Os detalhes das armaduras empregadas nas vigas do grupo III são mostrados na Figura 4.39 e na Figura 4.40. 

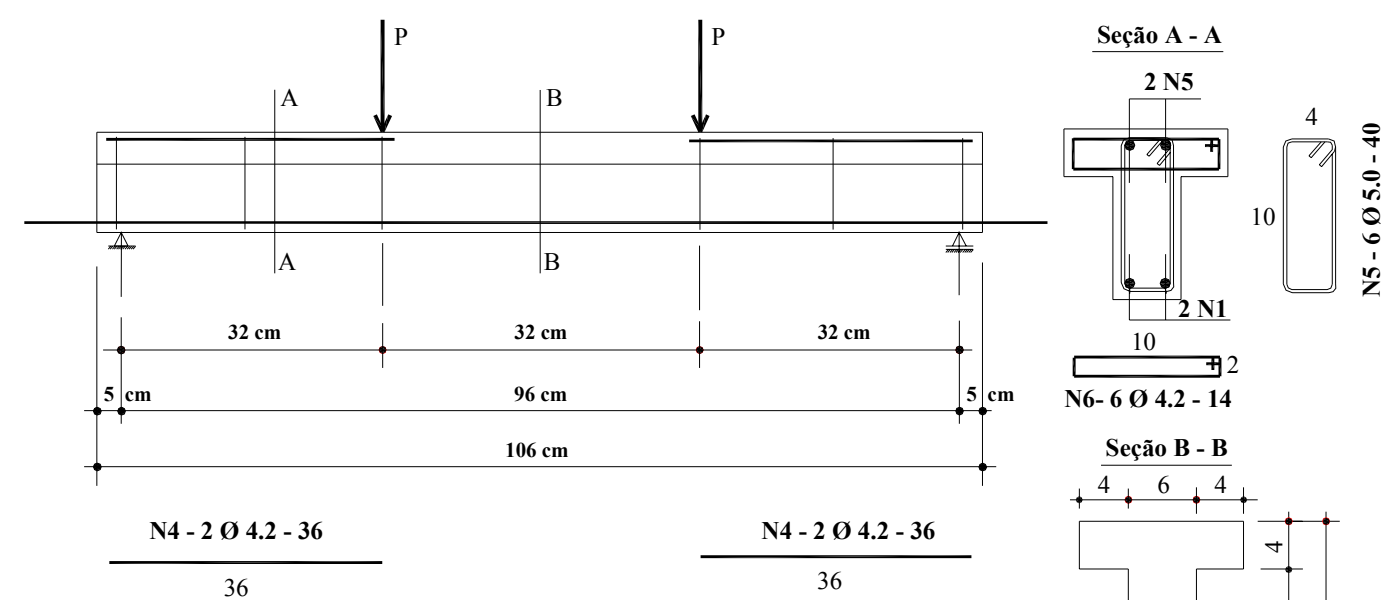

N4 - 2 Ø 4.2 - 36

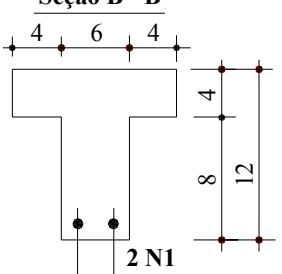

Figura 4.39 - Armação das vigas do tipo VT-NA-SE

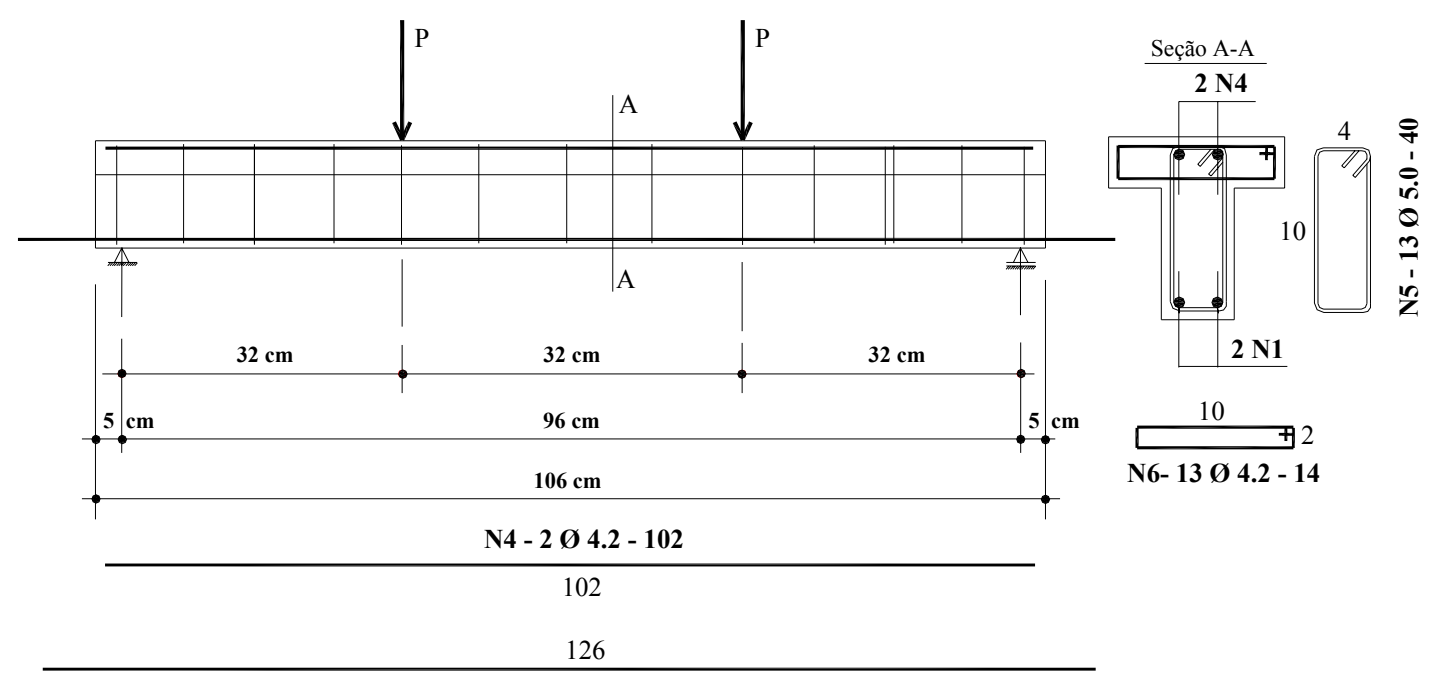

N1 - 2 Ø 10.0 - 126

Figura 4.40 - Armação das vigas do tipo VT-NA-CE

Todas as vigas são simétricas e foram submetidas a carregamento simétrico aplicado a uma distância dos apoios de 1/3 do vão, conforme esclarece a Figura 4.35. As barras longitudinais empregadas em todas as vigas são de aço CA-50 nervuradas. Todos os estribos foram confeccionados com barras de diâmetro $5.0 \mathrm{~mm}$ (CA-50).

A instrumentação de todas as vigas foi feita com extensômetros elétricos colocados na armadura e na superfície do concreto. Para os grupos I e II a instrumentação é a mesma mostrada na Figura 4.20. Para as vigas do grupo II, com 
seção transversal tipo "T", a Figura 4.41 esclarece melhor o posicionamento dos extensômetros. Os extensômetros de $\mathrm{n}^{\mathrm{o}} 1$ e 2 foram colocados em cada uma das barras de tração (barra N1) e o extensômetro $n^{\circ} 3$ na face superior do concreto, nas posições mostradas na Figura 4.41.
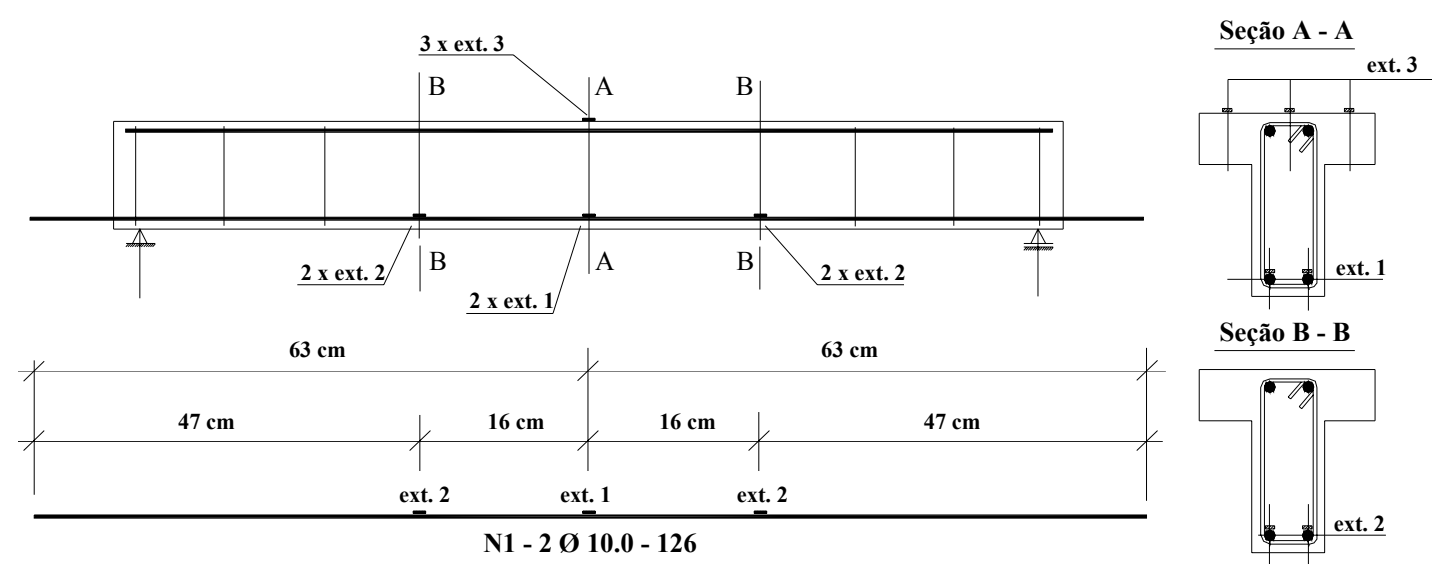

Figura 4.41 - Instrumentação das vigas do tipo "T"

A Figura 4.42 mostra o posicionamento dos extensômetros colados na face superior da mesa de uma das vigas tipo "T", no ponto correspondente à seção transversal do centro da viga.
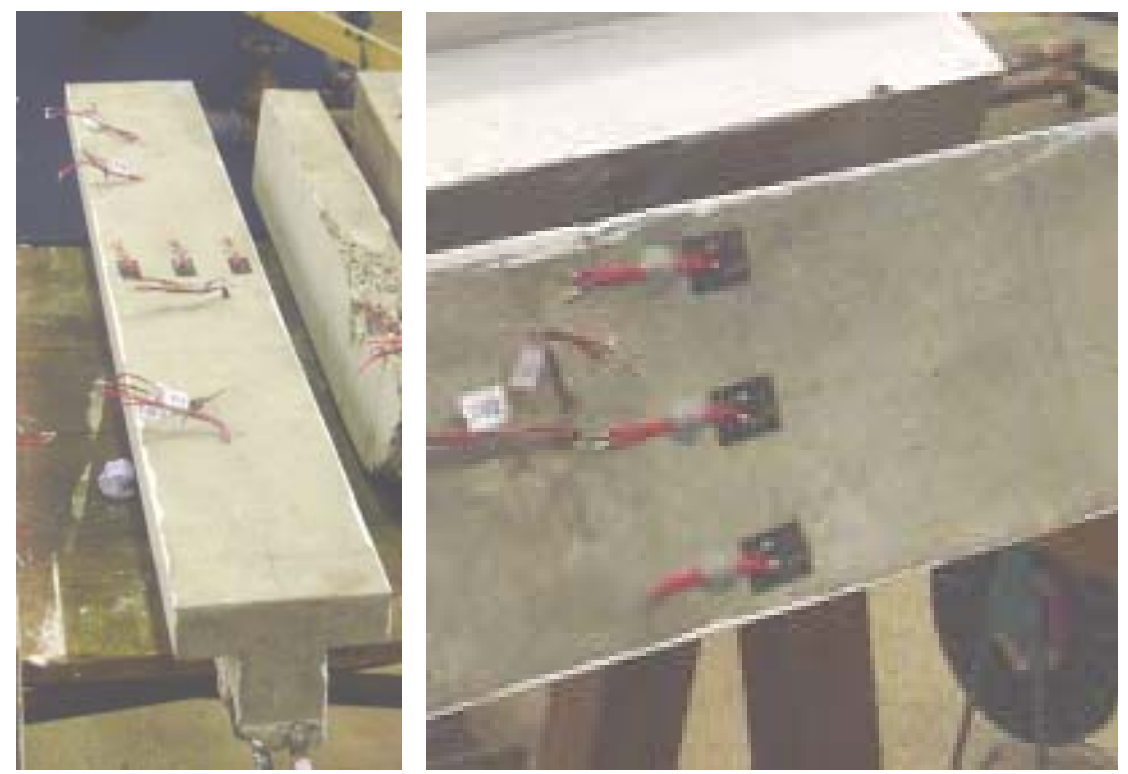

Figura 4.42 - Posicionamento dos extensômetros no concreto

Os ensaios foram realizados entre os dias 18 e 30 de outubro de 2004. As vigas, num total de 11 (onze), foram tiradas da câmara úmida no dia 10/10/04. Do total de vigas de cada grupo uma delas foi separada para teste. A finalidade de testar essa viga era, além de confirmar a carga última prevista, o de determinar uma freqüência tal 
que se pudesse obter o maior número possível de ciclos para um tempo disponível (um dia útil, no máximo - havia premência de tempo). Pelo curto tempo disponível dentro do laboratório o objetivo perseguido era ensaiar uma viga por dia conseguindo a marca de 30.000 ciclos.

\subsubsection{Ensaio das vigas do grupo I}

O primeiro ensaio foi feito com a viga VR-NA-CE-T (viga teste). Esse ensaio teve início na manhã do dia 18/10. Características do ensaio:

$$
\begin{aligned}
& \mathrm{P}_{\mathrm{u}}=21 \mathrm{kN} \text { (estimada) } \\
& \mathrm{P}_{\max }=18 \mathrm{kN} \text { (aproximadamente } 85 \% \text { da carga última) } \\
& \mathrm{P}_{\min }=8 \mathrm{kN} \text { (aproximadamente } 40 \% \text { da carga última). }
\end{aligned}
$$

A freqüência inicial adotada foi de $0,5 \mathrm{~Hz}$ (1800 ciclos/hora). A carga de excitação registrou $6,06 \mathrm{kN}$ (tomando uma carga média de $13 \mathrm{kN}$, o que equivaleria à uma carga estática de $5 \mathrm{kN}$ ). A aquisição de dados foi feita sempre na freqüência de 0,5 $\mathrm{Hz}$, com velocidade de leitura de 0.1 dados a cada segundo, ou seja, 20 leituras por ciclo. A Figura 4.43 mostra a amplitude da carga.

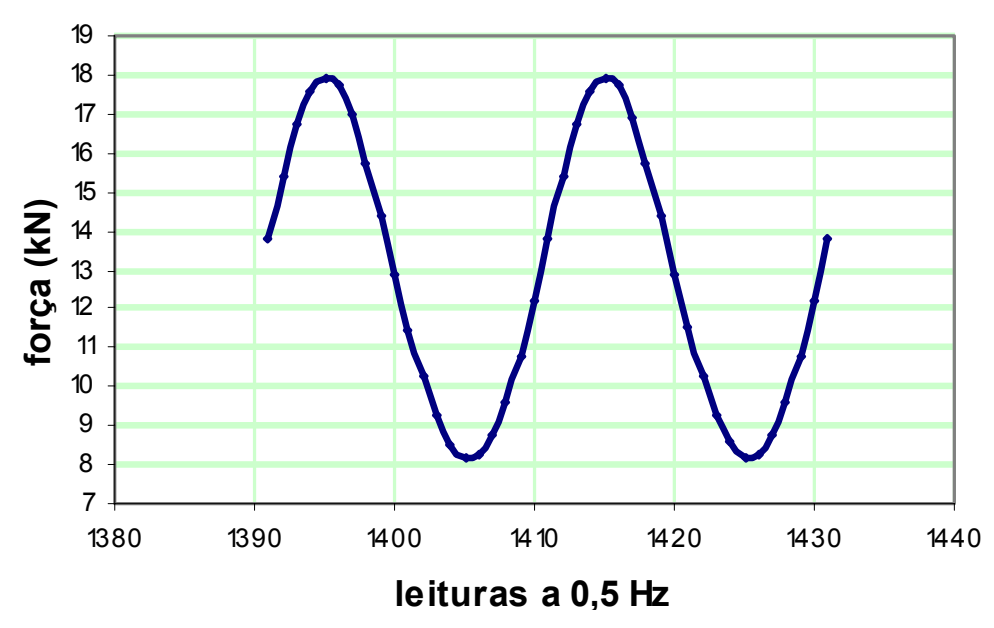

Figura 4.43 - Amplitude da carga

Após 2.300 ciclos e alguns ajustes a viga foi levada à ruptura. A carga de ruptura medida foi de $22,45 \mathrm{kN}$ ( $7 \%$ acima da carga estática prevista). A Tabela 4.14 registra o valor das flechas máxima e mínima para alguns ciclos de carga. Observar a queda e estabilização do valor da flecha à partir do $1800^{\circ}$ ciclo; supõe-se ter sido motivado pelo deslocamento num dos apôios. 
Tabela 4.14 - Flechas medidas na VR-NA-CE-T

\begin{tabular}{|c|c|c|}
\hline $\begin{array}{c}\text { Número de } \\
\text { ciclos }\end{array}$ & $\begin{array}{c}\text { Flecha min. } \\
(\mathrm{cm})\end{array}$ & $\begin{array}{c}\text { Flecha Max. } \\
(\mathrm{cm})\end{array}$ \\
\hline 1 & 2,30 & 3,54 \\
\hline 100 & 2,68 & 3,97 \\
\hline 450 & 2,82 & 4,13 \\
\hline 1.000 & 2,85 & 4,16 \\
\hline 1.800 & 2,82 & 4,10 \\
\hline 2.300 & 2,79 & 4,10 \\
\hline
\end{tabular}

A Figura 4.44 reflete o comportamento da flecha em função do número de ciclos aplicados no ensaio com a VR-NA-CE-T.

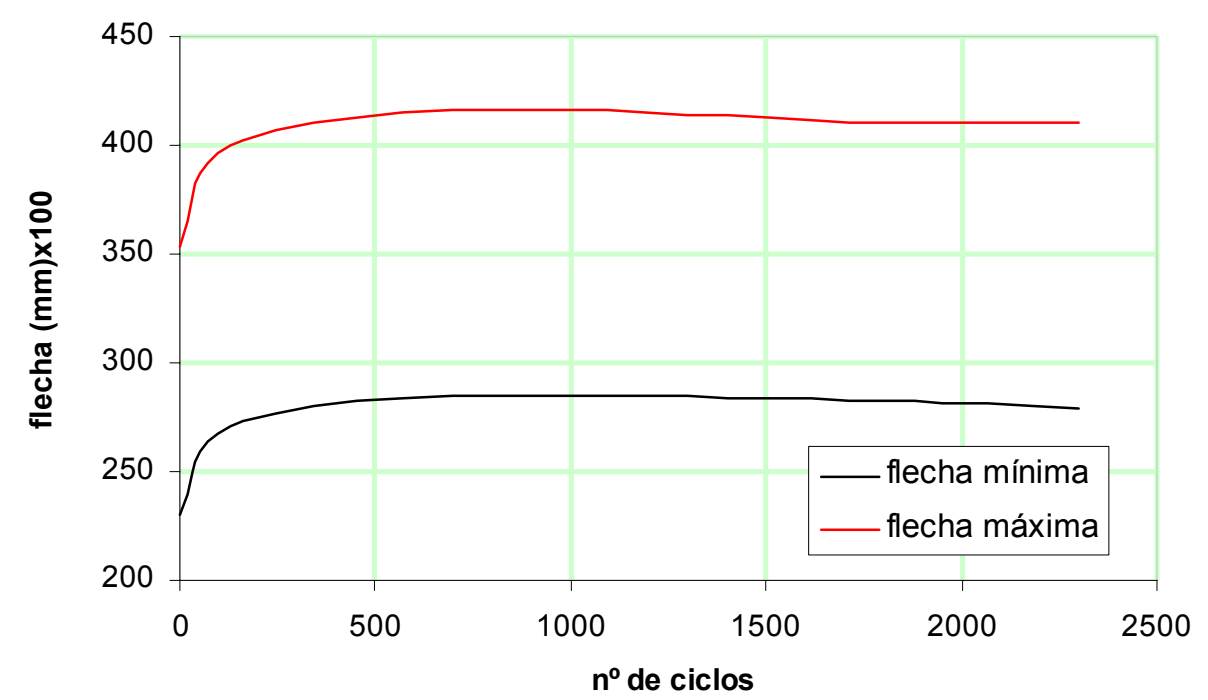

Figura 4.44 - Variação da flecha com o $\mathrm{n}^{0}$ de ciclos para a VR-NA-CE-T

Os ensaios com as outras duas vigas do grupo seguiram a mesma linha do ensaio anterior. A Tabela 4.15 mostra um resumo das principais características e resultados do ensaio do grupo I.

Tabela 4.15 - Características do ensaio com as vigas do grupo I

\begin{tabular}{|c|c|c|c|c|c|c|c|c|c|}
\hline \multirow[t]{2}{*}{ viga } & $\mathrm{P}_{\max }$ & $\mathrm{P}_{\min }$ & $\begin{array}{c}\mathrm{P}_{\mathrm{u}} \\
\text { estim. }\end{array}$ & $\begin{array}{c}\mathrm{P}_{\mathrm{u}} \\
\text { med. }\end{array}$ & $\begin{array}{l}\text { Freq. } \\
\text { excit. }\end{array}$ & $\begin{array}{l}\text { Freq. } \\
\text { p/ med. }\end{array}$ & $\begin{array}{l}\text { Flecha } \\
\text { max. }\end{array}$ & $\begin{array}{l}\text { Flecha } \\
\text { min. }\end{array}$ & \multirow{2}{*}{$\begin{array}{c}\text { Número } \\
\text { total } \\
\text { de ciclos }\end{array}$} \\
\hline & $\mathrm{kN}$ & $\mathrm{kN}$ & $\mathrm{kN}$ & $\mathrm{kN}$ & $\mathrm{Hz}$ & $\mathrm{Hz}$ & $\mathrm{mm}$ & $\mathrm{mm}$ & \\
\hline VR-NA-CE-T & 18 & 8 & 21 & 22,45 & 0,5 & 0,5 & 4,16 & 2,85 & 2.300 \\
\hline VR-NA-CE-01 & 18 & 8 & 21 & 22,00 & 1,0 & 0,5 & 4,19 & 2,75 & 25.000 \\
\hline VR-NA-CE-02 & 20 & 8 & 21 & 25,00 & 1,5 & 0,5 & 4,58 & 3,30 & 15.000 \\
\hline
\end{tabular}


A Figura 4.45 mostra a relação flecha no meio do vão $\mathrm{x}$ número de ciclos aplicados para as três vigas do grupo I.

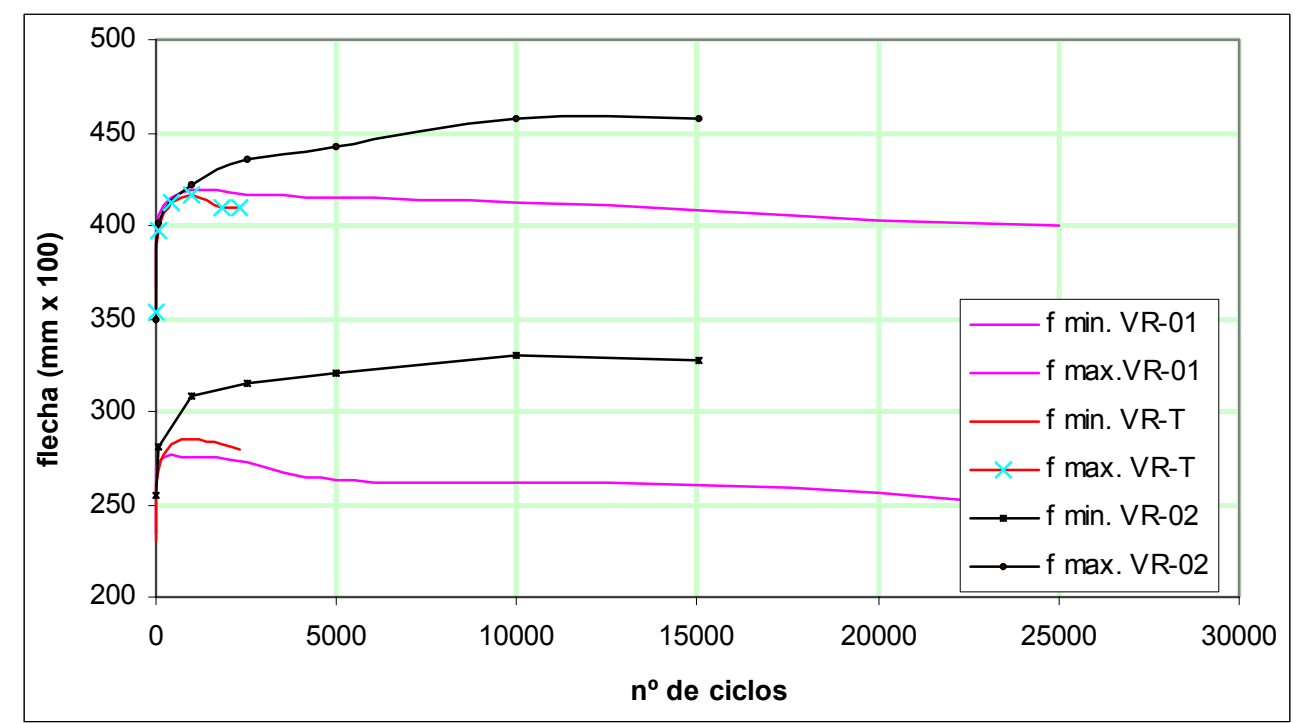

Figura 4.45 - Variação da flecha com o ${ }^{0}$ de ciclos para as vigas do grupo I

\subsubsection{Ensaio das vigas do grupo II}

O ensaio com as vigas do grupo II teve início no dia 20 de outubro de 2004. A Tabela 4.16 mostra um resumo das principais características do ensaio.

Tabela 4.16 - Características do ensaio com as vigas do grupo II

\begin{tabular}{|c|c|c|c|c|c|c|c|c|c|c|}
\hline \multirow{2}{*}{ Viga } & $\mathrm{P}_{\max }$ & $\mathrm{P}_{\mathrm{min}}$ & $\begin{array}{c}\mathrm{P}_{\mathrm{u}} \\
\text { estim. }\end{array}$ & $\begin{array}{c}\mathrm{P}_{\mathrm{u}} \\
\mathrm{med} .\end{array}$ & $\begin{array}{c}\text { Freq. } \\
\text { excit. }\end{array}$ & $\begin{array}{c}\text { Freq. } \\
\mathrm{p} / \text { med. }\end{array}$ & $\begin{array}{c}\text { Flecha } \\
\text { max. }\end{array}$ & $\begin{array}{c}\text { Flecha } \\
\text { min. }\end{array}$ & $\begin{array}{c}\text { Flecha } \\
\text { ultima }\end{array}$ & $\begin{array}{c}\text { Número } \\
\text { total } \\
\text { de ciclos }\end{array}$ \\
\cline { 2 - 12 } $\mathrm{kN}$ & $\mathrm{kN}$ & $\mathrm{kN}$ & $\mathrm{kN}$ & $\mathrm{Hz}$ & $\mathrm{Hz}$ & $\mathrm{mm}$ & $\mathrm{mm}$ & $\mathrm{mm}$ & 15.000 \\
\hline VR-AD-CE-T & 45 & 20 & 52 & 55,7 & 1,5 & 0,5 & 6,31 & 4,49 & 5,83 & 15.000 \\
\hline VR-AD-CE-01 & 45 & 20 & 52 & 56,2 & 2,0 & 0,5 & 5,67 & 3,96 & 8,39 & 30.000 \\
\hline VR-AD-CE-02 & 47 & 20 & 52 & 56,6 & 2,0 & 0,5 & 6,39 & 4,29 & 7,92 & 30.000 \\
\hline
\end{tabular}

A Figura 4.46 mostra a relação flecha no meio do vão x número de ciclos aplicados para as três vigas do grupo II. 


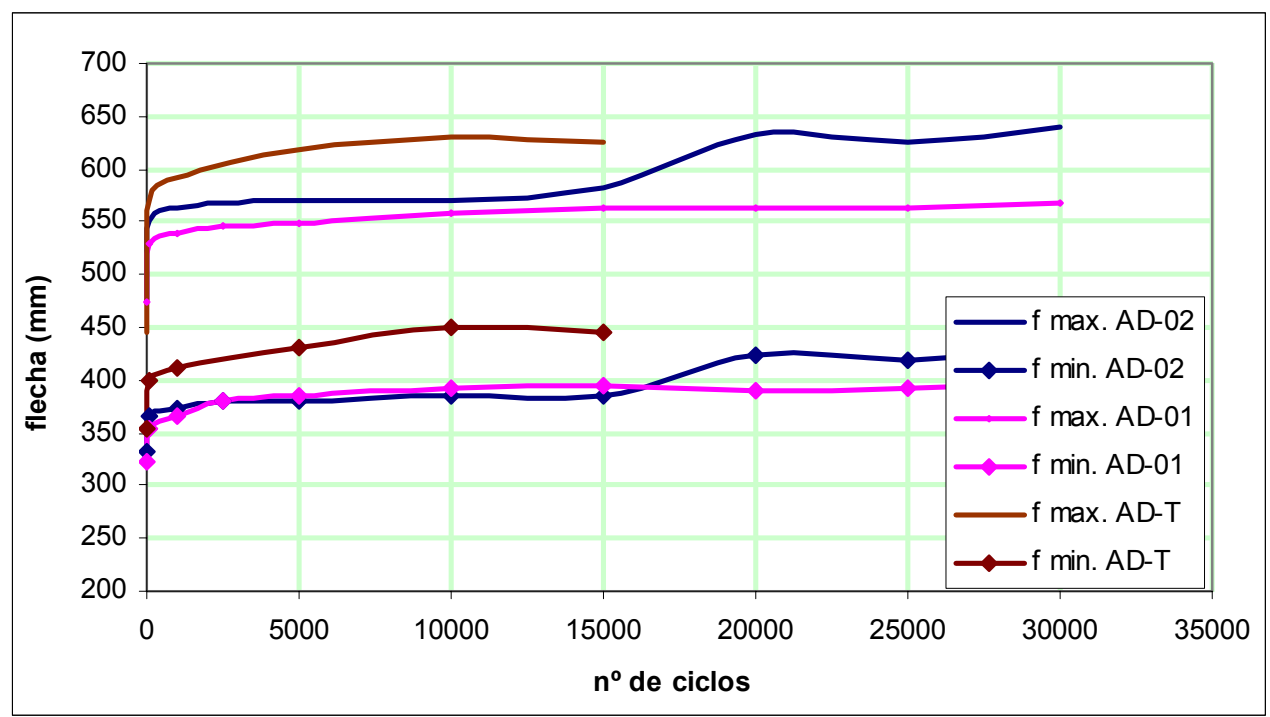

Figura 4.46 - Variação da flecha com o $n^{0}$ de ciclos para as vigas do grupo II

A discrepância mostrada na Figura 4.46 entre a viga AD-T e as outras duas deve-se ao fato do aparecimento de uma grande fissura de cortante, logo no início do ensaio, aumentando significativamente as deformações e deslocamentos. O ensaio foi paralisado momentaneamente, aproximadamente no $11.000^{\circ}$ ciclo; foi aplicada, então, protensão através de ganchos colocados estrategicamente na seção intermediária dentro da zona de atuação da força cortante. Para evitar transtornos com as duas outras vigas do grupo II foi aplicada a protensão antes mesmo do início dos respectivos ensaios, conforme ilustra a Figura 4.47.

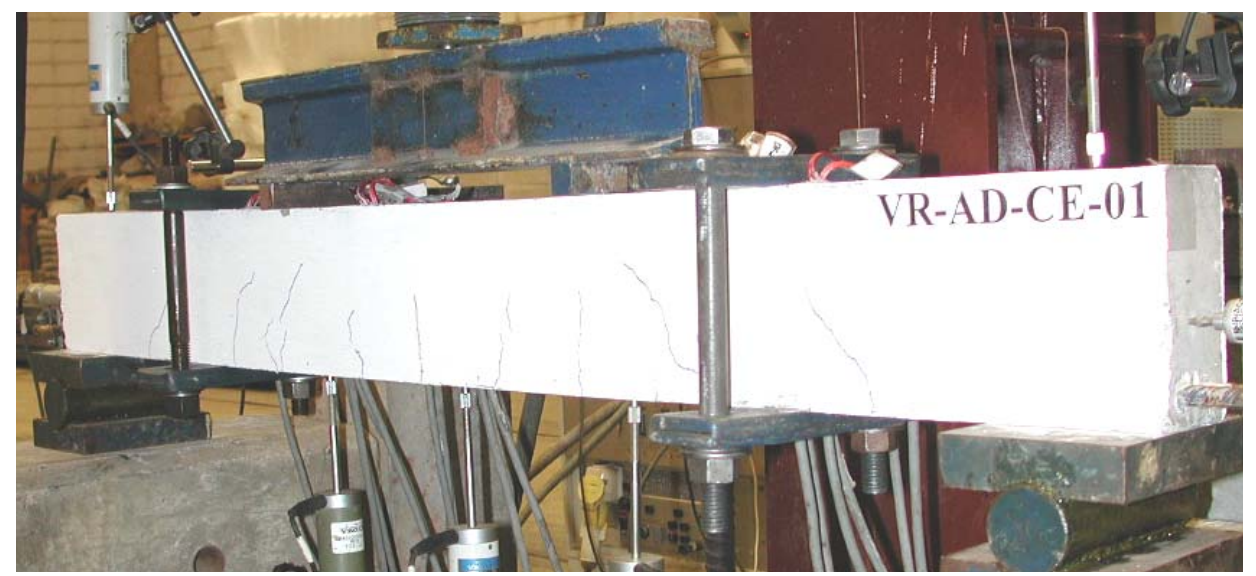

Figura 4.47 - Protensão nas vigas do grupo II

Após a aplicação do $10.000^{\circ}$ ciclo um dos apoios da viga AD-02 deslizou, aumentando o vão em alguns centímetros. Os efeitos podem ser observados na Figura 4.46, onde pode ser notado o aumento das flechas em relação à viga AD-01. 
A Figura 4.48 e a Figura 4.49 retratam o aumento da flecha e conseqüente perda de rigidez progressiva no meio do vão das vigas VR-AD-CE-T e VR-AD-CE-01, respectivamente.

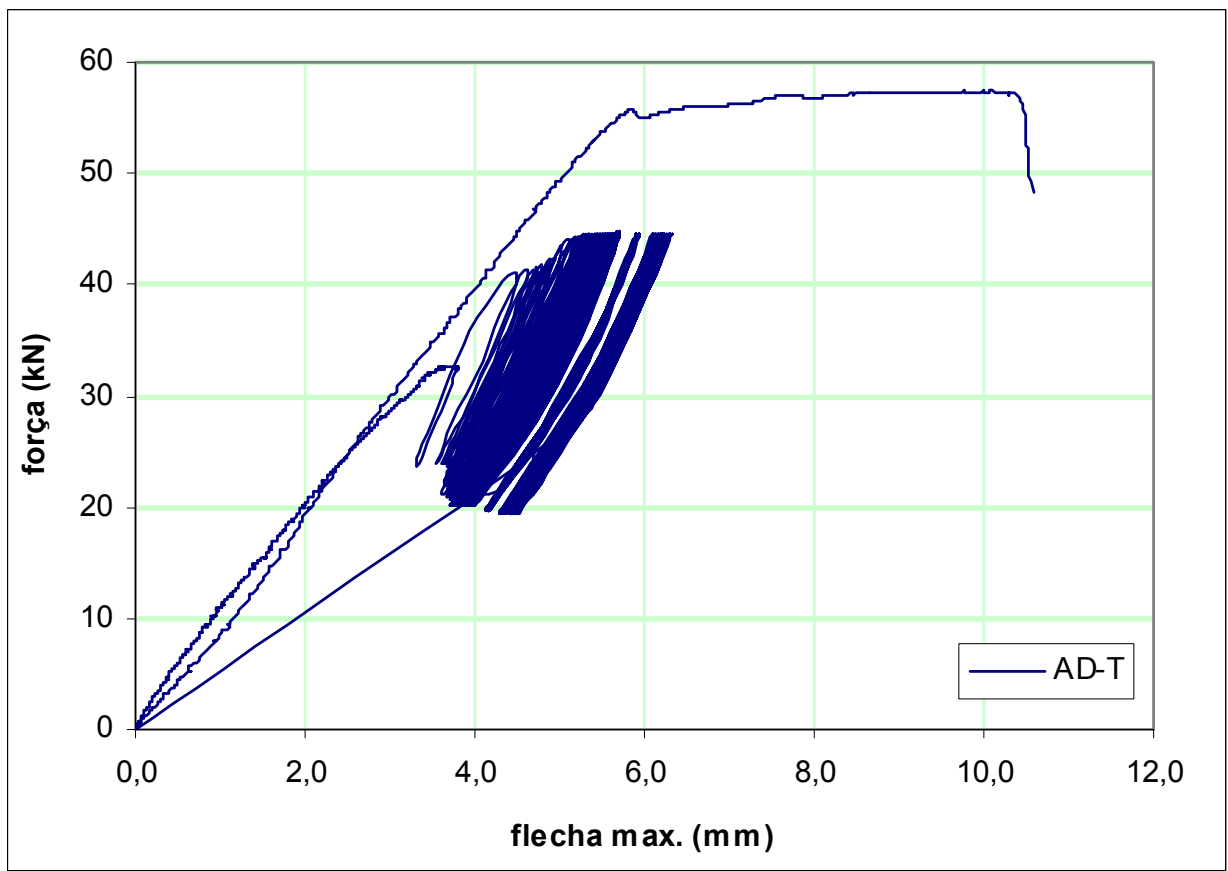

Figura 4.48 - Evolução da flecha na viga VR-AD-CE-T

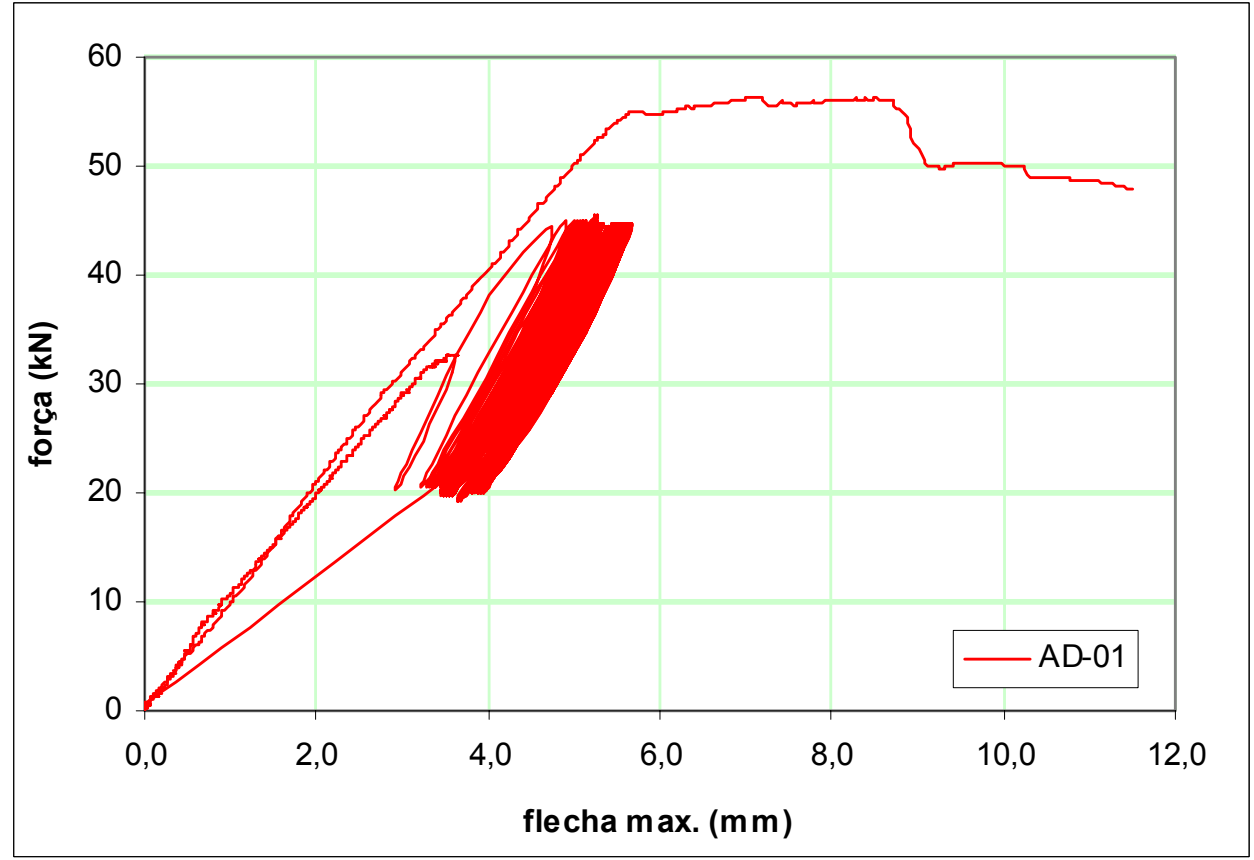

Figura 4.49 - Evolução da flecha na viga VR-AD-CE-01

A Figura 4.50 mostra a VR-AD-CE-02 e a Figura 4.51 um gráfico comparativo entre as três vigas. 


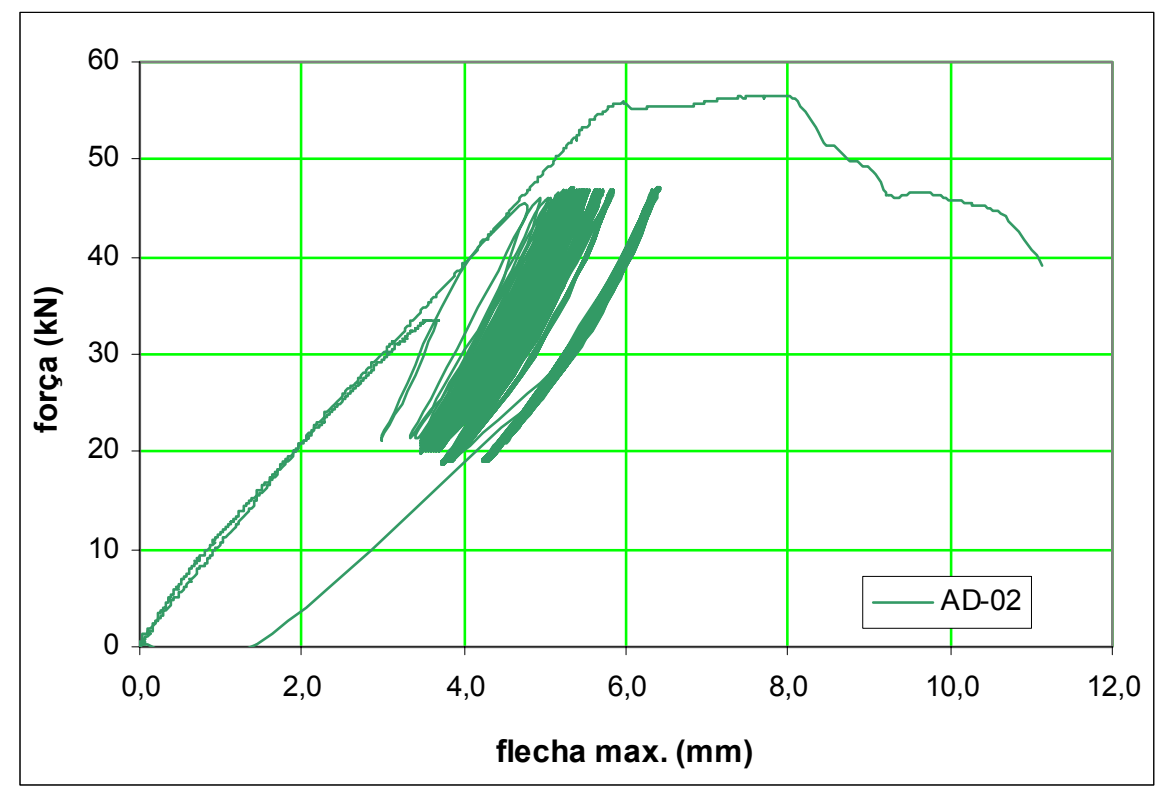

Figura 4.50 - Evolução da flecha na viga VR-AD-CE-02

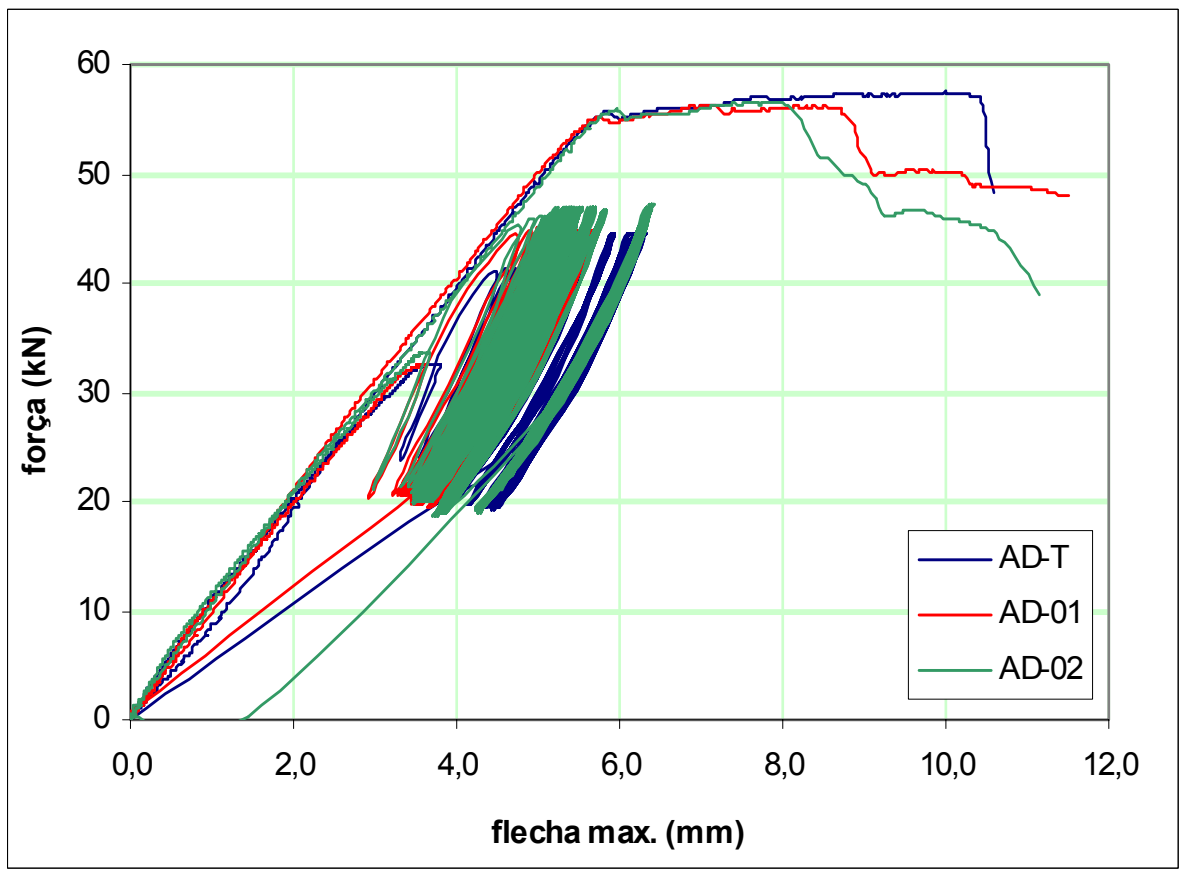

Figura 4.51 - Comparativo entre as três vigas

\subsubsection{Ensaio das vigas do grupo III}

O ensaio com as vigas do grupo II teve início no dia 22 de outubro de 2004 . A Tabela 4.17 mostra um resumo das principais características do ensaio. 
Tabela 4.17 - Características do ensaio com as vigas do grupo III

\begin{tabular}{|c|c|c|c|c|c|c|c|c|c|c|}
\hline \multirow{2}{*}{ Viga } & $\mathrm{P}_{\max }$ & $\mathrm{P}_{\min }$ & $\begin{array}{c}\mathrm{P}_{\mathrm{u}} \\
\text { estim. }\end{array}$ & $\begin{array}{c}\mathrm{P}_{\mathrm{u}} \\
\text { med. }\end{array}$ & $\begin{array}{c}\text { Freq. } \\
\text { excit. }\end{array}$ & $\begin{array}{c}\text { Freq. } \\
\mathrm{p} / \text { med. }\end{array}$ & $\begin{array}{c}\text { Flecha } \\
\mathrm{max} .\end{array}$ & $\begin{array}{c}\text { Flecha } \\
\mathrm{min} .\end{array}$ & $\begin{array}{c}\text { Flecha } \\
\text { ultima }\end{array}$ & $\begin{array}{c}\text { Número } \\
\text { total } \\
\text { de ciclos }\end{array}$ \\
\cline { 2 - 12 } & $\mathrm{kN}$ & $\mathrm{kN}$ & $\mathrm{kN}$ & $\mathrm{Hz}$ & $\mathrm{Hz}$ & $\mathrm{mm}$ & $\mathrm{mm}$ & $\mathrm{mm}$ & - & - \\
\hline VT-NA-CE-T & - & - & 52 & 58,45 & - & - & - & - & 6,56 & - \\
\hline VT-NA-SE-01 & - & - & 52 & 52,85 & - & - & - & - & 6,02 & - \\
\hline VT-NA-SE-02 & 40 & 20 & 52 & 57,62 & 2,0 & 0,5 & 4,68 & 3,29 & 5,52 & 30.000 \\
\hline VT-NA-CE-01 & - & - & 52 & 58,25 & - & - & - & - & 7,61 & - \\
\hline VT-NA-CE-02 & 44 & 20 & 52 & 57,50 & 2,0 & 0,5 & 4,64 & 3,05 & 5,05 & 30.000 \\
\hline
\end{tabular}

A Figura 4.52 mostra a relação flecha no meio do vão x número de ciclos aplicados para as vigas VT-NA-SE-02 e VT-NA-CE-02.

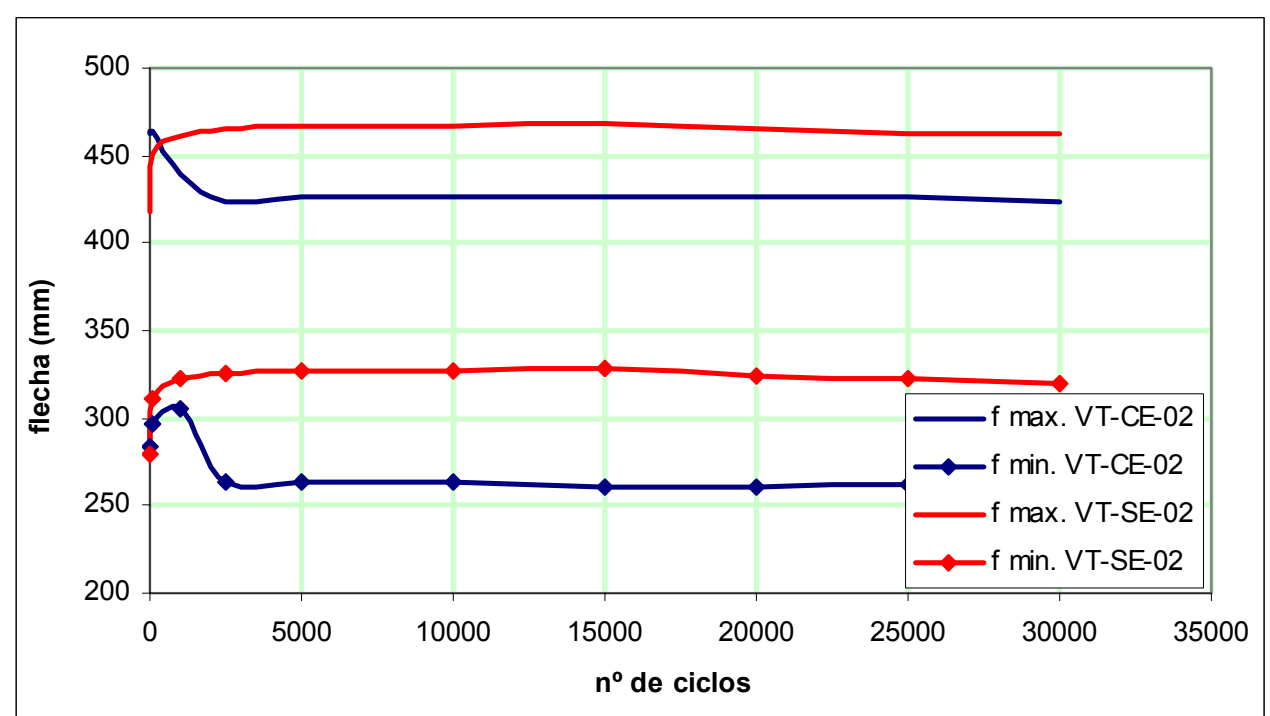

Figura 4.52 - Variação da flecha com o $\mathrm{n}^{0}$ de ciclos para as vigas VT-NA-SE-02 e VT-NA-CE-02.

Observa-se na Figura 4.52 um resultado inesperado para a evolução das flechas da viga VT-NA-CE-02. Logo no início do ensaio apareceu uma grande fissura junto ao prisma de aplicação da carga. Provavelmente alguma saliência no concreto tenha provocado o esmagamento localizado. O ensaio continuou, mesmo com a grande fissura, como ilustra a Figura 4.53. 


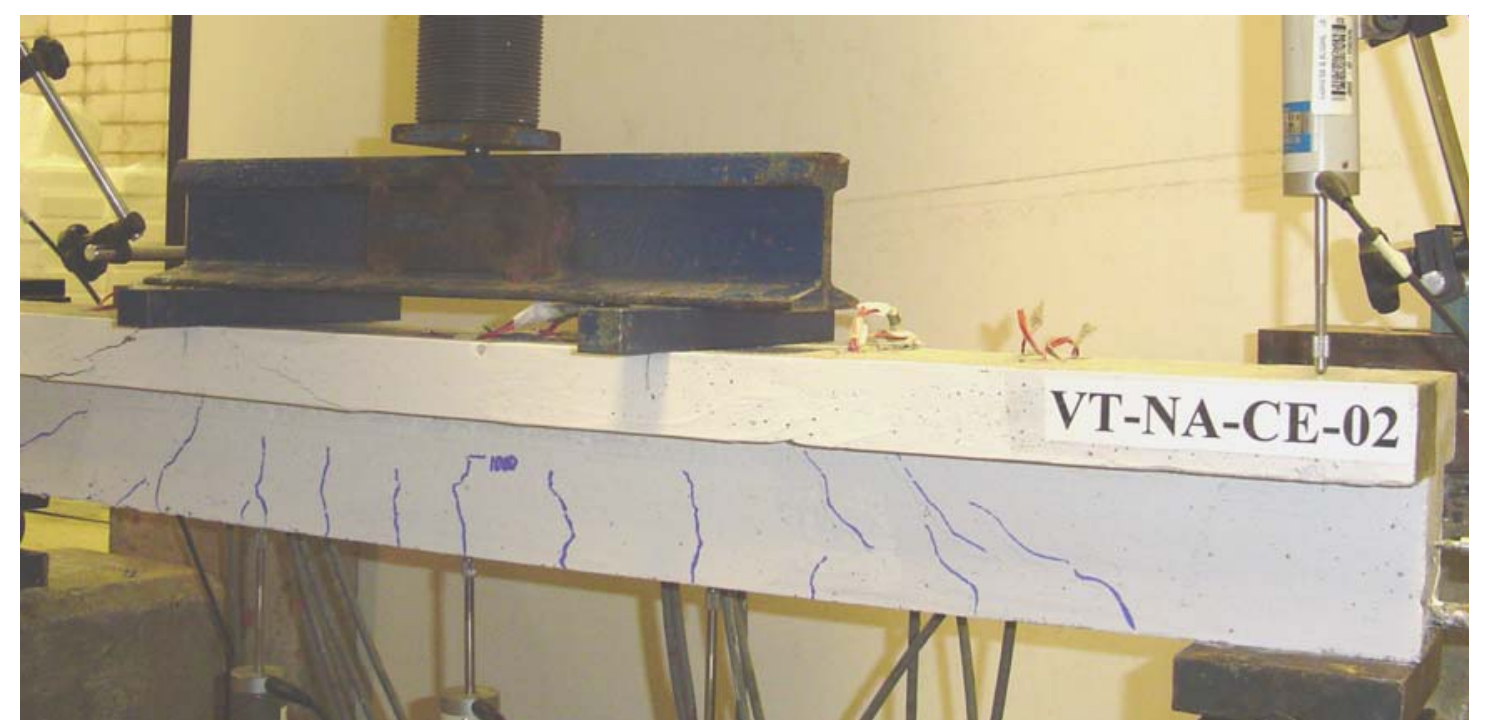

Figura 4.53 - Fissura na viga VT-NA-CE-02

A Figura 4.54 mostra o detalhe da fissura. Acredita-se que, não houvesse ocorrido o fato inesperado, o ensaio levaria a valores para a flecha máxima acima dos obtidos para a viga VT-NA-SE-02, como era a expectativa.

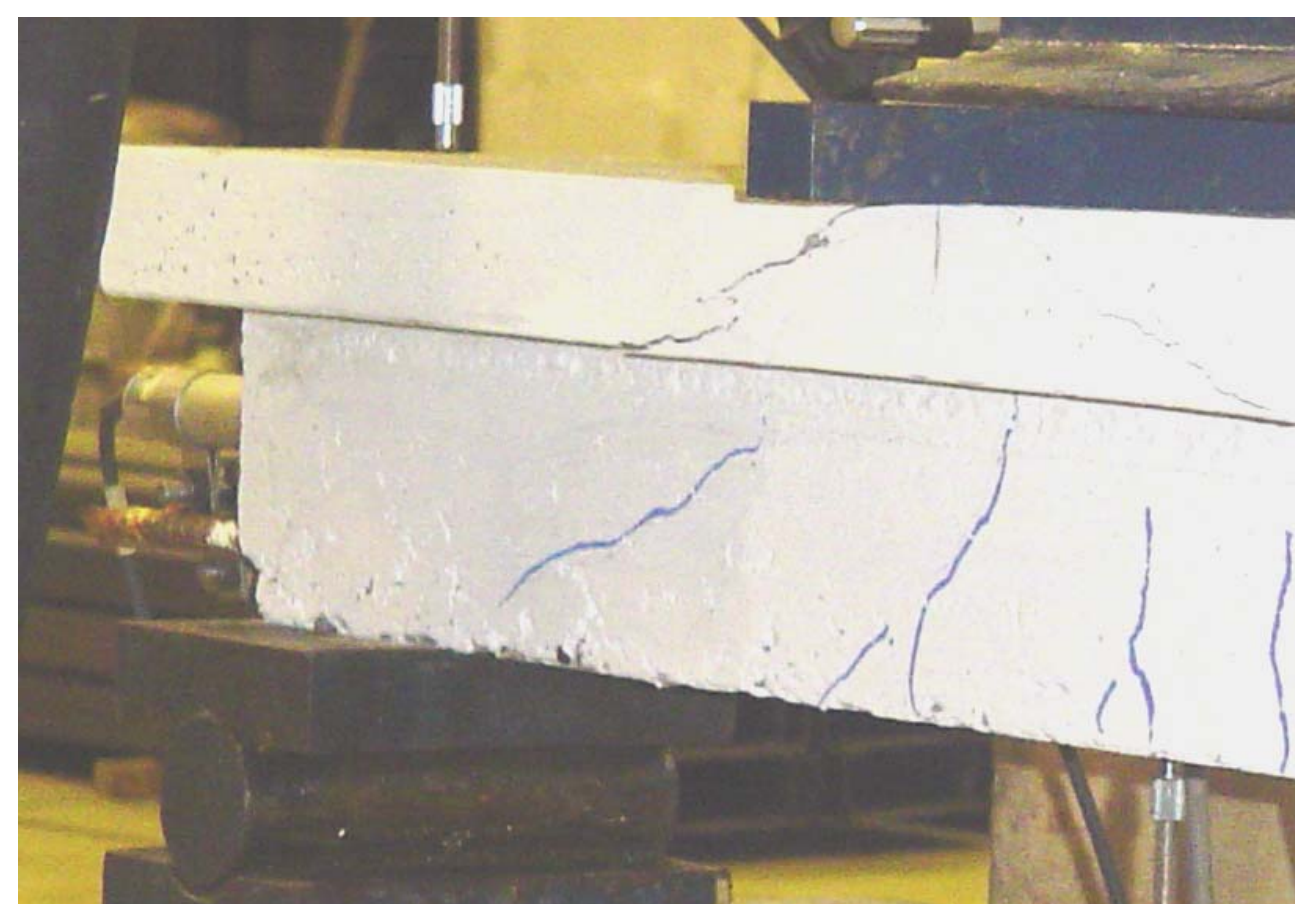

Figura 4.54 - Detalhe da fissura na viga VT-NA-CE-02

A Figura 4.55 e a Figura 4.56 retratam, respectivamente, o aumento da flecha e conseqüente perda de rigidez progressiva no meio do vão das vigas VT-NA-SE-02 e VT-NA-CE-02. 


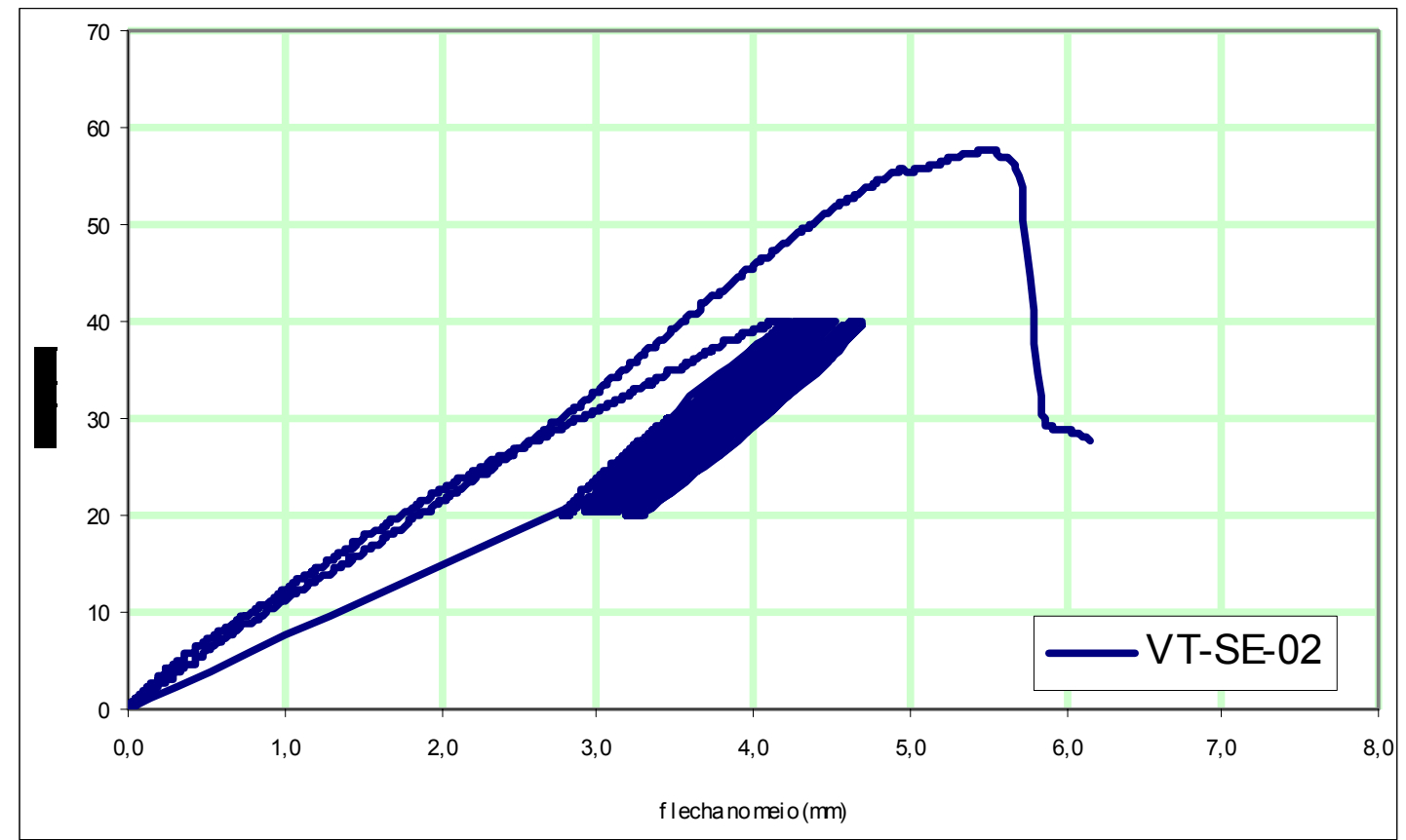

Figura 4.55 - Evolução da flecha na viga VT-NA-SE-02

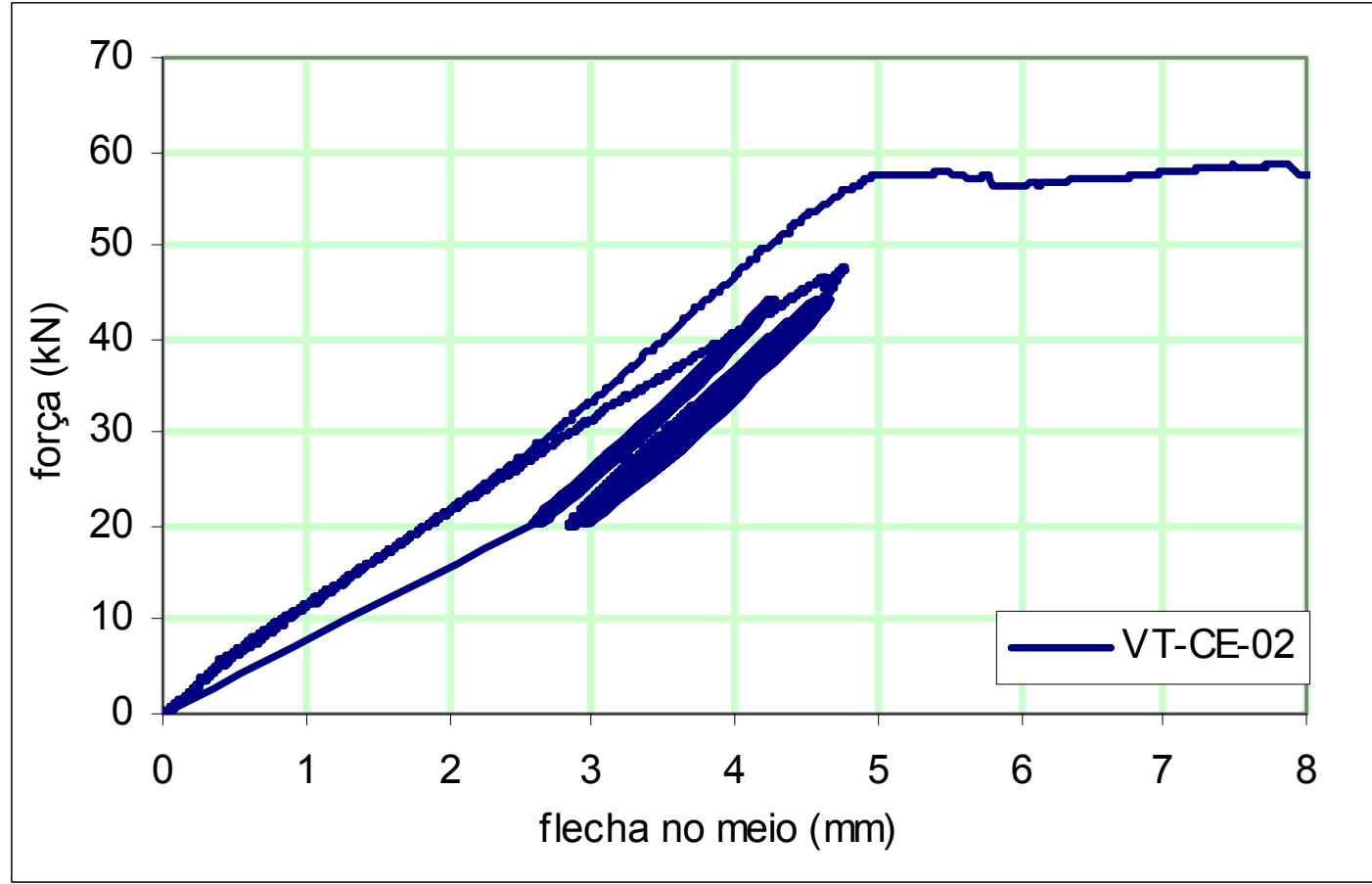

Figura 4.56 - Evolução da flecha na viga VT-NA-CE-02 


\section{Capítulo 5}

\section{ANÁLISE DOS RESULTADOS}

No capítulo 3 foram mostradas as metodologias empregadas para o desenvolvimento de modelos numéricos. No capítulo 4 foram apresentados os ensaios realizados no $\mathrm{LE}_{-} \mathrm{SET}^{8}$ com CP's e com vigas de concreto armado. Naqueles capítulos foram colhidos e apresentados alguns resultados e comentários julgados pertinentes no momento. Neste capítulo é feita uma análise dos resultados mais importantes tirados desta pesquisa.

\subsection{CARACTERIZAÇÃO DO AÇO E DO CONCRETO}

O resumo das propriedades dos aços empregados nesta pesquisa está apresentado na Tabela 4.13. Os valores colocados na tabela foram obtidos de ensaios realizados por outros alunos pesquisadores.

Tabela 5.1 - Propriedades elásticas e mecânicas dos aços utilizados

\begin{tabular}{|c|c|c|c|}
\hline $\begin{array}{c}\varnothing \mathbf{d a} \text { barra } \\
(\mathbf{m m})\end{array}$ & $\begin{array}{c}\mathbf{E}_{\mathbf{s}} \\
(\mathbf{M P a})\end{array}$ & $\begin{array}{c}\mathbf{f}_{\mathbf{y}} \\
(\mathbf{M P a})\end{array}$ & $\begin{array}{c}\mathbf{f}_{\mathbf{u}} \\
(\mathbf{M P a})\end{array}$ \\
\hline 5.0 & 194.330 & 666 & 756 \\
\hline 6.3 & 194.330 & 562 & 648 \\
\hline 10.0 & 194.330 & 515 & 658 \\
\hline
\end{tabular}

\footnotetext{
${ }^{8}$ Laboratório de Estruturas do Departamento de Estruturas da Escola de Engenharia de São Carlos EESC-USP
} 
As propriedades elásticas e mecânicas do concreto foram medidas em corpos de prova cilíndricos de dimensões $100 \mathrm{~mm}$ x $200 \mathrm{~mm}$. Os valores apresentados na Tabela 5.2 refletem a média de 5 (cinco) corpos de prova para cada ensaio. As idades do concreto em cada ensaio variaram de 28 e 121 dias para o ensaio piloto e 21 e 28 dias para o ensaio definitivo.

Tabela 5.2 - Propriedades elásticas e mecânicas do concreto

\begin{tabular}{|c|c|c|c|c|}
\hline \multirow{2}{*}{ Piloto } & $\operatorname{dias}$ & $\begin{array}{c}\mathbf{f}_{\mathbf{c}} \\
(\mathbf{M P a})\end{array}$ & $\begin{array}{c}\mathbf{E}_{\mathbf{c s}} \\
(\mathbf{M P a})\end{array}$ & $\begin{array}{c}\mathbf{f}_{\text {t,diam }} \\
(\mathbf{M P a})\end{array}$ \\
\cline { 2 - 5 } & 28 & 27,70 & 42.423 & 2,64 \\
\hline \multirow{2}{*}{ Definitivo } & 121 & 40,50 & 32.607 & 3,34 \\
\cline { 2 - 5 } & 21 & 38,74 & 26.781 & - \\
\hline
\end{tabular}

Para estimativa do valor da carga última de ruptura das vigas bem como da tensão de aderência foi adotada a idade de 121 dias para o ensaio piloto e 28 dias para o definitivo.

Algumas considerações podem ser feitas das observações tiradas dos ensaios realizados:

- A resistência média à compressão do concreto definida no projeto de pesquisa foi de $30 \mathrm{MPa}$ aos 28 dias. Foram obtidas, no entanto, resistências superiores à requerida, como se constata pela análise da Tabela 5.2 (exceção ao ensaio piloto aos 28 dias). Dentre outros fatores que exercem influencia nas propriedades do concreto, tais como condições climáticas no dia da concretagem, umidade dos agregados graúdo e miúdo empregados e ainda a utilização de tipos diferentes de cimento (comum e ARI), acredita-se que o fator água-cimento tenha contribuído fortemente para a dispersão dos resultados obtidos.

- Para a resistência à tração os resultados dos ensaios se mostraram coerentes e dentro do esperado.

- No ensaio definitivo observou-se um acréscimo, tanto para a resistência à compressão quanto para o módulo de elasticidade. No entanto, se comparados em relação aos 121 dias do ensaio piloto e aos 28 dias do definitivo, os resultados obtidos para a resistência à compressão e para o módulo de elasticidade mostraram-se bastante próximos. 


\subsection{CP'S DE CONCRETO ARMADO}

Os ensaios padronizados de arrancamento (até a ruptura) e ensaios cíclicos com carga em serviço foram realizados no LE-SET. As principais características dos ensaios estão abaixo listadas:

1) CP's com barra axial de diâmetro $\phi=10.0 \mathrm{~mm}$ :

- Quantidade: 2 (dois);

- Dimensões dos CP's: 100 mm de diâmetro x $150 \mathrm{~mm}$ de altura;

- Comprimento da barra: $600 \mathrm{~mm}$;

- Instrumentação da barra: 1 (um) transdutor elétrico colocado na seção extrema do CP oposta à aplicação da carga;

- Comprimento de ancoragem: $10 \phi=100 \mathrm{~mm}$;

- Ensaio estático realizado em 1 (um) CP, com aplicação de carga crescente e levada lentamente à ruptura;

- Ensaio cíclico realizado em 1 (um) CP, com aplicação de determinado número de ciclos de carga; levado à ruptura após o último ciclo;

2) CP's com barra axial de diâmetro $\phi=6.3 \mathrm{~mm}$ :

- Quantidade: 2 (dois);

- Dimensões dos CP's: 60 mm de diâmetro x 110 mm de altura;

- Comprimento da barra: $600 \mathrm{~mm}$;

- Comprimento de ancoragem: $10 \phi=6.3 \mathrm{~mm}$;

- Ensaio estático em 1 (um) CP, com aplicação de carga crescente e levada lentamente à ruptura;

- Ensaio cíclico em 1 (um) $\mathrm{CP}$, com aplicação de determinado número de ciclos de carga; levado à ruptura após o último ciclo;

OBS.: Para todos os CP's a instrumentação da barra foi feita com 1 (um) transdutor elétrico colocado na seção extrema do $\mathrm{CP}$ oposta à aplicação da carga. 
Além dos ensaios de laboratório foram também realizadas modelagens desses CP's com a utilização do aplicativo Abaqus', tendo sido analisados modelos axisimétricos e tridimensionais.

\subsubsection{Análise experimental}

\subsubsection{Ensaio com carga até a ruptura:}

A Figura 5.1 relaciona as tensões de aderência com os deslizamentos ocorridos nos CP's com barra de $6.3 \mathrm{~mm}$ e $10.0 \mathrm{~mm}$. A carga máxima suportada é de $16,6 \mathrm{kN}$ e $36,1 \mathrm{kN}$ para, respectivamente, os CP's com barra de $6.3 \mathrm{~mm}$ e de $10.0 \mathrm{~mm}$.. Observase da análise desse gráfico (e de outros plotados no capítulo 4) a queda brusca de tensão no CP com barra de $10.0 \mathrm{~mm}$ configurando a ruptura do $\mathrm{CP}$ por fendilhamento; observa-se ainda o comportamento da curva do CP com barra de $6.3 \mathrm{~mm}$ onde a tensão cai lentamente enquanto o deslizamento aumenta configurando, no final, a ruptura do CP por arrancamento da barra; isso vem corroborar com o que tantos outros pesquisadores disseram.

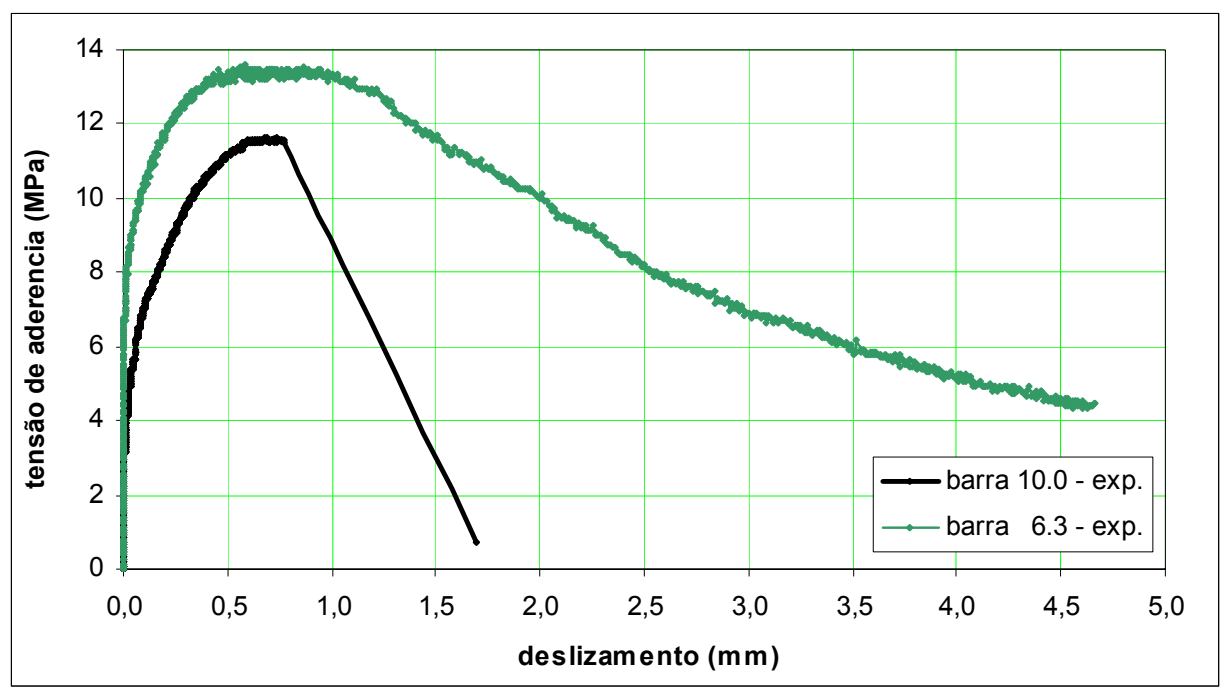

Figura 5.1 - Arrancamento e fendilhamento dos CP's

Constata-se, na Figura 5.2, que a curva descrita pelo CP com barra de $6.3 \mathrm{~mm}$ assemelha-se, no aspecto, com a curva do CEB-FIP MC 1990.

\footnotetext{
9 ABAQUS - programa baseado no MEF, nas versões 5.8 e 6.3, disponível no laboratório de computação do SET.
} 


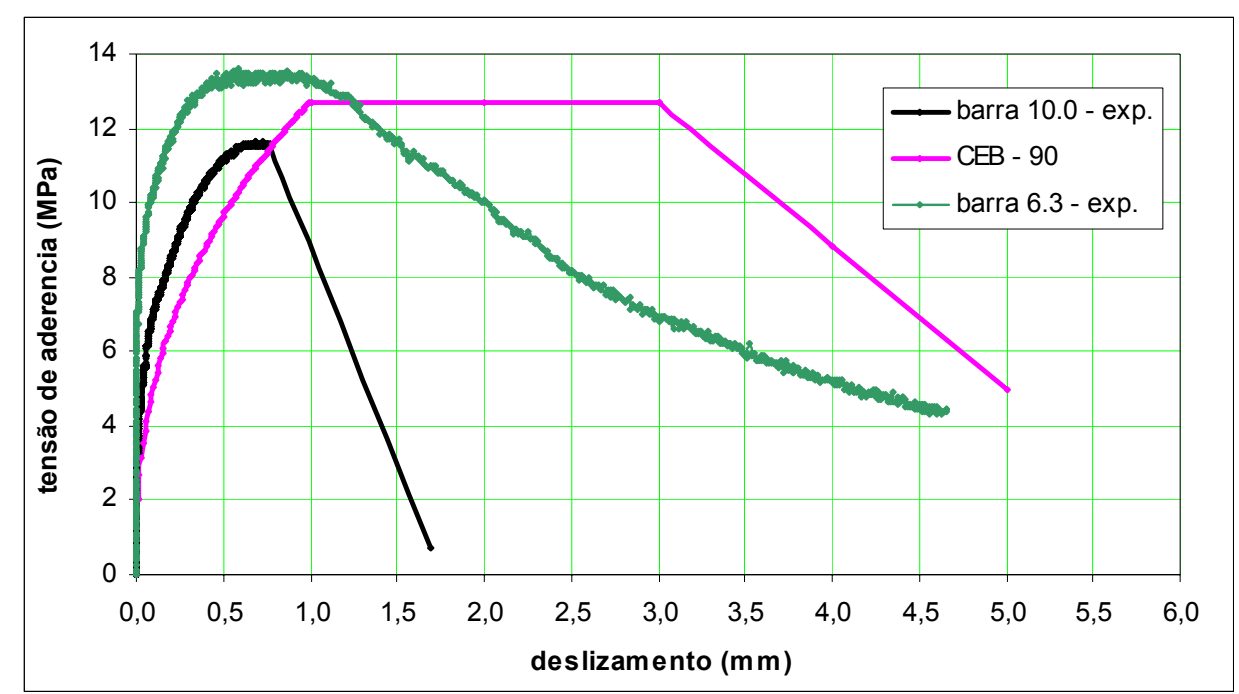

Figura 5.2 - Comparação com o CEB

O valor limite para a tensão de aderência correspondente a um deslizamento de 0,1 mm, segundo a NBR 6118:2003, é obtido pela expressão (5.1) e assinalado na Figura 5.3 juntamente com o limite dado pelo CEB.

$$
\mathrm{f}_{\mathrm{bd}}=\eta_{1} \cdot \eta_{2} \cdot \eta_{3} \cdot \mathrm{f}_{\mathrm{ctd}}
$$

Para cada CP vale:

$\mathrm{f}_{\text {bd }}=3,34 \mathrm{MPa}$ para o CP com barra de $6.3 \mathrm{~mm} \mathrm{e}$

$\mathrm{f}_{\mathrm{bd}}=5,96 \mathrm{MPa}$ para o CP com barra de $10.0 \mathrm{~mm}$.

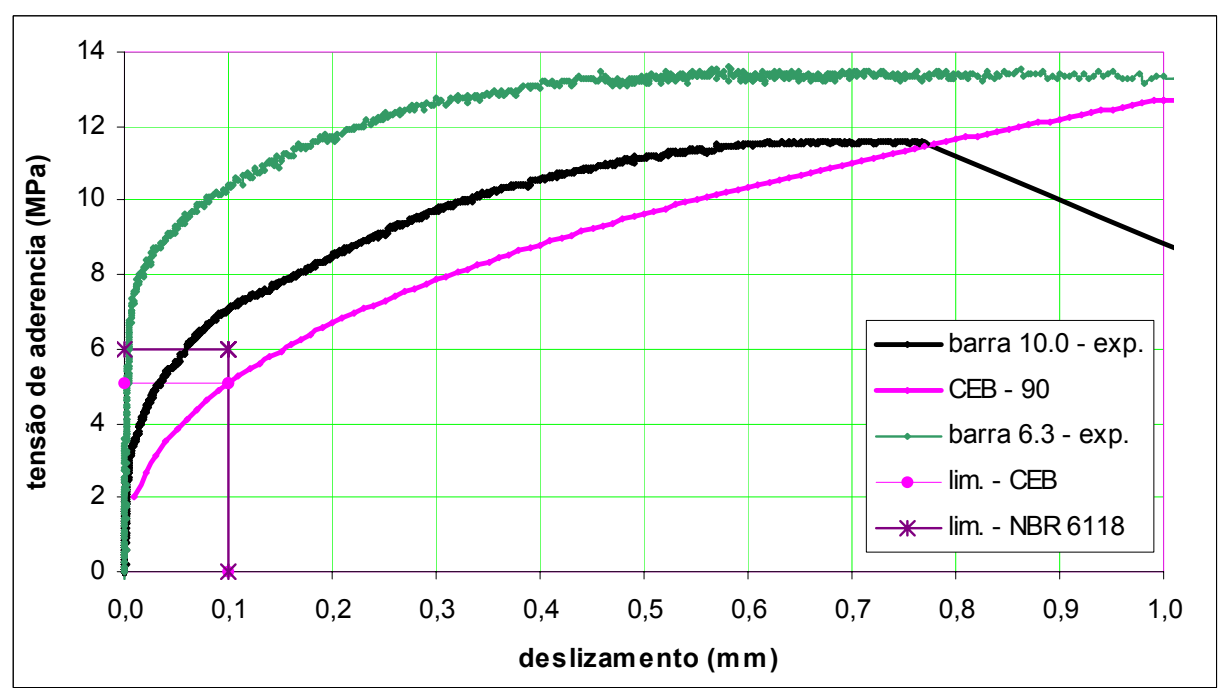

Figura 5.3 - Limites para a tensão de aderência segundo o CEB-90 e a NBR 6118

Algumas considerações podem ser feitas das observações tiradas dos ensaios à ruptura realizados com os CP's: 
- O ensaio foi realizado com apenas 2 (dois) CP's; os resultados obtidos não devem ser conclusivos; os resultados, no entanto, mostraram concordância com os resultados encontrados na literatura técnica;

- Ficaram bastante evidentes os modos de ruptura por arrancamento e por fendilhamento;

- O comprimento de ancoragem usado para o CP com barra axial de $6.3 \mathrm{~mm}$ foi de $10 \phi=63 \mathrm{~mm}$, contrariando, por conseguinte, o que recomenda a NBR 6118:2003, item 9.4.2.5. Observou-se, no entanto, que o valor registrado para a tensão de aderência correspondente a um deslizamento de $0,1 \mathrm{~mm}$ foi aproximadamente o triplo do valor limite;

- Para o CP com barra axial de $10.0 \mathrm{~mm}$ o valor registrado para a tensão de aderência correspondente a um deslizamento de $0,1 \mathrm{~mm}$ foi praticamente coincidente;

- O valor limite para a tensão de aderência correspondente a um deslizamento de 0,1 mm, segundo a NBR 6118:2003, mostrou-se conservador;

- Verificou-se que as barras não entraram em escoamento;

\subsubsection{Ensaio com carga cíclica}

A Tabela 4.4 apresenta uma síntese dos dados adicionais necessários à realização dos ensaios cíclicos e alguns resultados colhidos desses ensaios. $\mathrm{P}_{\mathrm{u}}$ é a carga de ruptura alcançada no ensaio estático de arrancamento; $\mathrm{P}_{\max }$ e $\mathrm{P}_{\min }$ são os limites superior e inferior da amplitude da carga cíclica aplicada e $\mathrm{P}_{\mathrm{uc}}$ é a carga alcançada na ruptura após a aplicação do último ciclo de carga.

Tabela 5.3 - Dados e resultados dos ensaios cíclicos com CP's

\begin{tabular}{|c|c|c|c|c|c|c|c|}
\hline $\mathbf{C P}$ & $\mathbf{P}_{\mathbf{u}}(\mathbf{k N})$ & $\mathbf{P}_{\max }(\mathbf{k N})$ & $\mathbf{P}_{\min }(\mathbf{k N})$ & $\mathbf{P}_{\max } / \mathbf{P}_{\mathbf{u}}$ & $\mathbf{P}_{\mathbf{m i n}} / \mathbf{P}_{\mathbf{u}}$ & $\mathbf{N}^{\mathbf{o}}$ ciclos & $\mathbf{P}_{\mathbf{u c}}(\mathbf{k N}$ \\
\hline $\mathbf{6 . 3} \mathbf{~ m m}$ & $\mathbf{1 6 , 6}$ & 13,0 & 7,0 & $80 \%$ & $40 \%$ & 230 & 18,5 \\
\hline $\mathbf{1 0 . 0} \mathbf{~ m m}$ & $\mathbf{3 6 , 1}$ & 30,0 & 22,0 & $80 \%$ & $60 \%$ & 200 & 37,9 \\
\hline
\end{tabular}

A Figura 5.4 mostra a evolução dos deslocamentos ocorridos no CP com barra axial de $6.3 \mathrm{~mm}$, em função do número de ciclos aplicado. Do mesmo modo a Figura 5.5 mostra a evolução dos deslocamentos ocorridos no CP com barra de $10.0 \mathrm{~mm}$. Na Figura 5.6 as curvas dos CP's de $6.3 \mathrm{~mm}$ e de $10.0 \mathrm{~mm}$ são plotadas juntas de modo a se 
ter uma visão comparativa da evolução relativa dos deslocamentos entre elas. Nessas figuras são plotados o $1^{\mathrm{o}}$ ciclo, alguns ciclos intermediários e os últimos ciclos, inclusive a última fase do ensaio quando o CP é levado à ruptura, após o último ciclo.

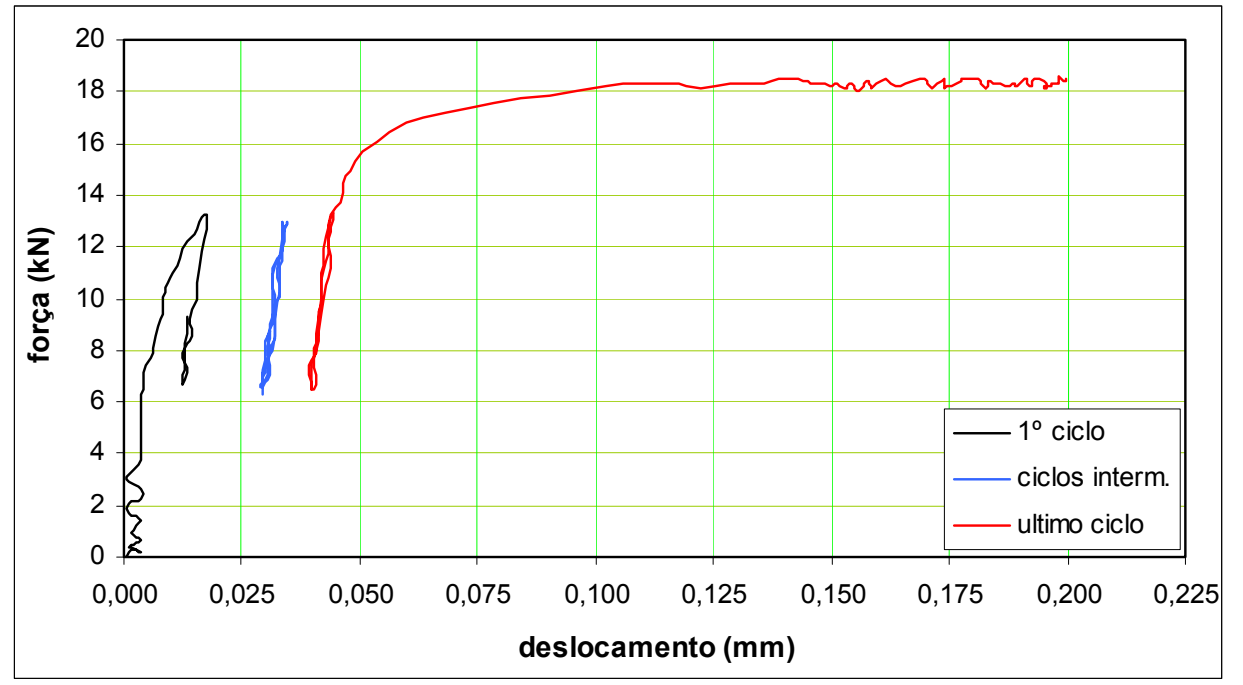

Figura 5.4 - Ciclos inicial, intermediários e últimos para o CP com $6.3 \mathrm{~mm}$

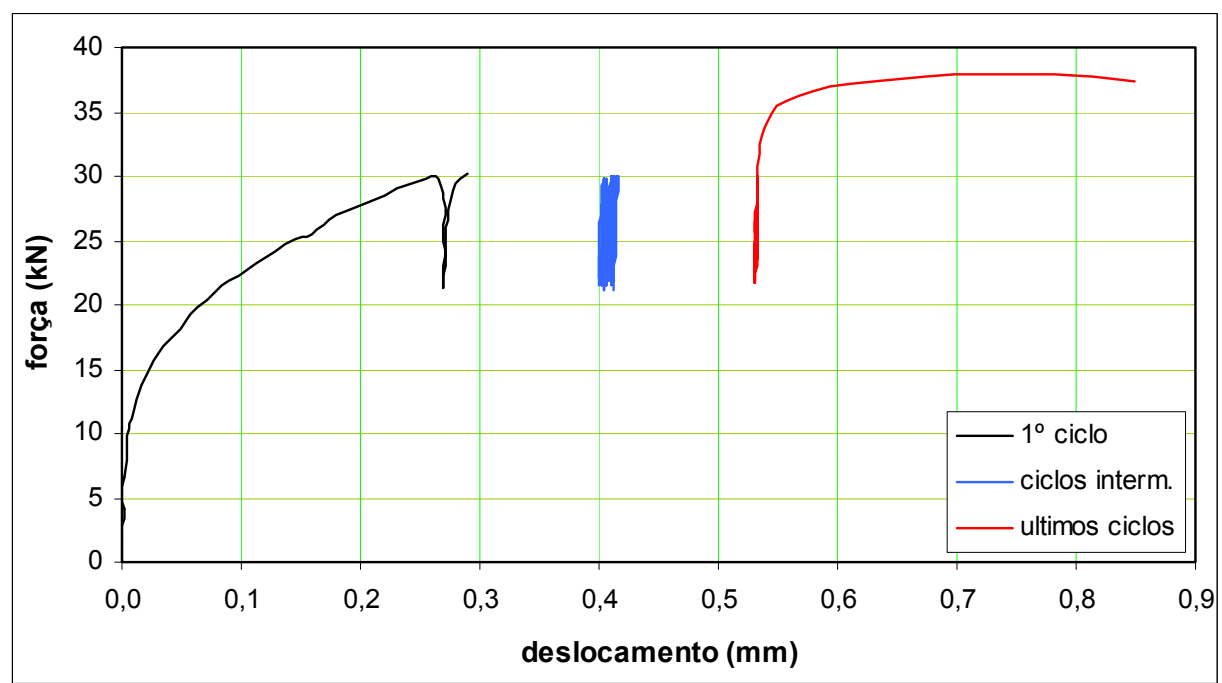

Figura 5.5 - Ciclos inicial, intermediários e últimos para o CP com $10.0 \mathrm{~mm}$ 


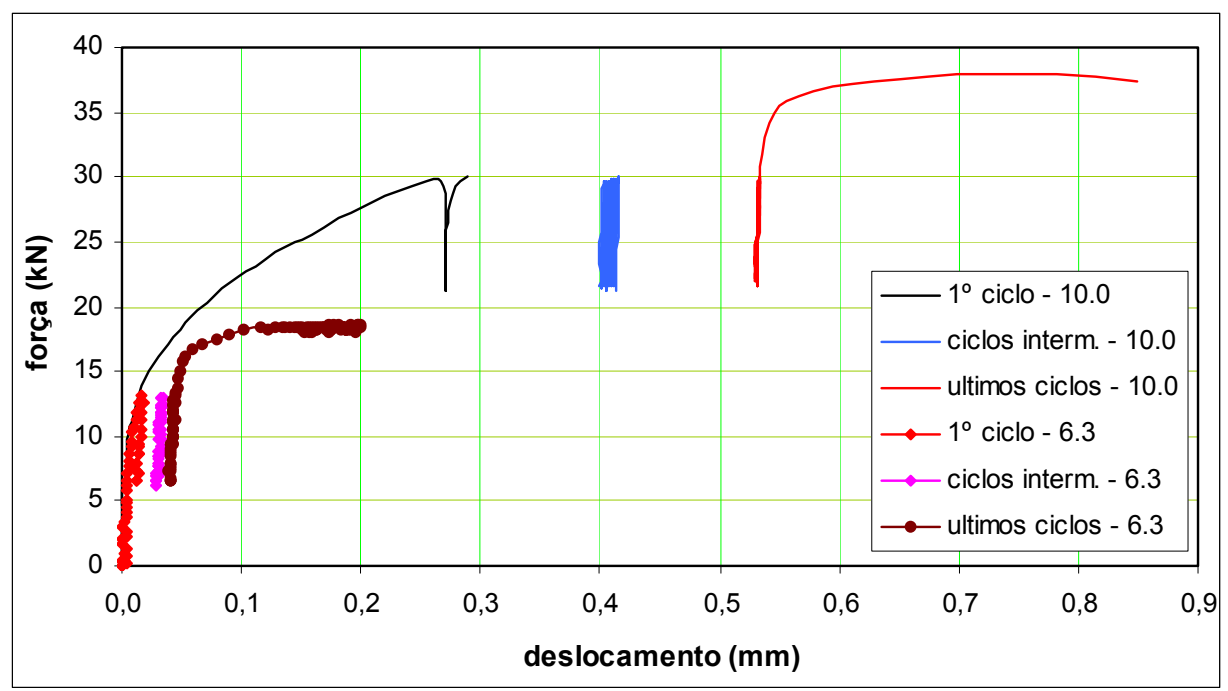

Figura 5.6 - Comparativo entre os CP's de $6.3 \mathrm{~mm}$ e $10.0 \mathrm{~mm}$

As Figura 4.30 e Figura 5.8 mostram comparativo entre o ensaio à ruptura e o ensaio cíclico para os CP's com barra axial de $6.3 \mathrm{~mm}$ e $10.0 \mathrm{~mm}$, respectivamente.

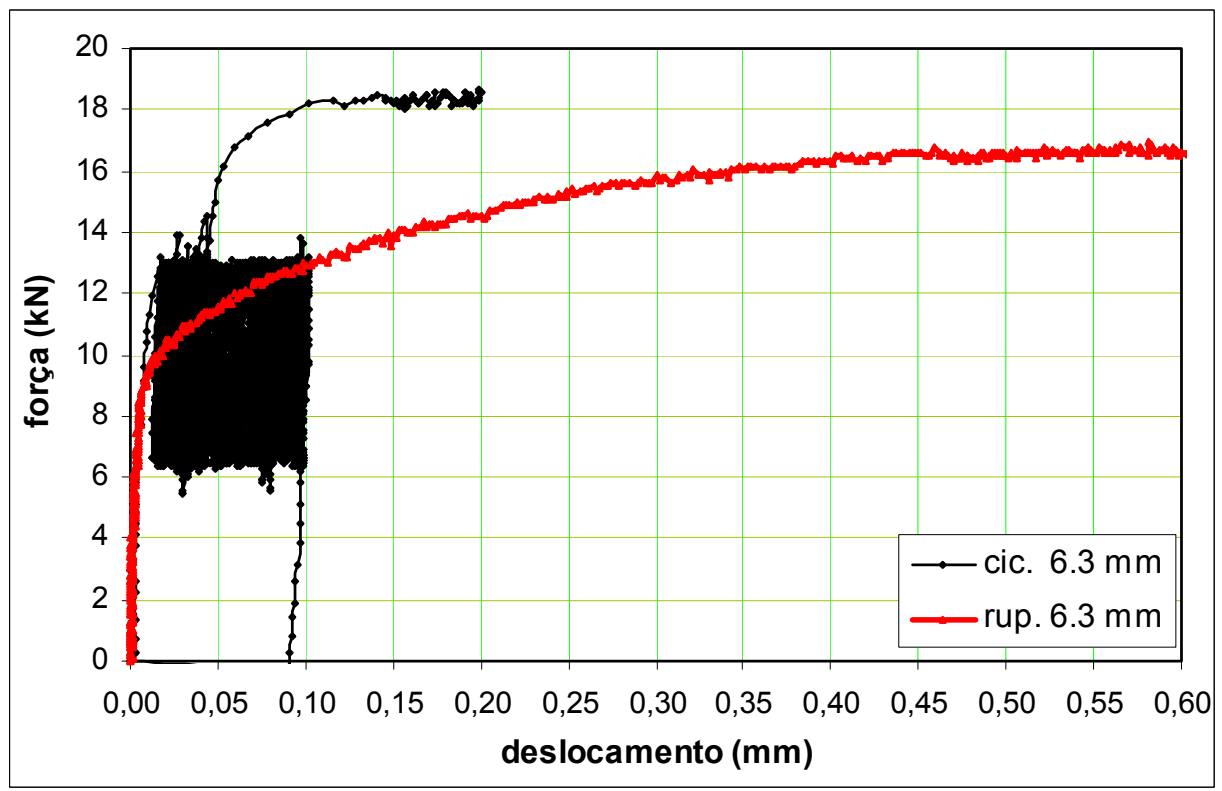

Figura 5.7 - Cíclico e ruptura para o CP de $6.3 \mathrm{~mm}$ 


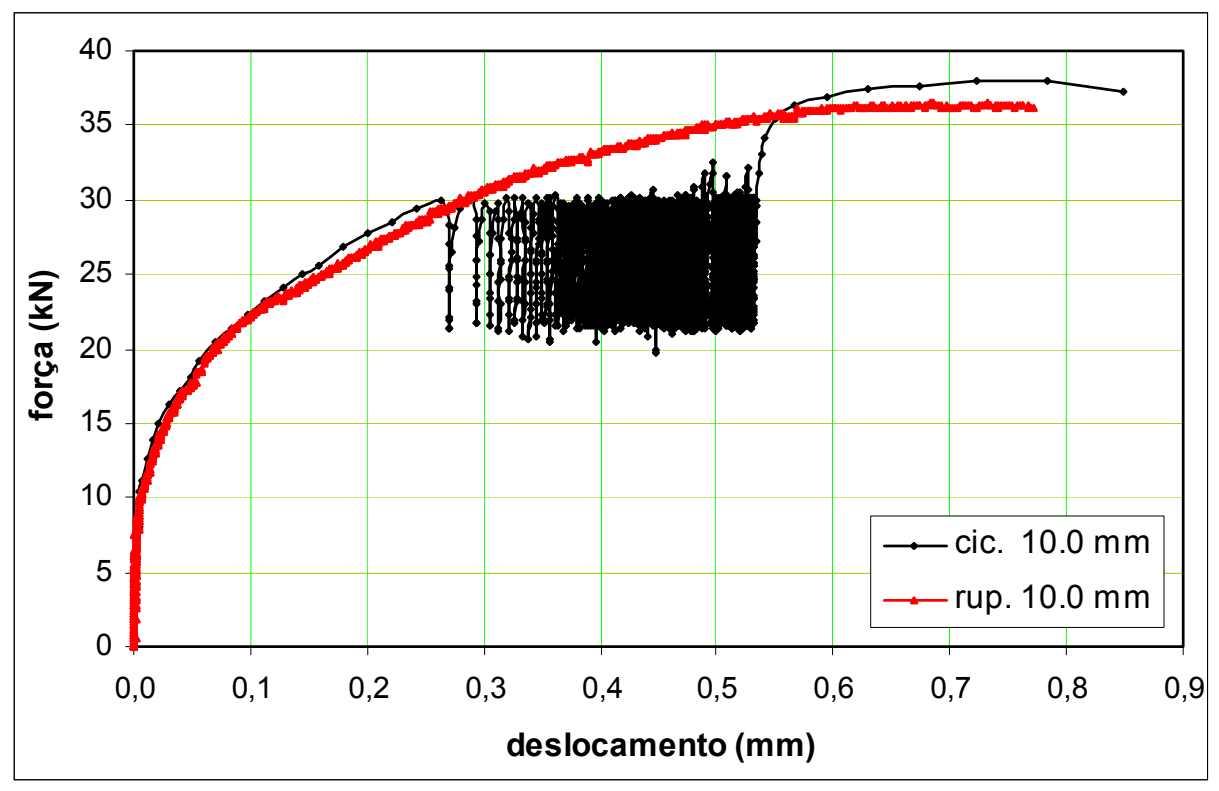

Figura 5.8 - Cíclico e ruptura para o CP de 10.0 mm

Algumas considerações podem ser feitas das observações tiradas dos ensaios com carga cíclica realizados com os CP's:

- O ensaio foi realizado com apenas 2 (dois) CP's;

- Aumento crescente do deslocamento em função da aplicação dos ciclos de carga, com conseqüente perda de rigidez;

- Aumento da carga de ruptura após a aplicação do último ciclo de carga e a conseqüente diminuição do deslocamento na ruptura;

- Para o CP com barra axial de $6.3 \mathrm{~mm}$ o aumento da carga de ruptura é de aproximadamente $12 \%$ (última coluna da Tabela 4.4) enquanto que o deslocamento na ruptura é 3,5 vezes menor;

- Para o caso do CP com barra axial de $10.0 \mathrm{~mm}$ o aumento da carga de ruptura é de aproximadamente $5 \%$ (última coluna da Tabela 4.4) enquanto que o deslocamento na ruptura é aproximadamente $25 \%$ maior.

\subsubsection{Análise numérica}

Com o ABAQUS/CAE, utilizando-se dos seus diversos módulos, foi criado o modelo axisimétrico representativo dos CP's de concreto armado. Adiante são fornecidas informações adicionais indispensáveis para a análise do modelo:

- modelo constitutivo do aço: elasto-plástico perfeito; 
- modelo constitutivo do concreto: "Concrete Damaged Plasticity"; faz-se necessário fornecer a curva "Tension Stiffening" do concreto;

- propriedades de interação entre as superfícies de contato: utilizado o modelo de friç̧ão de Lagrange; consideração de não-linearidade física e geométrica.

A Figura 5.9 mostra a discretização das superfícies de contato entre o aço (com suas nervuras) e o concreto envolvente; mostra ainda o detalhe de cada superfície, a master (aço) e a escrava (concreto).

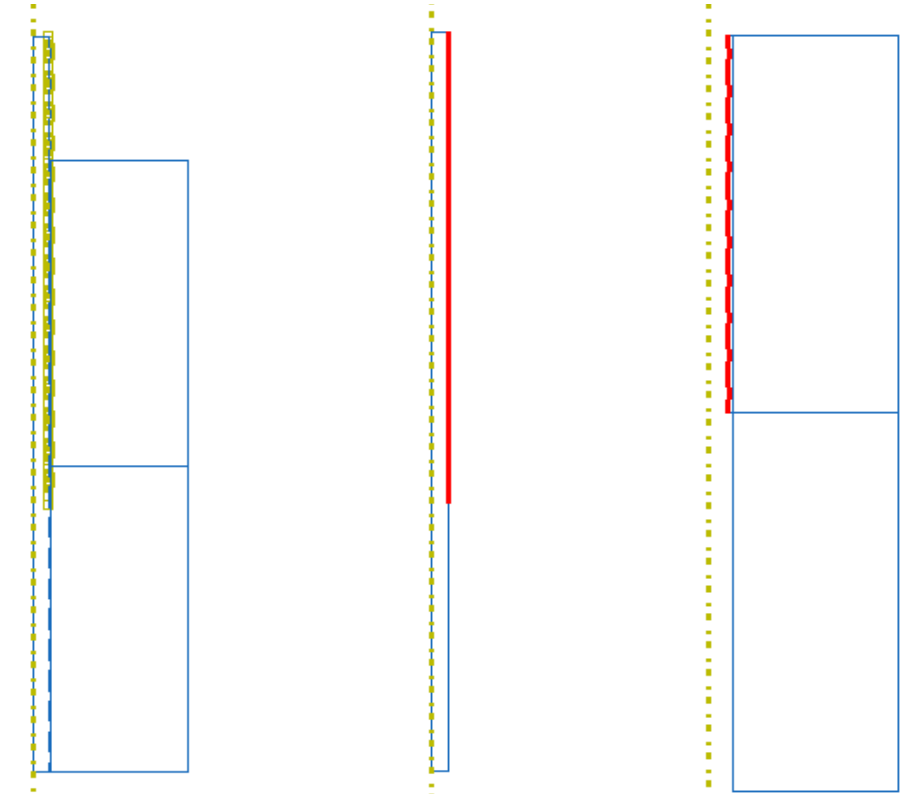

Figura 5.9 - Superfície de contato e detalhes para a master e escrava

A Figura 5.10 mostra as condições de contorno impostas ao modelo; num primeiro passo, para prevenir movimento de corpo rígido, são aplicadas restrições ao movimento do modelo de modo a estabelecer apenas o equilíbrio para as condições de contato. No passo seguinte são retiradas as restrições indesejadas e aplicado o carregamento (monotônico), em incrementos automáticos de deslocamento. É mostrada também na Figura 5.10 a malha construída com elementos tipo CAX4. 

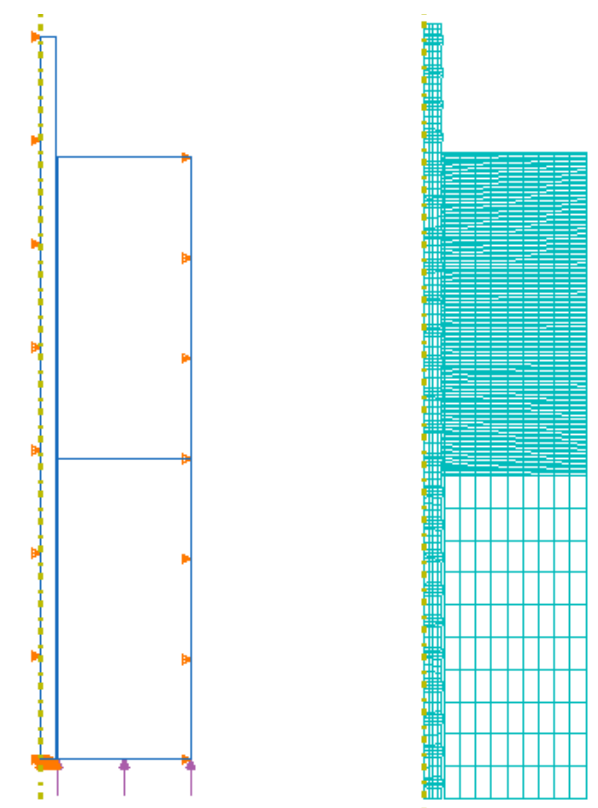

Figura 5.10 - Condições de contorno e malha

Adiante, a Figura 5.11 mostra o panorama do dano ocorrido em pontos pertencentes à superfície escrava.

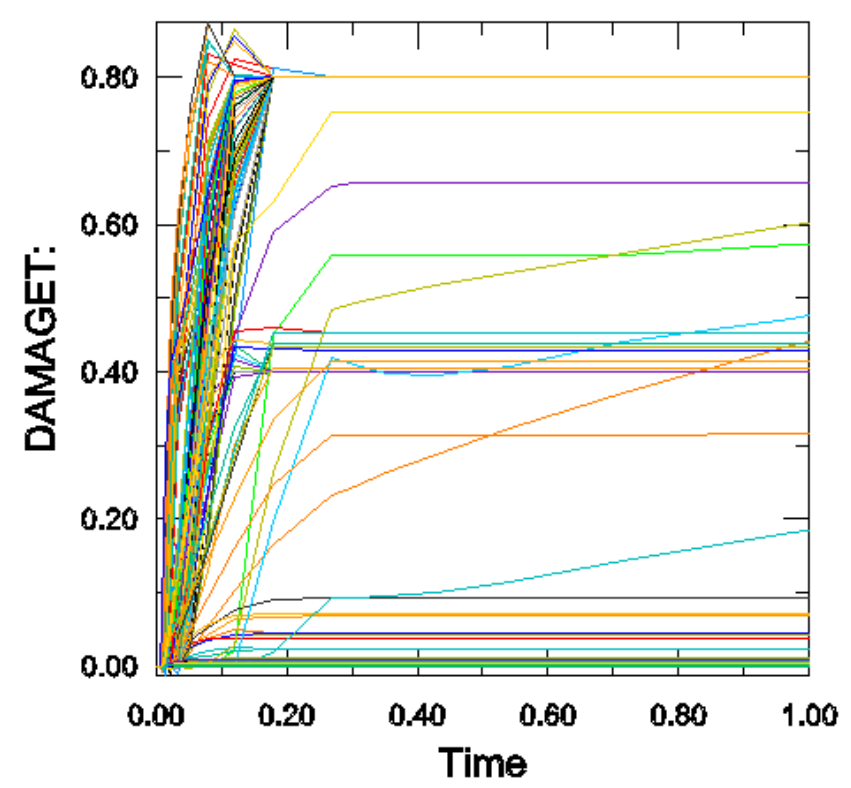

Figura 5.11 - Medida do dano dos pontos sobre a superfície escrava

A maioria dos pontos da superfície escrava atingiu valor próximo a 1.0, mostrando que o concreto circundante à barra perdeu rigidez levando o $\mathrm{CP}$, por conseguinte, ao colapso. A Figura 5.12 reforça o que foi afirmado acima. Observar que a maioria ( 3 dos 4 ) pontos pertencentes a um determinado conjunto de pontos (path) da 
superfície circundante de concreto atingiram o valor 0.75 para a medida do dano, valor esse que caracteriza a ruptura.

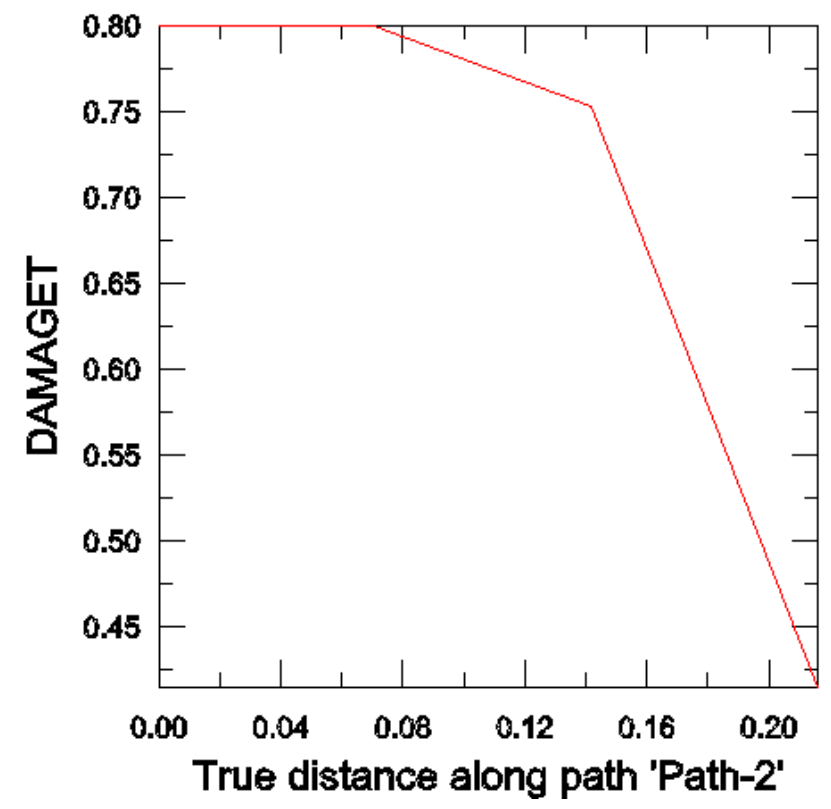

Figura 5.12 - Dano medido em alguns pontos

Na Figura 5.13 é mostrada a variação média da tensão de aderência e o respectivo deslizamento para um determinado ponto sobre a superfície de contato.

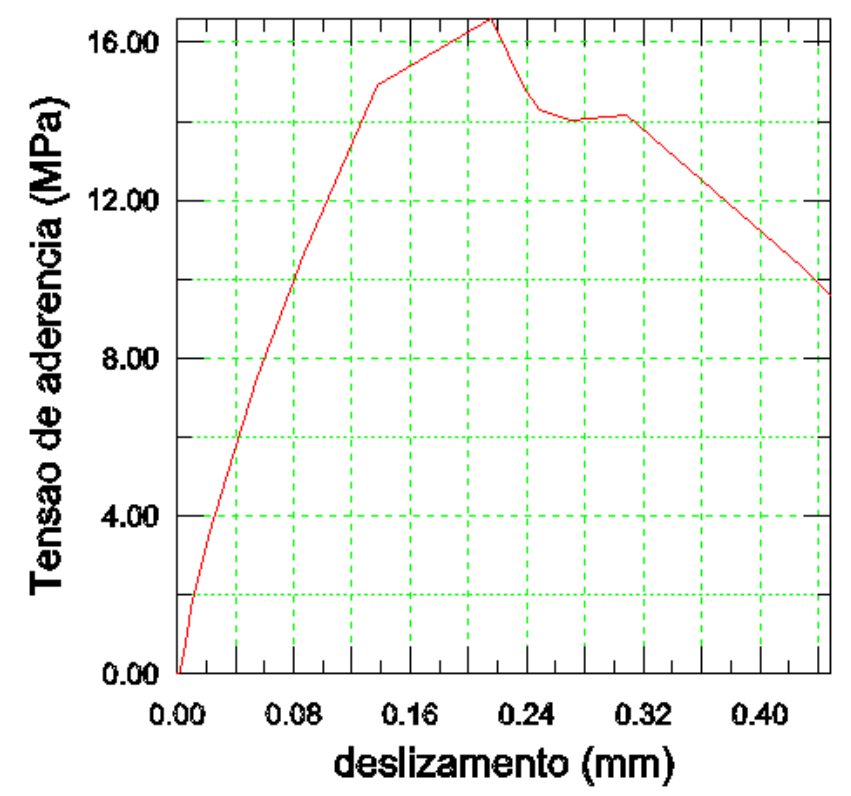

Figura 5.13 - Tensão de aderência $x$ deslizamento de um ponto

$\mathrm{Na}$ Figura 5.14 são apresentadas as curvas força $\mathrm{x}$ deslocamento para dois pontos adjacentes pertencentes à superfície de contato, obtidas diretamente da análise efetuada no ABAQUS/CAE; um dos pontos pertence ao aço, localizado na superfície 
máster, e o outro pertence ao concreto, sobre a superfície escrava; a comparação é feita com a curva obtida do ensaio experimental.

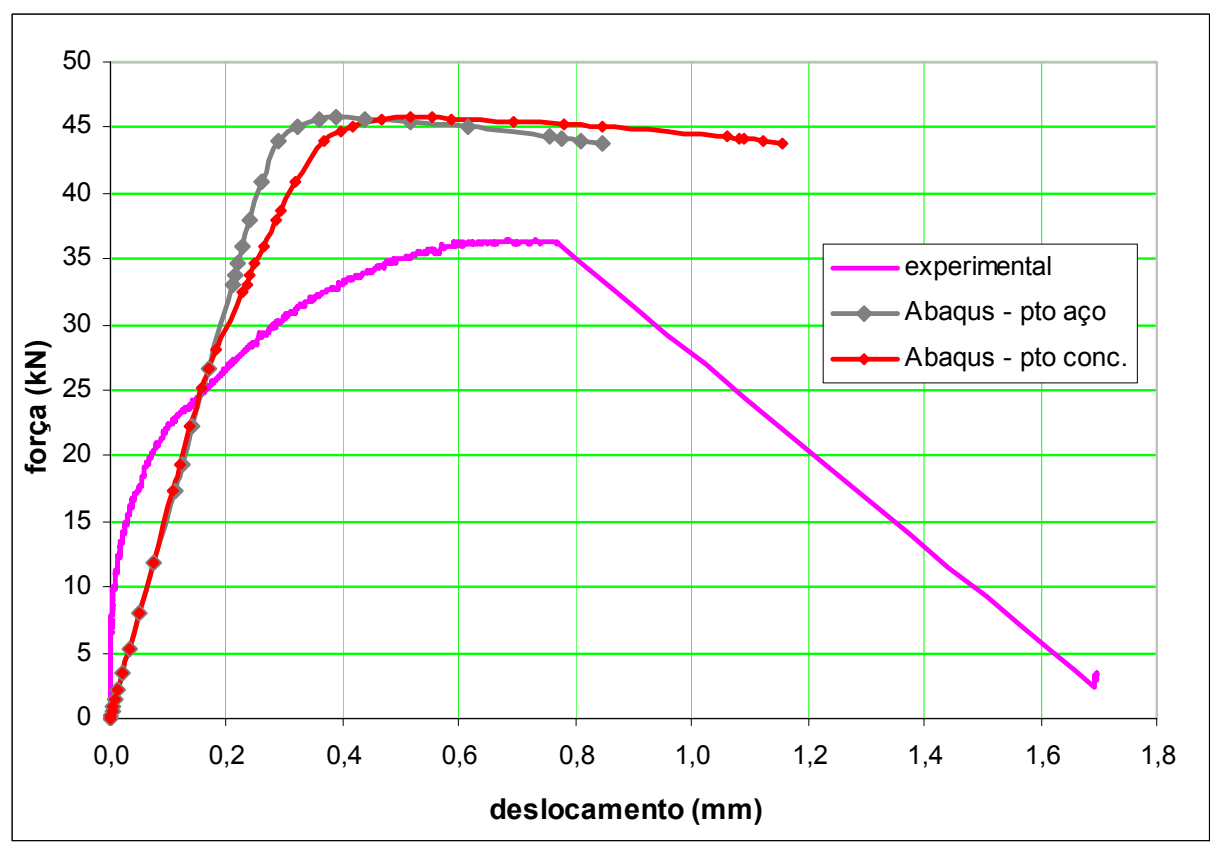

Figura 5.14 - Curva Abaqus x experimental

A Figura 5.15 mostra o gráfico para a tensão de aderência obtido diretamente da análise feita no Abaqus.

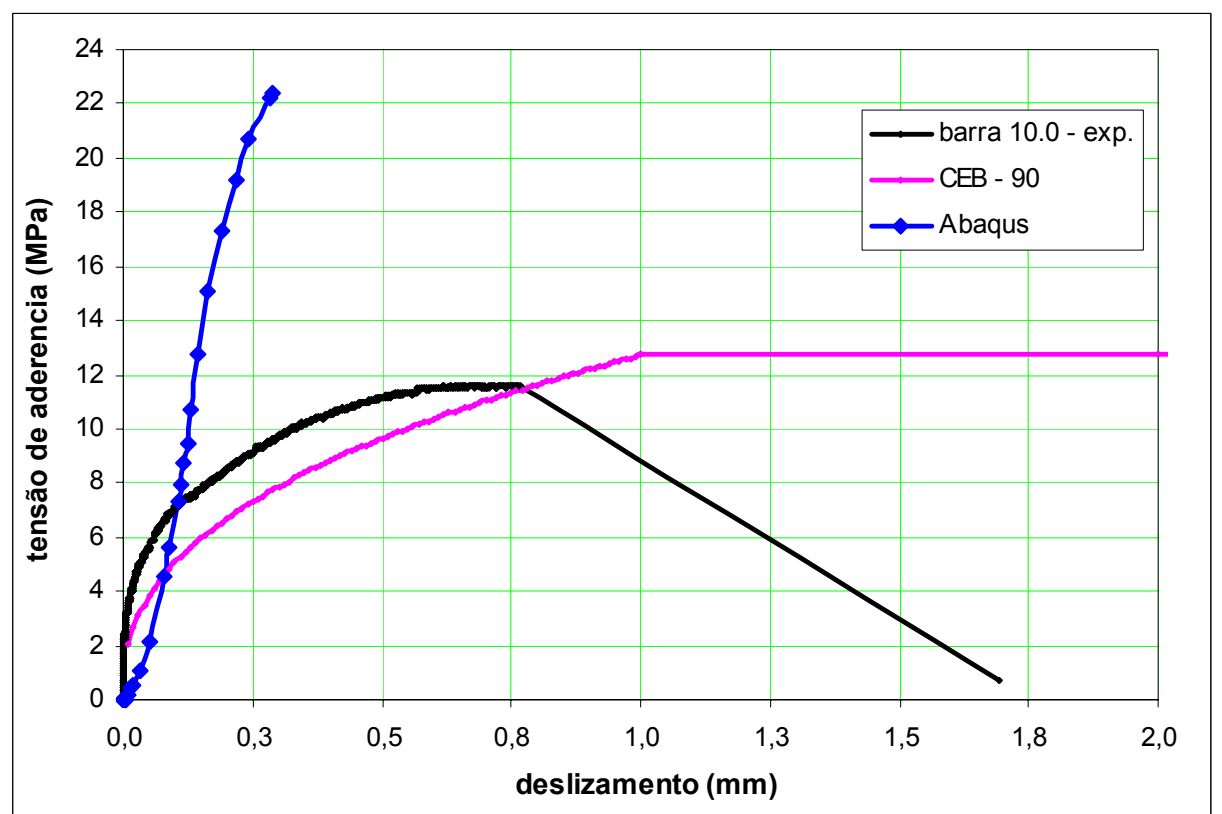

Figura 5.15 - Curva Abaqus x experimental para a tensão de aderência

A resposta do modelo dada pela Figura 5.14 mostrou-se razoável, com valores acima do esperado; na Figura 5.15, para as tensões de aderência, observa-se que o modelo mostrou-se bastante rígido. Muitas foram as tentativas para obter uma resposta 
mais adequada; de nada a mais valeram os esforços despendidos. A superfície de contato, por ser rugosa (nervuras da barra de aço) e produzir variações bruscas de direção da normal, torna o problema muito rígido e de difícil convergência.

No modelo submetido a carregamento cíclico a alteração ocorre apenas no módulo LOAD, com a introdução de uma sub-rotina denominada AMPLITUDE, que define o tipo da função cíclica adotada, a amplitude do carregamento e o correspondente número de ciclos. Diante das dificuldades de convergência já assinaladas, o número de ciclos se restringiu a apenas dois. A Figura 5.16 mostra a variação do deslocamento de um determinado ponto após a aplicação de 2 (dois) ciclos de carga. Chama-se a atenção para o número de ciclos assinalado na figura; um ciclo completo é, portanto, equivalente a 2 unidades; o "time", neste caso, é igual a quatro unidades.

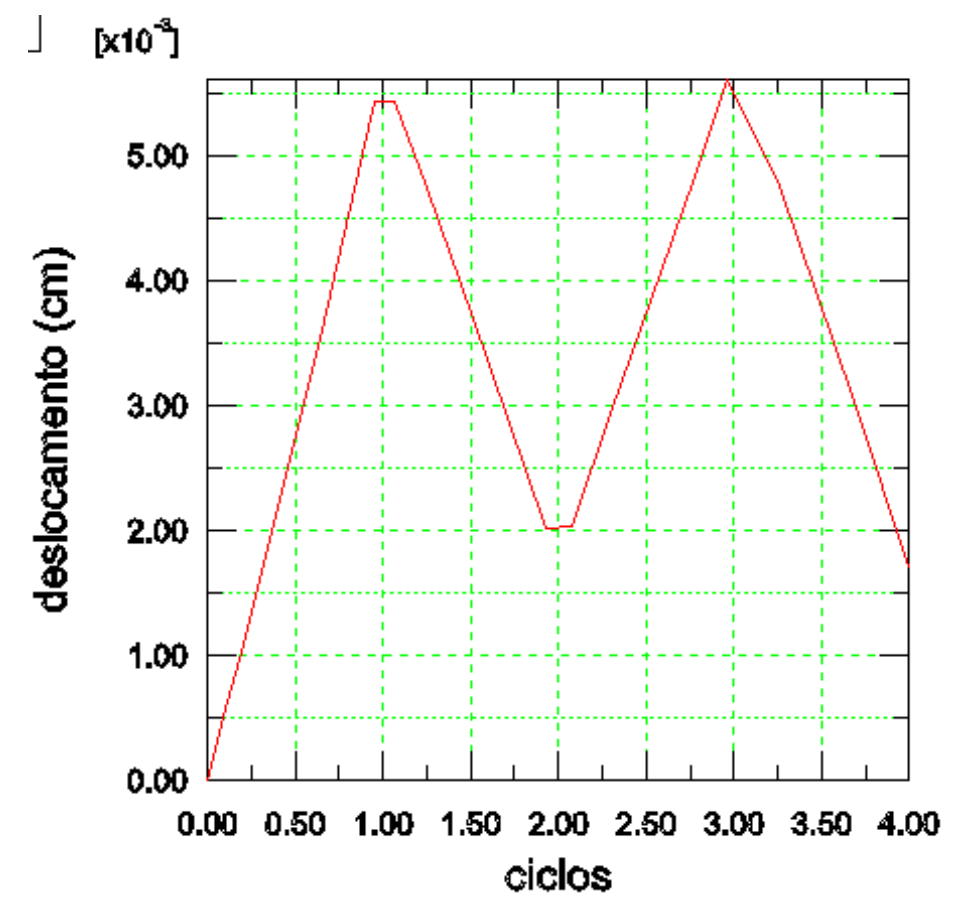

Figura 5.16 - Deslocamento após dois ciclos de carga

A Figura 5.17 mostra o dano à compressão ocorrido em um ponto pertencente à superfície escrava após a aplicação de 2 ciclos de carga. Observar que já no $1^{\circ}$ ciclo o valor do dano no ponto ultrapassou os $80 \%$, o que caracteriza o esmagamento do ponto. 


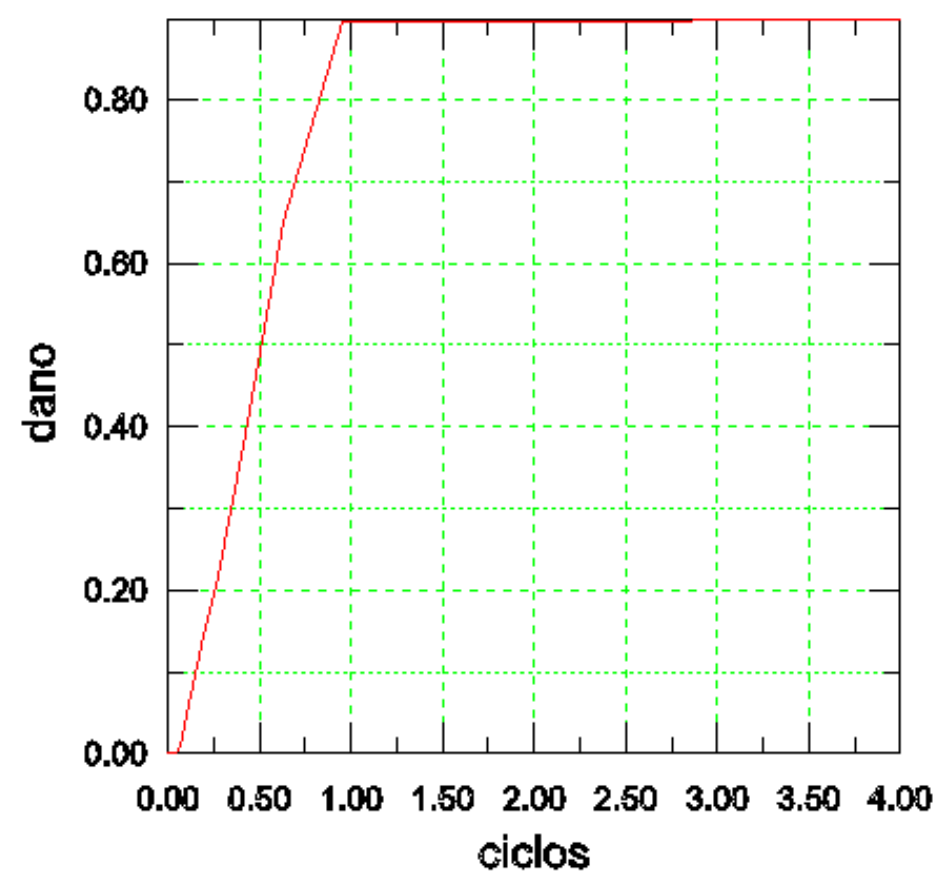

Figura 5.17 - Dano à compressão em um ponto após dois ciclos de carga

O dano à compressão registrado no elemento finito a que pertence o ponto do item anterior é mostrado na Figura 5.18. Observar a trajetória, demarcada na cor laranja, da danificação do ponto da Figura 5.17.

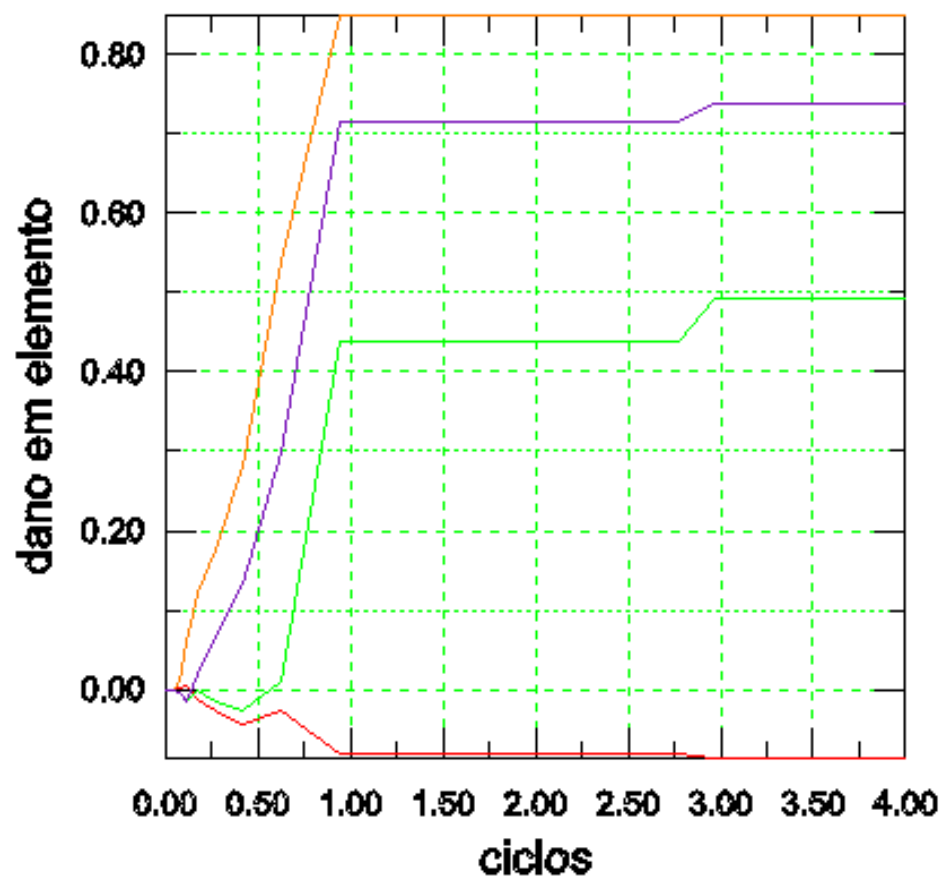

Figura 5.18 - Dano à compressão em elemento finito após dois ciclos de carga

A Figura 5.19 mostra o baixo nível de danificação à tração ocorrido no ponto assinalado na figura anterior, para os mesmos 2 ciclos de carga. 


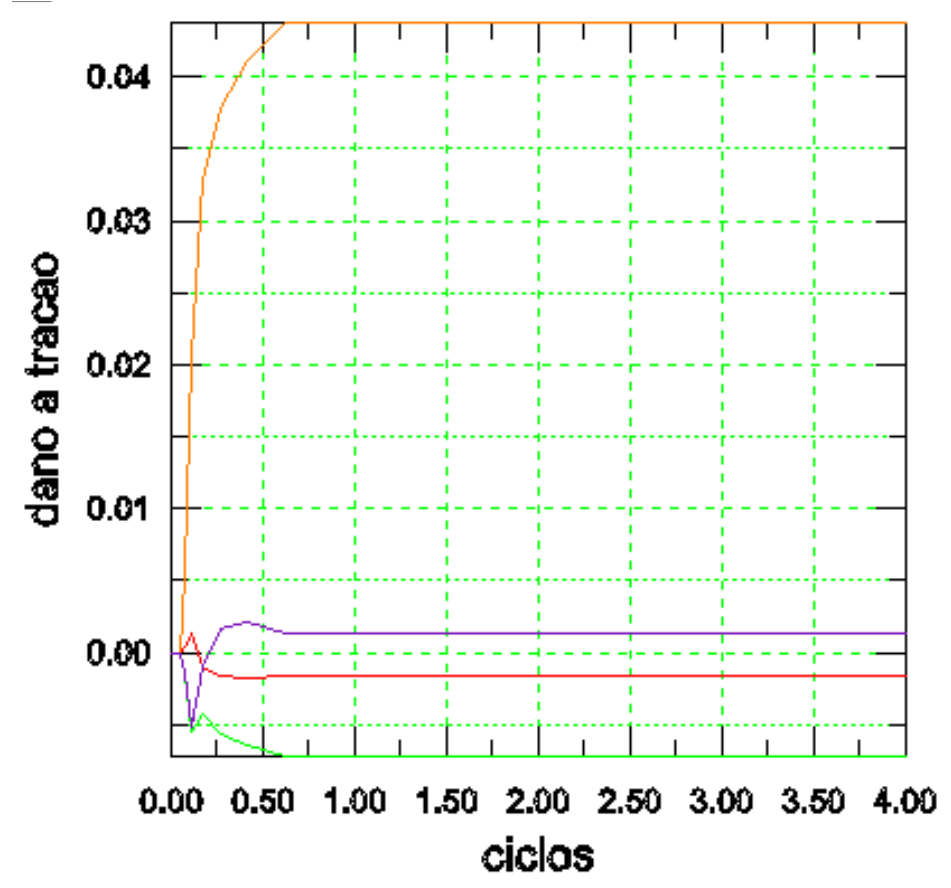

Figura 5.19 - Dano à tração em elemento finito após dois ciclos de carga

A Figura 5.20 mostra a variação da tensão de aderência média em pontos da superfície de contato e o deslizamento desses pontos após completados dois ciclos de carga.

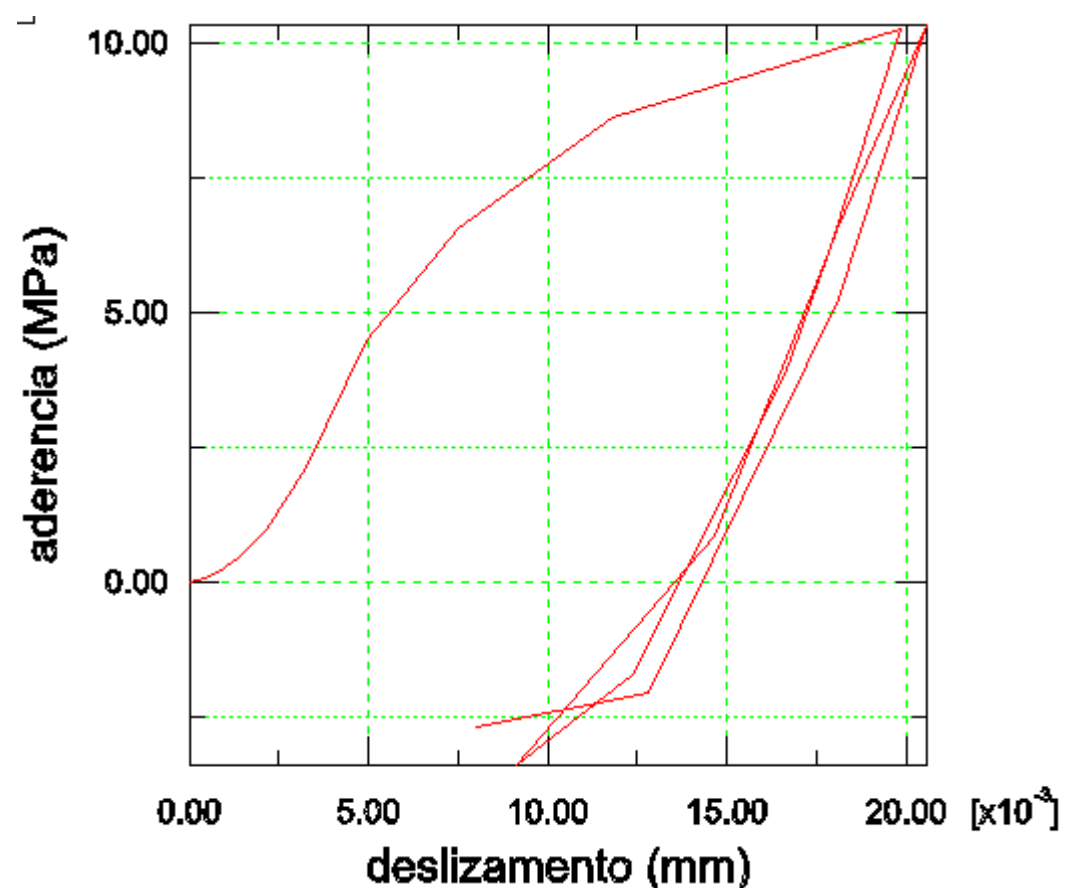

Figura 5.20 - Tensão de aderência $x$ deslizamento para dois de carga

Diante das análises numéricas apresentadas nesse item é possível tecer alguns comentários a respeito do comportamento dos CP's de concreto armado: 
- Para uma peça de concreto armado onde se consideram a barra de aço, com suas nervuras, e o contato entre o concreto envolvente (através suas superfícies de contato) e a barra a resposta foi considerada satisfatória ao final da análise, mesmo o modelo mostrando-se bastante rígido;

- As mudanças bruscas de direção da normal ao elemento da superfície escrava tornam o problema mais rígido e de difícil convergência; foram feitas algumas tentativas para suavizar o encontro dos trechos retos com os trechos curvos das nervuras;

- Em alguns trabalhos que tratam da análise numérica de peças de concreto armado, citados no capítulo 3, o modelo usado para a barra de aço é representado por elementos de barra, como o caso do REBAR do Abaqus, apresentando o inconveniente de perder sua característica tridimensional;

- Pode-se afirmar que a simulação feita com o modelo axisimétrico funcionou bem;

- O carregamento aplicado pode ser em incrementos de força ou de deslocamentos; constatou-se que a solução obtida para carga aplicada com incrementos de deslocamento converge mais rápido, com menos iterações;

- A discretização da malha utilizada para o modelo mostrou-se muito boa; foram feitos testes com outras discretizações; não houve mudança de resultados;

- Constatou-se que a malha da superfície de contato do concreto precisava ser bem refinada, sob pena de comprometer a convergência da solução;

- O modelo constitutivo "Concrete Damaged Plasticity" mostrou-se bastante adequado para retratar o funcionamento conjunto entre a barra de aço e o concreto; o autor não encontrou nenhum trabalho onde essa estratégia de modelagem tenha sido utilizada;

- Ficou evidente o aumento crescente do deslocamento em função da aplicação dos ciclos de carga, com conseqüente perda de rigidez;

- Em pontos sobre a superfície de contato ficou bastante evidente o dano localizado; os valores próximos à unidade encontrados para a variável $\mathbf{d}$ de dano indicam a degradação total do ponto;

- Nos dados fornecidos ao programa para indicar a resposta do concreto a compressão e a tração, com os respectivos valores do dano, o valor máximo 
atribuído ao dano na compressão tem que ser menor que a unidade (90\% já indica degradação total), sob pena de comprometer a convergência da solução;

- Foram aplicados apenas dois ciclos de carga para evitar dificuldades de convergência; o autor não realizou muitas tentativas para resolver esse problema e, por conseguinte, poder aplicar um número n qualquer de ciclos;

- Constatou-se no segundo ciclo a mudança de inclinação da curva tensão de aderência $\mathrm{x}$ deslizamento indicando perda de rigidez já depois de aplicado o $1^{\circ}$ ciclo.

\subsection{VIGAS DE CONCRETO ARMADO}

No decorrer desta pesquisa foram realizados ensaios experimentais e análises numéricas em vigas de dimensões reduzidas; algumas vigas possuem seção transversal retangular e outras vigas seção transversal do tipo chamado "T"; todas as vigas possuem a mesma altura total.

Nos ensaios experimentais algumas vigas foram levadas à ruptura e outras foram submetidas a ciclos de carga em nível de serviço.

$\mathrm{Na}$ análise numérica o enfoque foi considerar cada parte (barra de aço e concreto) como um corpo tridimensional onde pôde ser levado em conta o desenho das nervuras da barra de aço, o concreto envolvente e o contato aço-concreto através superfícies específicas.

\subsubsection{Análise experimental}

As principais características dos ensaios estão abaixo listadas:

- Quantidade de vigas ensaiadas: 15 (quinze);

- Quantidade de vigas por tipo de seção: 10 (dez) vigas de seção retangular e 05 (cinco) tipo "T";

- Quantidade de vigas por tipo de dimensionamento: 10 (dez) vigas subarmadas (linha neutra próxima à fronteira dos domínios 2 e 3) e 05 (cinco) com armadura dupla;

- Comprimento total das vigas: $1060 \mathrm{~mm}$;

- Distância entre apoios: $960 \mathrm{~mm}$;

- Dimensões da seção retangular: 60 mm de largura x 120 mm de altura; 
- Dimensões da seção tipo "T": $60 \mathrm{~mm}$ de largura da alma; $140 \mathrm{~mm}$ de largura da mesa; $120 \mathrm{~mm}$ de altura da alma e $40 \mathrm{~mm}$ de altura da mesa;

- Instrumentação das barras: 3 (três) extensômetros elétricos por barra;

- Instrumentação no concreto: 2 (dois) extensômetros elétricos no centro e na parte superior de cada viga de seção retangular e 3 (três) extensômetros elétricos no centro e na parte superior de cada viga de seção tipo "T";

- Comprimento de ancoragem: $50 \mathrm{~mm}$ para todas as vigas;

- Quantidade de ensaios estáticos: 05 (cinco) vigas; 02 (duas) dessas são do projeto piloto;

- Quantidade de ensaios cíclicos: 10 (dez) vigas; 02 (duas) dessas são do projeto piloto; todas levadas à ruptura após o último ciclo;

\subsubsection{Vigas sub-armadas}

As Tabela 5.4 e Tabela 5.5 apresentam uma síntese dos dados adicionais necessários à realização dos ensaios estáticos e cíclicos; apresentam também alguns resultados colhidos desses ensaios. $\mathbf{P}_{\mathbf{u}, \text { est }}$ é a carga de ruptura estimada para o ensaio

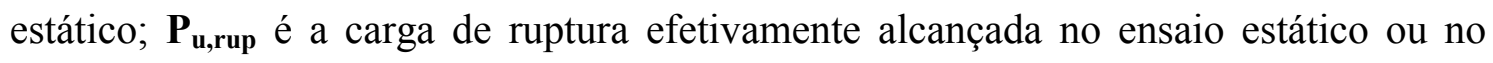
ensaio cíclico; $\mathbf{P}_{\max }$ e $\mathbf{P}_{\min }$ são, respectivamente, os valores máximo e mínimo da amplitude da carga no ensaio cíclico; a flecha máxima e mínima indicadas nas tabelas referem-se aos valores máximo e mínimo da flecha no ensaio cíclico.

Tabela 5.4 - Dados e resultados dos ensaios com vigas sub-armadas

\begin{tabular}{|c|c|c|c|c|c|c|c|}
\hline vigas & $\begin{array}{c}P_{\text {u,rup }} \\
(\mathbf{k N})\end{array}$ & $\begin{array}{l}P_{u, \text { est }} \\
(\mathbf{k N})\end{array}$ & $\begin{array}{c}\mathbf{P}_{\mathbf{u}, \text { rup. }} / \\
\mathbf{P}_{\mathbf{u}, \text { est. }} \\
\text { (\%) }\end{array}$ & $\begin{array}{l}P_{\max } \\
(\mathbf{k N})\end{array}$ & $\begin{array}{l}P_{\min } \\
(\mathbf{k N})\end{array}$ & $\begin{array}{c}\mathbf{P}_{\max } / \\
\mathbf{P}_{\mathrm{u}, \mathrm{est}} \\
(\%)\end{array}$ & $\begin{array}{c}\mathbf{P}_{\min } / \\
\mathbf{P}_{\mathrm{u}, \text { est }} \\
(\%)\end{array}$ \\
\hline VP-NA-01* & 21,9 & 21,0 & 4,3 & - & - & - & - \\
\hline VP-NA-02 & 23,5 & 21,0 & 11,9 & 14,0 & 2,0 & 65,0 & 10,0 \\
\hline VR-NA-T & 22,5 & 21,0 & 7,1 & 18,0 & 8,0 & 85,0 & 40,0 \\
\hline VR-NA-01 & 22,0 & 21,0 & 4,8 & 18,0 & 8,0 & 85,0 & 40,0 \\
\hline VR-NA-02 & 25,0 & 21,0 & 19,0 & 20,0 & 8,0 & 95,0 & 40,0 \\
\hline
\end{tabular}


Tabela 5.5 - Continuação dos dados e resultados com vigas sub-armadas

\begin{tabular}{|c|c|c|c|c|c|}
\hline vigas & $\begin{array}{c}\text { Freq. } \\
\text { excit } \\
\mathbf{( H z )}\end{array}$ & $\begin{array}{c}\text { Flecha } \\
\text { max. } \\
\mathbf{( m m )}\end{array}$ & $\begin{array}{c}\text { Flecha } \\
\text { min. } \\
\mathbf{( m m )}\end{array}$ & $\begin{array}{c}\text { flecha max./ } \\
\text { flecha min. } \\
\mathbf{( \% )}\end{array}$ & $\begin{array}{c}\mathbf{N}^{\mathbf{0}} \text { de } \\
\text { ciclos }\end{array}$ \\
\hline VP-NA-01* & - & 5,33 & - & - & - \\
\hline VP-NA-02 & 0,5 & 3,14 & 1,17 & 168,4 & 50 \\
\hline VR-NA-T & 0,5 & 4,16 & 2,85 & 46,0 & 2.300 \\
\hline VR-NA-01 & 1,0 & 4,19 & 2,75 & 52,4 & 25.000 \\
\hline VR-NA-02 & 1,5 & 4,58 & 3,30 & 38,8 & 15.000 \\
\hline
\end{tabular}

* Ensaio estático à ruptura.

É possível observar da Tabela 5.4 e da Tabela 5.5 que as vigas VR-NA-T e VR-NA-01 tiveram comportamento semelhante seja no tocante a carga última de ruptura seja na variação de amplitude da flecha; nota-se, no entanto, que o número de ciclos da segunda viga é bem maior (25.000 contra 2.300) o que leva a crer que os primeiros ciclos são os que causam maiores perdas de rigidez e conseqüente dano à estrutura; leva a crer, também, que o aumento da flecha tende a se estabilizar a partir de certo número de ciclos. Parece que o aumento da freqüência em $50 \%$ não alterou significativamente os resultados, o que leva a crer, também, ser de menor importância pelo menos para baixas freqüências.

Para a viga VR-NA-02 o limite superior de amplitude, a carga última de ruptura e a freqüência aumentaram em relação às duas vigas anteriores; o valor da flecha máxima aumentou aproximadamente 10\%; nota-se, porém, que a flecha tende a se estabilizar nos primeiros ciclos (10.000), segundo pode ser constatado pela Figura 5.21 . 


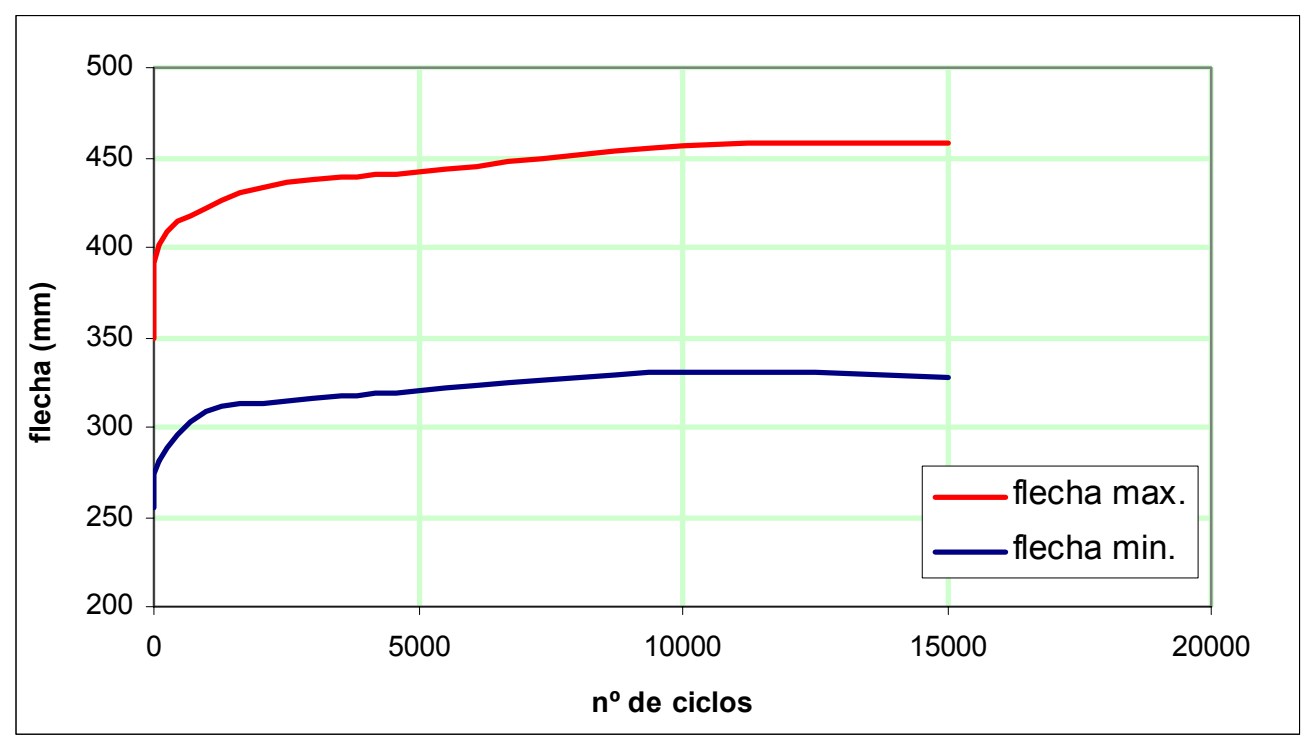

Figura 5.21 - Variação da flecha com o $\mathrm{n}^{0}$ de ciclos para a viga VR-NA-02

A Figura 5.22 mostra a deformação da barra de flexão na viga VR-NA-02, medidas em dois pontos diferentes, correspondente ao primeiro ciclo de carga. As medições foram obtidas com extensômetros colocados, respectivamente, na seção transversal do meio do vão e na seção correspondente à aplicação da carga.

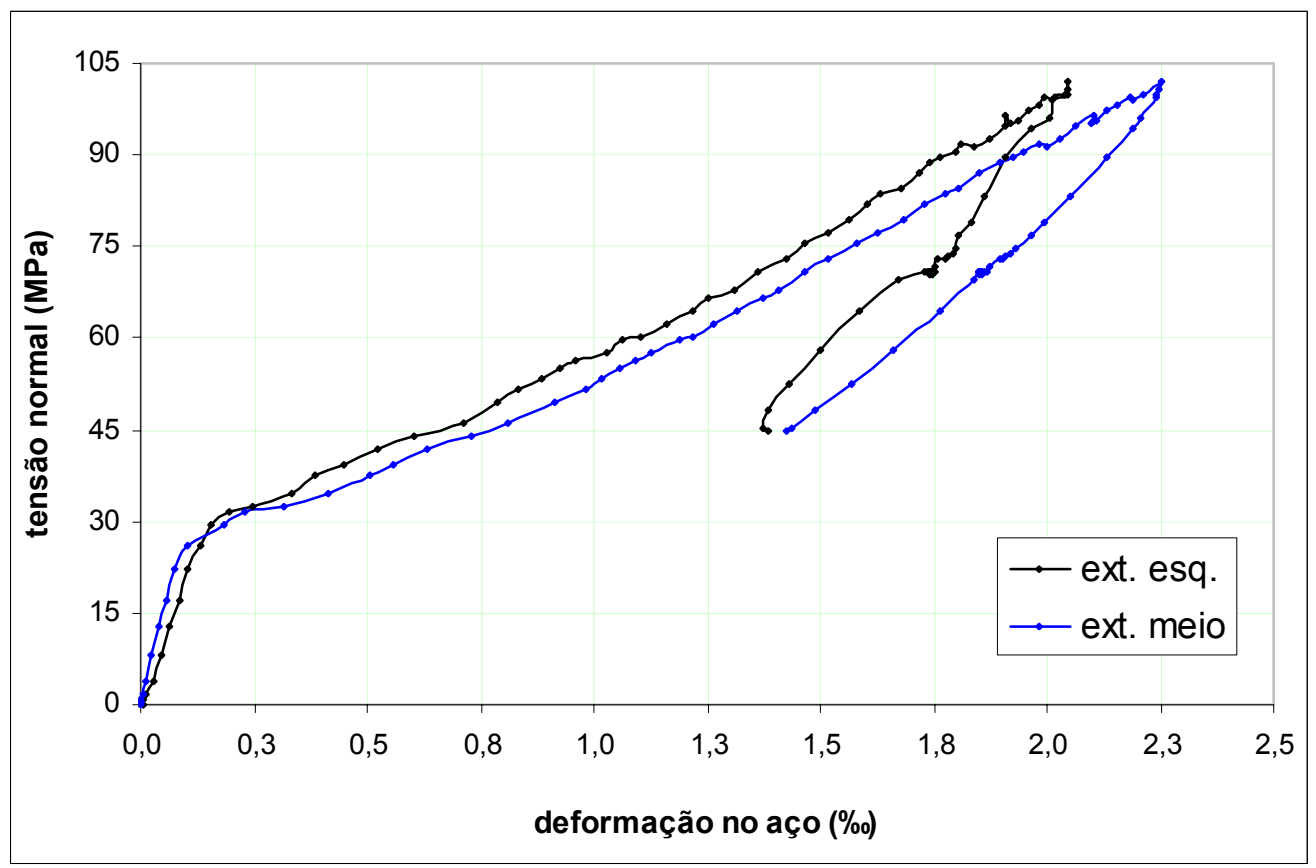

Figura 5.22 - Tensão x deformação para a barra de 6.3 no $1^{\circ}$ ciclo

A Figura 5.23 mostra que o aço não entrou em escoamento durante a aplicação dos ciclos de carga na viga VR-NA-02. A deformação referente à tensão de escoamento 
para a barra de diâmetro $6.3 \mathrm{~mm}$ (aço CA-50) é de aproximadamente 2,9 \%o, conforme Tabela 5.1; deformação limite, no ensaio, foi menor, com valor aproximado de 2,75 \%o.

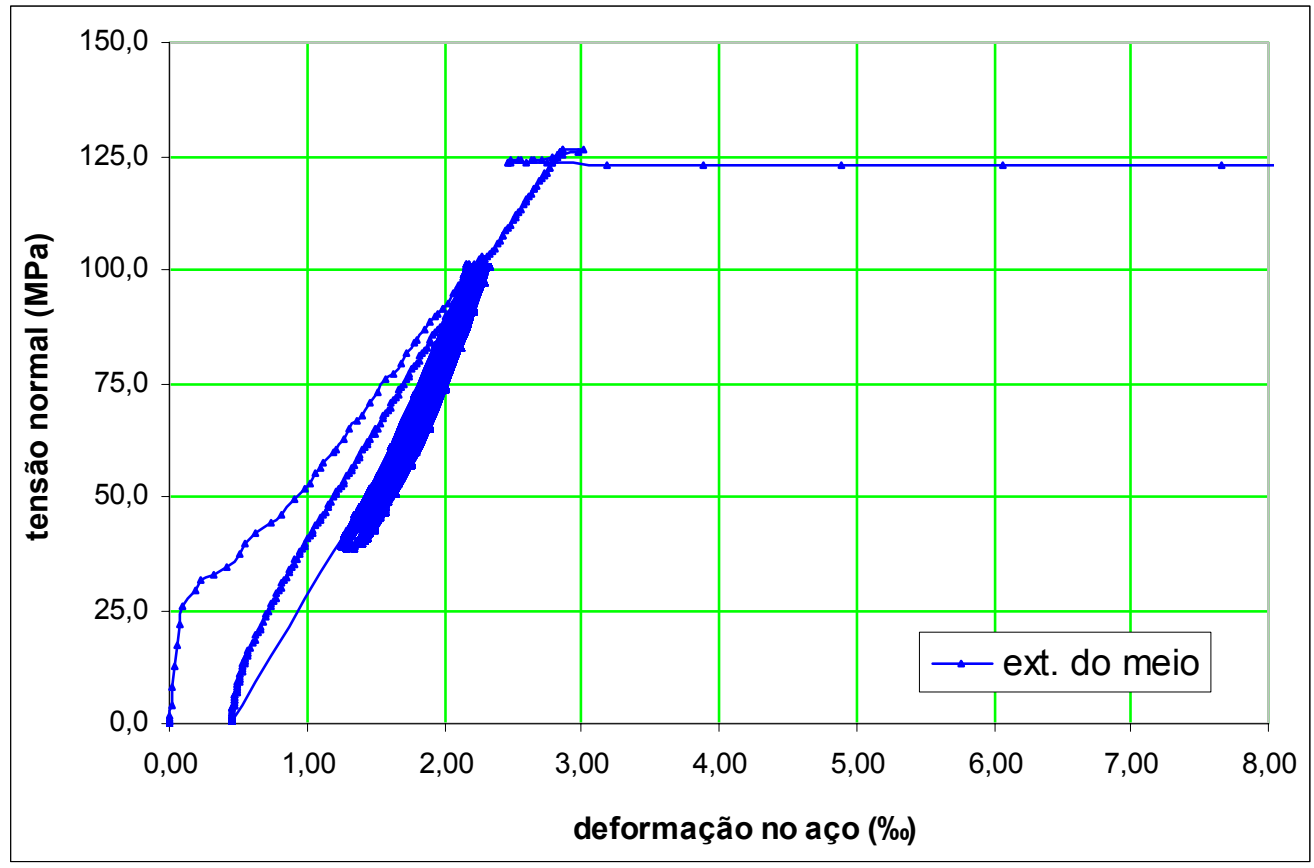

Figura 5.23 - Tensão x deformação para a barra de 6.3 no meio do vão

A Figura 5.24 mostra a deformação da barra de flexão e do concreto na face superior da viga VR-NA-02 correspondente aos 15.000 ciclos aplicados.

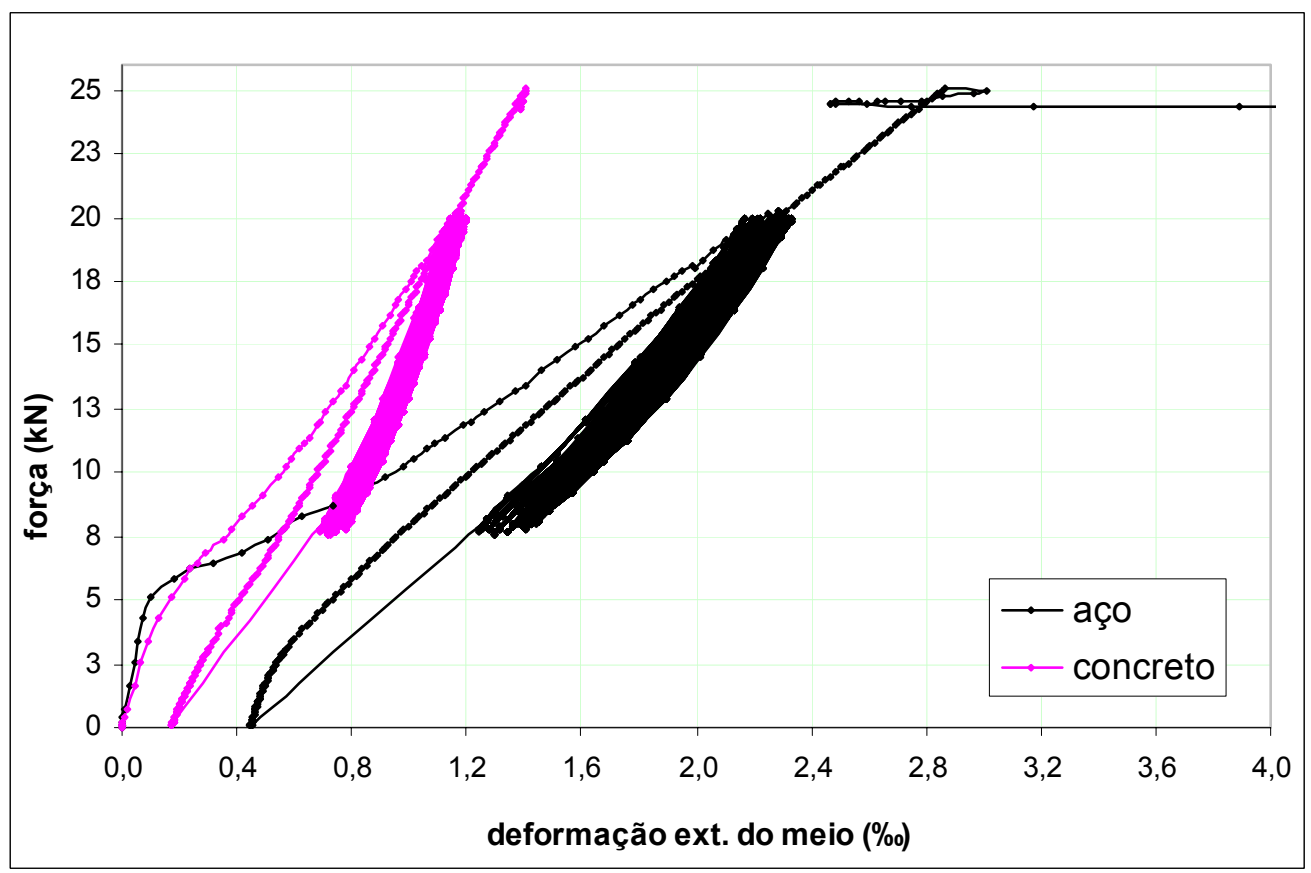

Figura 5.24 - Deformação para a aço e o concreto 
A Figura 5.25 mostra a deformação da barra e do concreto comprimido na seção do meio do vão da viga VR-NA-02, em função do momento fletor aplicado, correspondente ao primeiro ciclo de carga. É possível obter o valor do momento de fissuração, igual aproximadamente a $70,0 \mathrm{kN} . \mathrm{cm}$ e correspondente a uma carga de 4,4 kN. Esses resultados, confrontados com a expressão da NBR 6118:2003 que fornece o momento de fissuração $\left(\mathrm{M}_{\mathrm{r}}\right)$, igual a $69,12 \mathrm{kN}$.cm e correspondente a uma carga de $4,32 \mathrm{kN}$, se mostraram excelentes.

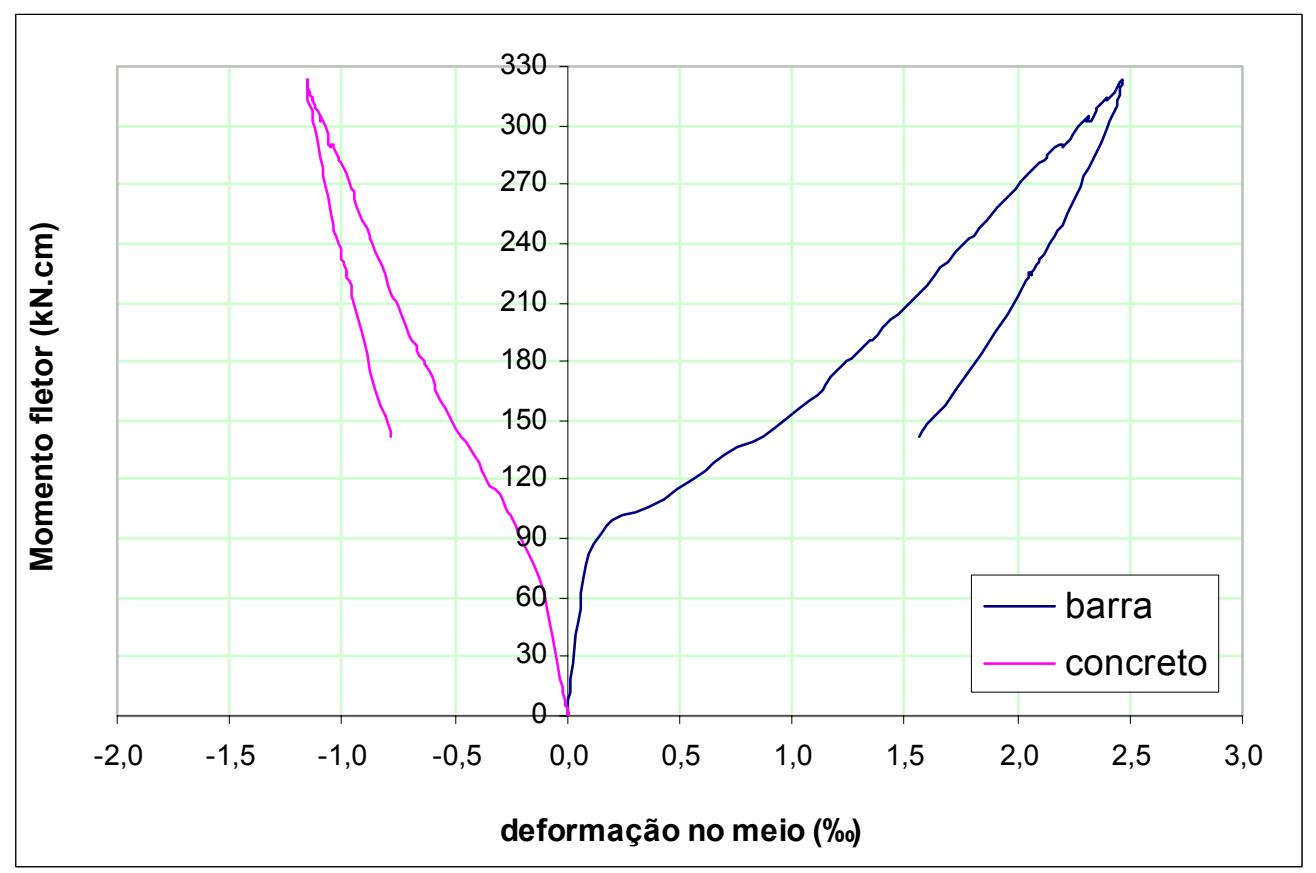

Figura 5.25 - Deformação da barra e do concreto no primeiro ciclo

A Figura 5.26 mostra, agora, a deformação da barra e do concreto comprimido na seção do meio do vão da viga VR-NA-02, em função do momento fletor aplicado, correspondente ao último ciclo de carga e depois levada à ruptura. 


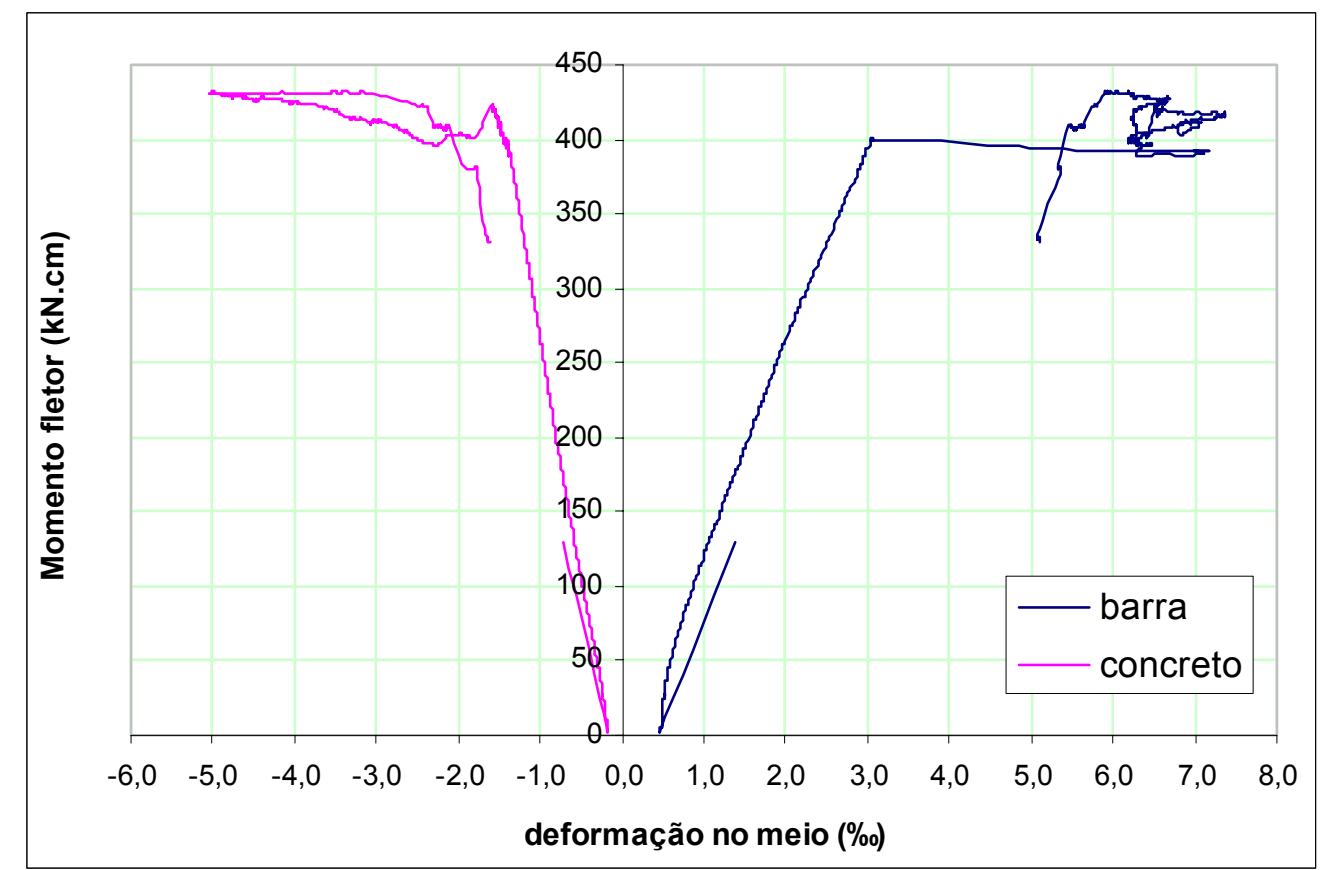

Figura 5.26 - Deformação da barra e do concreto no último ciclo

É possível notar, examinando a Figura 5.26, a deformação plástica acumulada para o concreto, ao fim dos 15.000 ciclos aplicados. A deformação plástica acumulada do concreto denota a danificação localizada ocorrida na seção do meio da viga; Observa-se, também, que a deformação da fibra mais comprimida do concreto atinge 5,0 \% na ruptura. Verifica-se deformação plástica acumulada do aço, mesmo sem ter sido atingida a tensão de escoamento durante os ciclos aplicados.

A análise numérica realizada no Abaqus com os modelos de viga sub-armada produziu apenas resultados parciais, haja vista as dificuldades encontradas para a convergência da solução. A Figura 5.27 retrata o caso em que foi aplicada uma carga da ordem de $10 \%$ da carga total, aplicada em incrementos de carga, em que o modelo convergiu depois de inúmeras iterações (devido a descontinuidades ocasionadas pelo contato e outras tantas para estabelecer o equilíbrio). Observar o baixo valor do deslocamento final. 


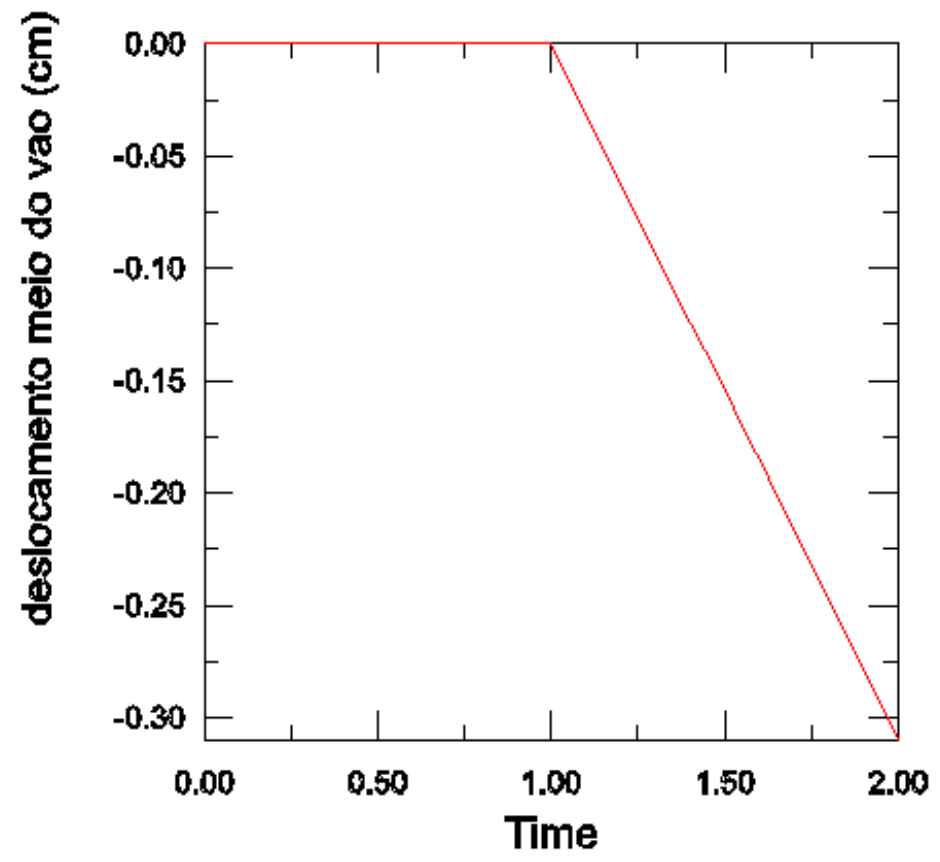

Figura 5.27 - Deslocamento máximo para uma viga sub-armada, pelo Abaqus

A Figura 5.28, no entanto, mostra o aspecto da flecha no meio do vão de um nó da superfície escrava (de concreto) posicionado no meio do vão. Observar que essas medidas foram tomadas apenas para um pouco mais de $20 \%$ da carga total aplicada, antes de ocorrer travamento da solução.

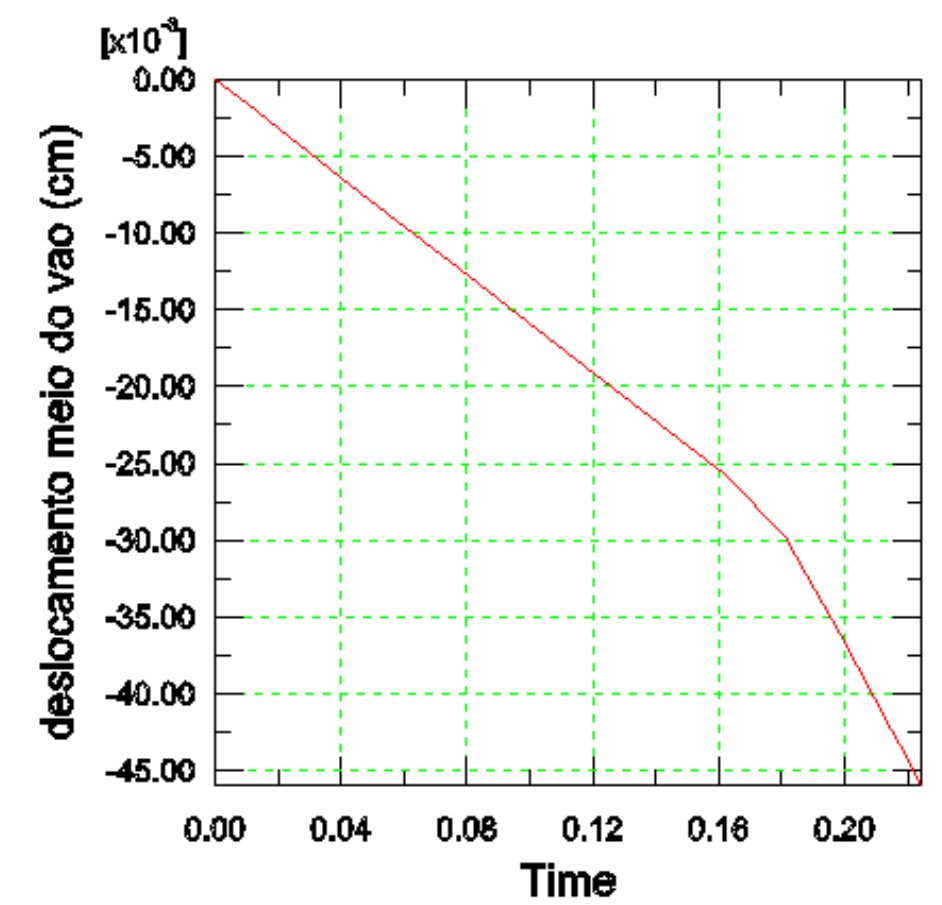

Figura 5.28 - Deslocamento no meio do vão da viga 
O mesmo ocorre com o valor do dano medido num nó da superfície escrava (de concreto) posicionado no meio do vão, antes de ocorrer travamento da solução. A Figura 5.29 esclarece melhor.

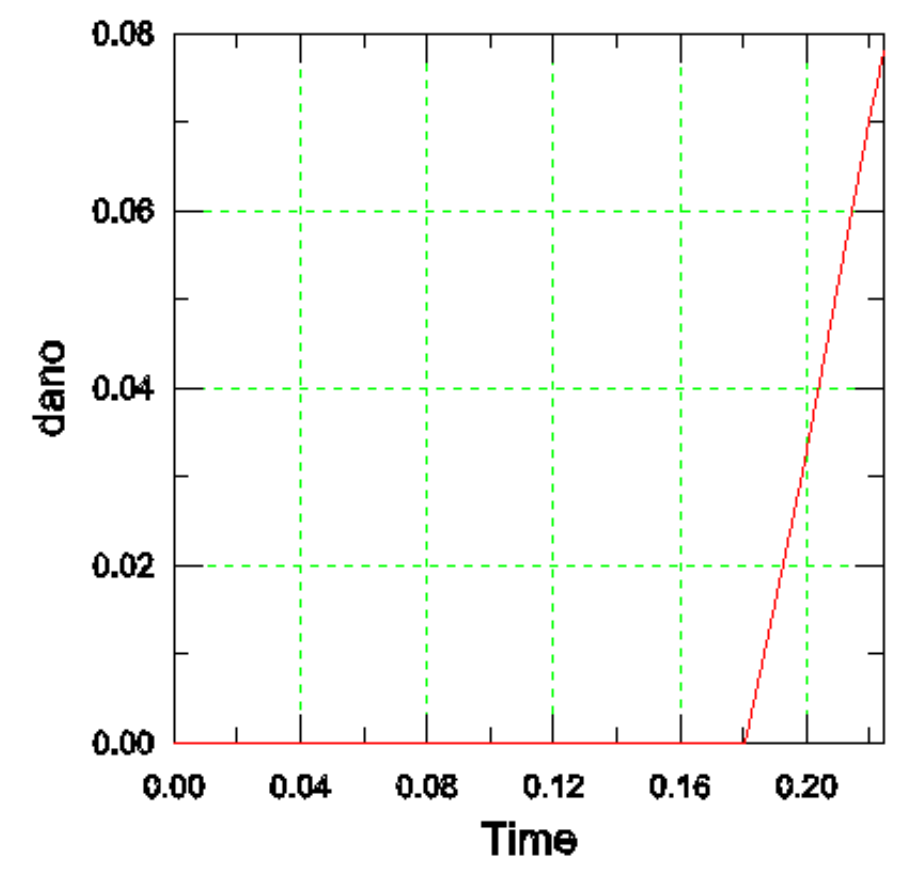

Figura 5.29 - Medida do dano num nó no meio do vão da viga sub-armada

No tocante à análise numérica, foram utilizados também os programas em linguagem FORTRAN desenvolvidos/adaptados por ARAÚJO (2003) e ALVA (2004). Esses programas foram adaptados pelos respectivos autores para atenderem a algumas necessidades da presente tese, destacando-se a possibilidade de solicitar a estrutura com diferentes e sucessivos casos de carregamentos, com ciclos de carga e descarga.

Com o programa adaptado por ARAÚJO (2003) foi possível modelar uma viga sub-armada, como as vigas da Tabela 5.4 e da Tabela 5.5, sendo fornecidos os dados de entrada requeridos pela formulação do programa (modelo de dano La Borderie ou de Mazars). A Figura 5.30 mostra a relação força $\mathrm{x}$ deslocamento para o carregamento aplicado em força e em deslocamento, comparados com o ensaio experimental da viga VR-NA-02. Observa-se o ótimo comportamento do modelo implementado por ARAUJO especialmente por representar muito bem o início da primeira fissura. 


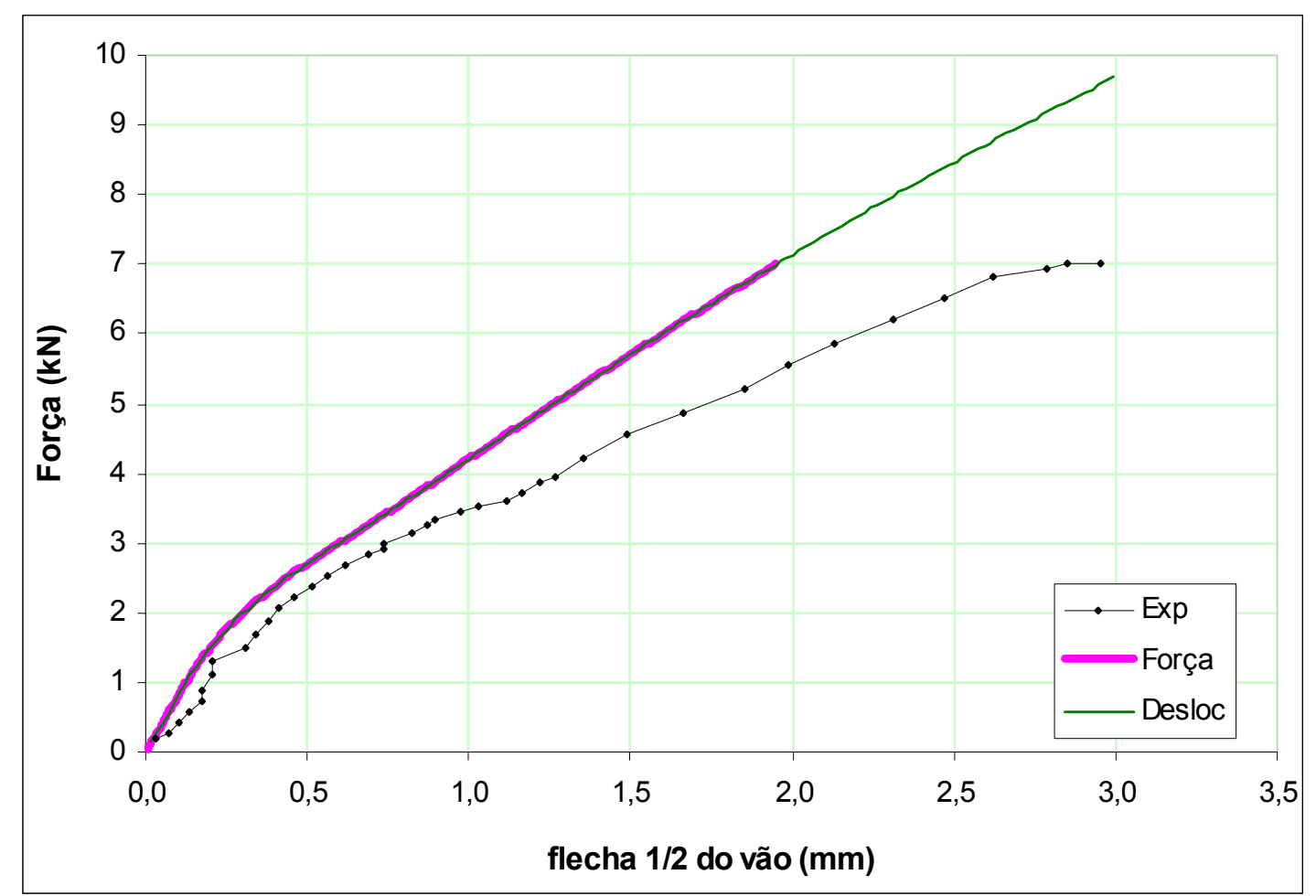

Figura 5.30 - Modelo de Mazars $x$ viga VR-NA-02

O programa fornece um panorama da danificação global da viga, como mostra a Figura 5.31.

Modelo de Mazars: $\mathrm{F}=10 \mathrm{KN}$

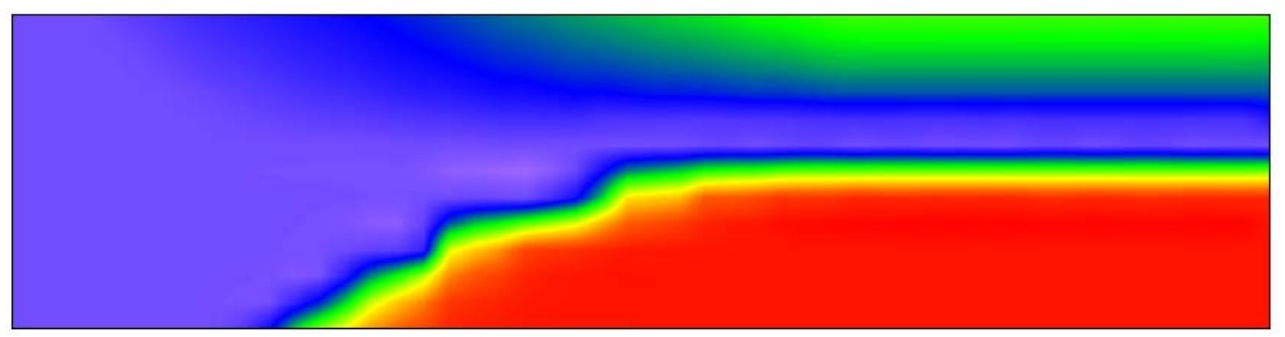

Escala de danificação

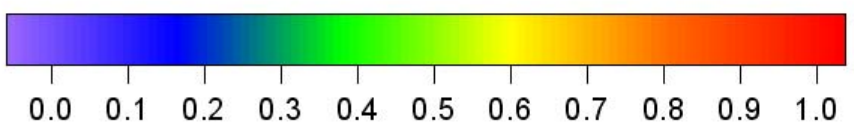

Figura 5.31 - Dano global em $1 / 2$ da viga VR-NA-02 - Modelo de ARAUJO

O programa desenvolvido por ALVA (2004) utiliza o modelo de dano de PICON \& FLOREZ-LOPEZ. Na realidade, esse modelo foi proposto para ações cíclicas de maior intensidade, ou seja, para a fadiga de poucos ciclos (low-cycle fatigue). $\mathrm{O}$ modelo leva em conta o acréscimo de dano em função do aumento do número de ciclos 
através de um parâmetro z. Para z tendendo ao infinito, o acréscimo de dano por fadiga (por ciclos) é nulo. De fato, para valores de z maiores que 30, o acréscimo de dano por fadiga é praticamente desprezível e isso acontece nos primeiros estágios de carregamento, onde a degradação do elemento é nula. Para $z=30$, o valor do dano é igual a 0 . Para $z=0$, o acréscimo de dano por fadiga é máximo. Na prática, isso acontece quando os elementos estão próximos ou já chegaram na ruína. Em outras palavras, cada ciclo a mais de carregamento tem como conseqüência uma perda muito grande de rigidez e de resistência. Para z=0, o valor do dano é igual a 1,0.

No caso do presente trabalho as cargas cíclicas aplicadas são de intensidade moderada. A variação do aumento da flecha, em termos comparativos, é maior nos primeiros ciclos (1 a 1000 ciclos, por exemplo). Após 15000 ciclos, existe uma tendência de estabilização da flecha da viga. Isso mostra que o acréscimo de dano por fadiga é maior nos primeiros ciclos, tendendo a diminuir com o número de ciclos. Ou seja, os valores de z são menores nos primeiros ciclos e maiores após milhares de ciclos.

Como as armaduras longitudinais da viga não atingiram o escoamento durante o ensaio cíclico, portanto com as deformações menores que a de escoamento, pode-se desprezar a plasticidade e utilizar apenas a função de dano, sem calcular rotações plásticas. Caso as deformações tivessem superado o escoamento, então deveria ser utilizada a função limite de plastificação, calculando as rotações plásticas na viga.

Nas simulações numéricas realizadas com o programa de ALVA não foram, então, considerados o efeito das deformações plásticas residuais, trabalhando apenas com o modelo de dano não-linear elástico. A Figura 5.32 mostra os resultados típicos obtidos pelo programa de Alva. Observa-se da figura a inclinação crescente da curva indicando a perda progressiva de rigidez. O inconveniente do modelo é não retratar o laço feito dentro de um ciclo de carga e descarga. 


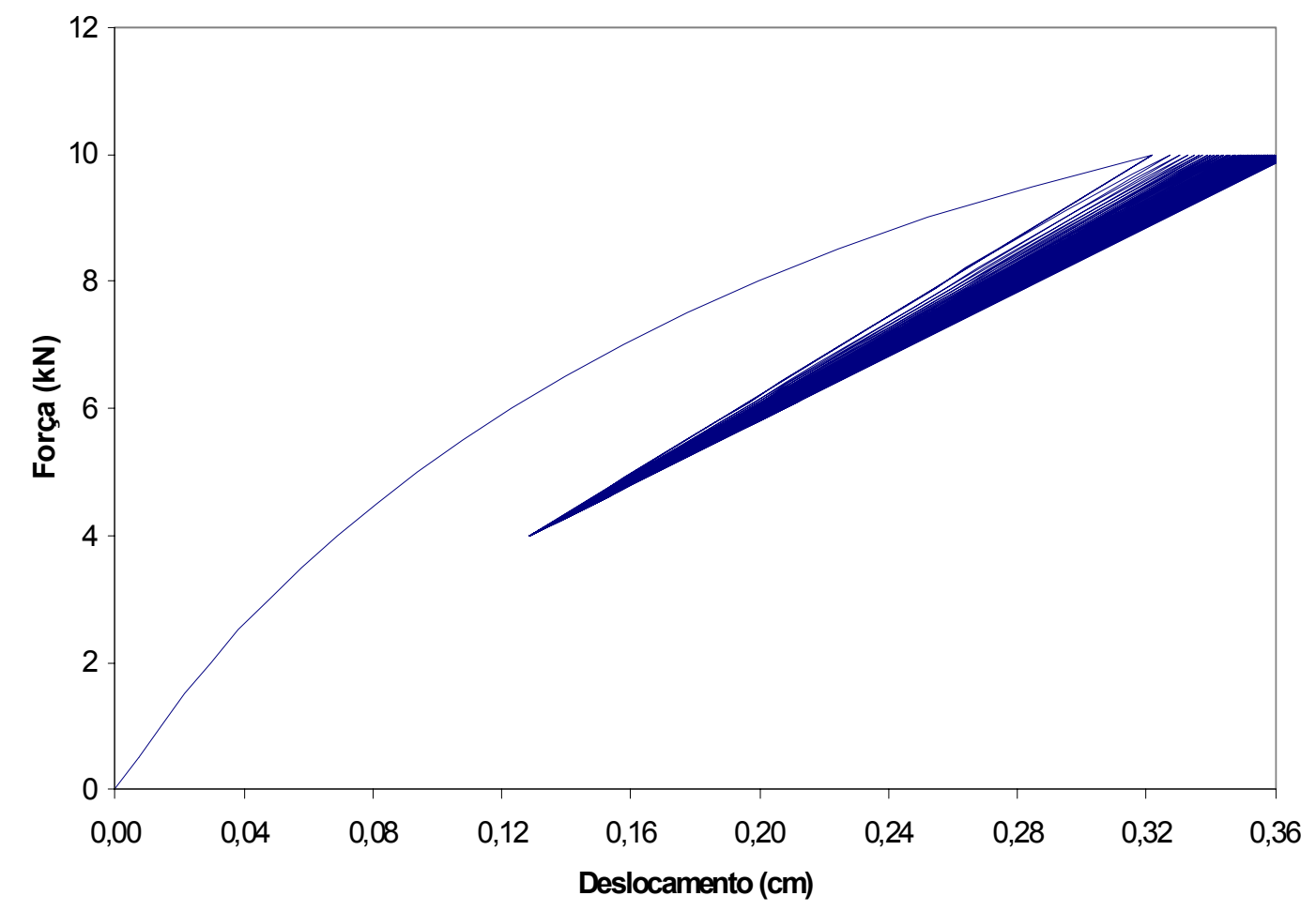

Figura 5.32 - Modelo de PICON \& FLOREZ-LOPEZ

Os acréscimos dos deslocamentos máximos na viga são mostrados na Figura 5.33 e comparados com a viga VR-NA-02 (experimental).

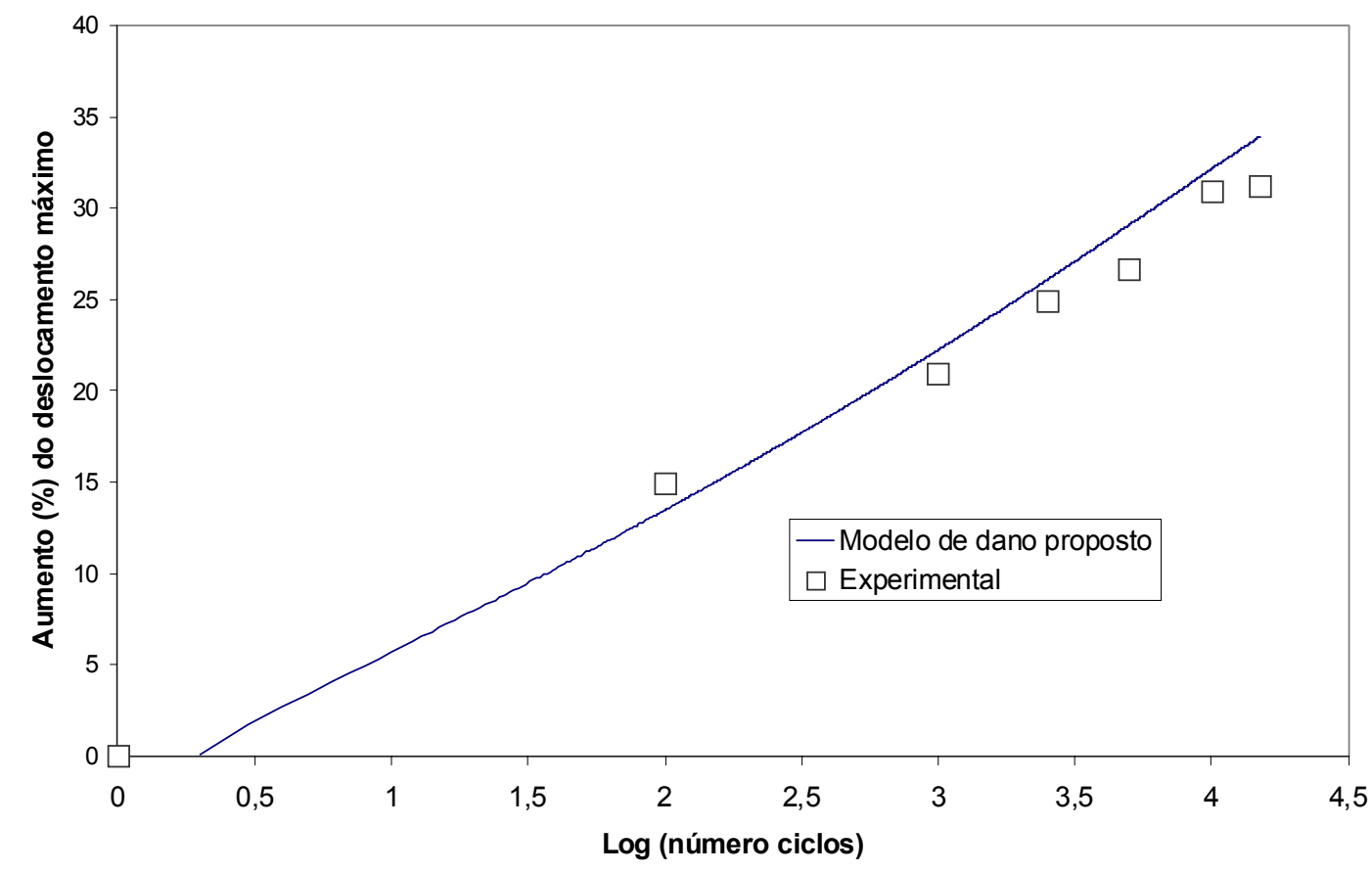

Figura 5.33 - Aumento do deslocamento - Modelo de ALVA x viga VR-NA-02 
A Tabela 5.6 apresenta um resumo dos deslocamentos máximos na viga ao longo dos ciclos de carregamento.

Tabela 5.6 - Deslocamentos máximos modelo ALVA e VR-NA-02

\begin{tabular}{|c|c|c|c|c|}
\hline Ciclo & $\begin{array}{c}\text { Modelo } \\
(\mathbf{m m})\end{array}$ & $\begin{array}{c}\text { Aumento } \\
\mathbf{( \% )}\end{array}$ & $\begin{array}{c}\text { Experimental } \\
(\mathbf{m m})\end{array}$ & $\begin{array}{c}\text { Aumento } \\
\mathbf{( \% )}\end{array}$ \\
\hline 1 & 3,2181 & - & 3,49 & - \\
\hline 100 & 3,6512 & 13,46 & 4,01 & 14,90 \\
\hline 1000 & 3,9933 & 24,09 & 4,22 & 20,92 \\
\hline 2500 & 4,0567 & 26,06 & 4,36 & 24,93 \\
\hline 5000 & 4,1537 & 29,07 & 4,42 & 26,65 \\
\hline 10000 & 4,2522 & 32,13 & 4,57 & 30,95 \\
\hline 15000 & 4,3093 & 33,91 & 4,58 & 31,23 \\
\hline
\end{tabular}

A Figura 5.34 retrata em forma de gráfico o conteúdo da Tabela 5.6.

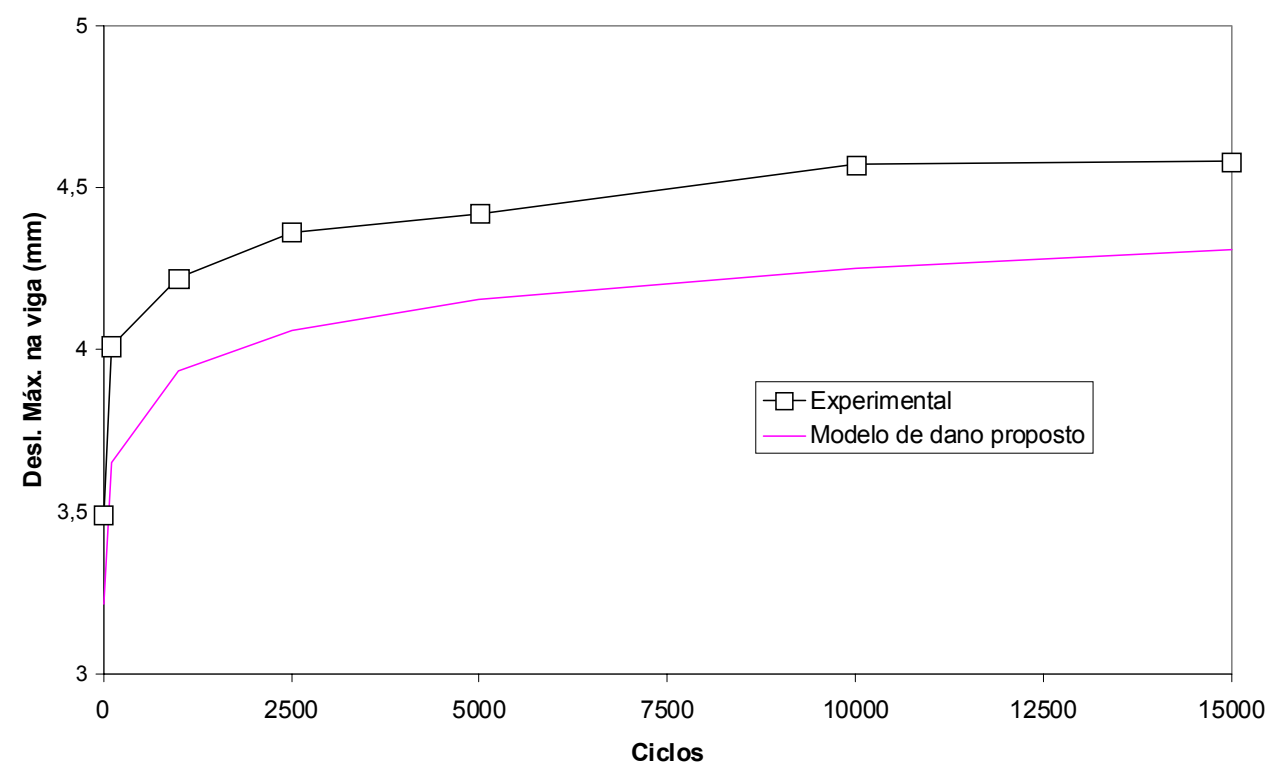

Figura 5.34 - Deslocamento máximo - Modelo de ALVA x viga VR-NA-02

Uma avaliação aproximada da flecha imediata em vigas de concreto armado é dada pela expressão da rigidez equivalente, desenvolvida por BRANSON, encontrada no item 17.3.2.1.1 da NBR 6118:2003. A Figura 5.35 mostra um gráfico comparativo com as curvas experimental (viga VR-NA-02), curva do modelo adaptado por ARAUJO (MAZARS), curva adaptada por ALVA (PICON \& FLOREZ-LOPEZ) e a de BRANSON. 


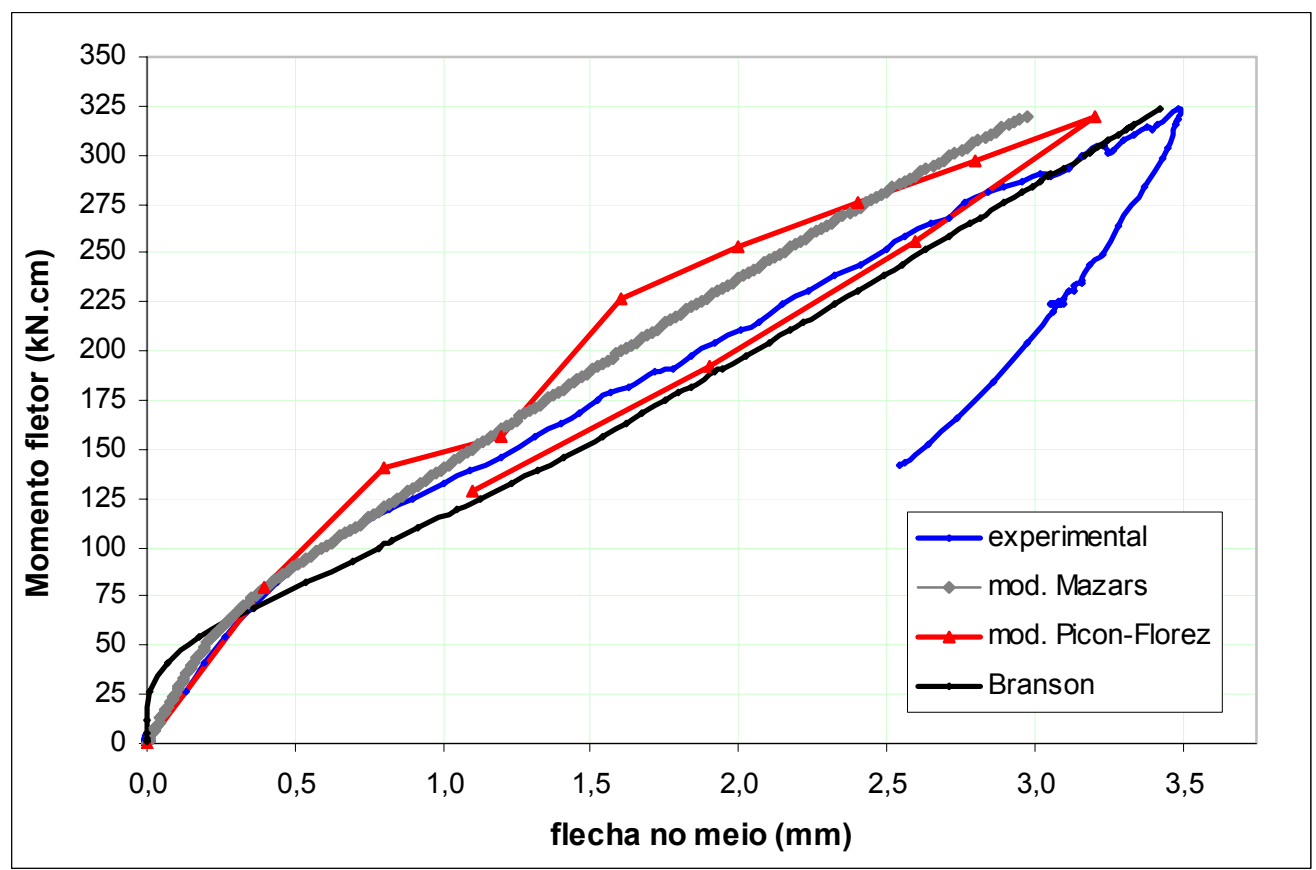

Figura 5.35 - Curvas comparativas para diversos modelos

\subsubsection{Vigas com armadura dupla}

As Tabela 5.4 e Tabela 5.5 apresentam uma síntese dos dados adicionais necessários à realização dos ensaios estáticos e cíclicos para as vigas dimensionadas com armadura dupla; apresentam também alguns resultados colhidos desses ensaios. $\mathbf{P}_{\mathbf{u}, \text { est }}$ é a carga de ruptura estimada para o ensaio estático; $\mathbf{P}_{\mathbf{u}, \text { rup }}$ é a carga de ruptura efetivamente alcançada no ensaio estático ou no ensaio cíclico; $\mathbf{P}_{\max }$ e $\mathbf{P}_{\min }$ são, respectivamente, os valores máximo e mínimo da amplitude da carga no ensaio cíclico; a flecha máxima e mínima indicadas nas tabelas referem-se aos valores máximo e mínimo da flecha no ensaio cíclico.

Tabela 5.7 - Dados e resultados dos ensaios para vigas com armadura dupla

\begin{tabular}{|c|c|c|c|c|c|c|c|}
\hline vigas & $\begin{array}{c}\mathbf{P}_{\mathbf{u}, \text { rup }} \\
\mathbf{( k N )}\end{array}$ & $\begin{array}{c}\mathbf{P}_{\mathbf{u}, \text { est }} \\
\mathbf{( k N )}\end{array}$ & $\begin{array}{c}\mathbf{P}_{\mathbf{u}, \text { rup. }} / \\
\mathbf{P}_{\mathbf{u}, \text { st. }} \\
\mathbf{( \% )}\end{array}$ & $\begin{array}{c}\mathbf{P}_{\mathbf{m a x}} \\
\mathbf{( k N )}\end{array}$ & $\begin{array}{c}\mathbf{P}_{\min } \\
\mathbf{( k N )}\end{array}$ & $\begin{array}{c}\mathbf{P}_{\max } / \\
\mathbf{P}_{\mathbf{u}, \text { est }} \\
\mathbf{( \% )}\end{array}$ & $\begin{array}{c}\mathbf{P}_{\min } / \\
\mathbf{P}_{\mathbf{u}, \mathbf{e s t}} \\
\mathbf{( \% )}\end{array}$ \\
\hline VP-AD-01* & 54,1 & 52,0 & 4,0 & - & - & - & - \\
\hline VP-AD-02 & $-* * *$ & 52,0 & - & 35,0 & 3,0 & 65,0 & 5,0 \\
\hline VR-AD-T & 55,7 & 52,0 & 7,1 & 45,0 & 20,0 & 85,0 & 40,0 \\
\hline VR-AD-01 & 56,2 & 52,0 & 8,1 & 45,0 & 20,0 & 85,0 & 40,0 \\
\hline VR-AD-02 & 56,6 & 52,0 & 8,8 & 47,0 & 20,0 & 90,0 & 40,0 \\
\hline
\end{tabular}




\section{Tabela 5.8 - Continuação dos dados e resultados para vigas com armadura dupla}

\begin{tabular}{|c|c|c|c|c|c|}
\hline vigas & $\begin{array}{c}\text { Freq. } \\
\text { excit } \\
\text { (Hz) }\end{array}$ & $\begin{array}{c}\text { Flecha } \\
\text { max. } \\
\mathbf{( m m )}\end{array}$ & $\begin{array}{c}\text { Flecha } \\
\text { min. } \\
\mathbf{( m m})\end{array}$ & $\begin{array}{c}\text { flecha max./ } \\
\text { flecha min. } \\
\mathbf{( \% )}\end{array}$ & $\begin{array}{c}\mathbf{N}^{\mathbf{0}} \text { de } \\
\text { ciclos }\end{array}$ \\
\hline VP-AD-01* & - & $8,45^{* *}$ & - & - & - \\
\hline VP-AD-02 & 0,5 & 5,08 & 1,49 & 241,0 & 190 \\
\hline VR-AD-T & 1,5 & 6,31 & 4,49 & 40,5 & 15.000 \\
\hline VR-AD-01 & 2,0 & 5,67 & 3,96 & 43,2 & 30.000 \\
\hline VR-AD-02 & 2,0 & 6,39 & 4,29 & 49,0 & 30.000 \\
\hline
\end{tabular}

* Ensaio estático à ruptura.

** Valor da flecha na ruptura.

*** Após o último ciclo os transdutores foram retirados.

É possível observar da Tabela 5.7 e da Tabela 5.8 que as vigas dimensionadas com armadura dupla apresentaram o mesmo comportamento seja no tocante a carga última (diferença máxima de 4,5 \%) seja na variação de amplitude da flecha (variação máxima de $12,5 \%$ para a flecha máxima e $8 \%$ para a flecha mínima); nota-se, no entanto, que o número de ciclos das duas últimas vigas da Tabela 5.8 é o dobro $(30.000$ contra 15.000) o que nos leva a crer que os primeiros ciclos são os que causam maiores perdas de rigidez e conseqüente dano à estrutura; nos leva a crer, também, que o aumento da flecha tende a se estabilizar a partir de um certo número de ciclos. Parece que o aumento da freqüência de $1,5 \mathrm{~Hz}$ para $2 \mathrm{~Hz}$ não alterou significativamente os resultados, o que leva a crer, também, ser de menor importância pelo menos para baixas freqüências.

A Figura 5.36 mostra o comportamento das 5 (cinco) vigas com armadura dupla. As três primeiras vigas da legenda apresentam comportamento bem semelhante, conforme comentado acima. A viga VP-AD-02, por ter sido ensaiada com amplitude de carregamento bem abaixo das outras (ela serviu de teste no ensaio piloto), apresenta números diferenciados porem comportamento semelhante mostrando uma tendência para os resultados apresentados nas outras três vigas. A VP-AD-01-rup, apenas ensaiada à ruptura, apresenta rigidez idêntica à viga VP-AD-02 e inferior às outras três vigas; explica-se esse fato pela diferença de idade do concreto ensaiado. 


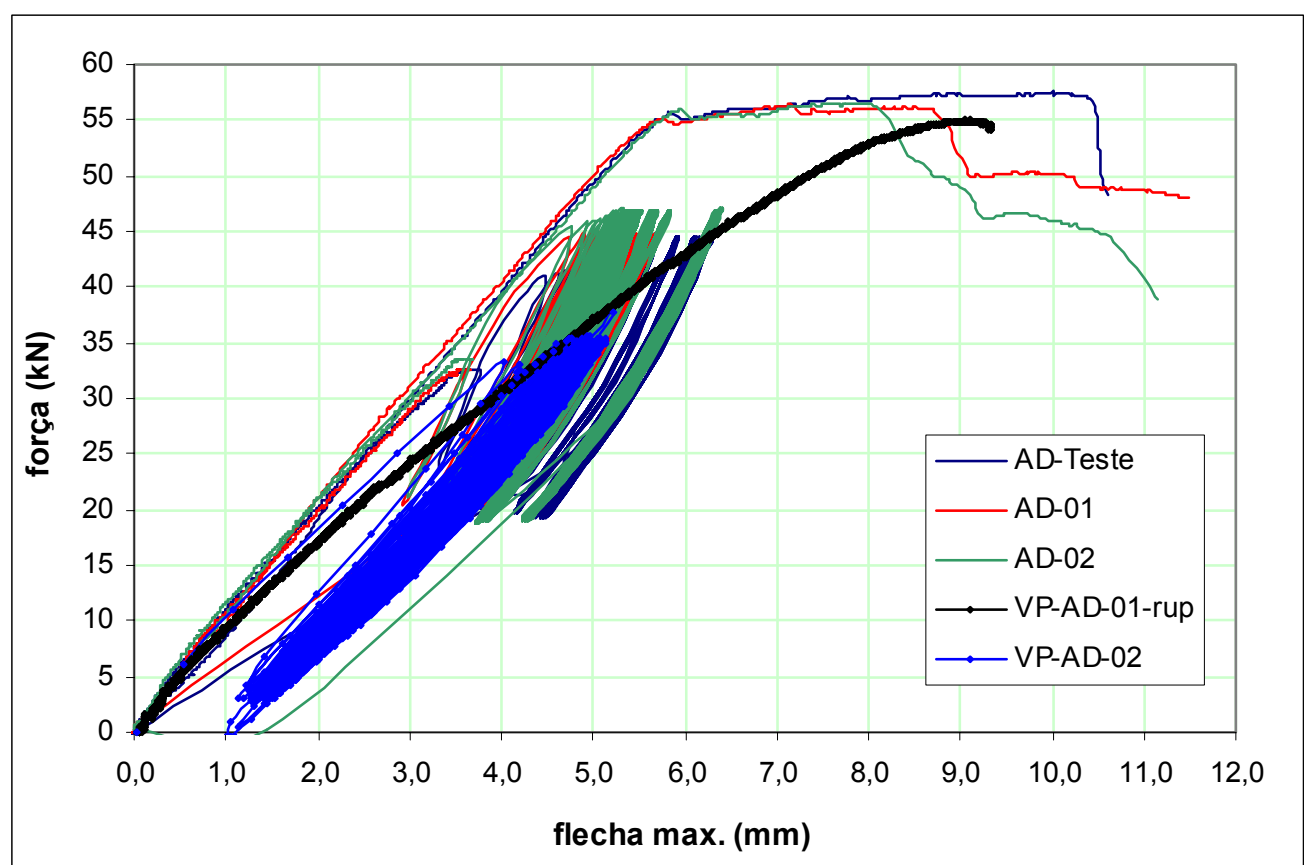

Figura 5.36 - Comparativo do aumento da flecha para as vigas com armadura dupla

A Figura 5.37 mostra um comparativo da deformação da barra e do concreto comprimido na seção do meio do vão das vigas VR-NA-02 e VR-AD-CE-T, em função do momento fletor aplicado, correspondente ao primeiro ciclo de carga e a Figura 5.38 mostra as mesmas vigas correspondentes aos últimos ciclos de cargas.

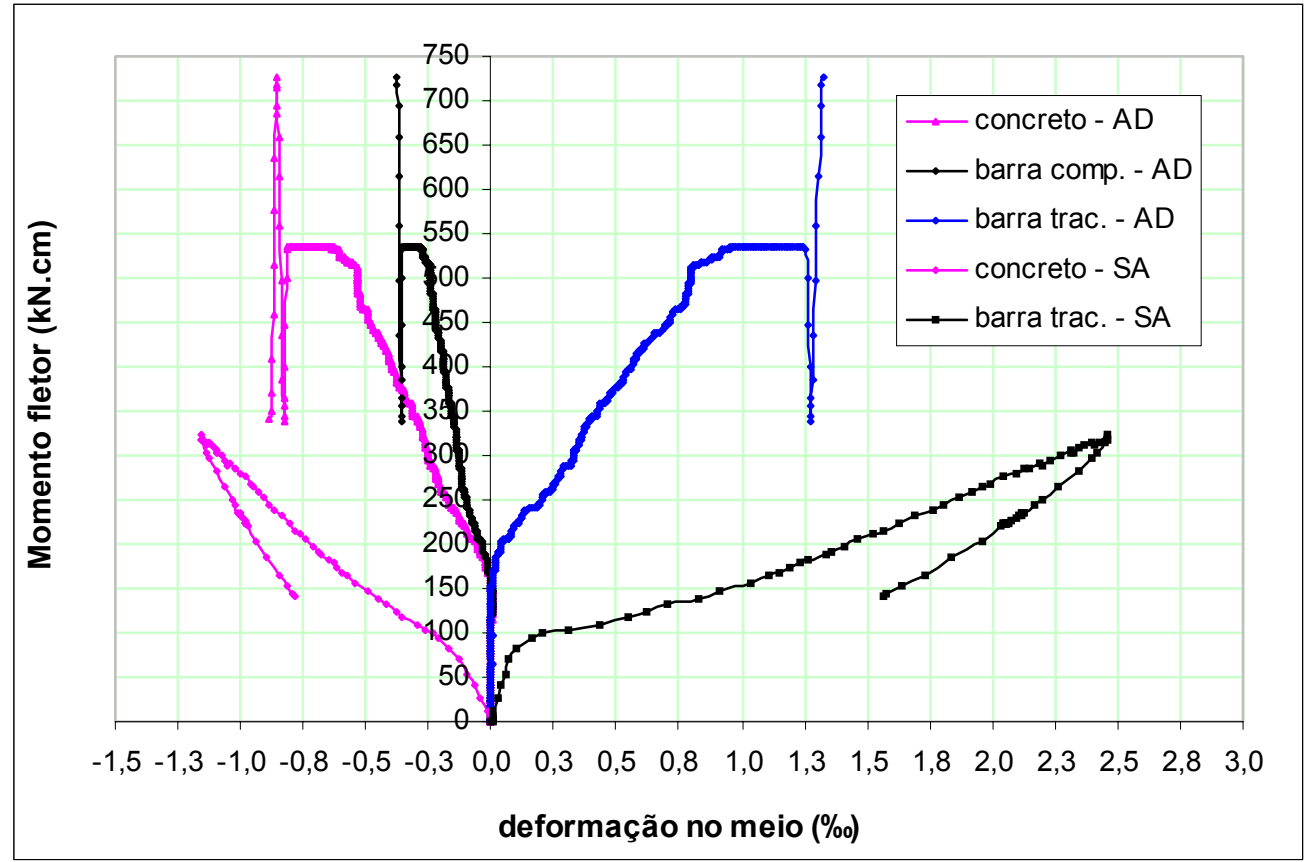

Figura 5.37 - Deformação da barra e do concreto no $1^{\circ}$ ciclo para as vigas SA e AD 


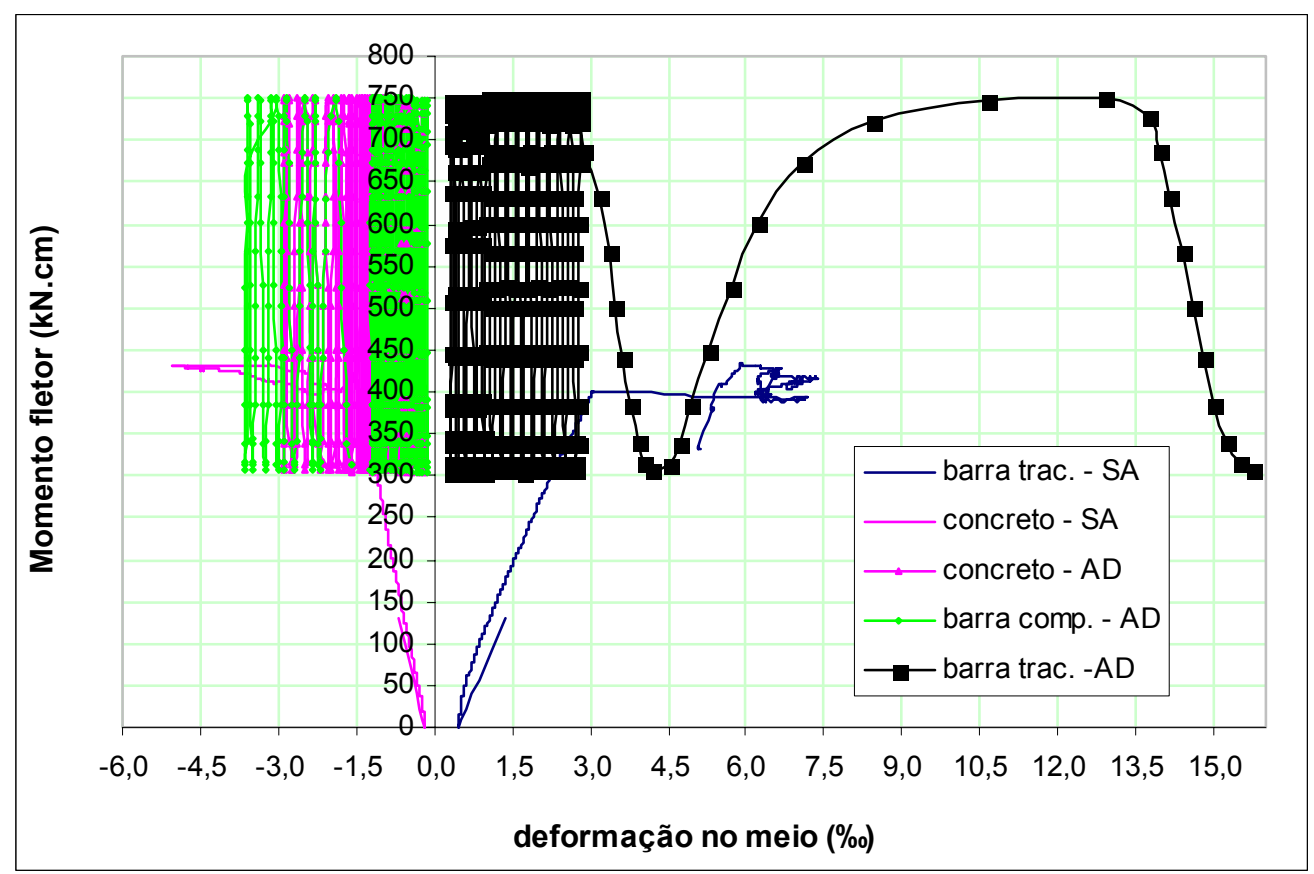

Figura 5.38 - Deformação da barra e do concreto para os últimos ciclos

É possível notar, examinando a Figura 5.38, que a deformação plástica acumulada do concreto atinge os 3,0 \% caracterizando a ruptura por esmagamento do concreto, como esperado. A foto da Figura 5.39 e da Figura 4.28 ilustra melhor.

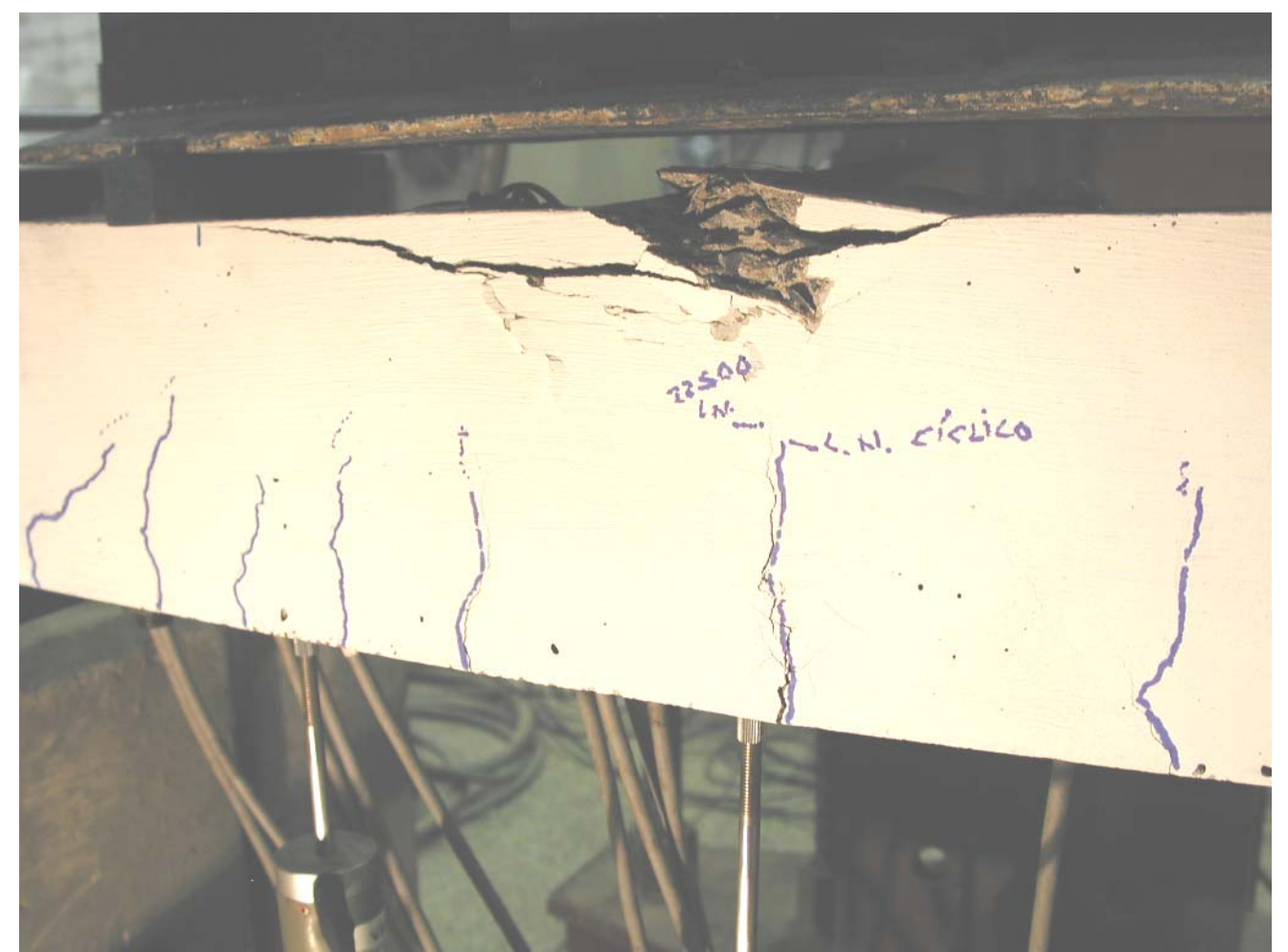

Figura 5.39 - Esmagamento do concreto na viga com armadura dupla 
Observe-se também a deformação plástica acumulada do aço de aproximadamente 3,0 \% mesmo sem atingir a tensão de escoamento durante os ciclos aplicados.

$\mathrm{Na}$ análise numérica para as vigas com armadura dupla foram feitas apenas verificações com o programa adaptado por ARAÚJO (2003). A Figura 5.40 mostra a relação força x deslocamento para o carregamento aplicado em força e deslocamento, comparados com o ensaio experimental da viga VR-AD-02. Observa-se, também no caso de armadura dupla, o ótimo comportamento do modelo implementado por ARAUJO.

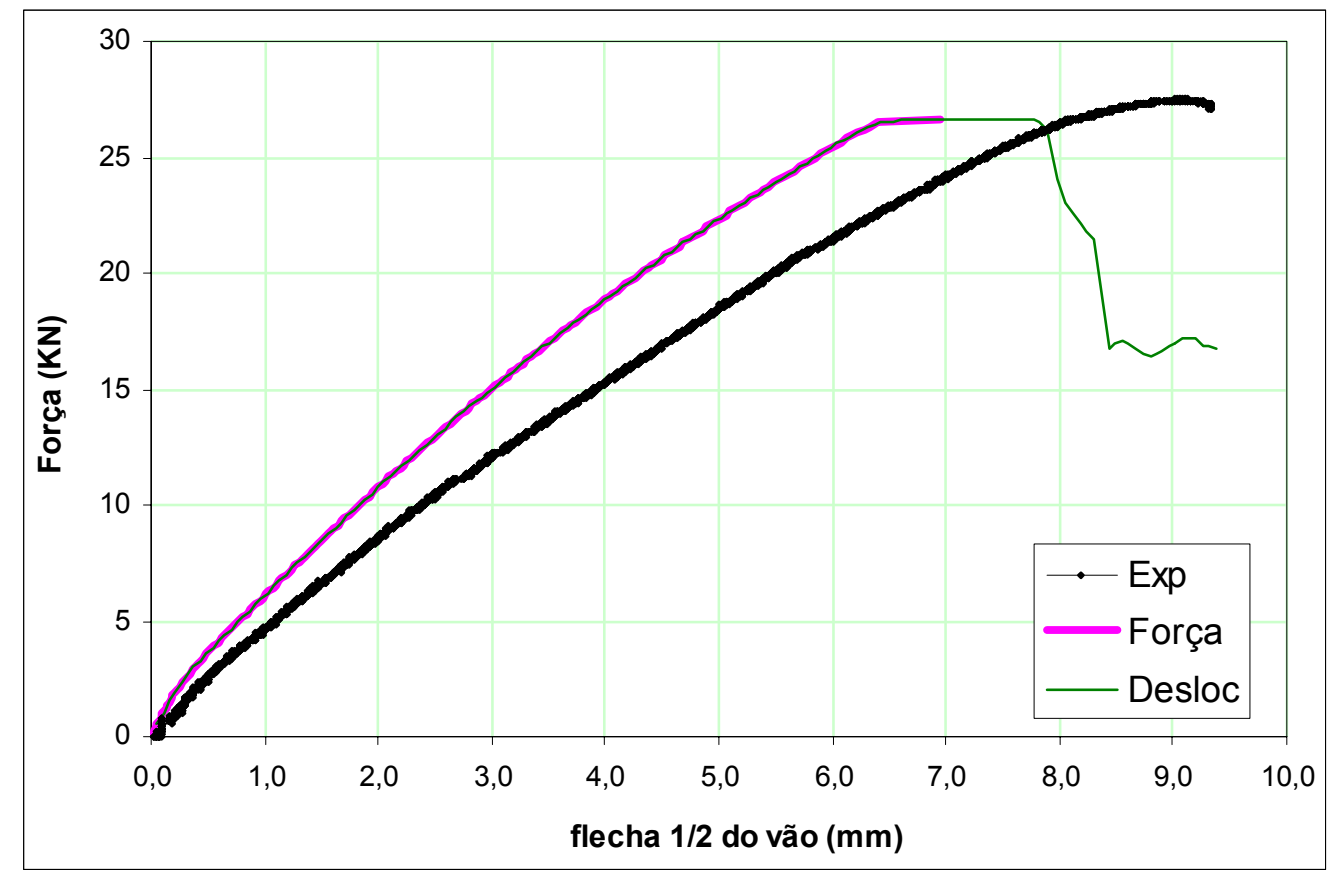

Figura 5.40 - Modelo de ARAUJO x viga VR-AD-02

O programa adaptado por ARAUJO também fornece um panorama da danificação global da viga, como mostra a Figura 5.41. 
Modelo de Mazars: $\mathrm{F}=10 \mathrm{KN}$

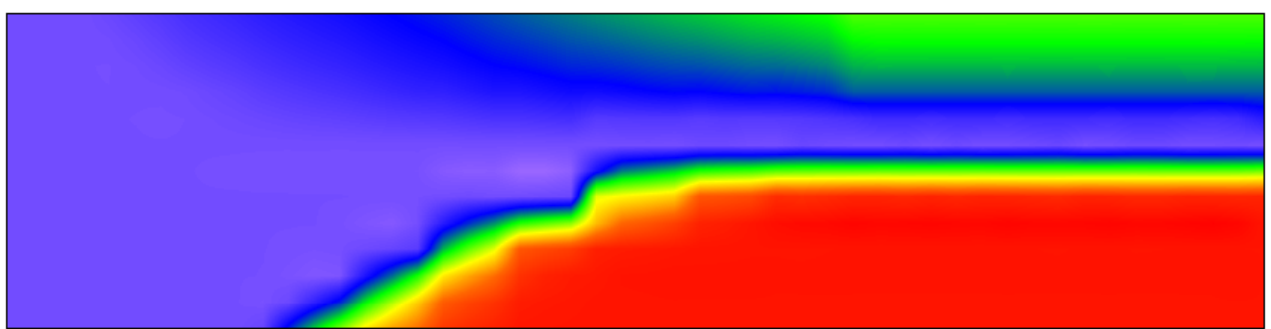

Escala de danificação

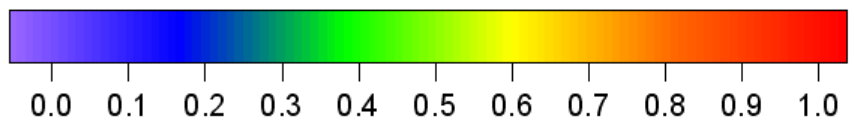

Figura 5.41 - Dano global em $1 / 2$ da viga VR-AD-02 - Modelo de ARAUJO

\subsubsection{Vigas tipo "T"}

As Tabela 5.9 e Tabela 5.10 apresentam uma síntese dos dados adicionais necessários à realização dos ensaios estáticos e cíclicos para as vigas de seção transversal do tipo "T". As tabelas apresentam também alguns resultados colhidos desses ensaios.

$\mathbf{P}_{\mathbf{u}, \text { est }}$ é a carga de ruptura estimada para o ensaio estático; $\mathbf{P}_{\mathbf{u}, \text { rup é a carga de }}$ ruptura efetivamente alcançada no ensaio estático ou no ensaio cíclico; $\mathbf{P}_{\max }$ e $\mathbf{P}_{\min }$ são, respectivamente, os valores máximo e mínimo da amplitude da carga no ensaio cíclico; a flecha máxima e mínima indicadas nas tabelas referem-se aos valores máximo e mínimo da flecha no ensaio cíclico.

Tabela 5.9 - Dados e resultados dos ensaios para vigas tipo " $\mathrm{T}$ "

\begin{tabular}{|c|c|c|c|c|c|c|c|}
\hline vigas & $\begin{array}{l}P_{u, \text { rup }} \\
(\mathbf{k N})\end{array}$ & $\begin{array}{l}P_{u, e s t} \\
(k N)\end{array}$ & $\begin{array}{c}\mathbf{P}_{\mathrm{u}, \text { rup }} / \\
\mathbf{P}_{\mathrm{u}, \text { est. }} / \\
(\%)\end{array}$ & $\begin{array}{l}P_{\max } \\
(k N)\end{array}$ & $\begin{array}{l}P_{\text {min }} \\
(\mathbf{k N})\end{array}$ & $\begin{array}{c}\mathbf{P}_{\max } / \\
\mathbf{P}_{\mathrm{u}, \mathrm{est}} \\
(\%)\end{array}$ & $\begin{array}{c}\mathbf{P}_{\min } / \\
\mathbf{P}_{\mathrm{u}, \text { est }} \\
(\%)\end{array}$ \\
\hline VT-NA-CE-T* & 58,45 & 52,0 & 12,4 & - & - & - & - \\
\hline VT-NA-SE-01* & 52,85 & 52,0 & 1,6 & - & - & - & - \\
\hline VT-NA-SE-02 & 57,62 & 52,0 & 10,8 & 40,0 & 20,0 & 75,0 & 40,0 \\
\hline VT-NA-CE-01* & 58,25 & 52,0 & 12,2 & - & - & - & - \\
\hline VT-NA-CE-02 & 57,50 & 52,0 & 10,6 & 44,0 & 20,0 & 85,0 & 40,0 \\
\hline
\end{tabular}


Tabela 5.10 - Continuação dos dados e resultados para vigas tipo "T"

\begin{tabular}{|c|c|c|c|c|c|}
\hline vigas & $\begin{array}{c}\text { Freq. } \\
\text { excit } \\
\mathbf{( H z )}\end{array}$ & $\begin{array}{c}\text { Flecha } \\
\mathbf{m a x} \\
\mathbf{( m m )}\end{array}$ & $\begin{array}{c}\text { Flecha } \\
\mathbf{m i n} . \\
\mathbf{( m m )}\end{array}$ & $\begin{array}{c}\text { flecha max./ } \\
\text { flecha min. } \\
\mathbf{( \% )}\end{array}$ & $\begin{array}{c}\mathbf{N}^{\mathbf{0}} \text { de } \\
\text { ciclos }\end{array}$ \\
\hline VT-NA-CE-T* $^{*}$ & - & $6,56 * *$ & - & - & - \\
\hline VT-NA-SE-01* $^{*}$ & - & $6,02 * *$ & - & - & - \\
\hline VT-NA-SE-02 & 2,0 & 4,68 & 3,29 & 42,2 & 30.000 \\
\hline VT-NA-CE-01* & - & $7,61 * *$ & - & - & - \\
\hline VT-NA-CE-02 & 2,0 & 4,64 & 3,05 & 52,1 & 30.000 \\
\hline
\end{tabular}

* Ensaio estático à ruptura.

** Valor da flecha na ruptura.

Observações feitas com o auxílio da Tabela 5.7 e da Tabela 5.8 mostram que as vigas com seção transversal tipo "T" apresentaram comportamento semelhante no tocante a carga última (a exceção se deu apenas com a viga VT-NA-SE-01); em relação à carga estimada de ruptura os valores obtidos se afastaram em torno dos $11,5 \%$. A variação de amplitude da flecha, tanto para a máxima quanto para a mínima, também mostrou ótima concordância de resultados. As duas vigas ensaiadas com carregamento cíclico foram excitadas com a freqüência de $2 \mathrm{~Hz}$ não dando para analisar a influência da freqüência sobre os resultados.

A Figura 5.42 mostra que o aumento da flecha tende a se estabilizar a partir de um certo número de ciclos (15.000).

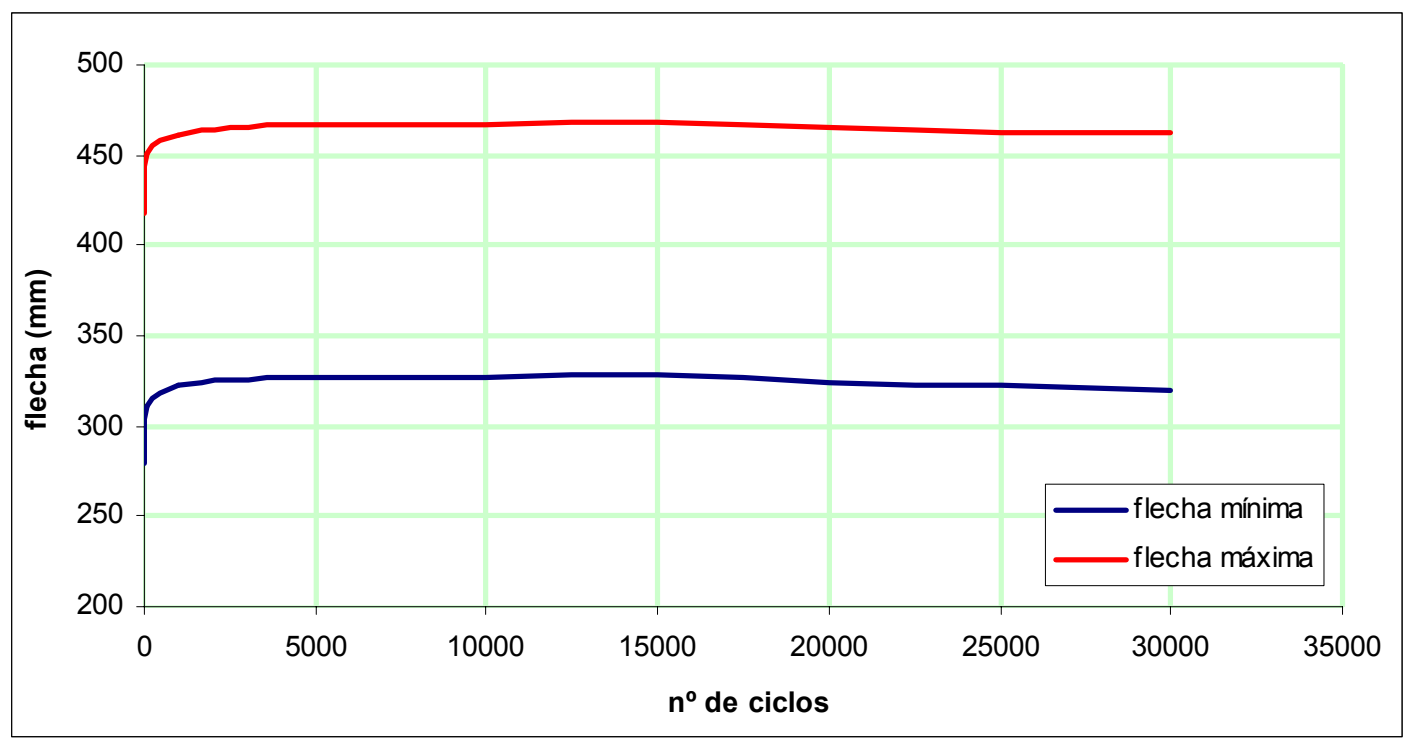

Figura 5.42 - Flecha máxima e mínima para a viga VT-NA-SE-02 
$\mathrm{Na}$ análise numérica para as vigas com seção transversal em " $\mathrm{T}$ " foram feitas apenas verificações com o programa adaptado por ARAÚJO (2003). A Figura 5.43 mostra a relação força $\mathrm{x}$ deslocamento para o carregamento aplicado por incrementos de forças, comparados com o ensaio experimental da viga VT-NA-CE-T. Observa-se o ótimo comportamento do modelo implementado por ARAUJO especialmente por representar bem o início da primeira fissura.

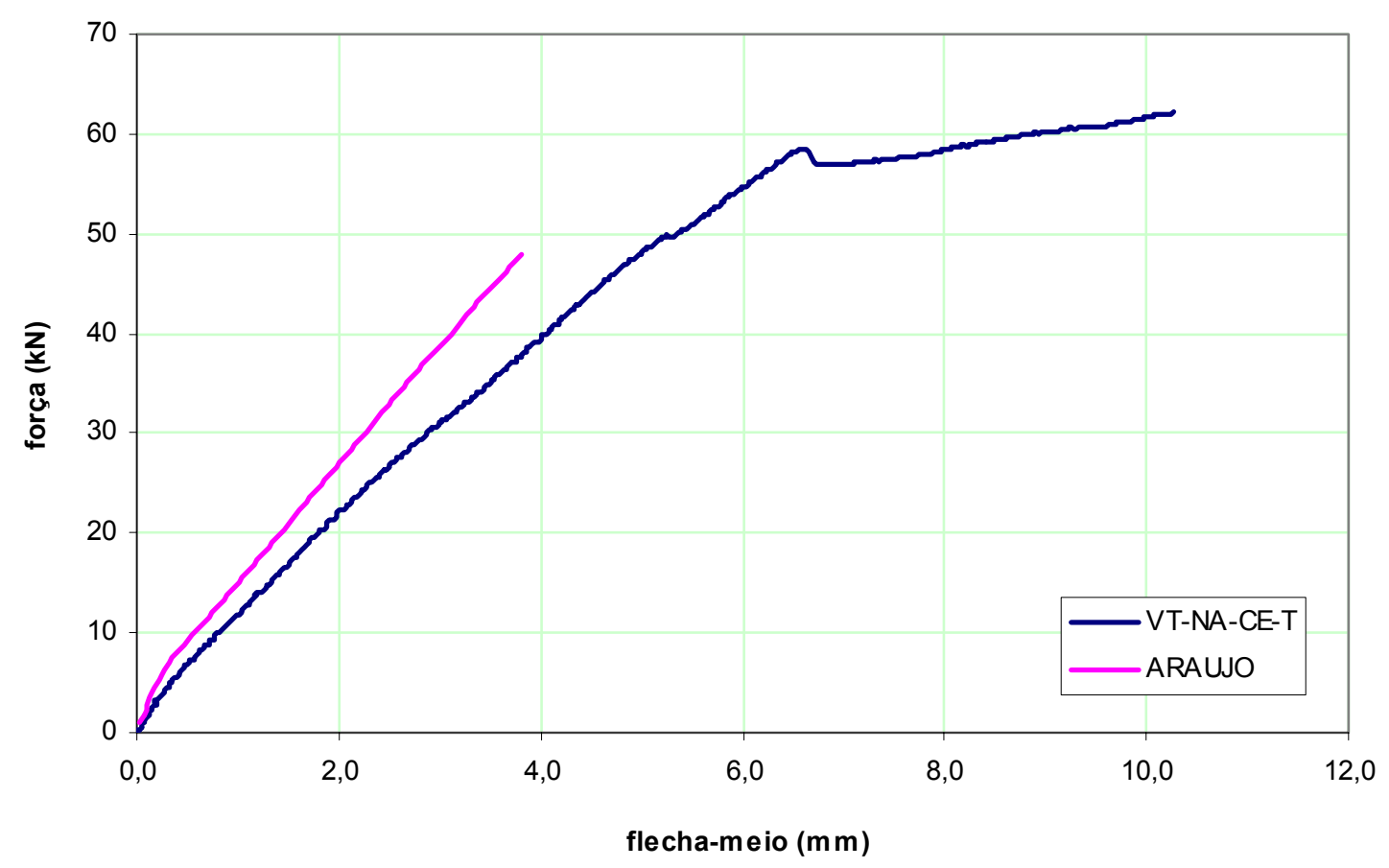

Figura 5.43 - Modelo de ARAUJO x viga VT-NA-CE-T

A Figura 5.44 mostra o comportamento das 5 (cinco) vigas tipo "T", três delas apenas levadas à ruptura e as outras duas solicitadas por carregamento cíclico. Das três levadas à ruptura duas delas romperam por cisalhamento; no entanto até um certo nível de carga apresentam boa concordância nos resultados. É possível observar a perda de rigidez pelo aumento de flecha registrado nas duas vigas $(0,45 \mathrm{~mm})$. A título de comparação, seja a Figura 5.45 que retrata o comportamento das 5 (cinco) vigas dimensionadas com armadura dupla (a mesma Figura 5.36). 


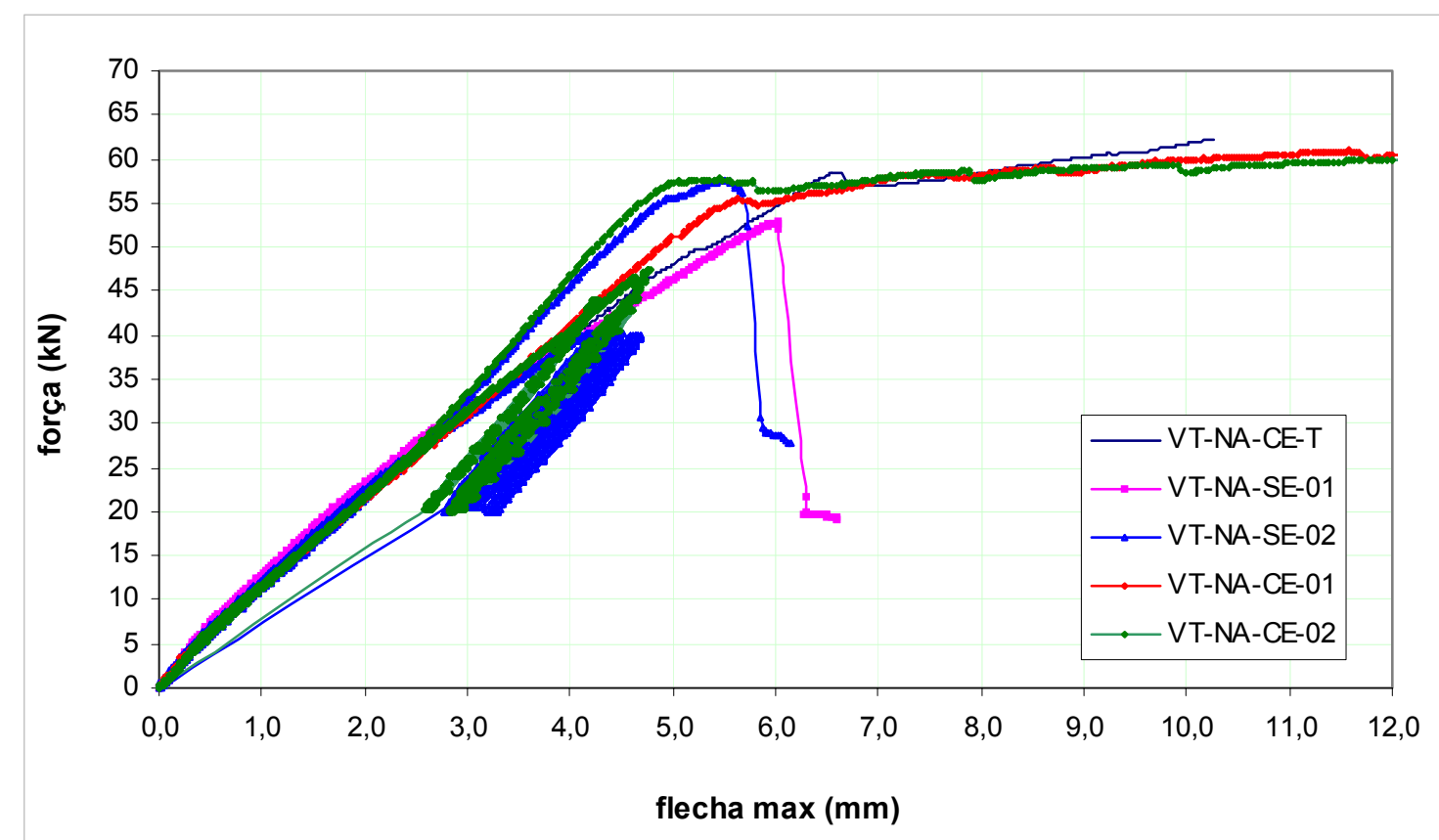

Figura 5.44 - Vigas com seção transversal tipo "T"

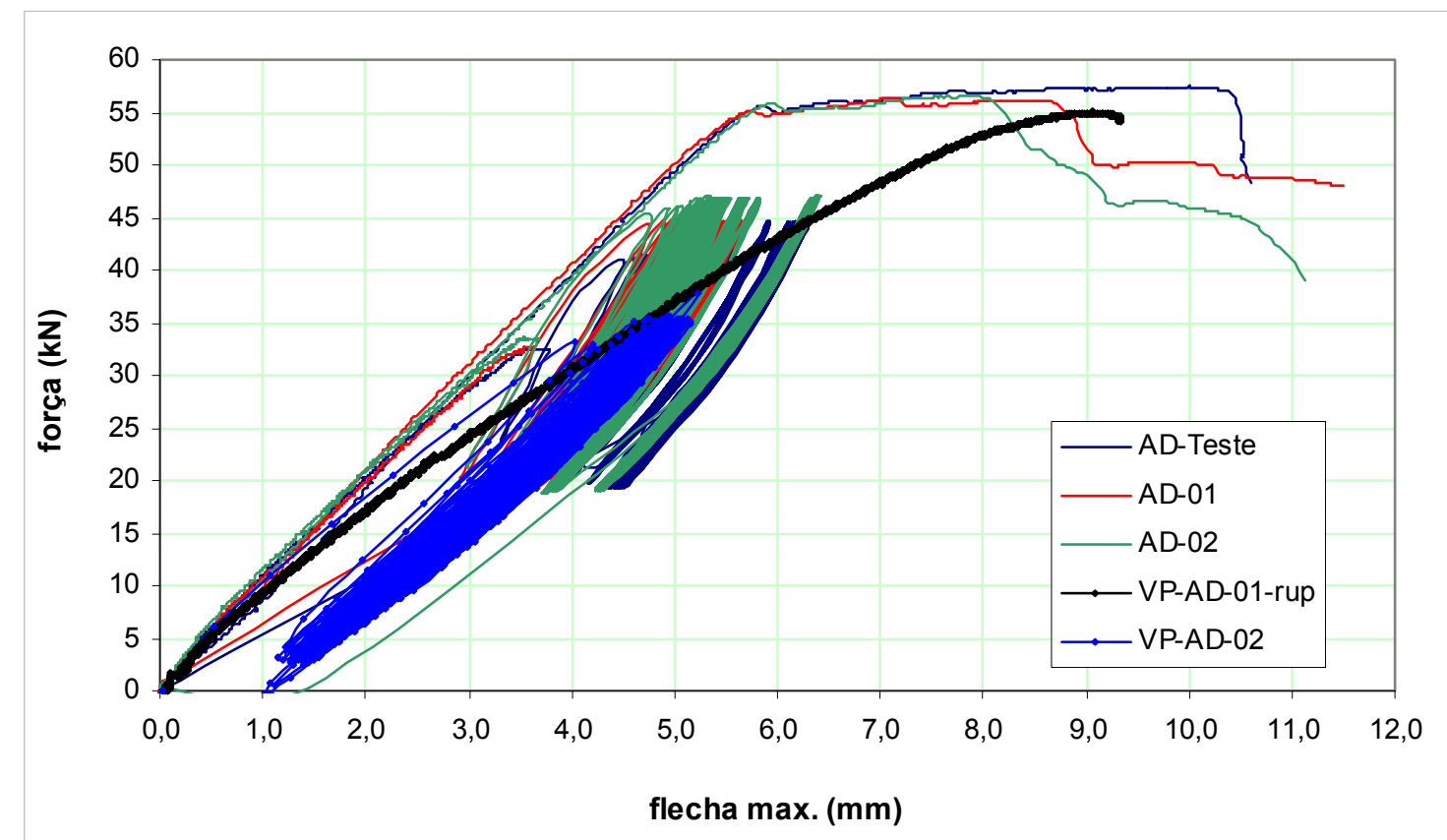

Figura 5.45 - Vigas com armadura dupla

A análise das duas figuras nos leva a constatar que as vigas com armadura dupla e com seção tipo "T" apresentam, de um modo geral, comportamento semelhante; no tocante à carga de ruptura e no tocante à flecha medida na ruptura. Tendo em conta que a seção transversal da alma das vigas tipo "T" é igual à seção transversal das vigas com armadura dupla e, ainda, que ambas as vigas foram armadas com $2 \varnothing$ de $10.0 \mathrm{~mm}$ 
- armadura de tração (lembrar que as vigas "T" são sub-armadas) é possível comparar diretamente a capacidade portante das vigas tipo " $\mathrm{T}$ " e das vigas com armadura dupla e ainda comparar as duas com as vigas de seção retangular sub-armadas ( $\varnothing \varnothing$ de $6.3 \mathrm{~mm}$ ). A Tabela 5.11 mostra uma comparação entre as diversas vigas no que se refere a carga portante e consumo de aço. $\mathbf{P}_{\text {ref }}$ é a carga estimada de ruptura para as vigas sub-armadas

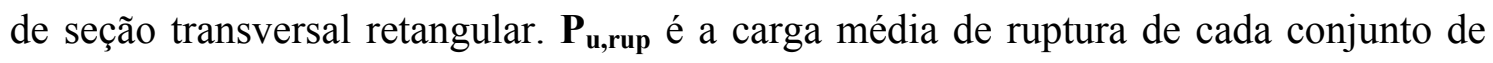
vigas ensaiado. As,ref é a área da seção de aço das vigas sub-armadas de seção transversal retangular. $\mathbf{A}_{\mathbf{s}}$ é a área da seção de aço de cada grupo de vigas. R-AS, RAD e T-AS indicam, respectivamente, vigas sub-armadas de seção transversal retangular, vigas com armadura dupla de seção transversal retangular e vigas de seção transversal tipo " $\mathrm{T}$ ".

Tabela 5.11 - Vigas sub-armadas, armadura dupla e tipo "T"

\begin{tabular}{|c|c|c|c|c|c|c|}
\hline \multirow{2}{*}{ Tipo de viga } & $\mathbf{P}_{\text {ref }}$ & $\mathbf{P}_{\mathbf{u}, \text { rup }}$ & $\mathbf{P}_{\mathbf{u}, \text { rup }} / \mathbf{P}_{\text {ref }}$ & $\mathbf{A}_{\text {s,ref }}$ & $\mathbf{A}_{\mathbf{s}}$ & $\mathbf{A}_{\mathbf{s}} / \mathbf{A}_{\mathbf{s}, \text { ref }}$ \\
\cline { 2 - 7 } & $\mathbf{k N}$ & $\mathbf{k N}$ & $\mathbf{\%}$ & $\mathbf{c m}^{\mathbf{2}}$ & $\mathbf{c m}^{\mathbf{2}}$ & $\mathbf{\%}$ \\
\hline R-SA & 21,00 & 22,98 & $+9,40$ & 0,62 & 0,62 & - \\
\hline R-AD & 21,00 & 55,65 & $+165,0$ & 0,62 & 1,96 & $+216,1$ \\
\hline T-SA & 21,00 & 56,93 & $+171,1$ & 0,62 & 1,57 & $+153,2$ \\
\hline
\end{tabular}

\subsubsection{Quantificação da perda de rigidez}

O objetivo precípuo desta pesquisa, em última análise, é determinar quantitativamente a perda de rigidez de vigas de concreto armado submetidas a carregamento cíclico em nível de serviço. Busca-se, na verdade, escrever uma expressão baseada em modelos empíricos que possa avaliar com relativa precisão, ao fim de um certo número de ciclos, a perda de rigidez dessas vigas em função das flechas medidas ou estimadas; ou mesmo determinar estimativamente a flecha máxima que se dará na viga após um certo número $\mathbf{N}$ de ciclos de carga.

$\mathrm{Na}$ bibliografia técnica podem ser encontrados alguns trabalhos experimentais, como os comentados no capítulo 2 (páginas 52 a 54), os quais sugerem expressões empíricas que servem para predizer o valor da flecha em vigas de concreto armado apos submetidas a um certo número de ciclos de carga. 
Dentre os poucos modelos disponíveis escolhemos o de PITONAK, A. (1992) para comparação com os valores obtidos dos ensaios realizados com as vigas.

Em sua pesquisa com vigas de concreto armado PITONAK, A. (1992) realizou medidas da flecha ao final de cada ciclo $\left(\mathrm{a}_{\mathrm{n}}\right)$ como função da flecha inicial $\left(\mathrm{a}_{0}\right)$ - ver Figuras 2.26 e 2.27. A relação entre $\mathrm{a}_{\mathrm{N}}$ e $\mathrm{a}_{0}$ é avaliada pela regressão linear dada pela eq. (5.2).

$$
\mathrm{a}_{\mathrm{N}}=\kappa \cdot \mathrm{a}_{0}
$$

que, rearranjada, toma a forma:

onde

$$
\mathrm{a}_{\mathrm{N}}=\mathrm{a}_{0}\left(1+\beta_{\mathrm{rN}}\right)
$$

$$
\beta_{\mathrm{rN}}=\kappa-1
$$

sendo $\beta_{\mathrm{rN}}$ obtido dos resultados dos ensaios cíclicos para os dois parâmetros da análise de regressão, $a_{N}$ e $a_{0}$ (ver Figura 2.28), cuja expressão é dada pela eq. (5.5):

$$
\beta_{\mathrm{rN}}=0.5\left(1-\mathrm{e}^{-0.03 \mathrm{~N}^{0.25}}\right)
$$

Para a predição das flechas cíclicas é suficiente assumir que $\mathrm{N}$ significa o número de ciclos para a máxima amplitude. Baseado, portanto, nos resultados obtidos com ensaios em vigas de concreto armado PITONAK, A. (1992) concluiu que uma relação linear pode ser assumida entre $a_{N}$ e $a_{0}$ independentemente do nível e da amplitude da carga cíclica para um dado número $\mathrm{N}$ de ciclos de carga; pode ser expressa pela relação, idêntica à relação contida no CEB-FIP MODEL CODE 1990 (1993), dada pela eq. (5.6):

$$
\mathrm{a}_{\mathrm{N}}=\mathrm{a}_{0}\left(1.5-0.5 \mathrm{e}^{-0.03 \mathrm{~N}^{0.25}}\right)
$$

onde $\mathbf{a}_{\mathbf{N}}$ representa a flecha da viga no $\mathrm{N}^{\mathrm{o}}$ ciclo, $\mathbf{a}_{\mathbf{0}}$ a flecha no $1^{\circ}$ ciclo de carga e $\mathbf{N}$ o número de ciclos de carga aplicado. $\mathrm{Na}$ eq. (5.6) as características das vigas (resistências do concreto, formas e dimensões das seções transversais, tipo do aço, diâmetro das barras longitudinais, etc) já estão incluidas no valor da flecha inicial $\mathbf{a}_{\mathbf{0}}$. No CEB-BULLETIN D'INFORMATION No 235 (1997) está escrito a respeito da validade do modelo de PITONAK, A. (1992): "uma relação linear entre as flechas cíclicas $\left(\mathrm{a}_{\mathrm{N}}\right)$ e a flecha inicial $\left(\mathrm{a}_{0}\right)$ parece ser bem razoável”. A relação dada na eq. (5.6), segundo o autor, apresenta boa concordância de resultados para até 10.000.000 de ciclos. 
Os valores encontrados com o modelo de PITONAK, A. (1992), dados pela eq. (5.6), são idênticos tanto para as vigas sub-armadas (SA) quanto para as vigas com armadura dupla (AD), desde quando são determinados em função de $\mathbf{a}_{\mathbf{0}}$. Além disso, a curva obtida com a eq. (5.6) afasta-se, em geral, dos resultados obtidos com as vigas experimentais. No intuito de melhor representar o tipo de curva sugerida por PITONAK, A. (1992) foram obtidas, para as vigas de seção retangular - SA e AD, e para as vigas de seção tipo "T" - SA, curvas do mesmo tipo variando apenas os valores de $\beta_{\mathrm{rN}}$. Neste trabalho as novas expressões foram chamadas de modelo de PITONAK ADAPTADO.

Para as vigas sub-armadas (SA) a expressão é dada pela eq. (5.7):

$$
\mathrm{a}_{\mathrm{N}}=\mathrm{a}_{0}\left(1.5-0.50 \mathrm{e}^{-0.10 \mathrm{~N}^{0.25}}\right)
$$

A Tabela 5.12 apresenta um resumo da evolução das perdas de rigidez obtidas dos ensaios realizados com as vigas sub-armadas; são comparadas com modelos teóricos utilizados nesta pesquisa, quais sejam, o modelo numérico desenvolvido e adaptado por ALVA (2004) e os modelos teóricos de PITONAK, A. (1992) e PITONAK ADAPTADO.

Tabela 5.12 - Perda de rigidez - resultados teóricos e experimentais para vigas

\section{sub-armadas}

\begin{tabular}{|c|c|c|c|c|c|c|c|c|c|c|c|c|}
\hline \multirow{4}{*}{$\begin{array}{c}\text { número } \\
\text { de } \\
\text { ciclos }\end{array}$} & \multicolumn{2}{|c|}{ VP-NA-02 } & \multicolumn{2}{|c|}{ VR-NA-Teste } & \multicolumn{2}{|c|}{ VR-NA-01 } & \multicolumn{2}{|c|}{ VR-NA-02 } & \multicolumn{2}{|c|}{ ALVA } & \multicolumn{2}{|c|}{ PITONAK } \\
\hline & flecha & & flecha & & flecha & & flecha & & flecha & & 1992 & Adap. \\
\hline & $\max$ & as $/ \mathbf{a} 0$ & max. & an $/ \mathbf{a} 0$ & max. & as $/ \mathbf{a} 0$ & $\max$. & as $/ \mathbf{a} 0$ & $\max$. & as $/ \mathbf{a} 0$ & as $/ \mathbf{a} 0$ & $\mathbf{a N} / \mathbf{a} 0$ \\
\hline & \begin{tabular}{|l|}
$(\mathrm{mm})$ \\
\end{tabular} & (\%) & $(\mathrm{mm})$ & (\%) & $(\mathrm{mm})$ & (\%) & $(\mathrm{mm})$ & $(\%)$ & $(\mathrm{mm})$ & (\%) & (\%) & $(\%)$ \\
\hline 1 & 2,90 & $\overline{0,00}$ & 3,54 & 0,00 & 3,67 & 0,00 & 3,49 & 0,00 & 3,22 & 0,00 & 0,00 & 0,00 \\
\hline 10 & 2,98 & 2,76 & 3,67 & 3,67 & 3,76 & 2,45 & 3,69 & 5,73 & 3,40 & \begin{tabular}{|l|}
5,68 \\
\end{tabular} & 2,60 & 8,15 \\
\hline 20 & 3,05 & 5,17 & 3,72 & 5,08 & 3,83 & 4,36 & 3,76 & 7,74 & 3,47 & 7,95 & 3,07 & 9,53 \\
\hline 30 & 3,14 & 8,28 & 3,78 & 6,78 & 3,88 & 5,72 & 3,81 & 9,17 & 3,52 & \begin{tabular}{|l|}
9,30 \\
\end{tabular} & 3,39 & 0,43 \\
\hline 40 & 3,14 & 8,28 & 3,84 & 8,47 & 3,92 & 6,81 & 3,86 & 10,60 & 3,55 & 10,27 & 3,63 & 11,12 \\
\hline 50 & 3,14 & 8,28 & 3,89 & 9,89 & 3,95 & 7,63 & 3,89 & 11,46 & 3,57 & 11,03 & 3,83 & 11,67 \\
\hline 100 & & & 3,97 & 12,15 & 4,05 & 10,35 & 4,01 & 14,90 & 3,65 & 13,46 & 4,53 & 3,56 \\
\hline 1000 & & & 4,16 & 17,51 & 4,19 & 14,17 & 4,22 & 20,92 & 3,93 & 22,22 & 7,76 & 21,51 \\
\hline 2500 & & & 4,10 & 15,82 & 4,16 & 13,35 & 4,36 & 24,93 & 4,06 & 26,06 & 9,56 & 25,35 \\
\hline 5000 & & & & & 4,15 & 13,08 & 4,42 & 26,65 & 4,15 & 29,07 & 11,15 & 28,43 \\
\hline 10000 & & & & & 4,12 & 12,26 & 4,57 & 30,95 & 4,25 & 32,13 & 12,96 & 31,61 \\
\hline 15000 & & & & & 4,08 & 11,17 & 4,58 & 31,23 & 4,31 & 33,91 & 14,13 & 33,47 \\
\hline
\end{tabular}

A viga VP-NA-02 fez parte do programa experimental chamado ensaio piloto e as demais vigas do ensaio definitivo. A Figura 5.46 mostra a evolução da perda de 
rigidez para todas as vigas e modelos plotados na Tabela 5.12, em função do número de ciclos.

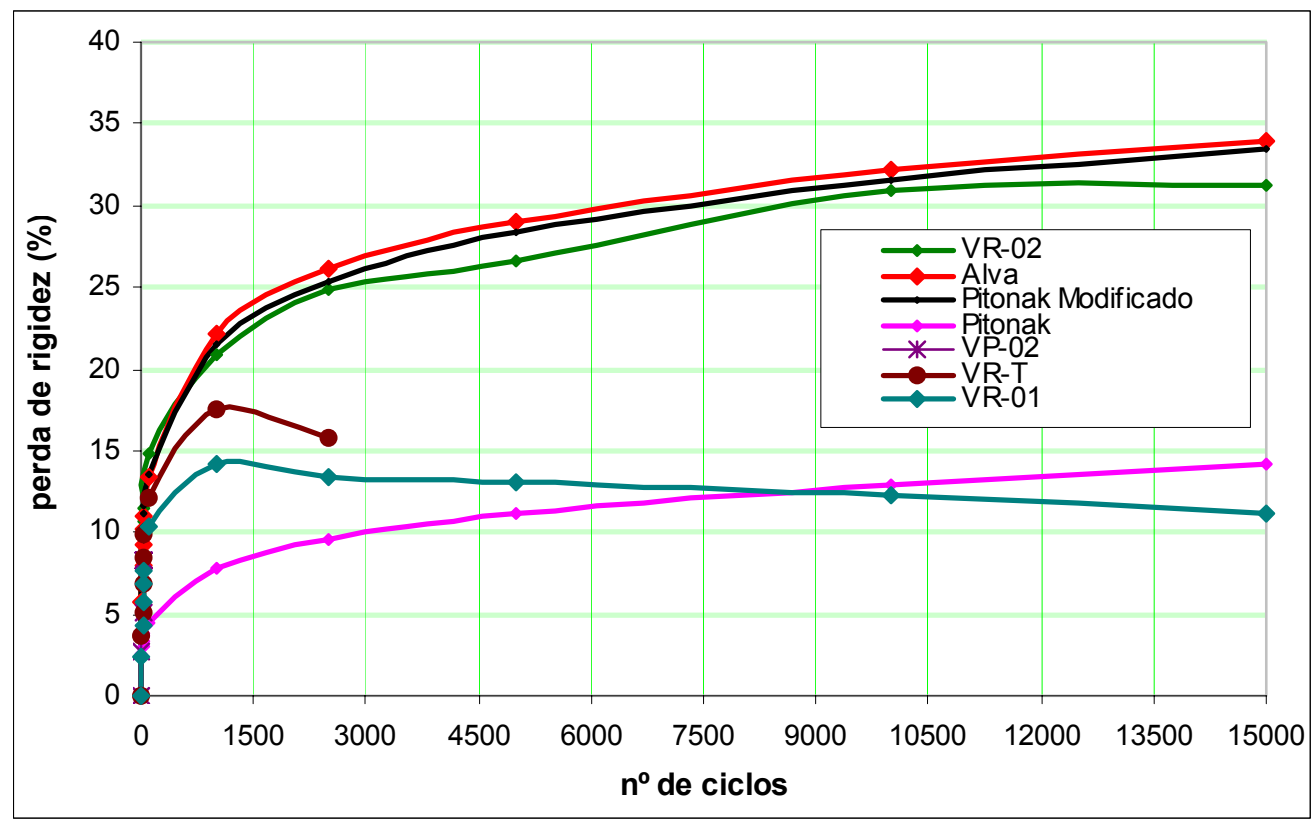

Figura 5.46 - Evolução da perda de rigidez para todas as vigas (SA)

A Figura 5.47 mostra a evolução da perda de rigidez verificada apenas na viga VR-NA-02, considerada representativa como viga experimental, e mais os modelos comparativos de ALVA, PITONAK e PITONAK ADAPTADO.

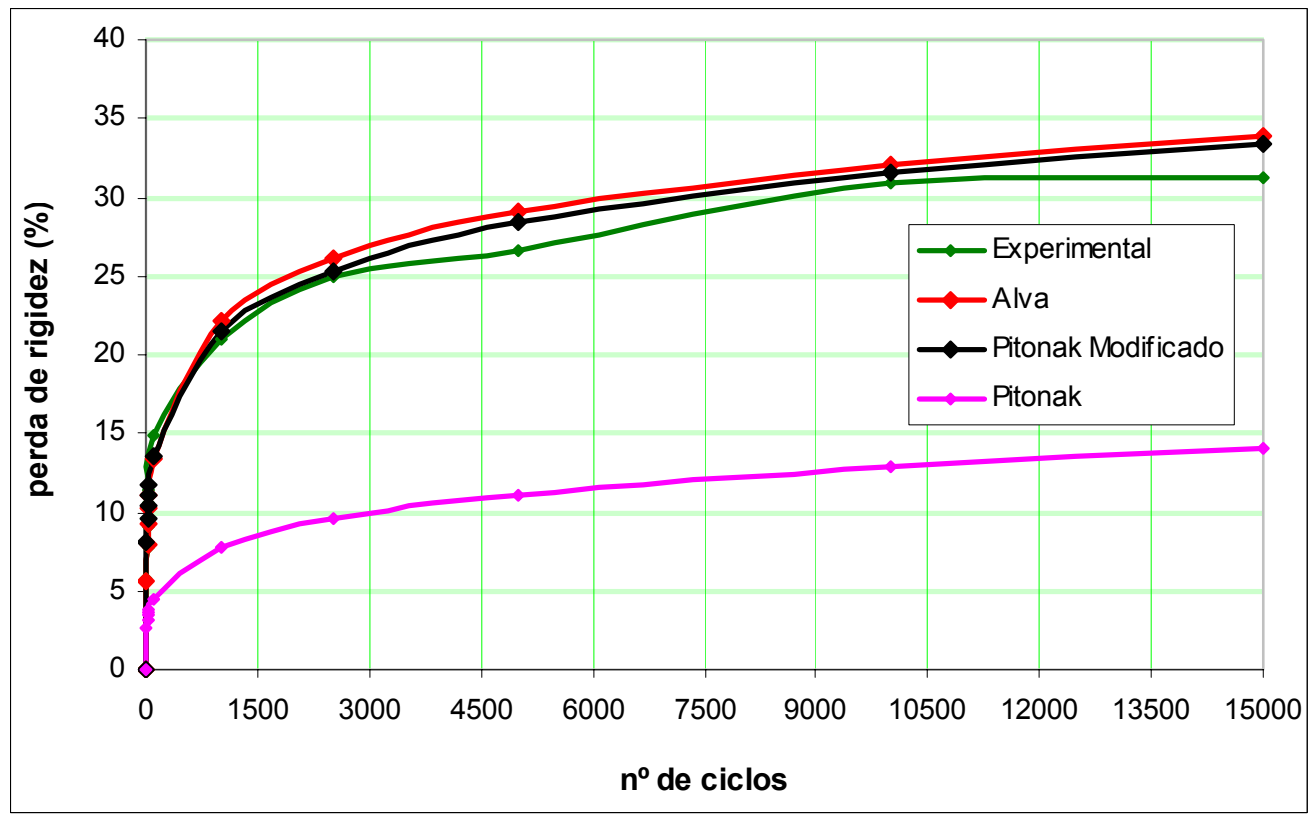

Figura 5.47 - Evolução da perda de rigidez da viga experimental (SA) e modelos comparativos 
A Figura 5.48 mostra a evolução da perda de rigidez verificada para a viga experimental porem simulando para os modelos de PITONAK e PITONAK ADAPTADO a extensão da curva até 50.000 ciclos.

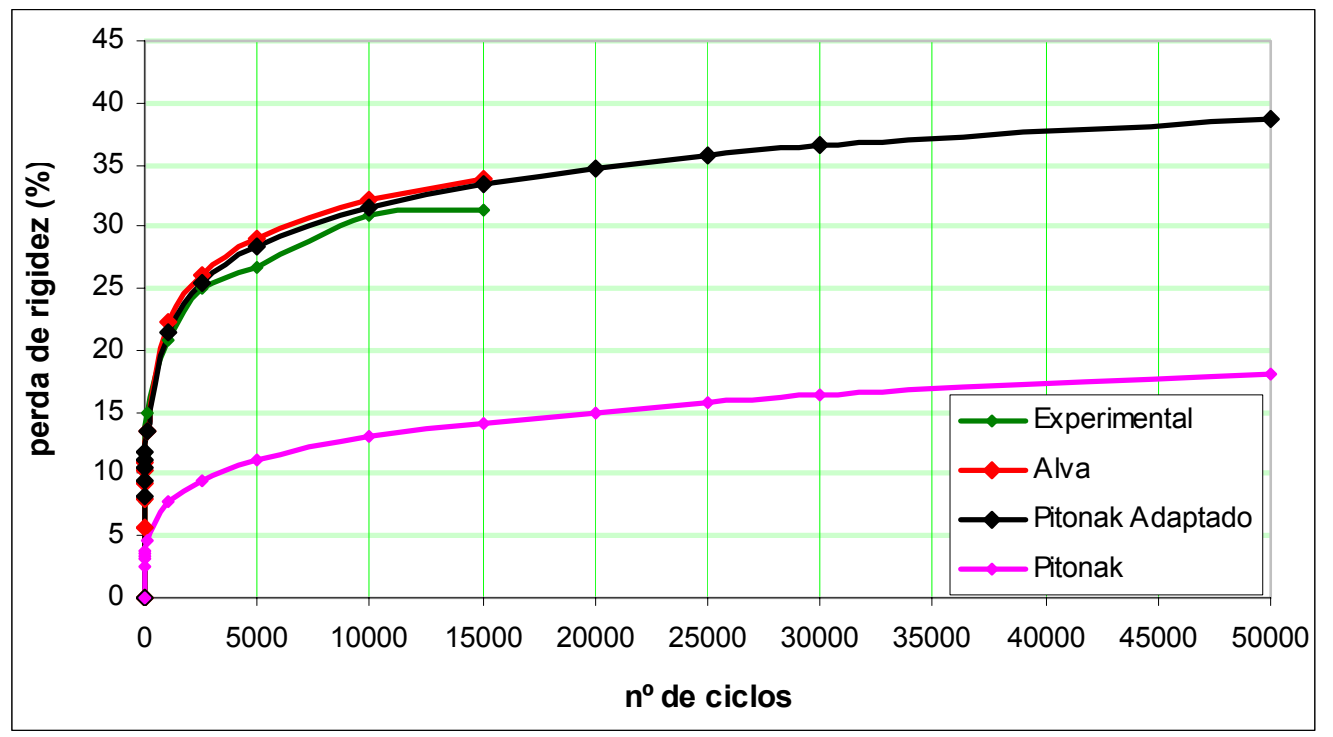

Figura 5.48 - Evolução da perda de rigidez da viga experimental (SA) e modelos comparativos para $\mathbf{5 0 . 0 0 0}$ ciclos

Observar a tendência da curva no modelo de PITONAK ADAPTADO para uma perda de rigidez próxima dos $40 \%$. Para os 10.000 .000 de ciclos a projeção da perda de rigidez chega à casa dos $40 \%$ para o modelo de PITONAK e próximo dos 50 \% para o modelo de PITONAK ADAPTADO. As curvas não se cruzam.

Para as vigas com armadura dupla (AD) a expressão de PITONAK ADAPTADO é dada pela eq. (5.8):

$$
\mathrm{a}_{\mathrm{N}}=\mathrm{a}_{0}\left(1.5-0.35 \mathrm{e}^{-0.02 \mathrm{~N}^{0.25}}\right)
$$

A Tabela 5.13 apresenta um resumo da evolução das perdas de rigidez obtidas dos ensaios realizados nas vigas com armadura dupla. 
Tabela 5.13 - Perda de rigidez - resultados teóricos e experimentais para vigas com armadura dupla

\begin{tabular}{|c|c|c|c|c|c|c|c|c|c|c|c|c|}
\hline \multirow{4}{*}{$\begin{array}{l}\text { Número } \\
\text { de } \\
\text { ciclos }\end{array}$} & \multicolumn{2}{|c|}{ VP-AD-02 } & \multicolumn{2}{|c|}{ VR-AD-CE-T } & \multicolumn{2}{|c|}{\begin{tabular}{|l|} 
VR-AD-CE-01 \\
\end{tabular}} & \multicolumn{2}{|c|}{ VR-AD-CE-02 } & \multicolumn{2}{|c|}{ ALVA } & \multicolumn{2}{|c|}{ PITONAK } \\
\hline & flecha & & flecha & & flecha & & flecha & & flecha & & 1992 & Adap. \\
\hline & $\max$. & $\mathbf{a}_{\mathrm{N}} / \mathbf{a}_{0}$ & $\max$. & $\mathbf{a}_{\mathrm{N}} / \mathbf{a}_{0}$ & $\max$. & $\mathbf{a}_{\mathrm{N}} / \mathbf{a}_{0}$ & $\max$. & $\mathbf{a}_{\mathrm{N}} / \mathbf{a}_{0}$ & $\max$ & $\mathbf{a}_{N} / \mathbf{a}_{0}$ & $\mathbf{a}_{N} / \mathbf{a}_{0}$ & $\mathbf{a}_{N} / \mathbf{a}_{0}$ \\
\hline & $(\mathrm{mm})$ & $(\%)$ & $(\mathrm{mm})$ & $(\%)$ & $(\mathrm{mm})$ & $(\%)$ & $(\mathrm{mm})$ & $(\%)$ & $(\mathrm{mm})$ & $(\%)$ & $(\%)$ & $(\%)$ \\
\hline 1 & 4,60 & 0,00 & 4,50 & 0,00 & 4,75 & 0,00 & 4,76 & 0,00 & 4,37 & 0,00 & 0,00 & 0,00 \\
\hline 10 & 4,73 & 2,83 & 5,10 & 13,33 & 5,14 & 8,21 & 5,25 & 10,29 & 5,25 & 20,14 & 2,60 & 16,22 \\
\hline 20 & 4,87 & 5,87 & 5,35 & 18,89 & 5,19 & 9,26 & 5,36 & 12,61 & 5,36 & 22,65 & 3,07 & 16,45 \\
\hline 30 & 4,97 & 8,04 & 5,47 & 21,56 & 5,24 & 10,32 & 5,41 & 13,66 & 5,43 & 24,26 & 3,39 & 16,60 \\
\hline 40 & 5,04 & 9,57 & 5,53 & 22,89 & 5,27 & 10,95 & 5,43 & 14,08 & 5,47 & 25,17 & 3,63 & 16,72 \\
\hline 50 & 5,06 & 10,00 & 5,55 & 23,33 & 5,27 & 10,95 & 5,45 & 14,50 & 5,5 & 25,86 & 3,83 & 16,81 \\
\hline 60 & 5,14 & 11,74 & 5,57 & 23,76 & 5,27 & 10,95 & 5,46 & 14,71 & 5,53 & 26,54 & 4,01 & 16,89 \\
\hline 70 & 5,14 & 11,74 & 5,63 & 25,00 & 5,27 & 10,95 & 5,48 & 15,13 & 5,56 & 27,23 & 4,16 & 16,97 \\
\hline 100 & & & 5,71 & 26,78 & 5,29 & 11,37 & 5,52 & 15,97 & 5,61 & 28,38 & 4,53 & 17,15 \\
\hline 1000 & & & 5,91 & 31,22 & 5,40 & 13,68 & 5,64 & 18,49 & 5,99 & 37,07 & 7,76 & 18,72 \\
\hline 2500 & & & 6,10 & 35,44 & 5,47 & 15,16 & 5,68 & 19,33 & 6,15 & 40,73 & 9,56 & 19,62 \\
\hline 5000 & & & 6,19 & 37,44 & 5,49 & 15,58 & 5,69 & 19,54 & 6,27 & 43,48 & 11,15 & 20,42 \\
\hline 10000 & & & 6,31 & 40,11 & 5,58 & 17,47 & 5,69 & 19,54 & 6,39 & 46,22 & 12,96 & 21,34 \\
\hline 15000 & & & 6,25 & 38,78 & 5,62 & 18,32 & 5,83 & 22,48 & 6,46 & 47,83 & 14,13 & 21,95 \\
\hline 20000 & & & & & 5,64 & 18,74 & 6,33 & 32,98 & 6,50 & 48,74 & 15,00 & 22,41 \\
\hline 25000 & & & & & 5,64 & 18,74 & 6,25 & 31,30 & 6,54 & 49,66 & 15,71 & 22,78 \\
\hline 30000 & & & & & 5,67 & 19,37 & 6,39 & 34,24 & 6,57 & 50,34 & 16,31 & 23,10 \\
\hline
\end{tabular}

A Figura 5.49 mostra a evolução da perda de rigidez verificada nas vigas VRAD-01 e VR-AD-02 comparadas com os modelos de ALVA, PITONAK e PITONAK ADAPTADO.

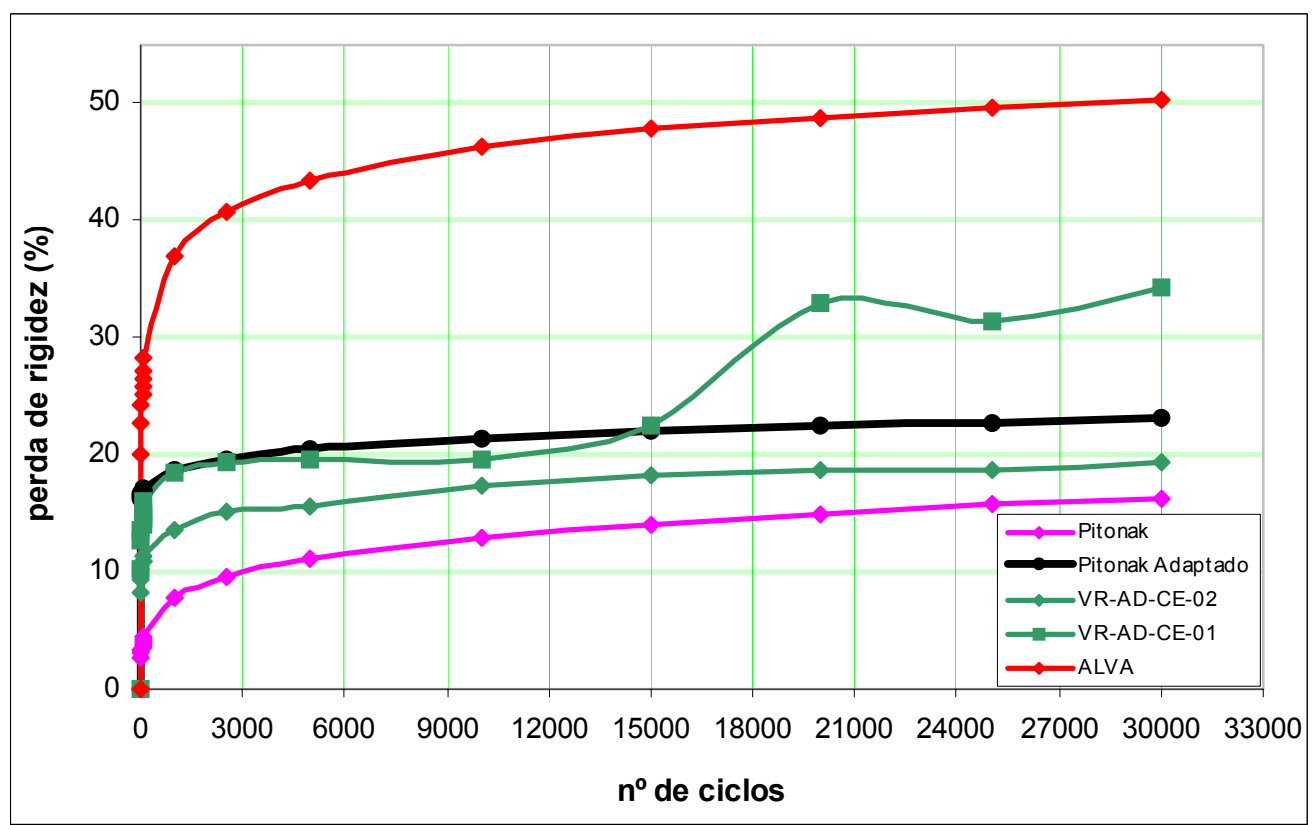

Figura 5.49 - Evolução da perda de rigidez das vigas VR-AD-01 e 02 (AD) e modelos comparativos 
A Figura 5.50 mostra a evolução da perda de rigidez verificada para as duas vigas com armadura dupla porem simulando para os modelos de PITONAK e PITONAK ADAPTADO a extensão da curva até 50.000 ciclos.

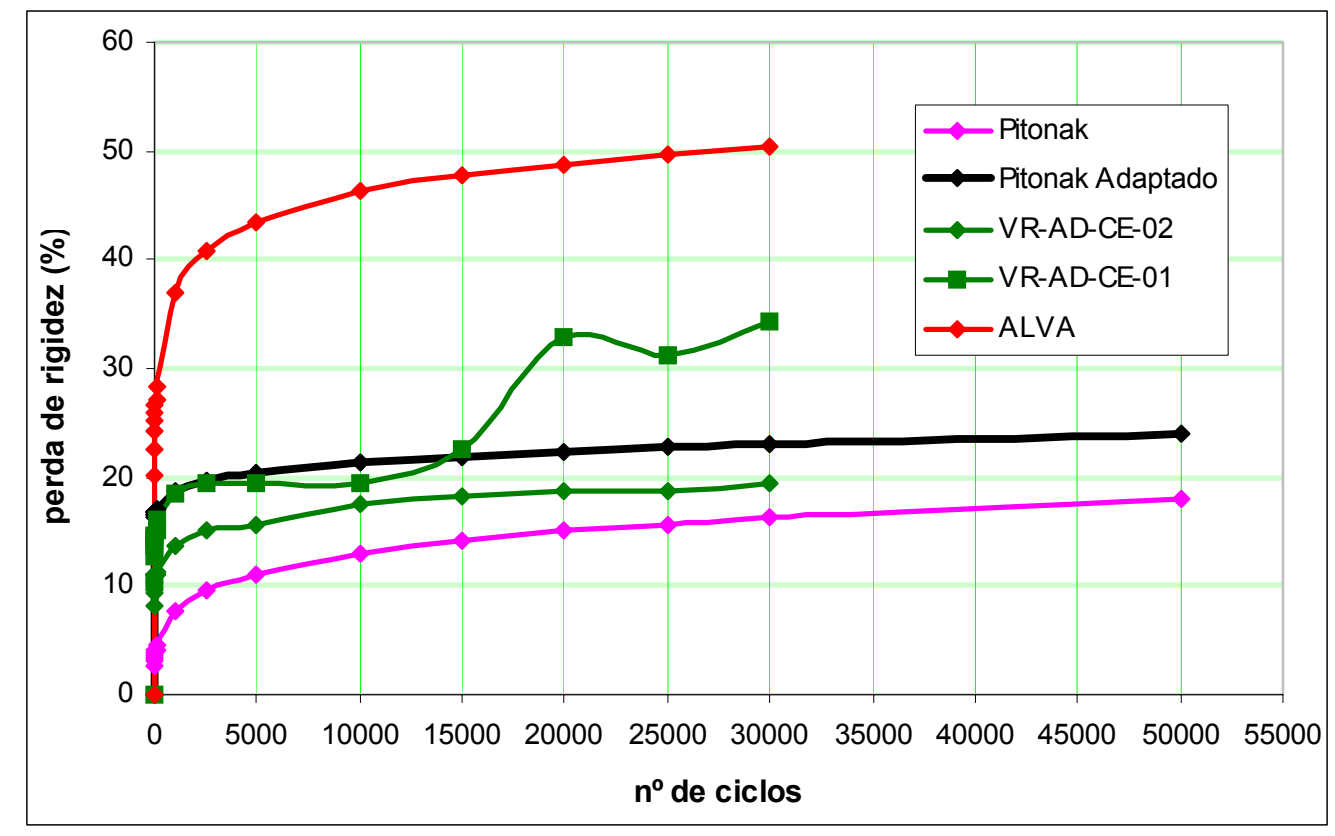

Figura 5.50 - Evolução da perda de rigidez das vigas com armadura dupla e modelos comparativos para $\mathbf{5 0 . 0 0 0}$ ciclos

Observar a tendência da curva para uma perda de rigidez próxima dos $25 \%$. Para os 10.000 .000 de ciclos a projeção da perda de rigidez tanto para o modelo de PITONAK quanto para o modelo de PITONAK ADAPTADO chega próximo dos $40 \%$. Nos 2.000.000 de ciclos a perda é idêntica para os dois modelos, com valor de aproximadamente $34 \%$.

Para as vigas com seção transversal tipo "T" (SA) a expressão de PITONAK ADAPTADO é dada pela eq. (5.9):

$$
a_{N}=a_{0}\left(1.5-0.435 e^{-0.025 N^{0.25}}\right)
$$

A Tabela 5.14 apresenta um resumo da evolução das perdas de rigidez obtidas dos ensaios realizados nas vigas sub-armadas com seção transversal tipo "T". 
Tabela 5.14 - Perda de rigidez - resultados teóricos e experimentais para vigas com seção tipo "T"

\begin{tabular}{|c|c|c|c|c|c|c|}
\hline \multirow{2}{*}{$\begin{array}{c}\text { número } \\
\text { de } \\
\text { ciclos }\end{array}$} & \multicolumn{2}{|c|}{ VT-NA-SE-02 } & \multicolumn{2}{|c|}{ VT-NA-CE-02 } & \multicolumn{2}{c|}{ PITONAK } \\
\cline { 2 - 7 } & flecha & & flecha & & $\mathbf{1 9 9 2}$ & Adap. \\
\cline { 2 - 7 } & max. & as/a0 & max. & an /a0 & as /a0 & as/a0 \\
\cline { 2 - 7 } & $(\mathrm{mm})$ & $(\%)$ & $(\mathrm{mm})$ & $(\%)$ & $(\%)$ & $(\%)$ \\
\hline 1 & 4,18 & 0,00 & 4,36 & 0,00 & 0,00 & 0,00 \\
\hline 50 & 4,44 & 6,22 & 4,63 & 6,19 & 3,83 & 9,30 \\
\hline 100 & 4,51 & 7,89 & 4,64 & 6,42 & 4,53 & 9,81 \\
\hline 1000 & 4,61 & 10,29 & 4,39 & 0,69 & 7,76 & 12,21 \\
\hline 2500 & 4,65 & 11,24 & 4,24 & $-2,75$ & 9,56 & 13,55 \\
\hline 5000 & 4,66 & 11,48 & 4,26 & $-2,29$ & 11,15 & 14,75 \\
\hline 10000 & 4,67 & 11,72 & 4,26 & $-2,29$ & 12,96 & 16,12 \\
\hline 15000 & 4,68 & 11,96 & 4,26 & $-2,29$ & 14,13 & 17,01 \\
\hline 20000 & 4,66 & 11,48 & 4,27 & $-2,06$ & 15,00 & 17,69 \\
\hline 25000 & 4,64 & 11,00 & 4,26 & $-2,29$ & 15,71 & 18,23 \\
\hline 30000 & 4,63 & 10,77 & 4,24 & $-2,75$ & 16,31 & 18,70 \\
\hline
\end{tabular}

A Figura 5.51 mostra a evolução da perda de rigidez verificada nas vigas VTNA-SE-02 e VT-NA-CE-02 comparadas com os modelos de PITONAK e PITONAK ADAPTADO.

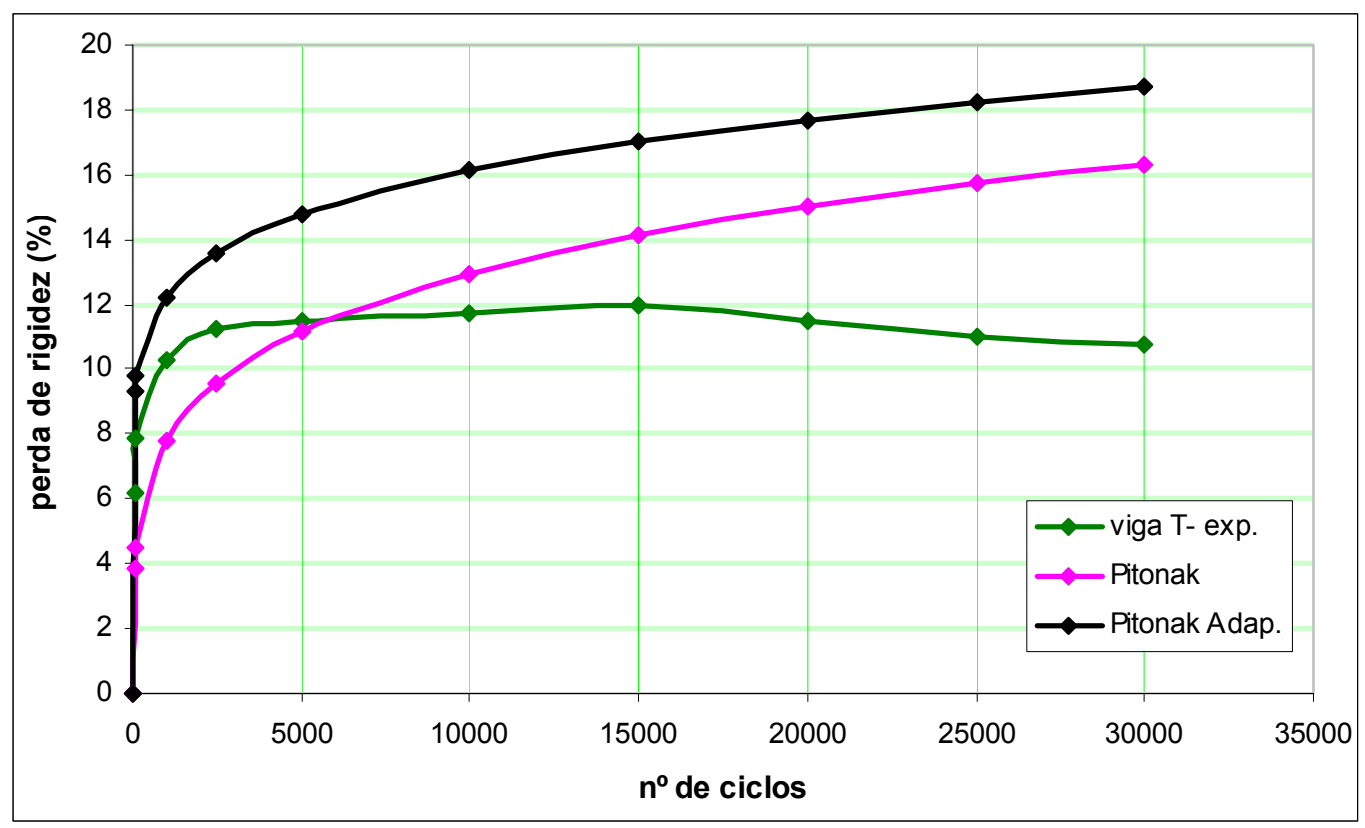

Figura 5.51 - Evolução da perda de rigidez da viga experimental tipo "T" e modelos comparativos

Observa-se, nesse caso, que a tendência das curvas tanto de PITONAK quanto de PITONAK ADAPTADO aproximam-se dos resultados experimentais (acima dos 
5.000 ciclos a viga apresentou problemas); com essa tendência, nos 30.000 ciclos, projeta-se uma perda de rigidez próxima dos $17 \%$, valor inferior ao obtido para as vigas com armadura dupla (25\%). Lembrar que a L.N. das vigas com seção tipo "T" encontra-se na mesa.

Diante das análises apresentadas nesse item é possível tecer alguns comentários a respeito do comportamento experimental e numérico das vigas de concreto armado:

- Ao todo foram ensaiadas 15 (quinze) vigas. 05 (cinco) R-SA, 05 (cinco) RAD e 05 (cinco) T-AS; todas as vigas são de dimensões reduzidas;

- Em geral as vigas apresentaram comportamento semelhante seja no tocante a carga última de ruptura seja na variação de amplitude da flecha;

- Verificou-se aumento da flecha em função da aplicação dos ciclos de carga, com conseqüente perda de rigidez;

- Verificou-se aumento da carga de ruptura após a aplicação do último ciclo de carga;

- Verificou-se que os primeiros ciclos são os que causam maiores perdas de rigidez e conseqüente dano à estrutura;

- Verificou-se, também, que o aumento da flecha tende a se estabilizar a partir de um certo número de ciclos;

- O aumento dos níveis de excitação, para baixas freqüências, não alterou significativamente os resultados;

- Constatou-se a existência de deformação plástica acumulada do concreto denotando a danificação localizada ocorrida numa seção da viga; a deformação da fibra mais comprimida do concreto atingiu 5,0 \%o na ruptura, bem acima dos $3,5 \%$;

- Verificou-se que as barras não entraram em escoamento durante os ensaios cíclicos, mesmo os que usaram $95 \%$ da carga estimada de ruptura como amplitude máxima;

- Verificou-se a deformação plástica acumulada do aço, mesmo sem ser atingida a tensão de escoamento durante os ciclos aplicados;

- A análise numérica foi realizada no aplicativo Abaqus, considerado pelo autor uma excelente ferramenta para modelar estruturas em geral;

- Para uma viga de concreto armado onde se considerou na análise numérica, com o Abaqus, a barra de aço, com suas nervuras, e o contato entre 
barra e concreto envolvente (através suas superfícies de contato), a resposta não foi considerada satisfatória. O modelo mostrando-se bastante rígido;

- Assim como funcionou bem o modelo axisimétrico para os CP`s para as vigas apenas parte da resposta foi alcançada;

- As mudanças bruscas de direção da normal ao elemento da superfície escrava tornam o problema mais rígido e de difícil convergência; inúmeras foram as tentativas para contornar o problema de convergência; vários modelos e refinamentos de malha foram utilizados, sem sucesso;

- Os modelos numéricos adaptados por ARAÚJO (2003) e ALVA (2004) apresentaram resultados muito bons e mostraram-se bem interessantes. Foi usado, como dito, para ajudar no balizamento da solução numérica. O modelo utilizado em ambos os citados trabalhos, no entanto, foge à idéia central da análise numérica deste trabalho que é considerar partes tridimensionais e o contato entre elas;

- A curva de BRANSON [eq. (5.11) e Figura 5.35] mostrou um resultado bem próximo do experimental; no início a curva é bem acentuada mostrando o ponto de perda de rigidez após a primeira fissura;

- Pelo exame da Tabela 5.1 pode-se concluir, como era de se esperar, que a viga tipo "T" possui capacidade portante da mesma ordem de grandeza da viga com armadura dupla, porém com menor taxa de armação.

- A pesquisa mostrou que as vigas sub-armadas tendem a apresentar uma perda de rigidez da ordem de $40 \%$.

- A pesquisa também mostrou que as vigas armadas duplamente tendem a apresentar uma perda de rigidez da ordem de $25 \%$ e as vigas com seção tipo “T” próximo dos $20 \%$.

- Mesmo para as vigas ensaiadas com amplitude de carga perto dos 50\% da carga última (viga VP-NA-02) e $60 \%$ da carga última (viga VR-AD-02) os resultados mostraram que a perda de rigidez segue a mesma tendência das vigas ensaiadas com amplitude próxima dos $80 \%$ da carga última. Isso deve sugerir uma reflexão quanto ao uso do fator de multiplicação das ações em pontes de concreto armado; esse fator de multiplicação das ações, ao que sugerem os resultados desta pesquisa, mostra-se ineficiente pois os danos causados pela carga cíclica ocorrem efetivamente. 
- Para a viga ensaiada com amplitude de 95\% da carga última verificou-se um ligeiro acréscimo da perda de rigidez.

- A eq. 5.11 é apenas uma sugestão para uma avaliação aproximada do valor da flecha final numa viga de concreto armado após aplicado um certo número $\mathrm{N}$ de ciclos de carga. A pesquisa, por ter utilizado um número bem limitado de vigas no seu programa experimental, carece de maior aprofundamento. 


\section{Capítulo 6}

\section{CONCLUSÕES}

\subsection{INTRODUÇÃO}

Este capítulo apresenta as conclusões do trabalho e algumas sugestões para pesquisas futuras. São expostos, de forma condensada, os principais resultados experimentais e numéricos da pesquisa. Embora a cada capítulo, após as análises dos resultados dos ensaios e dos modelos numéricos, tenham sido tecidas diversas considerações sobre cada assunto tratado, adiante é apresentada uma síntese dos principais resultados discutidos.

Neste trabalho foram realizados ensaios estáticos e dinâmicos (cíclicos) em vigas bi-apoiadas de dimensões reduzidas, a partir dos quais foi possível tirar algumas conclusões e reforçar outras a respeito da perda de rigidez verificada nestas vigas após a aplicação de um certo número de ciclos de carga.

Em adição ao trabalho experimental realizado com as vigas, foram feitos ensaios estáticos e cíclicos com corpos cilíndricos com os mesmos objetivos.

Além disso, foi desenvolvida modelagem numérica com o auxílio de programas que utilizam o método dos elementos finitos, notadamente o Abaqus. A expectativa sempre foi a de que os modelos numéricos validassem os resultados experimentais, o que nem sempre ocorreu. 


\subsection{CONCLUSÕES GERAIS}

O concreto é um material de comportamento complexo. A não linearidade decorrente da fissuração, proveniente dentre outras causas do processo de microfissuração interna do concreto presente mesmo antes de sua utilização, torna bastante complexa a execução de uma simulação numérica que permita reproduzir de forma fiel e realista o comportamento do concreto ao longo de um processo de carregamento, mormente para ações cíclicas.

A grande maioria dos modelos teóricos e numéricos existentes na literatura técnica e ao alcance de engenheiros e pesquisadores não consideram as dimensões reais isoladas de cada parte, do aço (com sua nervuras) e do concreto, junto com a ligação dessas partes através do contato na interface entre elas, seja pela complexidade do fenômeno ou mesmo pelas dificuldades inerentes ao desenvolvimento desses modelos.

O foco maior desta tese foi a análise numérica. Buscou-se exaustivamente chegar a uma solução, com a utilização do aplicativo Abaqus, que pudesse apresentar uma alternativa de análise em contra ponto ao que está dito no parágrafo anterior.

Dentre as diversas observações e constatações feitas ao longo deste trabalho, algumas foram consideradas relevantes e são apresentadas neste capítulo.

\subsubsection{CP's de concreto armado}

- Foram realizados ensaios experimentais com 4 (quatro) CP's; os resultados mostraram boa concordância com os resultados encontrados na literatura técnica;

- Ficaram bastante evidentes os modos de ruptura por arrancamento e por fendilhamento, mesmo com poucos espécimes;

- O valor limite recomendado pela NBR 6118:2003 para a tensão de aderência correspondente a um deslizamento de $0,1 \mathrm{~mm}$ mostrou-se conservador;

- Constatou-se o aumento crescente do deslocamento em função da aplicação dos ciclos de carga, com conseqüente perda de rigidez;

- Verificou-se o aumento da carga de ruptura (12\% no caso de arrancamento) após a aplicação do último ciclo de carga e a conseqüente diminuição do deslocamento na ruptura (aproximadamente 3,5 vezes menos); 
para o caso de fendilhamento o aumento da carga foi apenas de 5\% verificando-se aumento no deslocamento na ruptura em torno de $25 \%$.

- Foram realizadas simulações numéricas com o aplicativo ABAQUS em modelos axisimétricos e tridimensionais;

- Nas simulações a barra de aço foi modelada levando em conta suas características reais, com o desenho de suas nervuras;

- Nas simulações a barra de aço, com suas nervuras, e o concreto envolvente são unidos na interface através superfícies de contato; essa estratégia confere ao conjunto uma resposta mais realista podendo-se obter da análise, por exemplo, o deslizamento dos pontos da interface, dano ocorrido e perda de rigidez;

- O modelo constitutivo "Concrete Damaged Plasticity" mostrou-se bastante adequado para retratar o funcionamento conjunto entre a barra de aço, o concreto e o contato na interface; não foi encontrado nenhum trabalho onde essa estratégia de modelagem tenha sido utilizada;

- Para o modelo axisimétrico a resposta foi considerada satisfatória mesmo o modelo mostrando-se bastante rígido;

- $\mathrm{Na}$ análise os valores encontrados na interface para a variável $\mathbf{d}$ de dano localizado, próximos da unidade, indicam a degradação da interface indicando a perda de rigidez da peça e conseqüente ruptura;

\subsubsection{Vigas de concreto armado}

- Foram realizados ensaios experimentais com 15 (quinze) vigas; os resultados, em geral, mostraram boa concordância com os resultados esperados;

- Todas as vigas usadas na pesquisa possuem dimensões reduzidas; segundo Borges \& Arga e Lima (1961) é possível reproduzir todos os detalhes dos materiais tais como agregado graúdo e barras de aço com bastante precisão para reduções de escala até $1 / 4$. O fator de redução usado foi da ordem de 1/2.5 em relação às dimensões inicialmente previstas (dimensões "reais");

- Em geral as vigas apresentaram comportamento semelhante no tocante a carga última de ruptura para cada grupo analisado; 
- Entre os grupos o que mais chama a atenção é a relação entre a carga de ruptura das vigas com armadura dupla e tipo " $T$ "; a variação entre elas é de 2,5 $\%$; no dimensionamento da viga tipo "T" os dados constantes foram o vão e a largura e altura da alma; observar que a L.N. ficou na mesa;

- Todas as vigas ensaiadas apresentaram aumento da flecha em função da aplicação dos ciclos de carga, com conseqüente perda de rigidez;

- As vigas sub-armadas e tipo "T" apresentaram a mesma faixa de aumento da flecha: 0,40 mm para as sub-armadas e 0,45 $\mathrm{mm}$ para as vigas tipo " $\mathrm{T}$ "; lembrando que as vigas tipo " $\mathrm{T}$ " foram dimensionadas como sub-armadas a diferença a mais para o ganho de flecha se justifica pela maior carga de ruptura por elas suportada;

- As vigas duplamente armadas apresentam valores bem maiores para o aumento da flecha: $0,96 \mathrm{~mm}$; mais que o dobro verificado nas vigas do parágrafo acima o que justifica o acentuado dano no concreto, como mostra a Figura 5.37; a deformação da fibra mais comprimida do concreto atingiu 5,0 \%o na ruptura; a NBR 6118:2003 recomenda o diagrama retangular simplificado com 3,5\%;

- Fica evidente a deformação plástica acumulada do aço; nas vigas com armadura dupla a deformação plástica acumulada chega a próximos de 3,0 \%; os modelos teóricos e numéricos geralmente não levam em conta esse acúmulo de deformação;

- As barras não entraram em escoamento durante os ensaios cíclicos, mesmo os que usaram 95\% da carga estimada de ruptura como amplitude máxima;

- A análise numérica utilizou, alem do ABAQUS, os programas adaptados por ARAÚJO (2003) e ALVA (2004);

- A modelagem das vigas utilizando o ABAQUS considerou a barra de aço, com suas nervuras, e o contato entre barra e concreto envolvente (através suas superfícies de contato);

- A resposta não foi considerada satisfatória. O modelo mostrando-se bastante rígido;

- Mesmo assim, a idéia de tratar os elementos de viga como se fossem partes tridimensionais isoladas, com suas características físicas o mais próximas do 
real, continua válida para o autor; essa estratégia não é comumente usada na esmagadora maioria dos trabalhos encontrados na literatura;

- Os modelos adaptados por ARAÚJO (2003) e ALVA (2004) apresentaram bons resultados; não consideram, no entanto, o acúmulo de deformação plástica e nem levam em conta o ciclo de histerese desenvolvido na carga e descarga de um ciclo;

- A viga tipo "T" possui capacidade portante da mesma ordem de grandeza da viga com armadura dupla, porém com menor taxa de armação (25\% menor). É um bom indicativo de projeto.

Por fim, como sugestão para previsão da flecha $\mathbf{a}_{\mathbf{N}}$, determinada em função da flecha equivalente ao primeiro ciclo $\mathbf{a}_{\mathbf{0}}$ e de um número $\mathbf{N}$ de ciclos aplicados, pode ser utilizada a expressão dada pela eq. (6.1):

$$
\mathrm{a}_{\mathrm{N}}=\mathrm{a}_{0}\left(1.5-\beta_{1} \mathrm{e}^{-\beta_{2} \mathrm{~N}^{0.25}}\right)
$$

onde $\beta_{1}$ e $\beta_{2}$ tomam os valores:

- Para vigas sub-armadas:

$\left\{\begin{array}{l}\beta_{1}=0,50 \\ \beta_{2}=0,10\end{array}\right.$

- Para vigas com armadura dupla e seção tipo "T":

$\left\{\begin{array}{l}\beta_{1}=0,35 \\ \beta_{2}=0,02\end{array}\right.$

O valor da flecha $\mathbf{a}_{0}$ (flecha imediata) pode ser determinado através da expressão da rigidez equivalente fornecida pela NBR 6118:2003, no item 17.3.2.1.1, dada pela eq. (6.2):

$$
(\mathrm{EI})_{\mathrm{eq}}=\mathrm{E}_{\mathrm{cs}}\left\{\left(\frac{\mathrm{M}_{\mathrm{r}}}{\mathrm{M}_{\mathrm{a}}}\right)^{3} \mathrm{I}_{\mathrm{c}}+\left[1-\left(\frac{\mathrm{M}_{\mathrm{r}}}{\mathrm{M}_{\mathrm{a}}}\right)^{3}\right] \mathrm{I}_{\mathrm{II}}\right\} \leq \mathrm{E}_{\mathrm{cs}} \mathrm{I}_{\mathrm{c}}
$$

onde:

$\mathrm{I}_{\mathrm{c}}$ é o momento de inércia da seção bruta de concreto; 
$\mathrm{I}_{\text {II }}$ é o momento de inércia da seção fissurada de concreto no estádio II, calculada $\operatorname{com} \alpha_{\mathrm{e}}=\frac{\mathrm{E}_{\mathrm{s}}}{\mathrm{E}_{\mathrm{cs}}}$;

$\mathrm{M}_{\mathrm{a}}$ é o momento fletor na seção crítica do vão considerado;

$\mathrm{M}_{\mathrm{r}}$ é o momento de fissuração do elemento estrutural;

$\mathrm{E}_{\mathrm{cs}}$ é o módulo de elasticidade secante do concreto.

A Figura 6.1 mostra um comparativo da perda de rigidez para os três tipos de vigas analisados. Mostra a dificuldade de se adotar uma expressão única para previsão da flecha.

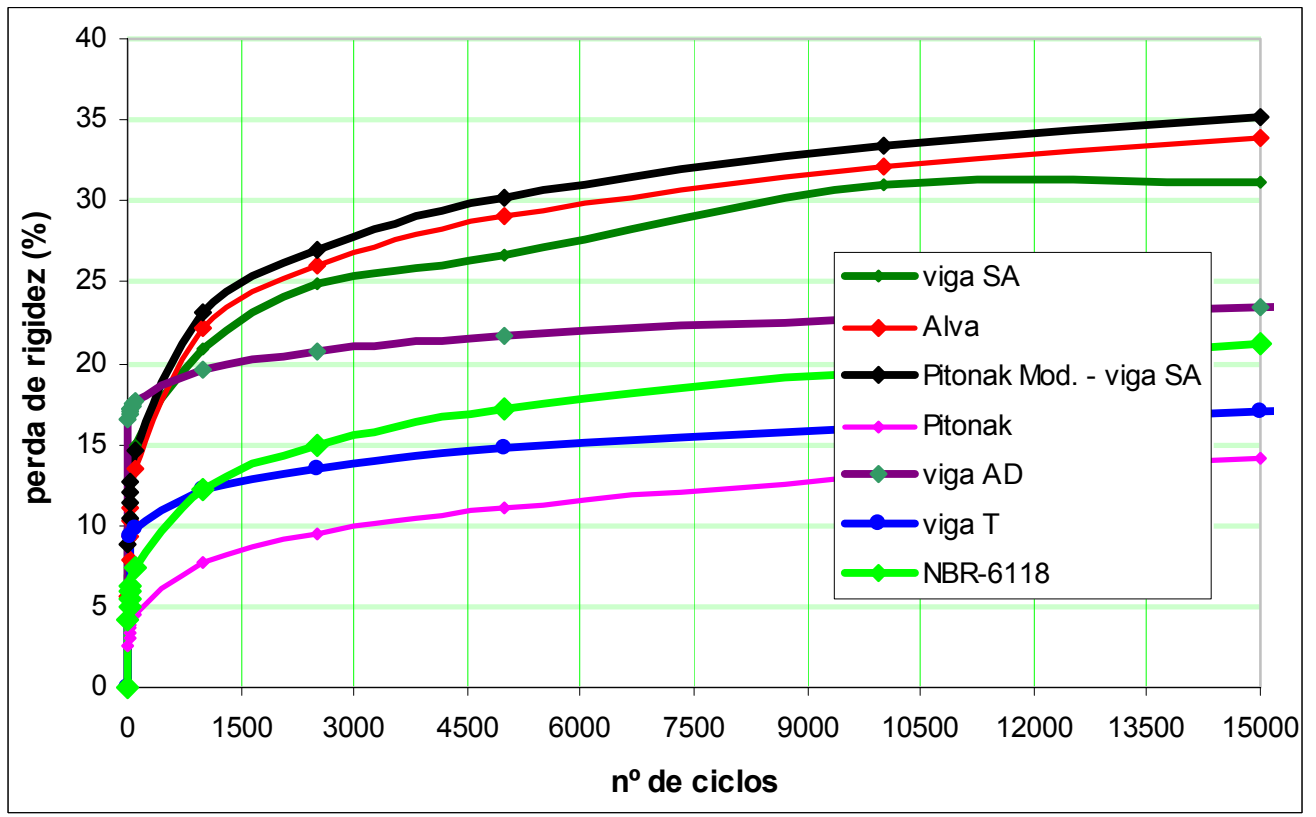

Figura 6.1 - Evolução comparativa da perda de rigidez para todas as vigas analisadas

A NBR:6118:2003 sugere, na falta de dados experimentais conclusivos, uma expressão igual à da eq. 6.1 onde:

$$
\left\{\begin{array}{l}
\beta_{1}=0,50 \\
\beta_{2}=0,05
\end{array}\right.
$$




\subsection{SUGESTÕES PARA NOVOS TRABALHOS}

A seguir são apresentadas algumas sugestões para trabalhos futuros visando primeiramente complementar e melhorar esta pesquisa e, também, num segundo momento, tomar novos rumos buscando aprimorar o conhecimento ainda em aberto sobre a perda de rigidez em estruturas de concreto armado submetidas a carregamento cíclico, mormente as vigas.

- Realização de ensaios com corpos de prova com $\mathrm{f}_{\text {ck }}=20 \mathrm{MPa}$ e $\mathrm{f}_{\text {ck }}=30$ MPa com a finalidade de extrair deles os parâmetros utilizados no modelo "Concrete Damaged Plasticity". Esses parâmetros seriam utilizados, os de $\mathrm{f}_{\mathrm{ck}}$ =30 MPa, para melhor calibrar os dados utilizados nesta tese; os parâmetros extraídos dos ensaios com $\mathrm{f}_{\mathrm{ck}}=20 \mathrm{MPa}$ seriam utilizados para uma nova pesquisa com vigas;

- Realizar uma nova pesquisa com as vigas utilizadas neste trabalho porém com concreto confeccionado com $\mathrm{f}_{\mathrm{ck}}=20 \mathrm{MPa}$ comparando-as com vigas de tamanho "real"; a intenção é comprovar a validade da teoria de dimensões reduzidas;

- Desenvolver uma pesquisa com vigas confeccionadas com concreto de resistência $\mathrm{f}_{\mathrm{ck}}=20 \mathrm{MPa}$ numa quantidade suficiente de espécimes para desenvolver um estudo estatístico e de confiabilidade dos resultados;

- Desenvolver uma pesquisa com vigas confeccionadas com concreto de resistência $\mathrm{f}_{\mathrm{ck}}=20 \mathrm{MPa}$ e armadas com barras de compressão e estribos devidamente dispostos de modo a se avaliar o confinamento do concreto;

- Retomar e ampliar a análise numérica desenvolvida neste trabalho, mantendo o uso do aplicativo ABAQUS, e implementando os parâmetros obtidos da pesquisa indicada no primeiro item; 


\section{Referências Bibliográficas}

ABAQUS/Standard User's Manual. Versão 5.8 (1998) e versão 6.2 (2002). Hibbitt, Karlsson \& Sorensen, Inc.

ABAQUS/Standard. Getting Started: interactive version. Versão 5.8 (1998) e versão 6.2 (2002). Hibbitt, Karlsson \& Sorensen, Inc.

ABAQUS/CAE User’s Manual. Versão 5.8 (1998) e versão 6.2 (2002). Hibbitt, Karlsson \& Sorensen, Inc.

ABAQUS Verification Manual. Versão 5.8 (1998) e versão 6.2 (2002). Hibbitt, Karlsson \& Sorensen, Inc.

ABAQUS Theory Manual. Versão 5.8 (1998) e versão 6.2 (2002). Hibbitt, Karlsson \& Sorensen, Inc.

ACI COMMITTEE 408. (1991). Abstract of: State-of-the-art-report: bond under cyclic loads. ACI Materials Journal, v.88, n.6, p.669-73, Nov./Dec.

ALLWOOD, R.J.; BAJARWAN, A.A. (1996). Modeling nonlinear bond-slip behaviour for finite element analyses of reinforced concrete structures. ACI Structural Journal, v.93, n.5, p.538-44, Sept. 
ALVA, G. M. S. (2004). Estudo teórico-experimental do comportamento de nós de pórtico de concreto armado submetidos a ações cíclicas. São Carlos. 225p. Tese (Doutorado) - Escola de Engenharia de São Carlos, Universidade de São Paulo.

ÁlVARES, M.S. (1999). Contribuição ao estudo e emprego de modelos simplificados de dano e plasticidade para a análise de estruturas de barras em concreto armado. São Carlos. 132p. Tese (Doutorado) - Escola de Engenharia de São Carlos, Universidade de São Paulo.

ALVES, B.K. ; LUBLINER, J. (1992). A damage mechanics model for beams. Aplication to reinforced concrete beams. In. ALDER, H. ; HEINRICH, J.C. ;

ARAÚJO, F. A. (2003). Contribuição ao emprego de mecânica do dano para a análise do comportamento dinâmico não-linear de vigas em concreto armado. São Carlos. 85p. Dissertação (Mestrado) - Escola de Engenharia de São Carlos, Universidade de São Paulo.

OÑATE, E. ; SUAREZ, B. ed. Numerical methods in engineering. Barcelona, Proc. CIMNE, p.277-286.

ALVIN, R. C. (1997). Avaliação da rigidez das vigas de concreto armado. São Paulo. 98p. Dissertação (Mestrado) - Escola Politécnica, Universidade de São Paulo.

ASSAN, A. E. (1999). Método dos Elementos Finitos: primeiros passos. Campinas. 298p. Editora da Unicamp. SP.

ASSOCIAÇÃO BRASILEIRA DE NORMAS TÉCNICAS (2003). NBR 6118 Projeto de estruturas de concreto - procedimento. Rio de Janeiro, ABNT.

AURICH, M. e CAMPOS FILHO, A. (2003). Modelo de aderência para análise através do método dos elementos finitos de vigas de concreto armado reforçadas. Porto Alegre. Teoria e Prática da Engenharia Civil, n.3, p.3-14.

BALÁZS, G.L. (1991). Fatigue of bond. ACI Materials Journal, v.88, n.6, p.620629, Nov./Dec. 
BALÁZS, G. L. et al. (1993). Acoustic emission monitoring on steel-concrete interaction. Otto Graf Journal, v.4, p.56-90.

BALÁZS, G.L. (1993). Cracking analysis based on slip and bond stresses. ACI Materials Journal, v.90, n.4, p.340-348, july/August.

BARBOSA, M.P. (1998). Uma contribuição experimental e numérica sobre estruturas de concreto armado de elevado desempenho: estudo da aderênciaancoragem e do comportamento de vigas fletidas. Ilha Solteira. 174p. Tese (Livre-docência) - Faculdade de Engenharia de Ilha Solteira, Universidade Estadual Paulista.

BORGES, J. F. e ARGA E LIMA, J. (1961). Crack and deformation similitude in reinforced concrete. Extraido do Bulletin RILEM n. 7, junho/1960. Lisboa.

BOLANDER Jr., J. e SATAKE, M. e HIKOSAKA, H. (1992). Bond degradation near developing cracks in reinforced concrete structures. Memoirs of the Faculty of Engineering, Kyushu University, v. 52, n. 4, Dec.

BRAGUIM, J.R. (1995). O comportamento em serviço de vigas de concreto armado sob carregamento cíclico. São Paulo. 114p. Tese (Doutorado) - Escola Politécnica, Universidade de São Paulo.

BUCHAIM, R. (2001). A influência da não-linearidade física do concreto armado na rigidez à flexão e na capacidade de rotação plástica. São Paulo. Tese (Doutorado) - Escola Politécnica, Universidade de São Paulo.

CASTRO, C. M. (2002). Concreto de alto desempenho: estudo da aderência com a armadura sob ações cíclicas. São Carlos. 233p. Dissertação (Mestrado) - Escola de Engenharia de São Carlos, Universidade de São Paulo.

CHEN, W. F. (1982). Plasticity in reinforced concrete. McGraw-Hill, New York.

CHEN, W. F. (1993). Concrete Plasticity: macro and microapproaches.Int. J. Mech. Sci., v. 35,n. 12, p. 1097-1109.

CILONI, A.D. (1993). Sobre o comportamento em serviço de estruturas planas de concreto armado. São Carlos. Tese (Doutorado) - Escola de Engenharia de São Carlos, Universidade de São Paulo. 
COMITE EURO-INTERNATIONAL DU BETON (1982). Bond action and bond behaviour of reinforcement: state-of-the-art report. Bulletin d'Information, n.151.

COMITE EURO-INTERNATIONAL DU BETON (1991). CEB-FIP Model code 1990. Bulletin D'Information n.203-205

COMITE EURO-INTERNATIONAL DU BETON (1996). RC elements under cyclic loading: state of the art report. Bulletin D'Information n.230.

DEBERNARDI, P. G. (1989). Behavior of concrete structures in service. Journal of Structural Engineering. V. 115, n. 1, jan.

DIAZ, B. E. (1974). Tabelas de dimensionamento de seção retangular de acordo com as normas do CEB-70. Curso de aperfeiçoamento em concreto armado. Rio de Janeiro. 31p. Departamento de estruturas. Universidade Federal do Rio de Janeiro.

DRIEMEIER, L. (1995). Considerações sobre a fadiga em metais e o comportamento do concreto sob solicitação cíclica. São Carlos. 149p. Dissertação (Mestrado) - Escola de Engenharia de São Carlos, Universidade de São Paulo.

DUMET, T. B. (2003). Aderência de cordoalhas em concretos de alta resistência com e sem fibras de aço. São Carlos. 331p. Tese (Doutorado) - Escola de Engenharia de São Carlos, Universidade de São Paulo.

DUCATTI, V. A. (1993). Concreto de elevado desempenho: estudo da aderência com a armadura.. 273p. São Carlos. Tese (Doutorado) - Escola de Engenharia de São Carlos, Universidade de São Paulo.

ELIGEHAUSEN, R. e POPOV, E. P. e BERTERO, V. V. (1983). Local bond stress-slip relationships of deformed bars under generalized excitations. Report $\mathrm{n}$. UCB/EERC-83/23. University of California, Berkeley. 162 p.

FEAP - A Finite Element Analysis Program. Version 7.4. (2002). Taylor, R. L.

FERNANDES, R. M. (2000). A influência das ações repetidas na Aderência Açoconcreto. São Carlos. 155p. Dissertação (Mestrado) - Escola de Engenharia de São Carlos, Universidade de São Paulo. 
FILIPPOU, F.C. (1986). A simple model for reinforced bar anchorages under cyclic excitations. Journal of Structural Engineering - ASCE, v.112, n.7, p.163959.

FLÓREZ-LÓPEZ, J. (1993). Modelos de daño concentrado para simulation numerica del colapso de porticos planos. Revista International de métodos Numéricos para Cálculo y Diseño en Ingeniería, v.9, n.2, p.123-139.

FUSCO, P. B. (1995). Técnicas de armar as estruturas de concreto.São Paulo. PINI.

GOTO, Y. (1971). Cracks formed in concrete around deformed tension bars. ACI Journal, April.

HOTA, S. ; NAAMAN, A. E. (1997). Bond stress-slip response of reinforcing bars embedded in FRC matrices under monotonic and cyclic loading. ACI Structural, V. 94, n.5, p.525-37, Sept./Oct.

KOCH, R.; BALÁZS, G.L. (1993). Slip increase under cyclic and long term loads. Otto Graf Journal, v.4, p.160-91.

KOH, C.G.; ANG, K.K.; ZHANG, L. (1997). Effects of repeated loading on creep deflection of reinforced concrete beams. Engineering Structures, v.19, n.1, p.2-18.

KRAL, E.R.; KOMVOPOULOS, K. (1996). Three-dimensional finite element analysis of subsurface stresses and shakedown due to repeated sliding on a layered medium. Journal of Applied Mechanics-Transactions of the ASME. v.63, n.4, p.967-73, Dec.

LA BORDERIE, C. (1991). Phenomenes unilateraux dans un materiau andomageable: modelisation et application a l'anlyse de structures en beton. Paris, 1991. Thèse (Doctorat) - Université Paris 6.

LARANJEIRAS, A.C.R (1976). Redução da aderência aço-concreto sob a ação de cargas repetidas. In: JORNADAS SUL-AMERICANAS DE ENGENHARIA ESTRUTURAL, 28., Salvador, 1976. Anais, Salvador, IBRACON, 1976, 25p. 
LEE, J. H., FENVES, G. L. (1998). Plastic-damage model for cyclic loading of concrete structures. Journal of Engineering Mechanics - ASCE, v.124, n.8, p.892-9.

LEONHARDT, F. ; MONNING, E. (1977). Construções de concreto: princípios básicos do dimensionamento de estruturas de concreto armado. $1^{a}$ ed. Rio de Janeiro, Interciência. V.1.

LUNDGREN, K. e GYLLTOFT, K. (2000). A model for the bond between concrete and reinforcement. Magazine of Concrete Research. V. 52. Iss. 1. Feb.

MAGGI, P.L.O. (2004). Comportamento de pavimentos de concreto estruturalmente armados sob carregamentos estáticos e repetidos. São Carlos. 205p. Tese (Doutorado) - Escola de Engenharia de São Carlos, Universidade de São Paulo.

MAZARS, J. e CABOT, G. P. (1989). Continuum damage theory-application to concrete. Journal of Engineering Mechanics, v. 115, n. 2, p. 345-65, Feb.

MONTI, G. e FILIPPOU, F.C. e SPACONE, E. (1997). Finite element for anchored bars under cyclic load reversals. Journal of Structural Engineering $A S C E$, v.123, n.5, p.614-23, May.

MONTOYA, P.J. e MESEGUER, A.G. e CABRÉ, F.M. (1976). Hormigón Armado, Barcelona, Editorial Gustavo Gili, S.A., $8^{\text {a }}$ ed.

NETO, J. M. e ASSAN, A. E. (2003). Modelagem computacional de estruturas considerando o deslizamento entre o aço e o concreto. TÉCHNE, Julho.

POPOV, E.P. (1984). Bond and anchorage of reinforcing bars under cyclic loading. ACI Journal, v.81, n.4, p.340-49, Jul./Aug.

PROENÇA, S.P.B. (1988). Sobre modelos matemáticos do comportamento nãolinear do concreto: análise crítica e contribuições. Tese (doutorado), Escola de Engenharia de São Carlos, EESC, Universidade de São Paulo.

RUSSO, G. e ZINGONE, G. e ROMANO, F. (1990). Analytical solution for bond-slip of reinforcing bars in R. C. joints. Journal of Structural Engineering, v. 116, n. 2, p.336-55, Feb. 
SAVASSI, W. (1996). Introdução ao Método dos Elementos Finitos: em análise linear de estruturas. São Carlos. 260p. EESC. SP.

SOMAYAJI, S. e SHAH, S. P. (1981). Bond stress versus slip relationship and cracking response of tension members. ACI Journal, p. 217-25, May-June.

TASSIOS, T.P. (1979). Properties of bond between concrete and steel under load cycles idealizing seismic actions. AICAP-CEB Symposium, Structural Concrete Under Seismic Actions. CEB, Bulletin d'Information, n.131, p.67-122.

TASSIOS, T.P.; YANNOPOULOS, P.J. (1981). Analytical studies on reinforced concrete members under cyclic loading based on bond stress-slip relationships. ACI Journal, v.78, n.3, p.206-16, May.

VALLE, A. (1994). Estudo da aderência entre concreto e armadura sob carregamento cíclico. São Paulo. 171p. Dissertação (Mestrado) - Escola Politécnica, Universidade de São Paulo.

YANKELEVSKY, D.Z. e ADIN, M. A. e FARHEY, D. N. (1992). Mathematical model for bond-slip behavior under cyclic loading. ACI Journal, v.89, n.6, p.69298, Nov./Dec.

YANNOPOULOS, P.J. e TASSIOS, T.P. (1981). Reinforced concrete axial elements analyzed under monotonic and cyclic actions. ACI Structural Journal, v.88, n.1, p.3-11, Jan.-Feb. 